\title{
A Good Example of \\ Peaceful Coexistence?
}

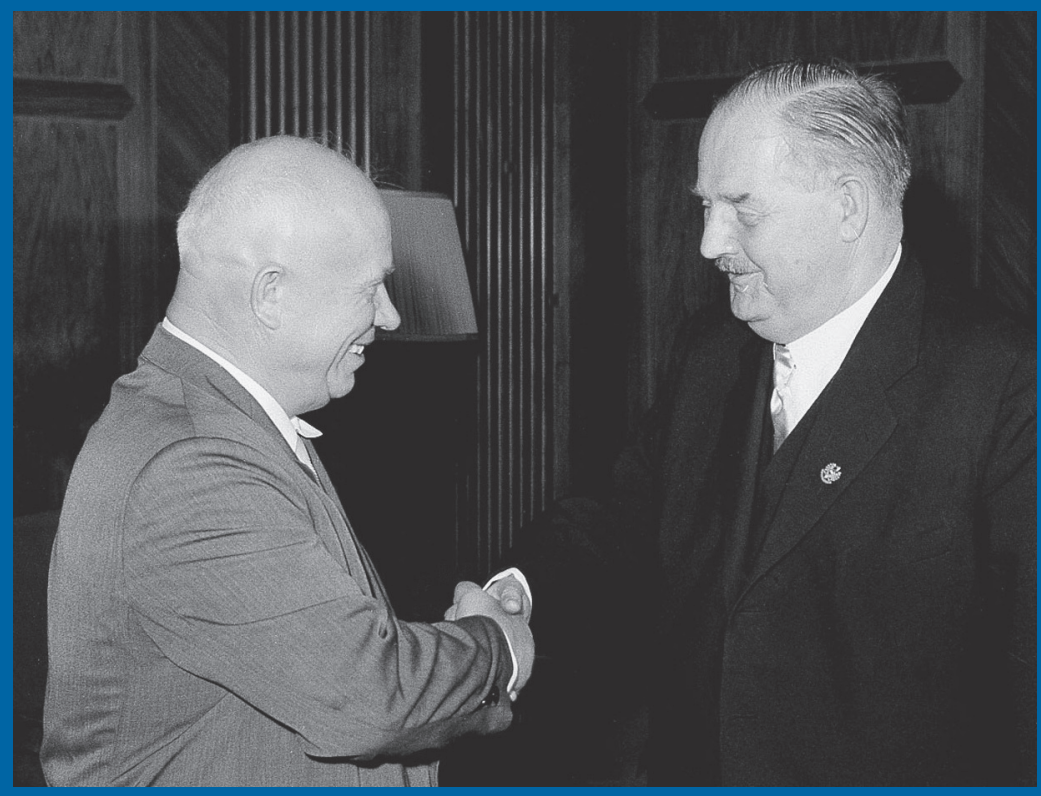

The Soviet Union, Austria, and Neutrality, 1955-1991

\section{WOLFGANG MUELLER}

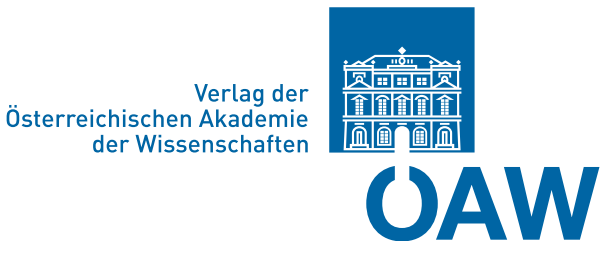




\section{WOLFGANG MUELLER}

A GOOD EXAMPLE OF PEACEFUL COEXISTENCE?

THE SOVIET UNION, AUSTRIA, AND NEUTRALITY, 1955-1991 


\title{
ÖSTERREICHISCHE AKADEMIE DER WISSENSCHAFTEN \\ PHILOSOPHISCH-HISTORISCHE KLASSE \\ HISTORISCHE KOMMISSION
}

\section{ZENTRALEUROPA-STUDIEN}

\author{
HERAUSGEGEBEN VON \\ ARNOLD SUPPAN \\ UND \\ GRETE KLINGENSTEIN
}

BAND 15

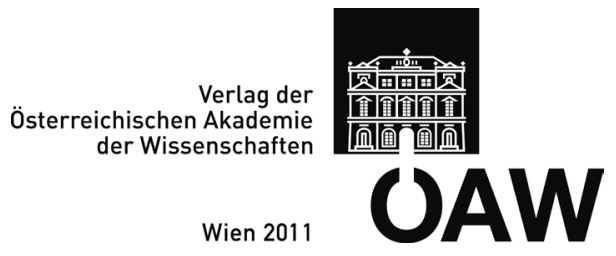




\section{WOLFGANG MUELLER}

\section{A Good Example \\ of Peaceful Coexistence?}

The Soviet Union, Austria, and Neutrality

1955-1991 


\section{Vorgelegt von w. M. Arnold Suppan \\ in der Sitzung am 18. Juni 2010}

\section{Cover:}

The Austrian chancellor, Julius Raab (r.), welcomes Nikita Khrushchev in his office, 30 June 1960, photograph by Fritz Kern, Österreichische Nationalbibliothek - Bildarchiv, FO504632 4 _48.

Cover design:

Oliver Hunger

British Library Cataloguing in Publication data.

A Catalogue record of this book is available from the British Library.

Die verwendete Papiersorte ist aus chlorfrei gebleichtem Zellstoff hergestellt, frei von säurebildenden Bestandteilen und alterungsbeständig.

Alle Rechte vorbehalten

ISBN 978-3-7001-6898-0

Copyright (C) 2011 by

Österreichische Akademie der Wissenschaften

Druck und Bindung: Prime Rate kft., Budapest

http://hw.oeaw.ac.at/6898-0

http://verlag.oeaw.ac.at 


\section{Contents}

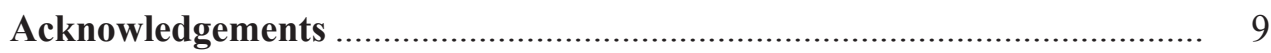

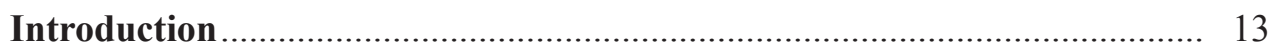

Soviet-Austrian relations, $1945-1955$.................................................... 13

"Peaceful coexistence" ........................................................................... 16

The Austrian state treaty and declaration of neutrality ............................. 20

The aim, sources and structure of this study......................................... 29

I. Laying the Groundwork and Changing Neutrality, 1955-1960 .......... 39

1. Two Differing Concepts of Neutrality .................................................... 41

The Soviet attitude towards neutrality.............................................. 43

The Soviet theory of neutrality in the late 1950s and 1960s ............... 56

Austria's neutrality, its Swiss model, and the Soviet interpretation ..... 67

2. The Post-State Treaty Honeymoon...................................................... 77

The establishment of friendly relations ............................................. 79

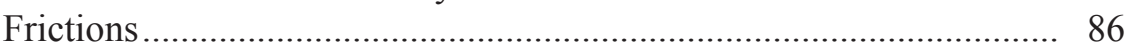

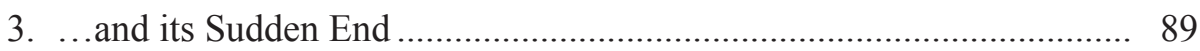

The Hungarian revolution.............................................................. 89

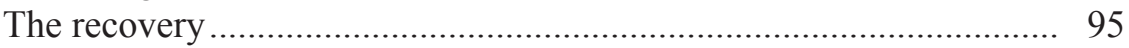

4. Starting Anew: After the Hungarian Revolution .................................... 103

The Raab visit and the Lebanon crisis................................................ 106

Cultural relations and the World Youth Festival 1959......................... 111

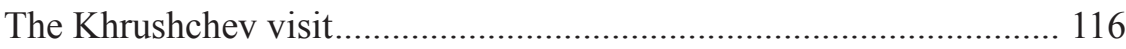

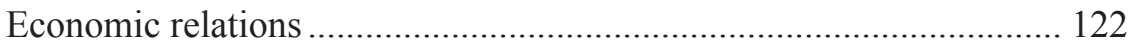

5. Summary: Soviet "Thaw" and the Making of a Neutral ........................ 127

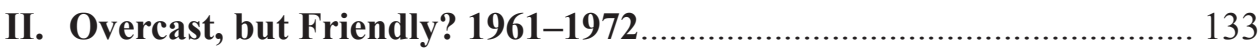

6. The Soviet Union, Austria's Rapprochement with the EEC, and the

Convocation of the CSCE

The Soviet attitude towards an Austrian rapprochement with the EEC,

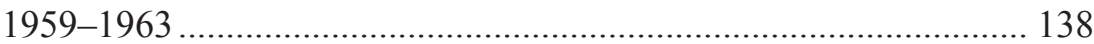

The Alleingang, 1963-1967 ............................................................. 150

The EEC issue and the Soviet encouragement for convoking the CSCE, 1967-1972 
7. The Czechoslovakian Crisis of 1968 and Austria's Military Vulnerability

The Warsaw Pact's intervention and the Soviet reputation in Austria.. 175

Warsaw Pact plans and Austria's self-defense.

8. Making Economic and Cultural Relations Mutual................................. 187

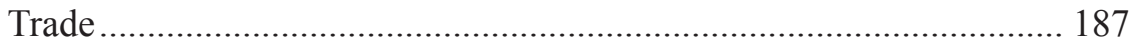

Cultural relations and personal contacts............................................. 192

9. Summary: Soviet Containment and Encouragement; Austria's Ostpolitik

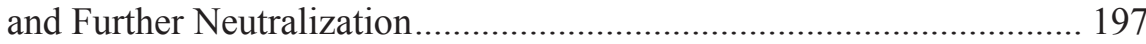

\section{Détente, the Heyday of Multilateralism, and the Last Peak of the Cold}

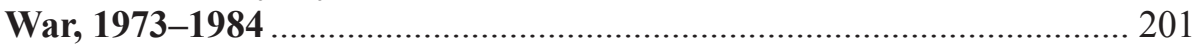

10. Political Relations and the Rise of Multilateralism.............................. 203

Kreisky, "active neutrality," and Austrian-Soviet relations ................ 207

The USSR and Austria on the international stage ............................ 215

11. A Thorn in the Side: Human and Cultural Contacts ............................. 225

Soviet dissidents, the Jewish exodus from the USSR, and the

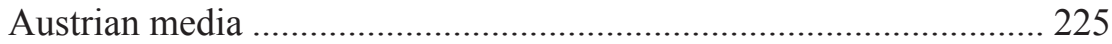

Cultural exchange, tourism, and the image of the other..................... 230

12. Booming, but not Enough: Economic Relations ................................. 235

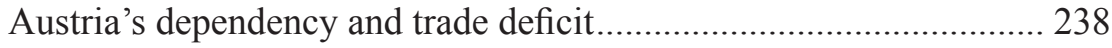

13. The Final Peak of the Cold War ........................................................ 245

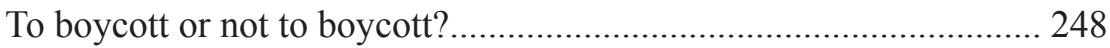

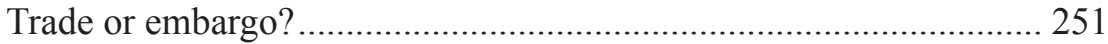

14. Summary: Declining Soviet Interest in Neutrality despite Austria's

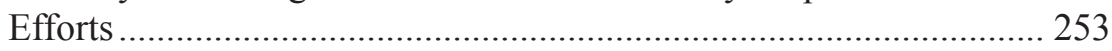

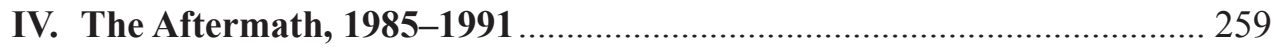

15. The End of the Cold War, European Integration, and the Obsolescence of the Special Relationship ................................................................. 261

Gorbachev, Austria's EC application, and the disintegration of the

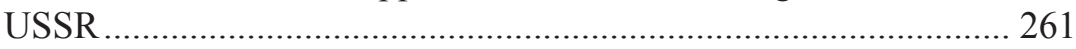

Humanitarian aid and economic relations ....................................... 269

Human contacts, scientific and cultural cooperation.......................... 271

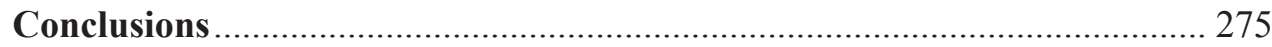

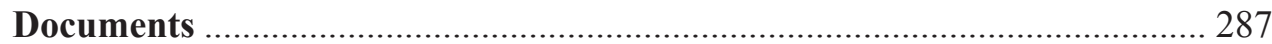

Document 1: Conversation A. Mikoian - J. Raab, Vienna, 24 April 1957

(in German). 
Document 2: Personal letter N. Bulganin - J. Raab, 8 January 1958 (in German and Russian) 293

Document 3: Conversation N. Khrushchev - A. Schärf and B. Kreisky, Moscow, 13 October 1959 (in German). 298

Document 4: Conversation A. Gorbach - N. Khrushchev, Moscow, 29 June 1962 (in German) 300

Document 5: Conversation N. Khrushchev - B. Pittermann, Moscow, 17 September 1962 (in German) 318

Document 6: The Democratic Lawyers Association's Theses on Neutrality,

Sofia, 14 October 1962 (in English) 327

Document 7: Conversation A. Gromyko - K. Waldheim, Moscow,

22 March 1968 (in English, translated from Russian) 328

Document 8: Conversation L. Brezhnev - B. Kreisky, Moscow, 8 February 1978 (in German) 330

Document 9: Report Austrian embassy Moscow - Austrian MFA, On Austrian Soviet Relations, 23 November 1985 (in German). 333

Soviet Ambassadors to Austria, Austrian Ambassadors to the USSR 339

Abbreviations 341

Bibliography ..... 343

Index 377 


\section{List of Tables}

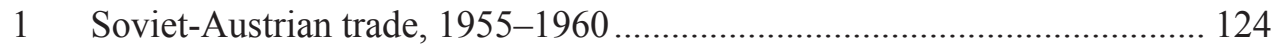

2 Defense indicators of neutral states in the mid-1980s ............................... 185

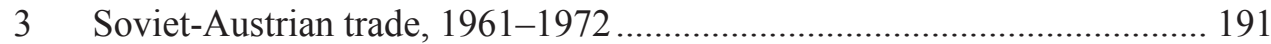

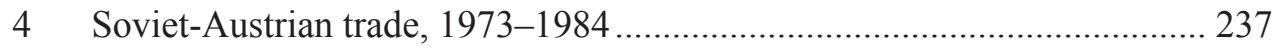

5 Soviet foreign trade with selected Western, neutral, and non-aligned countries in million rubles, $1955-1990$..................................................... 242

5.1 Shares in Soviet imports from selected Western, neutral, and nonaligned

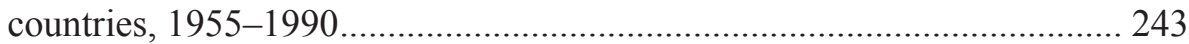

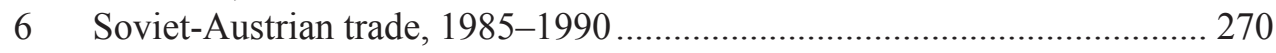




\section{Acknowledgements}

Writing this book required the help of many people and institutions. I would particularly like to thank the Historical Commission of the Austrian Academy of Sciences and its chairman, Professor Arnold Suppan, for making this project possible, and the Institute for General History of the Russian Academy of Sciences under the directorship of Academician Aleksandr O. Chubar'ian and his deputy Viktor $\mathrm{V}$. Ishchenko for providing me several fellowship grants to do archival research in Moscow. Furthermore, I wish to thank the directors and archivists of the Austrian State Archives, the Bruno Kreisky Archives, the Foreign-Policy Archives of the Russian Federation, the Russian State Archives for Contemporary History, and the Gorbachev Foundation, all of which were used to do research for this project. In the archives, Rudolf Jerabek, Dieter Lautner, Nadezhda P. Mozzhukhina, Heinz Placz, Mikhail Iu. Prozumenshchikov, Sergei V. Pavlov, Maria Steiner, and Natal'ia G. Tomilina were particularly supportive. Further thanks go to the Hoover Institution Archives and Library at Stanford University and the Library of the Austrian Ministry of Foreign Affairs, as well as the Diplomatic Academy in Vienna. Among other things, the Ministry was helpful in verifying the dates of accreditation of the Austrian ambassadors in Moscow. My colleagues Professor Peter Jordan and Florian Partl, granted me access to their collection of Soviet statistics and various documents.

I am greatly indebted to Professor Michael Gehler of the University of Hildesheim, Professor Andreas Kappeler of the University of Vienna, and Professor Norman M. Naimark of Stanford University for reading and commenting on parts of the manuscript. Three of Austria's former ambassadors to the Soviet Union, Herbert Grubmayr, Gerald Hinteregger, and Fritz Bauer shared their recollections with me, and I am particularly grateful for their thoughts. I am also indebted to Ambassador Paul Ullmann, who provided me a copy of his unpublished study on Austrian diplomats in Moscow, to Professor Oliver Rathkolb of the University of Vienna and to my colleague Maximilian Graf, who granted me the right to use their copies of some Soviet and GDR documents. Special thanks for their helpful remarks go to Mr. Ernst Aichinger of the Ministry of European and International Affairs, professors Thomas Angerer of the University of Vienna, Günter Bischof of the University of New Orleans, Thomas Fischer of the Graduate Institute of International and Development Studies, Geneva, Mark Kramer of Harvard University, Erwin A. Schmidl of the Austrian Defense Academy and, last but not least, to Professor emeritus Gerald Stourzh for his teaching, support, and comments. 
This work was written during a fellowship at Stanford University's Freeman Spogli Institute for International Studies, and I would like to thank its director, Professor Coit D. Blacker, as well as Professor Roland Hsu and Laura Seaman for making this stay a pleasant experience. I wish also to thank Cynthia PeckKubaczek for her editorial assistance, Vera Machat for her help in editing the published Russian and Austrian documents in the appendix of this volume, and all my other colleagues and friends at the Historical Commission, in particular Professor William D. Godsey, Jr., for helping me translate the most extravagant passages in archival documents, Barbara Haider-Wilson for recommending useful literature and Michael Portmann. Special thanks go to Gerald Reisenbauer for formatting the manuscript, to Oliver Hunger for designing the cover of this volume, and to the Austrian Academy of Sciences for accepting this study for publication in its series Zentraleuropa-Studien.

Vienna, October 2010 
"Royal families formerly used to employ whipping-boys, who had the honor of receiving condign punishment on their profane backs, whenever any of the scions of royalty had committed an offense against the rules of good behavior. The modern European political system continues this practice, in a certain degree, in the erection of small intermediate States, which have to act the scapegoat in any domestic squabble by which the harmony of the 'balance of power' may be troubled. And in order to enable these smaller States to perform this enviable part with suitable dignity, they are, by the common consent of Europe 'in Congress assembled,' and with all due solemnity declared 'neutral."' Frederick Engels, "Political Position of the Swiss Republic," [1853], in Karl Marx and Frederick Engels, Collected Works 12 (Moscow: Progress, 1979), 86-92, 86. 



\section{Introduction}

\section{Soviet-Austrian relations 1945-1955}

In Soviet-Austrian relations, much more than in Austrian dealings with any other great power, the year 1955 marked the beginning of a new era. Until then, Soviet intentions vis-à-vis the Alpine republic, located at the edge of what was to become the Eastern bloc, had been far from clear, and relations between the communist superpower and the small state with its roughly seven million inhabitants were generally strained. It seems that in 1945 Stalin hoped to bring this country, which had been liberated from Nazi rule and was occupied by the four Allied powers, gradually into the Soviet orbit by having a national-front government formed in Vienna and establishing close bilateral economic and political ties. With the Austrian communists' defeat in the general elections of 25 November 1945, the failure of this strategy was soon obvious. As a consequence, the Kremlin was not ready to do the Austrians any favors: the Allied control over the Austrian government was maintained; the former "German assets" in the Soviet zone of Austria were seized; communist tactics to destabilize the Austrian government received Soviet support; and the state treaty negotiations for withdrawing the Allied forces were left in limbo as long as it seemed useful to the Kremlin to keep troops in both Austria and, by alluding to their right to maintain communication lines, in neighboring Hungary. ${ }^{1}$ The dawning Cold War between the Soviet Union and the West convinced both sides that pulling out of Austria was not immediately possible. While the West feared that its withdrawal would be followed by a communist attempt to topple the Austrian government, Stalin neither wanted to surrender the country entirely to Western influence nor to give it up as a bargaining chip in his Grand Game over Germany. ${ }^{2}$

${ }^{1}$ For a history of the state treaty negotiations, see Gerald Stourzh, Um Einheit und Freiheit: Staatsvertrag, Neutralität und das Ende der Ost-West-Besetzung Österreichs 1945-1955, 5th ed. (Vienna: Böhlau, 2005). Stourzh has provided the most comprehensive history of the negotiations to date. On the history of the state treaty and on Austria's relations with the Allies in the postwar decade, see also Arnold Suppan, Gerald Stourzh, and Wolfgang Mueller (eds.), The Austrian State Treaty 1955: International Strategy, Legal Relevance, National Identity (Vienna: Verlag der Österreichischen Akademie der Wissenschaften, 2005). Cf. Günter Bischof, Austria in the First Cold War, 1945-1955: The Leverage of the Weak (Basingstoke: Palgrave, 1999); Manfried Rauchensteiner, Stalinplatz 4: Österreich unter alliierter Besatzung (Vienna: Steinbauer, 2005); Rolf Steininger, Der Staatsvertrag: Österreich im Schatten von deutscher Frage und Kaltem Krieg, 1938-1955 (Innsbruck: Studienverlag, 2005).

2 On Soviet policy in Austria in the postwar decade, see Wolfgang Mueller, "Stalin and Austria: New Evidence on Soviet Policy in a Secondary Theatre of the Cold War, 1938-1953/55," in 
Meanwhile, bilateral relations became increasingly unfriendly. From 1946-47 on, Soviet propaganda attacked Austrian noncommunist parties and politicians, and in 1948 the Soviet deputy high commissioner Aleksei Zheltov, in a conversation with Leopold Figl, called the Christian-social Austrian chancellor "a great enemy of the Soviet Union." ${ }^{\prime 3}$ The harsh Soviet policy proved counterproductive as it rendered the Austrian population even more anti-communist than it had already been. Notwithstanding these unpromising circumstances, the Soviet authorities in Austria, at least until 1953, did not give up their hope of "strengthening Soviet influence" in the country and leading Austria towards "people's democracy" by, albeit cautiously, supporting the local communists and trying to cause splits in the noncommunist parties. However, the Austrian communists' scheme to divide Austria, like the German model, into a communist and a capitalist half was rejected in a secret conversation by the Kremlin in February 1948 (most probably in order to avoid a new Anschluss of western Austria with West Germany). ${ }^{4}$

It was only during the "thaw" after Stalin's death in March 1953 that, in the course of the resulting global détente, a significant relaxation in Soviet-Austrian relations could be achieved. In response to US president Eisenhower's call upon the Kremlin to prove that it intended to relax tensions, the new Soviet leadership consented to various changes in policy: Negotiations with regard to the Korean War were resumed, and in July 1953 an armistice was signed. Western diplomats in Moscow were granted more freedom of movement, Soviet anti-Western propa-

Cold War History 6, no. 1 (2006), 63-84. For more detail, cf. idem, Die sowjetische Besatzung in Österreich 1945-1955 und ihre politische Mission (Vienna: Böhlau, 2005); and idem, "Gab es eine verpasste Chance? Die sowjetische Haltung zum Staatsvertrag," in Arnold Suppan, Gerald Stourzh and Wolfgang Mueller (eds.), The Austrian State Treaty 1955: International Strategy, Legal Relevance, National Identity (Vienna: Verlag der Österreichischen Akademie der Wissenschaften, 2005), 89-120. See also Stefan Karner, Barbara Stelzl-Marx, and Alexandr Tschubarjan (eds.), Die Rote Armee in Österreich: Krasnaia armiia v Avstrii, 1945-1955 (Graz: Oldenbourg, 2005); and Andreas Hilger, Mike Schmeitzner, and Clemens Vollnhals (eds.), Sowjetisierung oder Neutralität? Optionen sowjetischer Besatzungspolitik in Deutschland und Österreich 1945-1955 (Göttingen: Vandenhoeck \& Ruprecht, 2006). Key Russian documents on Soviet policy in Austria are published, in Russian and German, in Wolfgang Mueller, Arnold Suppan, Norman Naimark, and Gennadij Bordjugov (eds.), Sowjetische Politik in Österreich: Dokumente aus russischen Archiven: Sovetskaia politika v Avstrii: Dokumenty iz Rossiiskikh arkhivov (Vienna: Verlag der Österreichischen Akademie der Wissenschaften, 2005). For a history of Soviet-Austrian relations 1918-1955, see Wolfgang Mueller and Hannes Leidinger, "Tiefes Misstrauen - begrenztes Interesse: Die österreichisch-sowjetischen Beziehungen 1918 bis 1955," in Arnold Suppan, Klaus Koch, Walter Rauscher, and Elisabeth Vyslonzil (eds.), Von Saint-Germain zum Belvedere: Österreich und Europa 1919-1955 (Vienna: Oldenbourg, 2006), 70-114.

${ }^{3}$ Quoted in Stourzh, Um Einheit und Freiheit, 142

${ }^{4}$ Conversation of Zhdanov with the leaders of the Austrian Communist Party Koplenig and Fürnberg, 13 February 1948, in Mueller, Suppan, Naimark, Bordjugov, Sowjetische Politik: Sovetskaia politika, 452-465. A German translation is published in Wolfgang Mueller, "Die Teilung Österreichs als politische Option für KPÖ und UdSSR 1948), in Zeitgeschichte 32, no. 1 (2005), 47-54. 
ganda was tempered, territorial claims against Turkey were relinquished, and diplomatic relations with Yugoslavia, Greece, and Israel were reestablished. ${ }^{5}$ In the United Nations, the Soviet delegate ended his earlier blockade by giving a green light for the nomination of Dag Hammarskjöld for the position of Secretary General, and in Germany, Soviet traffic blocks around Berlin were loosened. Most sensationally, the US president's address to the Soviet people was published in Pravda. With regard to Austria, whose release from four-power control had also been demanded in Eisenhower's "Chance for Peace" speech of 16 April, as a test case for the seriousness of Soviet intentions to end the Cold War, ${ }^{6}$ the Kremlin allowed certain relaxations in its control over the Austrian authorities, which eased everyday life in the Soviet zone and slackened the bilateral tensions. ${ }^{7}$ The diplomatic representations in Vienna and Moscow were upgraded to embassies (roughly at the same time the USSR established an embassy in East Berlin).

The new Austrian chancellor, Julius Raab of the Christian-democratic Austrian People's Party (ÖVP), publicly expressed his gratitude for the Soviet concessions. He grasped that, given the Soviet reluctance hitherto shown for withdrawing from Austria, the country's path to full sovereignty was via Moscow, and he was therefore ready to please the Soviets in order to achieve this goal. His interest in developing trade and commerce, particularly Osthandel, (an interest partially based on Raab's roots in small business and his political activity as president of his party's organization for entrepreneurs, the Wirtschaftsbund) seemed to be a further incentive for developing ties with Eastern Europe. Austria's geographic location between the frontlines of the two emerging blocs, squeezed in between communist Hungary and Czechoslovakia, between NATO member Italy and soon-to-be member West Germany, between neutral Switzerland and nonaligned Yugoslavia, made an accommodation with the East appear even more desirable. Therefore Raab called on his fellow citizens not only to stop the "propaganda against the 'people's democracies" " but also to refrain from, as he famously put it, too often "pinching the tail of the Russian bear who is standing right in the middle of [our] garden."

Additionally, the Austrian government started to sound out whether an Austrian declaration of neutrality might improve chances for concluding the state treaty.

${ }^{5}$ Wilfried Loth, Overcoming the Cold War: A History of Détente (Basingstoke: Palgrave, 2001), 19.

${ }^{6}$ Vladislav Zubok and Constantine Pleshakov, Inside the Kremlin's Cold War: From Stalin to Khrushchev (Cambridge, Mass.: Harvard University Press, 1996), 157. On the background of including Austria into the speech, see Deborah Welch Larson, "Crisis Prevention and the Austrian State Treaty," in International Organization 41, no. 1 (1987), 27-60, 36.

7 Stourzh, Um Einheit und Freiheit, 220-239; Rauchensteiner, Stalinplatz, 213-215.

${ }^{8}$ Quoted in Günter Bischof, "The Robust Assertion of Austrianism: Peaceful Coexistence in Austria after Stalin's Death," in Klaus Larres and Kenneth Osgood (eds.), The Cold War after Stalin's Death: A Missed Opportunity for Peace? (Lanham: Rowman \& Littlefield, 2006), 233-256, 241. The Western powers remained suspicious of Raab's intentions. Cf. Warren W. Williams, "British Policy and the Occupation of Austria" (PhD Thesis, University of Wales, Swansea, 2004), $356-360$. 
Since the end of the Habsburg Monarchy in 1918, members of the political elite of the small country had repeatedly aired their support for the idea of adopting a neutral status. ${ }^{9}$ After 1945 some leaders of the main political parties in Austria had continued to do so; however, while social democrats and conservatives refused ideological neutrality and insisted on Austria's status as a Western democracy, the communists' advocacy of keeping the country out of the West contributed to the idea of neutrality being somewhat discredited. After Stalin's offer for neutralizing Germany was rejected, Soviet diplomats joined their Austrian colleagues in discussing the option for Austria. At a four-power conference in Berlin in January and February of 1954, the USSR's delegation seemed pleased with the idea of neutralizing Austria. However, no agreement could be reached regarding the Soviet foreign minister's demand of a prolonged military presence of the four powers in Austria until the conclusion of a peace treaty with Germany. If the Soviet government had, in the spring of 1953, intended to withdraw from Austria, it must have faltered in the wake of the anti-communist uprising in East Germany in June. After the Soviet crackdown on East German workers, the chances for further experiments in foreign relations such as a withdrawal from Austria looked dim. A new cooling down in Soviet-Austrian relations was the consequence. ${ }^{10}$

\section{"Peaceful coexistence"}

It seems doubtful that a breakthrough could have been achieved had not the new Soviet leadership underlined its readiness for global détente by embarking on a new policy called "peaceful coexistence." During the late Stalin years, the Soviet doctrine had stressed the permanent struggle between the forces of communism and capitalism. In consideration of mounting East-West tensions and with the Cold War actually turning into a hot war on the Korean peninsula, Stalin had repeatedly underlined the danger of a general conflagration between the two main opponents, the Soviet Union and the United States, and their allies. ${ }^{11}$ The confrontation between the two blocs in an age of thermonuclear weapons, however, included the risk of mutual or even global destruction.

9 Stephan Verosta, Die dauernde Neutralität: Ein Grundriss (Vienna: Manz, 1967), 47-60. Cf. Stourzh, Um Einheit und Freiheit, 242-282; and his "The Origins of Austrian Neutrality," in Alan Leonhard (ed.), Neutrality: Changing Concepts and Practices (Lanham: University Press of America, 1988), 35-57. It is therefore not entirely correct to claim that "neutrality in Austria has no historical roots prior to World War II," as stated in Joan Johnson-Freese, "Austria," in S. Victor Papacosma and Mark R. Rubin (eds.), Europe's Neutral and Nonaligned States: Between NATO and the Warsaw Pact (Wilmington: Scholarly Resources, 1989), 161-180, 161.

${ }^{10}$ William Lloyd Stearman, The Soviet Union and the Occupation of Austria: An Analysis of Soviet Policy in Austria, 1945-1955 (Bonn: Siegler, 1961), 146-148.

11 Vojtech Mastny, The Cold War and Soviet Insecurity: The Stalin Years (New York: Oxford University Press, 1996), 60. 
In addition to this risk that the new Russian leaders seemed eager to avoid, at least two other factors may have been involved when the Kremlin opted for a new course: In Western Europe, the expansion of communism had been stopped by Western Containment and various attempts had been made at creating a united West European bloc, attempts that the Kremlin tried to prevent from materializing. In Asia and Africa, vast areas, from Egypt to India to Indonesia, freed themselves of colonial rule and gained independence. Their leaders' political tendency was rather more nationalist and neutralist than communist, but they were open to advances from any supporters, including the USSR. ${ }^{12}$ The new Soviet leadership was interested in exploiting the former colonies' natural anti-colonialist sentiment as well as not letting these countries join the Western camp. ${ }^{13}$ To reach both goals, it was necessary to project a friendlier and more "peaceful" image of Soviet policy than had been possible in the late Stalin years.

Therefore, after Stalin's death the new Kremlin leadership launched a "peace initiative." ${ }^{\prime 14}$ Already in 1953, Georgii Malenkov revoked the thesis of the inevitability of war and declared that "peaceful coexistence between countries of different social systems" was not only possible but also the correct and "truly Leninist" basis for Soviet foreign policy. In his speech on the occasion of Stalin's funeral, on 9 March, the prime minister stated that there was a "possibility of a lasting coexistence and peaceful competition between the two different systems." 15 This received confirmation in his speech at the session of the Supreme Soviet on 8 August, in which he declared: "There is no outstanding issue of dispute which cannot be settled in a peaceful manner [...]. We stand for the peaceful coexistence of the two

${ }_{12}$ David Reynolds, One World Divisible: A Global History Since 1945 (London: Penguin, 2000), 58-66.

${ }^{13}$ Odd Arne Westad, The Global Cold War: Third World Interventions and the Making of Our Times (Cambridge: University Press, 2005), 67; Alexander Dallin, Soviet Foreign Policy After Stalin (London: Methuen, 1962), 286-295; on India, cf. Andreas Hilger, "The Soviet Union and India: The Khrushchev Era and its Aftermath until 1966," in idem, Anna Locher, Roland Popp, Shana Goldberg, Matthias Pintsch (eds.), Indo-Soviet Relations Collection (Zurich: Parallel History Project, 2009), http://www.php.isn.ethz.ch/collections/coll_india/documents/IntroII_final_001.pdf, 1; on Indonesia, see Ragna Boden, Die Grenzen der Weltmacht: Sowjetische Indonesienpolitik von Stalin bis Brežnev (Stuttgart: Franz Steiner, 2006), 99-114.

${ }^{14}$ Geoffrey Roberts, A Chance for Peace: The Soviet Campaign to End the Cold War, 1953-1955, Cold War International History Working Paper 57 (Washington, DC: Woodrow Wilson Center, 2008). Whether the initiative really was a "chance for peace" and a lasting East-West settlement is doubted by many scholars. See Mark Kramer, "International Politics in the Early Post-Stalin Era: A Lost Opportunity, a Turning Point, or More of the Same?," in Klaus Larres and Kenneth Osgood (eds.), The Cold War after Stalin's Death: A Missed Opportunity for Peace? (Lanham: Rowman \& Littlefield, 2006), xiii-xxxiv, xiii.

${ }^{15}$ Loth, Overcoming the Cold War, 19; Keesing's Contemporary Archives IX (1952-1954), 12869 and 13097-13099. The thesis of the inevitability of wars among capitalist powers had been recently reconfirmed by Stalin in his Economic Problems of Socialism in the USSR (Moscow: Foreign Languages Publishing, 1952), 32-37. 
systems." This claim was further underlined in Foreign Minister Molotov's speech ${ }^{16}$ at the session of the Supreme Soviet on 9 February 1955 and by the new Kremlin chief, Nikita Khrushchev, at the twentieth congress of the Communist Party of the Soviet Union (CPSU) in February 1956. ${ }^{17}$

Although Lenin, Foreign Commissars Leon Trotskii and Georgii Chicherin, and later Stalin had sometimes spoken of the possibility and even necessity of peaceful relations between the Soviet state and the capitalist world, ${ }^{18}$ the embracing of the idea could be regarded a major sea change in postwar international politics. Khrushchev's concept differed from Lenin's and Stalin's in many respects: The earlier leaders' theses had allowed for short periods of coexistence only, designed to create breathing space for the Bolshevik regime. Stalin's heir, however, claimed that the emergence of the socialist camp after World War II had created the preconditions needed for a longer lasting, albeit limited, period of "peaceful coexistence." As always in communist propaganda, avoiding war was depicted as the result not of Soviet insecurity or Western compromises, but exclusively of Soviet strength and the growth of the socialist bloc, which had allegedly disrupted Western war plans and forced the West to accept a continuation of peace. ${ }^{19}$ Nonetheless, it was

${ }^{16}$ Archiv der Gegenwart, 9 February 1955, 05003-1. On the Soviet doctrine of "peaceful coexistence," see Margot Light, The Soviet Theory of International Relations (New York: St. Martin's Press, 1988), 27-68; for further details, cf. Edward McWhinney, Peaceful Coexistence and SovietWestern International Law (Leyden: Sythoff, 1964); and Bernard A. Ramundo, Peaceful Coexistence: International Law in the Building of Communism (Baltimore: Johns Hopkins Press, 1967); Alois Riklin, Weltrevolution oder Koexistenz? (Zurich: Schweizerischer Aufklärungsdienst, 1969); Henn-Jüri Uibopuu, Die sovjetische Doktrin der friedlichen Koexistenz als Völkerrechtsproblem (Vienna: Notring, 1971); Jessica E. Martin, "Peaceful Coexistence," in Ruud van Dijk et al. (eds.), Encyclopedia of the Cold War (New York: Routledge, 2008), 689-690. The Soviet theory is elaborated in, e.g., N.S. Chruschtschow, Für dauerhaften Frieden und friedliche Koexistenz (Berlin: Dietz, 1959); A.A. Gromyko (ed.), Die friedliche Koexistenz: Der Leninsche Kurs der Außenpolitik der Sowjetunion (Berlin: Staatsverlag der DDR, [1964]); A.E. Bovin, "Peaceful Coexistence," in A. M. Prokhorov et al. (eds.), Great Soviet Encyclopedia 16, 3rd ed. (New York: Macmillan, 1977), 625-627; G.I. Tunkin, Theory of International Law (Cambridge, Mass.: Harvard University Press, 1974), 37-39; W.I. Jegorow, Friedliche Koexistenz und revolutionärer Prozess (Berlin: Staatsverlag der DDR, 1972); Schalwa Sanakojew and Nikolai Kaptschenko, Theorie der Außenpolitik des Sozialismus (Berlin: Staatsverlag der DDR, 1979), 90-102.

${ }^{17}$ N.S. Chruschtschow, Rechenschaftsbericht des Zentralkomitees der Kommunistischen Partei der Sowjetunion an den XX. Parteitag 14. Februar 1956 (Moscow: Verlag für Fremdsprachige Literatur, 1956), 21-25, 32-51; N.S. Khrushchev, O mirnom sosushchestvovanii (Moscow: Gospolitizdat, 1959). For an English version, see "On Peaceful Coexistence," in Foreign Affairs 38, no. 1 (October 1959), 1-18.

18 V.I. Lenin, On Peaceful Coexistence (Moscow: Foreign Languages Publishing, [1962]); J. Stalin, For Peaceful Coexistence: Postwar Interviews (New York: International Publishers, 1951). Cf. Riklin, Weltrevolution oder Koexistenz?, 27.

${ }_{19}$ N.S. Khrushchev, Otchetnyi doklad Tsentral'nogo Komiteta Kommunisticheskoi partii Sovetskogo Soiuza XX s" ezdu partii (Moscow: Gospolitizdat, 1956), 40; "Doklad tov. N.S. Khrushcheva," in Vneocherednoi [XXI] s"ezd Kommunisticheskoi partii Sovetskogo Soiuza: Stenograficheskii otch- 
made clear that a period of "peaceful coexistence" was seen as merely a transitory phase on the road to communism. Khrushchev's somewhat naïve and therefore over-optimistic belief in Marxism-Leninism and its victory convinced him that a few years of peace in the world would be sufficient for all mankind to recognize that communism was the most efficient system. ${ }^{20}$

Formally, the new doctrine drew heavily on non-Soviet sources such as the five Principles Guiding the Relations between the People's Republic of China and India that had been listed in the Chinese-Indian treaty of 29 April 1954 and solemnly declared by Nehru and Chou En-Lai in June, and the ten principles of the final declaration of the Third World countries' conference in Bandung in April 1955. According to the Chinese-Indian treaty, "peaceful coexistence" was comprised of mutual respect for sovereignty and territorial integrity, nonaggression, noninterference in internal affairs, equality and mutual benefit, coexistence and economic cooperation. Of these, the first four were part of the UN Charter. ${ }^{21}$

The adoption of such "peaceful" principles notwithstanding, Soviet leaders stressed that the ideological struggle between communism and capitalism had not been given up..$^{22}$ In their estimation, "peaceful coexistence," as a "special form of the class struggle," would even intensify such competition and promote the transition of the world to communism by demonstrating the superiority of the socialist bloc and by supporting the struggle of anti-imperialist and "progressive forces" in the West and in the southern hemisphere. ${ }^{23}$ At the same time, the economic advancement of the Soviet Union was expected to make it possible to win a nonviolent race with the West. Thus, "peaceful coexistence" did neither mean reconciliation with capitalism nor the elimination of the East-West conflict but merely its transformation into an ideological, political, economic, technological, and cultural "footrace" between the "two systems." Western observers were critical whether

et (Moscow: Gospolitizdat, 1959), 73; N.S. Khrushchev, Otchet Tsentral'nogo Komiteta Kommunisticheskoi partii Sovetskogo Soiuza XXII s"ezdu partii (Moscow: Gospolitizdat, 1961), 8.

${ }^{20}$ Khrushchev, "On Peaceful Coexistence," 5. Cf. Aleksandr Fursenko and Timothy Naftali, Khrushchev's Cold War: The Inside Story of an American Adversary (New York: Norton, 2006), 23.

${ }^{21}$ Gabriele Sinigoj, Indien und Blockfreiheit als außenpolitische Strategie (New York: Lang, 1998), $38-42$.

${ }^{22}$ See, e.g., N.S. Chruschtschow, "Gespräch mit dem Korrespondenten der amerikanischen Nachrichtenagentur United Press, Henry Shapiro, 14 November 1957," in idem, Für dauerhaften Frieden, 280-303, 290; Gromyko, Die friedliche Koexistenz, 115, 119; Programm der Kommunistischen Partei der Sowjetunion, angenommen auf dem XXII. Parteikongress 1961, in Boris Meissner (ed.), Das Parteiprogramm der KPdSU 1903 bis 1961 (Cologne: Wissenschaft und Politik, 1962), 143-244, 229; Erklärung der Beratung von Vertretern der kommunistischen und Arbeiterparteien in Moskau, November 1960, in Fritz Schenk (ed.), Kommunistische Grundsatzerklärungen 1957-1971 (Cologne: Wissenschaft und Politik, 1972), 86-130, 108; Jegorow, Friedliche Koexistenz und revolutionärer Prozess, 216.

${ }^{23}$ Gromyko, Die friedliche Koexistenz, 98; Michael S. Woslenskij, "Friedliche Koexistenz aus sowjetischer Sicht," in Osteuropa 23, no. 11 (1973), 848-855, 852. 
this kind of "coexistence" meant anything other than Cold War. ${ }^{24}$ If, in such a situation, war could be avoided depended - from the Soviet point of view - upon whether the leading classes in capitalist states finally conceded to communism. "Peaceful coexistence" did not comprise a renunciation of the "armed struggle of the proletariat," or of local wars. Not openly declared was that "peaceful coexistence," in particular economic cooperation with the West, was to provide the Soviet economy with much-needed imports, which would reduce the burden on the overstretched industry as well as raise the exhausted East European workers' mood.

In general, the Soviet aim of "peaceful coexistence" appears to have been twofold: first, avoiding a global war with the West while undermining Western resistance against communism, and secondly, strengthening the Soviet side by increasing trade, projecting a friendly image and winning new friends abroad. It was anticipated that this new strategy would make it easier for the USSR to achieve some of its main foreign policy goals by safeguarding beneficial international conditions for the development of communism in the Soviet Union and the "World Socialist System," the struggle of the Third World for decolonization and independence, as well as the class struggle abroad. ${ }^{25}$ At the same time, as claimed by the Soviet theory of international law and as proven by the Soviet interventions of 1956, 1968, 1979 and 1981 in the USSR's neighborhood, "peaceful coexistence" and noninterference in internal affairs did not apply to the Soviet relations with its small neighboring states. ${ }^{26}$

The Austrian state treaty and declaration of neutrality

It was within this framework of "peaceful coexistence" that Khrushchev, the emerging Soviet leader, took the opportunity to scale down international tensions and to improve the image of the USSR in the West and in the Third World by tak-

${ }^{24}$ Rodney Gilbert, Competitive Coexistence: The New Soviet Challenge (New York: Bookmailer, 1956), 17. Quoted in Gromyko, Die friedliche Koexistenz, 116.

${ }^{25}$ Programm der Kommunistischen Partei der Sowjetunion, angenommen auf dem XXII. Parteikongress 1961, in Meissner, Das Parteiprogramm der KPdSU, 181-184; Erklärung der Beratung von Vertretern der kommunistischen und Arbeiterparteien in Moskau, November 1960, in Schenk, Kommunistische Grundsatzerklärungen, 108.

${ }^{26}$ See, e.g., N.S. Chruschtschow, "Gespräch mit dem Chefredakteur der japanischen Zeitung Asahi Shimbun, Tomoo Hirooka, 18 June 1957," in idem, Für dauerhaften Frieden, 125; Gromyko, Die friedliche Koexistenz, 11. Among Western analyses, see Theodor Schweisfurth, Sozialistisches Völkerrecht? Darstellung - Analyse - Wertung der sowjetmarxistischen Theorie vom Völkerrecht „,neuen Typs “ (Berlin: Springer, 1979), 262-284. For a critical analysis of the content and development of "peaceful coexistence" from 1956 until the mid-1970s, see Standenat to Austrian MFA, 22 December 1975, in Österreichisches Staatsarchiv (hereafter: ÖStA), AVA, NL Bielka, File 115. On the Brezhnev doctrine, see Matthew J. Ouimet, The Rise and Fall of the Brezhnev Doctrine in Soviet Foreign Policy (Chapel Hill: The University of North Carolina Press, 2003). 
ing various steps, such as joining the Geneva conference on Indochina, reducing Soviet forces, withdrawing from obsolete Soviet bases such as Port Arthur, China, and Porkkala, Finland, settling the Soviet dispute with Yugoslavia, and agreeing on the Austrian state treaty, thus ending its Allied control and occupation. After Khrushchev had demoted Malenkov from leadership, on 8 February 1955 Molotov announced that the Austrian question should be solved soon, and following some bilateral exploratory contacts, the country's leaders were invited to Moscow. Their promise to see to it that Austria adopt a neutral status like the one of Switzerland, ${ }^{27}$ as agreed upon in bilateral negotiations in Moscow and laid down in a memorandum of 15 April, was an unofficial conditio sine qua non for the Soviet consent to join the Western powers in the signing of the state treaty. This Soviet promise was also inserted into the Soviet-Austrian Moscow memorandum. The trip of an Austrian governmental delegation to the Soviet capital - the first high ranking bilateral Austrian visit to the USSR ${ }^{28}$ - and the successful conclusion of the negotiations were highly celebrated in the communist propaganda.

The State Treaty for the Re-establishment of an Independent and Democratic Austria was signed on 15 May in Vienna by the foreign ministers of the four powers plus Austria. The document declared the union with Germany, as it had been established after Hitler's Wehrmacht had marched into Austria in March 1938, as null and void and recognized the reconstruction of a democratic independent Austria within its pre-Anschluss borders. As stipulated by article 4 of the treaty, a new Anschluss was prohibited, as were the purchase and use of certain categories of weapons, in particular torpedoes and missiles (article 13). Furthermore, it was codified, as had been agreed in the Moscow memorandum, that Austria buy the Sovietrun "German assets," including oil wells and the Danube Steamship Company, in eastern Austria for a lump sum of 150 plus 2 million dollars plus the delivery of 10 million tons of oil to the USSR. This provision was especially important, as the Western powers had feared that the prolonged existence of major Soviet enterprises in Austria might undermine the country's independence. But surprisingly, one searches the treaty in vain for a clause on Austria's neutrality, this despite the country's neutralization being the price that had to be paid for the Soviet's willingness to join the Western allies in its signing. Neutrality was declared only afterwards in an act of national legislation. This was thanks to the Western powers, who insisted

27 The official Swiss doctrine of neutrality of 26 November 1954, in Schweizerisches Jahrbuch für Internationales Recht (1957), 195-199. Also published in Verosta, Die dauernde Neutralität, 113-117. On the relation between Swiss and Austrian neutrality, see Christian Jenny, Konsensformel oder Vorbild? Die Entstehung der österreichischen Neutralität und ihr Schweizer Muster (Bern: Haupt, 1995). For Soviet comments on draft declarations of Austria's neutrality, see Stourzh, Um Einheit und Freiheit, 404-405.

28 The minister of agriculture Franz Thoma was invited to the All-Union Agricultural Exhibit in July 1954. Ludwig Steiner, “Zur Außenpolitik der Zweiten Republik,” in Erich Zöllner (ed.), Diplomatie und Außenpolitik Österreichs (Vienna: Österreichischer Bundesverlag, 1977), 169-187, 179. 
that Austria's neutrality should only be enacted if self-chosen. ${ }^{29}$ However, on the eve of the state treaty's signing, all four powers issued a joint declaration that they were willing to respect and honor Austria's neutral status.

Both the Soviet "green light" and the end-spurt towards the state treaty had come quite unexpectedly. Hitherto, a withdrawal from Austria had been obstructed mainly by the Soviet foreign minister, ${ }^{30}$ whose advisors warned that an end of the Soviet armed presence "would give the country into the hands of the Americans." This does not mean, however, that Molotov had been opposing mainstream Kremlin opinions that were pro-state treaty. It seems that his opinion was the mainstream until the end of 1954, and old "iron bottom," as Molotov was sometimes referred to, simply did not react quickly enough when the new leadership under Khrushchev changed its course in the Austrian question. After the treaty's successful conclusion, the Austrian solution and Molotov's alleged resistance against it came in handy in Khrushchev's subsequent power struggle to demote the experienced foreign minister and capture supremacy in foreign-policy issues. ${ }^{32}$ Apparently, the new

${ }^{29}$ Kurt Steiner, "Negotiations for an Austrian State Treaty," in: Alexander L. George, Philip J. Farley and Alexander Dallin (eds.), U.S.-Soviet Security Cooperation: Achievements, Failures, Lessons (New York: Oxford University Press, 1988), 46-82, 60.

${ }^{30}$ A. M. Aleksandrov-Agentov, Ot Kollontai do Gorbacheva: Vospominaniia diplomata, sovetnika A.A. Gromyko (Moscow: Mezhdunarodnye otnosheniia, 1994), 53-54, 94-98; Zubok and Pleshakov, Inside the Kremlin's Cold War, 156-158; Gerald Stourzh, "Der österreichische Staatsvertrag in den weltpolitischen Entscheidungsprozessen des Jahres 1955," in Arnold Suppan, Gerald Stourzh, and Wolfgang Mueller (eds.), The Austrian State Treaty 1955: International Strategy, Legal Relevance, National Identity (Vienna: Verlag der Österreichischen Akademie der Wissenschaften, 2005), 965-995, 979-983. For an English version, see "The Austrian State Treaty and the International Decision Making Process in 1955," in Austrian History Yearbook 38 (2007), 208-228. The Soviet diplomat Vladimir Semenov claims that it was Khrushchev who, in 1954, dismissed withdrawing from Austria as being premature. Wladimir S. Semjonow, Von Stalin bis Gorbatschow: Ein halbes Jahrhundert in diplomatischer Mission (Berlin: Nicolai, 1995), 309. However, as of today, there is no documentary evidence for the accuracy of this claim.

${ }_{31}$ Pushkin, Il'ichev, Gribanov to Molotov, 27 November 1953, in Arkhiv vneshnei politiki Rossiiskoi Federatsii (hereafter: AVPRF), 066/35/137/28, 1-5. Cf. Stourzh, Um Einheit und Freiheit, 298; Mueller, "Gab es eine verpasste Chance?," 119. On the following, see Roberts, A Chance for Peace, 42-43.

${ }^{32}$ Rostislav Sergeev, "Wie der Durchbruch in der österreichischen Frage erreicht wurde," in Arnold Suppan, Gerald Stourzh, and Wolfgang Mueller (eds.), The Austrian State Treaty 1955: International Policy, Legal Relevance, National Identity (Vienna: Verlag der Österreichischen Akademie der Wissenschaften, 2005), 195-204, 204. Khrushchev's and Mikoian's accusations against Molotov during the plenary session of the CPSU Central Committee, 11 July 1955, in Rossiiskii gosudarstvennyi arkhiv noveishei istorii (hereafter: RGANI), 2/1/159, 84-88; 2/1/176, 282-295. Cf. "Plenum Transcripts, 1955-1957," in Cold War International History Project Bulletin 10 (1998), 34-60, 42-43; Stourzh, Um Einheit und Freiheit, 454-461; Karner, Stelzl-Marx, Tschubarjan, Die Rote Armee in Österreich: Dokumente, 840-843. In the final reckoning with Molotov at the June 1957 plenum, Gromyko again brought up the charges against Molotov regarding the Austrian treaty. Cold War International History Project Bulletin 10 (1998), 56. For the context, see Mark Kramer, "Declassified Materials from CPSU Central Committee Plenums: Sources, Con- 
leader's readiness to withdraw from this Alpine country did not stem as much from Austrian as from inner-Soviet and international factors, as the social democratic state secretary in the Austrian Foreign Department at that time, Bruno Kreisky, cleverly assessed. ${ }^{33}$ The state treaty and the neutralization of Austria were only possible due to a number of special factors. These included a perceived balance of forces between the East and West in the international sphere that was roughly equal, relative stability and low conflict intensity in the area, Austria's peripheral location between the two military blocs, the country's relatively small size, weakness, and passivity on the international stage.

By consenting to the state treaty and insisting on Austria's neutralization, the Soviet leaders were able to aim at various objectives: ${ }^{34}$ Because denying the Austrian territory to the opposing alliance had been a goal in the policy of both superpowers since the beginning of the Cold War, the reciprocal withdrawal of forces under the condition of Austria's neutralization offered a classic solution. ${ }^{35}$ In the nineteenth century, the neutralization of a weak territory that was strategically located between two major powers or blocs had been applied in many cases that were similar to postwar Austria, such as Switzerland, Belgium, and Luxemburg. By withdrawing reciprocally from such contested territories, recognizing their neutrality, and, thus, creating a strategic buffer, the great powers - France and Germany in the nineteenth century or the United States and the Soviet Union after World War II - chose to avoid further tensions that could escalate into a major conflagration.

text, Highlights," ibid., 7-25; and Vladislav Zubok, "CPSU Plenums, Leadership Struggles, and Soviet Cold War Politics," ibid., 28-33.

${ }^{33}$ Karl Molin, "The Supportive Observer: Sweden and the Austrian State Treaty 1955," in Arnold Suppan, Gerald Stourzh, Wolfgang Mueller (eds.), The Austrian State Treaty 1955: International Policy, Legal Relevance, National Identity (Vienna: Verlag der Österreichischen Akademie der Wissenschaften, 2005), 397-415, 407. On the following, see Hanspeter Neuhold, "Der Staatsvertrag als Grundlage der österreichischen Außenpolitik," in Alois Mock, Ludwig Steiner, Andreas Khol (eds.), and Rainer Stepan (red.), Neue Fakten zu Staatsvertrag und Neutralität (Vienna: Politische Akademie, [1980]), 157-180, 161-162.

${ }^{34}$ For a discussion of the Soviet motives for ending their occupation of Austria, see also William L. Stearman, "An Analysis of Soviet Objectives in Austria," in Robert A. Bauer (ed.), The Austrian Solution: International Conflict and Cooperation (Charlottesville: University Press of Virginia, 1982), 99-125. The most comprehensive analysis, based on Soviet archival material, is found in Stourzh, Um Einheit und Freiheit, 450-485. Cf. Suppan et al., The Austrian State Treaty, here especially Aleksei Filitov, "The Post-Stalin Succession Struggle and the Austrian State Treaty," ibid., 121-143; Vojtech Mastny, "The Launching of the Warsaw Pact and Soviet Grand Strategy," ibid., 145-162.

35 The classic alternative was either the creation of a militarized buffer zone, the division of the territory - an option that was rejected by both sides for different reasons - or a condominium, an option that had failed in the early Cold War years due to the interallied rift. Daniel Frei, Dimensionen neutraler Politik: Ein Beitrag zur Theorie der internationalen Beziehungen (Geneva: Institut Universitaire de Hautes Études Internationales, 1969), 28-47. 
Furthermore, the Soviet readiness for withdrawing from Austria was very much increased by the integration of West Germany into the Atlantic alliance, a decision that was agreed upon by NATO members in the autumn of 1954 and in the process of being ratified. The French National Assembly had passed the Paris Treaty in December 1954, albeit by a narrow margin, the West German Bundestag approved it on 27 February 1955, and the French Senate followed in March. It seems unlikely that the Kremlin counted on fully preventing the ratification by means of signaling that neutrality might also open the way for Germany's reunification and demilitarization. Nevertheless, Soviet propaganda in early 1955 alluded to the theme, thus attempting to stir up resistance in Western Europe against West Germany's inclusion into NATO and to delay the implementation of its rearmament. ${ }^{36}$

By insisting on Austria's becoming neutral Khrushchev also managed to prevent it from following the neighboring FRG into the Atlantic alliance. This actually seems to have been the main reason for the Soviet urgency to solve the Austrian problem. Indeed, this was recognized by contemporaries: On 8 April 1955, US Ambassador Charles Bohlen wrote to Secretary of State John Foster Dulles: "The chief immediate motivation of the Soviets in reopening the Austrian question is to endeavor to ensure neutralization of Austria in order to prevent military integration three western zones of Austria into NATO. ${ }^{37}$ In the postwar decade, Austria had positioned itself on the Western side and was even treated by the United States as a "secret ally." ${ }^{38}$ In the early 1950s, Soviet internal reports and political statements increasingly warned against the growing possibility of Austria being integrated into NATO's military

36 Stourzh, Um Einheit und Freiheit, 466-480. This issue has sparked dicussion among historians whether Khrushchev was ready to abandon the GDR and consent to a German reunification if the FRG declared itself neutral. This possibility is refuted by Stourzh. Cf. Bruno Thoß, "Modellfall Österreich? Der österreichische Staatsvertrag und die deutsche Frage 1954/55," in Bruno Thoß and Hans-Erich Volkmann (eds.), Zwischen Kaltem Krieg und Entspannung. Sicherheits- und Deutschlandpolitik der Bundesrepublik im Mächtesystem der Jahre 1953-1956 (Boppard: Boldt, 1988), 93-136. Other authors avoid a clear answer, e.g. Rolf Steininger, "1955: The Austrian State Treaty and the German Question," in Diplomacy \& Statecraft 3, no. 3 (1992), 494-522, 517; Michael Gehler, “'L'unique objectif des Soviétiques est de viser l'Allemagne.' Staatsvertrag und Neutralität 1955 als „Modell“ für Deutschland?,” in Thomas Albrich, Klaus Eisterer, Michael Gehler, and Rolf Steininger (eds.), Österreich in den Fünfzigern (Innsbruck: Studienverlag, 1995), 259-297.

${ }^{37}$ Quoted in Günter Bischof, "The Making of the Austrian Treaty and the Road to Geneva," in idem and Saki Dockrill (eds.), Cold War Respite: The Geneva Summit of 1955 (Baton Rouge: Louisiana State University Press, 2000), 117-154, 139; 154.

${ }^{38}$ Stourzh, "The Origins of Austrian Neutrality,” 40; Günter Bischof, "Österreich - ein ,geheimer Verbündeter" des Westens?," in Michael Gehler and Rolf Steininger (eds.), Österreich und die europäische Integration 1945-1993: Aspekte einer wechselvollen Entwicklung (Vienna: Böhlau, 1993), 425-450; Günter Bischof, “'Austria looks to the West.' Kommunistische Putschgefahr, geheime Wiederbewaffnung und Westorientierung am Anfang der fünfziger Jahre," in Thomas Albrich, Klaus Eisterer, Michael Gehler, Rolf Steininger (eds.), Österreich in den Fünfzigern (Innsbruck: Studienverlag, 1995), 183-209. 
planning. ${ }^{39}$ As a result of the Allied occupation, the Western powers had been free to use the Western parts of the country for troop and supply transports between West Germany and Italy. With the FRG's full integration into the Atlantic alliance, opportunities like this became even more precious for the West. It was exactly at this moment, that the Kremlin agreed to a four-power withdrawal from Austria, thus forcing NATO transports between the Munich and Verona headquarters to make a considerable detour. It was clear that Austria's neutralization made life more difficult for the Atlantic alliance by driving a wedge between West Germany and Italy. ${ }^{40}$

In addition to disrupting the Western communication lines and forestalling western Austria's integration into NATO, the conclusion of the state treaty offered several positive side effects for the Kremlin on the international stage: In early 1955, the USSR had received further signals from the West that solving the Austrian problem was a precondition for a much-wanted summit with the Western powers - the first meeting of such kind since the end of the war. This summit later took place in the summer of the same year in Geneva. ${ }^{41}$ The US president had kept his word and in May extended an invitation for a four-power conference. The Soviet concessions regarding Austria therefore made it easier for the Soviet leadership to leave the international isolation it had found itself in since the Cold War. Furthermore, a Soviet withdrawal from Austria seems to have been repeatedly demanded by Belgrade as a precondition for relaxing the tense Yugoslav-Soviet relationship. ${ }^{42}$ On 13 May, Khrushchev announced his intention to go to Canossa and visit Stalin's old boogey man Tito. Besides straightening out relations with the Yugoslav leader, this initiative - like the Austrian one - would serve Khrushchev in undermining Molotov's position in the Kremlin.

39 Valentin Falin, Politische Erinnerungen (Munich: Droemer Knaur, 1993), 321; Vladislav Zubok, Soviet Intelligence and the Cold War: The "Small" Committee of Information, 1952-53, Cold War International History Project Working Paper 4 (Washington, DC: Woodrow Wilson Center, 1992), 12.

40 On the strategic context, see Bruno Thoß, "Festschreiben oder Auflockern der Blockkonfrontation? Der NATO-Beitritt der Bundesrepublik Deutschland im Kontext von Sicherheit und Entspannung," in Arnold Suppan, Gerald Stourzh, Wolfgang Mueller (eds.), The Austrian State Treaty 1955: International Policy, Legal Relevance, National Identity (Vienna: Verlag der Österreichischen Akademie der Wissenschaften, 2005), 33-56.

${ }^{41}$ Thomas Angerer, "Frankreich und die Österreichfrage: Historische Grundlagen und Leitlinien 1945-1955” (PhD Thesis, Vienna, 1996), 354-355. Cf. idem, "Re-launching East-West Negotiations while Deciding West German Rearmament: France, the Paris Treaties, and the Austrian State Treaty 1954/55," in Arnold Suppan, Gerald Stourzh, Wolfgang Mueller (eds.), The Austrian State Treaty 1955: International Policy, Legal Relevance, National Identity (Vienna: Verlag der Österreichischen Akademie der Wissenschaften, 2005), 265-334. On the Geneva summit, see Bischof, Dockrill, Cold War Respite.

42 Arnold Suppan, "Jugoslawien und der österreichische Staatsvertrag," in idem, Gerald Stourzh, and Wolfgang Mueller (eds.), The Austrian State Treaty 1955: International Policy, Legal Relevance, National Identity (Vienna: Verlag der Österreichischen Akademie der Wissenschaften, 2005), 430-471. 
Signing the Austrian treaty offered still more advantages for the Soviet Union: The postponement, prior to 1955, of the Soviet withdrawal from Austria had not only embarrassed Soviet diplomats on the international stage, but also increasingly strained Austrian-Soviet relations. Most economic enterprises that had been seized by the USSR in this country had turned from being assets to being financial burdens. ${ }^{43}$ By giving a green light for the state treaty, Khrushchev not only got rid of this political and increasingly economic liability. As Khrushchev recalled, the improvements at the bilateral level were not the least of his aims when he pushed for a quick conclusion of the state treaty. ${ }^{44}$

Since turning Austria into a pro-communist state and Soviet ally had failed in $1945,{ }^{45}$ the state treaty plus neutrality formed the second best solution from the Soviet perspective. For the Kremlin, permanent neutrality opened the chance for improving Soviet-Austrian relations and, in addition, having a say in future Austrian international behavior. Since neutrality was explicitly mentioned in the SovietAustrian Moscow memorandum (albeit not in the state treaty, as mentioned above), it promised to provide the Kremlin a lever over this country's foreign policy - a lever that could be useful for distancing Austria from the West, in particular from its traditional postwar patron, the United States.

Last but not least, by creating a showcase of the benefits of neutrality, Khrushchev reinforced the Soviet attempts to undermine the pro-Atlantic consensus in Western Europe. The Austrian solution was thus part of the Soviet campaign for promoting neutrality in order to contain or dissolve NATO and other pro-Western blocs and to neutralize Western Europe and South Asia. ${ }^{46}$ In order to make neutrality more attractive for other Western and pro-Western states, Soviet relations with neutral Austria were designed to serve as a "model for peaceful and mutually beneficial relations between states of different social systems," as was frequently claimed by Khrushchev and other Soviet voices. ${ }^{47}$ Soviet leaders repeatedly drew

${ }^{43}$ Michail Prozumenščikov, "Nach Stalins Tod: Sowjetische Österreichpolitik 1953-1955," in Stefan Karner and Barbara Stelzl-Marx (eds.), Die Rote Armee in Österreich: Beiträge (Graz: Oldenbourg, 2005), 729-753.

${ }^{44}$ Nikita S. Khrushchev, Vremia, liudi, vlast': Vozpominaniia 2 (Moscow: Novosti, 1999), 211-220. A similar explanation was given by Khrushchev and Presidium member Anastas Mikoian during the plenary session of the CPSU Central Committee on 11 July 1955. Stourzh, Um Einheit und Freiheit, 454-461; Karner, Stelzl-Marx, Tschubarjan, Die Rote Armee in Österreich: Dokumente, 840-843. For an English version, see Nikita Khrushchev, The Memoirs of Nikita Khrushchev III: Statesman 1953-1964, ed. by Sergei Khrushchev (University Park: The Pennsylvania State University Press, 2007), 4-28.

${ }^{45}$ Mueller, "Stalin and Austria," 67-68; idem, Die sowjetische Besatzung in Österreich, 71-135.

${ }^{46}$ See below, pages 48-54. Cf. Harto Hakovirta, "The Soviet Union and the Varieties of Neutrality in Western Europe," in World Politics 35, no. 4 (1983), 563-585.

${ }^{47}$ Quoted in William Banks Bader, Austria between East and West, 1945-1955 (Stanford: University Press, 1966), 208. See also, e.g., Sovremennik, "Das österreichische Beispiel," in Neue Zeit, no. 20 (1955), 6-8; S. Okhantsev, "An Example of Peaceful Coexistence," in International Affairs, no. 9 (1958), 85-86; L. Vidyasova, “An Impressive Example of Peaceful Coexistence," in 
the attention of their foreign guests to Austria, which, by declaring neutrality "had given an excellent model, which by following would be beneficial for other people as well." ${ }^{48}$ While the Austrian model, in Soviet eyes, should be imitated by as many Western states as possible, it seems to be one of the many ironic footnotes of the Cold War that the United States, in particular under the Kennedy administration, also envisaged Austria as functioning as a model - a model, however, that would work in the opposite direction, namely, attracting East European and nonaligned states and shaping their behavior. ${ }^{49}$ Gerald Stourzh seems to have been the first historian to draw our attention to this type of Soviet propaganda, in which Austrian neutrality is praised as a model for other Western states. ${ }^{50}$ This praise did not come without strings attached; its aim was to accomplish a certain goal. Khrushchev and his successors wanted to break states out of the Western bloc and to prevent others from entering. Therefore, they had to offer an acceptable alternative to them. Neutrality was meant as such an alternative. Soviet leaders also wanted their diplomatic initiatives to be successful and thus, needed them to be supported by Western countries as well. The neutral countries were expected to provide such helpful services by promoting communist proposals. Although neutrality underwent several changes during the next forty years as a consequence of the changing international environment, this approach proved highly serviceable.

For Austria, neutrality was the price to be paid for the Soviet willingness to join the West in signing the state treaty. When the country was offered the choice between the factual neutralization by foreign occupation or a declaration of permanent neutrality, it chose the latter. Solemnly adopted by the Austrian parliament on 26 October 1955, neutrality enabled the country to attain full sovereignty. This reflected the classical purpose of neutrality for neutral states, i.e. the realization and/ or preservation of independence. However, as we shall see, being small and neutral turned out to be less attractive, easy and secure than Austrian leaders had imagined.

The signing of the treaty, which was ratified by all contracting parties by 27 July, and the Austrian declaration of neutrality were perceived by Khrushchev as his first

International Affairs, no. 8 (August 1960), 11-15; Speech by N.S. Khrushchev in Vienna, 30 June 1960, in Druzhestvennyi vizit: Prebyvanie Predsedatel'ia Soveta Ministrov SSSR N.S. Khrushchëva v Avstriiskoi Respublike 30 iiuniia-6 iiulia 1960g. (Moscow: Gospolitizdat, 1960), 10; I.K. Kobliakov, G.G. Kuranov, and D.N. Mochalin, SSSR v bor 'be za nezavisimost'Avstrii (Moscow: Politizdat, 1965), 166; I.G. Zhiriakov, SSSR i Avstrija v 1945-1975 gody (Moscow: Molodaia gvardiia, 1982), 28.

48 Austrian embassy Moscow to Austrian MFA, 19 May 1959, in ÖStA, AdR, BMAA, II-Pol, Pol. Berichte Moskau.

${ }^{49}$ Martin Kofler, Kennedy und Österreich: Neutralität im Kalten Krieg (Innsbruck: Studienverlag, 2003), 26-27.

${ }^{50}$ Gerald Stourzh, “Grundzüge der österreichischen Außenpolitik, 1945-1960,” in Anton Kolabek (ed.), Österreichische Zeitgeschichte im Geschichtsunterricht (Vienna: Österreichischer Bundesverlag, 1961), 185-211, 209. Cf. Sovremennik, "Österreichs Neutralität und ihre Bedeutung," in Neue Zeit, no. 21 (1955), 7-9. 
Introduction

major "victory" in foreign policy and duly celebrated by Soviet propaganda. It had been only in 1954 that Khrushchev had started to focus on foreign affairs. In his recollections, the inexperienced country bumpkin's "trip to Europe had been a success," and the Austrian state treaty was

"a demonstration that we were capable of orienting ourselves in international affairs without Stalin's guidance and instructions. To put it in a more colorful way, in our international policy we had now changed from the short pants of boyhood into the trousers of grown men. Our successful debut was recognized not only in the USSR but in other countries as well, which was of great importance. We were feeling our strength." ${ }^{\text {51 }}$

In the following months and years, Soviet propaganda would elevate the state treaty into a gem of détente and a cornerstone of Soviet-Austrian relations. In order to keep the memory alive and to engrave it into Austrian public consciousness, on the occasion of the anniversary of the signing of the state treaty the Kremlin sent annual congratulatory messages and Soviet media published articles about the happy event. ${ }^{52}$ Kremlin leaders and propagandists would systematically claim that it was the USSR that had made the state treaty possible. ${ }^{53}$ In bilateral meetings, Khrush-

${ }^{51}$ Khrushchev, Memoirs III, 15. Cf. Sergei N. Khrushchev, Nikita Khrushchev and the Creation of a Superpower (University Press: The Pennsylvania State University Press, 2000), 79; William Taubman, Khrushchev: The Man: His Era (London: Simon \& Schuster Free Press, 2003), 349; $331 ; 333 ; 349$.

${ }^{52}$ See, e.g., Telegram Mikoian to Schärf, 14 May 1965, in Vneshniaia politika Sovetskogo Soiuza i mezhdunarodnye otnosheniia 1965 (Moscow: Mezhdunarodnye otnosheniia, 1966), 218: "The past decade shows convincingly that the state treaty and the policy of permanent neutrality satisfy the national interests of the Austrian people and other European peoples." Cf. "Das Jubiläum der österreichischen Neutralität," in Neue Zeit, no. 21 (1965), 9; S. Tarow, "20 Jahre Neutralitätspolitik," in Neue Zeit, no. 43 (1975), 23-24; G. Rozanov, "Austria: Twenty Years of Independent and Democratic Development," in International Affairs, no. 6 (June 1975), 66-72; Wjatscheslaw Jelagin, "Fundament der Neutralität," in Neue Zeit, no. 45 (1978), 8-9; Igor Melnikov, "Partner im Alpenland," in Neue Zeit, no. 7 (1980), 12-13; Lew Besymenski, "Belvedere, 25 Jahre später," in Neue Zeit, no. 21 (1980), 10-11.

${ }_{53}$ See, e.g. Die Initiative der Sowjetunion brachte Österreich den Staatsvertrag: Dokumente und Materialien zum Abschluss des Staatsvertrages mit Österreich (Vienna: Sowjetischer Informationsdienst, 1955); Sovremennik, "Das österreichische Beispiel," in Neue Zeit, no. 20 (1955), 6-8, "Gosudarstvennyi dogovor o vosstanovlenii nezavisimoi i demokraticheskoi Avstrii," in A.A. Gromyko, S. A. Golunskii, and V.M. Khvosotov (eds.), Diplomaticheskii slovar' 1, 2nd ed. (Moscow: Gospolitizdat, 1960), 403; V.N. Beletskii, Sovetskii Soiuz i Avstriia (Moscow: Institut Mezhdunarodnykh otnoshenii, 1962), 132-240; I.K. Kobliakov, G.G. Kuranov, and D.N. Mochalin, SSSR v bor'be za nezavisimost' Avstrii (Moscow: Politizdat, 1965), 148; "Avstriia," in A.M. Prokhorov et al. (eds.), Bol'shaia Sovetskaia Entsiklopediia 1, 3rd ed. (Moscow: Sovetskaia Entsiklopediia, 1970), 100; "Gosudarstvennyi dogovor o vosstanovlenii nezavisimoi i demokraticheskoi Avstrii," ibid. 7 (1972), 168; N. Polyanov, “Austria, Neutrality, Europe," in International Affairs, no. 9 (September 1973), 82-88, 84; A. A. Gromyko and B. N. Ponomarjow (eds.), Geschichte der sowjetischen Außenpolitik 1945 bis 1976 (Berlin: Staatsverlag der DDR, 1978), 291. Cf. Ludwig Steiner, Diplomatie - Politik: Ein Leben für Südtirol: Ein Leben für Österreich 1972-2007 (Bozen: Athesia, 2008), 351; Dallin, Soviet Foreign Policy, 258. 
chev repeatedly encouraged witnesses of the Soviet-Austrian state-treaty negotiations to testify the correctness of his thesis. When Austrian statements did not adopt the official Soviet version that the treaty had been concluded largely thanks to the Kremlin's efforts, the Soviets voiced their displeasure through official channels as well as the media. ${ }^{54}$ Since it was the Soviet Union that had blocked the treaty prior to 1955 , there was some truth to this claim. However, it was deeply unfair to assert that the Western powers had consistently boycotted the conclusion of a treaty; indeed, they had already agreed much earlier to sign one. Therefore, they were particularly displeased when Austrian leaders started to repeat the Soviet thesis.

This was only one of several changes in Austrian-Soviet and Austrian-Western relations, changes that Khrushchev seems to have hoped for. Even though the Soviet-Austrian honeymoon did not last long and certain tensions quickly arose, relations never again became as "icy" as they had been during the years of the Allied occupation of Austria.

The aim, sources and structure of this study

Austria was among the first to be an addressee of this kind of Soviet policy and became one of its most important models. Historian Timothy Snyder called the neutral state "perhaps the perfect creation" of its era. ${ }^{55}$ The aim of this book is to contribute, by looking at the Soviet and Austrian interpretations of neutrality and the two countries' foreign policies and relations with one another during the years 1955-91, to the general knowledge about Soviet foreign policy in the détente period and the Cold War. General analyses of Soviet foreign policy usually do not dedicate much attention to small states,${ }^{56}$ nor do syntheses of the history of the Cold War waste many words on neutrality. ${ }^{57}$ In their narratives, countries like Aus-

${ }^{54}$ See, e.g., Vorsprache des Gesandten Awramow, 11 May 1971, in ÖStA, AdR, BMAA, II-Pol, GZ. 105.880-6/71, Z.111.835; Staribacher Diaries, 16-21 July 1976, in Stiftung Bruno Kreisky Archiv (hereafter: SBKA).

55 Timothy Snyder, The Red Prince: The Secret Lives of a Habsburg Archduke (New York: Basic Books, 2008), 243.

${ }^{56}$ Cf., e.g., Adam B. Ulam, Expansion and Coexistence: Soviet Foreign Policy 1917-73, 2nd ed. (New York: Praeger, 1974); idem, Dangerous Relations: The Soviet Union and World Politics, 1970-1982 (New York: Oxford University Press, 1983); Robin Edmonds, Soviet Foreign Policy: The Brezhnev Years (Oxford: University Press, 1983); Mastny, The Cold War; Zubok and Pleshakov, Inside the Kremlin's Cold War; Geoffrey Roberts, The Soviet Union in World Politics: Coexistence, Revolution, and Cold War, 1945-1991 (London: Routledge, 1999); Fursenko and Naftali, Khrushchev's Cold War; Vladislav Zubok, A Failed Empire: The Soviet Union in the Cold War from Stalin to Gorbachev (Chapel Hill: University of North Carolina Press, 2007); Svetlana Savranskaya and William Taubman, "Soviet Foreign Policy, 1962-1975," in Melvyn P. Leffler and Odd Arne Westad (eds.), The Cambridge History of the Cold War II: Crises and Détente (Cambridge: University Press, 2010), 134-157.

57 The same holds true with regard to recent syntheses of the history of the Cold War, e.g. John Lewis Gaddis, The Cold War: A New History (New York: Penguin, 2005); Melvyn P. Leffler and 
tria or Finland usually pop up in the discussion of certain historic events, such as the signing of the state treaty or the return of Porkkala, only to fall into oblivion immediately afterwards. In a recent article, historian Jussi Hanhimäki called the role of small-state neutrality "one of the less researched topics of the Cold War." Understandably, the focus of most Cold War studies rests on the main features of the bipolar system, the big players and the hotspots of interbloc tension, as well as, increasingly, the various forms of intrabloc client-patron relationships, which were positioned between obedience and insubordination, support and brutal suppression. Nonetheless, during the Cold War neither small states nor neutrality were irrelevant, and Soviet-Austrian relations offer a case study for both.

It has been said that "it is rewarding when a bilateral state relationship of tertiary importance focuses our attention on fundamental questions of international relations." ${ }^{59}$ This study shows that Austria - despite its small size - was given disproportionate Soviet attention in order to achieve the Soviet goals outlined above. Neutral Austria was not only a product of Soviet foreign policy; the USSR also attempted to exploit it as an instrument of foreign policy. The Kremlin used official statements and the media as well as certain privileges to encourage desired behavior in Austria and suppress unwanted, with the latter being depicted as at odds with neutrality.

By analyzing the Austrian example from the Soviet perspective, this book, secondly, intends to add to our understanding of the role of small states as objects and actors in the European international system in the Cold War. ${ }^{60}$ In particular, if we want to better understand what constituted détente, we have to take into account the foreign relations of its small members on both sides of the Iron Curtain. ${ }^{61}$

Odd Arne Westad (eds.), The Cambridge History of the Cold War, 3 vols. (Cambridge: University Press, 2010). The massive, two-volume Encyclopedia of the Cold War contains neither articles on "neutralism" or "neutrality," nor on "nonalignment." Ruud van Dijk et al. (eds.), Encyclopedia of the Cold War, 2 vols. (New York: Routledge, 2008). A recent synthesis of the Cold War dedicates one chapter to the nonaligned movement. Bernd Stöver, Der Kalte Krieg 1947-1991: Geschichte eines radikalen Zeitalters (Munich: Beck, 2007), 110-116.

58 Jussi M. Hanhimäki, "The Lure of Neutrality: Finland and the Cold War," in Klaus Larres and Kenneth Osgood (eds.), The Cold War after Stalin's Death: A Missed Opportunity for Peace? (Lanham: Rowland \& Littlefield, 2006), 257-276, 257.

${ }_{59}$ Julie M. Newton, Russia, France, and the Idea of Europe (Basingstoke: Palgrave, 2003), 1.

${ }^{60}$ August Schou and Arne Olav Brundtland (eds.), Small States in International Relations, Nobel Symposium 7 (Stockholm: Almquist \& Wiksell, 1971); Efraim Karsh, Neutrality and Small States (London: Routledge, 1988); Otmar Höll, "Kleinstaaten im Spannungsfeld von Autonomie und Abhängigkeit am Beispiel Österreichs" (Habil. Thesis, Vienna, 1989); James J. Sheehan, "What Does It Mean To Be Neutral? Postwar Austria from a Comparative Perspective," in Amir Eshel, Roland Hsu, Wolfgang Mueller, Arnold Suppan (eds.), Austria and Central Europe Since 1989 (Vienna: forthcoming).

${ }^{61}$ For a history of détente, see Loth, Overcoming the Cold War; for recent research on its "European" roots, cf. idem and Georges-Henri Soutou, (eds.), The Making of Détente: Eastern and Western Europe in the Cold War, 1965-1975 (London: Routledge, 2008). 
While the small and neutral states, in order to increase their maneuvering room, were generally interested in a relaxed international climate, they, due to their lack of weight, were not able to "create" détente, but only to reinforce it. However, due to their small size and strong interest in détente they were often much quicker in establishing channels for East-West communication than the superpowers, which were generally less dependent on international exchange and more concerned about their prestige, the possible deceptiveness of the other side's initiatives, and the risks that détente or diplomatic failure might bring to the cohesion of their alliances.

Thirdly, this book will take a fresh look at certain key aspects of Austria's international relations and its shifting interpretation of neutrality. ${ }^{62}$ It will argue that the drift in the direction of the Soviet understanding of neutrality was, at least in part, a consequence of the Kremlin's "carrot and stick" policy. Open Austrian criticism of Soviet actions disappeared from official Viennese statements, and Austrian governments - in accord with the Soviet neutrality doctrine - tended towards replacing a commitment to armed defense with their claim of achieving security through foreign policy activism.

To write this monograph, the first on this topic in English or another West European language to rely on Soviet sources, this author drew on a large body of Soviet and Western literature, including Soviet texts and Western research on Soviet theories concerning international law, ${ }^{63}$ international relations in general ${ }^{64}$ and

${ }^{62}$ An analysis of and agenda for research on Austria's neutrality is set forth in Thomas Angerer, "Für eine Geschichte der österreichischen Neutralität," in Michael Gehler and Rolf Steininger (eds.), The Neutrals and the European Integration, 1945-1995 (Vienna: Böhlau, 2000), 702-708.

${ }^{63}$ Among Soviet works, see, e.g., F.I. Koschewnikow (ed.), Völkerrecht (Hamburg: Hansischer Gildenverlag, 1960); [D.B. Levin, and G.P. Kaliuzhnaia (eds.)], Mezhdunarodnoe pravo (Moscow: Iuridicheskaia literatura, 1964); Drei sowjetische Beiträge zur Völkerrechtslehre (Hamburg: Hansischer Gildenverlag, 1969); G.I. Tunkin, Theory of International Law (Cambridge, Mass.: Harvard University Press, 1974). For a Western bibliography of Soviet works, see Boris Meissner (ed.), Sowjetunion und Völkerrecht 1917 bis 1962: Eine bibliographische Dokumentation (Cologne: Wissenschaft und Politik, 1963); idem, Dietrich Frenzke, Erika Chilecki (eds.), Sowjetunion und Völkerrecht 1962 bis 1973: Bibliographie und Analyse (Cologne: Wissenschaft und Politik, 1977). For Western analyses, see, e.g. Hans Kelsen, The Communist Theory of Law (New York: Praeger, 1955), 148-192; Edward McWhinney, Peaceful Coexistence and Soviet-Western International Law (Leyden: Sythoff, 1964); Hans Werner Bracht, Ideologische Grundlagen der sowjetischen Völkerrechtslehre (Cologne: Wissenschaft und Politik, 1964); Bernard A. Ramundo, Peaceful Coexistence: International Law in the Building of Communism (Baltimore: Johns Hopkins Press, 1967); Henn-Jüri Uibopuu, Die sovjetische Doktrin der friedlichen Koexistenz als Völkerrechtsproblem (Vienna: Notring, 1971); Richard J. Erickson, International Law and the Revolutionary State: A Case Study of the Soviet Union and Customary International Law (Leiden: Sijthoff, 1972); Dietrich Geyer (ed.), Osteuropa-Handbuch Sowjetunion Außenpolitik III: Völkerrechtstheorie und Vertragspolitik (Cologne: Böhlau, 1976).

${ }^{64}$ Among Soviet works, see, e.g., [O.W. Kuusinen et al.,] Grundlagen des Marxismus-Leninismus (Berlin: Dietz, 1960); W.I. Jegorow, Friedliche Koexistenz und revolutionärer Prozess (Berlin: Staatsverlag der DDR, 1972); Schalwa Sanakojew and Nikolai Kaptschenko, Theorie der Au- 
Introduction

neutrality in particular, ${ }^{65}$ on Soviet political language and foreign propaganda, and on the Soviet foreign policy towards the European neutrals. ${ }^{66}$ The research that has already been done on Austrian general foreign policy and its neutrality is quite sufficient for the purpose of this study ${ }^{67}$ Furthermore, there are useful Soviet and

ßenpolitik des Sozialismus (Berlin: Staatsverlag der DDR, 1979). For Western analyses, see, e.g. Boris Meissner, "Die Entwicklungstendenzen in der sowjetischen außenpolitischen Theorie und Völkerrechtslehre 1962 bis 1973," in idem, Dietrich Frenzke, Erika Chilecki (eds.), Sowjetunion und Völkerrecht 1962 bis 1973: Bibliographie und Analyse (Cologne: Wissenschaft und Politik, 1977), 9-58; Margot Light, The Soviet Theory of International Relations (New York: St. Martin's Press, 1988).

${ }^{65}$ Among Soviet works, see, e.g., L.A. Modzhorian, Politika podlinnogo neitraliteta - vazhnyi factor bor'by narodov za mir i nezavisimost'(Moscow: Znanie, 1956); B.V. Ganiushkin, Sovremennyi neitralitet (Moscow: Institut mezhdunarodnykh otnoshenii, 1958); L.A. Modzhorian, Politika neitraliteta (Moscow: Znanie, 1962); B.V. Ganiushkin, Neitralitet i neprisoedinenie (Moscow: Mezhdunarodnye otnosheniia, 1965); O.I. Tiunov, Neitralitet $v$ mezhdunarodnom prave (Perm: Gosudarstvennyi universitet im. Gor'kogo, 1968); L.A. Mojoryan [Modzhorian], "Neutrality in Present-Day International Law," in Grigory Tunkin (ed.), Contemporary International Law: Collection of Articles (Moscow: Progess, 1969), 216-232. For a bibliography of Soviet works, see Stelianos Scarlis, Neutralität in Europa aus sowjetischer Sicht im Zeitalter der Entspannung: Die Rolle der neutralen Staaten Europas in der Außenpolitik der Sowjetunion 1969-1975 (Munich: Tuduv, 1984), 185-187. For Western analyses, cf. Heinz Fiedler, Der sowjetische Neutralitätsbegriff in Theorie und Praxis: Ein Beitrag zum Problem des Disengagement (Cologne: Politik und Wirtschaft, 1959); P.H. Vigor, The Soviet View of War, Peace, and Neutrality (London: Routledge, 1975).

${ }^{66}$ E.g. Bo Huldt and Atis Lejins (eds.), European Neutrals and the Soviet Union (Stockholm: Swedish Institute of International Affairs, 1986); Scarlis, Neutralität in Europa aus sowjetischer Sicht im Zeitalter der Entspannung; Harto Hakovirta, East-West Conflict and European Neutrality (Oxford: Clarendon Press, 1988); Bo Petersson, The Soviet Union and Peacetime Neutrality in Europe: A Study of Soviet Political Language (Stockholm: MH Publishing, 1990); Dominik Geppert and Udo Wengst (eds.), Neutralität - Chance oder Chimäre? Konzepte des Dritten Weges für Deutschland und die Welt 1945-1990 (Munich: Oldenbourg, 2005).

${ }^{67}$ E.g. E.N. Novosel'tsev, Vneshniaia politika Avstrii (Moscow: Mezhdunarodnye otnosheniia, 1962); Thomas O. Schlesinger, Austrian Neutrality in Postwar Europe: The Domestic Roots of a Foreign Policy (Vienna: Braumüller, 1972); Konrad Ginther, Neutralität und Neutralitätspolitik: Die österreichische Neutralität zwischen Schweizer Modell und sowjetischer Koexistenzdoktrin (Vienna: Springer, 1975); Felix Ermacora, 20 Jahre österreichische Neutralität (Frankfurt am Main: Metzner, 1975); Alfred Verdross, Die immerwährende Neutralität Österreichs (Vienna: Geschichte und Politik, 1980); Renate Kicker, Andreas Khol, Hanspeter Neuhold (eds.), Außenpolitik und Demokratie in Österreich: Strukturen - Strategien - Stellungnahmen (Salzburg: Neugebauer, 1983); Manfried Rauchensteiner, Die Zwei: Die Große Koalition in Österreich 19451966 (Vienna: Bundesverlag, 1987); Reinhard Meier-Walser, Die Außenpolitik der monocoloren Regierung Klaus in Österreich 1966-1970 (Munich: Tuduv, 1988); Michael Gehler, Österreichs Außenpolitik der Zweiten Republik: von der alliierten Besatzung bis zum Europa des 21. Jahrhunderts (Innsbruck: Studienverlag, 2005); Elisabeth Röhrlich, Kreiskys Außenpolitik: Zwischen österreichischer Identität und internationalem Programm (Göttingen: V\&R unipress, 2009). For bibliographies on postwar Austrian foreign relations, see Lilly Behrmann, Peter Proché, and Wolfgang Strasser (eds.), Bibliographie zur Außenpolitik der Republik Österreich seit 1945 (Vienna: Braumüller, 1974); Gehler, Österreichs Außenpolitik, 1175-1252. 
Western studies concerning the bilateral Soviet-Austrian relations ${ }^{68}$ and mutual perceptions. ${ }^{69}$ However, in contrast to the considerable number of archival sources on the occupation period that have been made available since the partial opening of Russian archives, almost no Soviet documents on Soviet-Austrian relations after 1955 have been published..$^{70}$ It is therefore the aim of this book not only to base itself on the large corpus of Soviet and Western official and semi-official publications, speeches, and media, as for instance the Moscow New Times and International Affairs (with the Soviet press seen as expressing an official point of view $^{71}$ ), available scholarly literature as well as eyewitness accounts ${ }^{72}$ of former

${ }^{68}$ Viktor N. Beletskii, Sovetskii Soiuz i Avstriia: Bor'ba Sovetskogo Soiuza za vozrozhdenie nezavisimoi i demokraticheskoi Avstrii i ustanovlenie s nei druzhestvennykh otnoshenii 1938-1960gg. (Moscow: Institut Mezhdunarodnykh otnoshenii, 1962); Hedwig Glasneck, "Die Sowjetunion und Österreich: Ein Beispiel für Beziehungen der friedlichen Koexistenz 1955-1965” (PhD Thesis, Halle, 1967). Glasneck's description is based "on Marxist-Leninist principles" (ibid., iv) and therefore cannot be considered balanced in its interpretation. For a Soviet account, see I.G. Zhiriakov, SSSR i Avstrija v 1945-1975 gody (Moscow: Molodaia gvardiia, 1982) and idem, Sovetskii Soiuz - Avstriia: Na puti k sozdaniiu obshcheevropeiskogo doma (Moscow: Akademiia obshchestvennykh nauk TsK KPSS, 1991). From the factographical point of view, these works have proved mostly reliable. See also Hanspeter Neuhold, "Austria and the Soviet Union," in Bo Huldt and Atis Lejins (eds.), European Neutrals and the Soviet Union (Stockholm: Swedish Institute of International Affairs, 1986), 83-118; Heike Malicek, "Die Beziehungen ÖsterreichSowjetunion 1945 bis 1975: Ein pragmatisches Verhältnis" (MA Thesis, Vienna, 1995); Ludmilla Lobova, "Die Außenpolitik und Neutralität Österreichs aus Sicht der UdSSR 1955-1972," in Arnold Suppan, Gerald Stourzh, and Wolfgang Mueller (eds.), The Austrian State Treaty 1955: International Strategy, Legal Relevance, National Identity (Vienna: Verlag der Österreichischen Akademie der Wissenschaften, 2005), 891-922; and N. M. Bogoliubova and Iu. V. Nikolaeva, Russko-avstriiskie kul’turnye sviazi v XVIII-XXI vv. (St. Petersburg: SPbKO, 2010).

${ }^{69}$ Monika Reitinger, "Österreich in den Augen der Sowjetliteratur nach 1945” (PhD Thesis, Vienna, 1969); Evelina Merhaut-Gurevitsch, "Die Innen- und Außenpolitik Österreichs in der sowjetischen Presse 1954-1961" (MA Thesis, Vienna, 1995); Ruth Stifter, "Das politische Österreichbild in der sowjetischen Berichterstattung vom Beginn der Zweiten Republik bis zum Zusammenbruch der UdSSR" (MA Thesis, Vienna, 1998); Ludmilla Lobova, "Die Moskauer Perzeption politischer, ökonomischer und sozialer Entwicklungen in Österreich in den 1980er und 90er Jahren," in Oliver Rathkolb, Otto Maschke, and Stefan Lütgenau (eds.), Mit anderen Augen gesehen: Internationale Perzeptionen Österreichs 1955-1990, Österreichische Nationalgeschichte 2 (Vienna: Böhlau, 2002), 91-160.

${ }^{70}$ Hans Mayrzedt and Waldemar Hummer (eds.), 20 Jahre österreichische Neutralitäts- und Europapolitik 1955-1975, Österreichische Gesellschaft für Außenpolitik Schriftenreihe 9 (Vienna: Braumüller, 1976); Ministerium für auswärtige Angelegenheiten der UdSSR (ed.), UdSSR - Österreich 1938-1979 (Moscow: Novosti, 1980).

${ }^{71}$ On the Soviet press in the Cold War, see Jeffrey Brooks, Thank you, Comrade Stalin! Soviet Public Culture from Revolution to Cold War (Princeton: University Press, 2001); Martin Ebon, The Soviet Propaganda Machine (New York: McGraw-Hill, 1987).

${ }^{72}$ For memoirs of Soviet diplomats and political actors, see, e.g., A. M. Aleksandrov-Agentov, Ot Kollontai do Gorbacheva: Vospominaniia diplomata, sovetnika A.A. Gromyko (Moscow: Mezhdunarodnye otnosheniia, 1994); Georgy Arbatov, The System: An Insider's Life in Soviet Politics (New York: Times Books, 1992); Anatoly Dobrynin, In Confidence: Moscow's Ambassador to 
political and diplomatic actors, but also to draw on internal political documents stored in the Archive of Foreign Policy of the Russian Federation (in particular the Third European Department of the Foreign Ministry which was responsible for dealing with German speaking countries), the former party archives of the CPSU, now the Russian State Archives of Contemporary History, the archives of the Gorbachev Foundation, the Austrian State Archives, and the Bruno Kreisky Archive.

The archival situation in Russia and Austria confronts the researcher with a number of problems. At the time this manuscript was completed, neither the papers of Khrushchev and Brezhnev, nor of the CPSU Central Committee's Foreign Department had been fully declassified. While the archives of the Russian Foreign Ministry and the Gorbachev Foundation do allow access to certain documents from the 1960s to the 1990s, search aids at the Foreign Ministry do not give the researcher a clear overview of what is available and what not. In Austria, the documents of the Political Department of the Foreign Ministry (upon which the "Austrian perspective" of the first two parts of this study is mainly based) and of the Council of Ministers have been transferred to the State Archives, but only for the years up to 1977. Copies of documents from the remaining period were acquired from the Bruno Kreisky Archive (covering the years up to 1983) and from published sources, in particular the Österreichische Zeitschrift für Außenpolitik. Unfortunately, the papers of the Bureau of International Law of the Austrian Foreign Ministry have not yet been transferred to the State Archives. The US perspective, as the view of the leading Western power, has been deduced from published documents. Due to the above-mentioned archival restrictions, some conclusions that are drawn in this volume are therefore preliminary, inasmuch as not all documents are declassified. However, the ground is solid enough for making quite well-based theses, and the general interpretation is unlikely to be changed fundamentally by any records that are released in the future. All quotations from languages other than English

America's Six Cold War Presidents 1962-1986 (New York: Times Books, 1995); Valentin Falin, Politische Erinnerungen (Munich: Droemer Knaur, 1993); Nikita Khrushchev, Memoirs of Nikita Khrushchev III: The Statesman, 1953-1964, ed. by Sergei Khrushchev (University Park: The Pennsylvania State University Press, 2007); Anastas I. Mikoian, Tak bylo: Razmyshleniia o minuvshem (Moscow: Vagrius, 1999). For memoirs of Austrian ambassadors in Moscow, see Heinrich Haymerle, "Die Beziehungen zur Großmacht im Osten," in Erich Bielka, Peter Jankowitsch, Hans Thalberg (eds.), and Reinhold Wagnleitner (red.), Die Ära Kreisky: Schwerpunkte österreichischer Außenpolitik (Vienna: Europaverlag, 1983), 143-193; Otto Eiselsberg, Erlebte Geschichte 1917-1997 (Vienna: Böhlau, 1997); Herbert Grubmayr, "In zwei Wochen gehst Du nach Moskau," in Demokratie und Geschichte (1999), 127-154; idem, "Streiflichter aus meiner Moskauer Zeit," in Alfred Stirnemann and Gerhard Wilflinger (eds.), Russland und Österreich, Pro Oriente XXIII (Innsbruck: Tyrolia, 1999), 258-277; Gerald Hinteregger, "Erinnerungen an Moskau 1978-1981," ibid., 244-257; idem, Im Auftrag Österreichs: Gelebte Außenpolitik von Kreisky bis Mock (Vienna: Amalthea, 2008); Friedrich Bauer, Russische Umbrüche: Von Gorbatschow über Jelzin zu Putin (Graz: Vehling, n.D.). 
have been translated by the author of this book. The system of transliteration from Cyrillic used in this volume is that of the Library of Congress, without diacritics.

Taking into account political, economic and cultural relations, personal contacts, and mutual perceptions (as far as they are decipherable from the media and a handful of opinion polls), this volume, inspired by the methods of New International History, ${ }^{73}$ aims at providing the reader with a comprehensive picture of various layers of international relations. Due to archival restrictions, the area of Soviet secret service activities in Austria had to be excluded from the project. In order to fully comprehend the Soviet-Austrian relationship and the role neutrality played in it, the author of this study has deemed it particularly important to complement the method with relevant aspects of ideology as well as both countries' theories of international law, factors that were especially important for Soviet foreign policy. Despite the declared primacy of internal affairs for the Marxist-Leninist doctrine and despite the influence that historic, power-political, and geostrategic factors doubtlessly exerted on Soviet behavior, the communist ideology played a fundamental role in shaping Soviet perceptions and foreign policy as well as providing its inward and outward justification. The "scientific" teachings of Marxism-Leninism made Soviet foreign policy, as its leaders always proudly emphasized, "unlike any other." 74 This is not to say that ideology left no space for pragmatism and realpolitik: While creating a system of beliefs, defining long-term goals and interpreting the outside world according to the "laws of historic materialism," Marxism-Leninism offered a set of rules for Soviet foreign policy that was, to a certain extent, flexibly applicable and regularly updated. The belief in the ultimate victory of communism never closed Soviet leaders' eyes to the possibility of alliances with noncommunists, tactical retreats and temporary compromises. Western compromising, in contrast, was generally depicted as a sign of the imminent decline of capitalism. Due to the principle that any gain for the USSR was a success for socialism, ideology was always used with regard to Soviet power interests. ${ }^{75}$

${ }^{73}$ See, e.g. Wilfried Loth and Jürgen Osterhammel (eds.), Internationale Geschichte: Themen Ergebnisse - Aussichten (Munich: Oldenbourg, 2000); Eckart Conze, Ulrich Lappenküper, and Guido Müller (eds.), Geschichte der internationalen Beziehungen: Erneuerung und Erweiterung einer historischen Disziplin (Cologne: Böhlau, 2004); Hans-Christof Kraus and Thomas Nicklas (eds.), Geschichte der Politik: Alte und Neue Wege, Historische Zeitschrift Beihefte 44 (Munich: Oldenbourg, 2007). For a classic study of bilateral relations, see Arnold Suppan, Jugoslawien und Österreich 1918-1938: Bilaterale Außenpolitik im europäischen Umfeld (Vienna: Oldenbourg, 1996); on methods, see 21-23.

${ }^{74}$ Vojtech Mastny, "Soviet Foreign Policy, 1953-1962," in Melvyn P. Leffler and Odd Arne Westad (eds.), The Cambridge History of the Cold War I: Origins (Cambridge: University Press, 2010), 312-333, 312 .

${ }^{75}$ Boris Meissner, "Triebkräfte und Faktoren sowjetischer Außenpolitik," in idem and Gotthold Rhode, Grundfragen sowjetischer Außenpolitik (Stuttgart: Kohlhammer, 1970), 9-40, 15. On the role of ideology in the Cold War and the relation between ideology and foreign policy in the Soviet Union, see Mark Kramer, "Ideology and the Cold War," in Michael M. Cox (ed.), Twentieth 
Although Soviet experts of international law claimed the opposite,$^{76}$ the same can be said with regard to the development of the Soviet theory of international law - a theory that, due to its politically motivated inconsistencies, consistent antiWestern bias and one-sided self-praise, was regarded by some Western observers as lacking most of the characteristics that define legal analysis. ${ }^{77}$ In the USSR, the theory of international law was and had for the most part been shaped by ideology and the aim of serving foreign policy. Since from time to time the revolutionary state was forced to enter agreements with noncommunist states and governments, the Marxist-Leninist theory of international law could not flatly deny the rules of the bourgeois world. In contrast to the Western understanding, however, international law was seen in the USSR as reflecting the balance of economic power and as serving the ruling classes by legally underpinning the "class struggle in the international arena." ${ }^{17}$ In order to best advance Soviet political interests in a chang-

Century International Relations 2: The Rise and Fall of the Cold War (London: Sage, 2008), 26-68. For a classic view of the role of ideology in Soviet foreign policy, cf. Zbigniew K. Brzezinski, Ideology and Power in Soviet Politics (New York: Praeger, 1962). Among recent works, see Gabriel Gorodetsky, "The Formulation of Soviet Foreign Policy: Ideology and Realpolitik," in idem (ed.), Soviet Foreign Policy, 1917-1991: A Retrospective (London: Frank Cass, 1994), 30-44; Nigel Gould-Davis, "Rethinking the Role of Ideology in International Politics during the Cold War," in Journal of Cold War Studies 1, no. 1 (1999), 90-109; Nikolaus Katzer, "Ideologie und Pragmatismus in der sowjetischen Außenpolitik," in Aus Politik und Zeitgeschichte, no. 1-2 (2009), 3-10; David C. Engerman, "Ideology and the Origins of the Cold War, 1917-1962," in Melvyn P. Leffler and Odd Arne Westad (eds.), The Cambridge History of the Cold War I: Origins (Cambridge: University Press, 2010), 20-43.

76 "Together with the growth of the forces of peace, which stand up for the strict observance of the principles and norms of international law, the influence of international law on the foreign policy and diplomacy of states increases.” „Mit dem Anwachsen der Friedenskräfte, die für die strikte Einhaltung der Prinzipien und Normen des Völkerrechts eintreten, erhöht sich der Einfluss des Völkerrechts auf die Außenpolitik und die Diplomatie der Staaten." G. I. Tunkin, Das Völkerrecht der Gegenwart (Berlin: Staatsverlag der DDR, 1963), 190.

77 Eberhard Menzel, "Vorwort des deutschen Herausgebers," in F.I. Koschewnikow (ed.), Völkerrecht (Hamburg: Hansischer Gildenverlag, 1960), xi-xxvii, xvi.

${ }^{78}$ D.B. Lewin, and G.P. Kaljushnaja (eds.), Völkerrecht (Berlin: Staatsverlag der DDR, 1967), 16. Among Western analyses, cf. Meissner, Sowjetunion und Völkerrecht, 22-25; 33. See also Erickson, International Law, 1-26; Theodor Schweisfurth, "Entwicklung und ideologische Grundlagen der sowjetischen Völkerrechtstheorie," in Dietrich Geyer (ed.), Osteuropa-Handbuch Sowjetunion Außenpolitik III: Völkerrechtstheorie und Vertragspolitik (Cologne: Böhlau, 1976), 27-48, 47. For further literature on the Soviet theory of international relations, see above, footnote 64 . For the "class character" of international law, see [E.A. Korowin,] "Begriff, Quellen und System des Völkerrechts," in F.I. Koschewnikow (ed.), Völkerrecht (Hamburg: Hansischer Gildenverlag, 1960), 1-20, 2-5. Kelsen, The Communist Theory of Law, 150, argues that "international law, in itself, is perfectly neutral with respect to the struggle of classes within the state subjects of this law and that, consequently, international law, guaranteeing state-domination of any kind, has in itself no class character at all. Just because international law is no class law in any sense of this term, the Soviet Government - and, following their government, the legal scientist - finally recognized the existing international law as a normative order [...]." 
ing environment and to justify the Kremlin's oft contradictory actions, the Soviet theory of international law, too, had to be regularly adjusted. This also applied to the Soviet view of neutrality, which will be put into the context of Soviet-Austrian relations.

The narrative of this volume mainly follows a chronological approach. The first five years, from the signing of the state treaty until Khrushchev's visit to Austria, outlined in Part I, are seen as a formative period in the Soviet attitude towards neutrality and Soviet-Austrian relations. The first chapter compares the Soviet and the Austrian concepts of neutrality as they emerged in the 1950s. While the Soviet Union was interested in defining neutrality in a manner that was as all-encompassing as possible, Austria initially confined it to mere nonparticipation in military alliances. Despite such disagreements, bilateral relations were established that were demonstratively friendly. The Hungarian revolution of 1956 and the resulting Soviet crackdown on it, which occurred in Austria's closest neighborhood, put bilateral relations to a hard test and ushered in a process that would finally lead to an Austrian reinterpretation of neutrality, a reinterpretation that was provoked, not only a little, by Soviet policy and, in particular, its criticism of Austria's implementation of neutral policy.

The following period, from 1961 to 1972, depicted in Part II, was dominated by Soviet-Austrian quarrels over (a) the Austrian wish to become part of West European integration and (b) the Soviet hope that Austria would initiate one of the Soviet Union's dearest détente projects - a conference on European security that, in the Soviet view, would rubberstamp the postwar status quo with regard to communist rule over Eastern Europe and East Germany and loosen the transatlantic bonds of Western Europe as well as the cohesion of NATO. Although neither wish was fulfilled, amicable Soviet-Austrian relations were nevertheless preserved despite the second major Soviet military intervention in Austria's neighborhood: the Warsaw Pact's crackdown on the "Prague Spring" of 1968. This will be dealt with in a separate chapter in Part II. In this context, the Eastern military alliance's war planning from the late 1950s to the 1980s with regard to Austria as well as the Soviet attitude towards Austria's armed defense will also be discussed.

After both the EEC and the conference issues were resolved in 1972-73 (the first by Austria's free-trade agreement with the Common Market, the second by the convening of the Conference on Security and Cooperation in Europe, the CSCE), bilateral relations entered the decade delineated in Part III that was defined, on one hand, by a dropping Soviet interest in having its projects promoted by neutrals as well as in promoting neutrality itself, and, on the other hand, by the foreign policy activism of Austrian chancellor Bruno Kreisky, which was devised to enhance his country's international reputation, security, and maneuvering space. Paradoxical as it may seem, although the détente of the 1970s saw a reduction in Austria's importance as an international mediator for Soviet diplomacy and as a supplier of Western goods on the Soviet market, it also marked, in Austria's understanding of 
neutrality, a further drift towards the more all-embracing Soviet interpretation. This was at least in part a consequence of the events of 1968 .

The Gorbachev years saw a reversal of some of these developments. While the final peak of the Cold War (had it lasted longer) might have brought about a revival of Austria's mediatory importance for the Soviet Union, the Cold War's end set the seal on the decline of the special relationship between the two countries. At the same time, the neutral discontinued respecting Soviet reservations about European integration and applied for EC membership. 


\section{LAYING THE GROUNDWORK AND CHANGING NEUTRALITY, 1955-1960}

"Neutrality is rather like virginity. Everybody starts off with it, but some lose it quicker than others, and some do not lose it at all. Unlike virginity, however, neutrality once lost can sometimes be recovered, albeit with difficulty." Roderick Ogley, The Theory and Practice of Neutrality in the Twentieth Century (London: Routledge \& Kegan Paul, 1970), 1. 



\section{Two Differing Concepts of Neutrality}

In Western theory and practice, neutrality is defined as a state of nonparticipation in war, including the refusal to lend the own territory to foreign military, and of impartiality towards belligerent countries. ${ }^{1}$ Until World War II, the main focus rested on classical, wartime neutrality, as codified in the Hague Conventions of $1907 .^{2}$ According to these documents, belligerents are obliged to refrain from attacking or using neutral territory, while the neutral state is to abstain from joining the war except for self-defense; to prevent belligerents from entering, crossing, or using neutral territory for military purposes; to refrain from supporting any belligerent; and to treat belligerents equally (except in economic matters). ${ }^{3}$

In the second half of the twentieth century, as a consequence of the waning acceptance of the "right to war" in international law on one hand, and the permanence of the Cold War on the other, permanent neutrality, as it had been adopted by Switzerland in 1815 and by Austria in 1955, garnered more interest. If in peacetime a country commits itself to observe neutrality in future wars, it may issue a declaration of permanent neutrality - an act that can happen either in the context of an international settlement (as in the case of Switzerland) or solely through a unilateral declaration of will (as was the case in Austria). In wartime, a permanently neutral state bears roughly the same obligations as any other wartime neutral. ${ }^{4}$ In peacetime, a permanent neutral must not start a war, although it is obliged to prepare for self-defense. Furthermore, a permanent neutral shall maintain a discretionary "neutral policy," i.e. refrain from any action that might draw it into a conflict or restrict its neutrality during a future war. ${ }^{5}$ In particular, it may not join a military alliance,

${ }^{1}$ On the history and Western theory of neutrality, see Verosta, Die dauernde Neutralität, 7-44; Hans Haug, Neutralität und Völkergemeinschaft (Zurich: Polygraphischer Verlag, 1962); Michael Schweitzer, Dauernde Neutralität und europäische Integration (Vienna: Springer, 1977), 95-103; Karsh, Neutrality and Small States, 13-30; Michael Gehler, Finis Neutralität? Historische und politische Aspekte im europäischen Vergleich: Irland, Finnland, Schweden, Schweiz und Österreich, Center for European Integration Studies Discussion Paper C 92 (Bonn: Rheinische Friedrich-Wilhelms-Universität, 2001), 3-29.

2 Verosta, Die dauernde Neutralität, 118-133.

${ }^{3}$ Gerhard Hafner, “Österreichs Neutralität 1955-2005," in Thomas Olechowski (ed.), Fünfzig Jahre Staatsvertrag und Neutralität (Vienna: WUV-Universitätsverlag, 2006), 15-44, 24.

${ }^{4}$ Boleslaw A. Boczek, "The Conceptual and Legal Framework of Neutrality and Nonalignment in Europe," in S. Victor Papacosma and Mark R. Rubin (eds.), Europe's Neutral and Nonaligned States: Between NATO and the Warsaw Pact (Wilmington: Scholarly Resources, 1989), 1-42, 8; on the following, see also 9-16.

${ }^{5}$ Schweitzer, Dauernde Neutralität, 111-145. 
permit the establishment of foreign military bases on its soil, or take on any (political, military, or economic) obligation that might render it impossible to maintain neutrality in a future war. In their entirety, such "secondary obligations" or "anticipatory effects" of permanent neutrality in peacetime were, however, never internationally codified, ill-defined and, therefore, subject to diverging interpretations and conflicting views. While most Western experts argued that such obligations had to be interpreted restrictively so that acts of prudence were not turned into legal duty, other actors indeed were interested in or contributed to making such acts obligatory.

In the wake of the Cold War and the decolonization process, the phenomena of neutralism and nonalignment emerged. Like the European permanent neutrals, the nonaligned states, mainly in South Asia, Africa, and Latin America, were not to join military alliances with any of the two big Cold War blocs or allow foreign military bases on their soil. Since neutralism was, in contrast to permanent neutrality, not an institute of international law but merely an orientation of foreign policy, such pledges were, however, not legally binding. ${ }^{6}$ The nonaligned, including small European states such as Yugoslavia and Malta, aimed at not getting involved in the Cold War. In contrast to the Western concept of permanent neutrality, however, their nonalignment did not apply to regional military alliances. In addition, the nonaligned states vowed to support the decolonization struggle of the Third World and actively contribute to the spread of disarmament and coexistence. While they strove for equal distance, not only between the military alliances, but also between the ideologies of the Western and the communist world and their societal, political, and economic systems, some of them turned out to be much more critical of the West than of the Soviet bloc ${ }^{7}$ and refrained from making the commitment of remaining neutral in the case of war.

\footnotetext{
${ }^{6}$ For a brief comparison of permanent neutrality and nonalignment, see Hanspeter Neuhold, "Permanent Neutrality and Nonalignment: Similarities and Differences," in Robert A. Bauer (ed.), The Austrian Solution: International Conflict and Cooperation (Charlottesville: The University Press of Virginia, 1982), 161-204, esp. 174, 180; Daniel Frei, Neutrality and Non-Alignment: Convergencies and Contrasts (Zurich: Forschungsstelle politische Wissenschaft, 1979); Jens Hacker, "Neutralität, Neutralismus und Blockfreiheit," in Aus Politik und Zeitgeschichte, no. 18 (1983), 3-20. Cf. on neutralism and nonalignment Peter Lyon, Neutralism (Leicester: University Press, 1963); Peter Willetts, The Non-Aligned Movement: The Origins of a Third World Alliance (London: Pinter, 1982); Paul Luif, "Neutralität - Neutralismus - Blockfreiheit: Ideologien und Interessen," in Österreichische Zeitschrift für Politikwissenschaft 8, no. 3 (1979), 269-285; Karl E. Birnbaum, and Hanspeter Neuhold (eds.), Neutrality and Non-Alignment in Europe, Laxenburg Papers 4 (Vienna: Braumüller, 1981).

7 Boczek, "Conceptual and Legal Framework," 18.
} 


\section{The Soviet attitude towards neutrality}

When Khrushchev decided that Austria should become a "life-size test of neutrality," he relied on a concept relatively fresh in postwar Soviet foreign-policy thinking. In Marxism-Leninism, the general attitude towards neutrality was defined by the theory of class struggle, a permanent conflict of historical dimensions taking place in all societies of the world between the proletariat, supported by "progressive," i.e. socialist, forces, and reactionary ones, the bourgeoisie. Until the final victory of socialism was achieved, this struggle would not allow any sort of indifference. Any person not supportive of the proletariat was by definition a bourgeois or "class enemy." Neutrality was often depicted by Marxists as camouflage, a cover-up for the neutral's preference for bourgeois forces. In a similar vein, Frederick Engels attacked neutral Switzerland's authorities for cracking down on exiled revolutionaries, thus giving in to the demands of the foreign reaction. ${ }^{9}$ In his "Tasks of the Left Zimmerwaldists," written during World War I, Lenin stated that neutrality was merely a "bourgeois deception or hypocrisy, that in fact it means passive submission to the bourgeoisie and to such of its particularly disgusting undertakings as imperialist war." 10

Once the Bolsheviks had taken power in Russia, the Marxist-Leninist attitude towards neutrality was influenced by Soviet state interests. This applied not only to (a) the Soviet interpretation of what duties neutrality comprised. As we shall see soon, ${ }^{11}$ in Soviet theory and practice, neutrality meant different things at different times, and its content was redefined several times according to the political aims of the USSR. The "highly changeable character of Soviet views on neutrality"12 also applied to (b) whether the USSR welcomed or promoted the neutrality of a particular state at a particular time. If neutrality was good or evil from the Soviet perspective depended on the side exercising it, the specific circumstances under which it was declared, and its effect on the fate of communism. ${ }^{13}$ In the case of a war between two imperialistic powers, the neutrality of a socialist state was con-

8 Thomas M. Verclytte, "Austria between East and West," in N.I. Egorova and A.O. Chubar'ian (eds.), Kholodnaia voina i politika razriadki: diskussionnye problemy 1 (Moscow: Institut Vseobshchei Istorii Rossiiskoi Akademii Nauk, 2003), 103-116, 104.

9 Engels, "Political Position of the Swiss Republic," [1853], 90-92.

${ }^{10}$ V.I. Lenin, "Tasks of the Left Zimmerwaldists in the Swiss Social Democratic Party," [1916], in idem, Collected Works 23, 4th English edition (Moscow: Progress, 1964), 137-148, 144.

${ }^{11}$ See below, pages 56-67, 205-207, 246-248.

12 Petersson, The Soviet Union and Peacetime Neutrality, 111. Cf. Harto Hakovirta, "East-West Tensions and Soviet Politics of European Neutrality," in Bengt Sundelius (ed.), The Neutral Democracies in the New Cold War (Boulder: Westview, 1987), 198-217.

13 "One must not decide, once and for all, that neutrality in general, or of this or that particular country is good or bad. It all depends on the concrete historical circumstances. Under contemporary historical conditions, as they emerged after World War II, the main criterion for evaluating neutrality is the neutral state's attitude towards supporting the cause of peace and the prevention of war." Ganiushkin, Sovremennyi neitralitet, 8. 
sidered possible. If a war was revolutionary, defensive, or a war of liberation, and therefore according to Lenin "just," no type of neutrality was justifiable. ${ }^{14}$ In such a case, all countries had to decide whether to be friend or foe.

The changing Soviet attitude towards neutrality can be traced through several decades. After the revolution, when the existence of Soviet Russia was endangered by the armed intervention of capitalist powers, the Marxist-Leninist attention shifted somewhat from wartime to peacetime (i.e. permanent) neutrality and the prestige of such neutrality improved. With an eye on the weakness of Soviet Russia and its perception of the threat of capitalist "encirclement," every neighbor that stepped out of the cordon sanitaire and declared itself neutral vis-à-vis the Bolshevik state was regarded a gain. When in 1920 some of Soviet Russia's newly independent neighbors, such as Lithuania and Estonia, showed interest in strengthening their independence by declaring neutrality, the Kremlin readily accepted. ${ }^{15}$ Similarly, the Copenhagen agreement of the same year between Soviet Russia and Austria on the repatriation of prisoners of World War I stipulated Austria's neutrality in the Polish-Soviet war. ${ }^{16}$

In the interwar years, the USSR continued to aim at weakening the capitalist camp by concluding agreements of neutrality and nonaggression with bourgeois countries, such as Afghanistan, China, Finland, Iran, Turkey and others. It has been argued that, from the Soviet point of view, nonaggression was not the objective in any of these treaties: ${ }^{17}$ On one hand, such pledges could be torn up as soon as an invasion took place, on the other, no sane human being would expect a tiny country like Estonia to attack its huge neighbor on its own. Therefore the real meaning of these treaties was rather the declaration that these countries would neither join alliances hostile to the Soviet state, nor allow foreign troops to use their soil as a base against the motherland of communism. For this reason, peacetime neutrality was hailed by Stalin as a guarantee against foreign aggression, and the respective treaties on neutrality and nonaggression were praised as a "weapon in our fight for the destruction of the imperialistic states' front against the USSR."18

This, however, did not change the utilitarian Soviet attitude towards neutrality as exercised by capitalist states: From 1939 to 1941 the Soviet Union provided Nazi Germany's war effort with raw material and also violated the neutrality agreements with Finland, the Baltic republics and Iran by attacking or occupying these states.

${ }^{14}$ Light, The Soviet Theory of International Relations, 229-237.

${ }^{15}$ Heinz Fiedler, "Politische Verträge mit westlichen Staaten und Entwicklungsländern," in Dietrich Geyer (ed.), Osteuropa-Handbuch Sowjetunion Außenpolitik III: Völkerrechtstheorie und Vertragspolitik (Cologne: Böhlau, 1976), 194-223, 195-197.

${ }^{16}$ Mueller and Leidinger, "Tiefes Misstrauen - begrenztes Interesse: Die österreichisch-sowjetischen Beziehungen 1918 bis 1955," 75.

17 Vigor, The Soviet View, 184-186.

18 "Neitralitet," in O. Iu. Shmidt et al. (eds.), Bol'shaia Sovetskaia Entsiklopediia 41 (Moscow: OGIZ, 1939), 487-489, 488. 
At the same time, Soviet propaganda castigated the "nonintervention" policy of the West during the Spanish Civil War as some "sort of special, unarmed participation in the war." ${ }^{19}$ According to this interpretation, countries that declared themselves neutral during World War II, such as Switzerland, Sweden and Turkey, in Soviet eyes supported the enemy's war effort. ${ }^{20}$ An exception was Japan, whose neutrality benefited the Soviet Union. In 1945, not only the USSR, but many nations were critical of the European neutrals for their behavior during the war and thus of neutrality in general. In the aftermath of World War II, neutrality was deemed incompatible with UN membership by many members and legal experts. ${ }^{21}$ It was even considered to include a passage banning neutrality into the Charter of the United Nations, and the Soviet representative delayed the Portuguese accession to this organization with reference to this country's wartime neutrality. ${ }^{22}$

Another kind of neutrality had emerged in Soviet wartime plans. These assigned to each of the great powers several European countries as a sphere of influence. Between these spheres, a neutral buffer zone consisting of Denmark, Germany, Austria, Switzerland and Italy was to be created. ${ }^{23}$ In this case, belonging to this zone was not a matter of permanent neutrality chosen by a sovereign state, but rather a consequence of great power politics. However, the Cold War and the formation of two blocs made neutrality virtually impossible. Zhdanov's doctrine of the "two camps," launched in 1947 by Stalin's mouthpiece, left little space between the blocs. Apparently, the Soviet leader did not consider neutrality feasible between the opposing powers; especially small states would ultimately gravitate to one or the other emerging bloc. ${ }^{24}$ The most prominent examples of small, permanently neutral states in Europe, Sweden and Switzerland, were repeatedly attacked by Soviet propaganda for allegedly following NATO, and their neutrality was accused of being "camouflage." 25

19 Ibid., 487.

20 "Neitralitet," in A. Ia. Vyshinskii (ed.), Diplomaticheskii slovar' 2, 1st ed. (Moscow: Gospolitizdat, 1950), 230-234, 232. Cf. George Ginsburgs, "Neutrality and Neutralism and the Tactics of Soviet Diplomacy," in The American Slavic and East European Review 19, no. 4 (1960), 531560, 534-537.

${ }^{21}$ O.I. Tiunov, Neitralitet $v$ mezhdunarodnom prave (Perm: Gosudarstvennyi universitet im. Gor'kogo, 1968), 59.

22 Menzel, "Vorwort," xxii.

23 Memorandum, Litvinov to Molotov, 11 January 1945, in G.P. Kynin and J. Laufer (eds.), SSSR $i$ Germanskii vopros 1941-1949: Dokumenty iz arkhiva vneshnei politiki 1 (Moscow: Mezhdunarodnye otnosheniia, 1996), 595-597.

24 Vladislav Zubok, "The Soviet Attitude towards European Neutrals during the Cold War," in Michael Gehler and Rolf Steininger (eds.), Die Neutralen und die europäische Integration 19451995 (Vienna: Böhlau, 2000), 29-43, 32.

${ }^{25}$ Quoted in Hans Rudolf Fuhrer, "Neutral zwischen den Blöcken: Österreich und die Schweiz," in Manfried Rauchensteiner (ed.), Zwischen den Blöcken: NATO, Warschauer Pakt und Österreich (Vienna: Böhlau, 2010), 193-252, 247. Cf. Denise Bindschedler-Robert, "Völkerrecht und Neu- 
Between 1950 and 1954, in the context of the Soviet struggle against the emergence of Western blocs, such as the European Defense Community (EDC), ${ }^{26}$ and of Soviet attempts at breaking up the Western anti-communist front, the Kremlin's assessment of neutrality began to shift. Neutrality was now seen mainly as a tool for preventing such blocs from coming into being, and it was recommended by West European communists. ${ }^{27} \mathrm{~A}$ particularly remarkable initiative of the late Stalin years was the dictator's proposal of March 1952, which offered the reunification of Germany at the price of the country's declaration of neutrality. However, there is consensus among most experts that the offer, rejected by the West, was not meant seriously. ${ }^{28}$ After Stalin's death and the abortive anti-communist uprising in the GDR in 1953, the idea of a neutral unified Germany (allegedly brought up again by KGB boss and Politburo member Lavrentii Beriiia ${ }^{29}$ ) remained unaccepted in the Politburo.

In the case of Austria, neutrality had not yet seemed a viable option to Soviet foreign-policy makers. ${ }^{30}$ In 1950, however, the Austrian communists joined the West European comrades in the propaganda campaign for neutral status to be adopted by their countries. ${ }^{31}$ While Austria was not a member of the planned EDC, the debates concerning this bloc made Soviet diplomats reconsider neutralizing the country for two reasons: First, such a move would prevent Austria from even thinking about joining the Western bloc; secondly, it would send out a signal strong enough to make France and West Germany waver in their determination to

tralität aus sowjetischer Sicht," in Österreichische Zeitschrift für Außenpolitik 5, no. 3 (1965), $144-163,158$.

${ }^{26}$ On the Soviet struggle against the EDC, see, e.g. Kevin Ruane, The Rise and Fall of the European Defence Community (Basingstoke: Macmillan, 2000); M. Narinski, "La construction européenne vue par l'URSS de 1948 à 1953,“ in: Saki Dockrill, Robert Frank, Georges Henri Soutou and Antonio Varsori (eds.), L'Europe de l'Est et de l'Ouest dans la Guerre froide 1948-1953 (Paris: PUPS, 2002), 61-72; Wolfgang Mueller, "The Soviet Union and West European Integration: From the Brussels Treaty to the ECSC and EEC, 1947-1957," in Journal of European Integration History 15, no. 2 (2009), 67-85.

27 Ginsburgs, "Neutrality and Neutralism and the Tactics of Soviet Diplomacy," 538-539.

${ }^{28}$ Ruud von Dijk, The 1952 Stalin Note Debate: Myth or Missed Opportunity for German Unification?, Cold War International History Project Working Paper 14 (Washington, DC: Woodrow Wilson Center, 1996); Jürgen Zarusky (ed.), Die Stalinnote vom 10. März 1952. Neue Quellen und Analysen (Munich: Oldenbourg, 2002); Peter Ruggenthaler (ed.), Stalins großer Bluff: Die Geschichte der Stalinnote in sowjetischen Dokumenten, (Munich: Oldenbourg, 2007). For different opinions, see Wilfried Loth, Die Sowjetunion und die deutsche Frage (Göttingen: Vandenhoeck \& Ruprecht, 2007), 101-174; idem, "German Historians and the German Question in the Cold War," in Juhana Aunesluoma and Pauli Kettunen (eds.), The Cold War and the Politics of History (Helsinki: Edita, 2008), 169-188, 185; and A. M. Filitov, Germaniia v Sovetskom vneshnepoliticheskom planovanii, 1941-1990 (Moscow: Nauka, 2009), 138-173.

${ }^{29}$ Such claims were made after Beriia's demotion and arrest. However, there is still little evidence as to whether a neutralization of Germany was seriously proposed or who was in favor thereof. Zubok, A Failed Empire, 86-93.

${ }^{30}$ Gribanov to Vyshinskii, 28 February 1950, in AVPRF, 66/29/49/11, 25-27.

${ }^{31}$ Stourzh, Um Einheit und Freiheit, 267. 
participate. In late 1952, Soviet representatives signaled that an Austrian declaration of neutrality might be conducive to their willingness to sign the state treaty. ${ }^{32}$ However, this did not mean that the Soviet leadership was no longer ambiguous about neutrality. On one hand, Molotov, at the Berlin conference in February 1954, reiterated the Soviet proposal for Germany's neutralization and named Austria's nonparticipation in military alliances as one of the preconditions for a conclusion of the state treaty. On the other hand, the Austrian Communist Party (KPÖ) was ordered by the Soviet leadership to abandon its neutrality campaign, because "such a small bourgeois country like Austria" would not be able to carry out a neutral policy. ${ }^{33}$ Furthermore, it would seem "questionable if the Communist Party acts as a promoter of neutrality between blocs, of which one is fighting for the preparation of war." However, Molotov's proposal at the Berlin conference and Dulles' positive reaction had proved that the idea of making Austria neutral was acceptable to both superpowers, although the secretary of state insisted that neutrality would be acceptable only if it followed the Swiss model. ${ }^{34}$

Thus, it was only once the general deadlock in the global arena became obvious and the new Kremlin leadership realized that the Stalin years had ended in "a Cold War of positions" or even a "dead end," ${ }^{35}$ that the Soviet attitude towards permanent neutrality changed to any fundamental degree. As Soviet experts in international law recognized, an international stalemate between two or more opposing powers of roughly equal strength had often fostered a tendency to neutralize certain disputed areas. ${ }^{36}$ Although no official Soviet statement would have applied this observation to Soviet policy, it was just such a stalemate that characterized the Cold War after Stalin's death. Therefore, Khrushchev started to look for new ways to get things moving again in the international balance of forces, and "peaceful coexistence" was declared as a strategy to reduce tensions while continuing the international struggle. ${ }^{37}$

Together with "peaceful coexistence," neutrality and nonalignment were rediscovered by the new Soviet leadership as possible, even desirable, means of détente and as a strategy to slow nonsocialist countries' integration into the Western sphere or eventually to lure them out of it. While the Austrian state treaty seems to have been

32 Ibid., 220-221; Wildmann to Austrian MFA, 27 November 1952, in Alfons Schilcher (ed.), Österreich und die Großmächte: Dokumente zur österreichischen Außenpolitik 1945-1955 (Vienna: Geyer, 1980), 158-160.

${ }^{33}$ Report CPSU Commission for Foreign Policy to Molotov, On the Austrian Communist Party's proclamation of neutral policy, [no later than 12 April 1954], in Rossiiskii gosudarstvennyi arkhiv sotsial'no-politicheskoi istorii (hereafter: RGASPI), 82/2/1121, 121-122.

${ }^{34}$ Stourzh, "Der österreichische Staatsvertrag," 976.

35 "Cold War of positions": Vojtech Mastny, "The Soviet Union and the Origins of the Warsaw Pact in 1955," http://www.php.isn.ethz.ch/collections/coll_pcc/into_VM.cfm (accessed 2008), 9; "dead end": Taubman, Khrushchev, 242.

${ }^{36}$ Ganiushkin, Neitralitet i neprisoedinenie, 7.

${ }^{37}$ See above, pages 16-20. 
the first case in which the new Soviet attitude towards neutrality was materialized, ${ }^{38}$ the Soviet re-evaluation of this status was the result of the international stalemate in Europe, and most likely also the integration of West Germany into NATO as a new member in 1955. Another factor was the new international dynamic triggered by the decolonization process in Asia and Africa. ${ }^{39}$ Some of the independent states of East Asia and the Middle East had already joined pro-Western blocs, such as the South East Asian Treaty Organization (SEATO), which was founded in 1954, and the Baghdad Pact of 1955. In order to block the expansion of pro-Western alliances, to keep newly independent territories out of such blocs, and, at the same time, to peacefully expand Soviet influence and socialism in independent countries that were nonsocialist, either neutralization or nonalignment was promoted. ${ }^{40}$

Obviously Malenkov and Khrushchev grasped that the rigid concept of "two camps" had had little to offer for the many nonsocialist countries in the West or for the even larger number of emerging independent states in the South. ${ }^{41}$ Therefore, the Soviet concept of "two camps" was transformed into one of three, with the third one consisting of the neutral or nonaligned states. This third group of states, which the Soviet Union was not yet strong enough to claim outright as a sphere of influence, was expected to be a natural ally for the USSR, to support Soviet initiatives in the international arena, and to block any further rapprochement of European, Asian, and African states with the Western camp. The Third World's anticolonialism made it likely that these countries would be critical of their former West European colonial powers, and the Kremlin seemed optimistic that it might be possible, by supporting the decolonization process and extending foreign aid, to win over the new camp, which comprised one third of the global population, as new allies, to merge the socialist and neutral camps into a "zone of peace," 42 and thus to tilt the

${ }^{38}$ Zubok, A Failed Empire, 103.

${ }^{39}$ Roy Allison, The Soviet Union and the Strategy of Non-Alignment in the Third World (Cambridge: University Press, 1988), 2; Ginsburgs, "Neutrality and Neutralism and the Tactics of Soviet Diplomacy," 531.

${ }^{40}$ Mojoryan [Modzhorian], "Neutrality in Present-Day International Law," 219: "It is no accident that the policy of peacetime neutrality became especially widespread in the $1950 \mathrm{~s}$, that is, in the years when the Western powers were knocking together their reactionary military-political blocs in Europe and Asia. Since these blocs endanger peace and imperil the independence and sovereignty of new national states, the policy of neutrality can no longer be a policy of passive observation of developments which could lead the world to a devastating thermonuclear war."

${ }^{41}$ Westad, The Global Cold War, 67.

42 "Neitralitet," in A.A. Gromyko, S.A. Golunskii, and V.M. Khvostov (eds.), Diplomaticheskii slovar' 2, 2nd ed. (Moscow: Gospolitizdat, 1961), 392-395, 394; Programm der Kommunistischen Partei der Sowjetunion, angenommen auf dem XXII. Parteikongress 1961, in Boris Meissner (ed.), Das Parteiprogramm der KPdSU 1903 bis 1961 (Cologne: Wissenschaft und Politik, 1962), 143-244, 183; Ganiushkin, Sovremennyi neitralitet, 3; D.B. Lewin, and G.P. Kaljushnaja (eds.), Völkerrecht (Berlin: Staatsverlag der DDR, 1967), 16. Tunkin, Das Völkerrecht der Gegenwart, 19 , avoids mentioning the neutral states and writes merely about socialist and nonsocialist states forming a "zone of peace." 
international balance in favor of the Soviet side. Even if Khrushchev - as former Soviet diplomats argue - did not understand the difference between the various forms of neutrality and neutralism, ${ }^{43}$ the new leader came to see it as a great success, regarding it as a means for weakening pro-Western forces worldwide and, in Europe, fostering "schemes of undermining NATO by building the bridges towards its smaller members." 44

For the Soviet Union, the neutralization of nonsocialist states offered several net effects: In the international system, permanent neutrals, depending upon their location, created safe buffer zones and thus reduced the likelihood of an interbloc conflagration. Since neutrality was promoted exclusively among nonsocialist states, Western alliances and blocs were weakened by "losing" potential allies, while the neutralized state was isolated from the Western collective defense and economic integration and, thus, also weakened. The Soviet Union, however, could demand that the neutrals, their Western traditions and convictions notwithstanding, distance themselves from the West and support Soviet initiatives. ${ }^{45}$

Communism did not accept peacetime neutrality as something stable and eternal, but rather as something intermediary and transitory, a status between capitalism and socialism. Nonetheless, for the time being, it was, from the Soviet side, a preferred status for Western countries, preferable to their full membership in the Western bloc. In Soviet eyes, neutrality was defined a status more progressive than capitalism but less progressive than socialism, a status that actually paved the way for this optimal condition. ${ }^{46}$ By means of ever closer political, economic, and cultural relationships with the Eastern bloc, neutrals were expected to lean towards socialism. For a socialist state, however, neutrality was not deemed a fit condition. Naturally, after socialism was reached in a certain country, Soviet ideology did not consider a return of the country to peacetime neutrality possible. ${ }^{47}$ Therefore, unlike during the interwar period, the Soviet Union did not consider declaring itself or its satellite states neutral.

The founding of the Warsaw Pact in May 1955 seems to have been an important precondition for the Soviet re-evaluation of neutrality. The new organization would reduce the danger of an East European state misunderstanding the role of neutrality and deserting into the neutral camp. The Soviet refusal to accept the Hungarian

${ }^{43}$ Rostislav Sergeev and Ludwig Steiner, "Die österreichisch-sowjetischen Beziehungen 19531955 und der Weg zum Staatsvertrag," in Arnold Suppan, Gerald Stourzh, and Wolfgang Mueller (eds.), The Austrian State Treaty 1955: International Strategy, Legal Relevance, National Identity (Vienna: Verlag der Österreichischen Akademie der Wissenschaften, 2005), 205-213, 210.

${ }^{44}$ Zubok, "The Soviet Attitude," 36.

${ }^{45}$ George Ginsburgs, "Neutralism à la Russe," in idem and Alvin Z. Rubinstein (eds.), Soviet Foreign Policy Toward Western Europe (New York: Praeger, 1978), 17-39, 37.

46 Tiunov, Neitralitet, 115; Tunkin, Das Völkerrecht der Gegenwart, 25. Cf. Dallin, Soviet Foreign Policy, 330-331.

${ }^{47}$ E. Korovin, "Proletarian Internationalism in World Relations," in International Affairs, no. 2 (February 1958), 29. Quoted in Allison, The Soviet Union and the Strategy of Non-Alignment, 18. 
1956 decision to leave the Warsaw Pact and become neutra ${ }^{48}$ proved that the Soviet purpose of neutrality as it had been advanced a year earlier in Austria "was to promote the dissolution of the military organizations of the Western powers only." 49 Neutrality was thus recommended by the USSR only in exchange for membership in Western alliances or for young nations that had recently emerged from colonial rule. At the Geneva conference of the heads of state of the four powers, from 18 to 23 July 1955, Soviet president Nikolai Bulganin made it clear that neutrality was not for the "people's democracies," when he stressed the Soviet support for this status among Western states and their former colonies and encouraged the leading Western powers to take a similar stance:

"It is a fact that for some time a movement in favour of a policy of neutrality, a policy of nonparticipation on military blocs and coalitions, has been gaining ground in some countries. Experience shows that some states which pursued a neutral policy in time of war were able to ensure security for their peoples and play a positive role. This was confirmed, in particular, by the experience of the Second World War, although the neutrality of some countries was not beyond reproach.

The Soviet Government is also of the opinion that should any nation desiring to pursue a policy of neutrality and nonparticipation in military groupings, while these groupings exist, raise the question of having their security and territorial integrity guaranteed, the Great Powers should accede to these wishes. In any case, as far as the Soviet Union is concerned, it is prepared to take part in such guarantees, as it has, for instance, declared in respect to Austria.

At this point mention was made of the countries of Eastern Europe - the people's democracies. To raise this question at this Conference, means interference in the internal affairs of these states." ${ }^{50}$

At the founding conference of the Warsaw Treaty Organization, on 11 May 1955, Bulganin lambasted the creation of NATO and SEATO, as well as the integration of "militaristic" West Germany into the former. However, he observed that "it would be incorrect to presume that the Austrian government is the only one adopting a position [of neutrality]"; quite the contrary, "there are a number of states, both in Europe and Asia, that are averse to joining aggressive military blocs." ${ }^{51}$ From the Soviet point of view, this type of aversion did not apply to the Warsaw Pact, which was by definition not "aggressive." At their first meeting in January 1956, the members of the Warsaw Pact declared:

"It is no accident that the policy of setting up aggressive military blocs is being condemned by an increasing number of countries. There is growing recognition of the desire of countries to make collective efforts in the struggle for peace, the desire of international cooperation on the basis of

48 Telegram Imre Nagy to Diplomatic Missions, 1 November 1956, in Vojtech Mastny and Malcolm Byrne (eds.), A Cardboard Castle? An Inside History of the Warsaw Pact 1955-1991 (Budapest: Central European University Press, 2005), 84-87.

49 Sven Allard, Russia and the Austrian State Treaty: A Case Study of Soviet Policy in Europe (University Park: Pennsylvania University Press, 1970), 221.

${ }^{50}$ The Geneva Conference of Heads of Government 1955 (Washington, DC: Government Printing Office, 1955), 41.

51 “Erklärung N.A. Bulganins," in Die Warschauer Konferenz, Beilage zu Neue Zeit, no. 21 (1955), $4-14,7$. 
mutual respect for territorial integrity and sovereignty, nonaggression, noninterference in internal affairs of other states, equality and mutual benefit, and peaceful coexistence. This aim is served by the efforts of a number of countries to pursue a policy of nonparticipation in aggressive military blocs, a policy of neutrality.

The states that are parties of the Warsaw Treaty acclaim these efforts, convinced that support for them strengthens the forces of peace and weakens the forces of war." ${ }^{2}$

In 1955-59, the Soviet campaign for promoting neutrality in the West and the Third World reached its highest level. The nonaligned states' Bandung conference in April 1955 was greeted enthusiastically in the Soviet media; however, after "the Khrushchev-Bulganin regime's first large experiment with neutralism," ${ }^{33}$ Soviet diplomats worried that the Third World might display not only too much independence from any power, but also struggle too fiercely against their internal challengers, most of them communist. ${ }^{54}$ At the conference, criticism of colonialism could not be voiced without also referring to Soviet domination in Eastern Europe. Nonetheless, Bandung opened the door for improving Soviet relations with the South Asian regimes, which had hitherto been discarded as "semi-feudal" or "lackeys of imperialism." ${ }^{55}$ On 23 May 1955, the Communist Party of Indonesia welcomed this rapprochement, and a few weeks later the Soviet media proudly reported that India's Communist Party was among the strongest supporters of Prime Minister Nehru's neutralistic foreign policy. ${ }^{56}$ Similarly, the foreign policy course of both countries was positively re-evaluated by Soviet scholars. In June 1955 Nehru was welcomed in Moscow, and in October the Burmese prime minister $\mathrm{U} \mathrm{Nu}$ followed suit. The new bonds to the nonaligned were strengthened by the triumphal tour of Khrushchev and Bulganin through India, Burma and Afghanistan in November and December 1955. With the aim of "attracting" such states "to our side," 57 the Kremlin offered hundred-million-dollar loans for Egypt, Syria and Afghanistan, and concluded trade agreements with Indonesia, India, Burma and other nonaligned states. While India and Indonesia rejected Soviet offers of arms sales, Afghanistan was flooded with Soviet and Czechoslovak weapons soon after the signing of a Soviet-Afghan convention on Afghanistan's neutrality. In 1956 President Sukarno of Indonesia visited Moscow to receive Soviet loans and aid; between 1955 and 1960 Soviet-Indonesian trade grew tenfold and the Soviet bloc quickly supplanted

52 Deklaratsiia gosudarstv-uchastnikov Varshavskogo Dogovora, 28 January 1956, in Organizatsiia Varshavskogo Dogovora: Dokumenty i materialy, 1955-1975 (Moscow: Gospolitizdat, 1976), 12-19.

${ }^{53}$ Dallin, Soviet Foreign Policy, 296. On the conference, see Sinigoj, Indien und Blockfreiheit, $97-$ 118; Westad, The Global Cold War, 99-103.

${ }_{54}$ Andreas Hilger, "Moskau und die Entwicklungsländer," in Stefan Karner et al. (eds.), Der Prager Frühling: Das internationale Krisenjahr (Vienna: Böhlau, 2008), 299-319, 303.

${ }_{55}^{5}$ Sinigoj, Indien und Blockfreiheit, 119.

${ }_{56}$ Dallin, Soviet Foreign Policy, 295.

${ }^{57}$ Quoted in Fursenko and Naftali, Khrushchev's Cold War, 82. 
the sterling area as the main trading partner of Burma. ${ }^{58}$ In the following years, the Soviet Union was a partner in the settlement leading to the neutrality of Laos in 1962 and, in the same year, it also recognized the neutrality of Cambodia, which had been declared in 1957..59 Egypt, Afghanistan, Mali, Burma, India, Indonesia were applauded in Soviet statements as "having a neutral policy." 60

The Soviet re-evaluation of neutrality was also reflected in praise for the Swiss status ${ }^{61}$ and Sweden's neutral policy, ${ }^{62}$ as well as by the recognition of Finnish neutrality. Scandinavia in particular, with its delicate Nordic Balance between NATO members Iceland, Denmark, and Norway (the latter two without foreign soldiers on their soil), neutral Sweden, and the special case Finland, as well as its strong leanings towards nuclear disarmament, was chosen by Soviet policy to be another test case for "peaceful coexistence" and neutralization. In 1948, Finland, which had been attacked by the USSR in 1939 and fought a "Continuation War" until 1944, rejected the Soviet offer of a military alliance, but was forced to agree to a Treaty of Friendship, Cooperation and Mutual Assistance. ${ }^{63}$ This treaty included three main stipulations: Finland was obliged not to tolerate foreign military bases (other than Soviet) on its soil, nor being used for aggression towards the USSR; the Soviet government recognized Finland's aspirations for staying outside the conflicts of the great powers; if unable to cope with an invasion by Germany or a state allied with it, Finland was to consult the Soviet government, which in this case would be ready to render military assistance. Both sides claimed that this treaty did not contradict Finnish neutrality, which was explicitly recognized by Khrushchev in 1956 at the twentieth congress of the CPSU. ${ }^{64}$ For more than thirty years, Finnish neutrality, much like the status of Austria, allowed the Soviet Union to hold the respective country "on a

\footnotetext{
${ }^{58}$ Boden, Die Grenzen der Weltmacht, 136-140, 171; Dallin, Soviet Foreign Policy, 306.

${ }_{59}$ Mojoryan [Modzhorian], "Neutrality in Present-Day International Law," 222-226.

60 "Neitralitet Postoiannyi," in A.A. Gromyko, S.A. Golunskii, and V.M. Khvostov (eds.), Diplomaticheskii slovar' 2, 2nd ed. (Moscow: Gospolitizdat, 1961), 396-397, 396; Modzhorian, Politika neitraliteta, 26-27.

${ }^{61}$ W. Durdenewski, "Zur schweizerischen Neutralität," Neue Zeit, no. 22 (1955), 28-30.

62 The Swedish-Soviet communiqué of 3 April 1956, quoted in Modzhorian, Politika neitraliteta, 9; 30; M. Andreyeva and K. Dmitrieva, "The Soviet Union and Swedish Neutrality in the Second World War," in International Affairs, no. 9 (September 1959), 66-71.

63 Jussi M. Hanhimäki, Containing Coexistence: America, Russia, and the "Finnish Solution," 1945-1956 (Kent, Ohio: Kent State University Press, 1997), 26-28; John Vloyantes, "Finland," in S. Victor Papacosma and Mark R. Rubin (eds.), Europe's Neutral and Nonaligned States: Between NATO and the Warsaw Pact (Wilmington: Scholarly Resources, 1989), 137-159, 141-145. On Finnish neutrality, cf. Max Jacobson, Finnish Neutrality: A Study of Finnish Foreign Policy since the Second World War (London: Hugh Evelyn, 1968); Roy Allison, Finland's Relations with the Soviet Union, 1944-84 (New York: St. Martin's Press, 1985); Max Jacobson, Finland in the New Europe (Westport: Praeger, 1998).

${ }^{64}$ Chruschtschow, Rechenschaftsbericht des Zentralkomitees der Kommunistischen Partei der Sowjetunion an den XX. Parteitag 14. Februar 1956, 51.
} 
leash." ${ }^{\prime 5}$ Even before Finland's neutrality was recognized, Khrushchev offered the Finnish president, Juho Paasikivi, who was in Moscow in September 1955, a special package that aimed at creating another showcase of Soviet generosity while securing the victory of a pro-Soviet candidate in the forthcoming presidential elections: The Finns had to sign an extension of the Soviet-Finnish treaty for another twenty years; in return, the Soviet naval base in Finnish Porkkala would be relinquished in January 1956 and Finland would be admitted into the UN. When the Norwegian, Danish, and Swedish prime ministers Einar Gerhardsen, Hans Christian Hansen, and Tage Erlander successively visited Moscow in late 1955 and early 1956, they were received with Soviet words of praise for neutrality and given the suggestion of making northern Europe a neutral "zone of peace." ${ }^{66}$ Khrushchev revealed to Hansen that the Kremlin would "shake NATO loose with peace initiatives" ${ }^{167}$ and in January 1956, the Communist Party of Sweden issued an appeal to the government to make Swedish neutrality internationally binding. ${ }^{68}$ Earlier Soviet attempts to woo Norway out of NATO had also used the attraction of neutrality. ${ }^{69}$ Iceland was offered a Soviet guarantee, if it chose to expel US forces and declare itself neutral. The initiative, which was combined with threats of the catastrophic consequences that the deployment of nuclear weapons would have for the host country, was not in vain: Denmark and Norway ruled out the deployment of such weapons on their soil, while the Icelandic parliament demanded a withdrawal of US troops and changed its mind only after the Soviet intervention in Hungary. Although the three NATO members remained firmly integrated into the alliance, the USSR, by accepting Finland's neutrality, had more leverage on the situation in Scandinavia if it did not force Finland into a closer alliance - a step that might have induced Sweden to join the Atlantic defense and its western neighbors to invite US bases onto their soil. Thus, when in the coming years the Soviet Union used pressure on Finland for communicating disagreement with perceived shifts in the strategic balance in Europe's north, it had to be careful not to try the Scandinavians' patience too far. ${ }^{70}$

${ }^{65}$ Hanhimäki, "The Lure of Neutrality: Finland and the Cold War," 263.

${ }^{66}$ Bernd Bonwetsch, "Sowjetische Westeuropapolitik II," in Dietrich Geyer (ed.), Osteuropa-Handbuch Sowjetunion: Außenpolitik 1955-1973 (Cologne: Böhlau, 1976), 146-228, 209-215. On the return of Porkkala, cf. Jussi M. Hanhimäki, "Containment, Coexistence, and Neutrality: The Return of the Porkkala Naval Base as an Issue in Soviet-American Relations, 1955-1956," in Scandinavian Journal of History 18, no. 3 (1993), 217-228.

${ }^{67}$ Quoted in Hanhimäki, "The Lure of Neutrality: Finland and the Cold War," 266.

${ }^{68}$ Sven Allard, Diplomat in Wien: Erlebnisse, Begegnungen und Gedanken um den österreichischen Staatsvertrag (Cologne: Wissenschaft und Politik, 1965), 218.

${ }^{69}$ Martti Häikiö, "Finland's Neutrality 1944-1994," in Michael Gehler and Rolf Steininger (eds.), The Neutrals and the European Integration, 1945-1995 (Vienna: Böhlau, 2000), 199-217, 205206.

${ }^{70}$ Conversely, had Denmark and Norway invited US troops or Sweden moved closer to NATO, the USSR would have probably drawn Finland fully into its orbit. Seppo Hentilä, "The Soviet Union, Finland, and the 'Northern Balance,"” in Wilfried Loth (ed.), Europe, Cold War, and Coexistence, 
In the years from 1955 till 1959, the Soviet Union promoted the adoption and exercise of neutrality not only by Austria, the Third World, and the Scandinavian countries, but also by other Western allies such as West Germany, Italy, Greece, Turkey, and Japan. ${ }^{71}$ All NATO members were warned of or threatened with disastrous consequences in the event of a war. In the case of Japan, Soviet proposals in 1958 and 1961 aimed at neutralizing the country and clearing it of US troops. In the case of Italy, Soviet offers were made to guarantee this country's neutrality and security - an offer that would later be extended to Austria. In order to make neutrality more attractive for West Germany, it was underlined that this status would not preclude its unification with "another state." 72 During the Berlin crisis, Khrushchev, in his struggle to rid West Berlin of the protection by the Western powers and to let the GDR "swallow" it, suggested "neutralizing" the western part of the city and replacing the Western garrison in the city with armed forces from neutral countries, thus aiming at weakening West Berlin's defense and flattering the self-esteem of the neutrals.

On as many official occasions as possible, Soviet leaders praised the benefits of neutrality: At the twentieth congress of the CPSU in 1956, the "strengthening of the amicable relations" to Asian nonaligned countries and European neutrals such as Finland and Austria was lauded as a major achievement of Soviet foreign policy. ${ }^{73}$ The communist world conference in Moscow in November 1960 welcomed the activities of the neutral and nonaligned countries for "peace and peaceful coexistence," "74 and at the twenty-second CPSU congress in 1961, Khrushchev commended all neutralists for "not being neutral with regard to the main question of our times, the question of war or peace," and assured them again of their unwavering Soviet support. ${ }^{75}$

In order to be better able to promote neutrality in the West, Soviet official and propaganda statements quickly developed a neutrality "myth." This myth under-

1953-1965 (London: Frank Cass, 2004), 239-257, 240. Cf. John Logue, "Sweden," in S. Victor Papacosma and Mark R. Rubin (eds.), Europe's Neutral and Nonaligned States: Between NATO and the Warsaw Pact, (Wilmington: Scholarly Resources, 1989), 71-102, 89; Raimo Väyrynen, "Adaptation of a Small Power to International Tensions: The Case of Finland," in Bengt Sundelius (ed.), The Neutral Democracies in the New Cold War (Boulder: Westview, 1987), 33-56, 51; Karl Molin, "Central Issues of Swedish Neutrality Policy," in Michael Gehler and Rolf Steininger (eds.), The Neutrals and European Integration (Vienna: Böhlau, 2000), 261-275, 264; Neuhold, "The Neutral States of Europe," 115.

${ }^{71}$ Modzhorian, Politika neitraliteta, 21-24; 30-31; Hakovirta, "The Soviet Union and the Varieties of Neutrality," 580.

${ }^{72}$ Ganiushkin, Neitralitet i neprisoedinenie, 113-116.

${ }^{73}$ Chruschtschow, Rechenschaftsbericht des Zentralkomitees der Kommunistischen Partei der Sowjetunion an den XX. Parteitag 14. Februar 1956, 51.

${ }^{74}$ Erklärung der Beratung von Vertretern der kommunistischen und Arbeiterparteien in Moskau, November 1960, in Schenk, Kommunistische Grundsatzerklärungen 1957-1971, 104.

${ }^{75}$ N.S. Khrushchev, Otchet Tsentral'nogo Komiteta Kommunisticheskoi partii Sovetskogo Soiuza XXII s"ezdu partii (Moscow: Gospolitizdat, 1961), 32, 8. 
lined the moral qualities of neutrality and stressed various benefits that were allegedly ready to be harvested by neutrals, such as friendly relations with all states, including the USSR, low defense spending, and thus the availability of more resources for welfare. ${ }^{76}$ In this myth, neutrality was depicted as a status enabling the respective country to maintain "peaceful and mutually beneficial relations" with the Eastern bloc. The benefits of neutrality were contrasted with the disadvantages of membership in Western alliances by Soviet politicians and legal experts, who claimed that "life shows that those capitalist states maintaining the policy of neutrality receive enormous political and economic benefits from it." ${ }^{17}$ Other capitalist states, such as West Germany and Japan, it was stated, had lost their sovereignty and security and had to live under the constant threat of being transformed into the battlefield of a nuclear war. However, the threat of nuclear annihilation applied also to those neutrals that, like Switzerland, declined to abdicate nuclear weapons. ${ }^{78}$ Similar claims were maintained by Khrushchev on many occasions. With regard to the benefits of neutrality, the leader, in an interview with an Italian newspaper correspondent in 1958, developed the thesis that neutrality increased the security of the neutrals and the globe, reduced international tensions and military expenditures, and raised the prestige of the neutral countries ${ }^{79}$ - a claim that found its way into the second edition of the official Diplomatic Handbook of the USSR.$^{80}$ However, it was also part of the Soviet "song of neutrality" that neutrals had always to be on their guard to not be recruited by "imperialists" for their "aggressive blocs." ${ }^{181}$ Since the neutrals had extricated themselves from the Western club, they, according to Soviet propaganda, attracted the "implacable enmity of their late overlords, whose determination to return the heretics to the fold posed a mortal threat to the survival of these seditionist regimes." $" 82$

${ }^{76}$ Speech by N.S. Khrushchev during a breakfast at the Austrian president, 30 June 1960, in Druzhestvennyi vizit: Prebyvanie Predsedatel'ia Soveta Ministrov SSSR N.S. Khrushchëva v Avstriiskoi Respublike 30 iiuniia-6 iiulia 1960g. (Moscow: Gospolitizdat, 1960), 15-17, 16; "Im Interesse beider Länder," in Neue Zeit, no. 19 (1957), 9-10; "Das Jubiläum der österreichischen Neutralität," in Neue Zeit, no. 21 (1965), 9; Amtsvermerk, Sowjetische Presse zum österreichischen Nationalfeiertag, 10 November 1971, in ÖStA, AdR, BMAA, II-Pol, GZ. 105.880-6/71, Z.121.033; G. Chernikov, "Europe's Smaller Countries in the Capitalist System," in International Affairs, no. 1 (January 1982), 105-111.

77 Modzhorian, Politika neitraliteta, 24.

${ }^{78}$ Mikoian in a conversation with the Austrian ambassador. Bischoff to Austrian MFA, 15 July 1958, in ÖStA, AVA, NL E/1770: Bischoff, File 108.

${ }^{79}$ Nikita S. Khrushchev, "Replies to Questions Put by Giuseppe Palozzi, Il Tempo Correspondent, March 24, 1958," in idem, For Victory in Competition with Capitalism (New York: Dutton, 1960), 231-248.

80 "Neitralitet," in A.A. Gromyko, S.A. Golunskii, and V.M. Khvostov (eds.), Diplomaticheskii slovar' 2, 2nd ed (Moscow: Gospolitizdat, 1961), 392-395, 394.

${ }^{81}$ Ganiushkin, Sovremennyi neitralitet, 3.

${ }^{82}$ Ginsburgs, "Neutralism à la Russe," 21. 
The Soviet theory of neutrality in the late 1950s and 1960s

The advent of "peaceful coexistence" and the changes in Soviet foreign policy regarding neutrality and neutralism in Western Europe, Asia and Africa were accompanied by the dawning of a new period in the development of the Soviet theory of international law. Early signs of these changes can already be noticed in 1955 and, in the context of the twentieth congress of the CPSU, the new theory was codified, with "peaceful coexistence" being officially adopted as a foreign policy doctrine. ${ }^{83}$ Outwardly less revolutionary than before, the new dogma of international law, as outlined by its champion, the head of the Soviet Foreign Ministry's Legal Department and Soviet representative in the UN Commission for International Law, Professor Grigorii Tunkin, contained, as its main feature, the acceptance of one universal system of international law. ${ }^{84}$ While some Western experts, as for instance Alfred Verdross, had voiced similar ideas, ${ }^{85}$ the new Soviet thesis differed from both the predominant Western opinion, in which such a legal system could only be created if all contracting parties had a minimum of common convictions, and the hitherto valid Soviet doctrine that there were two distinct sets of international law, communist and bourgeois. ${ }^{86}$ While the latter teachings had been appropriate in revolutionary or isolationist times, the new dogma seemed to better serve the integration of the USSR into the international system based on a lasting, albeit limited, "peaceful coexistence." In Marxism-Leninism, national law had always been seen as part of the superstructure of human societies and shaped by economic roots and the interests of the ruling classes; international law, however, Tunkin argued, was created by international custom and agreements. ${ }^{87}$ Since such agreements had been concluded between bourgeois and socialist states, international law was characterized as being universal. ${ }^{88}$ As in the interwar period, this change seemed to be a

${ }^{83}$ Meissner, Sowjetunion und Völkerrecht, 57-59; Erickson, International Law and the Revolutionary State, 14-16; Menzel, "Vorwort," xviii.

${ }^{84}$ Bracht, Ideologische Grundlagen der sowjetischen Völkerrechtslehre, 62.

${ }^{85}$ Alfred Verdross, Völkerrecht, 3rd ed. (Vienna: Springer, 1955), iv, 11. The Russian translation appeared under the title Mezhdunarnodnoe pravo (Moscow: Izdatel'stvo IL, 1959).

${ }^{86}$ Kelsen, The Communist Theory of Law, 156.

${ }^{87}$ G. I. Tunkin, Osnovy sovremennogo mezhdunarodnogo prava (Moscow: Vysshaia partiinaia shkola TsK KPSS, 1956). I have used the German edition: G. I. Tunkin, "Grundlagen des modernen Völkerrechts," in Drei sowjetische Beiträge zur Völkerrechtslehre (Hamburg: Hansischer Gildenverlag, 1969), 1-57, 3: "International law is the entirety of norms that are created by way of agreements between states, that regulate their relations in the process of war and cooperation, that express the will of the ruling classes of these states, and that are implemented by the states either individually or collectively, and, if necessary, by force." Cf. the definition by Tunkin's rival, the earlier mastermind of Soviet international law E.A. Korovin. "Begriff, Quellen und System des Völkerrechts," 1.

${ }^{88}$ Tunkin,"Grundlagen des modernen Völkerrechts,” 7. Cf. Lewin and Kaljushnaja, Völkerrecht, 16-18. It should be noted, however, that the relations between socialist states were exempt from universal international law. See above, page 20. 
concession to the needs of Soviet foreign policy; Khrushchev was quoted as having said: "We know very well that without respecting the norms of international law and fulfilling the assumed obligations in international relations there can be no trust; without trust, there can be no peaceful coexistence." ${ }^{89}$

Because achieving such coexistence had become a central task of Soviet foreign policy, it followed to agree on international norms being universal. This goal was linked with the second main feature of the Soviet theory of international law under Khrushchev's auspices, the attempt of equating the general principles of international law that had been recognized in the Charter of the United Nations (such as nonaggression, noninterference in internal affairs, the peaceful settlement of disputes, equal rights, the respect for sovereignty and territorial integrity) with the Soviet concept of "peaceful coexistence." "Since the latter comprised further obligations (such as decolonization, disarmament, a ban on hostile propaganda and others), the process aimed at making the Soviet principles internationally binding. ${ }^{91}$ In general, the new Soviet dogma of international law combined revolutionary postulates (e.g. recognizing "wars of liberation" as legal) with traditional values (e.g. the cult of sovereignty). While the former strove at fostering a legal basis for insurrection against colonial powers, the latter was to ward off Western influence in inner-Soviet or inner-socialist affairs such as issues of human rights or selfdetermination..$^{92}$

It can be argued that the new Soviet theory of international law, in particular its more flexible approach towards Western international law, made it easier for Soviet academics to deal with Western concepts such as neutrality. In any case, the new Soviet political attitude towards neutrality also triggered Soviet academic efforts to intellectually and legally substantiate the recently rediscovered status and to develop it into a genuine theory. ${ }^{93}$ Soviet theory differentiated between wartime and peacetime neutrality, with the latter falling under permanent or "positive" neutrality: While the first was characterized as having existed since the "age of slavery," per-

${ }^{89}$ „Wir wissen sehr gut, dass es ohne Einhaltung der Normen des Völkerrechts, ohne Erfüllung der übernommenen Verpflichtungen in den zwischenstaatlichen Beziehungen kein Vertrauen und ohne Vertrauen keine friedliche Koexistenz geben kann." Quoted in G. I. Tunkin, Das Völkerrecht der Gegenwart (Berlin: Staatsverlag der DDR, 1963), 181.

${ }^{90}$ [Korowin,] "Begriff, Quellen und System des Völkerrechts," 1; Tunkin, Das Völkerrecht der Gegenwart, 25-57; 164-172.

${ }^{91}$ Schweisfurth, "Entwicklung und ideologische Grundlagen der sowjetischen Völkerrechtstheorie," 44; Meissner, Sowjetunion und Völkerrecht, 78-79; Bracht, Ideologische Grundlagen der sowjetischen Völkerrechtslehre, 104-105; Uibopuu, Die sovjetische Doktrin, 218-231.

${ }^{2}$ Menzel, "Vorwort," xx-xxii.

93 Among other works, see, e.g., Ganiushkin, Sovremennyi neitralitet; Modzhorian, Politika neitraliteta; Ganiushkin, Neitralitet i neprisoedinenie; Tiunov, Neitralitet $v$ mezhdunarodnom prave. For an in-depth analysis of Soviet literature of the 1960s regarding neutrality, see Gerhard Hafner, "Die permanente Neutralität in der sowjetischen Völkerrechtslehre - Eine Analyse," in Österreichische Zeitschrift für öffentliches Recht 19, no. 2-3 (1969), 215-258. 
manent neutrality was seen as a product of the "age of capitalism and imperialism"; positive neutrality, the most recent phenomenon, was declared an outcome of the "age of coexistence," which was marked by the appearance of the Soviet state on the international scene. ${ }^{94}$ It was claimed by Soviet scholars that the meaning of neutrality had changed through these different periods of time; wartime neutrality had often been misused to the aggressor's advantage and the victim's detriment and thus, only contemporary positive neutrality could be recognized as "true" neutrality. ${ }^{95}$

In a note on 7 March 1955 to the Netherlands, the depositary country of the Hague Conventions of 1907, the Soviet Union subscribed to this international document defining wartime neutrality. Therefore, it does not come as a surprise that the contemporary Soviet interpretation of wartime neutrality was similar to that in the West. It included, among other duties: 1) nonparticipation in hostilities; 2) refusal to lend military help or military deliveries to the combating parties; 3 ) refusal to make the neutral's territory available for military use, including military action, military transports or recruitment of forces; 4) internment of military personnel of the combating parties; 5) equal treatment of all belligerents; 6) the defense of neutrality. A declaration of neutrality was not deemed necessary. ${ }^{96}$ According to the contemporary Soviet interpretation, wartime neutrality did not curb the right of the neutral to, e.g., 1) maintain self-defense; 2) have its territorial integrity respected; 3 ) conclude agreements and conduct negotiations and trade of a nonmilitary character; 4) intern the military personnel of the combating parties; 5) allow the transport of injured personnel of the combating parties if no weapons were being carried; 6) terminate its neutrality by entering the war, if the neutrality had not been based on a legal obligation. ${ }^{97}$ Even according to the Soviet theory, wartime neutrality did not limit the freedom of opinion or the press, nor did it oblige the neutral to abstain from conducting trade with the combating parties, with the exception of contraband. ${ }^{98}$ The subscription to the Hague Conventions did not rule out the Soviet criticism, albeit unofficial, that in the age of "coexistence" there was no general "right to war," and thus, wartime neutrality should follow Marxism-Leninism in distinguishing between just and unjust wars and between aggressors and victims. Some scholars went as far as claiming that, due to the general ban on war, wartime neutrality would soon disappear. ${ }^{99}$

${ }^{94}$ Ganiushkin, Neitralitet i neprisoedinenie, 7-18.

${ }_{95}$ Modzhorian, Politika neitraliteta, 3-4.

${ }^{96}$ Akademie der Wissenschaften der UdSSR - Rechtsinstitut (ed.), Völkerrecht: Lehrbuch (Berlin: VEB Deutscher Zentralverlag, 1960), 442-443; F.I. Koschewnikow, "Die Gesetze und Gewohnheiten des Krieges," in idem (ed.), Völkerrecht (Hamburg: Hansischer Gildenverlag, 1960), 415-469, 458-459.

97 Tiunov, Neitralitet $v$ mezhdunarodnom prave, 85-86.

${ }_{98}$ Ganiushkin, Neitralitet i neprisoedinenie, 13.

99 Tiunov, Neitralitet v mezhdunarodnom prave, 103-106. Cf. Stelianos Scarlis, Neutralität in Europa aus sowjetischer Sicht im Zeitalter der Entspannung: Die Rolle der neutralen Staaten Europas in der Außenpolitik der Sowjetunion 1969-1975 (Munich: Tuduv, 1984), 46-47. 
Contrary to the Western concept of neutrality, the Soviet interpretation of the late 1950s and the 1960s put a focus on peacetime obligations. ${ }^{100}$ This was, at least in part, due to the circumstances of the Cold War under which this new interpretation of neutrality emerged, i.e. the "coexistence" of two blocs with their tense struggle for political influence over as many countries as possible, albeit in the absence of a general war. This shift from wartime to peacetime obligations was legitimized by Soviet legal experts by referring to the nuclear threat, the emergence of the United Nations Organization, ${ }^{101}$ the changes in the international balance of forces, i.e. the rise of the socialist camp and the creation of a nonaligned one,${ }^{102}$ and a "general change in international law, which today not only strives at struggling against existing aggression, but also above all at preventing it.".103

The Soviet theory of international law gradually developed its own interpretation of peacetime neutrality. ${ }^{104}$ As we have seen above, ${ }^{105}$ the peacetime obligations of a permanently neutral state are poorly defined in Western international law. The absence of a generally accepted international doctrine was criticized by Soviet lawyers, who took on the task of formulating a set of rules that reflected the Soviet interest in turning both neutrals and nonaligned into useful promoters of Soviet policy. Numerous articles and monographs were written by Soviet experts, including Lidiia Modzhorian, Boris Ganiushkin and Oleg Tiunov, who aimed at (re-)defining and codifying internationally binding rules for neutral policy in times of peace. ${ }^{106} \mathrm{~A}$ major step in codifying the Soviet doctrine of neutrality and making it legally binding was made in the "Resolution on the Legal Aspects of Neutrality," adopted by the seventh conference of the Soviet-sponsored International Association of Democratic Lawyers, which took place in Sofia, Bulgaria, from 10 to 14 October $1960 .{ }^{107}$ During the conference it was stressed that it was necessary to analyze which stipulations of classic neutrality were still valid, which had grown obsolete, and which new obligations and rights of peacetime neutrals should be codified. A commission was set up to work out a new definition of neutrality. Soviet demands ${ }^{108}$ were hereby cast

100 "Neitralitet," in A. Ia. Vyshinskii (ed.), Diplomaticheskii slovar' 2, 1st ed. (Moscow: Gospolitizdat, 1950), 230-234; and "Postoiannyi Neitralitet," ibid., 439-440.

${ }^{101}$ Koschewnikow, "Die Gesetze und Gewohnheiten des Krieges," 469.

102 Ganiushkin, Neitralitet i neprisoedinenie, 9.

${ }^{103}$ M. I. Lazarev and V. K. Sobakin, in F. I. Kozhevnikov (ed.), Mezhdunarodnoe pravo (Moscow: Mezhdunarodnye otnosheniia, 1966), 599. Quoted in Hafner, "Die permanente Neutralität," 224.

104 Fiedler, Der sowjetische Neutralitätsbegriff, 100-105, 225-265.

105 See above, page 42 .

106 This aim is mentioned explicitly in Mojoryan [Modzhorian], "Neutrality in Present-Day International Law," 219; Tiunov, Neitralitet v mezhdunarodnom prave, 122; 142.

107 International Association of Democratic Lawyers (ed.), Legal Aspects of Neutrality: Proceedings of the Third Commission (Brussels: International Association of Democratic Lawyers, 1960), 113-114. Cf. Modzhorian, Politika neitraliteta, 11. For the full text of the resolution, see below, pages 327-328.

108 The Soviet delegate, Lidiia Modzhorian, had demanded the inclusion of the following obligations: 1) nonparticipation in military blocs and pacts; 2) a formal ban against foreign bases or forces on 
into legal sounding formulas and used to supplement the original stock. The end product thus emerged "as a curious mix composed in relatively equal proportions of 1) familiar principles of international law pertaining to wartime neutrality retooled for peacetime service and attuned to the spirit of the politics of nonalignment and 2) planks from the political platform of the movement of nonaligned countries dressed up as normative prescriptions to justify insistence upon strict compliance with their terms." ${ }^{109}$ The result contained "traditional Western concepts, adaptation to the realities of the politics of neutrality in today's Europe, and efforts to persuade the European neutral states to support the "peace policies' of the socialist camp." 110 This rather demanding definition concerning neutrals' peacetime obligations was published and later incorporated into semi-official Soviet publications. ${ }^{111}$

The teachings of the late 1950s and early 1960s distinguished between permanent neutrality (which was founded either on an international agreement or a national declaration that was recognized by other states) and "positive" or "active" neutrality or "neutral policy" (which was in the majority of cases declared unilaterally and a synonym for neutralism or nonalignment). ${ }^{112}$ According to the Soviet theory, the differences between permanent neutrality and neutralism were mainly formal ones: While permanent neutrality was an institute of international law and the permanent neutrals were legally obliged to maintain wartime neutrality and, in peacetime, to conduct a neutral policy, ${ }^{113}$ positive neutrality was merely a course of peacetime foreign policy, based on free will and without any legal obligations. The permanent neutral was bound "to permanently maintain neutrality, never to start a war, and to refrain from conducting a policy that might lead to war," and, therefore, "not to partake in military blocs or groupings, to ban the presence of foreign troops on their soil, and to maintain friendly relations with all states." ${ }^{114}$ Another

the neutral's territory; 3) a ban on nuclear weapons; 4) good relations with all states; 5) no aid to any aggressor. Legal Aspects of Neutrality, 111-112.

109 Ginsburgs, "Neutralism à la Russe," 19.

${ }^{110}$ Hakovirta, "The Soviet Union and the Varieties of Neutrality," 582.

111 "Neitralitet," in A. A. Gromyko, I. N. Zemskov, and V. M. Khvostov (eds.), Diplomaticheskii slovar' 2, 3rd ed. (Moscow: Politizdat, 1973), 373-374, 373.

112 See, for instance, "Neitralitet Pozitivnyi," and "Neitralitet Postoiannyi," in A.A. Gromyko, S. A. Golunskii, and V.M. Khvostov (eds.), Diplomaticheskii slovar' 2, 2nd ed. (Moscow: Gospolitizdat, 1961) 395; 396-397; Ganiushkin, Sovremennyi neitralitet, 15 . The subject is analyzed in great detail in Fiedler, Der sowjetische Neutralitätsbegriff, 84-89; Scarlis, Neutralität, 44-53. With respect to the various ways of adopting the status of positive neutrality, Tiunov mentions the following possibilities: 1) a unilateral declaration; 2) a bilateral communiqué or treaty; 3) a multilateral conference. Furthermore, Tiunov makes the case that neutralism was in the process of transforming itself into an institute of international law and, therefore, should be codified at an international conference sponsored by the UN. Tiunov, Neitralitet $v$ mezhdunarodnom prave, 5-7; 124; 139 $143 ; 156-157$. This latter demand was rejected by Ganiushkin. Scarlis, Neutralität, 48-49.

113 Ganiushkin, Sovremennyi neitralitet, 16, 83-84, 86.

114 Lewin and Kaljushnaja, Völkerrecht, 112. Cf. Ganiushkin, Sovremennyi neitralitet, 83-84: A permanently neutral state must "refrain from war except in self-defense and, in peacetime, follow 
formal difference between permanent and positive neutrality was that the former was regarded valid only if internationally notified and recognized. ${ }^{115}$ As in Western international law, the notification and recognition of neutrality were seen as creating a contractual relationship between a neutral state and other states: "As long and insofar the permanently neutral state fulfills his obligations, the other states are, according to international law, obliged to respect his permanent neutrality." 116

Here, however, the differences between permanent and positive neutrality, as based on the Soviet theory, ended. Soviet politicians and publications stressed that both groups, i.e. permanent as well as positive neutrals, had to conduct a neutral policy in peacetime (one by obligation, the other by free will) and refused to see any difference with regard to peacetime obligations. Ganiushkin postulated that

\footnotetext{
"regarding the comprehensiveness and character of the measures taken to carry out a policy of neutrality, there can be no difference between permanently neutral countries and countries that follow the path of nonalignment. However, there is a difference with regard to the fact that in general, nonaligned countries conduct a policy of nonalignment only by virtue of a unilateral declaration of intention, whereas permanently neutral states conduct such a policy on the basis of an international agreement." 117
}

Since the peacetime policy of permanently neutral and nonaligned countries was subsumed under "neutral policy," the differences between the foreign policies of countries as diverse as India, Yugoslavia, Finland, Austria, and Switzerland were blurred. ${ }^{118}$ Even more importantly, the Soviet claim that in peacetime permanent

neutral policies, i.e. not partake in military alliances and coalitions, not conclude agreements that might draw the permanently neutral state into a war, and strengthen the friendship with other states." Cf. Tiunov's definition: "Permanent neutrality is a status in international law of a sovereign state that is, according to a unilateral expression of will or an international contract, obliged not to participate in any war except in the case of self-defense, and, in peacetime, to conduct a policy that prevents him from being entangled in a war, i.e. not to enter military alliances, not to allow the locating of foreign military bases on its territory, not to conclude treaties that foster an economic or a political preparation for war, and not to provide its army with weapons of mass destruction, as well as obliged to struggle actively for peace and peaceful coexistence." Tiunov, Neitralitet $v$ mezhdunarodnom prave, 21.

115 Tiunov, Neitralitet $v$ mezhdunarodnom prave, 49. While Tiunov and Ganiushkin, Sovremennyi neitralitet, 94, deemed tacit recognition possible, the same was considered insufficient by Ganiushkin in Neitralitet $i$ neprisoedinenie, 114-115. Nonetheless, Ganiushkin declares that all countries which have recognized neutrality "either explicity or tacitly" are obliged to respect it. Ibid., 127. Cf. Hafner, "Die permanente Neutralität," 238. In any case, declaring neutrality without notification was not deemed sufficient for establishing permanent neutrality.

116 Ganiushkin, Sovremennyi neitralitet, 16.

117 Ganiushkin, Neitralitet i neprisoedinenie, 113.

118 In the East German edition of Tunkin's Voprosy teorii mezhdunarodnogo prava (Moscow: Gospolitizdat, 1962), references to "neutral states" do not differenciate between nonaligned and European neutrals. Tunkin, Das Völkerrecht der Gegenwart, 178, 181, 190. See also "Neutrality," in A. M. Prokhorov et al. (eds.), Great Soviet Encyclopedia 17, 3rd ed. (New York: Macmillan, 1974), 518-519; "Neprisoedineniia printsip," in A. M. Prokhorov et al. (eds.), Bol'shaia Sovetskaia Entsiklopediia 17, 3rd ed. (Moscow: "Sovetskaia entsiklopediia," 1974), 498-499. On the 
neutrals were legally obliged to follow the same foreign policy as the nonaligned massively increased the burden laid on the permanent neutrals. This was, actually, the main feature of the Soviet neutrality doctrine and its main bone of contention for the Western neutrals, which rejected such claims.

While neutrality was defined by Soviet theory as a "means to conserve the peace," it meant not only abstention from war, but also from the Cold War. ${ }^{119}$ This postulate was a clear example of how Soviet political demands were transformed by Soviet experts of international law into legal claims. In addition to nonparticipation in war, military alliances and closed economic blocs, as well as avoidance of any measure that might compel the neutral to join a conflict, including participation in economic embargoes or hostile propaganda against foreign powers, a neutral's international obligations, from the Soviet point of view, also comprised "neighborly" or "friendly" "peaceful relations with all other countries." 120 This concerned, in particular, the neutrals' relations to the socialist states. It aimed at obliging the neutrals to establish ties with socialist states that were not yet recognized by the West, such as the GDR and communist China, and not to partake in Western boycotts against the Eastern bloc.

In general, a neutral was not to be "passively indifferent to all occurrences in the international arena" or even "neutral in the question of war or peace," but to "actively struggle for peace and peaceful coexistence," fighting the "forces of war and imperialism" (i.e. the West), supporting the "forces of peace" (i.e. the Eastern bloc), and thus to augment a "zone of peace." ${ }^{21}$ It was to contribute to a reduction of tensions, promote neutrality, and struggle for all-European security, in short to be "one form of peaceful coexistence." 122 The active "struggle for peace" and "friendship" was seen as the highest duty of a neutral and as "the main criterion for

following, see Hafner, "Die permanente Neutralität," 225. Cf. L. A. Modzhorian, Politika neitraliteta (Moscow: Mezhdunarodnye otnosheniia, 1962).

119 D.B. Lewin, "Grundprinzipien des modernen Völkerrechts," in Drei sowjetische Beiträge zur Völkerrechtslehre (Hamburg: Hanseatischer Gildenverlag, 1969), 59-306, 225-228; Tiunov, Neitralitet v mezhdunarodnom prave, 119; Mojoryan [Modzhorian], "Neutrality in Present-Day International Law," 219.

${ }^{120}$ Ganiushkin, Sovremennyi neitralitet, 83-84; idem, Neitralitet i neprisoedinenie, 16-17, 118-119, 127; Tiunov, Neitralitet v mezhdunarodnom prave, 5-7. Cf. Fiedler, Der sowjetische Neutralitätsbegriff, 88, 96-103, with further reference to Soviet international-law literature, and Heinz Fiedler, "Neutralität," in C.D. Kernig (ed.), Sowjetsystem und demokratische Gesellschaft: Eine vergleichende Enzyklopädie 4 (Freiburg: Herder, 1971), 782-796.

121 E.A. Korovin, "Istoriia mezhdunarodnogo prava," in F.I. Kozhevnikov (ed.), Mezhdunarodnoe pravo (Moscow: Iurizdat, 1957), 24-85, 83; Ganiushkin, Sovremennyi neitralitet, 3; L. Vidyasova, "An Impressive Example of Peaceful Coexistence," in International Affairs, no. 8 (August 1960), 11-15, 13; Ganiushkin, Sovremennyi neitralitet, 15.

${ }^{122}$ Zhiriakov, SSSR - Avstriia, 32. Cf. Modzhorian, Politika neitraliteta, 5; Ganiushkin, Sovremennyi neitralitet, 10; G. Osnitskaya, "Neutrality and the Common Market," in International Affairs, no. 6 (June 1962), 52-55, 52. 
evaluating it." ${ }^{123}$ In Soviet political understanding, it was not possible for a positively or permanently neutral country to be content with its own neutrality, but it had to actively contribute, by means of its neutrality and policies, to a "relaxation of tensions." 124 Neutrality's international function was construed as a contribution towards the spreading of the "zone of peace," "a form of the struggle against the formation of blocs," 125 and a way to "limit the sphere of action of the aggressive NATO bloc" and to weaken its cohesion. Thus, the USSR, unlike the theory of neutrality as held in the West, thought neutrality to be a "means of changing the balance of power rather than preserving it." 126

Some accounts even claimed that, in the event of war, the neutral was not to treat the aggressor and the victim equally. ${ }^{127}$ While such thoughts were a result of the Leninist theory of "just wars," they were hardly reconcilable with the core concept of neutrality. Similarly inconsistent with the Western theory was the Soviet claim that a neutral should join the struggle for decolonization ${ }^{128}$ - a movement that was expected to dismantle Western bases worldwide, disrupt the flow of raw material from the colonies to Western Europe, and thus, to cripple global capitalism and Western power. While permanent neutrality meant the obligation to abstain from any war except for self-defense, in contrast, positive neutrality, in the Soviet understanding, did not comprise such obligation; the armed struggle for decolonization was, in any case, seen as justified.

Such obligations, Soviet publications claimed, were readily accepted by the neutrals:
"Step by step, the states exercising a neutral policy came to the awareness that, in our time, one must not confine oneself to mere nonparticipation in blocs, but rather, if one seeks to conserve and foster peace, one must fight a decisive battle for peace [...].
The states that follow the road of neutrality are not neutral in questions of war and peace; they stand up for peace and peaceful coexistence, for the friendship and cooperation of large and small states, of the peoples of all lands. This is why neutrality under the current conditions is assessed as positive by the Soviet Union and other states of the global socialist community, by Marxist- Leninist parties, and by the international communist and Labor movements." ${ }^{29}$

${ }^{123}$ Ganiushkin, Sovremennyi neitralitet, 8. Cf. idem, Neitralitet i neprisoedinenie, 14-15; 147; 162.

${ }^{124}$ Mojoryan [Modzhorian], "Neutrality in Present-Day International Law," 219, 226. See also Zhiriakov, Sovetskii Soiuz - Avstriia, 29: "The policy of permanent neutrality does not mean indifference regarding international developments but an appropriate contribution to the most important international problems, to the normalization of the situation in Europe, and to the increase of the mutual advantageous cooperation between European countries." Cf. Hafner, "Die permanente Neutralität," 215-220.

125 Zhiriakov, Sovetskii Soiuz - Avstriia, 39.

${ }^{126}$ Cyril E. Black, Richard A. Falk, Klaus Knorr, and Oran R. Young, Neutralization and World Politics (Princeton: University Press, 1968), 45.

127 Koschewnikow, "Die Gesetze und Gewohnheiten des Krieges," 469; International Association of Democratic Lawyers (ed.), Legal Aspects of Neutrality, 114.

128 Tiunov, Neitralitet $v$ mezhdunarodnom prave, 27-29.

${ }^{129}$ Ganiushkin, Neitralitet i neprisoedinenie, 181-184. 
In practice, the Soviet Union expected neutral countries to support Soviet or the "people's democracies" existing initiatives on détente, arms control, nuclear nonproliferation and the banning of nuclear weapons. Furthermore, the USSR, particularly after the experience of 1950 when the United Nations, against Soviet wishes, took active part in the defense of South Korea against communist armed aggression, encouraged neutral and nonaligned countries to join the UN and even its peace missions. ${ }^{130}$ Soviet scientists cited Austria as proof that it was not longer seen as incompatible to be neutral and also a member of the United Nations. Obviously, the Soviet Union was interested not only in making neutrality more attractive by inviting the neutrals into such organizations, but also in benefiting from the neutral countries' support for the Soviet struggle within the international forums. The reason was simple:

"The majority of nonaligned states in the UN support the peace-loving efforts of the USSR and other socialist states, and they stand up together with them. This enlarges the forces of peace in the United Nations Organization, even augments its possibilities for securing peace and security. The change of the balance of forces within the UN, which interrupts the US and other imperialistic states in using the formerly unchallenged 'voting machine,' delights all who hold peace dear."'131

Within the United Nations, neutral states, according to the Soviet doctrine, had to obey the following rule: If the Security Council unanimously, i.e. with Soviet support, sponsored a decision, a neutral state had to follow. If the General Assembly made a decision that was against the Soviet will, the neutrals were expected to remain "neutral" and not to follow. ${ }^{132}$

Another duty of permanent neutrals and nonaligned as claimed in Soviet theory and practice was nondiscrimination and economic equidistance between the blocs. ${ }^{133}$ Hence, the neutrals' participation in schemes of West European integration was ruled out. Both claims were deduced by Soviet theorists from the Hague Conventions on wartime neutrality and, without further legal basis, transferred to the list of the permanent neutrals' peacetime obligations. As far as economic equidistance was concerned, when criticizing the European neutrals' bonds with the West, Soviet experts tended to tacitly overlook the fact that many nonaligned states oriented themselves towards the Eastern bloc. This bias was justified in Soviet statements with the observation that the Eastern bloc, by definition, did not abuse economic links by using them to exert pressure. In fact, the more socialist components spotted in the neutralist's economy, the more "neutralist" it was considered in Soviet eyes. ${ }^{134}$

${ }^{130}$ Modzhorian, Politika neitraliteta, 18-19; Tiunov, Neitralitet $v$ mezhdunarodnom prave, 59-60. Cf. Alexander Dallin, Die Sowjetunion und die Vereinten Nationen (Cologne: Wissenschaft und Politik, 1965), 41.

${ }^{131}$ Ganiushkin, Neitralitet i neprisoedinenie, 213.

${ }_{132}$ Bindschedler-Robert, "Völkerrecht und Neutralität aus sowjetischer Sicht," 161.

${ }^{133}$ Osnitskaya, "Neutrality and the Common Market," 54. Cf. Ganiushkin, Neitralitet i neprisoedinenie, 171; International Association of Democratic Lawyers (ed.), Legal Aspects of Neutrality, 114.

134 Ginsburgs, "Neutralism à la Russe," 28. 
The question of whether neutrals would be allowed or had to defend themselves in the case of war was not unanimously answered by Soviet scholars. ${ }^{135}$ Unanimity existed regarding the demand that the neutrals' armies be moderate in size and the claim that the Swedish and Swiss armies clearly exceeded such dimensions. In addition, there was a Soviet tendency to discount small states' efforts for self-defense as futile. When Sweden, a small neutral, aimed at increasing its deterrence, Soviet propaganda criticized such efforts as obsolete and militaristic, and the Soviet navy and air force systematically violated Sweden's territorial waters and airspace, as if to demonstrate the futility of the neutral's efforts. ${ }^{136}$ This type of policy reflected the consistently one-sided depiction of self-defense in Soviet propaganda in general: While a Soviet build-up of armed forces (including nuclear weaponry and an offensive military doctrine) was hailed as strengthening the peace, Western self-defense was attacked as being aggressive. The neutrals were positioned somewhere in the middle: Since not even TASS dared to claim that the Swedish or Austrian armies were designed to invade the USSR, it aimed at demoralizing them. The possession of nuclear weapons was deemed incompatible with neutrality, for it would increase a neutral's dependence on foreign military technology and also the risk of being destroyed in a war by a nuclear counterattack. ${ }^{137}$ When Switzerland and Sweden, in the late 1950s and 1960s, considered introducing a program for nuclear defense, both countries were fiercely attacked by Soviet propaganda.

Even trickier than self-defense was the issue of freedom of opinion. Leaders of neutral states such as Austria's Julius Raab or Finland's Urho Kekkonen insisted that "our neutrality does not extend to political convictions." 138 Indeed, neither wartime nor peacetime neutrality, even according to Soviet theory, curbs the freedom of opinion or of the press. However, Soviet scholars insisted on a ban against "hostile propaganda" and - not without a side blow against Western ideas such as "freedom of the media" - advised the governments of both permanent and positive neutrals to take action against such behavior:

${ }^{135}$ While Durdenevskii, Tiunov and Ganiushkin, Sovremennyi neitralitet, 93-95, support the opinion that a permanently neutral state is obliged to defend itself, Ganiushkin, Neitralitet i neprisoedinenie, 121-127, casts doubt on whether such obligations were still valid and praises Austrian plans for full disarmament. Levin merely mentions the neutral states' right to defend themselves. Tiunov, Neitralitet v mezhdunarodnom prave, 24; Durdenewski, "Zur schweizerischen Neutralität," 28; Lewin and Kaljushnaja, Völkerrecht, 112. Cf. Scarlis, Neutralität, 48-51; Hafner, "Die permanente Neutralität," 236.

136 Nils Andrén, "Swedish-Soviet Relations: An Overview," in Bo Huldt and Atis Lejins (eds.), European Neutrals and the Soviet Union (Stockholm: The Swedish Institute of International Affairs, 1985), 59-81, 69; 74-75.

137 Hakovirta, "East-West Tensions," 209. Cf. "Neitralitet," in Diplomaticheskii slovar' 2, 2nd ed., 392-397, 396; Ganiushkin, Neitralitet i neprisoedinenie, 121; Tiunov, Neitralitet v mezhdunarodnom prave, 31-33.

${ }^{138}$ Urho Kekkonen, A President's View (London: Heinemann, 1982), 168. 


\begin{abstract}
"It is true that neutrality obliges the state as such, but not its individual citizens. It is also true - as has been mentioned - that international law does not demand that a neutral state conform to socalled ideological neutrality, the neutrality of the press, etc. However, [...] this type of activity from its individual citizens does not conform to the interests of a permanently neutral state as, for example, the propaganda of war, fostering an atmosphere of hostility in relation to a certain country or its representatives, etc. As much as they referred in such cases to 'freedom of conscience,' 'freedom of thought' or other 'democratic rights,' we cannot but remember that in the past, actions of this sort by individual citizens led Switzerland into serious conflicts with other countries. Therefore, it is primarily in the own interests of a permanently neutral state to put a stop to such activities by individuals, as it may draw the neutral state into conflict." 139
\end{abstract}

It is quite telling that the "other country," referred to by the Soviet author when recommending not criticizing foreign powers was Nazi Germany. Indeed, similar ideas had been put forward by German legal experts who had been instrumental in shaping the contemporary Swiss understanding of neutral policy. ${ }^{140}$

Fulfilling all these expectations and tasks (apparently believed by Soviet leaders to work to the Soviet advantage), in Western understanding, would have been interpreted as abandoning neutrality in favor of joining the Soviet "peaceful coexistence" rally. At the very least, it was considered nonalignment rather than neutrality. ${ }^{141}$ From the Soviet point of view, however, these points were declared necessary for being neutral.

While most claims of the Soviet theory of neutral policy could be dismissed as unofficial postulates without legal basis or international relevance - some were even mutually contradictory - the growing catalog of demands was nonetheless increasingly hard to ignore and, if unchallenged by the West, bore the risk of being transformed into legal claims. This threatened to become a constant strife factor, ${ }^{142}$ even more so, because Soviet experts on international law claimed the right of other states to evaluate the policies of each neutral and decide whether its obligations were being properly fulfilled. Only by faithfully observing the Soviet theses, we are told in Soviet statements, can a neutral guarantee that it will not be drawn into future conflicts. ${ }^{143}$

"If the permanently neutral state deviates from fulfilling his obligations of neutrality, then the guarantor and other interested powers may draw this state's attention to the inadmissibility of a unilateral change or the abandonment of the status that is based on a multilateral international

139 Ganiushkin, Neitralitet i neprisoedinenie, 146. Cf. ibid., 13, 118-120.

140 Schweitzer, Dauernde Neutralität, 107.

${ }^{141}$ Scarlis, Neutralität, 41-42. Konrad Ginther, Neutralität und Neutralitätspolitik: Die österreichische Neutralität zwischen Schweizer Modell und sowjetischer Koexistenzdoktrin (Vienna: Springer, 1975), 110, asks whether such a neutrality à la Soviétique is neutrality at all, or rather a terminologically disguised partiality. For a comparative analysis of the European neutrals' dilemma in the East-West conflict, see Hanspeter Neuhold, "The Neutral States of Europe: Similarities and Differences," in Alan T. Leonhard (ed.), Neutrality: Changing Concepts and Practices (Lanham: University Press of America, 1988), 97-144, esp. 122-127.

${ }^{142}$ Hafner, "Die permanente Neutralität," 133.

143 Ginsburgs, "Neutralism à la Russe," 18-19. 
agreement, and use the means at their disposal - with the exception of force or threat thereof - to prevent the status of permanent neutrality being abandoned without the consent of all interested powers." 144

If a neutral country did these things "correctly," it was highly praised by the Soviet side and rewarded. This might include tributes in the news media, other publications, or official statements, or increases in official exchanges or trade and cultural relations. If the Soviet side felt that a neutral was on the right path, the country was encouraged to continue steps in the same direction. If it did not fulfill Soviet expectations, however, it was criticized for not living up to its "international obligations," threatened with negative consequences and told what to do. Attempts at persuasion were made by references to "popular opinion" or a "sober assessment of the facts." In most such cases, the Soviet side relied on an instrumental approach: Since neutrality was portrayed as desirable, undesired actions by neutral states were branded as being at odds with neutrality and inspired by sinister militaristic and imperialistic circles, their local "lackeys," or "unreliable and adventurous elements." Therefore, it was stated that "neutrality" did not allow neutral countries to do what the USSR did not want them to do. ${ }^{145}$ If Soviet demands were neglected too long, reminders of its stipulations were published. Other means of "reminding" a neutral of the Soviet point of view included economic sanctions and political pressure, as were applied, for instance, by the Soviet Union against Finland during the "night frost crisis" of 1958, when the Kremlin, after a change of government in Finland and out of fear of a swing in Finnish policy towards the West, put pressure on the newly-elected cabinet, froze trade negotiations, and withdrew the Soviet ambassador. ${ }^{146}$

Austria's neutrality, its Swiss model, and the Soviet interpretation

Although the Austrian state treaty was one of the first results of the changed Soviet attitude towards neutrality and despite the Kremlin's paramount role in Austria's neutralization, ${ }^{147}$ the Soviet interpretation of neutrality was not automatically adop-

${ }^{144}$ Ganiushkin, Sovremennyi neitralitet, 97.

${ }^{145}$ For an in-depth study of this issue, see Bo Petersson, The Soviet Union and Peacetime Neutrality in Europe: A Study of Soviet Political Language (Stockholm: MH Publishing, 1990).

146 Aappo Kähönen, The Soviet Union, Finland, and the Cold War: The Finnish Card in Soviet Foreign Policy, 1956-1959 (Helsinki: Suomalaisen Kirjallisuuden Seura, 2006), 127-139. The crisis was resolved by Kekkonen, who toppled the coalition and formed a new government that was trusted by the Kremlin. With the "night frost crisis," the USSR increased its say in the composition of Finnish governments. Häikiö, "Finland's Neutrality 1944-1994," 208-209.

147 The term has raised a certain amount of discussion. For some, neutralization means the imposition of neutrality upon a small nation by an international agreement or by more powerful countries - a process that is not legal according to international law. For others, neutralization means the process of becoming neutral. Schweitzer, Dauernde Neutralität, 41-42. Since Austria's neutrality de iure was chosen freely, de facto however imposed by the USSR, some political scientists speak 
ted by Austria. In order to avoid any ambiguity and not to buy a neutrality "pig in a poke," the Western powers already before signing the state treaty, had made it clear that Austria would adopt neutrality only "as it was maintained by Switzerland." And in order to convince the Austrian delegation in Moscow, which had been reluctant to mention neutrality at all, the Soviet side had proposed this definition for the Moscow memorandum. ${ }^{148}$

The roots of Switzerland's neutrality are usually traced back to the Old Confederacy's army's defeat in the battle of Marignano in 1515, which put an end to all Swiss ambitions to become a great power. The idea of neutrality was also fostered by the religious and ethnic diversity of the Alpine cantons - a diversity that made taking sides in the various European religious wars seem a risky undertaking, indeed a risk to the very existence of the Confederation. Squeezed in between France and the Holy Empire, Switzerland henceforth strove at remaining neutral in numerous conflicts. After the Revolutionary and Napoleonic Wars had affected the country, the great powers at the Congress of Vienna fulfilled a Swiss request by officially recognizing this country's permanent neutrality and guaranteeing the inviolability of its territory. ${ }^{149}$ It was after the experience of two world wars, which in many ways challenged Switzerland's status and principles, and in the wake of a new challenge posed by the Cold War, that the Swiss Foreign Ministry, in November 1954, chose to write down the principles of permanent neutrality based on its own understanding. The internal document that was published soon afterwards defined the peacetime obligations of Swiss neutrality as having two main duties: 1) not to start a war, and 2) to be prepared for "defending [the country's] neutrality and independence." 150 Besides these main obligations, the Swiss doctrine contained the secondary duties "to do everything to avoid being drawn into a war and to refrain from anything that might draw [the neutral] into a future war." To this end, the neutral had to "maintain a neutral policy." Although the design of such policy was a "matter of [the neutral's] discretion," the doctrine drafted by law expert Rudolf Bindschedler listed the following points as obligatory: In politics and military matters, Switzerland must not

of Austria's factual neutralization. Ogley, The Theory and Practice of Neutrality, 2; Sigmund Widmer, "Forms of Neutrality," in Joseph Kruzel and Michael Haltzel (eds.), Between the Blocs: Problems and Prospects for Europe's Neutral and Nonaligned States (Cambridge: University Press, 1989), 17-28, 21.

148 Stourzh, Um Einheit und Freiheit, 434-435.

149 Verosta, Die dauernde Neutralität, 35-40. Cf. Edgar Bonjour, Geschichte der Schweizerischen Neutralität (Basel: Helbing und Lichtenhahn, 1978); Mark R. Rubin and Laurent Wehrli, "Switzerland," in S. Victor Papacosma and Mark R. Rubin (eds.), Europe's Neutral and Nonaligned States: Between NATO and the Warsaw Pact (Wilmington: Scholarly Resources, 1989), 43-70, 44-54.

${ }^{150}$ The official Swiss doctrine of neutrality of 26 November 1954, in Schweizerisches Jahrbuch für Internationales Recht (1957), 195-199, 195. Also published in Verosta, Die dauernde Neutralität, 113-117. See also Alfred Verdross, Die immerwährende Neutralität Österreichs (Vienna: Geschichte und Politik, 1980), 38-43. 
join any alliances nor allow the maintenance of foreign bases on its soil. In the economic field, the neutral must not conclude a customs or economic union with stronger partners, since such moves would compromise the country's sovereignty. The Swiss neutrality doctrine rejected the notion of "moral neutrality" or an obligation of the press or the individual to bow to concepts of this kind.

As soon became visible, the Austrian practice of neutral policy deviated in many respects from that of the Swiss, ${ }^{151}$ in particular with regard to Austria's earlier date of joining the United Nations (1955 vs. 2003) and the Council of Europe (1956 vs. 1963), and its not creating a strong army. Suffice it here to say that in 1955 the Swiss doctrine does not seem to have been publicized in Austria. Although the Austrian-Soviet Moscow memorandum mentioned Swiss neutrality in general terms, none of the official Austrian statements of 1955 referred to the Swiss doctrine, and it was publicly discussed by Austrian scholars only from 1967..$^{152}$ The Austrian Constitutional Law on Neutrality, adopted on 26 October 1955, stipulated that Austria

1) "voluntarily declares its permanent neutrality. Austria will maintain and defend [neutrality] by all means at [the country's] disposal.

2) In order to secure these objectives in the future, Austria will not join military alliances nor allow military bases of foreign powers to be created on its soil."."153

The official comments on the government's proposal for the motion explained that Austria was obliged to avoid any "relations that might draw it into a war," especially military alliances and foreign bases. ${ }^{154}$ In addition to this, neutrality would not cause any restrictions with regard to Austria's "design of internal or foreign policy," or the freedom of its citizens and the media. In contrast to the Swiss and, still more, the Soviet doctrine, Austrian leaders in 1955 imagined neutrality merely as a status of nonaggression combined with freedom from alliances and foreign bases. No further document was published to specify the so-called secondary obligations. Chancellor Raab in 1955 claimed that neutrality would "contain no com-

${ }^{151}$ Friedrich Koja and Gerald Stourzh (eds.), Österreich - Schweiz: Ähnlichkeiten und Kontraste (Vienna: Böhlau, 1986); esp. Luzius Wildhaber, "Neutralität, Außenpolitik und internationale Organisationen aus Schweizer Sicht," ibid., 209-227; and Hanspeter Neuhold, "Außenpolitik, dauernde Neutralität und internationale Organisationen aus österreichischer Sicht," ibid. 229-263.

152 Verosta, Die dauernde Neutralität, 79, 113-117; Ermacora, 20 Jahre österreichische Neutralität, 70-71. The first editions of Felix Ermacora, Österreichs Staatsvertrag und Neutralität (Frankfurt am Main: Metzner, 1957), and Alfred Verdross, Die immerwährende Neutralität der Republik Österreich (Vienna: Österreichischer Bundesverlag, 1958), do not contain references to the Swiss doctrine.

153 Text in Ermacora, Österreichs Staatsvertrag und Neutralität, 104. On the genesis of the Neutrality law, see Gerald Stourzh, "Die Entstehungsgeschichte des österreichischen Neutralitätsgesetzes," in Thomas Olechowski (ed.), Fünfzig Jahre Staatsvertrag und Neutralität (Vienna: WUV-Universitätsverlag, 2006), 67-94.

154 Text ibid., 100-103. 
mitments and obligations in economic and cultural areas." 155 This fell short even of the official Swiss neutrality doctrine, with its reference to economic neutrality. With the notable exception of the social democratic party leadership surrounding Bruno Pittermann, who spoke out for this type of neutrality, ${ }_{156}^{15}$ Raab's coalition partner, the SPÖ, like most West European social democratic parties at the time, stressed Austria's bonds to the Western world even more than Raab's own ÖVP and limited neutrality strictly to military matters. Prior to 1955, Bruno Kreisky, the social democratic state secretary in the Foreign Department, avoided mentioning neutrality and preferred instead to use the term "nonalliance" as being something Austria might adopt. ${ }^{157}$ Despite such differences, the Austrian consensus was similar to that of Switzerland or Sweden in that the country's neutral policy included a clear refusal of ideological neutralism. ${ }^{158}$ It was part of this consensus that neutrality bound only the actions of the government, not the right of the country's citizens or the media to state their opinions. ${ }^{159}$

Austrian scholars, for their part, began to develop a neutrality doctrine in the late 1950s. Their champion, Alfred Verdross, defined the following characteristics of permanent neutrality: 1) the obligation to refrain from starting a war and to maintain neutrality in future wars; 2 ) the obligation to defend the country's neutrality and territorial integrity; 3) not to undertake any obligations that might draw the neutral into a war; 4) neutrality can be guaranteed by foreign powers; 5) the neutral remains free with respect to its domestic and foreign policies; 6) there is no obligation for ideological neutrality. ${ }^{160}$ Despite the fact that citizens bore no international obligations, they, in Verdross' view, had the moral duty to their own country to be moderate and honest when criticizing foreign affairs in order not to cause difficulties for the neutral country's foreign policy. The idea of economic neutrality was publicly debated in Austria only from 1959. ${ }^{161}$

${ }^{155}$ Quoted in Stearman, The Soviet Union and the Occupation of Austria, 172. Cf. Verdross, Die immerwährende Neutralität Österreichs, 49.

156 Ermacora, 20 Jahre österreichische Neutralität, 79.

157 Röhrlich, Kreiskys Außenpolitik, 119.

158 Maximilian Gottschlich, Oswald Panagl, and Manfred Welan (eds.), Was die Kanzler sagten: Regierungserklärungen der Zweiten Republik 1945-1987 (Vienna: Böhlau, 1989), 126; Konrad Ginther, Österreichs immerwährende Neutralität (Vienna: Geschichte und Politik, 1975), 19; idem, Neutralität und Neutralitätspolitik, 42. Cf. Alfred Verdross, Die immerwährende Neutralität der Republik Österreich, 2nd ed. (Vienna: Bundesverlag, 1966), 14; Verosta, Die dauernde Neutralität, 100. On Sweden, see Molin, "Central Issues of Swedish Neutrality Policy," 263-264; on Switzerland, the official Swiss doctrine in Verosta, Die dauernde Neutralität, 113-117. The difference between neutrality and neutralism is exemplified using the Austrian case in Thomas O. Schlesinger, Austrian Neutrality in Postwar Europe: The Domestic Roots of a Foreign Policy (Vienna: Braumüller, 1972), 117-138.

159 Schweitzer, Dauernde Neutralität, 140.

${ }^{160}$ Verdross, Die immerwährende Neutralität der Republik (1958), 15-17, 29.

${ }^{161}$ Karl Zemanek, "Wirtschaftliche Neutralität," in Juristische Blätter 81, no. 10-11 (1959), 249251. 
The restrictive Austrian definition of the neutral's obligations was not approved by the Soviet side. There cannot be any doubt that the general Soviet attitude towards Austria's neutrality was positive: "Since the USSR was one of the architects of Austria's permanent neutrality, the benevolent and favorable attitude adopted by the Soviet Union towards it over the years should not come as a surprise." ${ }^{162}$ Andrei Gromyko, the generally bland Soviet foreign minister, was truly enthusiastic when remembering Austria in his memoirs:

"Which other country in central Europe can one consider a pillar of neutrality? The answer must be Austria [...] Those across the Atlantic who do not like Austria's neutrality and who criticize it as 'amoral' are deeply wrong. The Soviet Union's relations with Austria are a compelling example of balanced cooperation between states having different social systems. In fact, if there is amorality, it lies in any attempt to make Austria repudiate her neutrality. [...] Europe needs a neutral Austria, and so do the Austrian people." 163

This description contained all the main elements of Soviet neutrality propaganda: the high moral value of neutrality, its benefits, and its sinister enemies "across the Atlantic." As we shall see, Soviet statements were not always as positive, and the Austrian practice of neutral policy was repeatedly and quite explicitly subject to Soviet critique. This kind of disagreement concerned a number of facets of the Western understanding of neutrality in general and its Austrian variant in particular, its genesis as well as the legal obligations stemming from it.

Some consensus existed between Soviet and most Austrian experts and politicians that Austria's neutrality had been established through an act of national legislation that was made officially known to and was recognized by many other states. ${ }^{164}$ The combination of notification and recognition was generally interpreted as "creating a contractual relationship" under which Austria's permanent neutrality was based on international law; such a "relationship" could be terminated only in accordance with international law. ${ }^{165}$ As a result, Austria - like Switzerland - was considered to be "legally bound to practice permanent neutrality and to abide by the obligations stemming from it." 166 Therefore, until the 1990s Austria was generally seen as not free to modify or abandon its status at will. In the late 1950s, legal expert Felix Ermacora doubted this doctrine, but later conceded his error. ${ }^{167}$

162 Neuhold, "Austria and the Soviet Union," 87.

163 Andrei Gromyko, Memories (London: Hutchinson, 1989), 225-226.

164 Verdross, Die immerwährende Neutralität der Republik (1958), 12; Hanspeter Neuhold, "The Permanent Neutrality of Austria," in Karl E. Birnbaum and Hanspeter Neuhold (eds.), Neutrality and Non-Alignment in Europe, Laxenburg Papers 4 (Vienna: Braumüller, 1981), 44-61, 48; Ganiushkin, Sovremennyi neitralitet, 127; idem, Neitralitet i neprisoedinenie, 154; Zhiriakov, Sovetskii Soiuz - Avstriia, 37-38.

165 Verosta, Die dauernde Neutralität, 5.

166 Neuhold, "Austria and the Soviet Union," 89.

167 Ermacora, Österreichs Staatsvertrag und Neutralität, 108-109; idem, 20 Jahre österreichische Neutralität, 75 . 
Concerning the background of the country's neutralization, Austrian experts in international law did not subscribe to the Soviet thesis that neutrality was the consequence of a shift in the international balance of forces towards socialism. In contrast, they, more traditionally, saw the neutralization of a country to be the result of, or a solution for, a stalemate between two external great powers in their struggle for influence over said country. It entailed a postponement ad infinitum of the struggle. ${ }^{168}$ While Austrian official statements consistently repeated that Austria's neutralization had been a voluntary act - a claim that was correct from a purely legal point of view - interestingly, Ermacora acknowledged that this was only half of the truth, with Soviet insistence being the other side of the coin. ${ }^{169}$ Soviet statements, however, rejected any notion of Austria having been "neutralized." 170

Regarding other aspects of Austrian neutrality, further disagreements can be discerned. Some of them had to do with the legal value of the Moscow memorandum, which had stipulated the Soviet government's preparedness to join the Western powers in signing the state treaty and the Austrian delegation's promise to submit a declaration of neutrality to the Austrian parliament for consideration and adoption. Since the delegation had lacked the legal power to declare Austria's neutrality, and since the memorandum was not subject to ratification by the parliaments of the two countries, it was, as concurred by most Austrian legal experts, not an international agreement that was binding for anyone other than the two delegations. ${ }^{171}$ Only a minority of Austrian experts regarded the memorandum as binding to the state of Austria, thus making obligatory a declaration, if not adoption, of neutrality. On the Soviet side, legal expert Tiunov claimed that the Moscow memorandum created an obligation for Austria to declare and maintain neutrality, and his colleague Ganiushkin argued that the Moscow memorandum had been cited by Foreign Minister Molotov at the four-power gathering on the eve of the signing of the state treaty and thus acquired "the importance of an act of international law." 172 Since the memorandum was referred to in the state treaty, the entire contents of the memorandum allegedly became a part of the international agreement. Some (even semi-official) statements, as in the Soviet Diplomatic Dictionary, went so far as to allege that

168 Manfred Rotter, Die dauernde Neutralität (Berlin: Duncker \& Humblot, 1981), 98; Karl Zemanek, "Austria's Policy of Neutrality: Constants and Variables," in Hanspeter Neuhold and Hans Thalberg (eds.), The European neutrals in international affairs, Laxenburg Papers 7 (Vienna: Braumüller, 1984), 17-24, 17.

169 Ermacora, 20 Jahre österreichische Neutralität, 15. Ermacora underlines that the USSR was the only member of the four powers to insist on Austria's neutralization. Ibid., 76.

${ }_{170}$ Ganiushkin, Sovremennyi neitralitet, 126; idem, Neitralitet $i$ neprisoedinenie, 155.

171 Ermacora, Österreichs Staatsvertrag und Neutralität, 106; Verdross, Die immerwährende Neutralität der Republik (1958), 11; Hafner, "Die permanente Neutralität," 232-233; Schweitzer, Dauernde Neutralität, 81 .

172 Ganiushkin, Neitralitet i neprisoedinenie, 153-156; idem, Sovremennyi neitralitet, 127; Tiunov, Neitralitet $v$ mezhdunarodnom prave, 47. 
Austria's neutrality was founded or, at least, "recognized in the state treaty." 173 Andrei Gromyko, who served as foreign minister from Khrushchev to Gorbachev, in his consistently biased memoirs, even referred to "Austria, which acquired neutral status by the Vienna State Treaty, signed on 15 May 1955 by the USSR, the USA, Great Britain, France and Austria" ${ }^{174}$ - a minor, albeit in the Austrian case substantial, distortion that can hardly be attributed to a lapse in the impeccable diplomat's memory. Other Soviet statements claimed that the four powers had to be consulted if Austria wished to modify or abandon neutrality. ${ }^{175}$ Such claims, ultimately boiling down to creating an international obligation for Austria to declare and maintain neutrality, and a special Soviet entitlement for controlling its practice, were considered by Austrian experts to be "groundless." ${ }^{176}$ Austrian scholars and diplomats did their best to correct such claims. ${ }^{177}$

Another particularly controversial issue was the question of who was entitled to define the obligations comprised by a neutral peacetime policy. Since the internationally recognized catalog of legal duties only dealt with wartime obligations, the Swiss and Austrian governments claimed that the task of defining and shaping their neutral policy in peacetime rested on the respective government alone. ${ }^{178}$ Although the judgment of the Austrian government in this respect was accepted by the Soviet Union during Chancellor Raab's visit to Moscow, some Soviet scholars continued to declare such claims as unjustified. ${ }^{179}$

The main contrast between Soviet and Austrian interpretations, however, regarded the legal obligations stemming from permanent neutrality, in particular the fact that Austrian neutrality was, especially in the first years after its declaration, far from "total" (i.e. applied to politics, bilateral relations, trade, and the media), as was demanded by the Soviet side. Austria's neutral policy comprised neither re-

\footnotetext{
173 "Neitralitet Postoiannyi," in A.A. Gromyko, S. A. Golunskii, and V.M. Khvostov (eds.), Diplomaticheskii slovar', 2nd ed. (Moscow: Gospolitizdat, 1960-1964) 2, 397. Cf. Tiunov, Neitralitet v mezhdunarodnom prave, 38; Beletskii, Sovetskii Soiuz i Avstriia, 242.

174 Gromyko, Memories, 225. On Gromyko's memoirs, cf. Norman Stone, “Andrei Gromyko as Foreign Minister: The Problems of a Decaying Empire," in Gordon A. Craig and Francis L. Loewenheim (eds.), The Diplomats, 1939-1979 (Princeton: University Press, 1994), 593-608, 595.

175 Iu. M. Prusakov, Neitralitet v sovremennom mezhdunarodnom prave (Moscow: Znanie, 1972), $42-43$.

${ }^{176}$ Hafner, "Die permanente Neutralität," 231. Cf. Ermacora, Österreichs Staatsvertrag und Neutralität, 106.

177 Gerald Stourzh, "Once More about Austria's Neutrality," in International Affairs, no. 4 (April 1962), 110; Peter Marboe, "Letter to the Editor," in New York Times, 22 April 1981, quoted in Johnson-Freese, "Austria," 166.

178 Hans Mayrzedt and Waldemar Hummer (eds.), 20 Jahre österreichische Neutralitäts- und Europapolitik 1955-1975, Österreichische Gesellschaft für Außenpolitik Schriftenreihe 9 (Vienna: Braumüller, 1976) 1, 112; Verdross, Die immerwährende Neutralität der Republik (1958), 19; Ermacora, 20 Jahre österreichische Neutralität, 214. For the Swiss case, see Verosta, Die dauernde Neutralität, 114.

179 Zhiriakov, Sovetskii Soiuz - Avstriia, 37-38; Neuhold, “Austria and the Soviet Union,” 90.
} 
strictions against criticizing the Soviet Union or joining West European integration nor obligations to struggle against Western blocs or to "actively" promote peace and international understanding. The restrictive definition of a neutral's duties and the "passivity" of Austria's neutral policy were criticized by Soviet scholars as disregarding "the new character" of neutrality and limiting it to an alliance-free status. ${ }^{180}$ Making Austria more neutral in the Soviet sense was therefore a paramount goal of Soviet policy, which sometimes even referred to Finland as a model for Austria. ${ }^{181}$ As we have seen, Soviet statements produced their own catalog of the neutrals' obligations - a catalog that was much more demanding than the Western understanding, which, however, was quite poorly defined. Secondly, the same statements strove to make the Soviet wish list legally binding. It seems to have been the Soviet intention to make the neutrals less "Western" by such means. These two tendencies made it almost impossible for a neutral to fulfill the Soviet agenda if remaining true to its own identity as a Western state. If a neutral, however, adhered to its pro-Western posture, conflicts concerning the Western and Soviet definitions of neutrality seemed unavoidable.

The struggle for supremacy in defining the obligations of neutral Austria, and the Soviet attempts at molding the country's practice of neutral policy stretched well into the 1970s and 80s. It permeated diplomatic conversations, official statements and media reports. In order to induce or reinforce Austrian behavior as desired by the Soviet leadership and to prevent or deter the Austrian government from taking steps that ran counter to Soviet intentions, the main themes of Soviet neutrality propaganda were exploited: the claim that the Soviet interpretation of neutrality was the correct one, the need for and benefits of this kind of neutrality, the Soviet-Austrian "example of peaceful coexistence," and the distant villains who strove to dissuade Austria from its correct, i.e. neutral, path. While the general Soviet narrative of neutrality underlined the moral qualities and material benefits of this status, ${ }^{182}$ its variant regarding Austria stressed that the country owed not only its good relations with the Kremlin, but also its economic recovery to its neutral status ${ }^{183}$ - a recovery that hitherto has usually been attributed largely to US aid. ${ }^{184}$ Another characteristic of neutrality, claimed by Soviet propaganda, was a good relationship with the social-

${ }^{180}$ L. Vidyasova, “An Impressive Example of Peaceful Coexistence," in International Affairs, no. 8 (August 1960), 11-15, 13; Ganiushkin, Neitralitet i neprisoedinenie, 119, 148, 160-162; Modzhorian, Politika neitraliteta, 8.

181 Amtsvermerk, 14 June 1971, in ÖStA, AdR, BMAA, II-Pol, GZ. 105.880-6/71, Z.113.801.

182 See above, pages $54-55$.

183 "Im Interesse beider Länder," in Neue Zeit, no. 19 (1957), 9-10; Speech by N.S. Khrushchev during a breakfast at the Austrian president, 30 June 1960, in Druzhestvennyi vizit, 16; "Das Jubiläum der österreichischen Neutralität," in Neue Zeit, no. 21 (1965), 9; Amtsvermerk, Sowjetische Presse zum österreichischen Nationalfeiertag, 10 November 1971, in ÖStA, AdR, BMAA, II-Pol, GZ. 105.880-6/71, Z.121.033.

${ }^{184}$ Günter Bischof, Anton Pelinka, and Dieter Stiefel (eds.), The Marshall Plan in Austria, Contemporary Austrian Studies 8 (New Brunswick: Transaction, 2000). 
ist states. Whenever the Soviet side was interested in fostering East-West contacts, Austria was reminded of its alleged duty to maintain such relations. ${ }^{185}$

Among the "enemies of neutrality," ern powers, which were repeatedly accused of having hampered Austria's wish for neutrality before 1955 and having continued to do so ever since; West Germany and some unidentified circles of Austrian pan-German industrialists plotting a new Anschluss; and, last but not least, Austrian Nazis and political organizations close to them, such as the Freedom Party (FPÖ). Indeed, neutrality raised the suspicion of many Western leaders, from John Foster Dulles to Konrad Adenauer and Paul Henri Spaak, who feared that the spread of neutralism in the West might undermine the consensus of the alliances they considered necessary to defend the West. And indeed, some groups and individuals in Austria were not convinced that neutrality was the correct path. However, in Soviet propaganda, these "enemies of neutrality" served as voodoo dolls to denounce tendencies affecting the neutral's political posture - tendencies that were unwanted by the Soviet Union, such as Austria's traditional mainstream allegiance to the West, the country's close economic relations with West Germany, and, although an increasingly marginal phenomenon, pan-German or neo-Nazi sentiment.

Such Soviet statements aimed at either reinforcing or readjusting the Austrian practice of neutral policy. As we shall see, some of these Soviet demands fell on fertile ground: For Austria, which since the beginning of the Cold War had been isolated from its communist neighbors and shaken by East-West tension, permanent neutrality ensured not only the withdrawal of foreign troops and the achievement of the country's full sovereignty, but also opened opportunities for making relations with the East easier and for increasing the country's security by raising its international profile. ${ }^{187}$ Therefore, Austria was highly interested in exercising its

185 "Im Interesse beider Länder"; Valeri Begischew, "Wo sich Europas Straßen kreuzen," in Neue Zeit, no. 14 (1974), 14-16; Igor Melnikow, "Österreich - Land mit Funktion," in Neue Zeit, no. 48 (1974), 25-27; G. Rozanov, "Austria: Twenty Years of Independent and Democratic Development," in International Affairs, no. 6 (June 1975), 66-72; R. Krestjaninow, "Positive Wandlungen," in Neue Zeit, no. 1 (1977), 16.

186 Die Kommunisten im Kampf für die Unabhängigkeit Österreichs: Sammelband (Vienna: Stern, 1955); Sovremennik, "Österreichs Neutralität und ihre Bedeutung," Neue Zeit, no. 21 (1955), 7-9; "Im Interesse beider Länder," in Neue Zeit, no. 19 (1957), 9-10; M. Frolow, "Neutralität auf Widerruf?," in Neue Zeit, no. 51 (1959), 12-14; Ganiushkin, Sovremennyi neitralitet, 131-134; Beletskii, Sovetskii Soiuz i Avstriia, 253-256; Kobliakov, Kuranov, Mochalin, SSSR v bor 'be za nezavisimost' Avstrii, 176-186; G. Nikolajew, "Die Neonazis in Österreich," in Neue Zeit, no. 37 (1969), 30-31; G. Nikolayev, "Foreign Capital in Austria," in International Affairs, no. 9 (September 1971), 93-96; N. Polyanov, “Austria, Neutrality, Europe," in International Affairs, no. 9 (September 1973), 82-88, 86, Juri Orlow, "BRD - Österreich: Gefährliche Liebschaft," in Neue Zeit, no. 46 (1977), 14-26; Wjatscheslaw Jelagin, "Fundament der Neutralität," in Neue Zeit, no. 45 (1978), 8-9; I. Melnikow, "nicht verharmlosen!," in Neue Zeit, no. 2 (1979), 14.

187 Mayrzedt and Hummer, 20 Jahre österreichische Neutralitäts- und Europapolitik 1, 11 
neutral policy as actively as possible. However, while some of the Soviet wishes regarding neutrality dovetailed with Austria's ambitions, some of the differences led to sharp disagreement. 


\section{The Post-State Treaty Honeymoon}

The Khrushchev years were a rough period in international affairs. Probably the "last true believer" in the global victory of communism in the Kremlin, the Soviet leader, while earthy and energetic, also somewhat unrefined and naïve, declared that the Soviet system would enable the USSR to "catch up and surpass" the United States within fifteen years. ${ }^{2}$ His condemnation of some of the excesses of Stalinism in a secret speech at the twentieth CPSU congress 1956 and the signs of a cautious "thaw" triggered a process that, over time, not only undermined the Soviet-Chinese alliance, but also the prestige of communism in his own state and, ultimately, the stability of the Soviet empire. ${ }^{3}$ While Khrushchev's reconciliation with Tito, his visit to Yugoslavia in May and June 1955, and the signs of superpower détente had fostered hopes for a certain relaxation in the Soviet reign over Eastern Europe, the suppression of unrest in the Baltics and in Ukraine, and the crushing of the Hungarian people's uprising signaled the limits of this liberalization.

From 1957 Khrushchev's foreign policy, although at times attenuated in the CPSU Presidium (the Politburo) by Anastas Mikoian, was executed loyally and with "doglike devotion"4 by Andrei Gromyko, a technocrat who allegedly "played his cards so close to his chest that he paused carefully before answering a Western diplomat who asked him if he had had a good breakfast with a noncommittal 'perhaps." ${ }^{5} \mathrm{He}$ had been molded in Stalin's apparatus and was, very much like Prince Gorchakov's famous self-description, "a sponge in the hand of [his] master." After Molotov's ouster and the Shepilov intermezzo, Gromyko served as foreign minister until he was retired by Gorbachev in 1985 to the ceremonial rank of head of state.

${ }^{1}$ Mastny, "Soviet Foreign Policy, 1953-1962," 317-318.

${ }^{2}$ Nikita S. Khrushchev, "The Task of Surpassing the U.S.A.," [1957], in Robert A. Goldwin, Gerald Stourzh, and Marvin Zetterbaum (eds.), Readings in Russian Foreign Policy (New York: Oxford University Press, 1959), 450-463, 457.

3 On the wave of unrest that from 1953 to 1956 flowed over from Berlin to Plzen, Warsaw and Budapest, see Jan Foitzik (ed.), Entstalinisierungskrise in Ostmitteleuropa 1953-1956: Vom 17. Juni bis zum ungarischen Volksaufstand: Politische, militärische, soziale und nationale Dimensionen (Paderborn: Schöningh, 2001); and also Mark Kramer, "The Early Post-Stalin Succession Struggle and Upheavals in East-Central Europe: Internal-External Linkages in Soviet Policy Making," in Journal of Cold War Studies 1, no. 1 (1999), 3-55; no. 2 (1999), 3-38; no. 3 (1999), 3-66.

${ }^{4}$ Taubman, Khrushchev, 479.

5 Archie Brown, The Gorbachev Factor (Oxford: University Press, 1996), 217.

${ }^{6}$ Quoted in Stone, “Andrei Gromyko," 594. Cf. Aleksandrov-Agentov, Ot Kollontai do Gorbache$v a, 72$. 
Khrushchev had left his international debut, the 1955 Geneva summit, "without any agreements, yet with big sighs of relief" that no gaffe had been committed and that the US president was at least as afraid of nuclear war as the Soviet leadership. Some weeks later, Khrushchev received the West German chancellor Konrad Adenauer, who had, in Soviet propaganda, hitherto ranked as the right hand man of the devil, and a lively exchange of visits between Western and Soviet politicians was begun. Due to the Soviet leader's explosive temper, most of these occasions, such as Khrushchev's visits to Britain, the United States and France and the abortive Paris and Vienna summits, however, turned into platforms for ideological bickering and "verbal sparring."

In the meantime, the "thaw" was overshadowed by a chain of crises. They were, if not created, at least aggravated by Khrushchev's "surprising ignorance" of legal issues and his recklessness. Some historians claim that Khrushchev was determined to reach a lasting détente and did not grasp that his crisis mongering was not conducive for attaining such an objective. ${ }^{10}$ Others state that - despite the momentous effect of Soviet thermonuclear tests, the launching of Sputnik in 1957, and Iurii Gagarin's 1961 space flight on US insecurity and Soviet confidence ${ }^{11}$ Khrushchev remained aware of US power superiority. In order to cover up this disadvantage, the Soviet leader resorted to brinkmanship, risky provocations, and a "hot-cold therapy" of "peace initiatives" and nuclear intimidation designed to increase the USSR's leverage and demoralize its opponents. ${ }^{12}$ The Suez crisis misled Khrushchev to believe that his nuclear threat against Britain and France had convinced the two countries to retreat. The Soviet leader was prepared to repeat his bluff several more times, in particular during the Berlin crisis, which he staged, in his own words, in order to grab the West "at its balls."13 In the following years, most West European NATO states were, on various occasions, threatened by the USSR with nuclear annihilation. By bluffing with still-nonexistent Soviet missiles, Khrushchev, however, fanned the arms race. In the meantime, the USSR embarked on a massive nuclear build-up: In March 1955, two months before the signing of the state treaty, Khrushchev approved the secret deployment of medium-range ballistic missiles in border regions of the USSR, in Bulgaria and

7 Zubok, A Failed Empire, 107. On the Geneva summit, cf. Bischof, Dockrill, Cold War Respite.

${ }^{8}$ Dallin, Soviet Foreign Policy, 239.

9 Anastas Mikoian, Tak bylo: Razmyshleniia o minuvshem (Moscow: Vagrius, 1999), 604.

${ }^{10}$ Dmitri Wolkogonow, Die sieben Führer (Frankfurt: Societätsverlag, 2001), 219.

${ }^{11}$ David Holloway, Stalin and the Bomb: The Soviet Union and Atomic Energy, 1939-1956 (New Haven: Yale University Press, 1994), 306-307.

12 Fursenko and Naftali, Khrushchev's Cold War, 46, 414. "Hot-cold therapy" [Wechselbad] is a quotation from Haymerle to Kreisky, Z. 45-Pol/64, 28 April 1964, in ÖStA, AdR, BMAA, II-Pol, Pol. Berichte Moskau.

${ }^{13}$ Quoted in Oleg Grinevskij, Tauwetter: Entspannung, Krisen und neue Eiszeit (Berlin: Siedler, 1996), 24. 
the GDR; ${ }^{14}$ in 1959 the first Soviet intercontinental ballistic missile was successfully launched, and in 1962 the stationing of Soviet missiles in Cuba brought the world to the brink of nuclear war.

\section{The establishment of friendly relations}

In Soviet-Austrian relations, the first five years after the conclusion of the state treaty were a formative period. Both sides had to get accustomed to their new roles, to find their own positions and, without falling back into the behavior of the postwar decade, take steps to establish a lucid relationship. For the Austrian side, normalizing relations with the Soviet Union was not only an unwritten obligation stemming from the state treaty, as so aptly observed by international-law expert Hanspeter Neuhold, ${ }^{15}$ but a question of survival. While international relations between the superpowers after Stalin's death, with all good intentions to avoid nuclear war and to secure a lasting settlement, were still dominated by the residual dynamics of the early Cold War, caution and mutual distrust, ${ }^{16}$ a small neutral located at the edge of the Soviet bloc could not afford to be so cautious. For Austria, there was no alternative to making compromises: Before 1955, the country had been too weak to be an independent player, and with the Soviet military presence, there had been no chance of becoming exclusively a client of the United States or of joining other West European states in their integration efforts. Neutrality was therefore considered the only solution and an acceptable price for getting the "Russian occupation" out of eastern Austria. Once this goal was achieved, Austria, which continued to have good relations with the other three signatories of the state treaty, had to establish a modus vivendi with the superpower in the East.

From the Soviet side, which portrayed itself as the main architect and patron of Austria's independence and neutrality, relations to Austria were designed and presented as an "example," or even "model," for "peaceful coexistence." ${ }^{17}$ In Soviet understanding, the Austrian state treaty and its constitutional law on neutrality of 4 November 1955 "established the real preconditions for the peaceful coexistence of the USSR and Austria." 18 On 6 December 1955 the Soviet Union officially recognized Austria's declaration of neutrality. Some divergences between the Soviet and Austrian interpretations of neutrality would soon and, thereafter, repeatedly lead to conflict. However, as long as the Soviet Union was interested in promoting

${ }^{14}$ Matthias Uhl and Vladimir Ivkin, “Operation Atom: The Soviet Union's Stationing of Nuclear Missiles in the German Democratic Republic," in Cold War International History Project Bulletin, no. 12-13 (2001), 299-307.

${ }^{15}$ Neuhold, "Austria and the Soviet Union," 92.

${ }^{16}$ Kramer, "International Politics in the Early Post-Stalin Era," xiv-xvi.

17 See above, page 26.

${ }^{18}$ I. Zhiriakov, SSSR - Avstriia: itogi i perspektivy sotrudnichestva (Moscow: Mezhdunarodnye otnosheniia, 1985), 30. 
neutrality, "peaceful coexistence" and détente, and in using Austria as its living example, the Kremlin had to refrain from voicing its critique too sharply and from publicly damaging its relations to its own "creation" and that creation's prestige. Soviet-Austrian relations were therefore presented by the Kremlin not only as positive example for "peaceful coexistence," but, as stated on countless occasions, even as a model thereof. At the twentieth congress of the CPSU in 1956, in the report on the Soviet foreign policy tasks, the "strengthening of the amicable relations to Finland, Austria, and other neutral countries" was named right after "strengthening the fraternal relations to the people's democracies" and the amicable relations to the nonaligned. ${ }^{19}$

From the first moment after the successful conclusion of the Soviet-Austrian state treaty negotiations of April 1955, the recently established friendly bilateral relations as well as the reliability and farsightedness of the Austrian politicians were demonstratively praised, and this repeatedly, by Soviet leaders and media. At the official dinner during his visit to Yugoslavia in May, Khrushchev received the Austrian ambassador to express his satisfaction about the signing of the state treaty and stated that "the relations between the Soviet Union and Austria are very good today and will, I hope, become even better in the future." ${ }^{20}$ At the farewell ceremony for the Austrian delegation at the Moscow airport on 15 April, Molotov had shared with the Swedish ambassador that the Austrians seemed to be satisfied with the outcome of the negotiations; however, "we," Molotov emphasized, "are very satisfied." ${ }^{21}$ During an official reception for the Yugoslav national holiday, in the presence of several diplomats, the usually laconic foreign minister made "the most pleasant compliments" concerning the abilities of Chancellor Raab, ${ }^{22}$ and at a reception held during the visit of Khrushchev, Mikoian, and Bulganin to Bulgaria, the Austrian ambassador in Sofia was reportedly the only diplomatic representative with whom all three Soviet leaders spoke extensively - a distinction that "did not pass unnoticed" by the diplomatic corps. The honor was even higher when Khrushchev publicly characterized the Austrian chancellor an "extremely sympathetic man" and Mikoian also "found warm words about him." ${ }^{23}$ Similar statements were made in later years, as for instance in 1958, when Khrushchev, during another reception for the diplomatic corps in Moscow, pointed at the Austrian ambassador and declared publicly: "This is Austria, a capitalist country. Its chancellor is also

${ }^{19}$ Chruschtschow, Rechenschaftsbericht an den XX. Parteitag 14. Februar 1956, 51.

${ }^{20}$ Austrian embassy Belgrade to Austrian MFA, 31 May 1955, in ÖStA, AdR, BMAA, GZ. 322.691 pol/55, Z. 322.691-pol/55.

${ }^{21}$ Austrian embassy Moscow to Austrian MFA, 18 April 1955, in ÖStA, AdR, BMAA, GZ. 321.412 pol/55, Z. 312.593-pol/55. Emphasis mine.

22 Austrian embassy Moscow to Austrian MFA, 29 November 1955, in ÖStA, AdR, BMAA, GZ. 322.691-pol/55, Z. 326.422-pol/55.

${ }^{23}$ Austrian embassy Sofia to Austrian MFA, 4 June 1955, in ÖStA, AdR, BMAA, GZ. 323.080pol/55, Z. 323.076-pol/55. 
a capitalist, but a very decent one whom we communists hold in high regard. We remember his visit to Moscow with joy. Please send him my cordial regards." ${ }^{24}$ Such friendliness was after a certain goal. By lauding the state treaty and Austria's neutrality and leaders, Moscow was not only depicting Soviet-Austrian relations as a positive result of Soviet statecraft. Raising Austria's profile on the international scene was also a means of promoting neutrality in the West.

The personal relationships between the leaders of different states are, for the most part, difficult to evaluate. In the case of Khrushchev and Raab, the successful conclusion of the Moscow negotiations in April 1955 seems to have contributed to mutual sympathy. Due to his lack of foreign experience, which he covered with boasting, bluff and bluster, the Soviet leader concentrated on personal trust rather than political issues in his relationships with foreign politicians, ${ }^{25}$ and it is likely that in 1955 he was looking for a Western leader with whom he would be able to "do business," as Margaret Thatcher thirty years later famously described her impression after Gorbachev's first visit to Britain. ${ }^{26}$ Since the Austrian chancellor Raab was the first Western politician Khrushchev negotiated with (and this successfully), the Soviet leader may have developed an emotional bond to the "little capitalist," as Raab had described himself during the talks. In a typically totalitarian fashion, Raab was elevated by Soviet media and his political contenders were attacked by Khrushchev. This was very similar to the Soviet treatment of the Finnish long-time president Kekkonen, who was personally depicted in Soviet statements as a guarantor for his country's neutrality and friendship with the USSR; according to Khrushchev: "Whoever is for Kekkonen is for friendship with the USSR; whoever is against him, is against friendship with the USSR."27 Mikoian, who was familiar with Austrian affairs, even spoke of a "Raab Line"28 - a reminder of Finland's famous "Paasikivi-Kekkonen Line." But while after Khrushchev's ouster Kekkonen managed to establish a similar cordial relationship with Kosygin, Austrian leaders failed to do so.

The new Soviet attitude was underlined by a sudden shift in the image of Austria as depicted in the media. As in many other totalitarian regimes, the Kremlin used its media not only as a means of creating images of external enemies to legitimize its own rule, but also as a means of communicating approval and displeasure about the current ongoings in the world. Whereas the Alpine country had until then been pri-

${ }^{24}$ Austrian embassy Moscow to Austrian MFA, 28074, 11 November 1958, in ÖStA, AdR, AVA, NL E/1770: Bischoff, File 108.

${ }_{25}$ On Khrushchev's bargaining style in the domestic struggle for power and in the Cuban and Berlin crises, cf. James M. Goldgeier, Leadership Style and Soviet Foreign Policy: Stalin, Khrushchev, Brezhnev, Gorbachev (Baltimore: Johns Hopkins University Press, 1994), 21-25, 52-74.

${ }^{26}$ Brown, The Gorbachev Factor, 77.

${ }^{27}$ Quoted in Max Jacobson, Finnland im neuen Europa (Berlin: Arno Spitz, 1999), 66, 69.

28 Austrian embassy Moscow to Austrian MFA, 19 May 1959, in ÖStA, AdR, BMAA, II-Pol, Pol. Berichte Moskau. 
marily portrayed as a shelter for Nazism, a breeding ground of anti-Soviet conspiracies, and a country where the working masses were vegetating in poverty and being betrayed by corrupt leaders, this changed abruptly following the Soviet-Austrian negotiations of April 1955. Chancellor Raab underwent a remarkable metamorphosis from a "fascist Heimwehrführer" to a "statesman of great wisdom."29 Although the Austrian Communist Party (KPÖ), despite its insignificance, was still granted a disproportionately large amount of attention by the Soviet media (a tactic that was undoubtedly conceived to convince Soviet readers of its "leading role," thus supporting the claim for a similar role of communist parties in the East), the Austrian communists' opponents ceased to be depicted indiscriminately as villains, fascists, and traitors. In addition to communicating Soviet approval or displeasure about current Austrian actions, Soviet media reports about Austria generally focused on two other themes: praise for neutrality and for Austria's growing national consciousness, both preconditions for the country to remain independent from Germany; ${ }^{30}$ and warnings against "enemies of neutrality," in particular neo-Nazis in Austria, combined with criticism of the lax Austrian attitude in this regard. ${ }^{31}$ Mostly designed for Soviet readers, the media contained regular "invidious reports" 32 about Austria's social, political and economic system, about the allegedly catastrophic situation of workers, or about the country's "tricky electoral system that has nothing to do with democracy." 33

Some Soviet officials were well aware of the fallacy of such depictions. During a discussion in the CPSU apparatus, Sergei Lapin, in the 1950s Soviet ambassador to Vienna and then director of the Soviet news agency TASS, stated: "The pensioners' fate in our country is not easy. I have been living in Austria. There, the people can't wait to retire. They have a lot of time for leisure, go to cafés and bars. We only have factory clubs. Coffee is usually for young people and other purposes..." 34 Nonetheless, such claims seem to have been deemed necessary by propagandists

${ }^{29}$ Quoted in Stifter, "Das politische Österreichbild," 49, 152. Although the KPÖ after 1959 never again garnered the percentage necessary to be represented in the Austrian parliament, its leader was more often mentioned than the Austrian head of government.

${ }^{30}$ See, e.g., Ilja Konstantinowski, "Österreichische Impressionen," in Neue Zeit, no. 26 (1966), 29-32; and "Eine vernünftige Politik," in Neue Zeit, no. 44 (1968), 2-3.

${ }_{31}$ Pravda, 16 January 1962; "Gute Aussichten," in Neue Zeit, no. 48 (1966), 3-4.

${ }^{32}$ Eiselsberg to Kreisky, 25 September 1959, with report Hinteregger, Die Situation der österreichischen Arbeiterschaft in sowjetischer Sicht, in ÖStA, AdR, BMAA, II-Pol, Pol. Berichte Moskau. The report referred to O.V. Sal'kovskii, Ekonomicheskoe polozhenie rabochego klassa Avstrii posle vtoroi mirovoi voiny (Moscow: Sotsekgiz, 1958).

${ }_{33}$ Dmitri Motschalin, “Österreich nach den Wahlen,” in Neue Zeit, no. 12 (1966), 23-24.

${ }^{34}$ Zapis' soveshchaniia po voprosu doklada TsK KPSS, 3 February 1971, in Sergei Kudriashov (ed.), General'nyi sekretar' L.I. Brezhnev 1964-1982, Vestnik Archiva Prezidenta: Spetsial'noe izdanie (Moscow: Vestnik Archiva Prezidenta, 2006), 96-113, 101. For a short biography of Lapin, who after his term as ambassador to Austria from 1956-60, served as deputy foreign minister 1962-65 and as a general director of TASS 1967-70, see ibid., 232. 
to support Soviet contentions regarding the superiority of the social system in the USSR and to underline the thesis that workers in capitalist countries were poor and deprived of their rights. Despite such distortions, it seems that over the years the image of Austria that emerged among Soviet citizens was that of a Westernoriented country which was nevertheless progressive and friendly. ${ }^{35}$

Even in Soviet literature, which had hitherto used the dark image of a crisisridden, hungry and corrupt postwar Vienna as a foil for memoirs and novels, ${ }^{36}$ the Austrian image brightened and gave way to the idyllic and light clichés of waltzes, Vienna Woods, pretty girls and plucky workers, stereotypes that had been spread in the interwar period by Il'ia Erenburg's report about the social democratic Schutzbund's uprising or by the US movie "Great Waltz," which became popular in the USSR ${ }^{37}$ However, these stereotypes were moderated, to a certain extent, by some critical undertones, such as Austrians allegedly having an inherent retrospectiveness, melancholy and nonchalance that prevented them from confronting clandestine neo-Nazis or turning the Austrian labor movement into something more Soviet-like. ${ }^{38}$

Almost immediately after the visit of the Austrian governmental delegation to Moscow in the spring of 1955, direct bilateral links at all levels were intensified. Any vestiges of the war and Austria's postwar status were eliminated. Prisoners-ofwar and some expatriates were repatriated - a process that took several more years - although some Austrian prisoners of Soviet labor camps or other persons willing to return never made it back to their homeland. ${ }^{39}$

During the postwar decade, due to the Cold War, the Soviet obsession with secrecy, and the Austrian anti-communist boycott, Soviet-Austrian exchanges of delegations in the cultural, scientific, and political spheres or between trade unionists had been limited for the most part to pro-communist propaganda activities. ${ }^{40}$ This now changed, a change that reflected the interests of both sides. The Soviet leaders were eager to leave their isolation and, by hosting guests from a Western country and sending delegations abroad, to demonstrate that their country was not the backward and ugly prison it had seemed under Stalin. Since this exchange first took place with a neutral, it was expected to raise the prestige of neutrality in the

${ }_{35}$ Walter Wodak, Diplomatie zwischen Ost und West (Graz: Styria, 1976), 104.

36 See, e.g. A. V. Sofronov, Zarubezhnye vstrechi (Moscow: Sovetskii pisatel', 1952); G. Savenok, Venskie vstrechi (Moscow: Voennoe izdatel'stvo, 1961).

37 Victor Erlich, Modernism and Revolution: Russian Literature in Transition (Cambridge, Mass.: Harvard University Press, 1994), 252; Julia Köstenberger, "The Great Waltz/Bol'shoi Val's," in Karin Moser (ed.), Besetzte Bilder: Film, Kultur und Propaganda in Österreich 1945-1955 (Vienna: Filmarchiv Austria, 2005), 303-322.

${ }^{38}$ Reitinger, “Österreich in den Augen der Sowjetliteratur nach 1945," 13, 162-174.

${ }^{39}$ Moskau, July 1958, in SBKA, Länderboxen, UdSSR 1; and Information, 20 June 1962, Zl. 231.387-12/62, ibid., File Sprechprogramm Moskau 1962.

${ }^{40}$ Mueller and Leidinger, "Tiefes Misstrauen - begrenztes Interesse: Die österreichisch-sowjetischen Beziehungen 1918 bis 1955," 105-107. 
West. For Austrian leaders, as well as for leaders from other small and, in particular, neutral states, it was important on one hand to better understand what the Soviet Union expected from them and, on the other hand, to communicate as thoroughly as possible what they were willing to fulfill.

Soon after the last Soviet soldier had left Austria, a delegation of Austrian journalists traveled to Russia in October 1955; in December a group of parliamentarians followed suit, responding to a Soviet invitation that had been expressed already the previous February. ${ }^{41}$ The invitation had been addressed to all parliaments in countries with whom the USSR had diplomatic contacts, in order to break the Soviet isolation. It was accepted, by the end of 1957 , by thirty-one delegations. ${ }^{42}$ The Austrian visit was returned by members of the Supreme Soviet in June 1956, ${ }^{43} \mathrm{im}-$ mediately after the Leningrad Symphony Orchestra had finished a much acclaimed concert tour through Austria. In the months before, pianist Emil Gilel's and violinist Igor Oistrakh had been celebrated in Vienna's largest concert hall, and Austrian opera singer Wilma Lipp had made several appearances in the USSR. Bilateral travel was made easier, at least theoretically, with the creation of a regular and direct train connection between Vienna and Moscow in June 1956. ${ }^{44}$

The establishment of friendly relations seemed to be the materialization of the dreams of Austria's ambassador Norbert (von) Bischoff, who had been accredited as a diplomatic representative in Moscow since December $1946 .{ }^{45} \mathrm{~A}$ former nobleman and leftist-bourgeois enthusiast for everything Russian and Soviet, who because of his appearance was repeatedly mistaken for the French socialist Léon Blum, ${ }^{46}$ he had, before 1955, often criticized Austria's policy as being anti-Soviet. Bischoff saw the Cold War and the division of Europe as being solely a result of Western policy, "even though the Soviet Union has contributed to paving the way." ${ }^{47}$ Contemporaries and Austrian fellow-diplomats thought he tended to adopt the viewpoints

${ }^{41}$ Zhiriakov, SSSR - Avstriia, 35; Austrian embassy Moscow to Austrian MFA, 3 December 1955, in ÖStA, AdR, BMAA, GZ. 319.852-pol/55, Z. 326.606-pol/55.

${ }^{42}$ Gromyko and Ponomarjow, Geschichte der sowjetischen Außenpolitik 1945 bis 1976, 270.

${ }_{43}$ ÖStA, AdR, BMAA GZ. 511.246-pol/56, Z. 517.301-pol/56.

${ }^{44}$ Lobova, "Die Moskauer Perzeption," 151.

${ }^{45}$ Oliver Rathkolb, "Der Wiederbeginn der diplomatischen Beziehungen zwischen Österreich und der Sowjetunion 1945-1947 zwischen Kaltem Krieg und österreichischer Innenpolitik," in Mitteilungen des Österreichischen Staatsarchivs 50 (2003), 157-166, 163. For a short biography of Bischoff, see Rudolf Agstner, Gertrude Enderle-Burcel, and Michaela Follner, Österreichs Spitzendiplomaten zwischen Kaiser und Kreisky: Biographisches Handbuch des Höheren Auswärtigen Dienstes 1918 bis 1959 (Vienna: Dokumentationsarchiv des österreichischen Widerstandes, 2009), 133-135.

${ }^{46}$ Andrej Gromyko, Erinnerungen (Düsseldorf: Econ, 1989), 265. This passage is missing in the English edition.

${ }^{47}$ Austrian embassy Moscow to Austrian MFA, 7 June 1956, in ÖStA, AdR, BMAA, GZ., Z. 515.753-pol/56. In 1959, Bischoff claimed that the West German chancellor Konrad Adenauer had "set a disastrous course towards the division of Germany." Bischoff to Figl, 9 May 1959, in ÖStA, AdR, BMAA, II-Pol, Pol. Berichte Moskau. 
of his host country ${ }^{48}$ and even that he had pro-communist leanings. The ambassador's adoption of Soviet propaganda theses, his uncritical stance towards Soviet policy, and his anti-Western bias - all aspects that were probably reinforced by his twelve-year tenure in Stalinist Moscow - were mirrored in his reports to the Foreign Ministry. Carried away by propaganda slogans and (falsified) statistical data that he collected, ${ }^{49}$ Bischoff described the USSR and its sphere of power as "a single zone of peace [...] from which the Asian and African peoples can be hindered from joining only [...] by the use of force"; the seven-year plan, in his eyes, would bring about the "liquidation of poverty" in the Soviet sphere. ${ }^{50}$ Bischoff, whose reports often contained communist propaganda terms such as "Westdeutscher Wehrmachtsminister," ${ }^{51}$ had in Stalin's time already sounded so pro-Soviet that his Austrian colleagues ironically expected him, too, to be "purged" when Khrushchev expelled the Stalinists from the Soviet leadership in $1957 .{ }^{52}$ When the ambassador, obediently following the twists of official Soviet ideology, sent a report on Khrushchev's denunciation of the "gruesome past" and of Stalin's "Caesarian delusions of grandeur" after the twentieth CPSU congress to the Foreign Ministry on Vienna's Ballhausplatz, one of Bischoff's colleagues maliciously scribbled on the margin of the page: "If anybody had dared to talk to Bischoff like that two years ago...!"53 Indeed, some years earlier, Bischoff had argued that Stalin's terror, although killing hundreds of thousands of innocent people, had nonetheless "unmasked a fifth column" and thus strengthened the country on the eve of Hitler's aggression..$^{54}$ With Khrushchev's de-Stalinization, the Austrian ambassador, who died in 1960 shortly after leaving Moscow, considered the threat of dictatorship banned forever and the Soviet Union a respected constitutional state. ${ }^{55}$ His naiveté about not only Soviet political intentions but also practices was well known in Vienna, and there were

${ }^{48}$ Fritz Molden, Besetzer, Toren, Biedermänner: Ein Bericht aus Österreich, 1945-1962 (Vienna: Molden, 1980), 50; Eiselsberg, Erlebte Geschichte, 201. For a detailed account of Bischoff's view of the world, see Paul Ullmann, "Das Russlandbild der österreichischen Diplomatie in den ersten drei Jahrzehnten nach dem Ende des 2. Weltkrieges" (unpublished paper, Vienna, n.d.). Ullmann argues that Bischoff was impressed by the collectivist and authoritarian ideas of the 1920s and 30 s, and, therefore, attracted by the USSR. Ibid., 43. A copy of this paper was given by DDr. U11mann to the author of this book.

49 ÖStA, AdR, AVA, NL E/1770: Bischoff, Files 104-105. On Bischoff's views, cf. Matthias Pape, Ungleiche Brüder: Österreich und Deutschland 1945-1965 (Cologne: Böhlau, 2000), 253-258.

${ }^{50}$ Austrian embassy Moscow to Austrian MFA, 4 January 1955, in ÖStA, AdR, BMAA, GZ. $319.130-\mathrm{pol} / 55$.

${ }^{51}$ Bischoff to Austrian MFA, 28017, 2 February 1957, ÖStA, AdR, AVA, NL E/1770: Bischoff, File 108.

52 Grubmayr, "In zwei Wochen gehst Du nach Moskau," 138.

53 Austrian embassy Moscow to Austrian MFA, 10 March 1956, in ÖStA, AdR, BMAA, GZ. 511.069-pol/56, Z. 512.813-pol/56.

${ }^{54}$ Ullmann, "Das Russlandbild," 15.

55 Austrian embassy Moscow to Austrian MFA, 4 April 1958, in ÖStA, AdR, BMAA, GZ. 544.606pol/58, Z. 547.895-pol/58; 6 March 1959, ibid., BMAA, GZ. 236.076-pol/59, Z. 239.921-pol/59. 
rumors among Austrian diplomats that he sent his secret telegrams, open, with his Russian housemaid to the cipher service. ${ }^{56}$ The publication of his memoirs was, due to its containing official secrets and its pro-Soviet bias, suppressed by the Ballhausplatz. ${ }^{57}$ Already in 1946, Bischoff had been informed by the foreign minister that the ambassador's assessment of Soviet policy did not reflect the official Austrian line. ${ }^{58}$ Nonetheless, Bischoff, who in a memorandum in the fall of 1955 pleaded for Austria actively engaging in a dialog with Eastern Europe, seems to have had some influence on Raab's understanding of neutrality. ${ }^{59}$ In contrast to his assessment by the Soviet and Austrian sides during his lifetime, Bischoff"s "progressiveness" and "loyalty" was, after his death, acknowledged by Soviet diplomats. ${ }^{60}$

\section{Frictions}

It is clear that the friendly Soviet-Austrian atmosphere, established with the negotiation and conclusion of the state treaty, did not mean, however, that no problems arose in the bilateral relations. Frictions resulted from the differing Soviet and Viennese interpretations of Austrian neutrality with regard to, for example, international communist organizations. Soviet officials complained that Austria had refused visas to Soviet functionaries of such organizations. However, the reproach was parried by Bischoff with the argument that the Austrian refusal concerned only ten of more than six hundred applications, and that the USSR certainly was also not willing to grant visa to Austrians if they declared their intention of traveling to Moscow to anti-communist gatherings. ${ }^{61}$ When the headquarters of the communist World Federation of Trade Unions was officially expelled from Vienna in early 1956, the city's communist press, seconded on 8 February by Pravda, accused the Austrian government of violating neutrality. ${ }^{62}$ A year later, the communist World Peace Council was also banned from Austria, and the move was harshly criticized by Izvestiia on 5 February 1957 and Pravda four days later.

A second stumbling block was Austria's external neutrality, i.e. the maintenance of neutrality regarding foreign military alliances. Since the late 1940s, Austria had become accustomed to Western troop transports passing through Tyrol between West Germany and Italy. While this had not, prior to 1955, violated any Austrian

\footnotetext{
${ }^{56}$ Grubmayr, "In zwei Wochen gehst Du nach Moskau," 134.

${ }^{57}$ [Gutachten Verosta, 21 January 1959,] in Österreichisches Institut für Zeitgeschichte (hereafter: ÖIZG), NL 72 Fuchs, DO 842, File 111. Cf. Hinteregger, Im Auftrag Österreichs, 41.

${ }^{58}$ Ullmann, "Das Russlandbild," 6.

${ }_{59}$ Manfried Rauchensteiner, Die Zwei: Die Große Koalition in Österreich 1945-1966(Vienna: Bundesverlag, 1987), 320-322.

${ }^{60}$ Dölling to Ulbricht with Amtsvermerk, 12 July 1960, in Bundesarchiv Berlin, Stiftung Archiv der Parteien und Massenorganisationen der DDR (hereafter: SAPMO), NY 4182/1320, 8-10. I am grateful to Mag. Maximilian Graf for granting me access to his copy of this document.

${ }^{61}$ ÖStA, AdR, BMAA, GZ. 322.691-pol/55, Z. 325.503-pol/55.

${ }^{62}$ Merhaut-Gurevitsch, "Die Innen- und Außenpolitik Österreichs," 76-81.
} 
obligations, after its declaration of neutrality, the problem was trickier: In peacetime such transports could be allowed, in wartime not. But since Austria, on one hand, had learned to perceive the United States as a trusted friend and protector, and on the other, did not have the means to prohibit flyover troop transports, the neutral country continued to tolerate such actions and was, indeed, rather generous in permitting the US air force to use its airspace. Foreign Minister Leopold Figl asked US Ambassador Llewellyn Thompson in 1956 only to make sure that the flights would be undertaken at high altitudes and under weather conditions that would not enable the flights to be monitored from the ground. ${ }^{63}$ Military personnel traveling overland had to be in civil clothing. ${ }^{64}$ However, the Soviet Union was not a watchdog to let such shenanigans pass unnoticed. On 22 February 1956, Izvestiia accused NATO of violating Austrian neutrality by transferring troops between Germany and Italy through Austria, ${ }^{65}$ and on 20 March, Pravda charged Austria with letting US organizations use its territory for covert activities and ignoring its obligations as a neutral country.

A few weeks later, Soviet criticism eased. The transports were over, and Moscow could only hope that the neutral had learned its lesson. In April, Pravda stated that Austria's neutrality constituted a major setback for NATO, and it was for this reason that the Atlantic bloc was trying to undermine it. Despite such attempts, the relations between Austria and the "people's democracies" would continue to develop positively, as diagnosed by the CPSU organ and the May issue of the Soviet Foreign Ministry's periodical Mezhdunarodnaia zhisn'. The "true Austrian patriots," the Soviet press stated, would resist all temptations to give up neutrality.

Soviet-Austrian relations were not even strained by the Austrian failure to obtain the international guarantee for its territorial integrity that had been conceived by Austrian diplomacy and foreseen in the Moscow memorandum. ${ }^{66}$ Despite Soviet reminders, such as those published on the occasion of the first anniversary of the memorandum's conclusion, that Austria's status should be guaranteed by the four powers, no progress was achieved. The Western powers, after two world wars in which guarantees for Belgium and Poland had not helped to prevent aggressors from entering these countries, remained reluctant to guarantee the neutrality of Austria, a country that was considered by many a "military vacuum." ${ }^{967}$ Since the risks of such a guarantee, such as reducing Austria's own efforts to defend

${ }^{63}$ Gehler, Österreichs Außenpolitik, 184.

${ }^{64}$ Angebliche Verletzung der österr. Souveränität durch Amerika, 21 March 1956, in ÖStA, AdR, BMAA, GZ. 512.757-pol/56, Z. 512.786-pol/56.

${ }^{65}$ Malicek, "Die Beziehungen," 53.

66 On the genesis of the idea see Stourzh, Um Einheit und Freiheit, 354-356, 568-574.

${ }^{67}$ Rauchensteiner, Die Zwei, 324-330; quotation ibid., 329. Rauchensteiner, ibid., 514, points out that in 1955 Kreisky - in contrast to his later depiction of the event - supported the idea of obtaining a territorial guarantee issued by the four powers. Bruno Kreisky, Zwischen den Zeiten: Erinnerungen aus fünf Jahrzehnten (Vienna: Kremayr \& Scheriau, 1988), 469-470. 
itself and opening a door for Soviet intervention, seemed to outweigh the benefits, British diplomats decided to "kill the project" through "masterly inactivity." ${ }^{68}$ After repeated attempts to receive the desired declaration, the Austrian government finally acquiesced and concluded that it was better to do without a guarantee, than letting all four powers claim the right to decide whether Austria's neutrality had been violated or not. Despite such issues, Soviet-Austrian relations could generally be described as satisfactory, when they were exposed to their first serious test in the fall of 1956. As a consequence they cooled down noticeably, indeed to the "absolute low point" since $1955 .^{69}$

${ }^{68}$ Quoted in Michael Gehler, “'to guarantee a country which was a military vacuum.' Die Westmächte und Österreichs territoriale Integrität 1955-1957," in Manfried Rauchensteiner (ed.), Zwischen den Blöcken: NATO, Warschauer Pakt und Österreich (Vienna: Böhlau, 2010), 89-134, 109-116.

${ }^{69}$ Haymerle, "Die Beziehungen zur Großmacht im Osten," 163. 


\section{3. .... and Its Sudden End}

The conclusion of the Austrian state treaty and the withdrawal of Soviet troops from Austria had not gone unnoticed in neighboring Hungary. Both events, which were connected to the Austrian declaration of neutrality, were widely welcomed in the socialist state and left a deep impression on its population and on some leaders. The fate of Austria undoubtedly inspired Hungarian hopes for freedom and neutrality of its own. When, in connection with the unrest in Poland in the summer and autumn of 1956, the Hungarian revolution started, Austria was affected in a number of ways. The Austrian population, media and political representatives expressed their solidarity with the Hungarian people; Austria became, at least temporarily, refuge for thousands of Hungarians; and last but not least, Austria, as the only capitalist neighbor state of Hungary, was chosen as one of the "natural" scapegoats in Soviet propaganda and blamed for tolerating the infiltration of Hungary by the "fascist groups" and "Western agents" that were allegedly responsible for the "reactionary counterrevolution."

\section{The Hungarian revolution}

On 24 October, TASS accused "reactionary underground organizations" and similar "foreign forces" with having inspired the Hungarian revolution. The night before, following the request of the Hungarian communist government, the first intervention of Soviet troops in Hungary had started. Within days, thousands of Hungarians fled their homeland to neighboring Austria. Both developments as well as the perceived threat that Austria might also fall victim to a Soviet intervention led to anxiety in the Austrian population, but also to a wave of solidarity with the Hungar-

${ }^{1}$ On the Hungarian revolution, see, e.g. Csaba Békés, Malcolm Byrne, János M. Rainer (eds.), The 1956 Hungarian Revolution: A History in Documents (Budapest: Central European University Press, 2002). On Austria and the Hungarian revolution, see Andreas Gémes, Austria and the 1956 Hungarian Revolution. Between Solidarity and Neutrality (Pisa: Edizioni Plus, 2008); Johanna Granville, "Neutral Encounters of the Paranoid Kind: Austria's Reactions to the Hungarian Crisis of 1956," in Günter Bischof, Michael Gehler, and Anton Pelinka (eds.), Austrian Foreign Policy in Historical Context, Contemporary Austrian Studies 14 (New Brunswick: Transaction, 2006), 143-169; Ibolya Murber and Zoltán Fónagy (eds.), Die Ungarische Revolution und Österreich 1956 (Vienna: Czernin, 2006); Erwin A. Schmidl (ed.), Die Ungarnkrise 1956 und Österreich (Vienna: Böhlau, 2003); Michael Gehler, "The Hungarian Crisis and Austria 1953-58: A Foiled Model Case?" in Günter Bischof, Anton Pelinka, and Ruth Wodak (eds.), Neutrality in Austria, Contemporary Austrian Studies 9 (New Brunswick: Transaction, 2001), 160-213. See also the journalist account in James A. Michener, The Bridge at Andau (New York: Random House, 1957). 
ian freedom fighters and the incoming refugees. On 28 October, shortly before the cease-fire in Hungary went into effect, the Austrian government publicly appealed to the Soviet Union "to contribute to a termination of the hostilities and bloodshed." Although the memorandum underlined Austria's neutrality, it also expressed the hope that "the restitution of freedom with regard to human rights would strengthen peace in Europe." This unique and "courageous appeal" 3 was even more remarkable in light of the fact that the United States, until then, had only expressed its regret about the disaster, and had called for a meeting of the UN Security Council but refrained from publicly addressing the Soviet Union directly. The Austrian government was fully aware that its appeal would not be well received by the Soviet leadership. Nevertheless, Raab considered it necessary that "we have the guts to refer to our special status and to say that we do not agree with these events or the use of tanks." Such convictions were shared by other European neutrals as well. While the Swiss president Max Petitpierre regarded Austria's response "admirable but not worth imitating," ${ }^{5}$ in Zurich hundreds of students took to the streets in solidarity with the Hungarian uprising and the prime minister of Sweden, Tage Erlander, cited the revolution as proof that "dictatorships, no matter how strong they may appear and how effective the may organize the surveillance and oppression of their citizens, bear nevertheless within themselves the seed of their own destruction."6

The Austrian government and its mission in Budapest considered there to be no immediate danger of a Soviet invasion into Austria. Such an act, in fact, would have meant a failure of the Soviet policy vis-à-vis Austria. Nevertheless, the Austrian army was put on alert. The Austrian-Hungarian border, which in the summer of 1956 had been cleared of Hungarian mines, ${ }^{7}$ was closed on 24 October, and the Bundesheer was ordered to disarm all people crossing it. While in October only a few Hungarian refugees fled to Austria, starting with 4 November after the second Soviet intervention, a wave swept over the border. Help for refugees and the wounded was organized by the authorities; aid and medication was sent to Hungary by charitable organizations. The former noncommunist Hungarian prime minister,

${ }^{2}$ Text in Heinrich Siegler, Österreichs Weg zu Souveränität, Neutralität, Prosperität (Bonn: Siegler, 1959), 111. Cf. Michael Gehler, Der lange Weg nach Europa: Österreich von Paneuropa bis zum EU-Beitritt: Darstellung (Innsbruck: Studienverlag, 2002), 165; Granville, "Neutral Encounters," 145-146.

${ }^{3}$ Rainer Eger, Krisen an Österreichs Grenzen. Das Verhalten Österreichs während des Ungarnaufstandes 1956 and der tschechoslowakischen Krise 1968 (Vienna: Herold, 1981), 34.

${ }^{4}$ Council of Ministers, Protocol 12a, 28 October 1956, in ÖStA, AdR, BKA, MRP.

${ }^{5}$ Quoted in Johanna Granville, "Of Spies, Refugees and Hostile Propaganda: How Austria Dealt with the Hungarian Crisis of 1956," in History 91, no. 1 (2006), 62-90, 66.

${ }^{6}$ Quoted in Molin, "Central Issues of Swedish Neutrality Policy," 262.

7 Manfried Rauchensteiner, Spätherbst 1956: Neutralität auf dem Prüfstand (Vienna: Bundesverlag, 1981), 22. Cf. Erwin A. Schmidl, "Die österreichische Reaktion auf die Ereignisse in Ungarn 1956 und der Einsatz des Bundesheeres an der ungarischen Grenze," in Ibolya Murber and Zoltán Fónagy (eds.), Die Ungarische Revolution und Österreich 1956 (Vienna: Czernin, 2006), 93-115. 
Ferenc Nagy, who had lived in exile since 1947 and, during the uprising, had come to Austria, was asked to leave the country in order to prevent any cause for discussion about the Austrian role and its efforts to help the refugees.

No Soviet public statement concerning Austria was issued until 30 October, when Ambassador Bischoff was confronted in Moscow with charges that the uprising had been orchestrated by Hungarian émigré organizations in Austria and West Germany with American support. ${ }^{8}$ On 1 November, after the Hungarian prime minister Imre Nagy had declared his country's neutrality and the second Soviet intervention started, the Soviet delegate to the United Nations repeated these accusations. ${ }^{9}$ Pravda, Izvestiia, Radio Moscow and numerous other Soviet media referring to the Austrian communists' Volksstimme, which since 27 October had fiercely attacked the Austrian government for supporting the "counterrevolution" - joined in and accused Austria of not observing neutrality carefully enough, helping the insurgents and serving as a military base for them. The propaganda reported alleged US covert activities in Austria that supported Hungarian "fascist" fighters, ongoing flights between Austria and Hungary, and the smuggling of weapons and ammunition, secret service agents and saboteurs from Austria to Hungary. ${ }^{10}$ The Soviet effort to depict the Hungarian anti-communist revolution as the result of a plot organized by "fascist" and "reactionary" groupings based in Austria and supported by the United States was aimed at de-legitimizing the revolutionaries and legitimizing Soviet intervention. This policy, as assessed by the Austrian Foreign Service, was designed "to create, by incessantly repeating such claims, a legend that the events in Hungary had been orchestrated from abroad." 11

Having become a scapegoat of Soviet propaganda tactics, the Austrian government rejected all allegations. In a radio speech on 3 November, Raab stated that all Soviet accusations were invented "from A to Z," and Figl filed an official protest about the accusations with the Soviet ambassador. On 4 November, the issue of the Volksstimme which had printed the invented allegations was confiscated by the Austrian authorities. The military attachés of the four powers were invited to inspect the border zone, and the Hungarian government was assured that Austria would not tolerate any intrusion of émigrés into Hungary. ${ }^{12}$ Ambassador Bischoff in Moscow filed a protest with the Soviet Foreign Ministry. However, when he stated

${ }^{8}$ Rauchensteiner, Spätherbst 1956, 52.

${ }^{9}$ Békés, Byrne, Rainer, The 1956 Hungarian Revolution, 332; Eger, Krisen an Österreichs Grenzen, 45.

${ }^{10}$ Renáta Szentesi, "Anschuldigungen gegen Österreich von Seiten der Sowjetunion und der KPÖ während der Ungarnkrise von 1956 anhand österreichischer Quellen," in Ibolya Murber and Zoltán Fónagy (eds.), Die Ungarische Revolution und Österreich 1956 (Vienna: Czernin, 2006), 243-282.

${ }^{11}$ Besuch Mikojans, 17 April 1957, in ÖStA, AdR, BMAA, II-Pol, GZ. 215.864-pol/57, Z. 219.187$\mathrm{pol} / 57$.

12 Eger, Krisen an Österreichs Grenzen, 42-43. 
it would be better if the false accusations against Austria were terminated, Deputy Minister Valerian Zorin replied that it would be better if Austria's "activities" were terminated. ${ }^{13}$ The Soviet deputy minister called upon Austria to carefully observe neutrality and stated that "any lack of foresight would be exploited by others in order to weaken neutrality." 14

The Austrian position was strengthened by the United States' declaration of concern about Soviet troops near the Austrian border and by two statements made on 3 and 6 November stating that any attempt to violate the territorial integrity and inner sovereignty of Austria would be considered a "grave threat to peace." ${ }^{15}$ Although some Czechoslovakian and East German leaders and even the Soviet minister of defense, Marshal Georgii Zhukov, are said to have demanded the reoccupation of eastern Austria by Soviet troops, ${ }^{16}$ Soviet units, during most phases of the intervention, stayed away from the Austrian border. When the border was violated, Raab called Soviet Ambassador Sergei Lapin to receive the Austrian protest. ${ }^{17}$ Two weeks later, two Soviet soldiers who had chased Hungarian refugees were caught on Austrian territory, and one, M.P. Lopatin, was shot to death when trying to flee. Four days later the Soviet embassy delivered a formal note of regret stating that the USSR was determined to respect Austrian territory. ${ }^{18}$

With the second Soviet invasion, which reached Budapest on 4 November, claiming more than 3,000 lives and causing about 20,000 casualties, Austrian anger towards the Soviet Union and the pro-Soviet Austrian Communist Party reached a still higher level. The Austrian press published drastic and critical reports about the brutal crackdown on the uprising. In Vienna the police had to protect the Soviet army's monument, erected in 1945 in the center of the city, from being attacked by angry demonstrators $;{ }^{19}$ communist party offices were stormed and destroyed by Austrian citizens..$^{20}$ The dimensions of the Hungarian disaster and the flight of almost 200,000 refugees to neighboring Austria left a deep mark on the public consciousness. Most Austrians, who, as the Foreign Ministry later as-

${ }^{13}$ Iz dnevnika V. A. Zorina: Priem posla Avstrii, 3 November 1956, in RGANI, 89/45/21, 1.

${ }^{14}$ Quoted in Gehler, Österreichs Außenpolitik, 164.

${ }^{15}$ Quoted in Eger, Krisen an Österreichs Grenzen, 44.

${ }^{16}$ Manfried Rauchensteiner, "Sandkästen und Übungsräume: Operative Annahmen und Manöver des Bundesheeres 1955-1979," in idem (ed.), Zwischen den Blöcken: NATO, Warschauer Pakt und Österreich (Vienna: Böhlau, 2010), 253-322, 258; Malicek, "Die Beziehungen," 60.

${ }^{17}$ Eger, Krisen an Österreichs Grenzen, 50.

18 Glasneck, "Die Sowjetunion und Österreich," 92.

19 Schlesinger, Austrian Neutrality in Postwar Europe, 42.

${ }^{20}$ Manfred Mugrauer, “Zwischen Erschütterung, neuer Offenheit und „Normalisierung“: Die KPÖ, der 20. Parteitag der KPdSU und die Ungarn-Krise 1956," in Wolfgang Mueller and Michael Portmann (eds.), Osteuropa vom Weltkrieg zur Wende (Vienna: Verlag der Österreichischen Akademie der Wissenschaften, 2007), 257-298. See also A. S. Stykalin, "XX s"ezd KPSS: otkliki v Vengrii i Avstrii," in G.G. Litavrin, T.V. Volokitina, and R.P. Grishina (eds.), 1956 god: Sbornik statei (Moscow: Institut Slavianovedeniia Rossiiskoi akademii nauk, 2008), 220-235. 
sessed, felt historically "connected by countless bonds" to the Hungarian people, were thrown into "horror and shock" by the crushing of the revolution. ${ }^{21}$ Even the Soviet-friendly Bischoff claimed: "Never in history has anything similar taken place, and nobody should be surprised if such an unprecedented phenomenon has created psychological consequences, consequences that nobody regrets more than I, but which were, however, unavoidable." ${ }^{\prime 2}$ The leadership of the Austrian-Soviet Friendship Society ÖSG (which had been established on Soviet initiative in May 1945, and in the following years been systematically taken over by the Austrian communists) tried to justify the Soviet bloodshed in Hungary and declared that the society's activities would not be touched by the events. ${ }^{23}$ This outraged its newly gained noncommunist members and the public in general, and led the society back to the isolation of the pro-Moscow communist ghetto it had left only a short time earlier. When State Secretary Franz Grubhofer of the conservative People's Party, with an eye on the USSR, called for the introduction of a neutrality protection law that would oblige citizens and the media not to do things that might cause difficulties in observing neutrality, ${ }^{24}$ he was forced, because of the fierce reactions, to drop his proposal. The Austrian Federation of Trade Unions appealed to its Soviet counterpart to exert its influence on the actions in Hungary and to mediate. It called on Austrians for solidarity, collecting more that sixteen million schillings for aid, and organized a strike to protest the forceful oppression of the Hungarian resistance. ${ }^{25}$

On the international theater, Austria supported the UN resolution proposed by the United States on 4 November that demanded the Soviet army's withdrawal, the formation of a Hungarian government reflecting the people's will, the right of entry for UN observers, and organizing humanitarian help for the Hungarian people. Austria thus made it clear that it was not adopting a neutralistic stance towards freedom and democracy. ${ }^{26}$ However, Austria also supported an Indian motion for cancelling all references to the political background of the Hungarian disaster in a US draft, but did not support an Italian resolution calling for free elections in Hungary. The latter abstention was ostensibly due to the lack of new elements in the document. However, the true reason seems to be that Austria did not consider the Italian draft acceptable to the Soviet Union and wanted to avoid further alienation of the USSR before bringing forward its own proposal. ${ }^{27}$ The Austrian draft,

${ }^{21}$ Mikojan-Besuch, 9 March 1957, in ÖStA, AdR, BMAA, II-Pol, GZ. 215.864-pol/57, Z. 217.544pol/57.

22 Bischoff to Austrian MFA, 21 February 1957, in ÖStA, AdR, BMAA, II-Pol, GZ. 215.033-pol/57, Z. 217.176-pol/57.

${ }^{23}$ Glasneck, "Die Sowjetunion und Österreich," 99.

${ }^{24}$ Ermacora, 20 Jahre österreichische Neutralität, 96-97.

${ }^{25}$ Eger, Krisen an Österreichs Grenzen, 71.

${ }^{26}$ Wolfgang Strasser, Österreich und die Vereinten Nationen: Eine Bestandsaufnahme von $10 \mathrm{Jah}$ ren Mitgliedschaft (Vienna: Braumüller, 1967), 88-89.

27 Text in Archiv der Gegenwart, 6090, 9 November 1956. On UN aid for Hungary, see Georg Kastner, "Hilfsaktionen der Vereinten Nationen für die Volksrepublik Ungarn," in Ibolya Murber and 
focusing exclusively on an initiative for humanitarian aid, did not touch on political questions and won sixty-seven yes-votes with eight abstentions and no refusals - until then the highest level of support ever reached for a proposition in the UN General Assembly. The abstentions came mainly from the Soviet bloc, whereby Yugoslavia and even Poland voted in favor of the Austrian initiative. Concerning the NATO countries' boycott of Soviet diplomatic representations in response to the violent Soviet crackdown in Hungary, the Austrian conduct was not consistent: whereas the Austrian ambassador in Rome did not show up at the Soviet embassy on the USSR state holiday, Bischoff visited the reception in the Kremlin.

In the meantime, however, the Soviet propaganda campaign against alleged Austrian toleration of American and Hungarian revolutionary activities on Austrian soil did not cease. The attacks were even intensified; the number of Soviet newspaper articles concerning Austria published in 1956 almost reached the alltime high of 1955, and was three times more than the annual average of the following years. ${ }^{28}$ After the crackdown on the uprising, the new pro-Soviet Hungarian government joined in. Although covert American actions, such as the sending of propaganda balloons by Radio Free Europe over Austrian territory, ${ }^{29}$ could not be denied, it seemed clear that no Austrian official authorities were involved in such activities. Therefore, all allegations were rejected as unjustified by Raab in a radio speech on 11 November, in which the Austrian chancellor very bluntly criticized all oppressors of freedom and stated that "the domination over foreign nations and the oppression of free speech will never bring blessings." ${ }^{30}$ Three days later and again in the December issues, the Soviet Foreign Ministry's organ Mezhdunarodnaia zhisn' and the Literaturnaia gazeta attacked Raab and stated that Austria had failed the first test of neutrality. ${ }^{31}$ In late November, the Soviet delegate to the United Nations and the Komsomolskaia pravda accused Austria and its embassy in Budapest of having provided handguns to the insurgents, ${ }^{32}$ and in Moscow, Defense Minister Zhukov charged the neutral with having allowed US military flights from Munich to Vienna. ${ }^{33}$ When Ambassador Bischoff investigated further details in the Soviet Foreign Ministry, Gromyko appeared to be uninformed.

Zoltán Fónagy (eds.), Die Ungarische Revolution und Österreich 1956 (Vienna: Czernin, 2006), 187-206.

${ }^{28}$ Merhaut-Gurevitsch, "Die Innen- und Außenpolitik Österreichs," 11.

${ }^{29}$ Andreas Gémes, "Schade, schade, immer Spionage!," in Ibolya Murber and Zoltán Fónagy (eds.), Die Ungarische Revolution und Österreich 1956 (Vienna: Czernin, 2006), 207-242, 212-220.

${ }^{30}$ Quoted in Eger, Krisen an Österreichs Grenzen, 47-49.

${ }_{31}$ Malicek, "Die Beziehungen," 64-65.

${ }^{32}$ Szentesi, "Anschuldigungen gegen Österreich," 252; Austrian embassy Moscow to Austrian MFA, 3 December 1956, in ÖStA, AdR, BMAA, Pol. Berichte.

${ }_{33}$ Bischoff to Austrian MFA, 28099, 4 December 1956, ÖStA, AdR, AVA, NL E/1770: Bischoff, File 108. 
In mid-December the propaganda concerning the neutral's involvement in the uprising was scaled back; ${ }^{34}$ however, Izvestiia and Pravda continued to publish a series of communist horror stories about Austrian maltreatment of Hungarian refugees, particularly about children been kept in Austria behind barbed wire and sold into slavery in the United States. ${ }^{35}$ The Austrian Foreign Service felt particularly indignant about the Soviet accusations. ${ }^{36}$ Bischoff tried to counteract by sending a copy of an official note to the Soviet Foreign Ministry, in which the Hungarian government thanked Austria for its charitable activities, ${ }^{37}$ but the campaign did not cease before mid-February. The propaganda about alleged Austrian violations of neutrality seemed to be aimed at creating an external scapegoat for the uprising, destroying the attractiveness of neutrality for the East European peoples, and at warning the Austrian government and its citizens not to go too far in its solidarity with the Hungarian uprising. However, it soon became clear that the USSR was not interested in actually discrediting Austrian neutrality.

\section{The recovery}

It was noted that the Soviet leadership, even before the unfriendly agitation ended, had begun to send out signals that it did not want Soviet-Austrian relations or Austria's international reputation in the West to be damaged. When the Austrian ambassador visited the Soviet president to give condolences for the Soviet soldier who had been shot on Austrian territory on 23 November, he noticed that "no critical words were said from the Soviet side concerning the implementation of our neutrality." ${ }^{\prime 38}$ At a Kremlin reception in the honor of the Bulgarian delegation, Bulganin and Khrushchev, after criticizing Austria for allegedly letting "counterrevolutionaries" enter Hungary, tacitly acquiesced with Bischoff's reply that such foreign activists - if they had existed at all - were of no importance in comparison to the hundreds of thousands of Hungarian insurgents and refugees. ${ }^{39}$ At a similar event on 1 December, Khrushchev welcomed Bischoff with the words: "Greetings to the neutral Austria!" When the Romanian ambassador implicitly questioned the neutral's impartiality, the Soviet leader openly assured the Austrian representative that his words had been meant sincerely and honestly. ${ }^{40} \mathrm{~A}$ few days later, Austrian-

${ }^{34}$ Austrian embassy Moscow to Austrian MFA, 15 December 1956, in ÖStA, AdR, BMAA, Pol. Berichte.

${ }^{35}$ Merhaut-Gurevitsch, "Die Innen- und Außenpolitik Österreichs," 102-110.

${ }^{36}$ Mikojan-Besuch, 9 March 1957, in ÖStA, AdR, BMAA, II-Pol, GZ. 215.864-pol/57, Z. 217.544$\mathrm{pol} / 57$.

37 Austrian embassy Moscow to Shepilov, 4 December 1956, in ÖStA, AdR, BMAA, Pol. Berichte Moskau.

${ }^{38}$ Quoted in Szentesi, "Anschuldigungen gegen Österreich,” 253.

39 Bischoff to Austrian MFA, 21 February 1957, in ÖStA, AdR, BMAA, II-Pol, GZ. 215.033-pol/57, Z. 217.176-pol/57.

${ }^{40}$ Quoted in Lobova, "Die Außenpolitik Österreichs aus der Sicht der UdSSR," 901. 
Soviet negotiations concerning a delivery of 100,000 tons of Austrian oil to the USSR to be substituted with goods were concluded successfully. ${ }^{41}$

Not even Chancellor Raab's speech of 20 January 1957, which advocated the adoption of neutrality by Hungary, disrupted the upturn in the relations. Deputy Foreign Minister Andrei Gromyko, who was in Vienna in January for Austrian president Theodor Körner's funeral, is said to have - unsuccessfully - tried to press Raab to eliminate some passages. ${ }^{42}$ In a report of the Committee of Information of the Soviet Foreign Ministry, Raab's speech is depicted as an indication of growing "tendencies in Austrian foreign policy, in response to the plans of the Western powers and the Vatican, to use Austria for detaching the people's democracies from the socialist camp." 43 As further evidence for these plans, the report charged the Austrian deputy foreign minister Kreisky with having offered Austrian loans to Poland in order that it "not become dependent upon the USSR" and the social democratic foreign policy expert Karl Czernetz with calling for "full independence of the East European states." Although Raab's proposal of neutrality for Hungary was later denounced as "unacceptable interference in Hungarian affairs" by the Soviet press, it seems not to have hindered the Soviet-Austrian détente.

Neither did Foreign Minister Dmitri Shepilov's speech at the sixth session of the Supreme Soviet on 12 February 1957; it contained criticism of "certain actions of the Austrian government that hardly conform to Austria's chosen status of neutrality," such as "the use of Austrian territory by imperialistic forces during the counterrevolutionary plot against [...] Hungary" or "the prohibition of international democratic organizations being seated in Austria." However, the foreign minister also underlined that the USSR still "supported Austrian neutrality and independence" and was determined to "henceforth develop the amicable relations to this country." "After the bilateral Soviet-Hungarian declaration of 28 March 1957, issued on the occasion of the new Hungarian communist leader János Kádár's visit to Moscow, Austrian-Hungarian relations remained strained for some time. ${ }^{45}$ The communiqué repeated the accusations against the West in general and Austria in particular, accusations that were as well known as they were invented: According to the communiqué, "aggressive circles of the West" had overseen the "counterrevolutionary putsch" of the previous fall and taken part in it; Austria had allowed

${ }^{41}$ Eger, Krisen an Österreichs Grenzen, 51.

${ }^{42}$ Rauchensteiner, Die Zwei, 352-353. For extracts from the speech, see Mayrzedt and Hummer, 20 Jahre österreichische Neutralitäts- und Europapolitik 1, 110.

${ }^{43}$ Committee of Information to Suslov, Shepilov, Ponomarev, 27 February 1957, in RGANI, 5/30/224, 49-52.

${ }^{44}$ Rede des sow. Außenministers, 16 February 1957, in ÖStA, AdR, BMAA, GZ. 215.014-pol/57, Z. 216.660-pol.

45 Andreas Gémes, "Austria and Hungary," in Arnold Suppan and Wolfgang Mueller (eds.), Peaceful Coexistence or Iron Curtain? Austria, Neutrality, and Eastern Europe in the Cold War and Détente, 1955-1989 (Vienna: Lit, 2009), 301-327, 312-314. 
its territory to be used for activities "obviously hostile towards Hungary" - a policy that was "hardly in accordance with neutrality as declared by Austria."

Soviet-Austrian relations soon recovered. A symbol of this relaxation was the visit of Soviet leadership member Anastas Mikoian to Vienna from 23 to 27 April 1957. With hindsight, it seems safe to claim that it was "not a coincidence," as Russians might say, that the first visit of a Soviet statesman to the West (Finland excluded) after the violent crackdown on the Hungarian uprising went to Austria. Mikoian's trip, which had been scheduled for November 1956 and postponed by the $\mathrm{Kremlin}^{47}$ at the height of the Hungarian crisis, became proof that the Soviet Union was interested not only in restoring Soviet-Austrian relations and receiving some assurance that Austria had learned its lesson, but also in showing its intention to improve East-West relations after the crises of 1956. Mikoian's words carried even more weight since the Soviet envoy, after Molotov's dismissal from the leadership, functioned as number two of the party and as foreign-policy curator of its Presidium (the former Politburo).

On the Austrian side, the Hungarian revolution and the Soviet campaign against the neutral scapegoat loomed large in the Foreign Ministry's preparations for the visit. In Vienna, it was well understood that neither the Soviet nor the new Hungarian government "wants to admit that the cause for the events in Hungary in the previous autumn lay within Hungary itself." 48 Nonetheless, rejecting the groundless Soviet accusations against Austria's maintenance of neutrality was vital for keeping the country's international status from becoming stained.

In his conversations with the Austrian government, Mikoian, albeit in a very moderate tone, mentioned "forces struggling to dissuade Austria from observing neutrality and to disturb Austrian-Soviet relations" 49 and the "strange parallelism" of Austrian statements in the fall of 1956 with statements by NATO members. After expressing his appreciation of Austria's adoption of neutrality in 1955 and underlining that he did not want to interfere in Austrian affairs, Mikoian criticized "certain words and deeds of Austria in the last period" with which "we are not content," ${ }^{50}$ particularly the promotion of the Austrian policeman who had shot a

${ }^{46}$ Keesing's Archiv der Gegenwart, 1 April 1957, 6363.

${ }^{47}$ In November 1956, the Austrian MFA dicussed the inappropriateness of Mikoian's visit under the current conditions. A few days later, the USSR asked the visit to be postponed due to "lack of time" for preparations. A.A. Fursenko et al. (eds.), Prezidium TsK KPSS 1954-1964, 1 (Moscow: Rosspen, 2003), 970. After the death of the Austrian president Körner, the Kremlin offered to postpone Mikoian's visit once more in order to avoid any collision with the election campaign. Austrian embassy Moscow to Austrian MFA, 14 March 1957, in ÖStA, AdR, BMAA, GZ. 215.864-pol/57, Z. 217.823-pol/57.

48 Besuch Mikojans, 17 April 1957, in ÖStA, AdR, BMAA, II-Pol, GZ. 215.864-pol/57, Z. 219.187$\mathrm{pol} / 57$.

49 Quoted in Glasneck, "Die Sowjetunion und Österreich," 97-98.

${ }_{50}$ Besprechung im Bundeskanzleramt, 24 April 1957, in ÖStA, AdR, BMAA, GZ. 215.864-pol/57, Z. 222.278-pol. For the full protocol of the conversation, see pages 287-293. 
Soviet soldier on Austrian territory, and the ban of the World Federation of Trade Unions and the World Peace Council. By stating that "we cannot understand which interest Austria might have in meddling into Hungarian affairs," he also implied that the neutral may have interfered in its neighbors' politics. Nevertheless, he underlined Soviet interest in Austrian neutrality, "because Austria's role as a neutral state is more useful for peace than anything else." When Raab complained about the propaganda attacks of the new Hungarian government against Austria, Mikoian encouraged Raab to re-establish friendly relations with Austria's communist neighbor states and even to contact the new Hungarian leaders (and thus, to help them out of their international isolation).

The Austrian chancellor did not give in to Mikoian's criticism and stated that Austria had never violated neutrality, that the country was interested in friendly relations with its neighbors and the USSR, and that it was not Austria who had erected the Iron Curtain. He also did not let Austria be instrumentalized for Soviet initiatives. When preparing for the Mikoian visit, the Austrian Foreign Ministry had emphasized that it would be necessary in the negotiations to stick to a "purely Austrian" position, as "flattering" the Soviets would undermine Western trust in Austria. ${ }^{51}$ With this in mind, the Austrian delegation refused to include any reference to the Soviet proposal for an all-European security system in the communiqué..$^{52}$

On the bilateral level, Mikoian's visit contributed to a noticeable warming in the relations. The Soviet leader expressed the interest in consolidating "all the good that has been reached in our relations" and in endeavoring "to overcome all obstacles and prejudices that hinder the friendship between the Soviet and Austrian people." This did not mean, however, that he granted Austria its desired Soviet approval of a reduction in the Austrian oil deliveries stipulated by the state treaty (this "carrot" was held back by the Kremlin to get Raab to visit Moscow). Nevertheless, the "friendly relations" established in 1955 were, as stated in the joint communiqué, "again approved." Both sides underlined the importance of the preservation of peace, of disarmament, and of Austria's neutrality. In the communiqué, neither the Hungarian crisis nor Soviet-Austrian disagreements were mentioned. Only the reference to "open" talks hinted at Soviet disapproval of Austria. ${ }^{54}$

The most important aspect of Mikoian's visit to Vienna, however, was, as contemporary commentators from Poland to Italy and the United States agreed, that Austria had helped the Kremlin to leave the international isolation into which it

${ }^{51}$ Mikojan-Besuch in Österreich, 9 March 1957, in ÖStA, AdR, BMAA GZ. 215.864-pol/57, Z. 217.544-pol/57.

52 Schöner to Matsch, 30 April 1957, in ÖStA, AdR, BMAA, Z. 219.707-pol/57.

${ }_{53}$ The Austrian Foreign Ministry had considered it unlikely that the question would be solved during the visit. Austrian embassy Moscow to Austrian MFA, 14 March 1957, in ÖStA, AdR, BMAA, GZ. 215.864-pol/57, Z. 217.823-pol.

${ }^{54}$ Aus dem sowjetsch-österreichischen Kommuniqué, 28 April 1957, in UdSSR - Österreich, 105106. 
had fallen after its brutal invasion of Hungary ${ }^{55}$ In the words of the head of the Swiss Political Department, Fritz Gygax, "the visit of Mr. Mikoian to Vienna was one link in a chain of efforts to make the Soviet Union fit again for international society [wieder international hoffähig zu machen] after the events in Hungary, and to send some messages to the West from Vienna." Austria, the diplomat stated, was chosen for this visit of "extraordinary importance" as a sounding board for these messages, in order "to demonstrate the good intentions and the good will of the USSR towards all European states that were keeping out of military blocs and nuclear armament." ${ }^{\prime 56}$

Indeed, it soon became clear that Mikoian primarily used his stay in Vienna to "speak out of the window" to the West. ${ }^{57}$ The Soviet intention to invite not only Austria, but the West in general to a new start of détente was not to be misunderstood. "Everything," Mikoian explained, even the crises in Egypt and Hungary, which could have been used to incite a world war, had "good effects": now both the East and the West knew that the other side did not want war. ${ }^{58}$ This assessment was not to be underestimated, since some years earlier the Soviet Union, in the words of an Austrian official, had been convinced of the aggressive intentions of the United States. Mikoian's second message was even more important. He expressed his optimism about the possibility of getting international disarmament, which had gotten stuck, moving again and of even coming to an agreement. The Soviet Union, Mikoian stressed, had unilaterally reduced its army by 1.8 million men, and it advocated a nuclear test stop and the destruction of all nuclear weapons. ${ }^{59} \mathrm{He}$ welcomed the Western decision to drop the Baruch Plan for a complete ban on nuclear weapons and advocated a nuclear-weapons free zone 800 kilometers east and west of the Elbe River (similar to the Rapacki Plan, which was launched in October by the Polish foreign minister ${ }^{60}$ ). However, any ideas of creating a "neutral belt" in Europe were discouraged by the Kremlin. ${ }^{61}$ Raab's proposal for a neutral

${ }_{55}$ Austrian embassy Warsaw to Austrian MFA, 24 May 1957, in ÖStA, AdR, BMAA, GZ. 215.864pol/57, Z. 220.913-pol.

56 Austrian legation Bern to Austrian MFA, 8 May 1957, in ÖStA, AdR, BMAA, GZ. 215.864 pol/57, Z. 220.117-pol.

57 Schöner to Matsch, 30 April 1957, in ÖStA, AdR, BMAA, Z. 219.707-pol/57.

${ }_{58}$ Besprechung im Bundeskanzleramt, 24 April 1957, in ÖStA, AdR, BMAA, GZ. 215.864-pol/57, Z.222.278-pol. For the full protocol of the conversation, see pages 287-293.

${ }^{59}$ Ibid. On Khrushchev's troop cuts, cf. Matthew Evangelista, “Why Keep Such an Army?” Khrushchev's Troop Reductions, Cold War International History Project Working Paper 19 (Washington, DC: Woodrow Wilson Center, 1997), 4-5.

${ }^{60}$ On the Rapacki Plan, see Piotr Wandycz, "Adam Rapacki and the Search for European Security," in Gordon A. Craig and Francis L. Loewenheim (eds.), The Diplomats, 1939-1979 (Princeton: University Press, 1994), 289-317; and Wanda Jarczabek, Hope and Reality: Poland and the Conference on Security and Cooperation in Europe, 1964-1989, Cold War International History Project Working Paper 56 (Washington, DC: Woodrow Wilson Center, 2008), 4.

${ }^{61}$ Schöner to Matsch, 30 April 1957, in ÖStA, AdR, BMAA, Z. 219.707-pol/57. 
Hungary was rejected and the uniqueness of Austria's status underlined. When on 10 May the Austrian Neue Tageszeitung claimed that Mikoian's visit had showed that the USSR was ready to give up the GDR, the Soviet ambassador asked for an official correction. ${ }^{62}$

With Mikoian's trip, which left a "generally favorable impression" in Austria, ${ }^{63}$ the ice at the official bilateral level was broken. It must be noted, however, that it took much longer for the Soviet Union to regain acceptance among the general Austrian population after the bloodshed in Hungary. When the Viennese Eisrevue, an ice skating company that was later taken over by the United States' Holiday on Ice, traveled to Moscow in April 1957, its members were fiercely attacked in the Austrian media as "traitors." Similar reactions were published when the Austrian minister of justice followed a Soviet invitation to Moscow in July. The Austrian press criticized that Otto Tschadek, who was the first Western justice minister to accept a Soviet invitation, thus helped the "infamous Russian judiciary" to gain prestige equal to the Western one. ${ }^{64}$

While the Soviet image remained, in the Austrian public opinion, linked to the brutality of the Stalin era and that of 1956, Austria, in the eyes of its pro-Soviet ambassador in Moscow, seemed to be "one of the most-liked Western countries" among the Russians. All thirty-five performances of the Eisrevue, Bischoff claimed, were sold out. Whereas this success could also be attributed to a lack of variety in the Soviet capital's entertainment program, there might be some truth to Bischoff's assessment that "for average Muscovites, Austrians today are not 'the evil people who sent weapons to the Hungarian fascists,' and not even 'the wise people who kept out of NATO and declared neutrality,' but they are 'the people who gave the world Mozart and Johann Strauß and now sent their Eisrevue to us." "'65

The Soviet media, indeed, repeatedly called attention to Soviet-Austrian affinities with regard to culture, particularly high culture. ${ }^{66}$ This had been a stock theme of Soviet propaganda in Austria in 1945, and was used now in support of the current tendency in Soviet foreign policy towards Austria. However, in order that Austria not become too attractive as a model for Eastern Europeans and the Soviet people, the communist media kept up a certain medium-level criticism with regard to, on one hand, "political circles" attempting to derail Austria's neutral course, and, on the other, unjust social and economic conditions in Austria as a capitalist country. A generally positive report about Austria in the youth magazine Ogonek on 18 August

${ }^{62}$ Artikel in der Neuen Tageszeitung, 12 June 1957, in ÖStA, AdR, BMAA, GZ. 215.864-pol/57, Z. 222.136-pol.

${ }^{63}$ Foreign Relations of the United States, 1958-1960, IX: Berlin Crisis, Germany, Austria (Washington, DC: Government Printing Office, 1993), 768.

${ }^{64}$ Presseangriffe, 2 July 1957, in ÖStA, AdR, BMAA, GZ. 221.442-pol/57, Z. 221.795-pol/57.

${ }_{65}$ Austrian embassy Moscow to Austrian MFA, 14 May 1957, in ÖStA, AdR, BMAA, GZ. 215.633pol/57, Z. 220.793-pol.

${ }^{66}$ Stifter, "Das politische Österreichbild," 142. 
1957 was embellished with pictures of beggars and homeless on Viennese streets, and in the following months, several publications appeared featuring the allegedly poor living conditions of Austrian workers. ${ }^{67}$ However, once Pravda, on 27 August 1957, praised the idea of neutrality, which had "taken strong roots in Austria" and enabled the country to "exert a great deal of positive influence on international developments," nobody could doubt that Soviet-Austrian relations had been restored following the most severe test they had as yet undergone.

${ }^{67}$ Cf. Austrian embassy Moscow to MFA, 25 September 1959, in ÖStA, AdR, BMAA, GZ. 248.423$\mathrm{pol} / 59$. 



\section{Starting Anew: After the Hungarian Revolution}

In the meantime, Soviet diplomacy tried to strike the Austrian iron while it was hot: After Soviet Premier Bulganin had presented his "peace notes" of 10 December 1957 and of 8 January 1958 to the member states of the United Nations plus Switzerland, ${ }^{1}$ a document that proposed a nonaggression treaty between the two blocs and a conference of world leaders to end the Cold War, he, in a "personal message" to Chancellor Raab, called on Austria to support the initiative. The Bulganin notes, one of the most comprehensive Soviet disarmament proposals until that time, had come only after the Soviet decision to withdraw from the UN disarmament negotiations in Geneva; ${ }^{2}$ the notes were aimed at projecting a more peaceful image of the USSR, ${ }^{3}$ re-engaging the West in negotiations, and angling for a summit. Promoting the Rapacki Plan, they were likely to frustrate NATO plans for tactical nuclear rearmament in Western Europe, which was deemed indispensable by Western leaders for balancing the quantitative superiority of Soviet conventional forces in Europe. In Bulganin's proposal, a special status of "nuclear neutrality" was offered to all NATO states that gave up their launching sites. In the long run, the proposals, if accepted, were to create a Soviet preponderance in Europe by eliminating nuclear weapons from the Western parts of the continent and to undermine the US presence in Europe by expelling all "foreign troops" from Germany. Although the notes admitted that no quick success was likely to be reached at a summit, such a meeting was considered essential for building trust and also for fostering economic ties between the East and West. The participation of neutral and nonaligned states was welcomed explicitly.

By claiming that Austria, by virtue of its status, "must be interested" in securing peace and "could make a special contribution," Bulganin, in his personal message, encouraged Raab to take on the responsibility for proposing the conference as well as disarmament ideas to the West, while mobilizing Austria against the creation of

\footnotetext{
${ }^{1}$ Keesing's Archiv der Gegenwart, 11 December 1957, 6809; 10 January 1958, 6836. For the text of the letter to US president Eisenhower and other Western leaders, 10 December 1957, see Dokumente zur Deutschlandpolitik III/3, no. 3: 1957, bearb. von Ernst Deuerlein, Gisela Biewer und Hansjürgen Schierbaum (Frankfurt am Main: Metzner, 1967), 2030-2042; the follow-up letters to the West German chancellor Adenauer and to other Western leaders, and the Soviet proposal, 8 January 1958, in Dokumente zur Deutschlandpolitik III/4, no. 1: 1958, bearb. von Ernst Deuerlein und Gisela Biewer (Frankfurt am Main: Metzner, 1969), 21-81.

2 John van Oudenaren, Détente in Europe: The Soviet Union and the West (Durham: Duke University Press, 1991), 50-52.

3 Veljko Mičunović, Moskauer Tagebücher 1956-1958 (Stuttgart: Klett-Cotta, 1982), 392.
} 
nuclear launching sites in Italy. The letter contained pleasant compliments about the possibilities and also the responsibility carried, in Bulganin's eyes, by neutral Austria for relaxing tensions and "restoring confidence in international relations." $\mathrm{Such}$ advances were part and parcel of a Soviet campaign for a new détente, the neutralization of Western Europe, and the dissolution of the European-American alliance, a campaign that combined relaxing measures, such as Soviet conventional troop reductions, with a Soviet nuclear build-up and nuclear threats against Western countries, among them the United States, Britain, France, Italy, the Netherlands, Greece, Turkey, and Israel. ${ }^{5}$ Like most of the numerous Soviet proposals in the years 1955 to 1958 , it found little resonance abroad and was soon overshadowed by new crises.

In March 1958, Nikita Khrushchev encouraged the Austrian government to support his recent initiative for a nuclear test ban, and in July, Austria, among other countries, received a Soviet invitation for preparing the conclusion of an all-European treaty on friendship and cooperation. ${ }^{6}$ Even earlier, Chancellor Raab had been invited to come to Moscow, and signals were sent to Vienna that the USSR would be appreciative of Austria's good services in the German question. ${ }^{7}$

Concerning Bulganin's "peace initiative" and the Rapacki Plan, the chancellor's cautious answer, namely, that Austria appreciated both blocs' efforts to disarm and that he was ready to support any initiatives leading to détente, ${ }^{8}$ was greeted in both the East and the West. In the case of Germany, Raab, who, erroneously, was convinced that both parts of the country would be granted and willing to accept a status similar to Austrian neutrality, launched an initiative to found an interallied commission on Germany with the task of investigating the conditions necessary

${ }^{4}$ Correspondence Bulganin - Raab, in ÖStA, AdR, BMAA GZ. 227.665-pol/57, Z. 227.678pol/57 and GZ. 544.297-pol/58, Z. 544.588-pol/58. The full text is published on pages 293-297. In his message to US president Eisenhower dated 4 February 1958, Bulganin proposed a summit meeting dealing with a suspension of nuclear tests, an abandonment of nuclear weapons, and a nonaggression treaty between NATO and the Warsaw Pact. TASS, 4 February 1958.

5 On the troop cuts, see Evangelista, "Why Keep Such an Army? ”, 4-6. On the nuclear build-up, see Holloway, Stalin and the Bomb, 324-335; idem, "Nuclear Weapons and the Escalation of the Cold War," in Melvin Leffler and Odd Arne Westad (eds.), The Cambridge History of the Cold War I: Origins (Cambridge: University Press, 2010), 376-397. Cf. Frank Umbach, Das rote Bündnis: Entwicklung und Zerfall des Warschauer Paktes 1955 bis 1991 (Berlin: Links, 2005), 105-106.

${ }^{6}$ Rauchensteiner, Die Zwei, 381-382. On the Soviet proposal, see Bernhard Schalhorn, "Sowjetische Westeuropapolitik I," in Dietrich Geyer (ed.), Osteuropa-Handbuch Sowjetunion II: Außenpolitik 1955-1973 (Cologne: Böhlau, 1976), 61-145, 93-95; on further initiatives for disarmament, see ibid., 86-99. The text of the Soviet note and proposal, 15 July 1958, is published in Dokumente zur Deutschlandpolitik III/4, no. 2, 1464-1469.

${ }^{7}$ Michael Gehler, "Neutralität und Neutralisierungspläne für Mitteleuropa? Österreich, Ungarn, Tschechoslowakei und Polen," in Dominik Geppert and Udo Wengst (eds.), Neutralität - Chance oder Chimäre? Konzepte des Dritten Weges für Deutschland und die Welt 1945-1990 (Munich: Oldenbourg, 2005), 105-131, 111-115.

8 Verbalnote Bundeskanzleramt, Zl. 544.441-pol/58, 21 January 1958, Ministerratsprotokoll 64, 21 January 1958, in ÖStA, AdR, MRP. 
for its reunification and for free all-German elections (similar to what had been proposed by the Western powers between 1952 and 1954 but turned down by the Kremlin). ${ }^{9}$ The Soviet proposal for solving the problem by talks between the FRG and the GDR was characterized by Raab as "absurd" and "illusory." 10

It soon became clear that Raab's idea had no chance of realization and was dropped. Nevertheless, a few days before Khrushchev staged the second Berlin crisis by attempting to expel the Western powers from West Berlin and rid the city of its protection, Gromyko chose the Austrian ambassador, Bischoff, to convey secretly to the West German representative in Moscow, Ambassador Hans Kroll, the message that "the conclusion of a peace treaty with Germany could lead to the resolution of the entire German problem."11 In return, the West German government was to renounce nuclear weapons and recognize the "people's democracies" plus the GDR. Bischoff expressed his conviction that the USSR sincerely wanted to open the way to German unification - as it turned out, a serious misunderstanding on the Austrian ambassador's side. Though Bischoff fulfilled the request, it did not lead to the goal the Kremlin had hoped for: After the Soviet ultimatum to Berlin, there was no longer any basis for fruitful negotiations. In a conversation with Khrushchev on 11 November 1958, Bischoff looked into how the USSR would react if the West rejected the Soviet proposal about Berlin. The day before, Khrushchev, in a reception for the Polish delegation, had rebuffed any Western rights in West Berlin. ${ }^{12}$ The Soviet leader replied coolly: "In that case, our missiles are ready and aimed at the right targets. We only need a few of them.."13 Obviously Khrushchev again counted on Bischoff to pass this message on to Bonn.

An effort by Bruno Kreisky to arrange a meeting between Berlin mayor Willy Brandt and a "high ranking Soviet representative" in the spring of 1959 also failed after Brandt withdrew. ${ }^{14}$ During Khrushchev's visit to Austria, Gromyko asked

${ }^{9}$ Matthias Pape, "Die Deutschlandinitiative des österreichischen Bundeskanzlers Julius Raab im Frühjahr 1958," in Vierteljahrshefte für Zeitgeschichte 48, no. 2 (2000), 281-318. Cf. Report on Raab's interview with Industriekurier, 26 April 1958, in Dokumente zur Deutschlandpolitik III/4, no. 2: 1958, bearb. von Ernst Deuerlein und Gisela Biewer (Frankfurt am Main: Metzner, 1969), $1057-1058$.

${ }^{10}$ Quoted in Glasneck, "Die Sowjetunion und Österreich," 106.

${ }^{11}$ Fursenko and Naftali, Khrushchev's Cold War, 205, 207, 211. Cf. Austrian embassy Moscow to Austrian MFA, Z. 73-pol/58 and Z. 74-pol/58, 23 November and 1 December 1958, in SBKA, Länderbox UdSSR, 1; Bischoff to Figl, 28080, 26 November 1958, ÖStA, AdR, AVA, NL E/1770: Bischoff, File 108; Pape, Ungleiche Brüder, 499-500, 618-620. An extract of Kroll's memoir is published in Dokumente zur Deutschlandpolitik IV/1, no. 1: 10 Nov. 1958-31 Jan. 1959, bearb. von Ernst Deuerlein und Hannelore Nathan (Frankfurt am Main: Metzner, 1971), 121-122.

${ }^{12}$ Gerhard Wettig, Chruschtschows Berlinkrise 1958 bis 1963: Drohpolitik und Mauerbau (Munich: Oldenbourg, 2006), 25.

${ }^{13}$ Bischoff to Austrian MFA, 28073, 11 November 1958, ÖStA, AdR, AVA, NL E/1770: Bischoff, File 108.

${ }^{14}$ Gehler, Österreichs Außenpolitik, 200, 204. Cf. Martin Kofler, "Kreisky - Brandt - Khrushchev: The United States and Austrian Mediation during the Berlin Crisis 1958-1963," in Günter Bi- 
Kreisky to contact the West Germans and pass on a Soviet proposal, dated 2 July 1960, on the transformation of West Berlin into a "free city." Although Secretary of State Christian Herter asserted that the Soviet memorandum contained "nothing new," 15 Brandt and Adenauer were informed. However, information was leaked to the press, and the initiative did not bear any fruit. In 1959 and 1962, Khrushchev used his conversations with Kreisky and other Austrian representatives to repeat his threats against West Berlin. ${ }^{16}$ The Soviet leader indicated that he was concerned about a possible nuclear rearmament of West Germany and was prepared to sign a separate treaty with the GDR; while he ruled out German reunification any time soon, Khrushchev claimed West Berlin as part of East Germany and threatened to "cut [it] off." Despite their fruitlessness, these communications show, on one hand, the Soviet strategy of using the neutral not only for conveying Soviet messages to the West Germans, but also for repeatedly reminding the latter of the privileged status they could attain if they were ready to abandon their alliance with the West. On the other hand, these episodes prove that Austrian leaders were only too ready to offer their services (not just to improve their standing in the Kremlin, but also out of their sincere aspirations to help their friends in Germany). However, according to Brandt, neither Raab nor Kreisky seemed to grasp the differences between the Austrian solution of 1955 and the Soviet attitude towards Germany. ${ }^{17}$

\section{The Raab visit and the Lebanon crisis}

With Mikoian's trip to Vienna, a series of regular mutual visits at the high and intermediary political levels was taken up again. On the Austrian side, such visits were much more frequent with the USSR than with any other signatory power of the state treaty. ${ }^{18}$ The year 1958, with thirty-six Soviet and thirty-one Austrian delegations, marked an all-time high in the exchange. The Austrian chancellor's journey to the land of the soviets, which the Kremlin had encouraged in 1957, was particularly important to the Soviet side, since Raab was the first Western statesman to visit the USSR after the Hungarian disaster of 1956. While the Soviet invitation

schof, Michael Gehler, and Anton Pelinka (eds.), Austrian Foreign Policy in Historical Context, Contemporary Austrian Studies 14 (New Brunswick: Transaction, 2006), 170-185. Kreisky later claimed that Brandt had expressed the wish to meet a high ranking Soviet politician. Bruno Kreisky, Im Strom der Politik: Der Memoiren zweiter Teil (Vienna: Kremayr \& Scheriau, 1988), 10-22. For a critical assessment, cf. Röhrlich, Kreiskys Außenpolitik, 186-187.

${ }^{15}$ Martin Kofler, "Eine Art „Nabel der Welt“: Österreich und der Chruschtschow-Besuch 1960,” in Zeitgeschichte 26, no. 6 (1999), 397-416, 409. Cf. Egon Bahr, Zu meiner Zeit (Berlin: Siedler, 1996), 127-129.

${ }^{16}$ Conversation Khrushchev with Kreisky and Schärf, 13 October 1959, in ÖStA, AdR, BMAA, II-Pol, GZ. 236.711-pol/59, Z. 249.552-pol/59. For the full text of the conversation in 1959, see pages 298-300. For the conversations in 1962, see below pages 302-303, 310-312, 321-325.

17 Willy Brandt, Erinnerungen (Berlin: Siedler, 1999), 174.

${ }^{18}$ Neuhold, "Austria and the Soviet Union," 95; Glasneck, "Die Sowjetunion und Österreich," 114. 
clearly aimed at demonstrating to the world that "peaceful coexistence and friendly relations between states of different social systems" were possible and even mutually beneficial, ${ }^{19}$ the Austrian government's goal for its trip from 21 to 28 July 1958 was much more down-to-earth: Raab wanted to test the sincerity of these slogans at a practical economic level, seeking solely a reduction in the Austrian oils debts to the Soviet Union.

The circumstances of the visit were not easy. In June, the political trial and execution of Imre Nagy brought back dark memories of the Soviet crackdown on the Hungarian uprising two years earlier. On 15 July, the Soviet leadership launched its proposal for a "peace pact" between all European states and the United States, and it was anticipated that the Kremlin would press its Austrian guests to publicly endorse the initiative. The Ballhausplatz had warned already in June that, "due to the lacking political content of the visit and the absence of bilateral problems," the Austrian delegation might well be "exploited for propaganda statements in the contemporary Cold War in favor of the Soviet stance." ${ }^{20}$

Last but not least, Raab's trip to Moscow was overshadowed by the beginning of the Lebanon crisis, a pro-Egyptian Muslim rebellion against the country's Christian pro-Western president, who called on the United States for help. From 16 to 18 July, about a hundred US aircraft passed over the Alps on their way to the Near East. Austria, responding to a request by the US State Department, had given verbal permission for some thirty-two overflights. However, this number was exceeded considerably by the flights that had started before the official permission was received. When Austrian communist newspapers began to report the incident, the Austrian government, which was obliged to observe neutrality but did not have an air force to prevent foreign planes from flying over its territory, had to react officially. The Austrian dilemma - on one hand, to fulfill its obligations and, on the other, not to alienate its traditional patron, the United States - led to a double game. The Austrian government filed a protest with the US embassy in order to assuage the Soviet side, which was trying to pressure the Austrians into observing their neutrality more comprehensively. Therefore, the Kremlin itself also protested with the US government, and later even offered the Soviet air force to protect Austrian air space. At the same time, Foreign Minister Figl unofficially reassured US representatives that his protest was "just for the record." On 19 July, the State Department issued a press release stating that, as requested by the Austrian side, the US air force would henceforth respect Austrian neutrality. ${ }^{21}$ However, no official regret was expressed.

${ }^{19}$ Haymerle, "Die Beziehungen zur Großmacht im Osten," 164-165.

${ }^{20}$ Vorbereitung des Besuches, 20 June 1958, in ÖStA, AdR, BMAA, GZ. 544.163-pol/58, Z. $550.368-\mathrm{pol} / 58$.

${ }^{21}$ Gehler, Österreichs Außenpolitik, 184-186; Walter Blasi, "Die Libanonkrise 1958 und die US Überflüge,” in Erwin A. Schmidl (ed.), Österreich im frühen Kalten Krieg: Spione, Partisanen, Kriegspläne (Vienna: Böhlau, 2000), 239-259. On the Soviet protest, see Rauchensteiner, Die Zwei, 385. 
When the Austrian chancellor, vice-chancellor, minister of foreign affairs, and state secretary, bearing an original letter by Karl Marx and a film about Vienna's Spanish Riding School as gifts, arrived in the Soviet capital, banners with the motto "Long live Austrian-Soviet friendship" were hung above Moscow's main streets. On 21 July Pravda praised Raab and Austria's "international authority," which had risen as a consequence of the country's neutrality, applauded the Austrian protest against the US flights and expressed its wish that "the amicable relations between the Soviet Union and Austria will be strengthened." The claim that "by means of the Austrian example, the idea of neutrality has become popular among other West European peoples," hinted at the intentions Soviet diplomacy was pursuing in the bilateral relationship. At the airport, in the presence of a reception committee consisting of countless Soviet ministers, deputy ministers and ambassadors, ${ }^{22}$ a committee large enough to welcome the UN secretary general or the pope, Khrushchev personally praised the "statesmanlike wisdom" of his Austrian guest, which had made the successful conclusion of the state treaty possible. Raab took up this reference to the leitmotiv in Soviet-Austrian relations and thanked his host-country for its efforts, "owing to which preeminently the treaty was concluded" 23 - a statement that was neither historically fully correct nor well received in the United States. ${ }^{24}$ Both sides paid tribute to Austria's neutrality as a contribution to international peace. In his speech in the Kremlin on the next day, however, Khrushchev warned the guests of "groups, intent on getting Austria off its neutral path." 25

The negotiations, which according to the communique were conducted in an "atmosphere of friendship and cordiality," demonstrated the "good relations reflecting the national interests of both countries" and contributed to the "strengthening of peace in Europe," resulted in Austria's wish being fulfilled: its remaining obligation of delivering seven million tons of oil in the following seven years, as stipulated by the state treaty, was cut by 50 percent. ${ }^{26}$ An invitation to come to Austria was extended to Khrushchev and Mikoian, who was repeatedly referred to by Raab and Khrushchev as a "friend of Austria" or even as "Austrian." On their side, the Soviets were pleased to learn that Austria, as the first Western state and despite Western misgivings, declared itself ready to become a member of the Danube Convention of 1948 - a move that was perceived as a slap in the face of the West, which had condemned the founding document of this organization as a violation of interna-

${ }^{22}$ Vizit Avstriiskoi pravitel'stvennoi delegatsii, 21-28 July 1958, in AVPRF, 66/37/72/13, 15-19. Cf. Kreisky, Im Strom, 104-105.

${ }^{23}$ Reden, 29 July 1958, in ÖStA, AdR, BMAA, GZ. 544.163-pol/58, Z. 552.245-pol/58

${ }^{24}$ FRUS, 1958-1960, IX, 771.

${ }^{25}$ Daily Review of the Soviet Press, 23 July 1958.

${ }^{26}$ Schlusskommuniqué, 24 July 1958, in ÖStA, AdR, BMAA, GZ. 544.163-pol/58, Z. 552.061pol/58. Cf. Mayrzedt and Hummer, 20 Jahre Österreichische Neutralitäts- und Europapolitik 2, 138-140. 
tional law and a means of enforcing Soviet control in Eastern Europe..$^{27}$ The West had been assured by Foreign Minister Figl that Austria would not join the Belgrade Convention. ${ }^{28}$ Since the organization was entitled to make majority decisions about the free transport of any goods (including, e.g. arms) on the river, membership for a neutral state was deemed by legal experts to be at least problematic in the case of war. $^{29}$

In the negotiations on the communiqué, the Soviets pressed the Austrian delegation to include a paragraph stating that the USSR was ready to defend Austrian neutrality - an attempt that was refused by the delegation from Vienna. ${ }^{30}$ Nevertheless, Soviet diplomacy succeeded in advancing a paragraph stating that Austria had been informed about "all steps being taken by the Soviet government aiming at détente in international relations and at reducing the threat of a nuclear war." Austria would be ready "to contribute to a consolidation of peace - with respect to Austria's [limited] possibilities." For the first time, "peaceful coexistence" was mentioned in an Austrian-Soviet communiqué - a break of a diplomatic taboo, since the term, due to its communist connotation, was still rejected by the West. The statement was watered down, however, by the Austrian delegation, who added the words "as defined in the twelfth general assembly of the UN." 31 The Austrian delegation avoided qualifying recent Soviet "peace initiatives" and - in general words only - welcomed "all measures contributing to a consolidation of peace and to the reduction of the nuclear threat." While the Kremlin was interested in using the communique for promoting its political initiatives, it was particularly important for the Austrian government to draw this fine line and avoid becoming solely an instrument of Soviet propaganda. ${ }^{32}$ Khrushchev had emphasized the Soviet thesis that neutral states should actively contribute to the reduction of tensions, pressing Austria to be more active in this matter so as to become a "major force in the preservation of peace." The Austrian government, however, was interested in not alienating the Western powers and, therefore, only joining an initiative once it was clear that it would gain the approval of both blocs.

${ }^{27}$ Stephan Verosta, "Außenpolitik," in Erika Weinzierl and Kurt Skalnik (eds.), Österreich: Die Zweite Republik (Graz: Styria, 1972), 295-343, 328.

${ }^{28}$ FRUS, 1958-1960, IX, 780.

${ }^{29}$ Ermacora, 20 Jahre österreichische Neutralität, 100.

${ }^{30}$ Gehler, Österreichs Außenpolitik, 186.

${ }^{31}$ Aus dem sowjetisch-österreichischen Kommuniqué, 24 July 1958, in UdSSR - Österreich, 107111. The resolutions of 15 December 1957 and 10 December 1958 of the UN General Assembly had avoided using the term, at that time primarily a Soviet expression, and referred instead to "peaceful and good neighborly relations." Cf. "Mirnoe sosushchestvovanie," in A.A. Gromyko, S. A. Golunskii, and V.M. Khvostov, Diplomaticheskii slovar' 2, 2nd ed. (Moscow: Gospolitizdat, 1961), 297-300.

32 Richtlinien für die Ausarbeitung eines österr.-sow. Kommuniqués, 19 July 1958, in ÖStA, AdR, BMAA, GZ. 544.163-pol/58, Z. 552.250-pol/58. 
The Soviet reticence from pressing the delegation more strongly to make propagandistic statements, and the Austrians' ability to walk the fine line between complimenting the Soviets and insulting the United States, between advancing their country's international role and being put at the top of the Soviet propaganda chart, were recognized in Western media. On 25 July the Neue Zürcher Zeitung acknowledged that there had been "no Russian attempt to express wishes or demands that would embarrass the Austrians," and the Danish Finanstidende wrote on $15 \mathrm{Au}$ gust: "The Austrians took note of the incense offered to them without letting it go to their head." From the US State Department, some critical remarks on the Austrian failure to consult with the Western powers about the Danube Convention and on the Austrian excessive praise of the Soviet merits in concluding the state treaty were communicated via diplomatic channels. ${ }^{33}$ With regard to the Austrian invitation to Khrushchev, the US ambassador in Moscow criticized Austria's "unfortunate display of callousness" in inviting the Soviet leader "within few weeks of execution of [Hungarian leaders Imre] Nagy, [Pál] Maléter, et al. under Soviet orders." ${ }^{34}$

In Moscow, Raab's visit left, as Khrushchev, Mikoian and Zorin unanimously pointed out to the Austrian ambassador, "the best and most pleasant impressions." 35 Pravda characterized the Soviet-Austrian relations as a "convincing example of peaceful coexistence" and on 26 July Izvestiia praised the "further strengthening of mutual understanding, trust and cooperation" that had been achieved, as its editors had predicted. Both papers expressed their conviction that the example of amicable Soviet-Austrian relations could and should be followed by every good-willed Western country. In an internal report, the Soviet embassy in Vienna also assessed the results of the Austrian visit in Moscow positively. ${ }^{36}$ The position not only of Austria's neutrality, but also of Austrian circles advocating a rapprochement between the two countries was strengthened. The report continued by stating that in the People's Party, as among the social democrats, Raab was celebrating a comeback as the unquestioned leader. There had even been recent Austrian calls to improve the country's relations with the "people's democracies," ${ }^{37}$ a move that until that point, the Soviet embassy guessed, had been kept at a low level in order to placate the West for the cordial Austrian-Soviet relationship. As a result of the warm reception for the Austrian delegation, the USSR and the KPÖ had regained a certain degree

33 Austrian embassy Washington to Austrian MFA, 6 August 1958, in ÖStA, AdR, BMAA, GZ. 544.163-pol/58, Z. 553.023-pol/58.

${ }^{34}$ FRUS, 1958-1960, IX, 772-773.

35 Austrian embassy Moscow to Austrian MFA, 30 July 1958, in ÖStA, AdR, BMAA, GZ. 544.163pol/58, Z. 553.075-pol.

36 Soviet embassy Vienna to Soviet MFA, 9 September 1958, in AVPRF, 66/37/72/13, 31-40.

${ }^{37}$ These Austrian calls, which were stimulated by the Soviet-West German agreements of 1958, squared with Soviet demands. Amtsvermerk, Conversation Kreisky with Gromyko, 14 October 1959, in ÖStA, AdR, BMAA GZ. 236.711-pol/59, Z. 249.384-pol/59; Soviet embassy Vienna on Austrian reactions with regard to the Soviet-West German agreement, 13 May 1958, in AVPRF, $66 / 37 / 72 / 16,32-35$. 
of popularity in the Austrian population. As proof for the overwhelmingly positive impact of the trip on the bilateral relations, the daily Neues Österreich was quoted as stating that "the strained relations between the Soviet Union and Austria after 1945 are over now."

Once Raab had broken the international boycott against the Soviet Union that was a result of the events of 1956, further Austrian and Western guests followed. The Austrian minister of defense Graf traveled to Moscow still in 1958, and in October 1959, the Austrian president Adolf Schärf became the first Western head of state to visit the USSR after the Hungarian uprising..$^{38}$ In the communiqué, once again, bilateral relations were praised for developing "in friendship and mutual understanding and cooperation." ${ }^{39}$ It is not unlikely that, as was the opinion of the Soviet embassy, the demonstratively welcoming reception of Austrian delegations in Moscow as well as the Soviet economic concessions had had an impact on the public attitude towards the Soviet Union. ${ }^{40}$ Austrian media coverage on Soviet technical developments and economic progress, on Sputnik and the seven-year plan, also improved, although the anti-communist editor of the social democratic ArbeiterZeitung, Oscar Pollak, remained cautious in the face of any signs of overly benevolent attitudes towards the Soviet Union. Contrary to earlier occasions, however, after an incident of the paper being too critical of the USSR, the social democratic party leadership apologized in a conversation with the Soviet ambassador. ${ }^{41}$

\section{Cultural relations and the World Youth Festival}

Meanwhile, cultural relations between the two countries, which had been badly damaged by the Soviet intervention in Hungary 1956, began to revive. In the dealings between liberal democratic societies and their communist counterparts, cultural relations played a special role. While between open societies, in general, a free flow of ideas, contacts, and even individuals is possible and liberal states usually consider it unnecessary to regulate this exchange, this is not the case in closed systems, in which personal contacts as well as private and mass communication are under strict control and any exchange with foreign institutions is impossible without official permission. Despite this, communist leaders considered some sort of exchange necessary to gain prestige both nationally and internationally and to prevent their countries from falling into intellectual isolation and economic backwardness. While the travel of Western artists to communist countries remained

${ }^{38}$ Glasneck, "Die Sowjetunion und Österreich," 115; Schärf to Voroshilov, 20 September 1958, Russian translation, in AVPRF, 66/37/72/13, 43-45; Conversation Khrushchev with Kreisky and Schärf, 13 October 1959, in ÖStA, AdR, BMAA, II-Pol, GZ. 236.711-pol/59, Z. 249.552-pol/59. For the full text of the conversation, see pages 298-300.

${ }^{39}$ Quoted in Haymerle, "Die Beziehungen zur Großmacht im Osten," 166.

${ }^{40}$ Glasneck, "Die Sowjetunion und Österreich," 115-118.

${ }^{41}$ Conversation Lapin with Pittermann, 24 July 1957, in AVPRF, 66/36/68/10, 23-25. 
controlled, sending Eastern musicians abroad was considered by Soviet leaders as a fine tool for promoting their own culture and fostering détente. For this reason, communist governments proved quite eager to form new regulations for cultural relations, which were endorsed in solemn and formal intergovernmental agreements. This held true particularly for the Soviet Union, which strove at reinforcing its status as a beacon of progress and culture, as well as the leader of the "world communist system." As historian Vladislav Zubok has aptly observed, "In no other regime in modern history, aside from Nazi Germany, did the promotion of culture (kultura) preoccupy the political leadership to this degree or involve such large expenditures. ${ }^{~}{ }^{42}$ However, most Western governments did not share the totalitarian approach towards culture nor the eagerness of such regimes to establish the ritualized promotion of culture abroad. In addition, they did not want to contribute to the prestige of communist governments by formalizing bilateral exchanges of delegations, especially if it did not offer the opportunity of fostering the freedom of ideas in Eastern societies.

Here again, Austria was chosen by the Kremlin to serve as an icebreaker. In order to build a legal framework for cultural relations with Austria, Soviet diplomats in 1956 resumed pressuring for the signing of a cultural agreement, an agreement that Moscow and the Austrian-Soviet Society had already been advocating since the 1940s. ${ }^{43}$ After the conclusion of the state treaty, this pressure was intensified by the USSR, which, at that time, had almost no cultural contacts with Western countries ${ }^{44}$ The Soviet Union aspired to concluding new cultural agreements with Western states in order to promote "peaceful cooperation" in an area of East-West relations that was relatively unproblematic. As a neutral country with a well-reputed high culture and due to its weakness and vulnerability to Soviet pressure, Austria (in addition to Belgium, Britain, France, and Norway, with which Soviet agreements were signed in 1956-5 $7^{45}$ ) seemed a natural target for this initiative. In the spring of 1956, a cultural agreement became, in the words of an Austrian diplomat, the "favorite subject" of the Soviet embassy in Vienna, which raised the issue often, sometimes twice a week, and presented two agreement drafts to the Austrians. ${ }^{46}$ That autumn, deputy foreign ministers Smirnov and Zorin took an interest in these matters and deplored the - allegedly politically motivated - Austrian

${ }^{42}$ Zubok, A Failed Empire, 165.

${ }^{43}$ Mueller and Leidinger, "Tiefes Misstrauen," 106.

${ }^{44}$ In the wake of the 1955 Geneva conferences, the USSR had re-established cultural ties with Britain and France. Walter L. Hixson, Parting the Curtain: Propaganda, Culture, and the Cold War, 1945-1961 (New York: St. Martin's Griffin,1998), 108.

45 Yale Richmond, Cultural Exchange and the Cold War: Raising the Iron Curtain (University Park: The Pennsylvania State University Press, 2003), 15. Another Soviet-French agreement on cultural exchange was concluded 1963. Loth, Overcoming the Cold War, 90.

${ }^{46}$ Beziehungen zur Sowjetunion, 1 March 1956, in ÖStA, AdR, BMAA, GZ. 512.215-pol/56, Z. 512.215-pol/56; Abschluss eines Kulturabkommens, 29 June 1956, ibid., GZ. 512.215-pol/56, Z. 516.031-pol/56 
reluctance to react to the Soviet overtures ${ }^{47}$ However, both the Ballhausplatz and the Ministry for Education denied any political concerns and agreed between themselves that "the agreement will remain on paper, in which case it is worthless, or it will be implemented, in which case we cannot afford the associated obligations." 48 Increasingly under pressure, both from Soviet diplomatic circles and Austrian communists, Ambassador Bischoff, in order to defend the Austrian position, prepared an explanation stating that the four cultural agreements in effect between Austria and other countries were only remnants of the interwar period. Austria's reluctance to conclude a new culture treaty, Bischoff explained, was motivated by fears of pressure from the FRG to sign a West German-Austrian agreement. ${ }^{49}$ It was only in 1968 that Austria conceded to Soviet pressure and signed a cultural agreement. ${ }^{50}$

Without an official basic regulatory document, a major part of cultural relations depended, on one hand, upon nongovernmental organizations, and on the other, the openness and level of proactiveness each side displayed. Therefore, during Raab's visit to Moscow in 1958, a Soviet-Austrian Society, corresponding to the society already in existence in Austria, was founded under the presidency of composer Dmitri Shostakovich. It included several "corporate members," such as the Leningrad University and numerous Moscow theatres. Its aim was to "spread information about Austria" by organizing concerts, lectures, and exhibits and to receive Austrian guests in the USSR. The matching task in Vienna was taken over by the Austrian-Soviet Society, which "as a consequence of the Hungarian events had suffered great difficulties," and in 1957 took pains to reintensify its efforts. ${ }^{51}$ On the occasion of the fortieth anniversary of the October Revolution in 1957, the ÖSG organized more than three hundred events, including a film festival, twenty lectures (mostly by Austrian communist speakers), and concert tours of renowned classical and folk musicians. These efforts, the Soviet Foreign Ministry noted with satisfaction, were duly supported by the Austrian authorities, who "proved their loyalty with regard to these measures." ${ }^{52}$ This was even more remarkable as the society, due to its communist and pro-Soviet leanings, had been boycotted by Austrian authorities until the early 1950s. In 1956, the Austrian-Soviet Society ran forty-one libraries, the largest of which containing more than 14,000 Russian books. ${ }^{53}$ Since

${ }^{47}$ Austrian embassy Moscow to Austrian MFA, 4 September 1956, in ÖStA, AdR, BMAA, GZ. 512.215-pol/56, Z. 518.908-pol/56; Conversation with Zorin, 12 October 1956, ibid., Z. 518.397 $\mathrm{pol} / 56$.

${ }^{48}$ Einsichtsbemerkung Braunias, 27 March 1956, in ÖStA, AdR, BMAA, GZ. 512.215-pol/56, Z. 512.631-pol/56; Entwurf eines österr.-sowjetischen Kulturabkommens, 3 August 1956, ibid., Z. $517.086-\mathrm{pol} / 56$.

49 Austrian embassy Moscow to Austrian MFA, 4 September 1956, in ÖStA, AdR, BMAA, GZ. 512.215-pol/56, Z. 518.908-pol/56.

${ }^{50}$ See below, page 193.

${ }^{51}$ Informatsiia o provedenii merov v Avstrii, 4 January 1958, in AVPRF, 66/37/72/13, 2-6.

52 Ibid.

${ }^{53}$ Zhiriakov, SSSR - Avstriia, 60. 
the 1940s, courses in Russian language and literature were offered at a number of Austrian high schools; in 1957, 86 schools taught 2,373 students who had chosen Russian either as a major or as an elective. ${ }^{54}$ A Soviet-Austrian agreement on film exchange, concluded in 1956, enabled Soviet citizens to experience Austrian kitsch (Reich mir die Hand, mein Leben), and confronted Austrians with Socialist Realism (Letiat zhuravli). In 1959, thirteen Soviet movies were seen by 600,000 Austrians; however, they could not live up to the competition from Hollywood. In addition to these more serious types of cultural exchange, a year earlier, the soccer teams of the Soviet and Austrian armies had met for a friendship match.

It soon became clear that with regard to cultural exchange the Soviet side was much more proactive than the Austrian, and that Soviet regulations were still much more restrictive for foreigners than vice versa. Thus, until the early 1960s Austrian activities in the USSR remained rare. In the meantime, Soviet exhibitions on "The Peaceful Application of Atomic Energy in the Soviet Union" and other contemporary Soviet high-tech achievements were sent to Vienna; the Eisrevue tour of 1957, with its ice-breaking effect, was answered the same summer with several performances of the Soviet musicians David and Igor Oistrakh at the Salzburg Festival and, in 1959, by an overwhelmingly successful run of performances of the Soviet state circus, which was visited by more than 450,000 Austrians. The Moiseev folkdance company and a visit by Armenian composer Aram Khachaturian followed in $1961-62.55$

The largest Soviet-sponsored event in Vienna, however, did not have anything to do with bilateral relations. In July 1959, the World Youth Festival took place for the first time in a noncommunist country. Two years earlier, a similar mass event had been organized in Moscow. For the seventh such festival, with its cultural performances, sport competitions and political meetings, the motto "Struggle against Imperialism" had been chosen. The Austrian government reluctantly gave in to Soviet pressure and consented to host the event, under the condition that the organizers would respect Austria's neutrality and that any sort of political display such as parading in uniforms, or any measures that might strain Austria's relations to other countries would not occur. Chancellor Raab had rebuffed his ministers' doubts by declaring in the cabinet meeting that "we want something from the Russians." 56 While several Western ambassadors filed their protests against the holding of the communist festival with the Austrian government, the Soviet side seemed to use its influence on the organizers to find a compromise and to agree with the Austrian conditions. In any case, the international youth committee organizing the event was no match for the experienced Ballhausplatz diplomats and conceded to their de-

\footnotetext{
${ }^{54}$ Information Russischunterricht, BMAA, Z. 616.265-Kult/58, July 1958, in SBKA, Länderbox UdSSR 1, File Moskau Juli 1958.

${ }^{55}$ Zhiriakov, SSSR i Avstriia v 1945-1975 gody, 134-137.

${ }^{56}$ Ministerratsprotokoll 63, 14 January 1958, in ÖStA, AdR, BKA, MRP.
} 
mands ${ }^{57}$ When the festival opened with several thousand visitors in Vienna's biggest stadium, Raab had sent a welcome address. But conservative and social democratic Austrian organizations had prepared discussions and leaflets on the crimes of communist regimes and organized excursions from Vienna to the Iron Curtain at the Austrian-Hungarian border. $^{58}$

Although hand fighting between communist and anti-communist youth could not be avoided altogether during the week-long festival, in the end most parties involved seemed content. The organizers were clever enough to pass over all problems in silence and to praise the hospitality of neutral Austria - without forgetting to mention that "some circles" had attempted to wreck the festival. Western observers who had been critical of Vienna hosting the event were increasingly convinced by the Austrian argument that it was better to have the festival organized in a neutral country, thus being able to control it to some extent as well as to confront the participants with Western societies. They furthermore lauded the strategy, promoted by the social democratic Arbeiter-Zeitung and followed by all Austrian noncommunist media, to turn a deaf ear on the festival. ${ }^{59}$ The Austrian government, last but not least, was also happy for it had avoided getting into trouble with either the East or the West. In the same year, Vienna hosted the fourth World Congress of Women. Although Soviet and Austrian communist propaganda praised the success of the World Youth Festival highly, ${ }^{60}$ the Kremlin seems to have assessed the event more critically. After the Moscow gathering of 1957, during which the appearance of young Americans, Europeans, and Africans had involuntarily contributed to undermining the enemy image of the West as seen in Soviet propaganda as well as the state-sponsored xenophobia of the USSR, ${ }^{61}$ the Vienna festival was seen as likely to sow doubt among Soviet and East European youth about the superiority of their system. It remained the last such event ever held in a Western country (except Finland) for the rest of the Cold War.

With the exception of this kind of mass events, travel between the USSR and Austria during the 1950s increased only slowly. In 1955 the Austrian Foreign Ministry issued 599 visas to Soviet citizens, ${ }^{62}$ two years later it was $718 .{ }^{63}$ Of 154 Austrians who were registered in the USSR in 1959, eleven had already died, ten had

${ }^{57}$ Protokoll über eine Besprechung mit Vertretern der Ständigen Kommission des Vorbereitungskomitees für die Weltjugendfestspiele, 1 July 1959, in ÖStA, AdR, BMAA, GZ. 236.097-pol/59, Z. 244.387-pol/59.

${ }^{58}$ These countermeasures were inspired by a small group of Austrians, including Fritz Molden (a former anti-Nazi resistance member, liberal journalist, and ex-son-in-law of CIA Director Allen Dulles) and Bruno Kreisky. Molden, Besetzer, 275-303.

59 Runderlass, 6 August 1959, in ÖStA, AdR, BMAA, GZ. 245.731-pol/59.

${ }^{60}$ See, e.g. Bruno Frei, "Die Bilanz von Wien,” in Neue Zeit, no. 32 (1959), 6-7.

${ }^{61}$ Zubok, A Failed Empire, 175.

${ }^{62}$ ÖStA, AdR, BMAA, GZ. 322.691-pol/55, Z. 325.503-pol/55.

${ }^{63}$ Reiseverkehr, 1958, in ÖStA, AdR, BMAA, Sektion II-Pol, Liasse USSR-2, ad. Z. 574.091$\mathrm{GS} / 58$. 
returned to their homeland, and eighty-seven were unaccounted for ${ }^{64}$ Some of these had come to Soviet Russia in the interwar period and had fallen victim to Stalin's terror; others had been kidnapped from Austria by the Soviet secret police in the postwar years and deported to slave labor camps; one was even a prisoner-of-war who had been captured in World War I and sent to Central Asia. ${ }^{65}$ In February 1959, a consular agreement was signed. ${ }^{66} \mathrm{~A}$ month earlier, state-owned Austrian Airlines (AUA) had, as the first Western company after Finair, inaugurated a regular direct connection to Moscow. In the first year, this flight was hit by a terrible disaster, when an AUA plane crashed a few kilometers from Sheremetevo airport with many passengers and crew members dying. ${ }^{67}$

\section{The Khrushchev visit}

While it had been possible at the World Youth Festival in 1959 to prevent the communist guests in Vienna from straining the host country's relations with the West, not the same could be said with regard to Khrushchev's trip to Austria from 30 June to 8 July 1960. It was his second visit to Austria, the first having been some fourteen years earlier. Once again, the international atmosphere with respect to the Soviet visit was not unproblematic, since the general secretary's journey was his first visit to the West after the failure of the Paris summit and it was undertaken in the middle of the Berlin crisis. When Khrushchev arrived in Vienna, he was accompanied by a grand entourage including his wife Nina and family, the dry Gromyko, Aleksei Kosygin, and Ekaterina Furtseva, the attractive minister of culture ("the Austrian" Mikoian was in Norway at the time, where he praised Austria as a "model for healthy coexistence" 68 and recommended that Norway choose neutrality instead of its traditional NATO membership). On his way from the airport, Khrushchev was confronted, as Western media reported, by a "frigid" or even "the coolest" public reception he had experienced in the West to date. Only a few communists and bystanders, far fewer than the numbers of policemen, stood on the streets to greet him, forming a ridiculously meager line. Catholic bishops had called on their flock not to express any empathy for the chieftain of the dark, ${ }^{69}$ the papal nuncio had left the city in haste, priests had reminded Austrians of the suppression of the Church in communist countries, and Catholic youth organizations had distributed anti-Soviet

${ }^{64}$ Austrian embassy Moscow to Austrian MFA, 4 February 1959, in ÖStA, AdR, BMAA, GZ. 237.049-pol/59, Z. 238.925-pol/59.

${ }^{65}$ Hinteregger, Im Auftrag Österreichs, 32-35.

66 Zhiriakov, SSSR i Avstriia v 1945-1975 gody, 40.

${ }^{67}$ Hinteregger, Im Auftrag Österreichs, 44-47.

${ }^{68}$ Quoted in Kofler, “Eine Art „Nabel der Welt“,” 400. Cf. Bonwetsch, “Sowjetische Westeuropapolitik II," 219.

${ }^{69}$ Glasneck, "Die Sowjetunion und Österreich," 130. 
leaflets. ${ }^{70}$ The delegation could also not expect any mercy from Austria's social democrats, whose leaders had for decades been defamed by Soviet propaganda as the "revisionist lackeys of imperialism." The presence of Khrushchev's old nemesis, Molotov, in Vienna, where he had been dispatched as the Soviet representative to the International Atomic Energy Agency, also did nothing to contribute to a warm reception. Chancellor Raab tried to better the tone for the visit by calling on his anti-Soviet fellow citizens "not to forget that our guest is the head of a friendly great power." ${ }^{\text {71 }}$ However, he could not prevent the social democratic president of the Trade Unions' Federation Franz Olah from making a truly Freudian slip of the tongue at a reception ceremony, in which he publicly lauded the Soviet "struggle against freedom." $" 72$ Obviously, the 1956 Soviet crackdown on Hungary had left a deep mark in Austrians' minds.

From its first day, Khrushchev's journey by bus across Austria developed a dynamic of its own, the guest's behavior often living up to its usual bizarre and unpredictable manner. The official program included visits to the State Opera as well as to farms, negotiations with politicians, and meetings with factory workers. Many events were used by Khrushchev to stress Soviet economic, social, and technical achievements as proof of communism's superiority and to reiterate his claim that the USSR would soon catch up and surpass the United States economically. An impulsive orator as well as a cordial and down-to-earth guest, Khrushchev was clever and able to impress his audience. A former worker, he was careful to use socialist rhetoric when he addressed his Austrian "comrades," and coxed their national pride with compliments on their cultural heritage, the natural beauty of their country, and their wisdom in choosing neutrality. He also made humorous allusions to his friendship with their leaders, such as the "little capitalist" Raab or the popular socialist minister of the nationalized industries, "Karl Karlovich" Waldbrunner, who had spent the interwar years as an engineer in Soviet Russia. ${ }^{73}$

In his many confused speeches, the Soviet leader, who was trying to convince Austrian politicians to be more active with regard to détente, praised Austrian neutrality and Soviet-Austrian relations as a "convincing example of peaceful coexistence" 74 and sometimes went as far as announcing that the USSR "won't remain inactive, if someone violates Austrian neutrality." 75 This seemed to be some sort of unilateral Soviet guarantee for Austria, something the West had been afraid

${ }^{70}$ Kofler, “Eine Art „Nabel der Welt“,” 401. Cf. FRUS, 1958-1960, IX, 828-830.

${ }^{71}$ Glasneck, "Die Sowjetunion und Österreich," 136.

72 Rheinischer Merkur, 8 July 1960; Christ und Welt, 7 July 1960; Stuttgarter Nachrichten, 6 July 1960; and other newspaper reports, in SBKA, Länderboxen, UdSSR 1.

73 Sowjetunion heute 6, nos. 28-30 (1960).

74 Druzhestvennyi vizit: Prebyvanie Predsedatel'ia Soveta Ministrov SSSR N.S. Khrushchëva v Avstriiskoi Respublike 30 iiuniia-6 iiulia 1960g. (Moscow: Gospolitizdat, 1960), 10.

75 Österreichische Zeitschrift für Außenpolitik 1, no. 1 (1960-61), 75. Cf. Ermacora, 20 Jahre österreichische Neutralität, 111-112. 
of since 1955. A similar pledge had been given by Mikoian during his visit in $1957 .{ }^{76}$ Khrushchev's oath raised Austrian fears that the Soviet Union would claim the right to decide whether the country's neutrality had been violated and intervene militarily in such a case. Although he frequently stressed that he did not want to influence Austrian-German or Austrian-Italian relations, Khrushchev vigorously attacked NATO, the United States, Italy, and West Germany for their policy of maintaining army bases and deploying missiles around Austria's periphery. This kind of assault was not unusual for the fiery Cold Warrior from the Kremlin; on his famous trip to India in 1955, he had even accused the United States of having started World War II against the USSR. ${ }^{77}$ The recent attacks voiced in Austria were part of the Soviet offensive against deployments of nuclear missiles in Western Europe, an offensive that was launched exactly when the Soviet leader started stationing Soviet missiles in East Germany. ${ }^{78}$ During visits to the Nordic neutrals in 1958, Soviet guests had aired the thesis that NATO missiles launched from Norway were a violation of the neutrality of Sweden and Finland,$^{79}$ in November the Soviet government opined that if a missile were shot from an Italian launching site towards the north-east, this would violate Austria's neutrality, ${ }^{80}$ and in April 1959 Soviet notes of protest against Italian launching sites were sent to the Italian and Austrian governments. ${ }^{81}$ During his visit to Austria, Khrushchev repeated the allegations against Italian missiles - thus attempting to mobilize Austria against the Italian bases and implicitly threatening to hold Austria responsible for others' actions. ${ }^{82}$

Even in his speech at the Mauthausen Nazi concentration camp memorial, Nikita Sergeevich lashed out against "revanchist circles" among West German politicians, calling Konrad Adenauer a reincarnation of Hitler and warning against West German "militarism" and a new Anschluss. ${ }^{83}$ After having received two breeding bulls ("Komponist" and "Gustl") as welcoming gifts and talking to farmers in small towns along his route as well as workers at the Linz steel plant, the Soviet leader retabled his proposal for neutralizing the FRG and stripping West Berlin of its Western protectors, combined with threats of signing a separate treaty with the GDR if the Western allies refused to meet his conditions.

While the Austrian authorities became more and more embarrassed by their uncontrollable guest behaving like a loose cannon, something unexpected happened:

${ }^{76}$ Rauchensteiner, Die Zwei, 357-358.

77 Dallin, Soviet Foreign Policy, 309.

${ }^{78}$ On the anti-NATO missiles offensive, see Bonwetsch, "Sowjetische Westeuropapolitik II," 214 215; on the stationing of Soviet missiles, see Uhl and Ivkin, "Operation Atom," 299-307.

79 Frei, Dimensionen neutraler Politik, 143.

${ }^{80}$ Bischoff to Figl, Z. 71-pol/58, 15 November 1958, in ÖStA, AdR, AVA, NL E/1770: Bischoff, File 126.

${ }^{81}$ Beschlussprotokoll 116, Council of Ministers, 5 May 1958, in ÖStA, AdR, BKA, MRP; 3726$\operatorname{PrM} / 59$, ibid.

${ }^{82}$ Kofler, "Eine Art „Nabel der Welt"," 402.

${ }^{83}$ Gehler, Österreichs Außenpolitik, 205-212. 
the "traveling circus Nikita" began increasingly to attract Austrians. The longer his tour lasted, the more people stood along the streets, curious to see the short, rotund grandfather-like man with a bald head, said to be one of the most powerful men in the world, who shook his fists furiously against "the imperialists," sang Russian folksongs, and frequently invoked God while displaying un-statesmanlike vulgarity. The charismatic leader's strange attraction and his natural instinct to interact with ordinary people helped him to win over many Austrians. When he was greeted in Salzburg by anti-communist demonstrators who booed and whistled, he confronted the crowd, raised his short arms and roared: "Peace, Friendship!" This was much less aggressive than the energetic leader's reaction to a similar incident at the abortive Paris summit, ${ }^{84}$ and it seems to have had the wanted effect. The stunned demonstrators could not but answer, "Peace, Friendship!," and the satisfied Khrushchev veered off and continued his tour towards the Kaprun Alpine power plant, where he declared that before the end of his lifetime, he would see the red flag flying over the entire world (including the Austrian Alps) ${ }^{85}$

In the meantime Raab came increasingly under pressure from the Austrian media, Western diplomats, and even his own foreign Minister, Bruno Kreisky, not to let Khrushchev attack Western countries and leaders while on Austrian soil. Raab, who wanted to repeat his negotiating success of 1955 in order to stabilize his ailing position in Austrian politics, left the impression with his staff that he "could not care less" about the porcelain broken by Khrushchev. ${ }^{86}$ During a cabinet meeting, the social democratic foreign minister, who was supported by his conservative colleague Heinrich Drimmel, strongly opposed the Austrian communists' wish to have the Soviet guest's abusive speeches transmitted by loudspeaker on Vienna's Heldenplatz, where Adolf Hitler had been cheered by a crowd in the wake of the Anschluss. While Kreisky's and Drimmel's concerns were brushed off by Raab, who repeated his "we want something from the Russians," ${ }^{77}$ the US and the West German ambassadors filed their protests with the Austrian government and gave Raab a curtain lecture.$^{88}$ In a late-night private meeting which casts a bit of light on Khrushchev's personal relationship to Raab, the Soviet leader agreed to cut his adventurous tour d'Autriche short and also to reduce Austria's oil debts by one million tons. ${ }^{89}$

The bilateral communiqué was shorter than usual. Austrian-Soviet relations were described as "based on the principles of peaceful coexistence" (for the first time with-

${ }^{84}$ Wolkogonow, Die sieben Führer, 225.

${ }^{85}$ Newspaper reports, in SBKA, Länderbox UdSSR 1.

${ }^{86}$ Kofler, Kennedy und Österreich, 22.

87 Verhandlungsschrift 42, Council of Ministers, 28 June 1960, in ÖStA, AdR, BKA, MRP.

${ }^{88}$ Gehler, Österreichs Außenpolitik, 213-214. However, it seems unjustified to characterize the US ambassador's behavior as “erpresserische Großmachtallüre” as in Kofler, "Eine Art „Nabel der Welt"," 411.

${ }^{89}$ Grubmayr, "In zwei Wochen gehst Du nach Moskau," 142. 
out any qualifying clause) and as having "developed in a mutually satisfactory way." The visit was characterized as "an important contribution to peace" and as having "consolidated the amicable relations between the Austrian people and the peoples of the USSR. ${ }^{.90}$ However, no agreement was reached on several passages. ${ }^{91}$ Austria not only refused Soviet drafts about the Kremlin's right to protect Austrian neutrality, it also wanted to distance itself from certain statements made by Khrushchev. The latter point was declared unacceptable by Gromyko. The main focus of the dispute, however, was a Russian proposal stating the Soviet wish for peace. Austrian diplomats demanded the paragraph to include an acknowledgment that Western countries also wanted peace. Only after Kreisky threatened not to publish a communiqué at all, did the Soviet side accept Raab's proposal to cancel the entire paragraph. ${ }^{92}$ After the signing of the communiqué, Khrushchev, who was apparently trying to play Austria's two governing parties off one another, charged the social democrat Kreisky with being an "ally of the West," while he called the "little capitalist" and conservative leader Raab his "friend." The atmosphere in the negotiations had been further impaired by Gromyko's dogged attempts to talk Austria out of signing a trade agreement with the United States, an attempt that was rebuffed by Kreisky with the words: "We won't let anybody deny us this. We can conclude treaties with whom we want."

After a television address to the Austrian people and a last call on the Western powers to accept Soviet proposals, the guest left. During the departure press conference, the quick-witted Khrushchev refused to elaborate on how the USSR would react to a violation of Austria's neutrality, but reiterated his accusations against Adenauer and the United States, his threats against West Berlin, and his claims about the ultimate victory of communism. Boos from the audience were answered in a way that had already become customary: by stating that the booers were apparently Nazis who had escaped their death in Stalingrad. ${ }^{94}$ In his last speech during the Khrushchev

${ }^{90}$ Gemeinsames Kommuniqué über den offiziellen Besuch des sowjetischen Ministerpräsidenten in Österreich, 8 July 1960, in Mayrzedt and Hummer, 20 Jahre österreichische Neutralitäts- und Europapolitik 2, 140-142.

${ }^{91}$ Haymerle, "Die Beziehungen zur Großmacht im Osten," 167-169. The Russian draft also stated that Austria was ready to enter into "friendly relations with all states" - a notion that might have obliged Austria to recognize the GDR. Gemeinsames sowjetisch-österreichisches Kommuniqué, Entwurf, Inoffizielle Übersetzung, Russischer Gegenentwurf, überreicht von Gromyko, 7 July 1960, in SBKA, Länderboxen, UdSSR 1.

${ }_{92}$ Kommuniquéverhandlungen, July 1960, in ÖStA, AdR, BMAA GZ. 70033-6/60, Z. 79965$6 \mathrm{pol} / 60$. The following quotations are from Gedächtnisaufzeichnung, 14 July 1960, in ÖStA, AdR, BMAA GZ. 79.950-pol/60, Z. 80.202-6pol/60. This unofficial protocol reveals Khrushchev's bickering and the tense atmosphere.

93 Aufzeichnung über die Unterredung Kreisky - Gromyko, 7 July [1960], in ÖIZG, NL Fuchs, File 22.

${ }^{94}$ Druzhestvennyi vizit, 153-164. For a German version of the press conference, 8 July 1960, see Dokumente zur Deutschlandpolitik IV/5: 1 Jul.-31 Dec. 1960, bearb. von Gunther Holzweißig (Frankfurt am Main: Metzner, 1973), 28-32; for an English version, see Current Digest of the Soviet Press XII, no. 27 (3 August 1960). 
visit, given on 8 July at the airport, Raab reserved Austria's right to interpret and to defend its neutrality itself and denied such rights to any foreign power. ${ }^{95} \mathrm{He}$ also stated that Austria did not share Soviet views with regard to the leaders of Western nations, and that it rejected any kind of dictatorship as well as any restrictions of free speech. However, another speech two days later, in which Raab underlined his friendship with Adenauer and his gratitude towards the United States, was needed to appease the infuriated German chancellor and the disapproving US ambassador. ${ }^{96}$ Despite this, however, the affair created the third deep rift in US-Austrian relations in three years, after the Lebanon crisis and Raab's behavior in Moscow, relations that were already strained by bilateral negotiations regarding compensation for US oil rights in Austria.$^{97}$ Regarding Khrushchev's pledge to become active if Austria's neutrality were violated, the Austrian government officially stated that this announcement was not in accord with neutrality. The government reserved the right to define whether and when the country was endangered and how to react. ${ }^{98}$

In the face of the trouble Khrushchev's trip created for Austria, the East European press published enthusiastic reports about the neutral in general and the visit in particular - probably the friendliest articles that had been published until that time about a noncommunist country. ${ }^{99}$ The Soviet news agencies and media set the tone by repeatedly praising Austria from mid-May until mid-July, lambasting US policy for alleged attempts of torpedoing the visit and bringing Austria off its straight path of neutrality, and by celebrating the event as "proof of a humiliating defeat of the US 'policy of strength."' 100 During the Soviet visit to Austria, Pravda published its reports about Austria on the first page, reports that on 2 July lauded the "goodneighborly relations" and Austria's "good example for peaceful coexistence," and on 11 July stressed the "conformity" between Austria and the Soviet Union with regard to disarmament and the "approval by the Austrian people of the peace-loving Soviet foreign policy." The Soviet Union published a semiofficial account ${ }^{101}$ and Khrushchev shared his personal recollections in a speech on 9 July at the all-Union congress of Soviet teachers, in which he stressed his cordial reception, the friendliness of the bilateral talks, and their conduciveness to "peaceful coexistence" and to

${ }_{95}$ Österreichische Zeitschrift für Außenpolitik 1 (1960-61), 76-77.

${ }^{96}$ Dokumente zur Deutschlandpolitik IV/5, 34-39, 44-49.

${ }^{97}$ Oliver Rathkolb, Washington ruft Wien. US-Großmachtpolitik gegenüber Österreich 1953-1963 (Vienna: Böhlau, 1997), 164-172; Gehler, Österreichs Außenpolitik, 212-218.

${ }^{98}$ Report Kreisky, Annex B, 43th Session of the Council of Ministers, 12 July 1960, in ÖStA, AdR, BKA, MRP. Cf. Österreichische Zeitschrift für Außenpolitik 1, 77.

${ }_{99}$ Austrian legation Sofia to Austrian MFA, 15 July 1960, in ÖStA, AdR, BMAA GZ. 70033-6/60, Z. 80921-6.

${ }^{100}$ L. Vidyasova, “An Impressive Example of Peaceful Coexistence," in International Affairs, no. 8 (August 1960), 11-15, 11. Cf., e.g. "N.S. Chruschtschow in Österreich," in Neue Zeit 18, no. 27 (1960), 1-2; L. Bezymenski, "Die Ergebnisse der Österreichreise Chruschtschows," in Neue Zeit 18 , no. 29 (1960), 4-6.

${ }_{101}$ Druzhestvennyi vizit. 
an intensification of the bilateral relations. He emphasized that "Austria is a neutral country and its government maintains neutrality that we respect and value," and stated that "There are no unresolved problems between the two nations." 102 This harmony was passed off by the Soviet leader as international recognition and proof of the correctness of the Soviet system and of Soviet foreign policy:

\begin{abstract}
"What was particularly evident in all these statements and talks, was that the Austrian people, welcoming and supporting, as they do [sic], our policy of peaceful coexistence, do justice to the greatness of our country, to the gains of our revolution and to the historic victories which the peoples of the Soviet Union have scored during the years of Soviet government. This was a recognition and approval of the Soviet foreign policy of peace and, thereby a voluntary or involuntary recognition of the greatness of our revolution, of our Socialist system, and our ideas on the basis of which so great an advance of the economy, culture and the living standards of the Soviet people, and of the might of our country was achieved within so historically short a period of time."103
\end{abstract}

Such claims, politically shrewd albeit fuzzy and tinted with ideology, reflected Khrushchev's quest for the Soviet Union to be recognized as a communist superpower on both the national and international stages. The 1960 visit was therefore celebrated - as had been the state treaty of 1955 - by Soviet propaganda as "another triumph for the Soviet state's Leninist peaceful policy." ${ }^{104}$ But in order to keep Austria, as a capitalist country, from appearing too attractive to his Soviet audience, the orator did not refrain from mentioning alleged plotting of certain Western and reactionary Austrian Catholic, or even fascist, circles against the Soviet-Austrian rapprochement. These, however, were doomed to failure in the face of the "peaceloving Soviet policies," their alleged appeal to the broad masses of the Austrian people, and the sincerity of the Soviet leaders.

\title{
Economic relations
}

From an economic viewpoint, Khrushchev's visit, particularly his consent to a reduction in the Austrian oil deliveries to the USSR, was advantageous for Austria. Bilateral economic relations had been induced mainly by the Austrian deliveries of oil and goods to the USSR that were stipulated in the state treaty, and the Soviet sell-off of former German, then Soviet, enterprises and oil fields in eastern Austria. These enterprises had already created an economic link between Austria and the Soviet Union in the years before 1955, when their goods were primarily produced for the Soviet and East European market. ${ }^{105}$ The state treaty in 1955 had set de-

102 Daily Review of the Soviet Press VI, no. 164 (10 July 1960), 2-13, 2. Cf. Druzhestvennyi visit, 178-208.

${ }^{103}$ Ibid., 6.

104 Vidyasova, “An Impressive Example of Peaceful Coexistence," 13.

105 On the Soviet enterprises in Austria, see Otto Klambauer, "Die sowjetische Wirtschaftspolitik in Österreich," in Andreas Hilger, Mike Schmeitzner, and Clemens Vollnhals (eds.), Sowjetisierung oder Neutralität? Optionen sowjetischer Besatzungspolitik in Deutschland und Österreich (Göt- 
liveries to the USSR at a lump sum of 2 million dollars plus 150 million dollars in goods over six years, and ten million tons of crude oil within ten years. In the following bilateral negotiations, which were finalized in Moscow on 11 July 1955, the Austrian government had achieved its goal of reaching consensus that Austria was entitled to export goods of higher-added value instead of oil; furthermore, the Soviet request to control the production process in Austria was rejected. ${ }^{106}$ In 1958, Raab gained Soviet approval to cut the remaining seven million tons of oil in half (by Soviet re-deliveries of half a million tons per annum); two years later, Austria's oil debts were reduced a second time, the Soviet re-deliveries were stopped and the end of Austrian deliveries was set for 1964. Altogether Austria delivered six instead of ten million tons of oil. ${ }^{107}$

While the deliveries of goods resulting from the state treaty helped Austria to gain a lead over other Western states in the East European market, ${ }^{108}$ other remnants of the past did not have such a positive impact on Austrian-Soviet economic relations. When Austria, on the basis of article 27 of the state treaty, explored its chances of receiving Soviet compensation for the Austrian economic assets in the USSR that had been confiscated by the Soviet government, including real estate, company shares and mining rights, the Kremlin agreed to negotiate but at the same time tabled its own claims for the repatriation costs of Austrian prisoners-of-war. ${ }^{109}$ Since the Soviet claims, totaling seventeen million dollars, exceeded the estimated value of Austrian assets, and neither land nor resources could be used as compensation under Soviet law, the Austrian negotiators concluded that the Soviet side would not accept a negative balance and shifted to tactics of protraction. ${ }^{110}$

In the meantime, both sides showed an interest in developing bilateral trade. ${ }^{111}$ The Kremlin was interested in purchasing machinery and equipment for its industry, and consumer goods for the Soviet people; Austria needed raw material. The Austrian chancellor Raab took a particular interest in the Osthandel and expected the

tingen: Vandenhoeck, 2006), 435-450. On the Soviet oil industry in Austria, see Walter Iber, Die sowjetische Mineralölverwaltung in Österreich (SMV), 1945-1955 (Innsbruck: Studienverlag, 2010).

106 Andreas Resch, "Der österreichische Osthandel im Spannungsfeld der Blöcke," in Manfried Rauchensteiner (ed.), Zwischen den Blöcken: NATO, Warschauer Pakt, und Österreich (Vienna: Böhlau, 2010), 497-556, 517-518.

107 Glasneck, "Die Sowjetunion und Österreich," 148.

108 Andreas Resch, "Die Außenhandelsbeziehungen zwischen dem RGW-Raum und Österreich in der Nachkriegszeit," in Gertrude Enderle-Burcel, Dieter Stiefel, and Alice Teichova (eds.), Zarte Bande: Österreich und die europäischen planwirtschaftlichen Länder, MÖSTA Sonderband 9 (Innsbruck: Studienverlag, 2006), 39-72, 44.

109 Vortrag BMAA an Ministerrat, 31 August 1957, in ÖStA, AdR, BMAA, GZ. 218.211-pol, Z. 225.062-pol.

110 Amtsvermerk, 10 July 1957, in ÖStA, AdR, BMAA, GZ. 218.211-pol/57, Z. 223.432-pol/57; Information für den Herrn Bundesminister, 26 September 1958, ibid., GZ. 550.045-pol/58, Z. 554.708-pol/58.

111 Protocol 97, 10 June 1957, in Fursenko, Prezidium TsK KPSS 1, 258; 1008. 
USSR to deal with Western Europe via Austria. ${ }^{112}$ On 17 October 1955, one five-year agreement on trade and shipping and another on the exchange of goods and payments were signed by the Soviet and the Austrian ministers of trade. These agreements granted both sides most-favored nation status (as was stipulated by the state treaty) and foresaw deliveries of 650 million Austrian schillings per annum, respectively. ${ }^{113}$ The most-favored nation status was soon to create problems on both sides. Nevertheless, in 1959 the limit had been surpassed and in 1960, a new trade agreement for five years was concluded. In this agreement, the Soviet side accepted 60 percent of Austrian deliveries stipulated by the state treaty to be part of the volume as agreed upon in the new contract. In response, Austria agreed to increase the trade volume. ${ }^{114}$

In these five years, Austrian-Soviet trade that had developed within the framework of bilateral clearing had increased almost ten times. Austrian imports from the USSR grew from 4.1 (1955) to 40.3 million dollars and the total share of Soviet goods imported to Austria had risen from 0.5 to 2.8 percent. Austrian exports to the USSR, in the same period, rose from 5.6 to 39.2 million dollars; the Soviet share of Austrian exports had risen from 0.8 to 3.5 percent, figures that do not include Austrian deliveries resulting from the state treaty. If these were included, the Soviet share of Austrian exports in 1960 amounted to 5.5 rather than 3.5 percent. The 1958 "dent" in bilateral trade statistics was due to falling Austrian imports of Soviet grain. ${ }^{115}$

Table 1: Soviet-Austrian trade 1955-1960

\begin{tabular}{|l|r|c|c|c|c|c|}
\hline & $\begin{array}{c}\text { Austrian } \\
\text { exports }\end{array}$ & $\begin{array}{c}\text { Change from } \\
\text { previous year }\end{array}$ & $\begin{array}{c}\text { Share of Soviet } \\
\text { imports }\end{array}$ & $\begin{array}{c}\text { Soviet } \\
\text { exports }\end{array}$ & $\begin{array}{c}\text { Change from } \\
\text { previous year }\end{array}$ & $\begin{array}{c}\text { Share of Austrian } \\
\text { imports }\end{array}$ \\
\hline 1955 & 145.6 & 284.2 & 1.2 & 107.8 & 200.3 & 0.5 \\
\hline 1956 & 362.6 & 149.0 & 1.8 & 186.4 & 72.9 & 0.7 \\
\hline 1957 & 711.9 & 96.3 & 1.7 & 557.1 & 198.9 & 1.9 \\
\hline 1958 & 526.3 & -26.1 & 1.4 & 569.0 & 2.1 & 2.0 \\
\hline 1959 & 874.3 & 66.1 & 1.6 & 768.3 & 35.0 & 2.6 \\
\hline 1960 & $1,020.6$ & 16.7 & 1.4 & $1,049.0$ & 35.5 & 2.8 \\
\hline
\end{tabular}

Source: Butschek, Statistische Reihen; ${ }^{116}$ Vneshniaia togovlia ${ }^{117}$

Exports in millions of Austrian schillings; changes and shares in percent.

112 Gehler, Österreichs Außenpolitik, 180.

113 Abkommen über den Warenaustausch; Abkommen über den Zahlungsverkehr zwischen Österreich und der UdSSR; Vertrag über Handel und Schifffahrt zwischen Österreich und der UdSSR, all 15 October 1955, in Mayrzedt and Hummer, 20 Jahre österreichische Neutralitäts- und Europapolitik 2, 130-138.

${ }^{114}$ Glasneck, "Die Sowjetunion und Österreich," 158. Cf. J. M. Bartsch, "Der sowjetische und der österreichische Außenhandel und ihre beiderseitigen Beziehungen" (PhD Thesis, Graz, 1958).

115 Austrian embassy Moscow to Austrian MFA, 17 March 1959, in ÖStA, AdR, BMAA, GZ. 236.711-pol/59, Z. 239.920-pol/59.

${ }^{116}$ Felix Butschek, Statistische Reihen zur österreichischen Wirtschaftsgeschichte (Vienna: WIFO, 1999).

117 Vneshniaia togovlia SSSR za 1959-1963 gody (Moscow: Vneshtorgizdat, 1965), 12. 
Given this positive development in absolute numbers and from the perspective of Austrian trade statistics, it may seem surprising that from the Soviet perspective, the importance of Austria as an import source fell. Due to the sale of the Soviet enterprises in Austria and an increase in Soviet imports in general, the Austrian share dropped from 2 percent in 1950 to 1.4 in 1960, while the Western share of Soviet imports rose from 16 to 20 percent, and the West German share from 0 to 4 percent. ${ }^{118}$

Nevertheless, in Austrian eyes, the USSR was a huge market waiting for Austrian goods. At the Austrian industrial exhibition in Moscow in May 1959 (the first industrial exhibition by a Western democracy in the postwar USSR ${ }^{119}$ ), 240 Austrian companies presented some 4,000 products, which were seen by 300,000 visitors including Anastas Mikoian and even Nikita Khrushchev. ${ }^{120}$ The Soviet government had embarked on an initiative to boost trade with Western countries; among the European states that were approached next was Italy, which was invited for a similar exhibit in $1962 .{ }^{121}$ In the second half of the 1950s, Austrian deliveries to the Soviet market included above all finished and semi-finished investment goods, such as machinery, turbines, electric generators and electrical equipment, furthermore iron and steel, locomotives, excavators, barges, ships, cable, as well as consumer goods, such as shoes and textiles. The first list of products to be offered by Austria for export to the USSR in 1955 contained, among other things, two tugboats, twelve hydraulic turbines, some generators, forty-five diesel locomotives, and industrial machinery. ${ }^{122}$ Within a few years, the Soviet Union became Austria's most important customer for equipment, machinery, and cable. In some sectors, trade with the USSR was extremely important for the Austrian economy, as, for instance, in the shipbuilding industry, in particular the Korneuburg dockyards. However, Austrian attempts to export high-tech machinery and even entire steel plants to Eastern Europe, were frustrated by the United States and COCOM. ${ }^{123}$ When Anastas Mikoian visited Vienna, the Ballhausplatz was prepared to explain that Austria had to respect the Western embargo as otherwise Austria itself would fall under the restrictions. ${ }^{124}$ Similarly, the provincial government of Lower Austria chose to withdraw an application to the Soviet government for a twenty-year loan of 500 million schillings, after US diplomats had expressed their

118 Harald Hauke, "Handelspolitik und Außenwirtschaftsbeziehungen der Sowjetunion von 1945 bis 1991" (PhD Thesis, Vienna, 1994), 76, 81. According to other statistics, the FRG's share was 3.6 percent. Cf. below, page 243.

119 Hinteregger, Im Auftrag Österreichs, 51.

${ }^{120}$ Zhiriakov, SSSR - Avstriia, 50-51.

${ }_{121}$ Bonwetsch, "Sowjetische Westeuropapolitik II," 182.

${ }^{122}$ Resch, "Der österreichische Osthandel," 520.

${ }^{123}$ Oliver Rathkolb, "Austria's Ostpolitik in the 1950s and 1960s: Honest Broker or Double Agent?" in Austrian History Yearbook XXVI (1995), 129-146, 138-139.

124 Aktenvermerk, 24 April 1957, in ÖStA, AdR, BMAA, GZ. 215.864-pol/57, Z. 219.394-pol/57. 
concern and made it clear that this deal would make receiving US loans difficult in the future. ${ }^{125}$

In the 1950s, 80 percent of Soviet exports to Austria consisted of agricultural products (grain, corn and cotton), raw materials (such as coal, asbestos, manganese and iron ore), and steel. Although the Soviet deliveries of coal grew tenfold, from 60,000 tons in 1956 to 897,000 tons in 1964, they still could not fully satisfy Austrian demands. ${ }^{126}$ However, when in 1958 the USSR offered to export more wheat, Austrian traders reacted reluctantly and complained about its allegedly poor quality. In 1960, bilateral trade exceeded two billion schillings.

${ }^{125}$ Lower Austria had applied for 350 million schillings for railroad reconstruction and 150 million for investment into the tourism infrastructure. Kargl to Il'ichev, 25 October 1955, in Fursenko, Prezidium TsK KPSS, 1954-1964, 2 (Moscow: Rosspen, 2006), 111-112. The Soviet government decided to react positively. Protocol 169, 16 November 1955, in Fursenko, Prezidium TsK KPSS 1, 63; 903. On the US reaction, see Oliver Rathkolb, “'Austria - Sieve to the East:' Austria's Neutrality during the East-West Economic War 1945/1948/1989” (Paper presented at the IEHC, Helsinki, 2006), 4.

126 Austrian embassy Moscow to Austrian MFA, 11 February 1959, in ÖStA, AdR, BMAA, GZ. 236.711-pol/59, Z. 237.679-pol/59. 


\section{Summary: Soviet "Thaw" and the Making of a Neutral}

The second half of the 1950s was the heyday of the Soviet campaign to undermine NATO and other pro-Western blocs by promoting neutrality among its members or aspirants. The neutralization of Austria was one of the most prominent results of this policy, and the Kremlin was determined to present Austria as an "example" for the benefits a Western state might reap from becoming neutral and experiencing "peaceful coexistence" with the Kremlin. That the Austrian model of 1955 was not repeated in Western Europe was at least in part due to the Soviet actions after the Hungarian declaration of neutrality: Only "few in the West would doubt after November 1956 that peaceful coexistence was a strategy not a goal; that for Khrushchev and others neutrality was merely a vehicle for undermining the unity of the free world." While Khrushchev, in his struggle against UN secretary general Dag Hammarskjöld, maintained that there were neutral nations but no neutral men, ${ }^{2}$ the 1958 Soviet "night frost crisis" against Finland revealed the dark side of being neutral and exposed to Soviet pressure and interference in internal affairs.

During the first half decade after the signing of the state treaty and the declaration of Austrian neutrality, the communist superpower and the small neutral managed to lay the groundwork for a special relationship. This relationship, based on Austria's need to normalize its relations with the most difficult signatory of the state treaty, and on the Soviet determination to make Austria a showcase of neutrality and "peaceful coexistence," weathered the Hungarian hurricane of 1956. After a number of months of fierce propaganda, the relations were re-established, as cordial as they had ever been. Despite the setback that political relations received in connection with the Soviet intervention in Hungary, Austrian-Soviet relations, for the most part, developed on a friendly basis and quite intensively in the first five years after the signing of the state treaty. Each country was host to visits from the other, the guests including members of the Soviet leadership, the Austrian chancellor and president, as well as countless ministers and delegations, and these visits led even to the establishment of personal relationships.

Neutrality provided the Soviet Union a lever and the Kremlin was determined to use it, despite its limitations, to shape Austria's foreign policy and assign the neutral country a special role. When Austrian leaders did not behave as desired by the

\footnotetext{
' Hanhimäki, "The Lure of Neutrality," 268.

2 Michael R. Beschloss, Kennedy v. Khrushchev: The Crisis Years, 1960-63 (London: Faber, 1991), 213.
} 
Kremlin, such as during the Hungarian crisis, they were fiercely attacked by the Soviet media for allegedly violating neutrality; otherwise they were highly praised for having chosen this status. They were welcomed in Moscow and were fine hosts to visit. They were treated with friendliness, given economic discounts, and invited to support Soviet initiatives in order to make them more acceptable to the West. They were reminded of what a neutral country, according to the communist doctrine, should do and what not, and exposed to repeated Soviet calls for an intensification of Soviet-Austrian and Austrian-East European relations. Soviet armed forces were offered to defend Austria's neutrality, as was put forward after the Lebanon crisis and during Khrushchev's tour d'Autriche. If things went as planned by the Soviets, the neutral state would not only help the Kremlin to attain a friendlier image and move out of its post-1956 isolation, but would also promote the transition of other Western states to neutrality. If they did not and the Soviet-Austrian relationship was tainted by international or bilateral crises, the Kremlin was prepared to pressure Austrian politicians and to restrain the neutral's attractiveness by turning on the anti-Western propaganda machinery. In this relationship, the Soviet side had nothing to lose.

For Austria, the relationship was riskier. A balancing act had to be carried out between irritating the East and annoying the West. Overwhelmed by a rain of Soviet advances, the Austrian Foreign Ministry began to fear a Soviet tendency "to detach countries like Austria and Finland from the Western world and to lead them into neutralistic fairways à la India and Egypt."”3 Although nothing like this even nearly occurred during the 1950s and although the Austrian government seemed to be on guard when Khrushchev attempted to make Austria "some sort of protectorate,"4 the intense Soviet advances left their mark. Austria's neutrality was young and, therefore, moldable, and Austria's understanding of neutral policy was shaped by the steady stream of Soviet propaganda, criticism and encouragement. Events such as the brutal display of Soviet military might in Austria's neighborhood also had a serious impact. Indeed, the Soviet crackdown on the Hungarian revolution made a quantum leap in molding Austria's neutrality; it was an event that reminded the neutral's leaders that the post-state treaty harmony did not rule out armed violence forever. It is clear that within only four years after the Soviet intervention in Hungary, the Austrian interpretation of neutral policy had shifted significantly in the direction of that of the Soviets. ${ }^{5}$ While in 1955 neutrality had been conceived by the Austrian side primarily as a means for getting "the Russians out" of the country and as a purely military and formal matter of staying out of NATO while being part of

\footnotetext{
${ }^{3}$ Betrachtungen zum Besuch der öst. Regierungsdelegation in Moskau im Lichte der derzeitigen internationalen Lage, 1958, in ÖStA, AdR, BMAA, Sektion II-Pol 1958, Liasse USSR-2.

${ }^{4}$ Chancellor Raab in the 43th Session of the Council of Ministers, 12 July 1960, in ÖStA, AdR, BKA, MRP. Cf. Stourzh, Um Einheit und Freiheit, 603.

${ }^{5}$ Michael Gehler, "From Non-Alignment to Neutrality: Austria's Transformation during the First East-West Détente, 1953-1958," in Journal of Cold War Studies 7, no. 4 (2005), 104-136.
} 
the West, this attitude gave way to a more comprehensive understanding of neutrality and the growing feeling that the country should maintain equidistance between the two blocs and superpowers.

As a consequence of the Soviet's close watch on its foreign policy conduct, Austria rescinded its liberal policy with regard to military transports through Tyrol, protested the US overflights, and praised the Soviet contribution to the state treaty as having been the most vital. Chancellor Raab's "Soviet-friendly" course found its expression in his readiness to fulfill Russian wishes (e.g. by supporting Moscow's candidature for the World Exposition 1961) while trying to disregard Western ones (e.g. compensation for Jewish claims). When Austria, following Soviet encouragement, announced its intention to join the Belgrade Convention, the decision had not been sanctioned by the Western powers, but concerns that joining the Convention might contradict neutrality were readily ignored by Raab. Loudly praising the reduction of the Austrian "reparations" to the USSR, Khrushchev's "little capitalist" brushed aside the fact that the United States had not only abstained from claiming any reparations at all, but also handed over former German property rights in Austria to the Vienna government without compensation and even sponsored the country's reconstruction with the Marshall Plan. In fact, in the postwar decade the US had poured roughly as much money into Austria as the USSR had taken out. When Kreisky reminded the chancellor that "the littlest we receive from the West is more than [the USSR] can give us," Raab rebuffed him by claiming that "the Western powers haven't made gifts for us either." As a result of these convictions and his well-known "antipathy towards the Americans," the chancellor was instrumental in putting the decisions through to host the communist World Youth Festival in Vienna and to allow Khrushchev to address an audience on the city's Heldenplatz. His party colleague Secretary Grubhofer, in 1960, asserted that Austria had not protested US overflights clearly enough, and the social democratic state secretary for defense, Otto Rösch, caused an uproar among Western diplomats by declaring that Austria's neutrality was endangered more by NATO than by the East. ${ }^{8}$ While Kreisky disagreed with these opinions, the social democratic party leader, Vice-Chancellor Pittermann, claimed that "the Austrian people are beginning to say [...] that the Soviet [Union] has given Austria ten million dollars (through the recent, dubious oil deal), whereas the United States is taking away five million dollars for the persecutee Jewish claimants [i.e. victims of the Nazi regime]."

\footnotetext{
${ }^{6}$ Verhandlungsniederschrift 42, Council of Ministers, 28 June 1960, in ÖStA, AdR, BKA, MRP.

${ }^{7}$ Report by the West German ambassador to Vienna, Carl Hermann Mueller-Graaf, to the West German MFA, 4 August 1958, quoted in Kofler, Kennedy und Österreich, 15.

${ }^{8}$ Kofler, Kennedy und Österreich, 37-38; Röhrlich, Kreiskys Außenpolitik, 125.

${ }^{9}$ FRUS, 1958-1960, IX, 783. An internal fact sheet stated that the US gave Austria at least 1.4 billion dollars in aid since 1945. Ibid., 786.
} 
Despite such disagreements, Kreisky, too, declared that he considered Khrushchev's "peace initiative" genuine ${ }^{10}$ and later went as far as adopting the Soviet expression for Austria, a good "example for coexistence." It is not yet clear to what extent this was an intentional strategy or the result of simply adopting Soviet propaganda vocabulary, as seems to have been the case in the negotiations for the bilateral communiqué of 1960. In addition, Raab and Kreisky began to grasp that neutrality and "coexistence" opened several opportunities to break the diplomatic isolation Austria had suffered before 1955, to create a new identity for their country, as well as raise its prestige, wealth, international profile and, thus, security. ${ }^{11} \mathrm{In}$ just these years Raab and Kreisky conceived their own Ostpolitik with the intention of establishing, by means of travel diplomacy, ties to the USSR and later to the "people's democracies." This also dovetailed with Soviet claims that Austria, as a neutral, was obliged to develop friendly relations with all states, including the socialist camp.

In contrast to earlier Austrian declarations that neutrality would be limited to the military sphere and affect neither freedom of speech nor the individual citizen, the Soviet calls for a wide-ranging interpretation of neutrality seem to have been not fully in vain: State Secretary Grubhofer's abortive proposal, made as a result of Soviet propaganda, to require the individual citizen to abide by neutrality reflected this development, as did Chancellor Raab's call on Austrian citizens during Khrushchev's visit not to forget that the USSR was a "friendly power." While it had been claimed in 1955 that neutrality would not affect Austria's external economic relations, a similar "broadening" of the Austrian understanding of neutrality was reflected by the thesis, launched by SPÖ representatives such as Kreisky and Pittermann ${ }^{12}$ and then formulated in 1959 by the expert in international law Karl Zemanek, that Austria was not entitled to commit itself to any economic obligations in peacetime that might make neutrality in wartime difficult. ${ }^{13}$ This was relevant particularly with regard to Austria's intentions to join the European Coal and Steel Community. In view of the negative reaction of the Soviets, such plans were increasingly considered by Austrian officials as unwise and contradictory to neutrality, and they were finally modified.

These developments in Austria's official understanding of neutral policy and Raab's and Pittermann's lopsidedness did not pass unnoticed by a growing number of people. Within Austria, Günter Nenning broke a taboo by publicly stating in 1959 that Austria's neutrality had not been voluntarily declared but rather forced

${ }^{10}$ Bruno Kreisky, Neutralität und Koexistenz: Aufsätze und Reden (Munich: List, 1975), 122.

${ }^{11}$ Schlesinger, Austrian Neutrality in Postwar Europe, 87; Paul Luif, “Austria's Permanent Neutrality - Its Origins, Development, and Demise," in Günter Bischof, Anton Pelinka, and Ruth Wodak (eds.), Neutrality in Austria, Contemporary Austrian Studies 9 (New Brunswick: Transaction, 2001), 129-159, esp. 139.

${ }_{12}$ Ermacora, 20 Jahre österreichische Neutralität, 123.

${ }_{13}$ See below, pages 140-141. 
upon the country by Soviet insistence. The journalist also claimed that Austria was entitled to abandon its Neutrality Law or to join the EEC. ${ }^{14}$ Such claims were fiercely attacked by Soviet media ${ }^{15}$ and rejected by Austrian officials and experts as legally and historically incorrect. According to them, neutrality was not "a rabbit, produced by a Soviet magician out of his top hat," 16 but had actually been part of the Austrian government's deliberations for a long time. Even earlier, in a press conference after his return from Moscow in 1958, Raab had felt the need to deny "rumors" about the shifting Austrian understanding of neutral policy. In this conference the chancellor underlined that such reports were incorrect, and that "the character and content of our neutrality, as adopted by parliament in 1955 in a clear and unambiguous manner, did not change in any way, nor did the Soviet Union demand such a change." ${ }^{17}$ As is often the case, however, denying the correctness of the allegation made it appear even more likely.

A shift regarding Austria's relationship to the superpowers was noticeable as well. Social democratic publicists claimed that the neutral did not take its financial obligations to the West seriously; it was criticized that "since the Russian was dangerous and threatening, he got his unjustified share of our oil and products; since the West was correct and friendly, it still has to wait." ${ }^{18}$ US diplomats deplored Austria's "increasing tendency to try to avoid taking definitive stands on certain East-West issues and, in some cases, to adopt an attitude which, in effect, would put the US and the USSR on the same moral plane." ${ }^{19}$ And the British ambassador remarked critically that "Austria is often prepared to avoid angering the Russians at the expense of irritating her Western friends." ${ }^{20}$ Such developments, together with Raab's excessive praise for the Soviet contributions to the state treaty, Austria's Alleingang to the Belgrade Commission, the government's foot-dragging regarding the compensation for Jewish victims of the Nazi regime, and last but not least Khrushchev's attacks against the West during his visit to Austria, led to a growing distance between Austria and its traditional patron, the United States. ${ }^{21}$ As a con-

${ }^{14}$ Günther Nenning, "Die Neutralitätslegende," in Heute, 31 October 1959, 1; "Das 'Freiwillige' unserer Neutralität," ibid., 7 November 1959, 4; “Österreich will, was es muss," ibid., 14 November 1959, 4; "Neutralität auf Widerruf," ibid., 21 November 1959, 4; "UNO-Beitritt verletzte die Neutralität," ibid., 28 November 1959, 4; "Neutralität und EWG-Beitritt," ibid., 5 December 1959,5 .

${ }_{15}$ M. Frolow, "Neutralität auf Widerruf?," in Neue Zeit, no. 51 (1959), 12-14.

${ }^{16}$ Gerald Stourzh, "Zur Geschichte der österreichischen Neutralität," in Österreich in Geschichte und Literatur 5, no. 6 (1961), 273-288, 275. See also Gerald Stourzh and Peter Jankowitsch, "Wie steht es mit unserer Neutralität?," in Heute, 12 December 1959, 6.

${ }_{17}$ Ausführungen des Herrn Bundeskanzlers in der Pressekonferenz, Beilage 1 zu Ministerratsprotokoll 88, Council of Ministers, 29 June 1958, in ÖStA, AdR, BKA, MRP

${ }^{18}$ Heute, 14 February 1959,1

${ }^{19}$ FRUS, 1958-1960, IX, 775.

${ }^{20}$ Quoted in Kofler, Kennedy und Österreich, 38.

${ }^{21}$ Rathkolb, Washington ruft Wien, 132. 
sequence, the US froze payments from the ERP counterpart funds for two years. Distancing Austria from the US was not among the least of the Soviet objectives. In the 1960s, this trend, as well as the amicable Soviet-Austrian atmosphere, continued. However, new burdens were put on the bilateral relationship. 


\section{OVERCAST, BUT FRIENDLY? 1961-1972}

"[T]here are no universally recognized international legal norms for the policy of neutrality in peacetime." Lev Voronkov, Non-Nuclear Status to Northern Europe (Moscow: Nauka, 1984), 27. 



\section{The USSR, Austria's Rapprochement with the EEC, and the Convocation of the CSCE}

After the Berlin and Cuban crises, international relations steered into less troubled waters and the conclusion of the Partial Test Ban Treaty in 1963 signaled rising chances for a superpower détente. By the end of the year the treaty had been ratified by twenty-three countries. Austria deposited its ratification document in July 1964. By the time Malawi, which had recently gained independence, did so in November, Khrushchev's reign in the Kremlin had come to an end. Owing to his foreign-political rollercoaster course, his tendency to abandon collective decisionmaking, and his failure to stabilize the ailing Soviet economy, the leader had been ousted in October by a group of Politburo members and his political protégé Leonid Brezhnev. A novice in foreign policy, the new CPSU leader was less ambitious to dictate his private wishes than Khrushchev had been. ${ }^{1}$ Therefore, he relied on the loyal Gromyko and the technocratic premier Aleksei Kosygin, while defining the strategic goals as a primus inter pares of the leadership. It was only in the wake of the rapprochement with West Germany in 1969 that Brezhnev assumed supremacy in high diplomacy. ${ }^{2}$ While the change from Khrushchev to Brezhnev calmed the character of Soviet foreign policy, the dichotomy of competitive "coexistence," i.e. the tension between the promotion of détente abroad and the military build-up, remained unchanged. ${ }^{3}$ The Soviet crushing of the "Prague Spring" of 1968 demonstrated that democratization, even if loyal to Moscow, was more than the Kremlin was willing to accept among its satellites.

Both, the blossoming of the Czechoslovakian reform movement and the Soviet decision to end it, were alleviated by détente. Before the Soviet invasion, Gromyko had anticipated that "the international relations now are such that extreme measures cannot produce aggravation of the international situation. There will be no big war." Indeed, after the events had taken place, the West did not terminate détente

1 Aleksandrov-Agentov, Ot Kollontai do Gorbacheva, 69-72.

2 Andrey Edemskiy, "Dealing with Bonn: Leonid Brezhnev and the Soviet Response to West German Ostpolitik," in Carole Fink and Bernd Schaefer (eds.), Ostpolitik, 1969-1974: European and Global Responses (Cambridge: University Press, 2009), 15-38, 22.

3 Svetlana Savranskaya and William Taubman, "Soviet Foreign Policy, 1962-1975," in Melvyn P. Leffler, and Odd Arne Westad (eds.), The Cambridge History of the Cold War II: Crises and Détente (Cambridge: University Press, 2010), 134-157, 134. For “competitive coexistence," see Stephan Merl, "Außenpolitik und Wettlauf der Systeme," in Stefan Plaggenborg (ed.), Handbuch der Geschichte Russlands V/1 (Stuttgart: Hiersemann, 2002), 273-308, 279.

${ }^{4}$ Quoted in Zubok, A Failed Empire, 208. Emphasis mine. 
nor did it isolate the aggressor, and the Soviet leadership saw the continuation of détente as proof of the "rising strength of the socialist camp." On the Western side, détente had been initiated as a result of European hopes of reducing the threat of war on the continent. The neutrals had contributed to making the Soviet Union an acceptable partner for dialog and trade, in 1964 Italy signed a long-term trade agreement with the USSR as the first NATO and EEC member, ${ }^{5}$ and the subsequent Soviet-French rapprochement brought détente to fruition. ${ }^{6}$ Five years later, the Kremlin's policy of isolating the FRG gave way to an even more spectacular rapprochement that outshone all other Soviet partnerships in Western Europe. The relaxation of tension was also supported by the United States, and in 1967 the Harmel Report welcomed the developments. ${ }^{7}$ From the Soviet perspective, the new trend was to serve an old aim. After Brezhnev had received the prime ministers of Norway, Denmark and Sweden in 1965, he revealed to his comrades: "Our reception of the Scandinavians, our relations now with France - they are all steps for undermining NATO." $"$

Keeping in mind the unfriendly Soviet attitude towards the emerging West European Economic Community, one might add: "and the EEC." European integration, both in the East and the West, and the Cold War were "separate but intertwined" phenomena. ${ }^{9}$ Hence, it does not come as a surprise that the Kremlin - after a brief "thaw" in 1962 - continued to condemn the Common Market as a hostile organization and watched jealously when three European neutrals, Sweden, Switzerland, and Austria, drew nearer to the organization. For some reason, Austria was the most attentively watched among the three; indeed, some West European political lead-

${ }^{5}$ Gromyko and Ponomarjow, Geschichte der sowjetischen Außenpolitik 1945 bis 1976, 544. On Soviet-Italian détente, see I. A. Khormach, SSSR - Italiia i blokovoe protivostoianie v Evrope (Moscow: Institut Rossiiskoi istorii Rossiiskoi akademii nauk, 2005), 797-845.

${ }^{6}$ On French-Soviet détente, see Marie-Pierre Rey, La tentation du rapprochement: France et URSS à l'heure de la détente 1964-1974 (Paris: Sorbonne, 1991); Newton, Russia, France, and the Idea of Europe, 57-104.

7 Jussi M. Hanhimäki, "Détente in Europe, 1962-1975," in Melvyn P. Leffler and Odd Arne Westad (eds.), The Cambridge History of the Cold War II: Crises and Détente (Cambridge: University Press, 2010), 198-218, 207. Cf. Mark Trachtenberg, "The Structure of Great Power Politics, 1963-1975," ibid., 483-502, 484; and Angela Romano, From Détente in Europe to European Détente: How the West Shaped the Helsinki CSCE (Brussels: Peter Lang, 2009), 67-71.

${ }^{8}$ Stenogramma vystupleniia L. Brezhneva na vstreche s rukovoditeliami raionnykh komitetov partii, 12 July 1965, in Kudriashov (ed.), General'nyi sekretar' L.I. Brezhnev, 32-51, 47.

${ }^{9}$ N. Piers Ludlow, "European Integration and the Cold War," in Melvyn P. Leffler and Odd Arne Westad (eds.), The Cambridge History of the Cold War II: Crises and Détente (Cambridge: University Press, 2010), 179-197, 179.

${ }^{10}$ In 1962, Khrushchev had announced his readiness to recognize the EEC, but after the failure of the British accession to the Brussels club, he seems to have lost interest in it. Wolfgang Mueller, "Die UdSSR und die europäische Integration," in Michael Gehler (ed.), From the Common Market to European Union Building: 50 Years of the Rome Treaties (Vienna: Böhlau, 2009), 617-662, 631-640. 
ers, Paul Henri Spaak among them, saw Austria's rapprochement with the EEC as a way to "free" the country from the neutrality that the USSR had "imposed" upon it. $^{11}$

While the Soviet leaders must have realized that their hopes to dismantle NATO and the EEC by neutralizing Western Europe would materialize less quickly than expected, their interest in neutrality did not cease, but it changed somewhat. In the wake of the big bang of decolonization, the Soviet focus shifted to the nonaligned, which at the 1961 Belgrade summit numbered twenty-five countries, among them no less than twenty-one that had previously hosted Western military bases. ${ }^{12}$ Denying their soil to foreign troops was advantageous for the USSR. As Soviet propaganda often pointed out, a certain parallelism of interests existed between the nonaligned and socialist states. ${ }^{13}$ Taken together, the nonaligned and the socialist countries comprised two thirds of the global population. In addition, the USSR could score propagandistic points in the United Nations - to which the new nations were admitted - by supporting the nonaligned states' struggle for decolonization and nondiscrimination. In return, the USSR received the nonaligned countries' support for Soviet proposals on disarmament and "anti-imperialism."

The increased interest in nonalignment did not mean, however, as was stressed by the Soviet media, that permanent neutrality had become obsolete. ${ }^{14}$ While some authors claimed that neutrality was a bulwark against European integration and condemned the neutrals for their interest in joining the EEC, ${ }^{15}$ others criticized "that the permanent neutrality of Switzerland and Austria, and the traditional neutrality of Sweden - in contrast to the active and dynamic Afro-Asian neutralism - is significantly more passive and plays a less positive role in international relations." 16 Such passivity was deemed incorrect, for not only the nonaligned states, but also the permanent neutrals should "take an active part in the struggle for world peace and security, peaceful coexistence of states and international friendship." ${ }^{17}$ It would be wrong, however, to assume that such Soviet appeals aimed exclusively at encouraging neutrals to support Soviet initiatives against "imperialism." There were other projects for which the Kremlin desired endorsement by the neutral states, in particular the idea of an all-European conference designed to legitimize the postwar

${ }^{11}$ Michael Gehler, "Von Unabhängigkeitsgaranten zu internationalen Partnern: Die Signatarmächte des österreichischen Staatsvertrages 1955-2005," in Christian Fornwagner and Richard Schober (eds.), Freiheit und Wiederaufbau: Tirol in den Jahren um den Staatsvertrag (Innsbruck: Universitätsverlag Wagner, 2007), 21-36, 26.

12 Vigor, The Soviet View, 190; Lyon, Neutralism, 177-195.

13 Allison, The Soviet Union and the Strategy of Non-Alignment, 23.

${ }^{14}$ Ganiushkin, Neitralitet i neprisoedinenie, 179-180.

15 Osnitskaya, "Neutrality and the Common Market"; K. Timashkova, "Neitral'nye strany v usloviiakh imperialisticheskoi integratsii," in M.M. Maksimova (ed.), Ekonomicheskie gruppirovki v zapadnoi Evropy (Moscow: Nauka, 1969), 269-280.

${ }^{16}$ Ganiushkin, Neitralitet i neprisoedinenie, 176.

${ }^{17}$ Mojoryan [Modzhorian], "Neutrality in Present-Day International Law," 219. 
order, to foster détente in the West, and to weaken the cohesion of NATO and the EEC. In the early Brezhnev period, this project shifted to the top of the agenda. As we shall see, it was the neutrals who were chosen by the Kremlin to promote this idea.

The Soviet attitude towards an Austrian rapprochement with the EEC, 1959-1963

Although the Soviet Union had not been able to prevent Austria from accepting Marshall Plan aid or from joining, in 1948, the US-launched Organization for European Economic Cooperation (OEEC), it had never stopped criticizing these decisions. ${ }^{18}$ In the following years, the Kremlin condemned the gradual West European economic integration as being an American ploy to strengthen economically NATO's dominance and to remilitarize West Germany. ${ }^{19}$ In order not to complicate the state treaty negotiations with the Soviet Union, the Austrian government, despite its interest in joining the European Coal and Steel Community as an associate member, did not pursue this goal for some time after negotiations on tariffs between Austria and the ECSC failed in the fall of $1954 .{ }^{20}$ The Soviet side did not miss any opportunity, in conversations with Austrian diplomats, to point out the community's aim "to put small members into a straitjacket." 21 After the conclusion of the state treaty, Moscow continued to keep an eye on any Austrian ambitions to participate in West European integration.

The Austrian decision to join the Council of Europe, a decision that was taken despite Chancellor Raab's reservations, was heavily criticized by the Austrian communist press and the Soviet media, with Pravda, on 8 February 1956, even accusing Austria of violating neutrality. ${ }^{22}$ The Soviet ambassador in Vienna was instructed

${ }_{18}$ Wilfried Mähr, Der Marshallplan in Österreich (Graz: Styria, 1989), 106-115. This also held true for the 1960s. Radio Moscow, 19 May 1961. On the Marshall Plan in Austria cf. Günter Bischof and Dieter Stiefel (eds.), 80 Dollar: 50 Jahre ERP-Fonds und Marshall-Plan in Österreich (Vienna: Ueberreuter, 1999); Günter Bischof, Anton Pelinka, and Dieter Stiefel (eds.), The Marshall Plan in Austria, Contemporary Austrian Studies 8 (New Brunswick: Transaction, 2000).

${ }_{19}$ Mueller, "The Soviet Union and Early West European Integration," 83.

${ }^{20}$ Gehler, Der lange Weg nach Europa: Darstellung, 139, 163-164. The Soviet side assessed that the conditions offered by the ECSC were too strict for Austria, which had hoped to enjoy conditions reserved for ECSC members without joining the community. Bericht der Abteilung für innenpolitische und wirtschaftliche Fragen, 5 October 1954, in Karner, Stelzl-Marx, Tschubarjan (eds.), Die Rote Armee in Österreich: Dokumente, 779-783.

${ }^{21}$ Austrian embassy Rome to Austrian MFA, 15 April 1955, in ÖStA, AdR, BMAA, GZ. 321.383pol/55, Z. 321.383-pol/55.

${ }_{22}$ Merhaut-Gurevitsch, "Die Innen- und Außenpolitik Österreichs," 76-81. Cf. Izvestiia, 13 January and 22 February 1956. See also Wolfgang Burtscher, "Österreichs Annäherung an den Europarat von 1949 bis zur Vollmitgliedschaft im Jahre 1956," in Waldemar Hummer and Gerhard Wagner (eds.), Österreich im Europarat 1956-1986: Bilanz einer 30jährigen Mitgliedschaft (Vienna: Verlag der Österreichischen Akademie der Wissenschaften, 1988), 37-52; and Walter Schwim- 
not to react positively, but nevertheless not to obstruct Austria's accession. ${ }^{23}$ Soviet legal experts considered Austria's membership in the Council "not a direct violation of neutrality" as long "as article 1 of the statute of the Council of Europe is observed and all questions of military issues are excluded from the organization's sphere of action." 24

However, the focus of Soviet criticism soon returned to Austria's rapprochement with the ECSC, an effort that had been renewed after the state treaty was signed. In March 1956, the Soviet ambassador in Vienna, Sergei Lapin, recommended publishing "in the Soviet press an article about the ECSC and our negative attitudes towards this organization." ${ }^{25}$ Vienna, which had announced its application for membership in the ECSC in October 1956, dropped it during the Soviet intervention in Hungary, after the majority of Austria's leaders had come to the conclusion that full membership was incompatible with neutrality. ${ }^{26}$ Nonetheless, the Kremlin remained vigilant. On 10 February 1957, Izvestiia warned that Austria's membership in the ECSC would not be compatible, on one hand, with neutrality, or with the state treaty, on the other. Making these opinions known had been suggested by the Soviet embassy in Austria and was quickly approved by the Soviet Foreign Ministry, which ordered its media to "publish, within three to four months," several newspaper articles and radio broadcasts in this regard. ${ }^{27}$

The Soviet argument, as put forward by Professor Tunkin, ran that the ECSC was an industrial basis of NATO and that therefore membership would violate neutrality; secondly, within the community, West Germany was the dominating country, which is why joining the ECSC would mean a new Anschluss and, thus, violate the anti-Anschluss clause of the state treaty. ${ }^{28}$ This second point was obviously considered necessary by the Soviet ministry, since the reference to neutrality was not without weaknesses; the ECSC was definitely not a military alliance. ${ }^{29}$ However, pointing out the FRG's dominating position within the ECSC was not much more

mer, "Der Europarat: Entstehungsgeschichte, Rolle und Stellenwert für Österreich," in Waldemar Hummer (ed.), Österreich im Europarat 1956-2006: Bilanz einer 50jährigen Mitgliedschaft (Vienna: Böhlau, 2008), 55-96.

${ }^{23}$ Michael Gehler, "Austria and the European Integration," in Arnold Suppan and Wolfgang Mueller (eds.), Peaceful Coexistence or Iron Curtain? Austria, Neutrality, and Eastern Europe in the Cold War and Détente, 1955-1989 (Vienna: Lit, 2009), 143-163, 146.

${ }^{24}$ Ganiushkin, Sovremennyi neitralitet, 130.

${ }^{25}$ Lapin to Semenov, 19 March 1956, in AVPRF, 66/35/66/26, 1-4.

${ }^{26}$ Gehler, Österreichs Außenpolitik, 175. Cf. Florian Weiß, “'Gesamtverhalten: Nicht in den Vordergrund stellen.' Die österreichische Bundesregierung und die westeuropäische Integration 19471957," in Michael Gehler and Rolf Steininger (eds.), Österreich und die europäische Integration 1945-1993 (Vienna: Böhlau, 1993), 21-54; Schweitzer, Dauernde Neutralität, 207-208.

${ }^{27}$ Lapin to Zorin, 21 November 1956; Tunkin to Aleksandrov, 12 December 1956; Lavrichenko to Aleksandrov, 20 December 1956, all in AVPRF, 66/35/66/26, 5-6, 19-20.

28 Tunkin to Aleksandrov, 12 December 1956, in AVPRF, 66/35/66/26, 19.

29 Black, Falk, Knorr, and Young, Neutralization and World Politics, 58. 
convincing, since it was hardly possible to equate the Coal and Steel Community with a new incarnation of Hitler's Greater Germany.

The project of creating a European Free Trade Area (FTA) within the OEEC, launched by the United Kingdom in 1956, seemed just as unacceptable to the Kremlin, which considered it "directed against the USSR." ${ }^{30}$ Soviet ambassador Lapin repeatedly questioned members of the Austrian government about their attitude towards the project, suspecting that membership would be "used as a camouflage for joining the ECSC." He concluded that membership with either would be incompatible with the state treaty. ${ }^{31}$ Austria nevertheless joined the FTA negotiations and, despite the fact that on 24 September 1957 Pravda stressed that Austria's participation in a future European Free Trade Area would have an "unfavorable" effect on the country's neutrality, ${ }^{32}$ the Austrian government even announced in the summer of 1958 that it considered signing a contract with the recently founded European Economic Community (EEC) of France, West Germany, Italy and the Benelux countries. ${ }^{33}$ Long before the failure of the FTA project in November, the highly respected Austrian daily Die Presse, by arguing that a full integration of neutral Austria into the Common Market would prevent the latter from turning into a branch of NATO, had sent up a trial balloon to find out whether this point would make Austria's membership in the EEC better digestible for Moscow. ${ }^{34}$ This argument, however, did not convince the Kremlin. On 22 January 1959, Pravda warned that "certain political circles" aimed at wrecking neutrality and pushing Austria into the EEC, and brought forward the thesis that Western economic integration would threaten Austria's independence.

In the meantime, among the Austrian political parties the debate concerning the country's relationship to the EEC intensified. In 1955, possible negative consequences of Austria's newly adopted neutral status with regard to trade and the economy in general and economic integration in particular had been either denied or ignored by both the Austrian elite and the general population. ${ }^{35}$ However, when, some years later, economic and industrialist groups within the ÖVP and the rightwing FPÖ advocated Austria's participation in European integration, full membership in the EEC was declared legally incompatible with neutrality not only by Foreign Minister Kreisky and the social democrats, but also by a majority of the

${ }^{30}$ Mueller, "Die UdSSR und die europäische Integration," 626.

${ }^{31}$ Conversation Lapin with Lugmayer, 8 February 1957; Lapin with Bock, 22 February 1957; Lapin with Kreisky, 8 April 1957, in AVPRF, 66/36/68/10, 4-5, 9-11, 18-20.

${ }^{32}$ Cf. Oskar Wictora, 10 Jahre österreichische Integrationspolitik 1956-1966 (Vienna: Bundesministerium für Handel und Wiederaufbau, [1966]), 26.

${ }^{33}$ Rudolf Kirchschläger, "Integration und Neutralität," in Erich Bielka, Peter Jankowitsch, Hans Thalberg (eds.), and Reinhold Wagnleitner (red.), Die Ära Kreisky: Schwerpunkte österreichischer Außenpolitik (Vienna: Europaverlag, 1983), 61-95, 63-72.

${ }^{34}$ Gehler, Der lange Weg: Darstellung, 180.

${ }^{35}$ Ermacora, 20 Jahre österreichische Neutralität, 61. 
country's international law experts, led by Karl Zemanek and Alfred Verdross. ${ }^{36}$ This was a strange alliance: Austrian social democrats abhorred the Common Market mainly for ideological and protectionist reasons, SPÖ chairman Pittermann in summer 1959 criticizing it as a "bourgeois bloc." In contrast, the basis of Zemanek's and Verdross' claims was that, in accordance with the Swiss doctrine, neutral policy (which hitherto had not been defined in Austria) would not allow the acceptance of any economic obligations in peacetime which might restrict the neutral's freedom of action during a war. ÖVP leader Raab also called for the careful adherence to neutrality. Kreisky and Pittermann even went so far as to subscribe to the Soviet thesis that joining the EEC would mean a violation of not only the country's neutrality but also the Soviet-Austrian Moscow memorandum and the anti-Anschluss clause of the state treaty - an interpretation that was rejected by international law professor Felix Ermacora. ${ }^{37}$ Within the debate, which stretched well into the 1970s, Soviet and Austrian communis $\mathrm{t}^{38}$ voices underlined their call for "total" neutrality. This obviously did not fail to have an impact on the Austrian side's increasing tendency to interpret neutrality extensively and thus to rule out EEC membership.

It was decided to join the newly-founded European Free Trade Association (EFTA) and to hold talks on a multilateral association between the EEC and EFTA. Only after a Soviet memorandum, dated 28 January 1960, demanded an Austrian declaration that the creation of EFTA would not have any consequences for Soviet foreign trade,$^{39}$ on 5 April Austria officially informed the USSR that it had joined the recently founded association. This was a significant deviation from the course of Austria's co-neutral Finland, which, after its rapprochement to EFTA had been criticized by the USSR, chose only to become an associate member. The association was obviously viewed by Soviet leaders with less hostility than the stronger EEC. While EFTA's existence was presented by Soviet propaganda as proof of the correctness of the Marxist-Leninist theory of intercapitalist contradictions, the organization was denounced by Soviet voices as another "closed bloc" and an ob-

${ }^{36}$ Verdross, Die immerwährende Neutralität der Republik (1966), 17; idem, Die immerwährende Neutralität Österreichs, 66-72; Zemanek, "Wirtschaftliche Neutralität," 249-251. Cf. Schweitzer, Dauernde Neutralität, 246; Anselm Skuhra, "Österreichs Sicherheitspolitik," in Herbert Dachs et al. (eds.), Politik in Österreich (Vienna: Manz, 2006), 838-854; Paul Luif, Der Wandel der österreichischen Neutralität: Ist Österreich ein sicherheitspolitischer ,,Trittbrettfahrer"? 2nd ed. (Vienna: Austrian Institute for International Affairs, 1998), 13-16.

37 Ermacora, 20 Jahre österreichische Neutralität, 114-116.

38 Aurel B.J. Moser, "Die Stellung der Kommunistischen Partei Österreichs zur österreichischen Neutralitätspolitik von 1955-1972” (PhD Thesis, Salzburg, 1973), 183-184. Moser's characterizations of the Austrian press as "antisowjetische Provokationskampagne" or of Radio Free Europe as "berüchtigter Hetzsender" reflect his anti-Western bias. Ibid., 55, 68.

39 Sowjetisches Aide-Mémoire, 28 January 1960, Abschrift, Anlage 1, in SBKA, Länder, UdSSR 1, File Sprechprogramm Moskau 1962. 
stacle for East-West trade. ${ }^{40}$ A Soviet memorandum of 20 May deplored Austria's decision, once again condemned the formation of blocs, and attacked EFTA as being linked to NATO. Furthermore, with reference to the Austrian-Soviet trade agreement of 1955, Austria was called on to grant the Soviet Union the same trade conditions as within the Free Trade Association. ${ }^{41}$ Since this would have gone against the association's rules, Austria and all other EFTA founding members refused; only EFTA associate Finland agreed. As a consequence, tariffs on Soviet goods were up to 70 percent higher than those on comparable goods from the EFTA area, and the USSR, after protesting such "discrimination," 42 in a retaliatory move, raised tariffs on Austrian goods imported to the USSR, until now 7 percent, to 20 percent. ${ }^{43}$

During his visit to Austria in the summer of 1960, Khrushchev had criticized both the EEC and EFTA as being obstacles to free trade between East and West, ${ }^{44}$ warned against the country's rapprochement with the former and declared it incompatible with neutrality. The question, however, became increasingly important in the spring of 1961. When Alfons Gorbach ${ }^{45}$ took over the chancellorship from the neutralist-leaning Raab, it was signaled by the Soviet media that he was expected to be just as staunch a defender of neutrality as his much-praised predecessor had been. ${ }^{46}$ However, the change in leadership to Gorbach, who strongly advocated European integration, and pressure from his party's youth and trade organizations had an impact on the government's strategy, while at the international level, the British and Danish applications for EEC membership brought the other EFTA states under pressure to regulate their relationships to the Common Market. All EFTA neutrals, i.e. Austria, Sweden and Switzerland, came to the conclusion that an association with the EEC, provided that it curbed neither the neutrals' treaty-making powers nor their right to withdraw, would not impede neutrality. ${ }^{47}$ Despite warnings and criticism voiced by Soviet diplomats, ${ }^{48}$ by International Affairs in January and May

${ }^{40}$ Mueller, "Die UdSSR und die europäische Integration," 628; Conversation Haymerle with Patolichev, 9 December 1960, in ÖStA, AdR, BMAA, II-Pol, Pol. Berichte Moskau.

${ }^{41}$ Sowjetisches Aide-Mémoire, 20 May 1960, in Gehler, Der lange Weg: Dokumente, 253-254.

${ }^{42}$ Soviet memoranda, 17 August 1961 and 12 December 1961, Abschrift, Anlage 4-5, in SBKA, Länder, UdSSR 1, File Sprechprogramm Moskau 1962.

${ }^{43}$ Glasneck, "Die Sowjetunion und Österreich," 162-163.

${ }^{44}$ Druzhestvennyi vizit, 38-39, 59.

${ }^{45}$ On Gorbach's political background, see Robert Kriechbaumer, "Alfons Gorbach," in Herbert Dachs, Peter Gerlich, Wolfgang C. Müller (eds.), Die Politiker: Karrieren und Wirken bedeutender Repräsentanten der Zweiten Republik (Vienna: Manz, 1995), 160-167.

${ }^{46}$ Petersson, The Soviet Union and Peacetime Neutrality, 52.

${ }^{47}$ Ermacora, 20 Jahre österreichische Neutralität, 120; on the following, ibid., 249-250. Summaries of Soviet statements concerning Austria's relations to the EEC are given in ibid., 134; and in Dienstzettel des Außenministeriums über sowjetische Äußerungen zur Frage der Assoziierung Österreichs an die EWG, 22 May 1964, in Gehler, Der lange Weg: Dokumente, 346-349.

${ }^{48}$ Karasek to Kreisky, 13 April 1961, in ÖStA, AdR, BMAA, Pol. Berichte Moskau. Cf. F. Fürnberg, "Neutrality and the Struggle for Peace," in International Affairs, no. 1 (January 1961), 55-61. 
and by Radio Moscow on 25 and 26 April about plans "to incorporate Austria into the Common Market," the Austrian government shortly thereafter declared itself ready for negotiations with the EEC - in its declaration, however, the government stressed its intention to stick to neutrality ${ }^{49}$ While the EEC Commission reacted by stating that neutrality was not compatible with full membership in the EEC but only with an association to the community, the Soviet ambassador in Vienna, Viktor Avilov, on 27 August, handed over a note claiming that the EEC was closely linked to NATO, that any negotiations with the community would contradict neutrality, and asking for explanations regarding Austria's intentions..$^{50}$ The federal government, in a note of reply that was handed over on 2 October, answered that it was seeking an economic arrangement only, and would not commit itself to any obligations that might jeopardize Austria's international status ${ }^{51}$ - an assurance that, however, did not convince the Soviet Foreign Ministry. Hence, the systematic attempts by Soviet diplomats to warn their Austrian colleagues against the EEC continued. ${ }^{52}$ Even earlier, during a visit to Vienna in June, Foreign Minister Gromyko had warned that the Common Market was "a bad thing." 53 In a conversation with Leopold Figl, the usually grim diplomat went as far as acknowledging that Austria had hitherto maintained and earned credit for a "good policy of neutrality" - an achievement that would be at risk if Austria continued to tend towards becoming associated with the EEC.

In the following months, the atmosphere surrounding such conversations deteriorated. In November the deputy director of the Soviet ministry's Third European Department, Aleksandr Bondarenko, in a conversation with Austrian diplomats attempted to equate the EEC with a new Anschluss. He observed that in Austria until then only isolated groups had advocated a "rapprochement with West Germany," whereas now even members of the government claimed that membership in the Common Market was compatible with neutrality. He refused to accept that Austria was only discussing an associative membership in the Community. After this con-

${ }^{49}$ Kirchschläger, "Integration und Neutralität," 79-80.

${ }^{50}$ Sowjetisches Aide-Mémoire, 27 August 1961, Abschrift, Anlage 9, in SBKA, Länder, UdSSR 1, File Sprechprogramm Moskau 1962. Cf. Österreichische Zeitschrift für Außenpolitik 1, 410. On Viktor I. Avilov, a diplomat who had served as ambassador to Belgium in 1952-58 and was retired in 1965, see A.A. Fursenko et al. (eds.), Prezidium TsK KPSS 1954-1964, 3 (Moscow: Rosspen, 2008), 1070.

${ }^{51}$ Kurt Waldheim, The Austrian Example (London: Weidenfeld and Nicholson, 1973), 103. Text in Österreichische Zeitschrift für Außenpolitik 2 (1961-62), 45. See also Oskar Wictora, 10 Jahre österreichische Integrationspolitik 1956-1966 (Vienna: Bundesministerium für Handel und Wiederaufbau, [1966]), 105-106.

${ }_{52}$ Karasek to Kreisky, 13 October 1961; Haymerle to Kreisky, 17 November 1961; 12 December 1961; 15 December 1961; Karasek to Kreisky, 30 December 1961, in ÖStA, AdR, BMAA, Pol. Berichte Moskau.

${ }_{53}$ Aktenvermerk Hausberger, Conversation Gromyko - Figl, 3 June 1961, in ÖIZG, NL 72: Fuchs, DO 823, File 23. 
versation, the Austrian ambassador in his report to the Ballhausplatz warned, with an eye to the recent Soviet-Finnish "note crisis," that "we cannot guarantee that the Austrian government won't be confronted with similar Soviet pressure." ${ }^{54}$ The Soviet demands of Finnish-Soviet military consultations according to the bilateral Friendship and Cooperation Treaty, demands that were underpinned by the detonation of a Soviet 50-megaton nuclear device, had come after Denmark, Norway, and the FRG had discussed joint naval defenses in the Baltic Sea. It was therefore most probably a Soviet attempt to isolate West Germany and to forestall what Moscow perceived as a shift in the delicate Nordic Balance. In addition, the imminent presidential elections in Finland might have contributed to the Kremlin's insecurity. ${ }^{55}$ The entire affair appeared even more dangerous, as it overlapped with the Berlin crisis and occurred only two months after the erection of the Berlin Wall. In its internal assessment, the embassy in Moscow warned that the Soviet government, in order to exert pressure on Austria, might withdraw its recognition of neutrality, and it recommended remaining alert to the possibility of a similar Soviet-Austrian crisis. However, such an event was deemed unlikely before Austria's negotiations with the EEC had officially started.

Despite warnings by the local correspondent in Pravda on 1 December 1961 that an Austrian "cold Anschluss" with the EEC would harm the country's economy and turn the neutral into a colony of NATO, ${ }^{56}$ and despite the "amicable" but critical Soviet memorandum of 12 December, which warned against the "enemies of neutrality" and equated the Common Market with the Atlantic organization, ${ }^{57}$ three days later the neutral EFTA members Austria, Sweden, and Switzerland applied for association with the EEC. On 19 October, the foreign ministers of the three neutrals

${ }^{54}$ Information Austrian MFA, 23 November 1961, Copy, in ÖIZG, NL 72 Fuchs, DO 832, File 26. Cf. on the Austrian perception of the "note crisis," Haymerle to Kreisky, 1 November 1961, in ÖStA, AdR, BMAA, II-Pol, Pol. Berichte Moskau.

${ }_{55}$ Hentilä, “The Soviet Union, Finland, and the 'Northern Balance,”” 248; Kari Möttölä, "Managing the Finnish-Soviet Relationship: Lessons and Experiences," in Bo Huldt and Atis Lejins (eds.), European Neutrals and the Soviet Union (Stockholm: The Swedish Institute of International Affairs, 1985), 35-57, 45-46. Cf. the Memorandum of the Soviet government to the government of Finland, 30 October 1961, in Vneshniaia politika Sovetskogo Soiuza i mezhdunarodnye otnosheniia 1961 (Moscow: Mezhdunarodnye otnosheniia, 1962), 475-483. The crisis was defused after Kekkonen visited Khrushchev, his opponent had withdrawn his candidacy in the presidential elections, and Norway had threatened to invite NATO troops to be stationed on its soil.

${ }^{56}$ See also O. Afanasyeva, "A Threat to Neutrality," in International Affairs, no. 12 (December 1961), $85-86.2$

57 The memorandum is attached to Aktenvermerk Bielka, Z. 172.787-9/61, 15 December 1961, in SBKA, Länderboxen UdSSR, 1; copies are in ÖIZG, NL 72 Fuchs, DO 832, File 28; and in SBKA, Länder, UdSSR 1, File Sprechprogramm Moskau 1962. Cf. Österreichische Zeitschrift für Außenpolitik 2 (1961-62), 126; and Kirchschläger, "Integration und Neutralität," 82-86. A German translation of the Pravda article is attached to Haymerle to Kreisky, 1 December 1961, in ÖStA, AdR, BMAA, Pol. Berichte Moskau. 
had reached agreement on their attitude to the organization..$^{58}$ With the unspoken final aim of participating in the Common Market and regulating its relations to the ECSC, Austria, in July 1962, declared itself ready to harmonize its tariffs, trade policy and other areas of its economic relations with the Common Market, and to support the principles of the Rome Treaties as far as its neutral status allowed. However, Austria reserved "a certain measure of its freedom of action towards third countries," the right not to participate in economic sanctions that were directed against third parties and that exclusively served political aims, and the right to take "certain measures" in the case of war. ${ }^{59}$

The move was followed by a full blown East European campaign against the neutral's attempted rapprochement with Brussels. Still in December 1961, the Hungarian prime minister, Gyula Kallay, repeated the Soviet theses, in January 1962 Czech and Polish newspapers followed suit, in February the Soviet delegate to the United Nations Zorin focused his criticism on Austria, and in March, a Czech memorandum to Vienna expressed concern that an Austrian arrangement with the EEC would violate the state treaty. While the Soviet diplomatic statements vis-à-vis Austrian officials were voiced for the most part in a friendly and cautionary manner, the East European allies were more outspoken and their propaganda was not friendly at all. ${ }^{60}$ If the early Soviet warnings had left it unclear whether they were referring to Austria's membership in the EEC or to an association with it, Pravda's 10 February 1962 article explicitly mentioned the latter, which was declared just as unacceptable as a membership in the community. ${ }^{61}$ On 13 March, Izvestiia repeated that "any arrangement" with the EEC would force Austria to give up neutrality. The fact that Moscow, seemingly indiscriminately, switched in its terminology from a condemnation of Austria's "Anschluss" to the EEC to its association, from an "arrangement of any form" to membership and back again, seems to have been a deliberate tactic to unsettle the Austrian leaders' convictions and to limit their room to maneuver with Brussels and in the internal Austrian discussion. ${ }^{62}$

In general, five points were brought forward by Soviet propaganda and legal statements warning against the integration of European neutrals into the Common Market. 1) Since the EEC, in Soviet eyes, was allegedly an economic basis for

58 Alan S. Milward, "European Uses of Neutrality," in Wiener Zeitschrift zur Geschichte der Neuzeit 1, no. 1 (2001), 103-116, 110.

59 Österreichische Erklärung vor dem EWG-Ministerrat, 28 July 1962, in Österreichische Zeitschrift für Außenpolitik 2 (1961-62), 288-294.

${ }^{60}$ Gehler, Der lange Weg: Darstellung, 216-217.

${ }^{61}$ Dienstzettel des Außenministeriums über sowjetische Äußerungen zur Frage der Assoziierung Österreichs an die EWG, 22 May 1964, in Gehler, Der lange Weg: Dokumente, 346-349, 347. Cf. Österreichische Zeitschrift für Außenpolitik 2 (1961-62), 186-187.

${ }^{62}$ Report Haymerle, 22 June 1963, in ÖStA, AdR, BMAA, II-Pol, GZ. 67129-6/64, Z. 75215-6/64. Overviews of the terminology used in Soviet warnings against various forms of arrangements with the EEC are in ÖStA, AdR, BMAA, II-Pol, GZ. 44264-6/66, Z. 48063-6pol/66; ibid., GZ. 17042-6/67, Z. 31717-6/67; SBKA, Länderboxen, UdSSR, 2. 
NATO, membership in it was deemed intolerable for a neutral. 2) Membership in a supranational organization such as the EEC was seen as damaging a neutral's sovereignty and, thus, its ability to maintain neutrality. 3) Since the EEC, by its nature, like all regional economic organizations, treated outsiders differently from members, this was seen as a violation of the Soviet thesis that neutrals were obliged not to discriminate against third countries. 4) The close ties to NATO of most EEC countries would make it impossible for the neutrals to maintain neutrality in wartime. 5) All claims that it might be possible to limit the obligations for neutrals by their being associates rather than members of the EEC were unjustified and merely a "maneuver" to blind the public. ${ }^{63}$ Or as Soviet legal expert Ganiushkin argued: If the EEC had not accepted a special relationship with mighty Britain, why should the small neutrals receive special conditions? G. Osnitskaia, in an article for the Soviet monthly International Affairs, declared that any hopes of preserving neutrality while an associate member of the EEC were "illusory." Since the Brussels club would "require the associated state to fulfill definite commitments to the Common Market," Osnitskaia argued, "any form of association, partnership or any other variant of cooperation with this organization cannot guarantee the preservation of neutrality in a state that agrees to such cooperation." 64

Most of these allegations were debatable: The EEC was hardly identical with NATO, the Common Market's supranationality was anything but fully achieved, and its discrimination against outsiders was similar to the principles of other regional trade organizations. Regarding the compatibility between neutrality and an associative membership in the EEC, the Soviet posture was clearly inconsistent: Whereas the West European neutrals were attacked for their desire to gain associative membership in the EEC, African associates of the same organization were still recognized by Soviet propaganda as being neutral or nonaligned. ${ }^{65}$

For Austria, the rest of the Soviet arguments against an association with the EEC remained the same as they had been regarding its rapprochement with the ECSC; both organizations were allegedly supporters of NATO and therefore unacceptable organizations for a neutral state to join; the FRG was the leading country in the ECSC and EEC, and therefore a rapprochement between Austria and either of the communities would lead to a new Anschluss and thus be incompatible with the state treaty. The warnings against a new Anschluss were underlined by repeated Soviet criticism of veterans' meetings in Austria and the country's mild treatment of neo-Nazis. ${ }^{66}$ The Austrian position - that an association with the EEC would not interfere with neutrality - was rejected by Soviet law experts, who emphasized the "political character" of the community and argued that any association with the

${ }^{63}$ Ganiushkin, Neitralitet i neprisoedinenie, 168-175.

${ }^{64}$ Osnitskaya, "Neutrality and the Common Market," 54-55.2

${ }^{65}$ Daniel Tarschys, "Neutrality and the Common Market: The Soviet View," in Cooperation and Conflict 6, no. 2 (1971), 65-75, 72-74.

${ }^{66}$ E.g. Radio Moscow, 3 May 1961; Pravda, 22 March 1962. 
Common Market would limit Austria's freedom of action towards third parties and thus also curb neutrality. ${ }^{67}$

Roughly the same points were made by Austrian international law experts, who pointed at the failure of the Austrian-German tariffs union of 1931. Nevertheless, on several occasions Austrian officials tried to explain that Austria's interest in an arrangement with the EEC was strictly economic and that this would not diminish Austria's ability to fulfill its international obligations. In a conversation with Avilov, Foreign Minister Kreisky referred to recent Soviet hints that even the USSR might be ready for relations with the EEC, but he could not convince the ambassador. ${ }^{68}$ Khrushchev had, indeed, in 1962 sent out some friendly signals regarding the establishment of mutual relations with the Brussels club, but later, once the British accession to the EEC had failed, he did not follow up on the matter. ${ }^{69}$

Four main reasons for the Soviet policy with regard to the European neutrals' striving towards the EEC can be extrapolated. First of all, the Kremlin was interested in preserving the status quo it had achieved in Europe after World War II. ${ }^{70}$ This status quo was comprised of a Western sphere of power, a Soviet-controlled power sphere in Eastern Europe, and some neutral states in between. It was in Soviet interests to keep the Western sphere as weak as possible. "Divide and rule" long served as the motto of Moscow's policies towards Western Europe. An alarming aspect of European integration was, however, that the continent's capitalist areas seemed to be increasingly unified and less involved in intracapitalist struggles than had been preached in Marxism-Leninism. From the Kremlin's perspective, any form of West European integration ran counter to the Soviet aim of keeping the West divided and playing Western states (including the US) off one another. It was part of the Soviet strategy, therefore, to obstruct, as far as possible, the emergence of a strong and integrated Western bloc, to hamper European integration by building strong ties to the EEC's individual member states, to fan intra-European differences, and to deter potential member states or associates from joining and strengthening the community, which was depicted as an economic basis for NATO. In his crusade against the Common Market, Khrushchev even went as far as encouraging EEC members such as Italy and France to leave the community.

Secondly, the Soviet dominance in Eastern Europe as had been accomplished by 1945 seemed endangered, on one hand, by growing economic difficulties and public discontent in the Eastern bloc, and on the other, by the wealth and hence, the attractiveness of Western Europe. The Soviet propaganda war orchestrated from the

${ }^{67}$ K voprosu ob assotsiatsii Avstrii k "Obshchemu rynku," 14 March 1964, in AVPRF, 66/43/90/19, 2-13.

${ }^{68}$ Conversation Kreisky with Avilov, 16 October 1962, in ÖStA, AdR, BMAA, GZ. 60566-4/62, Z. 74556-4pol/62. Cf. FRUS 1961-1963, XVI, 379.

${ }^{69}$ Mueller, "Die UdSSR und die europäische Integration," 632-638.

70 Austrian embassy Moscow to Austrian MFA, 8 November 1966, in ÖStA, AdR, BMAA, Pol. Berichte Moskau, 958-960. 
early 1950s against West European integration, therefore, aimed at least as much at deterring East Europeans from the temptations of European integration and prosperity, as at abetting West Europeans to resist their governments" "wicked plans." If the neutrals now joined the EEC, this would seriously undermine the Soviet strategy of depicting European integration as an evil ploy.

The third reason for Soviet dissatisfaction was that the European ambitions of the neutrals ran counter to their role as it had been envisaged by the Kremlin in 1955 and still was. This applied not only to Austria; the same can be said about Soviet plans regarding Finland, Switzerland, and Sweden. A common trait of these states was that they were not part of the Western bloc. If their rapprochement with the EEC succeeded, from the Soviet perspective, they would become even more "Western" than they already were and, as a consequence, would also draw nearer to other Western institutions such as NATO. To the Soviet leaders, such a shift in the European balance of power seemed unacceptable. In addition, a neutral country, in Soviet eyes, was to serve as a promoter of Soviet strategic concepts, such as "peaceful coexistence" and (as will be discussed below) all-European security and cooperation. ${ }^{72}$ It was to promote neutrality and East-West trade and struggle against Western "closed blocs," such as the EEC. ${ }^{73}$ Therefore, it did not suit the Soviet strategy for a neutral country to leave its space between the blocs and slip into an organization that was not only considered close to NATO, but also economically attractive. Any move from the neutral sphere, which was from the ideological point of view regarded more "progressive" than the capitalist sphere, to the latter by becoming part of a Western organization like the EEC was considered a forceful attempt at reversing the course of history and a setback for Soviet policy. It would set an unwanted example and probably trigger dangerous dynamics with critical consequences for Soviet rule in Eastern Europe.

Last but not least, association of the neutrals with the EEC ran counter to Soviet interests in East-West trade. As a regional economic organization aiming at creating a unified economic sphere, the Common Market contained characteristics that were considered discriminatory for the outside world. Since the Soviet Union wanted to foster East-West trade on a state-to-state basis, any rapprochement of third states with the EEC was criticized by Soviet propaganda, also from an economic point of view. ${ }^{74}$

The entire issue overshadowed Chancellor Gorbach's visit to Moscow, Leningrad, Irkutsk and Bratsk from 28 June to 5 July 1962. In his cordial welcome speech, Khrushchev stressed the mutual bonds and feelings between the Soviet and the Austrian people and commended Austria's "policy of permanent neutrality" and

71 The New York Times, 28 November 1966.

${ }^{72}$ Light, The Soviet Theory of International Relations, 229-235.

${ }^{73}$ Amtsvermerk Fuchs über Gespräch mit Botschafter Avilov, GZ. 34.699-Pol/61, Z. 35.131-Pol/61, 24 November 1961, Copy, in ÖIZG, NL 72 Fuchs, DO 832, File 26.

${ }^{74}$ Cf. Hakovirta, "East-West Tensions," 201-202. 
the "Soviet-Austrian friendship." ${ }^{75}$ Although the official communique of the visit praised the "amicable atmosphere," lauded "Austria's neutrality as a positive contribution to détente and the consolidation of peace," and declared that there were "no unresolved problems" in Soviet-Austrian relations, ${ }^{76}$ the bilateral talks were tough. The main Austrian aim was to get Soviet consent for an association with the EEC. While the Austrian delegation declared that neutrality was only a military matter, Khrushchev denied this, as well as - with reference to a recent declaration by Chancellor Konrad Adenauer that the EEC would develop further into a political union - the compatibility between an Austrian association to the Common Market and neutrality. ${ }^{77}$ The CPSU chief indicated, in a friendly manner but firmly, that Austria's "Anschluss" with this new "Holy Alliance against the East" would be understood by the Soviet Union as a violation of the state treaty and of neutrality. In such a case, Austria would not only lose all benefits of its status, but also "destroy the basis of Austrian-Soviet relations," "78 and the hitherto friendly attitude of the Soviet government towards Austria would "change fundamentally." 79 Invoking God not to let a new "Anschluss" happen and referring to the patronage he had conferred on Gorbach's predecessor, Khrushchev warned against damaging what had been built up by his "friend" Raab, the "little capitalist." 80 The references to his personal relationship to the ex-chancellor was interpreted by the Austrian side as a sign that their country had managed to preserve the Soviet leaders' trust, while their ostentatious friendliness was perceived as a demonstration of what Austria would forfeit if it fell from grace with the Kremlin. ${ }^{81}$ As a solution for the dilemma regarding the EEC, the Soviet leadership hinted at the possibility that Austria might conclude a trade agreement. Nonetheless, Kreisky, who had accompanied Gorbach, displayed optimism and, at a press conference, formulated cryptically (and somewhat misleadingly) that the Soviet government had signaled trust in Austria's diplomacy "at

${ }^{75}$ Sowjetunion heute 8, no. 27 (1962), 2.

${ }^{76}$ Gemeinsames Kommuniqué anlässlich des offiziellen Besuches des Bundeskanzlers in der Sowjetunion, 5 July 1962, in Mayrzedt and Hummer, 20 Jahre österreichische Neutralitäts- und Europapolitik 2, 142-143; cf. Vneshniaia politika Sovetskogo Soiuza i mezhdunarodnye otnosheniia 1962 (Moscow: Mezhdunarodnye otnosheniia, 1963), 292-294.

${ }^{77}$ Rede des Ministerratsvorsitzenden der UdSSR, 4 July 1962, in Mayrzedt and Hummer, 20 Jahre österreichische Neutralitäts- und Europapolitik 1, 358-359.

${ }^{78}$ Dienstzettel des Außenministeriums über sowjetische Äußerungen zur Frage der Assoziierung Österreichs an die EWG, 22 May 1964, in Gehler, Der lange Weg: Dokumente, 346-349, 347.

79 Verhandlungsschrift 54, Council of Ministers, 5 July 1962, and Beilage A, in ÖStA, AdR, BKA, MRP.

${ }^{80}$ Haymerle, "Die Beziehungen zur Großmacht im Osten," 176. Cf. Report Gorbach to the Council of Ministers, 5 July 1962, in ÖStA, AdR, BMAA, II-Pol, GZ. 66649-6/62, Z. 70081-6pol/62. See also the Protocol of the Conversation Gorbach with Khrushchev, 29 June 1962, in SBKA, Länderboxen UdSSR, 1. For the full text of the conversation, see pages 300-318.

${ }^{81}$ Beilage A, Verhandlungsschrift 54, Council of Ministers, 5 July 1962, in ÖStA, AdR, BKA, MRP. Cf. Report Haymerle, 23 June 1963, in ÖStA, AdR, BMAA, II-Pol, GZ. 67129-6/64, Z. 75215$6 / 64$. 
a time when we are trying to reach an association with the countries of the Common Market." ${ }^{\prime 82} \mathrm{He}$ also stressed that after the visit to Moscow, Austrian hopes for a rapprochement were still intact. In the Austrian draft communiqué, which was almost fully accepted by the Soviet side, ${ }^{83}$ no reference was made to the EEC. The same was the case during Bruno Pittermann's visit to Moscow from 13 to 18 September. ${ }^{84}$

Instead, Khrushchev used a conversation with the Austrian vice-chancellor that took place in the run-up to the Cuban missile crisis to convey some propaganda messages and to wage psychological warfare against the West by depicting US president John F. Kennedy as mentally instable and threatening that a US blockade against Cuba would lead to nuclear war. ${ }^{85}$ Soviet ships, Khrushchev boasted, perhaps referring to the recently launched top secret operation for stationing Soviet missiles in the Caribbean, were already on their way to Cuba. If something went wrong, the USSR would exert pressure on "the Americans' Achilles heel," West Berlin. He also renewed his classic threat to deprive the city of its allied protection by signing a "peace treaty" with East Germany and transferring the four-power rights to its communist government. Khrushchev's threats against West Berlin had also loomed large in a conversation with Gorbach and Kreisky held in June. ${ }^{86}$ The extensive misuse of bilateral meetings with Austrian leaders by the Soviet government for propaganda purposes, characteristic for Khrushchev, bore the risk of Austria becoming an instrument of Soviet psychological warfare.

\section{The Alleingang, 1963-1967}

After the British application for EEC membership was vetoed by French president Charles de Gaulle in January 1963 and despite the EEC's reluctance to accept neutrals as associates, the Austrian government - against the wishes of Kreisky, whose SPÖ had lost two seats in the 1962 elections - on 26 February declared its wish to continue the Alleingang towards European integration, ${ }^{87}$ thus provoking still more Soviet countermeasures. Switzerland had decided to terminate its rapprochement with the EEC, and in the Swedish case, the neutral's reluctance to accept the Com-

${ }^{82}$ Österreichische Zeitschrift für Außenpolitik 2 (1961-62), 310.

${ }_{83}$ Amtsvermerk, 12 July 1962, in ÖStA, AdR, BMAA, GZ. 66649-6/62, Z. 70015-6pol/62. For the text, see Mayrzedt and Hummer, 20 Jahre Österreichische Neutralitäts- und Europapolitik 2, $142-143$.

${ }^{84}$ Austrian embassy Moscow to Austrian MFA, 25 September 1962, in ÖStA, AdR, BMAA, GZ. 73544-4/62, Z. 73804-6pol/62; Conversation Pittermann - Kosygin, 14 September 1962, ibid., Z. 73544-6pol/62.

${ }^{85}$ Conversation Pittermann - Khrushchev, 17 September 1962, in ÖStA, AdR, BMAA, II-Pol, GZ., Z. 73544-6pol $/ 62$. For the full text of the conversation, see pages 318-326.

${ }^{86}$ Protocol of the Conversation Gorbach with Khrushchev, 29 June 1962, in SBKA, Länderboxen UdSSR, 1. For the full text of the conversation, see pages 300-318.

${ }^{87}$ Rolf Steininger, “Österreichs ‘Alleingang' nach Brüssel 1963-1969," in Michael Gehler and idem (eds.), The Neutrals and European Integration (Vienna: Böhlau, 2000), 577-644. 
mon Commercial Policy and its demand that an associative agreement be "supervised" had virtually "killed any chances of an agreement" well before de Gaulle's veto against the British accession did. ${ }^{88}$ Austria's ambassador to Moscow, Heinrich (von) Haymerle, a more critical observer than his predecessor Bischoff and in Soviet eyes a "reactionary," $"$ believed that from the Soviet point of view, any further Austrian rapprochement with the Common Market had become even more dangerous, since without the other neutrals Austria would be more susceptible to Western influence..$^{90}$

While the Austrian press had understood the Soviet stance during the Gorbach visit as being a green light for an Austrian association with the EEC, this assumption proved to be a misunderstanding. ${ }^{91}$ Between 13 January 1963, with the publishing of an article in Pravda, and April, at least nineteen direct and indirect Soviet warnings were issued to the Ballhausplatz. Radio Moscow aired about the same number of broadcasts claiming the inadmissibility of a rapprochement between Austria and the EEC. ${ }^{92}$ On 28 February and 9 April, TASS underlined that the Soviet position remained unchanged. ${ }^{93}$ However, whereas West Germany, the US, NATO, as well as economic and pan-German circles in the FPÖ had until this time been depicted in Soviet propaganda as the main culprits responsible for Austria's strive towards the EEC, from this point in time the blame was more frequently put directly on the Austrian government. On 8 March, the CPSU daily, which published three editorials on the subject in these months, stated, in response to Austrian claims of having the exclusive right to interpret its own neutral policy, that neutrality was an international obligation not to be defined by Austria alone. ${ }^{94}$ A Soviet memorandum of 3 May forecast "serious, negative consequences" for Austrian-Soviet relations in the case of Austria's "participation" in the Common Market, ${ }^{95}$ and less than three weeks later, Ambassador Avilov followed up on the topic in a lively conversation with

${ }^{88}$ Milward, "European Uses of Neutrality," 110.

${ }^{89}$ Dölling to Ulbricht with Amtsvermerk, 12 July 1960, in BA Berlin, SAPMO, NY 4182/1320, 8-10. Cf. Ullmann, "Das Russlandbild," 44. On Haymerle, who had served in London and Paris before being sent to Moscow, see Agstner, Enderle-Burcel, Follner, Österreichs Spitzendiplomaten, 236-238.

${ }^{90}$ Report Haymerle, 23 June 1963, in ÖStA, AdR, BMAA, II-Pol, GZ. 67129-6/64, Z. 75215-6/64.

${ }_{91}$ Haymerle to Kreisky, 7 Februar 1963; Karasek to Kreisky, 9 April 1963, in ÖStA, AdR, BMAA, Pol. Berichte Moskau.

${ }_{92}$ Gehler, Der lange Weg: Darstellung, 229; Pravda, 8 and 31 March 1963.

93 TASS über Österreich, 28 February 1963, in Mayrzedt and Hummer, 20 Jahre österreichische Neutralitäts- und Europapolitik 1, 370-371; extracts of the TASS article of 9 April 1963, in Österreichische Zeitschrift für Außenpolitik 3 (1963), 243-244.

${ }^{94}$ Extracts in Österreichische Zeitschrift für Außenpolitik 3 (1963), 134.

95 The memorandum and a report on the conversation are in Ministerrat, 29 May 1963, Abschrift, in ÖStA, AdR, BKA, 4215-PrM/63. Cf. Dienstzettel des Außenministeriums über sowjetische Äußerungen zur Frage der Assoziierung Österreichs an die EWG, 22 May 1964, in Gehler, Der lange Weg: Dokumente, 346-349, 348; Wictora, 10 Jahre österreichische Integrationspolitik, 154. 
Kreisky. ${ }^{96}$ The Soviet warnings continued well into 1964, Pravda repeating on 10 July that, with regard to Austria and the EEC, there was no difference between association and membership. ${ }^{97}$ Within the Soviet Foreign Ministry, the negative position was supported by recent reports from the Soviet embassy in Brussels pointing out that "the [EEC] Commission's proposals for negotiations with Austria would result in Austria's de facto accession to the EEC with regard to its economy." "98

On the Austrian side, Ambassador Haymerle expressed the opinion that Austria should not renounce its hopes to find an economic arrangement with the Common Market that in the end would be accepted by the Soviet Union. ${ }^{99}$ If Austria yielded too soon, this would bring about further Soviet pressure for Austrian concessions and a subsequent constriction in the neutral's freedom of action. Nevertheless, he anticipated that the Austrian ambitions with regard to the EEC would become a touchstone of Soviet-Austrian relations and any Austrian rapprochement with Brussels would put Moscow's patience to a serious test. ${ }^{100}$ But since Vienna did not intend to sign anything other than an economic arrangement with the EEC, it was thought that Moscow would finally comply with a fait accompli. Thus, Kreisky, in his conversations with Soviet officials, pleaded for a wait-and-see approach with regard to the Austrian EEC negotiations. ${ }^{101}$ Internally, at least from May 1963, Kreisky recommended focusing on the creation of a free-trade area between Austria and the Common Market and giving up other ways for reaching a rapprochement with the EEC. ${ }^{102}$

In order to avoid a deterioration of Austrian-Soviet relations, Vienna had, from the beginning, regularly informed the Soviet side about its aims and the steps being taken in the decision-making and negotiating process with the EEC. ${ }^{103}$ Emphasis was laid thereby on assuring that under no circumstances would Austria enter into an agreement contradicting the neutral's international obligations, but also on the economic necessity of Austria joining the Common Market in order to forestall financial and economic losses, as it accounted for approximately half of Austria's foreign trade. On 22 November 1963, the Soviet ambassador jokingly conceded to Fritz Bock that the Austrian minister of trade had almost succeeded in convincing

${ }^{96}$ See Kreisky's report in Ministerrat, 29 May 1963, Abschrift, in ÖStA, AdR, BKA, 4215-PrM/63; and Amtsvermerk, 5 July 1963, in SBKA, Integration, Box 4, File USSR.

97 Text in Archiv der Gegenwart, 11321, 10 July 1964.

${ }_{98}$ Soviet embassy Brussels to Soviet MFA, 23 March 1964, in AVPRF, 66/41/85/19, 14-16.

${ }^{99}$ Austrian embassy Moscow to Austrian MFA, 12 December 1961, in SBKA, Länderboxen, UdSSR 1.

${ }^{100}$ Report Haymerle, 22 June 1963, in ÖStA, AdR, BMAA, II-Pol, GZ. 67129-6/64, Z. 75215-6/64.

${ }^{101}$ Conversation Kreisky with Gromyko, 16 May 1965, Z. 136.736-6pol/65, in SBKA, Länderboxen, UdSSR 2.

102 Kreisky's report in Ministerrat, 29 May 1963, Abschrift, in ÖStA, AdR, BKA, 4215-PrM/63.

${ }^{103}$ Kreisky had informed Gromyko in advance about the Austrian negotiations to be held in Brussels in July 1962. Conversation Kreisky with Gromyko, 4 July 1962, in SBKA, Länderboxen, UdSSR 1. 
the Soviets. Nonetheless, the diplomat reminded Bock of the "strong links" between the EEC and NATO. ${ }^{104}$ In a more "dramatic" meeting, Avilov told his designated Austrian counterpart Walter Wodak on 12 June 1964 that Austrian-Soviet relations had entered a "critical phase," 105 while Ambassador Haymerle, in his farewell visits to Mikoian and Kosygin, was informed of the negative Soviet opinion of Austria's being associated with the EEC. ${ }^{106}$ Similar sermons were given to Wodak upon his arrival in Moscow by Mikoian, ${ }^{107}$ who as head of state had developed the habit of turning such ritualized diplomatic events into serious political discussions. ${ }^{108}$ Wodak, whose "sharp-wittedness" was highly respected by one of the keenest minds among his Soviet counterparts, ${ }^{109}$ did his best to reassure the Soviet side. A conversation, described as the "friendliest in tone, however most serious in content," had been reported by Haymerle in May, ${ }^{110}$ and in June, Ambassador Avilov told Kreisky that the Soviet Union would no longer feel bound to the state treaty [sic] if it was violated by Austria by entering the EEC. ${ }^{111}$ On 30 September, a Soviet memorandum repeated that an "Austrian Anschluss with the EEC, in whatever form," would be considered a turning point in Austria's neutral policy and a de facto economic unification with Germany, which was prohibited in the state treaty.

Remarkably enough, all these conversations were conducted in a forthcoming and amicable atmosphere. The Soviet Union was interested in communicating its doubts about the rapprochement between Austria and the EEC in a well-balanced way, so that the neutral country would not feel alienated. As if to demonstrate that Soviet-Austrian relations were not suffering, on 23 October 1964, shortly before the ninth anniversary of Austria's declaration of neutrality, Radio Moscow broadcast the CPSU motto "Long live the friendship and cooperation between the peoples of the Soviet Union and Austria!" and called Soviet-Austrian relations again a good "example of peaceful coexistence," coexistence that was threatened only by the

104 Rücksprache mit dem russischen Botschafter, 22 November 1963, in Gehler, Der lange Weg: Dokumente, 339-340.

105 Amtsvermerk [Wodak?], 16 June 1964, in ÖStA, AdR, BMAA, GZ. 73367-6/64, Z. 73367-6/64.

106 Austrian embassy Moscow to Austrian MFA, 11 April and 7 May 1964, in ÖStA, AdR, BMAA, GZ., Z. 70255-6/64 and Z. 71604-6/64.

107 Conversation Mikoian with Wodak, 17 July 1964, in AVPRF, 66/43/89/6, 3-8. Mikoian suggested that Austria could respond to German pressure with an Austrian boycott of German goods.

108 Mikoian, Tak bylo, 618.

109 Valentin Falin, Politische Erinnerungen (Munich: Droemer Knaur, 1993), 79. On Wodak's career, see Agstner, Enderle-Burcel, Follner, Österreichs Spitzendiplomaten, 482-485.

${ }^{110}$ Haymerle über Gespräch mit Semenov, 20 May 1964, in Gehler, Der lange Weg: Dokumente, 349-351.

111 Stephan Hamel, "Eine solche Sache würde der Neutralitätspolitik ein Ende machen: Die österreichischen Integrationsbestrebungen 1961-1972," in Michael Gehler and Rolf Steininger (eds.), Österreich und die europäische Integration 1945-1993: Aspekte einer wechselvollen Entwicklung (Vienna: Böhlau, 1993), 55-86, 68-71. The Soviet memorandum was a response to an Austrian document that had been handed over by Wodak on 23 July 1964. Cf. Aide mémoire, in ÖStA, AVA, NL Bielka, File 115. 
plans in "certain circles" of incorporating Austria into the EEC - a subject that was further delineated in an Izvestiia article the same day. An Austrian memorandum explaining that the country was forced to seek an arrangement with the Common Market solely for economic reasons was answered by the Kremlin on 20 September by a repetition of its well-known views. ${ }^{112}$

The official USSR opinion was that an agreement on tariffs and trade would be sufficient to solve the economic problems resulting from Austria's nonparticipation in the EEC. During his meeting with Gorbach in the summer of 1962, Khrushchev had hinted at this possibility. The Austrian embassy in Moscow was also of the opinion that an "arrangement of purely trade-political [handelspolitisch] nature" between Austria and the EEC would be accepted by the Kremlin despite all its loud warnings, as long as it did not discriminate against third parties. But anything more would not leave Soviet-Austrian relations untouched. ${ }^{113}$ This was underlined by an article in Sovetskaia Rossiia on 26 September $1964 .{ }^{114}$ Within the Soviet apparatus, the only viable option that was considered remained a trade agreement between Austria and the EEC according to articles 111 or 114 of the Rome Treaty, as had been concluded between the Common Market and Iran. ${ }^{115}$ Both other alternatives, a customs union between Austria and the EEC or a free-trade area according to article 24 of the 1947 General Agreement on Tariffs and Trade (GATT), were ruled out as incompatible with neutrality and the state treaty. ${ }^{116}$

When direct negotiations between Austria and the EEC started in March 1965, Pravda, Izvestiia and TASS issued further warnings towards Austria not to continue its EEC ambitions as otherwise it would risk coming under the dictate of the aggressive forces responsible for World War II. ${ }^{117}$ During his visit to Vienna on the tenth anniversary of the state treaty, Foreign Minister Gromyko stated that Austria had a special international position and good relations with the USSR. Both would be at risk if Austria joined the EEC. ${ }^{118}$ When the Soviet ambassador followed up on the topic the next day, he was less discrete and prophesized "irreparable damages" to Soviet-Austrian relations if Austria continued to steer its course towards

112 Österreich und die EWG, 19 October 1966, in ÖStA, AdR, BMAA, II-Pol, GZ. 45707-6/66, Z. 49028-6pol/66.

113 Vertraulicher Bericht der österreichischen Botschaft in der UdSSR, 29 May 1964, in Gehler, Der lange Weg: Dokumente, 351-353.

114 Ibid., 366.

115 Soviet embassy Brussels to Soviet MFA, 23 March 1964, in AVPRF, 66/41/85/19, 14-16.

${ }^{116} \mathrm{~K}$ voprosu o vozmozhnosti sozdanii torgovykh otnoshenii, 16 Februar 1965, in AVPRF, 66/44/93/19, 17-20.

117 Cf. Österreichische Zeitschrift für Außenpolitik 5 (1965), 44, 107-108, 402; Wictora, 10 Jahre österreichische Integrationspolitik, 225, 232, 235, 241.

${ }^{118}$ Haymerle, "Die Beziehungen zur Großmacht im Osten," 177. See the protocols of the conversations in Unterredung des Herrn Bundesministers mit Außenminister Gromyko [16 May 1965], ÖStA, AVA, NL E/1736 Bielka, File 115. Gromyko's official speech did not touch upon the topic. See the text in Österreichische Zeitschrift für Außenpolitik 5 (1965), 81-82. 
the EEC. ${ }^{119}$ The Soviet foreign minister also used the opportunity to promote his proposal of complete disarmament in both German states.

In the meantime, the Austrian government had modified its goal: it was no longer seeking an association with the EEC, but rather an "arrangement of a special kind." It remains yet to be shown to what extent this was due to reservations by the Community and the United States (which wanted to avoid the EEC being watered down by an association of the neutrals ${ }^{120}$ ) or to the steady stream of Soviet propaganda. A change of terminology had been recommended by the Austrian embassy in Moscow in 1961 and then again in 1963, when it was claimed that gaining an associative membership was possible only in collaboration with Switzerland and Sweden. ${ }^{121}$

However, after the ÖVP's triumph in the general elections of 1966, the rapprochement with the EEC was intensified. This shift in the Austrian political landscape, as well as the resolution of the internal "empty chair" crisis in the EEC, which had been provoked by de Gaulle's power struggle against the Commission of the EEC, led to a certain amount of concern on the Soviet side. ${ }^{122}$ Soon after the elections, the head of the Austrian desk at the Soviet Foreign Ministry expressed his uneasiness that "the circles seeking Austria's entry into the EEC had been given leeway in the elections." 123 A few weeks later, the Austrian ambassador reported that the formation of Chancellor Josef Klaus' one-party government had "sparked astonishment in Moscow and, in parts, even dismay," as well as fears of a change in Austria's foreign policy. ${ }^{124}$ Soviet media had dubbed the new cabinet an "advance payment to the Western blocs." 125 Their disquiet increased when Fritz Bock, one of the strongest advocates of Austria's rapprochement with the EEC, was appointed vice-chancellor. An indication of Soviet insecurity was a sharp Izvestiia editorial of 25 April 1966 stating that "if Viennese reactionary circles intend, by linking Austria with the EEC, to use the election success of the ÖVP for a semi-masked Anschluss with Bonn and the aggressive military bloc of NATO, they would do their country

119 Gespräch Bundesminister Dr. Kreisky - Außenminister Gromyko, 17 May 1965, Copy, in ÖStA, AVA, NL E/1736 Bielka, File 115.

${ }^{120}$ Kofler, Kennedy und Österreich, 78-95.

${ }^{121}$ Karasek to Kreisky, 13 October 1961; Haymerle to Kreisky, 17 November 1961; Karasek to Kreisky, 9 April 1963, in ÖStA, AdR, BMAA, Pol. Berichte Moskau.

122 Austrian embassy Moscow to Austrian MFA, 17 February 1966, in ÖStA, AdR, BMAA, Pol. Berichte Moskau, 683-685.

${ }^{123}$ Austrian embassy Moscow to Austrian MFA, 10 March 1966, in ÖStA, AdR, BMAA, Pol. Berichte Moskau, 725-731.

124 Austrian embassy Moscow to Austrian MFA, 16 June 1966, in ÖStA, AdR, BMAA, Pol. Berichte Moskau, 814-816. Cf. Stifter, "Das politische Österreichbild," 118, 168. On Klaus, see Ernst Hanisch, "Josef Klaus," in Herbert Dachs, Peter Gerlich, Wolfgang C. Müller (eds.), Die Politiker: Karrieren und Wirken bedeutender Repräsentanten der Zweiten Republik (Vienna: Manz, 1995), 299-306.

${ }^{125}$ Quoted in Petersson, The Soviet Union and Peacetime Neutrality, 58. 
a disservice." Klaus was severely attacked for having omitted, in his declaration of the new government, any reference to the state treaty. ${ }^{126}$ Izvestiia openly asked whether this indicated a change in the neutral's political line and on 29 April, the Austrian communist Volksstimme spread the word as quickly as possible. ${ }^{127}$ Shortly thereafter, a severe warning was published by Nikolai Polianov, an influential Izvestiia correspondent, in the journal of the Austrian Society for Foreign Policy. ${ }^{128}$

Despite these discussions, the bilateral relations, which had been in a state of limbo after Khrushchev's ouster, received some sort of consolidation by the visit of Petr Demichev to Austria in June 1966 - although Klaus did not succeed in convincing the CPSU Presidium member of the economic necessity of Austria's association with the Common Market. The Soviet guest repeated that such an arrangement would seriously flaw Soviet-Austrian relations. ${ }^{129}$ In reassessing the results of the visit, on 15 June Lev Tolkunov, the Izvestiia editor, drew an ambiguous picture: On one hand, he expressed Soviet "concern" about Austria's ambitions regarding the EEC, depicted the alleged West German threat to the neutral's independence in dark colors, and criticized Austria's policy, which was, in his eyes, not neutral enough - Austria neither "condemned aggressive US policy" nor did it recognize the GDR. He also rejected the idea that neutrality was merely a military matter. On the other hand, Tolkunov commended Klaus for his loyal course with regard to the Soviet Union. Similar points were raised in a Pravda article on 30 June. Despite such ambivalence, the Demichev journey paved the way for the Soviet president's state visit to Vienna in November 1966.

The trip of the new chairman of the Supreme Soviet, Nikolai Podgorny, had been preceded, on one hand, by a "wave of Austrian visits" to the USSR in the fall, including delegations of parliamentarians, trade-unionists and industrialists, the mayor of Vienna, and the Austrian minister of defense. ${ }^{130}$ On the other hand, on 3 November Izvestiia published, in the Austrian ambassador's eyes, the "frankest ever" declaration of the Soviet standpoint concerning Austria and the EEC, which, as Wodak stated, "sailed close to the shore of meddling in our most internal affairs." ${ }^{31}$ The article had depicted Austria as being again on the brink of 1938, and portrayed West German and EEC leaders as apostles of Adolf Hitler. Since Soviet

${ }^{126}$ For the text of Klaus' governmental speech, which indeed did not mention the state treaty but stressed neutrality, see Gottschlich, Was die Kanzler sagten, 171-181.

127 Moser, "Die Stellung der Kommunistischen Partei Österreichs," 48.

${ }^{128}$ Nikolaj Poljanow, "Europa, die Politik der Neutralität und Österreich," in Österreichische Zeitschrift für Außenpolitik 6 (1966), 443-451.

${ }_{129}$ Conversation Demichev with Klaus, 10 June 1966, in AVPRF, 66/45/95/11, 8-9; Austrian embassy Moscow to Austrian MFA, 22 June 1966, in ÖStA, AdR, BMAA, Pol. Berichte Moskau, 843-846.

130 Austrian embassy Moscow to Austrian MFA, 22 September 1966, in ÖStA, AdR, BMAA, Pol. Berichte Moskau, 915-917.

131 Austrian embassy Moscow to Austrian MFA, 8 November 1966, in ÖStA, AdR, BMAA, Pol. Berichte Moskau, 958-960. 
soldiers had spilled their blood on Austrian soil in 1945, the article claimed the right for the USSR to have a say in Austria's future.

The program for the Soviet state visit to Vienna from 14 to 21 November 1966, which was Podgorny's first journey to the West as head of state, reflected the wish of both sides to overcome these political burdens and to repeat the success of Khrushchev's trip in 1960. A tour through the country included a visit to the house where Mozart was born and meetings with factory workers at the VÖEST steel plants. The guest's wife, Natal'ia Podgornaia was presented an Alpine Dirndl and invited by the chancellor to a dance during an evening visit to his native province Salzburg. ${ }^{132}$ On many occasions neutrality was praised by Podgorny as a contribution to peace; the president repeated the well-known Soviet thesis that the neutrals were in the favorable position of not having to spend money on self-defense. He also expressed his satisfaction with the positive development of bilateral relations, the friendly personal contacts between the political leaders of the two countries, and the tradition of discussing all questions "in the spirit of a good neighborhood, mutual understanding and equal rights." ${ }^{133}$ Regarding Austria's rapprochement with the EEC, the Soviet position was repeated that "an arrangement in any form" other than a bilateral treaty on tariffs and trade would mean a violation of the state treaty and neutrality. The explicit mentioning of such a treaty between Austria and the EEC itself (and not its member-states) seems to have been Podgorny's blunder. Both the Soviet delegation and the embassy later disclaimed the suggestion and tried to leave the impression that the president had spoken about treaties between Austria and the EEC countries. ${ }^{134}$

If Austria suffered from discrimination from the Common Market or the ECSC, it should, Podgorny recommended, join the Soviet struggle against closed blocs. Podgorny also repeated the suggestion that Austria should recognize the GDR and support the Soviet project of an all-European conference on security. Furthermore, the Soviet president brought the Austrian government under pressure by calling upon all neutral states to condemn the US policy in Vietnam. Similar demands had

132 Sowjetunion heute 12, no. 49 (1966), 2-7.

133 Conversation Klaus with Pogorny, 15 November 1966, in ÖStA, AdR, BMAA, II-Pol, GZ. 49.225-6/66, Z. 49.860-6/66. Cf. Gehler, Der lange Weg: Darstellung, 243-245; Österreichische Zeitschrift für Außenpolitik 6 (1966), 473-486.

134 Austrian MFA to all heads of mission, 25 November 1966, in ÖStA, AdR, BMAA, GZ. 461416/66, Z. 49720-6/66. In an article, Kreisky mentioned that in 1962 Khrushchev had explicitly stated that the USSR was ready to sign a trade agreement with the EEC. Bruno Kreisky, "Der Podgornybesuch und die EWG-Frage," in Neue Zeit, 18 November 1966. However, in 1966 this was no longer an option. Mueller, "The UdSSR und die europäische Integration," 639-641. When Ambassador Wodak, in a conversation with Vladimir Semenov in 1970, reminded the Soviet viceminister for foreign affairs of Podgorny's statement, Semenov claimed that the Austrian protocol of the Soviet president's conversation "obviously does not conform to ours." Wodak to Waldheim, 10 April 1970, in ÖStA, AdR, BMAA, II-Pol, GZ. 80916-6/70, Z. 85182. 
been communicated to other West European delegations in Moscow. ${ }^{135}$ After tough negotiations, no reference was made to the EEC in the communiqué; ${ }^{136}$ the issue was hinted at only in the mention of "open" talks. In addition, neutrality and the "mutually beneficial" development of bilateral trade were praised and the Vietnam War deplored. ${ }^{137}$

Podgorny's adherence to the well-known Soviet stance regarding Austria's policy vis-à-vis the EEC mirrored Moscow's internal assessment. A report of the Soviet Foreign Ministry, which had been prepared a few weeks before the state visit, acknowledged that the Austrian plans were motivated by the fact that "Austria, in the area of foreign trade, is closely linked to the countries of the Common Market, especially West Germany." " 138 However, negotiations had gotten stuck because the EEC allegedly demanded "nothing less than Austria's de-facto giving up neutrality." Neither within the Common Market, where France was against strengthening the "German position," nor in the Austrian government was there a consensus about how to solve the problem. With regard to Soviet-Austrian relations, the report acknowledged that

"the Austrian government tries not to spoil its relations to the Soviet Union with its association with the Common Market. It makes great efforts not to give any pretext for charging Austria, from the Soviet side, with violating the state treaty or abandoning neutrality, and it takes pains not to demote the economic relations to the Soviet Union and the other socialist countries." 139

The Soviet position should therefore be understanding, but firm. Furthermore, the report pointed out that

"the difficult political situation resulting from Austria's intention to associate with the Common Market creates certain opportunities, in the future, for the Soviet Union to exert influence on the Austrian government and to strengthen the position of those Austrian circles that stand for the strict observation of the state treaty and of neutrality and that disapprove of Austria's association with the Common Market." 140

Access to Soviet documents on this subject is still too insufficient for an exhaustive delineation of all internal shifts in the Kremlin's attitude towards the Austrian aspirations to become an associate of the EEC. However, there are indications that within the Soviet apparatus, various opinions started to emerge. In addition to the groups that rejected the idea entirely and those that were "understanding, but firmly against" it, there were, as the communist secretary of the Austrian-Soviet Society,

135 Bonwetsch, "Sowjetische Westeuropapolitik II," 155.

136 Austrian MFA to all heads of mission, 26 November 1966, in ÖStA, AdR, BMAA, II-Pol, GZ. 46141-6/66, Z. 49028-6/66.

137 Mayrzedt and Hummer, 20 Jahre Österreichische Neutralitäts- und Europapolitik 2, 144-145; Vneshniaia politika Sovetskogo Soiuza i mezhdunarodnye otnosheniia 1966 (Moscow: Mezhdunarodnye otnosheniia, 1967), 293-297.

${ }^{138}$ Obshchii rynok i Avstriia, [26 September 1966], in AVPRF, 66/45/96/20, 31-37.

139 Ibid.

${ }^{140}$ Obshchii rynok i Avstriia, [26 September 1966], in AVPRF, 66/45/96/20, 31-37. 
Martin Grünberg, stated in a conversation with the Austrian ambassador, also Soviet officials who thought "that they had to take into account our economic necessities if we [i.e. the Austrians] were ready to respect their [i.e. the Soviets'] political concerns." 141 These officials were interested in the progress of the negotiations between Austria and the EEC and their consequences on Austrian-Soviet trade.

It is very likely that the Austrian chancellor was informed of Grünberg's assessment, because he tried to address this alleged Soviet demand for respect of "their political concerns." However, the dismissive attitude with regard to the EEC remained the Soviet mantra during Klaus' visit to Moscow, Leningrad, Lipetsk, Tbilisi, and Kiev from 14 to 21 March 1967. Prior to the visit, Soviet officials had signaled to the Austrian embassy that the decision to receive Klaus in Moscow was a sort of Soviet "advance"; within the Kremlin and the Foreign Ministry there had been significant resistance to the chancellor's visit and serious doubts about his loyalty, i.e. responsiveness to Soviet wishes. ${ }^{142}$ According to Ambassador Wodak, the Soviet side would not put the EEC issue on the agenda unless the Austrian side proposed discussing it. Instead, concrete steps should be made regarding an agreement on cultural exchange as well as the building of a Soviet pipeline to Western Europe.

In order to prepare the visit, the Kremlin had activated a back channel and commissioned political analyst Mikhail Voslenskii to convey to the Austrian ambassador that the Soviet side wished to preserve its good relations with Austria and therefore recommended not proceeding with the rapprochement with the EEC. ${ }^{143}$ An agreement on tariffs and trade was the maximum the USSR would be ready to tolerate. Even earlier, Voslenskii had pointed out that Moscow was not convinced of the Austrian motives for concluding a special arrangement with the EEC and encouraged the Austrian chancellor to send out a memorandum on the topic. ${ }^{144}$ In order to promote the Austrian point of view, the chancellor handed over such an unofficial memorandum on the subject to Soviet ambassador Boris Podtserob, a month before his departure to Moscow. ${ }^{145}$

While it was obviously the aim of the memorandum to convince its readers of the economic necessity for Austria to associate with the Common Market, it did not have the wanted effect on the Soviet Foreign Ministry experts. In its evaluation of the paper, the Institute for World Economy and International Relations

${ }^{141}$ Austrian embassy Moscow to Austrian MFA, 20 February 1967, in ÖStA, AdR, BMAA, II-Pol, GZ. 14838-6/67, Z. 16543-6/67.

${ }^{142}$ Memorandum Wodak, Austrian embassy Moscow to Austrian MFA, 4 February 1967, Copy, in ÖStA, AVA, NL E/1736 Bielka, File 115

${ }_{143}$ Wodak to Austrian MFA, 2 March 1967, in ÖStA, AdR, BMAA, II-Pol, Pol. Berichte Moskau.

144 Austrian embassy Moscow, 11 November 1966, Copy, in ÖStA, AVA, NL E/1736 Bielka, File 115.

145 Blatov to Semenov, 23 February 1967, in AVPRF, 66/46/99/16, 5; Russian translation ibid., 66/46/99/20, 4-38. On Podtserob, an experienced diplomat who had served in 1949-52 and 1957-65 as general secretary of the Soviet MFA, see SSSR $i$ Germanskii vopros 1, 750. 
of the Soviet Academy of Sciences criticized the Austrian essay, stating that "in order to demonstrate that an associative status is based only on economic aims, [it] does not deal with the state treaty, neutrality, and political consequences." 146 With regard to foreign trade, in the eyes of the Soviet experts the Austrians gave undue importance to the neutral's discrimination by the EEC and did not pay the necessary attention to the structural problems of the Austrian economy, which included a disproportionately high percentage of heavy industry and the production of semi-finished goods, insufficient research and capital formation, falling productivity, and, consequently, sinking competitiveness in relation to the EEC. Austria, the Soviet experts stated, wanted to become an associate for economic reasons; however, it should solve its problems through internal reforms that increased competitiveness, rather than by entering the Common Market. This would boost imports of capital and make Austrian exports easier, but at the same time increase competition on the domestic market. From a political point of view, the Soviet experts predicted, any type of association with the EEC would, as in the case of Greece and Turkey [sic], after a certain period of time lead to full membership. This would be intolerable for Austria and have "negative consequences for the Soviet Union." Concerning further action, the experts suggested a "new serious explanation" of the Soviet standpoint towards the Austrian government, Soviet proposals for what form of cooperation between Austria and the EEC would acceptable for the USSR, and an increase in Austrian trade with CMEA countries (Council of Mutual Economic Assistance). In order to allow Austria to step up its exports to the Soviet Union within the framework of the trade agreements and their stipulated trade balance, Moscow, having reached its limits in the export of raw materials, should offer helicopters, trucks, and technical goods such as teletypewriters and television sets.

Following these recommendations, the Soviet hosts of Chancellor Klaus, including Advisor Mikhail Voslenskii, tried to explain to their Austrian guest and his foreign minister, Lujo Tončić-Sorinj, that any sort of Austrian participation in the Economic Community would mean a violation of the state treaty. The chancellor, in a speech at the Soviet Academy of Sciences entitled "Neutrality - Austria's New Political Way," 147 again attempted to convince his hosts that the Common Market was, as explicitly stated by Khrushchev in $1962,{ }^{148}$ a "reality" that Austria had to deal with. Neutrality, Klaus stressed, was not to be understood as an obligation to ideological neutralism; Austria had never hidden that it belonged to the Western democratic and economic model, and it had even joined the Council of Europe. The chancellor did not attempt to cover up the difference between the Soviet and Western understandings of neutrality; he reserved the right to define Austria's neutral

\footnotetext{
146 IMEMO to Semenov, 10 March 1967, in AVPRF, 66/46/99/20, 39-91.

${ }^{147}$ For the text and further documents, see Österreichische Zeitschrift für Außenpolitik 7 (1967), $165-176$.

148 Mueller, "Die UdSSR und die europäische Integration," 636.
} 
policy and repeated the plea to allow Austria to acquire the necessary weapons ${ }^{149}$ to defend itself. In an attempt to calm down Soviet worries, Klaus, who was briefly received by Brezhnev ${ }^{150}$ and later given the opportunity to address the Soviet people in a televised speech, underlined that the Austrian government understood Moscow's concerns "very well," that it would not deal irresponsibly with neutrality, and that the final result of the talks between Austria and Brussels would not be "at variance with the status of permanent neutrality."151

However, the USSR remained adamant, only tolerating a trade agreement or a free-trade area between Austria and the Common Market. ${ }^{152}$ Despite this, Podgorny encouraged the chancellor to continue the "open and objective exchange of opinions concerning questions of the further development of the amicable relations between the USSR and neutral Austria." 153 In addition, the Soviets made attempts to encourage Austria to launch an initiative for an all-European conference on security. ${ }^{154}$

The Klaus visit demonstrated the clash of two opposing concepts of neutrality. ${ }^{155}$ The Austrian chancellor had traveled to the Soviet capital in order to achieve Soviet acquiescence to a special arrangement between Austria and the EEC and a less strict interpretation of article 13 of the state treaty, which banned the possession and use of missiles, even for defensive purposes. Neither wish ran counter to the Western understanding of permanent neutrality. On the other side, the Soviet Union wanted Austria to promote the Soviet project of an all-European conference, which was, by then, suspected by many in the West to be a sinister move to undermine NATO. While advancing such a conference was exactly what the Soviet side wanted the guest to do, Klaus felt that launching such a call was inappropriate for a permanent neutral. In the end, the wishes of neither side were fulfilled and the differences remained unreconciled.

In the communiqué, which mirrored the differences in the Soviet and Austrian interpretations of neutrality, "friendship," "cooperation," and the "open exchange of views consolidating [...] the mutual understanding" were again extolled; the bilateral rejection of "economic discrimination" hinted at Austria's EEC aspira-

${ }^{149}$ For a discussion of defense issues, see pages 181-184.

${ }^{150}$ Lujo Tončić-Sorinj, Erfüllte Träume: Kroatien - Österreich - Europa (Vienna: Amathea, 1982), 381.

151 Josef Klaus, Neutralität, der neue politische Weg Österreichs, 16 March 1967, in AVPRF 66/46/99/16, 33-40. Cf. Reinhard Meier-Walser, Die Außenpolitik der monocoloren Regierung Klaus in Österreich 1966-1970 (Munich: Tuduv, 1988), 303-304. For Klaus' conversation with Kosygin, see ÖIZG, NL 72: Fuchs, DO 837, File 68.

152 Gehler, Der lange Weg: Darstellung, 245, 255.

${ }_{153}$ Conversation N.V. Podgorny with Josef Klaus, 14 March 1967, in AVPRF, 66/46/99/16, 19-20.

154 See below, page 164.

${ }^{155}$ Konrad Ginther, "Austria's Policy of Neutrality and the Soviet Union," in George Ginsburgs and Alvin Z. Rubinstein (eds.), Soviet Foreign Policy Toward Western Europe (New York: Praeger, 1978), 66-85, 74. 
tions. ${ }^{156}$ In a rather unusual move, the Soviet government, shortly after Klaus' departure, published an unsigned Izvestiia editorial declaring that "the development of the amicable relations between the Soviet Union and Austria is an important and positive aspect of international life" and "proof for the validity of the principles of peaceful coexistence between countries of different social systems." 157

Klaus, who was fascinated by Russia and started to learn its language, demonstrated his gratitude and goodwill towards the Kremlin by intensive travel activities in Eastern Europe, including a trip to Hungary in May, to Romania in July, and to Bulgaria in October. The chancellor even spent his two-week holidays in August on a leisure cruise down the Danube in Eastern Europe, for which he was criticized by social democratic circles of "political lopsidedness." ${ }^{58}$ Nevertheless, two articles on 26 September and 27 October in the weekly Novoe vremia warning of the danger of a "cold Anschluss" of Austria to the EEC signalized that Moscow still remained vigilant.

The EEC issue and Soviet encouragement for convoking the CSCE, 1967-1972

As usual at that time, a considerable share of the Soviet-Austrian talks during the Klaus visit was devoted to the Soviet concept of an all-European conference on security. The roots of this concept dated back to the Berlin conference of 1954, when Moscow had proposed replacing NATO with an all-European security system that included the USSR but assigned the United States merely observer status. ${ }^{159}$ Since then, proposals for a security conference or security system were periodically relaunched in various Soviet attempts to gain legal blessings for the postwar order, including the borders of Eastern Europe and East Germany, to foster détente in the West and weaken the cohesion of NATO and the EEC.

From 1955 it had been part of the Kremlin's patronizing attitude towards Austria to encourage the neutral country to take the initiative in the international arena and to support Soviet proposals for disarmament and security conferences. Communist

${ }^{156}$ Gemeinsames Kommuniqué anlässlich des offiziellen Besuches des Bundeskanzlers in der Sowjetunion, 21 March 1967, in Mayrzedt and Hummer, 20 Jahre österreichische Neutralitäts- und Europapolitik 2, 145-146.

157 Austrian embassy Moscow to Austrian MFA, 23 March 1967, in ÖStA, AdR, BMAA, II-Pol, GZ. 14838-6/67, Z. 18477-6/67; ibid., GZ. 14838-6/67, Z. 19786-6/67. Cf. Izvestiia, 23 March 1967; "Gutes Beispiel der Zusammenarbeit," in Sowjetunion heute 13, no. 10 (1967), 2, 26.

158 Meier-Walser, Die Außenpolitik, 466; Österreichisches Jahrbuch (1967), 236-239. On Klaus' relations to the USSR, cf. Meier-Walser, Die Außenpolitik, 295-300; on his Ostpolitik ibid., 345-349; Michael Gehler and Günter Bischof, “Austrian Foreign Policy after World War II," in Günter Bischof, Michael Gehler, and Anton Pelinka (eds.), Austrian Foreign Policy in Historical Context, Contemporary Austrian Studies 14 (New Brunswick: Transaction, 2006), 1-24, 6.

159 Proposal of the Soviet delegation on ensuring European security, 10 February 1954, in Foreign Relations of the United States, 1952-1954, VII: Germany and Austria 1 (Washington, DC: Government Printing Office, 1986), 1189-1192. 
propaganda had cited "voices from Austria" who demanded that Vienna take the lead in promoting the Soviet ideas; such behavior was depicted as consistent both with the neutral's international obligations and geographic position. ${ }^{160}$ In 1958, in reply to the Bulganin notes, Austria had agreed in principle to back the Soviet proposal launched a month earlier for an all-European summit on security, albeit under the condition of the summit being "well prepared." ${ }^{161}$ However, since the Western attitude towards the Soviet proposal was rather lukewarm, the Austrian government was reluctant to go out on a limb and become a spokesperson for the initiative.

Nevertheless, in the following years, particularly after the change in power from Khrushchev to Brezhnev, the Soviet advances towards the neutral countries concerning this matter were intensified. In the Warsaw Treaty Organization's Bucharest declaration of July 1966, the neutrals were assured that they "could play a positive role" in the convocation of an all-European summit ${ }^{162}$ and in November of the same year Podgorny expressed his hope for the neutrals' support, particularly from Austria. Some weeks earlier, the Soviet Foreign Ministry had recommended, in an above-cited internal document, to make use of the "opportunity" created by Austria's European ambitions "to exert influence over the Austrian government."163 During his visit to Vienna in 1966, the Soviet president declared that the USSR welcomed any initiative from the Austrian side that would lead to such a conference, as well as the active participation of all the neutral countries. ${ }^{164}$ The Soviet insistence on an initiative from the Austrian side was quite remarkable as Finland showed much more willingness to support the plan. However, this was not to the Soviet liking because in the 1960s, Austria's neutrality seemed to be better accepted in the West than that of Finland.

A large number of Soviet statements criticizing Austria's attempts to be part of the EEC, such as an article in Izvestiia on 16 June 1966, actually linked the two issues and demanded that the neutral country rather engage in more "peaceful" activities, as for instance in instigating an all-European conference on security. ${ }^{165}$ Similar demands were published in the above-mentioned article by Nikolai Polian-

${ }_{160}$ Pravda, 15 May 1957.

${ }^{161}$ Zhiriakov, Sovetskii Soiuz - Avstriia, 42-46; Erklärung des Bundeskanzlers J. Raab über die Österreichische Antwortnote auf die Note der sowjetischen Regierung vom 10.12.1957 im Nationalrat, 22 January 1958, in Mayrzedt and Hummer, 20 Jahre Österreichische Neutralitäts- und Integrationspolitik 2, 230-232.

${ }^{162}$ Memorandum of the members of the Warsaw Pact, 6 July 1966, in Friedrich-Karl Schramm, Wolfram-Georg Riggert, and Alois Friedel (eds.), Sicherheitskonferenz in Europa: Dokumentation 1954-1972: Die Bemühungen um Entspannung und Annäherung im politischen, militärischen, wirtschaftlichen, wissenschaftlich-technologischen und kulturellen Bereich (Frankfurt am Main: Metzner, 1972), 425-435, 434.

163 Obshchii rynok i Avstriia, [26 September 1966], in AVPRF, 66/45/96/20, 31-37.

${ }^{164}$ Conversation with the Soviet president, 15 November 1966, in ÖStA, AdR, BMAA, II-Pol, GZ. 49225-6/66, Z. 49860-6/66.

165 Petersson, The Soviet Union and Peacetime Neutrality, 82-89; Pravda, 26 October 1970. 
ov in the Österreichische Zeitschrift für Außenpolitik ${ }^{166}$ shortly before the Soviet president's visit to Austria. Throughout the following months, the Soviet media campaign encouraging Austria to give up its European ambitions and to launch an initiative for a European security conference instead continued. With such pressure from the Soviets, it became an ever more viable option for Austria to try to balance its strivings towards the EEC by offering the USSR its help in the conference issue. ${ }^{167}$ During Podgorny's visit to Vienna in November 1966, both sides agreed that a "well prepared" summit on European security would have a favorable influence on the global situation. ${ }^{168}$ Austria, which in Soviet declarations had repeatedly been singled out for the role it could play in an all-European security system, ${ }^{169}$ thus became the first Western country to endorse the proposal in a joint communiqué with the USSR. ${ }^{170}$ Similar endorsements had been made earlier on the occasion of Polish-Swedish and Soviet-Finnish meetings in June; further endorsement by Italy and Britain followed during Soviet visits to these two countries in early $1967 .{ }^{171}$ During Klaus' visit to Moscow in March, Kosygin again underlined that, in the Soviet understanding, neutrality not only provided an opportunity for an "active peace policy," but even made such a policy obligatory. The Soviet prime minister continued to argue strongly in favor of an Austrian initiative for an all-European conference on security. ${ }^{172}$ Klaus, who at first had tried to beat the Soviets at their own game by stating that Austria had no opinions concerning this question because that would be in violation of Austria's neutrality, conceded. ${ }^{173}$

After this agreement was reached, the Soviet interest in more substantial Austrian contributions to Soviet initiatives, particularly the all-European conference, increased, as Martin Grünberg reported in early 1967. ${ }^{174}$ It became clear that Moscow would have welcomed an Austrian decision to launch a call for the summit. The European communist parties' Karlovy Vary declaration of 26 April stated that, in preparing the conference, much depended upon a "more active peace policy" of the

166 Poljanow, "Europa, die Politik der Neutralität und Österreich," 445-447.

167 Thomas Fischer, "Die Sowjetunion, Österreich, und die finnische KSZE-Initiative vom 5. Mai 1969," in Wolfgang Mueller and Michael Portmann (eds.), Osteuropa vom Weltkrieg zur Wende (Vienna: Verlag der Österreichischen Akademie der Wissenschaften, 2007), 313-340, 324-329.

168 Kommuniqué, 22 November 1966, in UdSSR - Österreich, 118-121, 119.

169 Austrian embassy Moscow to Austrian MFA, 22 June 1966, in ÖStA, AdR, BMAA, II-Pol, Pol. Berichte Moskau, 843-846.

${ }^{170}$ Otmar Höll, "The Foreign Policy of the Kreisky Era," in Günter Bischof and Anton Pelinka (eds.), The Kreisky Era in Austria. Contemporary Austrian Studies 2 (New Brunswick: Transaction, 1994), 32-71, 41.

171 Schalhorn, "Sowjetische Westeuropapolitik I," 121. The Soviet-Italian communiqué in Schramm, Riggert, Friedel, Sicherheitskonferenz in Europa, 45-46.

172 Ginther, Neutralität und Neutralitätspolitik, 55.

173 Zhiriakov, Sovetskii Soiuz - Avstriia, 50.

174 Austrian embassy Moscow to Austrian MFA, 20 February 1967, in ÖStA, AdR, BMAA, II-Pol, GZ. 14838-6/67, Z. 16543-6/67. 
neutrals; ${ }^{175}$ in his speech in the Czech spa, Brezhnev made this appeal even more explicit by encouraging the neutrals to offer their "good services" to the cause. ${ }^{176}$ Keeping in mind the imminent expiration of the NATO Treaty in 1969, the Soviet leader also used the opportunity to call upon the European member states of the Western alliance to reconsider their options; he declared that "for a number of [NATO] countries, in particular in Europe's north, neutrality might be an alternative to participation in military-political groupings." In order to make the communist invitation more tempting, the Karlovy Vary declaration tried to bait the neutrals with the offer of including an official "recognition of the principle of neutrality and of unconditional respect for the inviolability of neutral states" into the conference agenda. The Soviet intentions behind this demand seemed to be clear: Since the communist proposal obviously had little chance of being accepted by the West if it came directly from the Warsaw Pact, the neutrals should step in and promote the idea. While Sweden and Switzerland were traditionally less susceptible to Soviet pressure, the weaker neutrals Austria and Finland were regarded as more likely to fulfill Brezhnev's wishes. However, with the prestige of Finnish neutrality in decline both in the East and the West, Austria remained the favorite addressee for the Soviet demand.

It did not take long for a more explicit Soviet invitation for Austria to be issued: In an article commemorating the signing of the state treaty in May, Pravda repeated that "in our times, much depends upon the role of the neutrals." Novosti underlined their role and, alluding to the question at hand, stated that "every state has to decide whether it wants to strengthen cooperation [i.e., the conference project] or closed blocks [i.e., the EEC]." ${ }^{177}$ In his correspondence with Klaus, Kosygin hinted that the Soviet Union might be ready to fulfill the Austrian chancellor's wish and support Austria's candidature for hosting the United Nation's nuclear research center CERN; however, the Soviet premier coupled this information with further praise for the Soviet idea of an all-European system of security being created and statements that this should be promoted by the neutral. ${ }^{178}$

In addition to inspiring Austria to initiate an all-European conference, Soviet diplomacy aimed at inducing the neutrals to recognize the GDR. Already in 1959, Khrushchev had charged Austria with violating the principles of neutrality by main-

175 Erklärung der Konferenz der kommunistischen und Arbeiterparteien Europas in Karlovy Vary, [26 April 1967,] in Für den Frieden und die Sicherheit in Europa: Konferenz der kommunistischen und Arbeiterparteien Europas zu Fragen der europäischen Sicherheit, Karlovy Vary, 24. bis 26. April 1967 (Berlin: Dietz, 1967), 12-23, 18. Cf. Hans-Adolph Jacobsen, Wolfgang Mallmann, and Christian Meier (eds.), Sicherheit und Zusammenarbeit in Europa (KSZE): Analyse und Dokumentation II/1 (Cologne: Wissenschaft und Politik, 1973), 90-93, 91.

176 Rede des Leiters der Delegation der Kommunistischen Partei der Sowjetunion, Leonid Iljitsch Breshnew, in Für den Frieden und die Sicherheit in Europa, 77-101, 91-92.

177 ÖStA, AdR, BMAA, II-Pol, GZ. 14838-6/67, Z. 19786-6/67.

178 Kosygin to Klaus, 18 November 1967, Copy, in ÖStA, AdR, BMAA, II-Pol, GZ. 110732-6a/71, Z.120.003; Klaus to Kosygin, 8 August 1967, Copy, ibid. 
taining diplomatic relations with West Germany while not recognizing the East German Republic. Foreign Minister Kreisky had apologized by referring to the Hallstein Doctrine of powerful West Germany. ${ }^{179}$ In the 1960s, together with growing pressure for an all-European conference, the Soviet appeals to become active in the recognition process of the GDR were intensified in numerous diplomatic conversations as well as during the Demichev and Podgorny visits to Austria. ${ }^{180}$ The Soviet argument ran that it would be easier for neutral states to extend their recognition to the GDR than for NATO members. ${ }^{181}$ Austria's "passivity" and "inconsequent position in the German question" were criticized by Soviet statements on many occasions. ${ }^{182}$ When the CSCE drew nearer, the Austrian government signaled support for an accession of both German states into the UN, support that was further encouraged by Soviet diplomacy. ${ }^{183}$ Nonetheless, Austria recognized East Germany only after the Bonn government had established diplomatic relations with the GDR. ${ }^{184}$

However, the background for all these Soviet attempts to influence Austria's policy soon changed fundamentally. In March 1967, after Klaus' return from Moscow, the Austrian Foreign Ministry had drawn the conclusion that the Soviet government, despite its negative official statements, might be prepared to accept an economic arrangement between Austria and the Common Market that guaranteed maximum economic benefits for Austria. ${ }^{185}$ The ministry therefore recommended that Austria continue negotiating with the EEC. Yet in June 1967, Italy, due to Ger-

${ }^{179}$ Conversation Khrushchev with Schärf and Kreisky, 13 October 1959, in ÖStA, AdR, BMAA, II-Pol, GZ. 236.711-pol/59, Z. 249.552-pol/59. For the full text of the conversation, see pages 298-300.

180 Conversation Pogorny with Klaus, 15 November 1966, in ÖStA, AdR, BMAA, II-Pol, GZ. 49.225-6/66, Z. 49.860-6/66. Similar conversations with the deputy head of the Third European Department of the Soviet Ministry, Lavrov, were reported in Haymerle to Kreisky, 25 September 1961, in ÖStA, AdR, BMAA, II-Pol, Pol. Berichte Moskau; and Karasek to Kreisky, 11 January 1962, ibid.

181 Austrian embassy Moscow to Austrian MFA, 17 May 1967, in ÖStA, AdR, BMAA, II-Pol, GZ. 13.847-6/67, Z. 21.951-6/67.

182 Zhiriakov, Sovetskii Soiuz - Avstriia, 47; Poljanow, "Europa, die Politik der Neutralität und Österreich," 448.

${ }^{183}$ Conversation Kirchschläger with Deputy Foreign Minister Semenov, 1 June 1971, in ÖStA, AdR, BMAA, II-Pol, GZ. 105.880-6/71, Z.112.831.

184 A monograph by Maximilian Graf on this topic is forthcoming. See also Maximilian Graf, "Austria and the GDR 1949-1972: Diplomatic and Political Contacts in the Period of Nonrecognition," in Arnold Suppan and Maximilian Graf (eds.) From the Austrian Empire to Communist East Central Europe (Vienna: Lit, 2010), 151-177.

185 „Gewisse Anzeichen [...] lassen die Vermutung zu, dass ungeachtet der offiziellen Stellungnahmen innerhalb der sowjetischen Führungsspitze möglicherweise Überlegungen in der Richtung angestellt werden, ob es nicht eine Formel geben könnte, die ermöglichen würde, den österreichischen wirtschaftlichen Wünschen bis zu jener nach sowjetischer Auffassung maximalen Grenze entgegenzukommen, die für Moskau noch politisch tragbar wäre." Besuch des Herrn Bundeskanzlers in der Sowjetunion: Konklusionen, 22 March 1967, in ÖStA, AVA, NL E/1736 Bielka, File 115. 
man-speaking South Tyrol's struggle for autonomy from Rome (which had been denounced by Radio Moscow as nationalist and condoning terrorist acts sponsored by West Germany [sic]), vetoed any further EEC negotiations with Austria. France, until then supportive of an Austrian association, but now, in light of promising developments in Soviet-French relations, ${ }^{186}$ suddenly also came to the conclusion that such an association would not be compatible with neutrality. During his visit to Austria in September 1967, French prime minister Georges Pompidou took up a suggestion that had recently been made by Podgorny, namely that Austria should conclude trade agreements with the EEC members instead of further striving for a special arrangement with the community. ${ }^{187}$ Due to this profound change in the West as well as the constant Soviet pressure, the Austrian government finally gave up its ambition of reaching such an arrangement with the EEC. Within the cabinet, the staunchest supporter of the EEC course, Vice-Chancellor Bock, resigned as did Tončić-Sorinj; EEC matters were transferred to the newly appointed foreign minister Kurt Waldheim, who in September 1968 ruled out any special arrangements with the EEC. ${ }^{188}$ After still another conversation on the topic with the adamant Kosygin, a frustrated Klaus acquiesced, stating that Austria would remain "rather poor, but neutral." 189

In the Soviet press, the reshuffle of the Austrian cabinet caused the usual signs of uneasiness. ${ }^{190}$ It took some time for Moscow to assess that the changes reflected the fading Austrian chances of renewing negotiations with the Common Market. Even though the Austrians received some encouragement by Pompidou, once he succeeded de Gaulle as president of the republic in 1968, their prospects remained dim. The Italian position was, if perhaps no longer entirely negative, at least unclear. The EEC's priorities favored the accession of the northern candidates Britain, Ireland, and Denmark over an Austrian association. In August 1969, the Soviet embassy in Vienna came to the conclusion that "despite all efforts by the Klaus administration, the Austrians have no real chance for renewing the talks with the Commission of the Common Market in the near future. It is unlikely that such negotiations can begin this year." 191

The failure of its European ambitions seems to have had a negative impact on Austria's readiness to support the Soviet all-European conference plan. Although

186 Newton, Russia, France, and the Idea of Europe, 75-77.

187 Gehler, Österreichs Außenpolitik, 334. Gehler suspects that this decision by France was not only influenced by internal considerations regarding the EEC, but also by the consideration that French support for an Austrian association with the EEC might strain de Gaulle's relations to Moscow. With regard to the French attitude as well as EEC doubts about Austria's association, Gehler furthermore concludes that these obstacles were much more significant for Austria than the constant Soviet criticism of the Austrian ambitions.

188 Ginther, "Austria's Policy of Neutrality and the Soviet Union,” 74.

189 Quoted in Ermacora, 20 Jahre österreichische Neutralität, 121.

190 Conversation Gromyko - Waldheim, 19 March 1968, in AVPRF, 66/47/101/11, 23.

191 Soviet embassy Vienna to Soviet MFA, 18 August 1969, in AVPRF, 66/48/104/19, 6-10. 
the CSCE became the main "nonbilateral" theme of Austrian-Soviet communiqués, Austria remained reluctant and no initiatives were made to call for the conference. During the visit of Waldheim to Moscow from 18 to 25 March 1968, Gromyko again harped on the role the neutrals could and should play in convening an allEuropean conference and, anonymously, criticized those politicians who verbally endorsed the project but did not take any actions to move it forward. ${ }^{192}$ The Austrian side did not want the communiqué to include the Soviet reference to inviting all "interested European states" (thus excluding the United States and Canada) to the summit, but Waldheim did not succeed in making this clear, which resulted in a grave gaffe. ${ }^{193}$ On the other hand, the Soviet wish that Austria follow the Swedish example and condemn alleged Israeli "provocations" in the Near East and the so-called US "aggression" in Vietnam did remain unfulfilled: ${ }^{194}$ The communiqué mentioned both sides" "concern" about the two hotbeds, but did not repeat Soviet propaganda slogans. When the Austrian minister made the mistake of mentioning the Austrian attitude towards the EEC, he, as the Soviet protocol of the conversation stated, was "told in strict terms" that the Soviet Union, for known reasons, remained dismissive about any plans of Austria entering the Common Market and would vigilantly monitor any measures that might damage Austria's independence and neutrality. ${ }^{195}$ In contrast, Waldheim's report in the Austrian cabinet depicted the Soviet criticism of Austria's EEC ambitions as "less dramatic than it had been earlier." 196 The reason was, as Waldheim guessed, that "they [the Soviet leaders] know that nothing can possibly happen any more" regarding an Austrian association. A month before Waldheim's visit, the Soviet press, in an article that the Austrian embassy considered "the most unfriendly in a long time," had criticized the Austrian striving to become an associate of the EEC. ${ }^{197}$

No reference was made to the EEC issue throughout Franz Jonas' stay in Moscow. ${ }^{198}$ During the visit from 20 to 25 May 1968, which was ennobled by the unexpected appearance of Leonid Brezhnev, Podgorny repeated to the Austrian presi-

192 Zapis' besed A.A. Gromyko s ministrom inostrannykh del Avstrii, 30 April 1968, in AVPRF, 66/47/101, 23-29. Cf. Conversation Waldheim with Gromyko, 19 March 1968, in ÖStA, AdR, BMAA, II-Pol, GZ. 110.044-6/68, Z. 115.353-6pol/68. For extracts of the protocol, see pages 328-330.

${ }^{193}$ Sprachregelung, 26 March 1968, in ÖStA, AdR, BMAA, II-Pol, GZ. 110.044-6/68, Z. 115.350$6 \mathrm{pol} / 68$.

${ }^{194} \mathrm{O}$ vizite v Sovetskii Soiuz ministra inostrannykh del Avstrii, 10 April 1968, in AVPRF, 66/47/101/11, 11-16; the communiqué is printed in UdSSR - Österreich, 134-136, 135; cf. the Russian text in Vneshniaia politika Sovetskogo Soiuza i mezhdunarodnye otnosheniia 1968 (Moscow: Mezhdunarodnye otnosheniia, 1969), 65-67.

${ }^{195}$ O vizite v Sovetskii Soiuz ministra inostrannykh del Avstrii, 10 April 1968, in AVPRF, 66/47/101/11, 11-16.

196 Verhandlungsniederschrift 77, 26 March 1968, in ÖStA, AdR, BKA, MRP.

197 Information, March 1968, in ÖStA, AdR, BMAA, II-Pol, GZ. 17.042-6/67, Z. 31.717-6/67.

${ }^{198}$ Haymerle, "Die Beziehungen zur Großmacht im Osten," 178. 
dent the Soviet call for an Austrian contribution to convening the CSCE, to forming an "initiative group" in the matter, and also for Austria's recognition of the GDR. ${ }^{199}$ Waldheim, who accompanied Jonas, had expected that he would have to defend his government against Soviet claims that they had verbally endorsed the conference project but remained inactive. Such charges had been published by the Soviet press, which criticized that Austria was not doing all it could to find a solution to the European problem. However, Gromyko, who rejected the Western idea to form a group of nine countries that would be charged with organizing the conference, refrained from pressing the issue too hard. ${ }^{200}$ Other East European leaders, such as Bulgaria's Todor Zhivkov, also encouraged Austria to launch an invitation. ${ }^{201}$ However, once the EEC application had failed, the USSR had lost one of its levers over Austria. ${ }^{202}$

Another neutral had to step in. In 1968, Finland, which of the European neutrals was traditionally the one most exposed to Soviet demands, had come under increased pressure. While the neutral had hitherto avoided recognizing either of the two Germanies, the USSR and the GDR demanded with growing insistence that the Finnish government recognize the East German state. With the waning power of West Germany's Hallstein Doctrine, the pressure on Helsinki to give in to Soviet demands grew. ${ }^{203} \mathrm{~A}$ further menace could be seen in the decreasing Soviet willingness to recognize Finland's neutrality, a change that had been noted since early 1968. In the official report to the Supreme Soviet on 27 June 1968, Finland was not counted among the neutrals when Gromyko praised the role of neutrality and the USSR's good relations with Austria, Sweden and Switzerland. ${ }^{204}$ During a bilateral visit in 1969, the Soviet side forestalled the hitherto traditional mentioning of Finnish neutrality in the communiqué. ${ }^{205}$ In 1970 President Kekkonen threatened to resign and thus managed to convince the Soviet leaders to again include the reference in a declaration. But this was to be the last such mention for many years.

${ }^{199}$ Conversation Podgorny with Jonas, 20 May 1968, in AVPRF, 66/47/101/11, 35-42. Cf. Verhandlungsniederschrift 85, 28 May 1968, in ÖStA, AdR, BKA, MRP; Communiqué, 25 May 1968, in Mayrzedt and Hummer, 20 Jahre Österreichische Neutralitäts- und Europapolitik 2, 148-149; Vneshniaia politika 1968, 110-112.

${ }^{200}$ Conversation Gromyko with Waldheim, 21 May 1968, in AVPRF, 66/47/101/11, 49-56.

${ }^{201}$ Gerhard Wettig, Europäische Sicherheit: Das europäische Staatensystem in der sowjetische Außenpolitik 1966-1972 (Düsseldorf: Bertelsmann, 1972), 94. On the occasion of Zhivkov's visit, Austria made up for Waldheim's mistake in Moscow of not insisting on the inclusion of the United States in a European conference. However, the Soviet press, in its reports on the Bulgarian-Austrian talks, again only referred to European states. Scarlis, Neutralität, 95-96.

${ }^{202}$ Fischer, "Die Sowjetunion, Österreich, und die finnische KSZE-Initiative," 329-330.

${ }^{203}$ Seppo Hentilä, Neutral zwischen den beiden deutschen Staaten: Finnland und Deutschland im Kalten Krieg (Berlin: BWV, 2006), 74-77, 89-92.

204 Vneshniaia politika 1968, 151.

${ }^{205}$ Kimmo Rentola, "Der Vorschlag einer europäischen Sicherheitskonferenz und die stille Krise zwischen Finnland und der Sowjetunion," in Dominik Geppert and Udo Wengst (eds.), Neutralität - Chance oder Chimäre? Konzepte des Dritten Weges für Deutschland und die Welt 19451990 (Munich: Oldenbourg, 2005), 177-202, 178-185. 
Until 1989 reference was only made to Finland's "striving for neutrality," and the so-called Paasikivi-Kekkonen Line of foreign policy was praised in Soviet statements. Although the Soviet reasons for downgrading Finland's neutrality are yet to be fully analyzed, it seems that in the wake of the "Prague Spring," the Kremlin was interested in limiting the attractiveness of neutrality in Eastern Europe. Hence, Finland was promoted by Soviet propaganda as a model for "friendship with the Soviet Union" rather than as a model for neutrality. Finland saw the writing on the wall, which was all the more threatening since from 1966 to 1971, the Soviet Union seemed to support what appeared to be a major, final attempt at gaining power by Finland's pro-communist People's Democratic League. ${ }^{206}$ Against this background it does not come as a surprise that the Warsaw Pact's invasion in Czechoslovakia in August 1968 created widespread fear in Finland; even the crafty Kekkonen felt his country might be the next on the list.

In this situation, the Finnish president decided to strengthen his country's prestige and independence vis-à-vis the USSR by following the Soviet proposal and calling for an all-European conference - without, however, assessing the chances very high that such a conference might actually come into being. ${ }^{207}$ It was only after Finland, in a declaration issued on 5 May 1969 to all European states plus the United States and Canada, proposed holding a CSCE and declared itself ready to host the conference ${ }^{208}$ that Austria reacted positively, submitting its own memorandum on 28 May. During talks with Soviet Foreign Ministry officials in December of the same year, their Austrian counterparts underlined their country's interest in the conference and insisted on meticulous preparations; it was announced that Austria was prepared to serve as a mediator during the conference, to which all "interested European states plus the US and Canada" were to be invited. ${ }^{209}$ Some weeks earlier, Vienna had hosted a conference of "representatives of the public on problems of security and cooperation in Europe," which had supported the Soviet project and was

${ }^{206}$ Heikki Larmola, "Finnland zwischen sowjetischem Versuchslabor und beginnendem KSZEProzess," in Stefan Karner et al. (eds.), Prager Frühling: Das internationale Krisenjahr 1968 (Vienna: Böhlau, 2008), 633-657, 638-639.

207 Thomas Fischer, “'A Mustard Seed Grew into a Bushy Tree': The Finnish CSCE Initiative of 5 May 1969," in Cold War History 9, no. 2 (2009), 177-201.

${ }^{208}$ Finnish memorandum, 5 May 1969, in Jacobsen, Mallmann, Meier, Sicherheit und Zusammenarbeit in Europa (KSZE) II/1, 128-129.

${ }^{209}$ Protokoll über die vom Generalsekretär für auswärtige Angelegenheiten Botschafter Dr. Platzer am 16. und 17. Dezember 1969 im sowjetischen Außenministerium geführten Gespräche, in ÖStA, AdR, BMAA, II-Pol, GZ. 152.678-6/69, Z. 168.408-6(pol)/69. The Austrian delegation used the opportunity for communicating the US standpoint as well, which pictured US and Canadian participation at the conference and a clear agenda that included troop reductions and the laying down of a set of principles concerning relations between sovereign states. With regard to the conference agenda, the Soviet side criticized the recent NATO proposal on arms control, troop reductions, and the German question as being "unclear," and called on Austria to support the Eastern draft. NATO proposals are published in Schramm, Riggert, Friedel, Sicherheitskonferenz in Europa, 104-108. 
highly publicized in communist propaganda. ${ }^{210}$ Furthermore, in a memorandum in July 1970 to all interested states (including the United States and Canada), Austria offered a meeting place for the conference and support for the Soviet bloc's twopoint agenda as well as for portions of the NATO proposal on mutual and balanced reductions of armed forces. ${ }^{211}$ In an earlier declaration, dated 22 June, of the Eastern foreign ministers, which had been forwarded to all interested states by Hungary, the Warsaw Treaty Organization had tabled the proposal to create a permanent body following the conference. ${ }^{212}$

In the meantime, French president Pompidou had withdrawn de Gaulle's veto against the British accession to the EEC and, in December 1969, the EEC had decided to restart negotiations with all EFTA members. As a result, Soviet warnings, despite having grown fewer in 1968, again began to intensify towards Austria and the other neutrals Sweden and Switzerland, which had decided to rejoin Austria in striving for some sort of EEC participation. Soviet propaganda against the Swedish leader Olof Palme was particularly vehement, as it long remained unclear whether Sweden was perhaps even aiming for full membership in the EEC, not merely a free-trade agreement. ${ }^{213}$ Communist propaganda castigated the Common Market as a basis for NATO and a branch of "West German imperialism," criticized the wavering of the neutrals, warned against their loss of sovereignty, and offered favorable bilateral trade agreements and an increase in EastWest trade as an alternative to the EEC-EFTA rapprochement. With regard to Austria, the Soviet voices referred to the Anschluss ban in the state treaty and the country's neutrality. On 26 October 1970, on the eve of the preparatory talks between the EEC and Austria, TASS declared that Austria's "accession to the EEC in whatsoever guise" would contradict the country's international obligations. In January 1971 Podgorny told Rudolf Kirchschläger, the new Austrian foreign minister, that the Soviet position was unchanged. He also repeated the argument that, since the EEC was not merely an economic organization, if Austria finalized an agreement with it, this could not but affect the country's neutrality. ${ }^{214}$ Due to such

210 Schalhorn, "Sowjetische Westeuropapolitik I," 128.

211 Austrian memorandum, 24 July 1970, in Österreichische Zeitschrift für Außenpolitik 10 (1970), 250-251. Cf. Jacobsen, Mallmann, Meier, Sicherheit und Zusammenarbeit in Europa (KSZE) II/1,234-236. The Austrian proposal made it clear that the reductions should apply to all forces in Europe, not only non-European ones. For the further Austrian contribution in the pre-conference stage, see Thomas Fischer, Neutral Power in the CSCE: The N+N States and the Making of the Helsinki Accords (Baden-Baden: Nomos, 2009), 120-128.

${ }^{212}$ Text in Jacobsen, Mallmann, Meier, Sicherheit und Zusammenarbeit in Europa (KSZE) II/1, 225 227.

213 Scarlis, Neutralität, 126-127, 132-143.

${ }^{214}$ Conversation Kirchschläger - Podgorny, 29 January 1971, in ÖStA, AdR, BMAA, II-Pol, GZ. 105.456-6/71, Z.108.141 Cf. Österreichische Zeitschrift für Außenpolitik 11 (1971), 50. The communiqué omitted the topic. Vneshniaia politika Sovetskogo Soiuza i mezhdunarodnye otnosheniia 1971 (Moscow: Mezhdunarodnye otnosheniia, 1972), 9-11. 
contentions and Kirchschläger's failure to attain Soviet consent regarding Austria's wish to buy defense missiles, the visit was considered a disappointment by the Austrian media. ${ }^{215}$

After EEC-Austrian talks were recommenced in November 1970, Soviet diplomats requested that their Austrian colleagues continue to inform the USSR about the negotiating progress. However, when Ambassador Wodak invited the Soviet side to feel free to ask whatever it deemed necessary, Deputy Foreign Minister Semenov responded that he did not wish to "meddle in [Austria's] domestic affairs." In addition, he confessed in a "confidential" aside, the Soviets had lost track of the twists and turns of Austria's integration into the EEC and "no longer knew what questions to ask, since they simply no longer understood the European Community issue and no one at the Soviet embassy in Vienna was able to formulate relevant questions." ${ }^{216}$

As it turned out, in the neutrals' negotiations with the EEC, only free-trade agreements with the EFTA members were in the cards and a special arrangement with Austria, as had been discussed prior to 1968, was out - a fact that was noted positively by Izvestiia on 1 December 1970. The agreements between EFTA member states and the EEC, which were signed on 22 July 1972, were, as the Soviet ambassador in Vienna Averkii Aristov stated afterwards, not considered a threat to neutrality nor to Soviet interests. ${ }^{217}$ In the meantime, Brezhnev had signaled, in a speech at the all-Union congress of the Soviet trade unions in March 1972, that the Soviet Union might be prepared to revise its hitherto negative attitude towards the EEC. The Soviet leader had been convinced to modify his stance in light of prospects for European détente, for smoothing the ratification of the Soviet-West German Moscow Treaty of 1970, and for realizing an all-European conference on security. ${ }^{218}$ During an audience with the Austrian ambassador in April, Brezhnev insisted that if the EFTA states concluded agreements with the EEC, Soviet economic interests in free trade must be safeguarded. ${ }^{219}$ In the case of Finland, the Soviet Union achieved several extra concessions: an extension of both the Soviet-Finnish Treaty and the term of President Kekkonen, the conclusion of an associative agreement with the CMEA, and the signing of bilateral free trade agreements with the

${ }^{215}$ Press survey, 8 February 1971, in ÖStA, AdR, BMAA, II-Pol, GZ. 105.456-6/71, Z.106.893.

216 Wodak to Kirchschläger, Streng Vertraulich, 2 June 1971, in ÖStA, AdR, BMAA, II-Pol, GZ. 105.880-6/71, Z.113.202.

217 Soviet embassy Vienna to Soviet MFA, 8 September 1972, in AVPRF, 66/51/110/12, 4-12. On Averkii B. Aristov, a politician who had been, in 1952-53 and 1957-61, a member of the CPSU Presidium before serving as Soviet ambassador, first in Warsaw and then from 1971 to 1975 in Vienna, see Fursenko, Prezidium 1, 1190.

${ }^{218}$ On the background of Brezhnev's decision, see Wolfgang Mueller, "Recognition in Return for Détente? Brezhnev, the EC, and the Moscow Treaty with West Germany, 1970-1973," in Journal of Cold War Studies (forthcoming).

219 Austrian embassy Moscow to Austrian MFA, 14 April 1972, in ÖStA, AdR, BMAA, II-Pol, GZ. 153.589-6/72, Z. 155.752. 
CMEA members. This delayed the Finnish agreement with the EEC, which was signed only in October 1973.220

When Austria's free trade agreement with the EEC was concluded, the Pravda report of 28 July 1972 displayed some modest misgivings. A month later, a Soviet aide-mémoire reminded the Austrian government of its duties resulting from the state treaty and neutrality. The document stressed the importance of a statement made by Chancellor Kreisky on the day of the signature of the free trade agreement, "that Austria takes this step in due consideration of its obligations as a neutral state." ${ }^{221}$ Furthermore Moscow expressed concerns that the Austrian free trade with the EEC might create discriminatory conditions for the Soviet Union on the Austrian market. In its response of 20 September, the Austrian government declared that the new agreements with the EEC and ECSC "cannot and shall not" in any way impede the fulfillment of the obligations resulting from the state treaty and neutrality. In order to reduce any negative side effects for the trade between Austria and the Soviet Union, both sides entered into negotiations on a new trade agreement, which was signed in May 1975 and granted the USSR most-favored nation status.

By this time, the CSCE had almost reached its conclusion. At the conference, many things had developed differently than the USSR had hoped. Soviet-Austrian relations had been affected as well. The Austrian memorandum of 24 July 1970, which was addressed to all European states as well as the United States plus Canada and supported the Finnish proposal for a CSCE, the Eastern agenda, as well as the Western calls for mutually balanced force reductions (MBFR) of all (not only "foreign") troops in Europe, had been received frostily in Moscow. Since the USSR did not favor MBFR, Pravda, on 26 October of the same year, called upon Austria to show "more activity" as well as "more independence" from the West. In contrast, Swiss contributions, which omitted the troop reduction issue, were welcomed by Soviet propaganda. ${ }^{22}$ When Kirchschläger traveled to Moscow in January 1971, Gromyko, Kosygin and Podgorny reproached him about the Austrian proposals, and in order to put further pressure on the Austrian minister, they struck up the old tune about "recognizing the GDR." 223 In addition, Gromyko and Kosygin stated that they considered Kreisky's proposal to put the Near East issue on the CSCE agenda "absolutely incomprehensible." ${ }^{224}$ The Soviet Union had no interest in tor-

220 Scarlis, Neutralität, 140-143.

221 Aide-mémoire der sowjetischen Regierung an die österreichische Regierung, 18 August 1972; Aide-mémoire der österreichischen Regierung an die sowjetische Regierung, 20 September 1972, in Europa-Archiv 27, no. 21 (1972), D 520-522. Cf. Gehler, Der lange Weg: Darstellung, 261262.

${ }_{222}$ Petersson, The Soviet Union and Peacetime Neutrality, 90; Scarlis, Neutralität, 97-100.

${ }^{223}$ Conversation Kirchschläger - Gromyko, 26 and 29 January 1971; Kirchschläger - Kosygin and Kirchschläger - Podgorny, 29 January 1971, in ÖStA, AdR, BMAA, II-Pol, GZ. 105.456-6/71, Z.106.503.

${ }^{224}$ See Kreisky's speech in the Consultative Assembly of the Council of Europe, 25 January 1971, in Jacobsen, Mallmann, Meier, Sicherheit und Zusammenarbeit in Europa (KSZE) II/1, 260-262, 262. 
pedoing the conference by including a major crisis into its program. Kirchschläger, who at that point in time had not even read Kreisky's idea, as he stated during the conversation, could only register the Soviet objection.

Despite earlier Soviet dissatisfaction with Austria's hesitation regarding the convocation of the CSCE, in 1972 Soviet propaganda about Austria took on a predominantly friendly tone. For the first time in many years, on the occasion of that year's state treaty anniversary celebrations, Pravda correspondent Boris Dubrovin, in his commentary "A Good Basis," neither criticized the country's EEC policy nor its inactivity regarding the CSCE. ${ }^{225}$ Nonetheless, as soon became apparent, the activities of Austria and the other neutrals at the CSCE were not much to the liking of the Soviet leadership.

${ }^{225}$ Austrian embassy Moscow to Austrian MFA, 15 May 1972, in ÖStA, AdR, BMAA, II-Pol, GZ., Z. $156.959-6 / 72$. 


\section{The Czechoslovakian Crisis of 1968 and Austria's Military Vulnerability}

After the failure of Austria's European ambitions in 1967, the generally friendly Soviet-Austrian relations as well as the signs for a general European détente became overshadowed by the Warsaw Treaty Organization's military intervention in Czechoslovakia in August 1968. In May of that year, Austrian president Jonas had told his Soviet colleague that the neutral country had watched the "Prague Spring" with empathy. ${ }^{1}$ When the Soviet crackdown on reformist Czechoslovakia started in the summer, the Austrian government was caught by surprise, although it had received warnings of an imminent Warsaw Pact action five weeks earlier. ${ }^{2}$

The Warsaw Pact's intervention and the Soviet reputation in Austria

Due to lengthy internal disputes on questions of authority, and in striking contrast to Klaus' public claim that "the federal government acted quickly" and that "all necessary measures have been taken," it took the cabinet a total of eight hours to have the marching order issued for the army, which was moreover ordered to stay twenty-five kilometers away from the border. Also in contrast to his later claims, the chancellor, in his first speech on 21 August, broadcast on the radio at 7 a.m., did not express any regret or sympathy with the victims nor did he judge or criticize the invasion; he barely mentioned "the events in Czechoslovakia." ${ }^{3}$ Although the federal government did not consider Austria threatened by a Soviet invasion, ${ }^{4}$ Foreign Minister Waldheim, who in contrast to Austria's behavior in 1956 ruled out any Austrian comments on the Warsaw Pact's invasion in its neighborhood save disapproval, was said to have deleted two passages from Klaus' speech that he considered too outspoken. ${ }^{5}$ The second speech by Klaus, which was televised, remained cautious - in opposition leader Kreisky's words, "obedient" and "appeasing." It adopted the terminology that no country should meddle in the "internal affairs of

\footnotetext{
${ }^{1}$ Conversation Podgorny with Jonas, 25 May 1968, in AVPRF, 66/47/101/11, 45-47.

${ }^{2}$ Eger, Krisen an Österreichs Grenzen, 104-107.

${ }^{3}$ Erklärungen des Bundeskanzlers Dr. Josef Klaus und des Staatssekretärs für Information Karl Pisa, 21-30 August 1968, in Österreichische Zeitschrift für Außenpolitik 8 (1968), 251-254.

${ }^{4}$ Gehler, Österreichs Außenpolitik, 341.

${ }^{5}$ Meier-Walser, Die Außenpolitik der monocoloren Regierung Klaus, 429, 432; Eger, Krisen an Österreichs Grenzen, 87-89.

${ }^{6}$ Quoted in Eger, Krisen an Österreichs Grenzen, 115. The text of Klaus' speech ibid., 195.
} 
other states." Whether this referred to Austria or the USSR was - on purpose or unwittingly - left open by Klaus. That the events of August 1968 did not constitute "internal affairs," but a violation of international law remained unsaid. In the meantime, other West European governments had already protested the Soviet invasion, which was denounced in a British memorandum of the same day as a "flagrant violation" of the Charter of the United Nations and of all commonly recognized norms of international law. ${ }^{7}$ Only in his third speech on the subject did Klaus mildly criticize the invasion as a "blow against détente policy," expressing regret about the damage that had been brought to the "peaceful cohabitation of peoples" and calling for respect for the rules of international law, the Charter of the United Nations and the rights of small countries. In addition to Klaus' desire to avoid being charged by the USSR with overstepping neutrality, this cautious approach has also been attributed to the Austrian wish to host the SALT talks in Vienna and therefore not to alienate the Soviet leadership. ${ }^{8}$

The Austrian government, in its "hesitant and maneuvering behavior" towards the Warsaw Pact, ${ }^{9}$ did not even go as far as the Austrian Communist Party, which in a spontaneous declaration by its Central Committee publicly condemned the invasion. ${ }^{10}$ The KPÖ was not brought in line by the Kremlin until some days later. The CPSU Politburo dispatched the Soviet ambassador in Vienna to inform the KPÖ leaders about the Soviet "surprise" at the Austrian comrades' support for the idea of the French communists to organize a conference of West European leftists to discuss the consequences of the Warsaw Pact's intervention in Prague. ${ }^{11}$ The crisis led to a rift within the KPÖ between apologists and critics of the intervention. Former party leader Ernst Fischer, who condemned the military action, was expelled from the party. ${ }^{12}$

The Austrian self-restraint was not honored by the Soviet Union. When Ambassador Podtserob, on 21 August at 12:30 p.m., met with Klaus to explain the operation, he assured the chancellor that the USSR did not intend to take any actions against Austria and that the Warsaw Pact's invasion would not harm Soviet relations with Austria. Nonetheless, he warned that "any [Austrian] greater military measure would be considered an unfriendly act, if not even a violation of

${ }^{7}$ Quoted in Bonwetsch, "Sowjetische Westeuropapolitik II," 158.

${ }^{8}$ Anselm Skuhra, "Austria and the New Cold War," in Bengt Sundelius (ed.), The Neutral Democracies in the New Cold War (Boulder: Westview, 1987), 117-147, 128.

${ }^{9}$ Gehler, Der lange Weg: Darstellung, 250.

${ }_{10}$ Österreichische Zeitschrift für Außenpolitik 8 (1968), 245-246.

${ }^{11}$ Politburo CPSU, protocol 104/3, 8 October 1968; Conversation Podtserob - Waldheim, 29 August 1968, in Stefan Karner, Natalja Tomilina, and Alexandr Tschubarjan (eds.), Der Prager Frühling: Dokumente (Vienna: Böhlau, 2008), 1331-1335.

12 Manfred Mugrauer, "Der Prager Frühling und die Parteikrise der KPÖ," in Stefan Karner et al. (eds.), Der Prager Frühling 1968: Das internationale Krisenjahr (Vienna: Böhlau, 2008), 10431061 . 
neutrality." ${ }^{13}$ Despite his reassurances, Soviet planes committed systematic and repeated reconnaissance flights into Austria's air space. On the evening of 21 August, Waldheim called Podtserob, warned that if the Soviet flights continued, the federal government would be forced to file a protest, and announced the reinforcement of Austrian garrisons near the border. The Soviet ambassador again expressed his regret about the Soviet intrusions. ${ }^{14}$ The violations were explained away as being due to technical problems - an explanation that lost its credibility after the flights continued for several days. After further Austrian semi-protests were communicated to Podtserob, ${ }^{15}$ on 23 August the Austrian ambassador was ordered to file a protest in Moscow, but he was not received until 26 August. ${ }^{16}$ Wodak was, then, again given Soviet reassurance that these violations would be discontinued. Nonetheless, Soviet flights over Austrian territory were still reported on 1 September. ${ }^{17}$

Instead of discontinuing these violations immediately, the Soviet side began to accuse Austria of disregarding its neutrality. As in 1956, but less intensely, Literaturnaia gazeta charged Austria with tolerating training centers for Western secret services and with smuggling Western soldiers and weapons into the Eastern bloc. After checking the information, Waldheim, in a conversation with Podtserob, ${ }^{18}$ rejected the allegations and Minister of Defense Georg Prader invited the Soviet military attaché to visit Austrian military facilities in order to assure him of the incorrectness of the Soviet claims. In Moscow, Ambassador Wodak insisted on an official correction. ${ }^{19}$ Both attempts were unsuccessful and the Soviet propaganda attacks intensified. Pravda on 27 September charged the Austrian media with conducting a "disinformation campaign," and on 1 October Radio Moscow attacked President Jonas, who had dared to criticize the Soviet intervention. As in 1956, the Soviet media campaign against Austria had several aims: warning the neutral against going too far in its empathy with the architects of the "Prague Spring," destroying the country's attractiveness for East Europeans, as well as externalizing

${ }^{13}$ Quoted in Lobova, "Die Außenpolitik Österreichs aus der Sicht der UdSSR,” 904. This threat was not mentioned in Podtserob's report of the meeting. Conversation Podtserob - Klaus, 21 August 1968, in Karner, Der Prager Frühling: Dokumente, 1293-1293.

${ }^{14}$ Österreichische Zeitschrift für Außenpolitik 8 (1968), 244. Cf. Conversation Podtserob - Waldheim, 21 August 1968, ibid., 1295-1297.

${ }_{15}$ Conversation Podtserob - Platzer, 23 August 1968, in Karner, Der Prager Frühling: Dokumente, 1301-1303.

${ }^{16}$ Bericht Waldheim an Ministerrat, 10 September 1968, in Eger, Krisen an Österreichs Grenzen, 213-216. On the basis of the Austrian cabinet protocols, see Maximilian Graf, "Internationale Reaktionen auf die Intervention der Warschauer-Pakt-Staaten in der ČSSR 1968" (MA Thesis, Vienna, 2008), 145-153.

${ }_{17}$ Meier-Walser, Die Außenpolitik der monocoloren Regierung Klaus, 428.

${ }^{18}$ Conversation Podtserob - Waldheim, 29 August 1968, in Karner, Der Prager Frühling: Dokumente, 1309.

19 Austrian embassy Moscow to Austrian MFA, 4 September 1968, in ÖStA, AdR, BMAA, II-Pol, GZ. 111298-6/68, Z. 127871-6pol/68. 
the responsibility for the events in the Eastern bloc and thus legitimizing Soviet behavior.

In the meantime the USSR had put pressure on the Austrian government to impose restrictions on media coverage of the Soviet intervention. On 29 August, Podtserob paid back Waldheim's rejection of Soviet allegations by criticizing the "unfriendly and nonobjective" character of Austrian media coverage, and two days later, the ambassador handed over a note protesting the "hostile conduct" of the Austrian television and press with regard to the USSR and other socialist countries. ${ }^{20}$ This type of conduct, the note claimed, would contradict Austria's neutral status. Furthermore, the USSR charged Austria with tolerating organizations on its soil that were providing "immediate help for counterrevolutionary forces in Czechoslovakia." All these factors, the note claimed, had "damaged Austria's foreign policy."

Klaus, who wanted to avoid giving the Soviet Union any pretext for such accusations, answered that the Austrian government was observing neutrality but that neither the public nor the media were bound by or obliged to neutrality. Nevertheless, he tried to influence the Austrian Broadcasting Corporation's (ORF) managing director Gerd Bacher and other representatives of the mass media to "soften" media coverage..$^{21}$ Even earlier, State Secretary Karl Pisa had caused an uproar among Austrian journalists by appealing to the media not to "dramatize" the events in Czechoslovakia. And in a conversation with the Soviet ambassador on 29 August, Waldheim had agreed that the freedom of the Austrian press was limited by obligations resulting from the state treaty. ${ }^{22}$

While the Austrian and, to some extent, the Soviet government tried to avoid damaging the bilateral relations, the Soviet reputation in the Austrian population seemed to have been badly harmed. The military intervention was condemned by the entire media, the opposition parties and the Federation of Trade Unions. Even the Austrian-Soviet Society communicated its "great consternation" to its Soviet "brother society" and stated that all its efforts "to explain, in decade-long activities, the foreign policy of the Soviet Union as a policy of peaceful coexistence, respect for the sovereignty of other states, and nonintervention in their internal affairs," activities that had achieved "a positive attitude" among the Austrian people, had been ruined and trust in the USSR was "deeply shaken." ${ }^{23}$ The general anger was

${ }^{20}$ Text of the Soviet note in Eger, Krisen an Österreichs Grenzen, 210-212. The Soviet protocol of the conversation, 31 August 1968, in Karner, Der Prager Frühling: Dokumente, 1313-1317.

${ }^{21}$ Berthold Molden, "Die 'Ost-West-Drehscheibe': Österreichs Medien im Kalten Krieg," in Manfried Rauchensteiner (ed.), Zwischen den Blöcken: NATO, Warschauer Pakt und Österreich (Vienna: Böhlau, 2010), 687-774, 724, 728.

22 Conversation Podtserob - Waldheim, 29 August 1968, in Karner, Der Prager Frühling: Dokumente, 1311. Cf. Peter Ruggenthaler, "Der Neutralität verpflichtet: die sowjetisch-österreichischen Beziehungen 1968," in Stefan Karner et al. (eds.), Der Prager Frühling 1968: Das internationale Krisenjahr (Vienna: Böhlau, 2008), 993-1006, 1001.

${ }^{23}$ Austrian-Soviet Society to Soviet-Austrian Society, 28 August 1968, in ÖStA, AdR, BMAA, IIPol, GZ. 110879-6/68, Z. 127319-6pol/68. 
demonstrated on 21 August, when the Soviet embassy in Vienna was attacked with a Molotov cocktail. ${ }^{24}$ According to an Austrian opinion poll, the likelihood of a Soviet invasion of Austria was, in September 1968, considered impossible by 21 percent, slightly possible by 29 percent, possible by 37 percent, and probable by 8 percent..$^{25}$

In contrast to the image of the Soviets (and of the Austrian government) held by ordinary Austrians, official relations quickly recovered. The Soviet minister for natural gas, Aleksei Kortunov, who traveled to Vienna in September to celebrate the start of gas deliveries to Austria, was officially received by Jonas, Klaus, and Waldheim, ${ }^{26}$ thus revealing Klaus' statement that the invasion would jeopardize détente to have been an empty threat. As Austrian leaders had made clear in a parliamentary session the same month, they were still interested in continuing to foster détente; in their eyes, only a relaxation in tensions would provide Austria greater room to maneuver. ${ }^{27}$ By receiving Kortunov, the Austrian government, as in 1957, again played the role of being the first Western country to make Soviet politicians respectable after a violation of international law. In December, a visit by the Soviet minister of trade, Nikolai Patolichev, followed. His September trip had been postponed by the USSR, although on 31 August, only ten days after the invasion, the Austrian government had confirmed its interest in soon receiving the Soviet guest. On the economic side, Austria's passivity in August was rewarded by an increase in Soviet oil deliveries from 500,000 tons to 750,000 tons per annum and with an invitation to an Austrian delegation including Minister of Trade Otto Mitterer and the president of the Austrian chamber of commerce, Rudolf Sallinger, and of the board of industrialists, Franz Josef Mayer-Gunthof. The visit of the president of the Austrian parliament, Alfred Maleta, from 10 to 18 March 1969, for which the Soviet side specially coined the expression "official friendship visit," was the first high-ranking Western official trip (after the Finnish foreign minister) to the Soviet Union after the crackdown on the "Prague Spring." 28

In general, the crisis demonstrates that the Austrian government's interpretation of neutrality had become much more extensive than it had been during the Hungarian crisis in 1956, covering not only military matters, but also its own readiness for speaking frankly. That Klaus and Waldheim attempted to curb the freedom of speech and influence the Austrian media coverage of the events reveals the extent of their "mental neutralization." Secondly, the crisis underlined that neutrality did not automatically mean Austria's protection from violations from without, not even from the USSR, a signatory power of the Austrian state treaty.

${ }^{24}$ Graf, "Internationale Reaktionen auf die Intervention der Warschauer-Pakt-Staaten," 152.

${ }^{25}$ Eger, Krisen an Österreichs Grenzen, 121.

${ }^{26}$ Ibid., 101-102.

${ }^{27}$ Hanspeter Neuhold and Karl Zemanek, "Die österreichische Neutralität im Jahr 1968," in Österreichische Zeitschrift für Außenpolitik 9, no. 2 (1969), 144-169, 145.

28 Austrian embassy Moscow to Austrian MFA, 19 March 1969, in ÖStA, AdR, BMAA, II-Pol, GZ. 151532-6/69, Z. 154983. Cf. Österreichische Zeitschrift für Außenpolitik 9 (1969), 116. 


\section{Warsaw Pact plans and Austria's self-defense}

This appears quite surprising, as the Soviet Union, like the other three great powers, in article 2 of the Austrian state treaty of 1955, had obliged itself to respect the independence and territorial integrity of Austria. However, the Soviet respect for neutrality in military terms seems to have been defined by considerations of utility rather than international law. ${ }^{29}$ When the Soviet minister of defense, Marshal Rodion Malinovskii, during his visit of the Austrian Bundesheer's 1959 exercises, stated that "the Soviet Union would never violate Austria's neutrality as an initiator," the emphasis rested on the last words: In their war games, Warsaw Pact planners took it almost for granted that the enemy would soon occupy Austrian territory. From that moment on they were ready to enter it too and to use it as a battlefield. An authentic detailed plan for a Hungarian command-staff war game, dated May 1965, foresaw Hungarian troops confronting NATO forces, which under the cover of the Bundesheer had entered the country. The Hungarian troops were to deliver a main strike in the direction of Vienna and Linz and another in the direction of Graz and Villach, and thus within five to six days "to eliminate Austria from the war." 11 Vienna was to be either totally destroyed or at least largely demolished by two Soviet 500-kiloton nuclear devices launched from Hungarian soil.

Whereas such plans always assumed that NATO would be the first to violate Austria's neutrality, it remains up to debate whether the USSR was prepared to "cast the first stone." When the Czech general Jan Šejna defected to the West, he caused an uproar by publishing alleged war plans of the Warsaw Pact. He claimed that from 1963, the USSR was ready to commit a first strike. ${ }^{32}$ When some of the

${ }^{29}$ Erich Reiter and Georg Bautzmann, "Kriegsführungspläne des Warschauer Paktes in der so genannten Zeit des Kalten Krieges," in Erich Reiter and Ernest König (eds.), Österreichs Neutralität und die Operationsplanungen des Warschauer Paktes, Informationen zur Sicherheitspolitik 20 (Vienna: Landesverteidigungsakademie, 1999), 11-14, 13. On Soviet war planning in general, cf. Vojtech Mastny, "Imagining war in Europe: Soviet strategic planning," in idem, Sven G. Holtsmark, and Andreas Wenger (eds.), War Plans and Alliances in the Cold War: Threat perceptions in the East and West (London: Routledge, 2006), 14-45.

${ }^{30}$ Stuttgarter Nachrichten, 23 June 1959. Emphasis mine.

${ }^{31}$ Róbert Széles, "Die strategischen Überlegungen des Warschauer Paktes für Mitteleuropa in den 70er Jahren und die Rolle der Neutralen," in Manfried Rauchensteiner (ed.), Tausend Nadelstiche: Das österreichische Bundesheer in der Reformzeit 1970-1978 (Graz: Styria, 1994), 25-45. Cf. Czechoslovakia's Strategic Position in a European War, April 1961; Plan for a Hungarian Command-Staff War Game, May 1965, in Mastny and Byrne, A Cardboard Castle?, 118-119, 189-191. See also Erwin Schmidl, "The Warsaw Pact and Austria: Threats and Threat Perceptions," in Arnold Suppan and Wolfgang Mueller (eds.), Peaceful Coexistence or Iron Curtain? Austria, Neutrality, and Eastern Europe in the Cold War and Détente, 1955-1989 (Vienna: Lit, 2009), 203-217; Wolfgang Mueller, "Der Warschauer Pakt und Österreich 1955-1991," in Manfried Rauchensteiner (ed.), Zwischen den Blöcken: NATO, Warschauer Pakt und Österreich (Vienna: Böhlau, 2010), 135-191.

32 Jan Sejna, We Will Bury You (London: Sidgwick \& Jackson, 1982) 42-43, 119-121. Cf. below, page 212. On the following, see Alfred Schätz, "Die sowjetische Militärpolitik im Kalten Krieg 
Warsaw Pact's war plans were declassified after 1991, defense analysts and representatives of all political parties concluded that it appeared unlikely that the Eastern alliance would have respected Austria's status in the case of a general war. This could be seen by the preponderance of Blitzkrieg offensives in Soviet preparations for war in Europe, as well as the Soviet interest in the case of such a war to quickly eliminate West Germany and France: While the concentration of NATO forces in the FRG let a quick advance on the German front appear unlikely, the military vacuum in Austria almost invited an attack along the Danube.

While such war games luckily never became reality, the frequent violations of Austria's airspace by Soviet planes during their intervention in Czechoslovakia 1968 underline the low Soviet respect for Austrian neutrality from a military point of view. Eleven years later, Minister of Defense Otto Rösch, after a visit to the USSR, reported in an Austrian cabinet meeting: "Neutral Austria's political importance for détente and peace in Central Europe has been repeatedly acknowledged by the Soviet minister of defense. At the level of the military command and below, however, there seems to be no understanding whatsoever with regard to permanent neutrality." 33 This assessment conforms to research results that have seen the fate of Austria, in the case of a military conflict between the two alliances, to have been a matter of strategic deliberations, particularly in view of its geographical position as a corridor between Hungary and West Germany. A similar curse of geography had been the fate of neutral Belgium in 1914 and 1940. Indeed, even after 1945, for a small country "it was still the worst thinkable mistake to be located in the wrong place." ${ }^{34}$ Only after 1989, following the new "defensive" defense doctrine of the Warsaw Pact introduced by Gorbachev, East European military exercise planning foresaw Austria retaining her neutrality. ${ }^{35}$

Given that Warsaw Pact military planners took a Western, and then Eastern, violation of Austria's neutrality for granted, it comes hardly as a surprise that the USSR did not make significant investments in Austria's capability to defend itself and turned a deaf ear on Austrian requests to enable the country to acquire modern defense weaponry. In comparison to the US donations to the Austrian army of

und die österreichische dauernde Neutralität" (PhD Thesis, Vienna, 2008), 72-73, 201-209; Martin Malek, "Österreich und der Auflösungsprozess des Warschauer Paktes, 1989-1991," in Manfried Rauchensteiner (ed.), Zwischen den Blöcken: NATO, Warschauer Pakt und Österreich (Vienna: Böhlau, 2010), 557-614, 595-596; Andrew E. Harrod, "Felix Austria? Cold War Security Policy between NATO, Neutrality, and the Warsaw Pact, 1945-1989“ (PhD Thesis, Medford, 2007), 822-830.

33 Mündlicher Bericht Rösch an Ministerrat, BMLV Zl. 10061/54-1.1/80, 2 January 1980, in SBKA, Länderboxen, UdSSR 5.

${ }^{34}$ Wilhelm Agrell, "Silent allies and hostile neutrals: Nonaligned states in the Cold War," in Vojtech Mastny, Sven G. Holtsmark, and Andreas Wenger (eds.), War Plans and Alliances in the Cold War: Threat Perceptions in the East and West (London: Routledge, 2006), 141-162, 145.

${ }^{35}$ Czechoslovak Description of "Vltava-89" Exercise, 23 May 1989, in Mastny and Byrne, A Cardboard Castle, 634-635. 
military equipment, worth 100 million dollars, the Soviet side gave only symbolic assistance. ${ }^{36}$ Furthermore, Austria's (albeit weak) efforts to beef up its defense were treated by the Kremlin with suspicion and foot-dragging, while calls for the country's complete disarmament, such as the initiative of the Austrian physicist, social democrat, and member of the peace movement Hans Thirring met with Soviet approval. ${ }^{37}$ In the 1970 s, the Soviet army's newspaper voiced concerns about alleged increases in the country's military spending; it was claimed that peace policies would better contribute to Austria's security than investments in its defense. ${ }^{38} \mathrm{Such}$ statements conformed to the Soviet understanding of neutrality and Soviet criticism of the defense policies of other Western neutrals, in particular those of Sweden and Switzerland, as was repeatedly voiced during the 1960s and 70s. ${ }^{39}$

In contrast to the Swiss concept of neutrality, to US insistence, and, indeed, to the Austrian declaration of neutrality, the Soviet understanding of neutral policy comprised no obligation for self defense, ${ }^{40}$ and the state treaty contained a number of significant restrictions against Austria possessing or using ground-based antiaircraft and other missiles. These stipulations of the state treaty's article $13 \mathrm{had}$ been copied from the United Nations' peace treaties of 1947 with Hitler's former allies, when missiles had been banned as offensive weapons. Due to the development of missile-based anti-tank defense, however, such weapons were increasingly used for defensive purposes and the restrictions acquired a new meaning, namely they prevented Austria from purchasing the necessary means for this type of defense. Although Austria, with US consent, regularly approached the USSR to obtain its blessing for buying these weapons, the Kremlin remained adamantly against such purchases, even after Finland had successfully amended the anti-missile article in its peace treaty. ${ }^{41}$ During Minister of Defense Prader's visit to Moscow in 1966, Austria was granted the right to order anti-tank missiles; ${ }^{42}$ however, similar requests by Klaus, Waldheim, Kreisky, Kirchschläger, and Rösch concerning ground-air-missiles in the late 1960 s and 70 s were refused. ${ }^{43}$ Klaus, in a lecture at the Soviet Academy of Sciences in 1967, argued in favor of lifting

${ }^{36}$ Kofler, Kennedy und Österreich, 117-118.

${ }^{37}$ Ganiushkin, Neitralitet i neprisoedinenie, 125. Cf. Hans Thirring, Mehr Sicherheit ohne Waffen: Denkschrift an das österreichische Volk und seine gewählten Vertreter (Vienna: Jugend und Volk, [1962]).

${ }^{38}$ Krasnaia zvezda, 4 February 1975. Cf. Austrian embassy Moscow to Austrian MFA, 4 February 1975, ÖStA, AdR, BMAA, II-Pol, Z. 225.05.40/1-II/75.

${ }^{39}$ Petersson, The Soviet Union and Peacetime Neutrality, 68.

40 See above, page 65 .

${ }^{41}$ Austrian embassy Moscow to Austrian MFA, 22 September 1966, in ÖStA, AdR, BMAA, II-Pol, Pol. Berichte Moskau, 915-917.

${ }^{42}$ Ministerratsvortrag Prader, 23 September 1966, in ÖStA, AdR, BMAA, II-Pol, GZ. 45707-6/66, Z. 49028-6pol/66.

${ }^{43}$ O vizite v Sovetskii Soiuz Ministra inostrannykh del Avstrii, 10 April 1968, in AVPRF, 66/47/101/11, 11-16; Conversation Kreisky with Kosygin, 31 May 1974, in SBKA, NL Thalberg, 
the restrictions on Austria's self-defense; only by acquiring all necessary defensive means, including missiles, would the prestige of the country's neutrality be ensured and its function as a deterrent possible. ${ }^{44}$ While some of these requests were met by the Soviets encouraging Austria, as in 1965 and 1971, to order Soviet missiles or planes with air-to-air missiles ${ }^{45}$ others were fended off with the thesis that, as a neutral, Austria should rather focus on peaceful foreign policy instead of wasting money on obsolete defense. ${ }^{46}$ Such postures can be explained by the Soviet interest to keep Austria weak and unarmed in case of a war between the Warsaw Pact and NATO. In addition, there seems to have existed a certain Soviet distrust of Austria's impartiality. In 1965, press reports cited a Soviet diplomat with the words: "Why do you [i.e. the Austrians] need rockets? You would shoot down a Czech plane violating your airspace, but would you shoot down an American plane?"47

During a visit of an Austrian delegation in 1979, the Soviet army demonstrated various types of missiles and thus raised Austrian hopes that it might be possible to order some. The Austrian minister of defense Otto Rösch, however, felt that this would be, from the Austrian standpoint, politically inopportune. ${ }^{48}$ His predecessor Karl Lütgendorf, who had discussed the issue two years earlier, had been stopped by Kreisky. ${ }^{49}$ When Rösch in 1979 drew his Soviet colleague's attention to the problem that Austria still had no anti-aircraft missiles, he was rebuffed by Ustinov's words: "You don't need them." ${ }^{50}$ While politicians of the opposition party ÖVP demanded the modernization of Austria's self-defense, Soviet commentators ridiculed their "lust for rockets." ${ }^{51}$ By this time, all of the former Axis allies that had joined the Warsaw Pact, and even Finland had already freed themselves from similar anti-missile restrictions contained in their 1947 peace treaties, and had bought, mostly from the USSR, anti-aircraft missiles. ${ }^{52}$ In addition to such double standards, the Soviet attitude towards Austrian defense included a certain

Depositum 1, Box 2, File 3; Report, 28 April 1975, in AVPRF, 66/54/115/13, 34-35. On the Kirchschläger visit, see Österreichische Zeitschrift für Außenpolitik 11 (1971), 49.

44 Österreichische Zeitschrift für Außenpolitik 7 (1967), 168.

${ }^{45}$ Conversation Prader with Malinovskii, 30 September 1965, in SBKA, Länderboxen, UdSSR 2; Conversation Kirchschläger with Gromyko, 26 and 29 January 1971; Kirchschläger with Kosygin and Kirchschläger with Podgorny, 29 January 1971, in ÖStA, AdR, BMAA, II-Pol, GZ. 105.4566/71, Z.106.503.

46 Austrian embassy Moscow to Austrian MFA, 14 May 1971, in ÖStA, AdR, BMAA, II-Pol, GZ. 105.880-6/71, Z.111.995; Hanspeter Neuhold and Karl Zemanek, "Die österreichische Neutralität im Jahr 1967," in Österreichische Zeitschrift für Außenpolitik 8, no. 1 (1968), 14-32, 25.

${ }^{47}$ The New York Times, 6 October 1965. Quoted in Schlesinger, Austrian Neutrality in Postwar Europe, 123.

${ }^{48}$ Hinteregger, Im Auftrag Österreichs, 241-243.

49 Ginther, "Austria's Policy of Neutrality and the Soviet Union," 78, 80-81.

${ }^{50}$ Conversation Rösch with Ustinov, 17 December 1979, in SBKA, Länderboxen, UdSSR 5.

${ }^{51}$ S. Tarow, "Gier nach Raketen," in Neue Zeit, no. 14 (1979), 16.

${ }^{52}$ Harrod, "Felix Austria?," 283. 
amount of hypocrisy: On one hand, it was taken for granted that Austria's integrity and neutrality would be violated by NATO; on the other, Austrian efforts to improve its poor defense were blocked. And when in 1983 NATO secretary Joseph Luns questioned Austria's capability to defend itself, Izvestiia on 2 April issued a sharp reprimand against this "blunt intervention in the internal affairs of a sovereign state." ${ }^{53}$

The Soviet "nyet" does not seem to have particularly disturbed the Austrian government, which indeed usually shied from providing the necessary means for the country's security. Austria's per capita defense expenditure was, during the 1960s, 70s and 80s, among the lowest of all European states, lagging significantly behind comparable, despite their being strategically less exposed, neutral states such as Sweden and Switzerland, both in absolute and relative numbers. During theses years, the Austrian government spent 0.9-1.4 percent of the country's GDP on defense purposes, while Finland assigned 1.1-1.7 percent, Switzerland 1.7-2.3 percent, and Sweden 2.9-3.7 percent; in 1968, per capita spending for defense amounted in Austria to $\$ 19$, in Finland to $\$ 27$, in Switzerland to $\$ 68$, and in Sweden to $\$ 128 .{ }^{54}$ This was paralleled by the rudimentary mobilization of Austria's population: while in the late 1960s, the Swedish and Swiss armies were able to mobilize about 10 percent of the entire population, the Austrian figure was 2 percent. In the 1970s, Switzerland (which, as the proverb goes, does not "have an army, but is one") was able to mobilize 15 soldiers per square kilometer, West Germany 7, nonaligned Yugoslavia 6.4, and Austria 1.8. The indicators for Austria's defense capability began to improve somewhat at the end of the Cold War. It was only in 1985 that the Austrian government decided to upgrade the Bundesheer's air force with twenty-four Saab Draken jets - a decision highly welcomed by the US government. ${ }^{55}$

${ }^{53}$ Quoted in Ludmilla Lobova, "Russland und die Neutralität Österreichs: Aktuelle Einschätzungen vor dem Hintergrund des Verhältnisses zur NATO," in Jahrbuch für internationale Sicherheitspolitik (2000), 371-389, 373. Cf. S. Tarow, "Luns provoziert," in Neue Zeit, no. 5 (1980), 17.

${ }^{54}$ Dieter A. Binder, "Trittbrettfahrer des Kalten Krieges," in Johann Starlinger (ed.), Armee, Zeitgeist und Gesellschaft 1955-2005 (Vienna: Wissenschaftskommission beim Bundesministerium für Landesverteidigung, [2006]), 57-65, 59; Neuhold, "The Neutral States of Europe," 116; Harrod, "Felix Austria," 297, 309; Otto Heller, "Die Schild-Schwert-These und die Neutralen: Eine strategisch/operative Betrachtung über die Zeit von der Aufstellung des zweiten Bundesheeres bis zum Beginn der Reform 1970," in Manfried Rauchensteiner and Wolfgang Etschmann (eds.), Schild ohne Schwert? Das österreichische Bundesheer 1955-1970 (Graz: Styria, 1991), 61-88, 78.

55 Ingemar Dörfer, "The European Neutrals in the Strategy of the Reagan Administration," in Bengt Sundelius (ed.), The Neutral Democracies in the New Cold War (Boulder: Westview, 1987), 182197, 184. 
Table 2: Defense indicators of neutral states in the mid-1980s

\begin{tabular}{|l|c|c|c|c|}
\hline & Austria & Finland & Sweden & Switzerland \\
\hline Mobilization strength & 240,000 & 734,000 & 776,000 & 645,000 \\
\hline$\%$ of population & 3.2 & 15.1 & 9.3 & 9.8 \\
\hline Tanks & 170 & 165 & 985 & 875 \\
\hline Armored vehicles & 460 & 230 & 1,000 & 1,475 \\
\hline Fighting aircraft & 32 & 80 & 501 & 295 \\
\hline Defense expenditure as \% of GDP & 1.3 & 1.4 & 3 & 2.3 \\
\hline as \$ per capita & 106 & 168 & 341 & 301 \\
\hline
\end{tabular}

Source: Karsh, Neutrality and Small States, 151.

The alarming shortage of funding, arms, and manpower raised concern not only within the Austrian army but also in the West. In the 1960s, both US reports and internal Austrian documents claimed that the Bundesheer was only capable of maintaining order within the country. ${ }^{56}$ In 1974, the Austrian army's Limes exercises led to the conclusion that the Warsaw Pact would probably need only a day to reach its strategic objectives in Austria. That the country did not have the necessary means to control or defend its airspace was proven by a Soviet pilot making an alleged emergency landing on the neutral's territory on 30 November 1967, only six months before the Warsaw Pact's intervention in Czechoslovakia. But neither of these incidents nor the systematic Soviet violations of Austria's airspace in the summer of 1968 increased the Austrian government's readiness to ensure that its airspace was efficiently defended. To make things worse, the Austrian government, despite having adopted a Comprehensive Defense Doctrine in 1965, two years later was still unwilling to approve any of the Bundesheer's strategic plans for the country's defense. Such disregard of the obligation to prepare for self-defense was quite remarkable, since the creation of a credible Austrian deterrent and neutrality being "self-chosen" had been the only Western preconditions for agreeing to Austria's neutrality.

Several factors have been discerned by analysts as reasons for this military weakness: While two world wars and the concentration of troops and nuclear devices in the Cold War made defense an increasingly unpopular undertaking in Western Europe in general, ${ }^{57}$ in Austria the overwhelming numeric superiority of Warsaw Pact forces at the country's border might have contributed to considerations such as "our situation is hopeless, why try to change it?" 58 In addition, some Austrians seem to

${ }^{56}$ Rauchensteiner, "Sandkästen und Übungsräume: Operative Annahmen und Manöver des Bundesheeres 1955-1979," 266-281, 319; Franz Freistetter, "Das strategische Konzept des Ostens und Österreich 1955-1970," in Manfried Rauchensteiner and Wolfgang Etschmann (eds.), Schild ohne Schwert? Das österreichische Bundesheer 1955-1970 (Graz: Styria, 1991), 29-60, 56.

${ }^{57}$ On the "rise of the Civilian State" in Europe, see James J. Sheehan, Where Have All the Soldiers Gone? The Transformation of Modern Europe (Boston: Houghton Mifflin, 2008), 172-197.

58 The Times (London), 7 May 1985, quoted in Johnson-Freese, “Austria," 177. 
have taken NATO's protective "nuclear umbrella" for granted - a tendency that led to repeated accusations that the neutral was taking a "free ride" on Western defense efforts. ${ }^{59}$ Even more important, however, may have been the gradual integration into Austrian official statements of the Soviet neutrality myth that neutral countries, first, were more secure than members of alliances, and, secondly, should focus on fostering détente and "peaceful coexistence" instead of creating armed deterrents. ${ }^{60}$

${ }^{59}$ Binder, “Trittbrettfahrer des Kalten Krieges," 63; Luif, Der Wandel der österreichischen Neutralität, 60-82.

${ }^{60}$ See below, pages 199-200. 


\section{Making Economic and Cultural Relations Mutual}

Despite the Soviet-Austrian debates about Austria's participation in the EEC and despite the Soviet invasion in Czechoslovakia, the 1960s were a period of steady growth in the area of economic and cultural relations. In July 1961 the last delivery of goods stipulated by the state treaty was made, and in February 1964 the USSR acknowledged the receipt of the last million tons of Austrian crude oil that had been the price for the Austrian buy-back of its oil wells seized by the USSR in 1945-46, shipments that in the end totaled six million tons instead of the ten originally negotiated. ${ }^{1}$ These deliveries, in combination with a growing number of delegation visits and several barter agreements, helped to get Soviet-Austrian trade moving. In 1963 the Soviet Union purchased Austrian goods worth twenty-five million dollars, which included mainly rolled steel, machine tools, electric machinery, and barges, and delivered, in return, coal (for 14.3 million dollars), crude oil (8.4 million dollars) and iron ore (6.7 million dollars). ${ }^{2}$

\section{Trade}

Under Brezhnev and Kosygin, the USSR continued to intensify its commercial trade with Western countries. Industrial cooperation was begun, such as the Italian-Soviet Fiat/VAZ car-plant project in Toliatti on the Volga. From 1966 to 1970, Soviet imports from the West increased on the average by 11.2 percent a year, the increase mainly consisting of imports of machinery and equipment. ${ }^{3}$ The Soviet-Austrian trade agreement for this period, signed in 1965 in Vienna by Trade Minister Patolichev and his counterpart Bock, foresaw increases in volume and in the types of goods. ${ }^{4}$ Austria continued to export largely machinery, industrial equipment, and electrical goods (altogether one third of Austrian exports to the Soviet Union), sheet metal and metal goods (a quarter), and cable, lacquer, paper, spun rayon, textiles, shoes, and breeding cattle (of the kind that had been presented to Khrushchev in 1960). The Soviet Union delivered feed grain, cotton, coal,

1 Österreichische Zeitschrift für Außenpolitik 4 (1964), 37-38; Stourzh, Um Einheit, 774-775.

2 Report Alekhin, 6 August 1963, in AVPRF, 66/42/87/11, 17-21.

${ }^{3}$ Philip Hanson, The Rise and Fall of the Soviet Economy: An Economic History of the USSR from 1945 (London: Longman, 2003), 120; 122. Soviet imports of Western machinery rose from 489 million dollars in 1964 to 1,574 million dollars in 1973 .

${ }^{4}$ Langfristiges Abkommen zwischen Österreich und der UdSSR über den gegenseitigen Warenverkehr, 14 July 1965, in Mayrzedt and Hummer, 20 Jahre österreichische Neutralitäts- und Europapolitik 2, 143-144. 
crude oil, iron ore, chemicals, as well as a small amount of machinery (only 2 percent of the Soviet exports to Austria). However, neither the list of goods nor its implementation fully satisfied the Soviet side. On 26 December 1967, Radio Moscow accused the Austrian side of having neither fulfilled its import obligations to buy natural rubber, tobacco, and tea, nor fully exhausted its import quota for coal and iron ore. ${ }^{5}$ The allegations were justified, as the Soviet-Austrian trade balance, indeed, persistently favored the Austrian side. The situation for Soviet machinery was especially poor, since for years Austria had not imported enough to fulfill the import quota. Many of these goods, Radio Moscow criticized, were purchased by Austria from the West, although the latter did not import the same quantities of Austrian goods. As a solution, Radio Moscow proposed that Austria buy Soviet helicopters and airplanes, and, in return, export pipes for Soviet pipelines.

Negotiations concerning the use of Austrian pipes for a gas pipeline to Italy, between the Soviet natural gas exporting company Soiuznefteksport and a consortium consisting of several companies including Ferngas, VÖEST steel and the ÖMV oil refineries had started in 1966. Prior to this, Austria had already declared itself willing to import natural gas from the USSR, but had been refused since the Soviet capacity was insufficient. ${ }^{6}$ During the Klaus visit to Moscow in March 1967, a deal was concluded for integrating Austria into the Soviet-Italian pipeline project; the agreement with Italy had been reached during Prime Minister Kosygin's trip to Rome two months earlier. ${ }^{7}$ However, since Austria could not produce pipes of sufficient diameter (just as the USSR could not), VÖEST had to strike a deal with Mannesmann and Thyssen of West Germany for Austrian deliveries of steel in return for German pipes. ${ }^{8}$ The Soviet side repeatedly encouraged the Austrian government to organize pipe production in Austria itself, but Waldheim signaled that Austria was reluctant to start producing pipes without a Soviet purchase guarantee. The 2.6 billion schillings deal on the delivery of 520,000 tons of West German pipes made of Austrian steel was signed in Vienna by the Soviet deputy minister of foreign trade, Nikolai Osipov, on 1 June 1968; the Soviet Union paid with natural gas and oil. Austria thus became the first West European state to import natural gas from the USSR. ${ }^{9}$ The agreement foresaw gas deliveries for twenty-three

${ }^{5}$ Sowjetische Vorwürfe, 16 January 1967, in ÖStA, AdR, BMAA, II-Pol, GZ. 13847-6/67, Z. 13847-6/67. Similar allegations had been raised in July 1966. Ibid., GZ. 32503-6/66, Z. 41205$6 \mathrm{pol} / 66$.

${ }^{6}$ Report, 31 May 1966, in AVPRF, 66/45/96/21, 2-6.

${ }^{7}$ Gromyko and Ponomarjow, Geschichte der sowjetischen Außenpolitik 1945 bis 1976, 545547.

${ }^{8}$ Conversations Waldheim with Deputy Prime Minister Kuznetsov and Prime Minister Kosygin, March 1968, in ÖStA, AdR, BMAA, II-Pol, GZ. 110044-6/68, Z. 115353-6pol/68 and Z. 115779-6pol/68.

9 Lobova, "Die Moskauer Perzeption," 144-146. 
years, starting with 300 million cubic meters in 1968 and reaching 1.5 billion cubic meters per annum in $1971 .{ }^{10}$

The gas and pipeline agreement was preceded by another on economic-scientific-technical cooperation signed in May 1968 during President Jonas' visit to Moscow, which was followed in July by an agreement on air transport that cleared the way for intensified cooperation between Austrian Airlines, which as the first Western airline received landing rights in Kiev, ${ }^{11}$ and Aeroflot, which was granted the right to fly from Vienna to Zurich. A new five-year trade agreement, signed in 1970 and replacing all previous trade agreements, was the first without fixed quotas and clearing in freely-convertible currency. ${ }^{12}$

On the Austrian side, trade with the Soviet Union was primarily conducted in the nationalized sector. The Soviet minister for foreign trade Ivan Kabanov had visited the state-owned VÖEST as early as in 1955. His visit was followed, in 1960, by Khrushchev's, who proposed several long-term contracts between the Soviet side and the steel plant in Linz. The first deal, concerning 10,000 tons of VÖEST steel for the USSR, had been signed in 1956. A year later, the company received its first delivery of Soviet coal and iron ore. ${ }^{13}$ In 1963, 45 percent of all Austrian goods exported to the USSR were produced by state-owned companies, with VÖEST and machine producer Voith the primary exporters. ${ }^{14}$ According to Soviet data, the state-owned share of Austria's exports to the Soviet Union was on average as high as 60 percent. ${ }^{15}$ Voith, in 1960 , exported 40 percent of its paper-producing machinery to the USSR. In 1971, the Linz plant celebrated the delivery of its second million tons of steel to the Soviet Union with a ceremony and a bilingual brochure. ${ }^{16}$ The biggest deal landed by VÖEST in these years, however, was the delivery to Belarusian Novo-Lipetsk of an entire steel plant of the "Linz-Donawitz" (LD) type, including an oxygen processor and a production site of industrial dolomite, and its construction. The deal was worth 36 million dollars and boosted VÖEST's share

10 Archiv der Gegenwart 13957, 1 June 1968.

${ }_{11}$ Österreichische Zeitschrift für Außenpolitik 8 (1968), 233.

${ }^{12}$ Langfristiges Abkommen über den Waren- und Zahlungsverkehr zwischen Österreich und der UdSSR, 5 August 1970, in Mayrzedt and Hummer, 20 Jahre österreichische Neutralitäts- und Europapolitik 2, 149-152.

13 VÖEST, Die 2millionste Tonne VÖEST-Stahl für die UdSSR: Dvukhmillionaia tonna stali firmy VEST dlia SSSR (Linz: no publisher, 1971).

${ }^{14}$ Zhiriakov, SSSR - Avstriia, 52-54. Other state-owned Austrian companies involved in Soviet trade were the Böhlerwerk and Schoeller-Bleckmann steel companies, Chemie Linz, SimmeringGraz-Pauker railcar construction, the Korneuburg dockyard, and the Elin-Union, a producer of electrical goods.

${ }_{15}$ Report Alekhin, 6 August 1963, in AVPRF, 66/42/87/11, 17-21. In 1968-69 the share of Austrian state-owned companies in the Austrian trade with the USSR even reached 73.3 percent of the exports and 54.3 percent of the imports. File Offizieller Besuch des Herrn Bundeskanzler in der Sowjetunion, May 1974, in SBKA, Länderboxen, UdSSR 3.

16 VÖEST, Die 2millionste Tonne. 
in Austria's trade with Eastern Europe from 27 to 35 percent. ${ }^{17}$ The Soviet side, in return, stepped up its coal and iron ore deliveries to the Linz steel plant.

These deliveries, however, added even more to the much-deplored dominance of raw materials in Soviet exports. In order to diversify the list of trading goods, in 1967 the Soviet Union participated in the trade fairs in Vienna, Graz and Klagenfurt, and exhibited, among other things, excavators, machinery, helicopters, sea vessels, and Moskvich cars. ${ }^{18}$ The previous year, the USSR had organized an exposition in Austria of Soviet electronics and optics, the first such exposition in a capitalist country. ${ }^{19}$ Austria did not remain inactive either and took part, together with about twenty other countries, in all ten international fairs held in Moscow in the years 1964-69. Even earlier, in 1963, a special exposition of Austrian machinery had been shown in the Soviet capital. ${ }^{20}$ The Austrian disregard for Soviet machinery and technology and its lively exporting activities as well as the Soviet inability, during the 1960 s, to step up deliveries in crude oil and natural gas tended to result in a trade imbalance favoring Austria, an imbalance that was nevertheless nearly within the framework of the trade agreements. The low attractiveness of Soviet goods in the West also troubled Soviet economic relations with other West European states. ${ }^{21}$ It was only in 1971 that the newly built gas pipeline and booming Soviet exports of natural gas turned the tide.

The third significant problem for Soviet-Austrian trade, in addition to the passive trade imbalance and Austrian unwillingness to purchase little more than raw materials from the Soviet Union, was Austria's EFTA membership. At least five times between Austria's accession in 1960 and 1963, the Soviet Union demanded, due to its most-favored nation status that had been granted in 1955, the same trading conditions as intra-EFTA trade. Austria, naturally, was not allowed to fulfill such wishes. ${ }^{22}$ The USSR, in frustration, raised its tariffs for Austrian goods. ${ }^{23}$ When the Austrian minister of trade Otto Mitterer traveled to the USSR in 1969, he was confronted by Kosygin and Patolichev, who bitterly criticized Austria's preferential treatment of the Free Trade Association's co-members. ${ }^{24}$

Despite these problems, due to many efforts in the decade following 1961, Soviet-Austrian trade doubled.

${ }^{17}$ Sowjetunion heute 11, no. 1 (1965), 18.

18 Zhiriakov, SSSR i Avstriia v 1945-1975 gody, 123.

19 Report, 31 May 1966, in AVPRF, 66/45/96/21, 2-6.

${ }^{20}$ Sowjetunion heute 9, no. 42 (1963), 6.

${ }^{21}$ Bonwetsch, "Sowjetische Westeuropapolitik II," 183.

22 Information, [1973], in SBKA, Länderboxen UdSSR, 2.

${ }^{23}$ Report Alekhin, 6 August 1963, in AVPRF, 66/42/87/11, 22-25.

${ }^{24}$ Austrian embassy Moscow to Austrian MFA, 17 July 1969, in ÖStA, AdR, BMAA, II-Pol, GZ. 160920-6/69, Z. 160920. 
Table 3: Soviet-Austrian trade 1961-1972

\begin{tabular}{|c|c|c|c|c|c|c|}
\hline & $\begin{array}{c}\text { Austrian } \\
\text { exports }\end{array}$ & $\begin{array}{c}\text { Change from } \\
\text { previous year }\end{array}$ & $\begin{array}{c}\text { Share of Soviet } \\
\text { imports }\end{array}$ & $\begin{array}{c}\text { Soviet } \\
\text { exports }\end{array}$ & $\begin{array}{c}\text { Change from } \\
\text { previous year }\end{array}$ & $\begin{array}{c}\text { Share of Austrian } \\
\text { imports }\end{array}$ \\
\hline 1961 & $1,122.8$ & 10.0 & 1.3 & $1,191.8$ & 13.6 & 3.1 \\
\hline 1962 & $1,402.4$ & 24.9 & 1.0 & $1,138.4$ & -4.5 & 2.8 \\
\hline 1963 & $1,612.6$ & 15.0 & 1.0 & $1,348.0$ & 18.4 & 3.1 \\
\hline 1964 & $1,501.4$ & -6.9 & 0.8 & $1,354.2$ & 0.5 & 2.8 \\
\hline 1965 & $1,485.0$ & 4.0 & 0.8 & $1,371.0$ & 1.2 & 2.5 \\
\hline 1966 & $1,547.2$ & 4.2 & 0.9 & $1,267.8$ & -7.5 & 2.1 \\
\hline 1967 & $1,545.6$ & -0.1 & 1.0 & $1,271.7$ & 0.3 & 2.1 \\
\hline 1968 & $1,779.5$ & 15.1 & 0.9 & $1,519.0$ & 19.4 & 2.3 \\
\hline 1969 & $1,784.7$ & 0.3 & 0.9 & $1,720.1$ & 13.2 & 2.3 \\
\hline 1970 & $2,134.1$ & 19.6 & 0.8 & $2,067.9$ & 20.2 & 2.2 \\
\hline 1971 & $1,738.2$ & -18.2 & 0.7 & $2,685.0$ & 29.8 & 2.6 \\
\hline 1972 & $2,177.6$ & 25.3 & 0.6 & $2,621.6$ & -2.4 & 2.2 \\
\hline
\end{tabular}

Source: Butschek, Statistische Reihen; Vneshniaia togovlia

Exports in millions of Austrian schillings; changes and shares in percent.

At the twenty-fourth CPSU congress in March-April 1971, Brezhnev and Kosygin mentioned Austria as an important capitalist trading partner, albeit only after France, West Germany and Italy. ${ }^{25}$ For most of the 1960s, however, Britain and Finland had been the leading Western trading partners of the USSR, followed by Japan. In some years they were even overtaken by the FRG, although its trade with the USSR, due to volatile political relations, followed a sort of rollercoaster track. ${ }^{26}$ After having ranked sixth in the 1950s, Austria fell back to the rank of ninth and even thirteenth of the Soviet Union's Western partners, and its share in Soviet foreign trade declined, from 1.1 percent (1960) to 0.6 percent (1972). This was a result of the increasing diversification of Soviet foreign trade during the détente years and its shift from neutral to Western partners. A similar development had affected Finland's share in Soviet trade already in the 1950s, falling from 3.6 percent (1955) to 2.4 percent (1960). For Austria, compared to its other trading partners the general importance of the USSR decreased also. With its roughly three-percent share in Austrian foreign trade in 1961 falling to little more than 2 percent in $1972,{ }^{27}$ the USSR ranked only seventh or eighth among Austria's trading partners.

${ }^{25}$ Rechenschaftsbericht des Zentralkomitees der KPdSU an den XXIV. Parteitag der Kommunistischen Partei der Sowjetunion, Referent: L. I. Breshnew, 30 March 1971, in XXIV. Parteitag der Kommunistischen Partei der Sowjetunion 30. März-9. April 1971: Dokumente (Moscow: APN, 1971), 3-198, 49.

${ }^{26}$ See Table 5, on page 242. Cf. Eberhard Schulz, Moskau und die europäische Integration (Munich: Oldenbourg, 1975), 230-231.

${ }^{27}$ The Soviet share of Austrian exports sank from 3.6 percent in 1961 to 2.4 percent in 1972; the Soviet share of Austrian imports from 3.1 percent in 1961 to 2.2 percent in 1972. 
Although Austria was often attacked by the Soviet side for being economically less independent from the West than other neutrals, particularly Switzerland and Sweden ${ }^{28}$ in some economic sectors the Soviet Union and Eastern Europe became overwhelmingly important markets for Austria. While the member states of the Council of Mutual Economic Assistance were the recipient of only 14.6 percent of all Austrian foreign trade, on par with EFTA (14.1 percent) but ranking far behind the EEC (with 55.5 percent), more than 60 percent of the veneered plates and 40 percent of the shoes exported by Austria went to Eastern Europe. ${ }^{29}$ This reliance, in the 1980s, was to create problems for Austrian exporting industries. ${ }^{30}$ With regard to Austrian imports, more than 47 percent of imported cast iron, 33 percent of imported iron-ore, and a little less than a quarter of imported coal came from the USSR. Even before the Soviet deliveries of natural gas started, Austria had become increasingly dependent on Soviet exports of energy sources. In the late 1960s, more than 69 percent of Austria's imports of crude oil came from the USSR. ${ }^{31}$

\section{Cultural relations and personal contacts}

In the area of cultural relations, the decade of the 1960s saw Austria starting to respond to earlier Soviet visits and to intensify cultural activities in the USSR. During the late 1950s, the Soviet side had begun to be very active in promoting cultural contacts and this continued. In 1961 musicians such as Mstislav Rostropovich, David and Igor Oistrakh, and Sviatoslav Richter made guest appearances in Vienna, the Bolshoi Ballet, with 120 dancers, performed at the Vienna State Opera in 1965, ${ }^{32}$ and in 1967 the Moscow Artists' Theater MKhAT traveled to Austria. Such events had taken place before, but only now did this cultural love affair cease to be unidirectional. For years, the Austrian embassy in Moscow had appealed to the Ballhausplatz to encourage cultural visits to the land of the soviets. After the enthusiast Bischoff died in 1960, the chargé d'affaires Otto Eiselsberg continued his pleas, criticizing that "in 1955, in the area of culture as in the question of airline connections, Austria had had unique chances it had not known to exploit." ${ }^{\prime 33}$ Thus, it was only after the spectacular tours through the communist empire, profiting from Khrushchev's thaw, of the New York Philharmonic under Leonard Bernstein, a series of fashion shows by Christian Dior, the Hamburg Theater with Gustav Gründ-

${ }^{28}$ Austrian embassy Moscow to Austrian MFA, 14 November 1969, in ÖStA, AdR, BMAA, II-Pol, GZ. 166927-6/69, Z. 166927.

${ }^{29}$ Report Alekhin, 6 August 1963, in AVPRF, 66/42/87/11, 12-16.

${ }^{30}$ See below, pages 238-239.

${ }^{31}$ Report, 31 May 1966, in AVPRF, 66/45/96/21, 2-6.

${ }^{32}$ Zhiriakov, SSSR i Avstriia v 1945-1975 gody, 135.

${ }^{33}$ Austrian embassy Moscow to Austrian MFA, 14 January 1960, in ÖStA, AdR, BMAA, II-Pol, GZ. 70176-6/60, Z. 77276-6/60. On Eiselsberg, see Agstner, Enderle-Burcel, Follner, Österreichs Spitzendiplomaten, 169f. 
gens, and several exhibits of Western paintings and publications that Austrian musicians and actors followed in greater numbers. It was not until 1962 that a tour of the Vienna Philharmonic under Herbert von Karajan took place, a tour that had been planned for 1959 but delayed due to disagreements concerning the contract. ${ }^{34}$ The orchestra was enthusiastically greeted in Moscow and Leningrad, and its performances of pieces by Mozart, Bruckner, and Johann Strauß were even honored by the presence of Khrushchev and Mikoian. The same year the annual tour of the Eisrevue was extended to Kiev and Tbilisi, and in 1963 the show was attended by more than half a million Soviet visitors. ${ }^{35}$ In 1965 the Mozarteum Orchestra under Bernhard Paumgartner visited the USSR, and in 1967 and 1968, the long-awaited trips of the Burgtheater and the State Opera finally took place.

Also in 1968, in a "demonstratively amicable atmosphere" as noted by Waldheim, ${ }^{36}$ two cooperation agreements, one scientific and the other cultural, were signed. Austria had agreed to prepare the agreement, while still under Soviet pressure because of its EEC ambitions. The former included arrangements concerning exchanges of delegations and knowledge, support for cooperation between scientific and technical institutions, the protection of industrial and scientific copyrights, and the creation of a joint advisory board to facilitate collaboration. ${ }^{37}$ The Soviet side, which by then maintained sixty-two cultural agreements world wide and, since the 1940s, had fought for the signing of yet another with Austria, regarded the cultural agreement's conclusion, as expressed earlier, "a demonstration of the amicable relationship with the concluding country." ${ }^{38}$ In 1971, an agreement on cooperation was signed between the Soviet Academy of Sciences and its Austrian counterpart.

At the broader level, it was above all the Austrian-Soviet and the Soviet-Austrian friendship societies that struggled to propagate the culture of their respective countries. The Soviet side organized Grillparzer, Lenau, Nestroy, Schnitzler, and

${ }^{34}$ Hinteregger, Im Auftrag Österreichs, 55-58. After the tour, the orchestra was confronted with a Soviet request for extra payment of $\$ 6,000$. Schwierigkeiten und Hemmnise in der Durchführung kultureller Projekte, in SBKA, Länder, UdSSR 1, File Sprechprogramm Moskau 1962.

${ }^{35}$ Sowjetunion heute 9, no. 30 (1963), 17.

${ }^{36}$ Report Waldheim to Austrian parliament, 1968, in ÖStA, AdR, BMAA, II-Pol, GZ. 110044-6/68, Z. 12022-6pol/68.

${ }^{37}$ Abkommen über die kulturelle und wissenschaftliche Zusammenarbeit zwischen Österreich und der UdSSR, 22 March 1968, in UdSSR - Österreich, 128-133; Abkommen über die wirtschaftlich-wissenschaftlich-technische Zusammenarbeit zwischen Österreich und der UdSSR, 24 May 1968, in Mayrzedt and Hummer, 20 Jahre österreichische Neutralitäts- und Europapolitik 2, 146-148. Austria, in 1968 and the early 1970s, signed further agreements on scientific and cultural exchange with Romania and Bulgaria. Cf. Paul Ullmann, "Austria and Romania," in Suppan and Mueller, Peaceful Coexistence or Iron Curtain, 456-477, 465; Peter Bachmaier, "AustrianBulgarian Cultural Relations," ibid., 478-499, 487.

38 Conversation Piffl-Perčević with Romanovskii, 16 November 1966, in ÖStA, AdR, BMAA, IIPol, GZ. 13850-6/67, Z. 13850-6/67. 
Zweig festivals in the USSR, as well as countless concerts of Austrian music, and even an Austrian film festival. In 1966, the honorary president of the Soviet-Austrian Friendship Society, composer Dmitri Shostakovich, was decorated with the Golden Medal of Merit of the Republic of Austria. In 1967, KPÖ leader Koplenig was awarded the Lenin Order by the Soviets. The ÖSG, under its president Hugo Glaser, organized in 1961 more than 1,000 events promoting the USSR which were visited by about 100,000 persons, ${ }^{39}$ and later managed to bring cosmonauts Iurii Gagarin and Pavel Popovich to Austria. Both friendship societies organized exhibits, as for instance, an exhibit held in Armenia on the Austrian resistance 1938-45, and another in Vienna and Innsbruck of photographs of the USSR. These two exhibits were seen by some 23,000 visitors. In September 1961, a friendship soccer match was played between the Soviet and Austrian national teams in Moscow.

In the 1970s, about one percent of all foreign-language students in Austria, i.e. about 2,000 high school and 300 university students, studied Russian. ${ }^{40}$ To promote the Russian language, Austria was invited to join the "Russian-language Olympics" that were organized annually in Moscow. In the years 1955 to 1975, Russian translations of 125 Austrian books were published in the Soviet Union in more than eleven million copies, among them some eight million copies of works by Stefan Zweig. ${ }^{41}$ In Austria, the number of Russian books owned by the Austrian-Soviet Society's libraries (largely donated by the USSR) by 1970 had reached 29,000 volumes. While the Soviet image among Austrians and the Austrian media (which did not have its own correspondents in Moscow until the 1970s and whose delegations from time to time were refused Soviet visas for alleged anti-Sovietism ${ }^{42}$ ) had been dealt a serious blow by the Warsaw Pact's intervention in Czechoslovakia in 1968, in the USSR, despite periodical, albeit infrequent, criticism in the press and radio about Austrian neo-Nazis, Austria's anti-Soviet media, its enemies of neutrality and allegedly poor living conditions, ${ }^{43}$ the image of Austria was generally positive. Austria was pictured as "a clearly Western-oriented, independent country, which nevertheless does not look with hostility at the Eastern world but with kindness."

39 Zhiriakov, SSSR i Avstriia v 1945-1975 gody, 144.

${ }^{40}$ Zum Russischunterricht in Österreich, April 1971, in ÖStA, AdR, BMAA, II-Pol, GZ., Z. 115.490$6 / 71$.

${ }^{41}$ Zhiriakov, SSSR - Avstriia, 60-63.

42 Austrian embassy Moscow to Austrian MFA, 4 March 1969, in ÖStA, AdR, BMAA, II-Pol, GZ. 151532-6/69, Z. 153671. In 1958, the visa applications of the Austrian journalists Hugo Portisch and Hans Dichand were refused because of their alleged "anti-Sovietism." Il'ichev to Zorin, 19 February 1958, AVPRF, 66/37/72/16, [14a]. Of Soviet periodicals, Pravda had permanent correspondents in Vienna: from 1951 V. Mikhailov; 1957-62 M. Podkliuchnikov; 1962-66 V. Men'shikov; 1966-74 B. Dubrovin, 1974-91 I. Mel'nikov. Stifter, "Das politische Österreichbild," 69.

${ }^{43}$ Pravda, 17 November 1967; Stifter, "Das politische Österreichbild," 172. 
The Austrian embassy, which had summarized the Soviet attitude in these words, considered it "of prime importance to maintain this picture." 44

Nevertheless, personal contacts started slowly and remained sporadic. Allegedly due to Austrian "sins of omission," 45 a bilateral student exchange of five Austrians and five Soviets was not implemented until 1961-62 and this quota remained until the end of the 1960s. In the 1970s, nine Austrian and nine Soviet university students participated annually in the government-sponsored exchange programs. ${ }^{46}$ Although tourism grew, it was not without setbacks. In 1959, six hundred Austrian tourists had visited the Soviet Union; ten years later the number had quadrupled. ${ }^{47}$ However, in 1962 the number of Soviet tourists to Austria was reduced to half, to a mere two hundred. When the Austrian embassy investigated the reasons, Soviet officials suggested that, since the "Soviet people are not yet mature enough for tourism," new restrictions had to be applied. ${ }^{48}$

${ }^{44}$ Austrian embassy Moscow to Austrian MFA, 8 May 1966, in ÖStA, AdR, BMAA, II-Pol, Pol. Berichte Moskau, 785-790. An analysis of all articles related to Austria in Pravda, Izvestiia, Trud, and Literaturnaia gazeta shows a "clearly affirmative" picture. Stifter, "Das politische Österreichbild," 234.

45 Austrian embassy Moscow to Austrian MFA, 14 January 1960, in ÖStA, AdR, BMAA, II-Pol, GZ. 70176-6/60, Z. 77276-6/60. By this time, West Germany already sent three students per annum to the USSR. The Austrian-Soviet exchange was agreed upon during the visit of education minister Heinrich Drimmel to Moscow in 1961.

${ }^{46}$ Ministerratsvortrag und Wortlaut Kulturabkommen, September 1971, in ÖStA, AdR, BMAA, IIPol, GZ. 107.781-6/71, Z.117.793-6pol/71.

${ }^{47}$ Zhiriakov, SSSR - Avstriia, 62.

48 Austrian embassy Moscow to Austrian MFA, 16 December 1962, in ÖStA, AdR, BMAA, II-Pol, GZ. 78033-6/62, Z. 78033-6pol/62. 



\section{Summary: Soviet Containment and Encouragement; Austria's Ostpolitik and Further "Neutralization"}

The year 1972, with the formalization of Austria's free-trade agreement with the EEC and the beginning of the CSCE, relieved Soviet-Austrian relations of two burdens, thereby concluding the period begun in 1960-61 that had been overshadowed by these two matters: on one hand, by Austria's ambitions to participate in the developing West European integration and the Kremlin's determination to contain these ambitions, and, on the other hand, by Soviet endeavors to encourage the neutral to convoke an all-European conference for sanctioning the postwar status quo. The late 1960s had brought Soviet attempts to link the two issues.

In the end, both the Austrian and Soviet hopes remained unfulfilled. Austria was not accepted as an associate of the EEC; in the case of the convocation of the CSCE, Finland had to step in, playing the role the Kremlin had most probably conceived to be Austria's. Remarkably enough, both sides' ambitions and frustrations did not result in a deterioration of the bilateral relations. This maintenance of friendly, even cordial, albeit sometimes tense, relations was due to the interests and efforts of both sides. Austria could not afford to anger the Soviet Union and therefore meticulously communicated its plans and the steps it was taking with regard to the EEC to the Kremlin. The latter, too, did not want to alienate Austria or jeopardize its goal of European détente, and therefore used the small Western neutral as a showcase of Soviet friendliness. Even the Soviet intervention in the "Prague Spring," with its propaganda campaign against Austria, did not cause more than a brief interruption of these generally friendly relations.

It should be noted, however, that the "special" position Austria had held in Moscow began to be less significant during the 1960s due to the general movement towards détente, both within Europe and between the superpowers. While in the 1950 s the neutral had been used to demonstrate that "peaceful coexistence" between states of different social systems was possible, such a showcase was not as necessary during the $1960 \mathrm{~s}$. The decline in Austria's importance was probably reinforced by Khrushchev being toppled, but détente, the general diversification of East-West relations, and the Soviet interest in dealing with larger industrialized trading partners and in reaching out to NATO states were the main reasons for the shift in status, as was assessed by Ambassador Haymerle. ${ }^{1}$ Nevertheless, until the

${ }^{1}$ Haymerle to Kreisky, 18 March 1964 and 26 October 1964, in ÖStA, AdR, BMAA, II-Pol, Pol. Berichte Moskau. 
CSCE was actually convened, the Soviet tactic of encouraging the neutral to promote the idea of a security conference still made Austria an important addressee for Soviet diplomacy.

Despite this shift in the USSR's focus, as a consequence of Soviet policy, Austria's "neutralization," i.e. its becoming more neutral, intensified. This can be seen in two aspects: Firstly, in the 1960s the neutral's Ostpolitik was stepped up under Foreign Minister Kreisky and Chancellor Klaus. ${ }^{2}$ The roots of Austria's "neighborhood policy" (Nachbarschaftspolitik) went back to the early 1950s, when Austria had tried to reestablish its economic links with its Eastern neighbors and to please the Kremlin by being gracious to the communist satellites. In 1957, after the Hungarian crisis, Mikoian had encouraged the Austrian government to proceed with developing friendly relations with the East European states. This encouragement was continued in the following years. In April 1960, for instance, the Moscow New Times explained that neutrality meant not only abandoning all ambitions of participating in the EEC, but also developing the trade ties with Eastern Europe. ${ }^{3}$ Sovetskaia Rossiia, on 21 November 1967, called upon the neutrals to maintain equal relations with the East and the West.

As a neutral, Austria was a natural addressee for such encouragement. Confronted with the necessity to deal with its Eastern neighbors, and under the influence of this Soviet encouragement, it did not take long for the Austrian government, after the Soviet crackdown on the Hungarian revolution, to adopt a friendlier attitude towards the Kádár regime in Budapest. Throughout the 1960s and 70s, this kind of "neighborhood policy" remained Austria's foreign policy axiom and a priority. In the years 1961-75, Finland, Bulgaria, Hungary and Romania each received nine visits by the Austrian president, chancellor, or foreign minister, and the USSR received eight. ${ }^{4}$ This policy actively promoted relations with the East European states in order to improve the international climate in general and thus, to widen Austria's maneuvering space and bolster its security. In addition, Nachbarschaftspolitik was meant to appease the Soviet Union and create favorable conditions for Austrian

${ }^{2}$ Cf. Erich Bielka, "Österreich und seine volksdemokratischen Nachbarn," in idem, Peter Jankowitsch, Hans Thalberg (eds.), and Reinhold Wagnleitner (red.), Die Ära Kreisky: Schwerpunkte österreichischer Außenpolitik (Vienna: Europaverlag, 1983), 195-231; Meier-Walser, Die Außenpolitik der monocoloren Regierung Klaus, 170-171, 179-180, 195; Rathkolb, "Austria's Ostpolitik in the 1950s and 1960s"; Alexander Jehn, "Nachbarschaftspolitik im Donauraum: Die besonderen Beziehungen Österreichs zur Tschechowakei, zu Ungarn und Jugoslawien in der Ära Kreisky" (PhD Thesis, Vienna, 1996); Arnold Suppan, "Österreichs Ostpolitik 1955-1989," in Ibolya Murber and Zoltán Fónagy (eds.), Die Ungarische Revolution und Österreich 1956 (Vienna: Czernin, 2006), 75-92; Arnold Suppan and Wolfgang Mueller (eds.), Peaceful Coexistence or Iron Curtain? Austria, Neutrality, and Eastern Europe in the Cold War and Détente, 1955-1989 (Vienna: Lit, 2009).

3 Malicek, "Die Beziehungen," 84-85.

${ }^{4}$ Of Western states, Switzerland received fourteen Austrian visits, the FRG eight, Britain and the US each four. Neuhold, "Der Staatsvertrag als Grundlage," 165. 
trade. However, not only the USSR wanted Austria to establish these relations. Since it was also a tool for displaying "democratic presence" behind the Iron Curtain, ${ }^{5}$ the United States, too, was supportive of Austria's Ostpolitik. With this aim in mind, when Kreisky visited socialist states, he sought the opportunity to give public lectures. Despite these ambitions, Raab, Kreisky and Klaus - much like Berlin mayor Willy Brandt - knew what it was like to live under a communist regime, and thus all three were realistic enough to understand that they first had to accept the postwar reality in order to later, possibly, change it. ${ }^{6}$ In contrast to the first steps of the FRG's Ostpolitik in the late Adenauer and the Erhard years, which were further burdened by the Hallstein Doctrine, the existence of the GDR, and the lingering question of lost eastern territories, Austria's Ostpolitik was wanted and supported by the Kremlin. Austria had initiated its neighborhood policy directly with Moscow and was not considered strong enough to be a threat to the Eastern bloc's stability.

The second major aspect of Austria's "neutralization," also brought about by Soviet policy, at least in part, was a further transformation of Austria's self-definition of neutrality. For a long time, Austria had adhered to the theory that an association with the EEC was compatible with neutrality. Changing this goal was a result not only of Italian and French resistance and US doubts, but also of persistent Soviet warnings and threats concerning the inadmissibility and the possible consequences of this step. An even more important shift in Austria's definition of neutrality happened roughly around the time of the Warsaw Pact's invasion of Czechoslovakia. In contrast to Soviet claims concerning the broad tasks of permanent neutrals, Austria had until then insisted that its neutrality was a military matter that was to be achieved chiefly by staying out of military alliances. However, in November 1968 this notion of "so-called military neutrality" was explicitly rejected by the new foreign minister, Kurt Waldheim. ${ }^{7}$ Shortly thereafter, the new doctrine was presented to the Austrian parliament. ${ }^{8}$ In stressing the "secondary obligations" of permanent

${ }^{5}$ Bruno Kreisky, "Die österreichische Außenpolitik: Vortrag, Helsinki, 28 Mai 1965," in idem, Reden 1 (Vienna: Verlag der Österreichischen Staatsdruckerei, 1981), 571-580, 579. On US support, see Kofler, Kennedy und Österreich, 30.

${ }^{6}$ André Biever, "L'Autriche et les origines de l'Ostpolitik de la République fédérale d'Allemagne," in Relations Internationales 114 (2003), 213-230. Cf. Gottfried Niedhart, "The East-West Problem as Seen from Berlin: Willy Brandt's Early Ostpolitik," in Wilfried Loth (ed.), Europe, Cold War, and Coexistence, 1953-1965, Cold War History 4 (London: Frank Cass, 2004), 285-296; Peter Jankowitsch, "Das Problem der Äquidistanz: Die Suche der Zweiten Republik nach außenpolitischen Leitlinien," in Manfried Rauchensteiner (ed.), Zwischen den Blöcken: NATO, Warschauer Pakt und Österreich (Vienna: Böhlau, 2010), 451-495, 467.

7 Vortrag des Außenministers Dr. K. Waldheim über "Perspektiven der österreichischen Außenpolitik" in Wien, 7 November 1968, in Mayrzedt and Hummer, 20 Jahre Österreichische Neutralitäts- und Europapolitik 1, 144-146, 145. Cf. Luif, “Austria’s Permanent Neutrality," 137-138; Ginther, Neutralität und Neutralitätspolitik, 62-64; Meier-Walser, Die Außenpolitik der monocoloren Regierung Klaus, 180-183.

8 Ginther, "Austria's Policy of Neutrality and the Soviet Union," 79. 
neutrality, Waldheim relied on recent publications by the Austrian lawyers Verdross and Verosta. The former, in the second edition of his treatise on Austria's neutrality, dealt comprehensively with the permanent neutral's peacetime obligation to avoid any economic association that might draw it into a conflict, ruled out EEC membership for a permanently neutral state, and briefly referred to the Swiss neutrality doctrine of 1954. Verosta contributed to the latter's "discovery" by publishing it in Austria and presenting it as binding. ${ }^{9}$

In lieu of "military neutrality," the neutral's task of actively promoting détente and peace was underlined. Waldheim's understanding of neutral policy, thus, was much closer to that of the Soviets than any earlier Austrian interpretation. Waldheim was treated with striking approval in the Soviet media and his understanding that neutrality comprised more than just military obligations was highly praised. ${ }^{10}$ Although Klaus continued to reject the Soviet interpretation of "peaceful coexistence" as "a continuation of the ideological struggle" and "an active dissemination of ideology," Waldheim, by equating neutrality with an active peace policy, thus, from 1968 on, adopted two further key aspects of the Soviet doctrine, anticipating the developments of the 1970s. In his book The Austrian Example, he went as far as equating "peaceful coexistence" with détente and adopting the Soviet topos of Austria's role as being a showcase for the former. ${ }^{12}$ During the Czechoslovakian crisis, Klaus and Waldheim furthermore tried to make public statements more "neutral" with regard to the Soviet Union. While the Austrian parliament, in the wake of the crisis, reasserted its right of defining neutrality, ${ }^{13}$ the year 1968 created a "watershed" in Austrian neutrality policy, ${ }^{14}$ and though not publicly acknowledged, it was a turning point due, at least in part, to Soviet policy.

9 Verdross, Die immerwährende Neutralität der Republik (1966), 15-20; Verosta, Die dauernde Neutralität (1967), 113-117.

${ }^{10}$ E.g., Polyanov, "Austria, Neutrality, Europe," 84-88. Cf. Petersson, The Soviet Union and Peacetime Neutrality, 89.

${ }^{11}$ Österreichische Zeitschrift für Außenpolitik 7 (1967), 224-228, 224; Ginther, Neutralität und Neutralitätspolitik, 58; Meier-Walser, Die Außenpolitik der monocoloren Regierung Klaus, 158 159.

12 Waldheim, The Austrian Example, 5.

${ }_{13}$ Ermacora, 20 Jahre österreichische Neutralität, 150.

${ }^{14}$ Ginther, Neutralität und Neutralitätspolitik, 43, 49, 52. For a discussion of Ginther's theses, see below, pages 254-255. Cf. Helmut Kramer, "Strukturentwicklung der Außenpolitik 1945-2005," in Herbert Dachs et al. (eds.), Politik in Österreich (Vienna: Manz, 2006), 807-837, 816. 


\section{DÉTENTE, THE HEYDAY OF MULTILATERALISM, AND THE LAST PEAK OF THE COLD WAR, 1973-1984}

"There is probably no policy so controversial, so subject to contrasting and contradictory treatment and interpretation, as neutrality." Efraim Karsh, Neutrality and Small States (London: Routledge, 1988), 1.

"If an elephant has its foot on the tail of a mouse, and you say that you are neutral, the mouse will not appreciate your neutrality. If you are neutral in situations of injustice, you have chosen the side of the oppressor." Archbishop Desmond Tutu 



\section{Political Relations and the Rise of Multilateralism}

The twenty-fourth CPSU congress in March-April 1971 and the adoption of the party's "Peace Program" marked Brezhnev's takeover of supremacy in his country's foreign policy. Although the reconciliation with West Germany and the signing of the Moscow Treaty of 1970 had briefly reminded Soviet citizens of the Hitler-Stalin pact and sparked fears around the country that a new war was imminent, ${ }^{1}$ détente became highly popular in the USSR. Brezhnev, like Gromyko, was convinced that a relaxation of international tensions best suited the interests of the USSR and its leadership. ${ }^{2}$ The popularity of détente among the Soviet population strengthened the CPSU's legitimacy, and the USSR's urgent need for high technology could not be met without Western partners and, thus, détente. Furthermore, the escalating conflict with the People's Republic of China made peace on the USSR's western border even more precious. Nonetheless, Brezhnev - who, despite a circle of a few young and enlightened thinkers in the Central Committee apparatus, some of whom later became Gorbachev's advisors, ${ }^{3}$ was surrounded by powerful hawks who demanded ever growing sums for the military-industrial behemoth - remained convinced that the unrestricted Soviet nuclear build-up that continued during the détente years promoted the relaxation of tensions rather than endangered it.

In the West the FRG, which Brezhnev became the first Soviet leader to visit, with its strong economic and financial basis, soon became the main trade and détente partner for the Soviet Union. In addition, with first steps at solving the US entanglement in the Vietnam War being taken, détente between the superpowers dawned. With North Vietnam's intransigence, the United States had been desperate to gain Soviet mediation for a diplomatic solution. The Kremlin, too, was interested in a rapprochement with the Western superpower. In 1969, the USSR had declared strategic parity with the United States and arms limitation negotiations seemed a wise choice. After President Lyndon B. Johnson's visit to Moscow in 1968 was cancelled due to the Warsaw Pact's invasion in Prague, ${ }^{4}$ the summit of 1972 witnessed the signing of the SALT-I and ABM treaties and the declaration of the Basic Principles of US-Soviet Relations. Back channel diplomacy with the FRG and the

\footnotetext{
${ }^{1}$ Edemskiy, "Dealing with Bonn," 21.

2 Zubok, A Failed Empire, 225, 203.

${ }^{3}$ Robert D. English, Russia and the Idea of the West: Gorbachev, Intellectuals and the End of the Cold War (New York: Columbia University Press, 2000), 119-157.

4 Adam Ulam, Dangerous Relations: The Soviet Union and World Politics, 1970-1982 (New York: Oxford University Press, 1983), 50-51.
} 
US had brought about something like personal trust between Brezhnev and Chancellor Brandt and, later, US President Nixon.

An indicator for the friendly international climate was the Conference on Security and Cooperation in Europe, one of Brezhnev's prestige projects, which was held in Helsinki and Geneva in 1972-75. But what had been expected to legitimize Soviet rule in Eastern Europe, to undermine Western organization, and to usher in a new era of East-West trade, also made human rights a growing concern for international relations and, in the long term, undermined rather than strengthened détente and the legitimacy of communist rule. ${ }^{5}$ Furthermore, as a consequence of détente and the CSCE, East and West became more interdependent. During the 1970s, the Western share of Soviet foreign trade rose from 14 to more than 30 percent. ${ }^{6}$ Western Europe became an importer of Soviet oil and gas and a provider of technology. The Kremlin calculated on some political consequences as a result of this interdependence: Oil and gas, Brezhnev revealed to his comrades in 1971, "change our possibilities, our relations to all of Europe (and not only to the socialist states where we can deliver gas and oil) - with France, with the FRG, Italy. We hold the keys." " What he did not envisage was that, in return, Eastern Europe became dependent on Western goods. Those who had no fossil fuels to offer in return, like Poland and Hungary, started to rely on Western credit.

Very much like the Moscow Treaty, détente, in Soviet eyes, was never seen to be a result of compromise, but of Soviet strength. ${ }^{8}$ The CPSU "Peace Program" reaffirmed "peaceful coexistence" in its already traditional communist meaning of a "specific form of class struggle in the international arena." Convergence between socialism and liberal capitalism was explicitly ruled out, and it was claimed that "for all mankind there is only one future - communism." The Soviet military preponderance in Europe was justified by the large civilian population of Western Europe. In general, the Soviet definition of "coexistence" remained a theoretical foundation for exactly what communist propaganda accused the West of: a continuation of the Cold War and a policy of "strength" and intimidation. ${ }^{10}$

${ }^{5}$ Daniel C. Thomas, The Helsinki Effect: International Norms, Human Rights, and the Demise of Communism (Princeton: University Press, 2001), 159-184.

${ }^{6}$ Gromyko and Ponomarjow, Geschichte der sowjetischen Außenpolitik 1945 bis 1976, 559.

7 Zapis' soveshchaniia po voprosu doklada TsK KPSS, 3 February 1971, in Kudriashov (ed.), General'nyi sekretar' L.I. Brezhnev, 96-113, 103.

${ }^{8}$ Aleksandrov-Agentov, Ot Kollontai do Gorbacheva, 186-187. Cf. L.I. Breshnew, Rechenschaftsbericht des Zentralkomitees der Kommunistischen Partei der Sowjetunion und die nächsten Aufgaben der Partei in der Innen- und Außenpolitik, Informationsbulletin Sonderausgabe 1 (Prague: Frieden und Sozialismus, 1976), 22.

9 Quoted in Michael S. Woslenskij, "Friedliche Koexistenz aus sowjetischer Sicht," in Osteuropa 23, no. 11 (1973), 848-855, 855. See also idem "Klassenkampf - Kalter Krieg - Kräfteverhältnis - Koexistenz," in Osteuropa 24, no. 4 (1974), 259-269, 264-265.

${ }^{10}$ For Western reactions to Voslenskii's article, see Klaus Mehnert, "Friedliche Koexistenz - Eine deutsche Meinung," in Osteuropa 24, no. 4 (1974), 270-274; and Gerhard Wettig, "Das sowjeti- 
In the wake of 1968, a growing number of Soviet theoreticians of international law aimed at theoretically underpinning the Brezhnev Doctrine of limited sovereignty of the socialist states; they shifted their attention to the differences between the sets of laws regulating the relations between capitalist states or capitalist and socialist states, on one hand, and those regulating the relations between socialist states on the other. This new stage in the Soviet development of the theory of international law was marked by the appearance of the second edition of Professor Tunkin's Theory of International Law. ${ }^{11}$ Despite the Soviet recognition of a single universal international law in 1955, the issue of "socialist international law" had been lingering in Soviet discussions ever since..$^{12}$ In the aftermath of the declaration of the Brezhnev Doctrine, the thesis was confirmed that neither general international law nor "peaceful coexistence" was applicable to relations between socialist states. These allegedly formed a higher stage of international relations and followed the rules of Socialist Internationalism, which were designed to preserve the "achievements of socialism" and foster the transition to communism. ${ }^{13}$

The neutrals, which had been able to contribute to a relaxation of tensions but not bring it about, remained determined to adhere to détente, as it widened their maneuvering room. ${ }^{14}$ However, in the age of détente and most probably as its consequence, the Soviet interest in neutrality and nonalignment declined. Once the USSR had established more friendly relations with the leading Western powers and the CSCE was convened, the European neutrals seemed less crucial as mediators and promoters of Soviet ideas. In the Third World, the nonaligned movement had not achieved the historic shift of power the Soviet Union seems to have expected. And last but not least, the "Prague Spring" had shown how feeble the cohesion of the Eastern bloc was, and promoting neutrality was seen as endangering this cohesion further. All of these developments were reflected in the decreasing number of official statements promoting neutrality and nonalignment. The reports to the twenty-fourth (1971), the twenty-fifth (1976), and the twenty-sixth (1981) CPSU congresses did not promote neutrality ${ }^{15}$ and the Diplomaticheskii Slovar' reduced

sche Koexistenz-Konzept: Grundlage eines friedlichen Verhältnisses zwischen Ost und West?," in Osteuropa 24, no. 3 (1974), 180-187.

${ }^{11}$ Gregorij I. Tunkin, Völkerrechtstheorie (Berlin: Berlin Verlag, 1972); Theodor Schweisfurth, "Einleitung," ibid., 9-19, 10-15.

${ }^{12}$ Schweisfurth, "Entwicklung und ideologische Grundlagen der sowjetischen Völkerrechtstheorie," 44-46.

${ }^{13}$ Meissner, Frenzke, Chilecki, Sowjetunion und Völkerrecht 1962 bis 1973, 16. On the genesis of the Soviet theory of socialist international law, see Theodor Schweisfurth, Sozialistisches Völkerrecht? Darstellung - Analyse - Wertung der sowjetmarxistischen Theorie vom Völkerrecht „,neuen Typs “ (Berlin: Springer, 1979), 182-220; on its contents, see ibid., 248-340.

${ }^{14}$ Bernard von Plate, Zur Position und Rolle der Neutralen Staaten in der Entwicklung der Europäischen Ost-West-Beziehungen (Eggenberg: Stiftung Wissenschaft und Politik, 1975), 4.

${ }^{15}$ XXIV. Parteitag der Kommunistischen Partei der Sowjetunion 30. März-9. April 1971: Dokumente (Moscow: APN, 1971); Breshnew, Rechenschaftsbericht [XXV. Parteitag]; XXVI. Parteitag der 
its coverage of neutrality, in its third edition published in 1971-73, from five pages to one. The nonaligned states' summit in Lusaka in 1970, which was attended by fifty-four countries, received only scanty coverage in Soviet media. This was also accompanied by a shift in the Soviet understanding of neutrality, whereby the gap between permanent neutrality and nonalignment was recognized more explicitly than before. 16 "Positive" or "active" neutrality was now equated by the USSR with neutralism or nonalignment, and proclaimed a characteristic of the emerging nations of the Third World, while permanent neutrality as maintained by Austria was no longer seen as a "form of peaceful coexistence." In addition, the growing assertiveness of the Kremlin convinced Soviet leaders that they should promote the interests of the USSR without being assisted by the neutrals, and more attention was given in Soviet statements to the differences between the neutral and socialist viewpoints. The problems the neutrals had created for the socialist camp at the CSCE might have been involved in these tendencies.

The decline in the Soviet interest in permanent neutrality did not mean, however, that the Soviet criticism of its allegedly improper implementation ceased. While in the following years, Austria, Sweden and Switzerland were criticized by the Soviet Union for not being neutral enough, paradoxically, Finland, from 1970 to 1989, was no longer recognized by the Kremlin as being neutral. ${ }^{17}$ The Soviet tactic of including specific political wishes into an ever-growing list of alleged "legal obligations" of the neutrals continued: A monograph published in 1972 listed, in addition to the already well-known duty of "peaceful cooperation," other obligations of "neutral policy" such as the support of nuclear-weapon free zones in Europe, the struggle against the deployment of foreign (i.e. US) troops in Europe (in particular the Sixth US Fleet), the struggle for the liquidation of NATO, the recognition of the GDR, the maintaining of systematic consultations at interparliamentary and intergovernmental levels, and economic cooperation with socialist states. ${ }^{18} \mathrm{In}$ order to balance out such obligations, the publication named numerous "special entitlements" of neutrality, which was praised as the "highest form of sovereignty." These included a "right to jurisdiction," a "right to honor," and other trivialities. ${ }^{19}$ Likewise, the Soviet tradition continued of criticizing permanent neutrals for their unwillingness to fulfill such "obligations" or to recognize specific aspects of Marx-

KPdSU: Rechenschaftsbericht des Zentralkomitees der Kommunistischen Partei der Sowjetunion und die nächsten Aufgaben der Partei in der Innen- und Außenpolitik, Berichterstatter: L.I. Breshnew, Generalsekretär des ZK der KPdSU, 23. Februar 1981 (Berlin: Dietz, 1981).

16 "Neitralitet," in A.A. Gromyko, I.N. Zemskov, V.M. Khvostov (eds.), Diplomaticheskii slovar' 2, 3rd ed. (Moscow: Politizdat, 1971), 373-374; "Neprisoedineniia politika," ibid., 379-380; "Neutrality," in A. M. Prokhorov et al. (eds.), Great Soviet Encyclopedia 17, 3rd ed. (New York: Macmillan, 1974), 518-519. Cf. Vigor, The Soviet View, 191-194.

${ }^{17}$ See above, page 170 .

${ }^{18}$ Iu. M. Prusakov, Neitralitet v sovremennom mezhdunarodnom prave (Moscow: Znanie, 1972), 60.

${ }^{19}$ Ibid., 13-14, 20, 28. 
ism-Leninism, such as the theory of "just wars." ${ }^{20}$ While it was seen disapprovingly "that the European permanent neutrals do not follow the principle of maintaining an active peace-loving policy and prefer to remain inactive and stand to the side in this regard, contradicting their international legal status," ${ }^{21}$ Switzerland had to bear the brunt of the criticism. It was attacked for maintaining an army that was considered too large for a neutral state and for having failed to establish real relations with the socialist states. In the Austrian case, the alleged violation of neutrality during the Hungarian uprising 1956, violations of the state treaty articles 9 and 12 regarding neo-Nazism and rearmament, and anti-Soviet propaganda were cited in the "book of sins." Despite such flaws, it was concluded that, "notwithstanding the cases of reactionary circles in and around Austria violating its international status of neutrality, the latter has passed the examination of time and become one of the factors preserving peace in the center of Europe." ${ }^{22}$

Kreisky, "active neutrality," and Austrian-Soviet relations

In 1970, the Austrian social democrats won the elections and Bruno Kreisky became chancellor. ${ }^{23}$ Although the Kremlin in general preferred broad and stable coalition governments in Austria, and in 1966 the Soviet press had harshly criticized the formation of Klaus' "unicolored" cabinet, nothing of the like was expressed four years later. This was most probably due to the Soviet confidence in Kreisky's planned course. As foreign minister during the late 1950s and the 1960s, Kreisky had earned a certain amount of credit among Soviet diplomats for his cautious position with regard to Austria's European ambitions, ${ }^{24}$ and even prior to that, for his commitment to strengthening détente. This is not to say that Kreisky and his party were not regularly reproached by Soviet propaganda on ideological grounds, for the SPÖ's reluctance to implement the revolutionary parts of its program, or for its critical statements about Soviet policy. ${ }^{25}$ In a conversation during Khrushchev's visit to Austria in 1960, the Soviet leader had repeated this type of ideological criticism and even accused the Austrian minister of being "an ally of the West" in the

${ }^{20}$ V.I. Lisovskii, Mezhdunarodnoe pravo (Moscow: Vysshaia shkola, 1970), 428.

${ }^{21}$ Prusakov, Neitralitet $v$ sovremennom mezhdunarodnom prave, 24, 23, 32.

${ }^{22}$ Ibid., 43, 38.

${ }^{23}$ For a brief biography, see Wolfgang C. Müller, "Bruno Kreisky," in Herbert Dachs, Peter Gerlich, Wolfgang C. Müller (eds.), Die Politiker: Karrieren und Wirken bedeutender Repräsentanten der Zweiten Republik (Vienna: Manz, 1995), 353-365.

${ }^{24}$ Report Obshchii rynok i Avstriia, 26 September 1966, in AVPRF, 66/45/96/20, 31-37.

${ }_{25}$ G. Ardajew, "Eine Schlappe der österreichischen Revisionisten," in Neue Zeit, no. 23 (1958), 6-8; Vikenti Matwejew, "Wo liegen die Perspektiven?," ibid., no. 39 (1970), 18-19; W. Tschernoussow, "Vokabular von gestern," ibid., no. 14 (1974), 23; Hinteregger to Austrian MFA, 19 October 1978, in SBKA, UdSSR 4, Sammelakt. On several occasions, such as on 10 March 1971, in the summer of 1976, and in December 1979, Izvestiia and Radio Moscow criticized Kreisky's anticommunism. 
Austrian cabinet. ${ }^{26}$ Kreisky, indeed, had been an anti-communist and an Atlanticist, convinced that Containment had fostered détente and that steadfastness was needed to counter Soviet pressure (a conviction that had served him well in his clashes with Raab, Khrushchev and Gromyko). ${ }^{27}$ Kreisky's staunch pro-Americanism seemed not to have deterred Soviet diplomacy from using him for certain missions - on the contrary: Whenever Khrushchev wanted a secret proposal or other statement be communicated or leaked to the US, he felt that Kreisky was the right man for the job. ${ }^{28}$ Moreover, Kreisky's broad interpretation of his country's obligations arising out of neutrality as well as his active promotion of détente dovetailed with Soviet expectations concerning Austria's role. Due to these expectations, Kreisky's international activism, and his friendship with Willy Brandt, the Austrian foreign minister had been approached by the Soviet side as a "diplomatic postman" in the Berlin crisis - although, as it turned out, without success. ${ }^{29}$ His image in the Kremlin seems nevertheless to have remained undamaged by this letdown. When, at the West German social democrats' conference in Munich in November 1960, Kreisky publicly advocated cooperation between socialist and capitalist states, the Soviet ambassador, in a letter to Deputy Foreign Minister Vladimir Semenov, recommended "that Kreisky [...] be told in Vienna that he has made a contribution to good international relations and that this is very much appreciated." ${ }^{30}$ Kreisky had also expressed in Munich his personal trust in the sincerity of the USSR's strategy to reach its goals by peaceful means - a belief that he later repeated in an interview in which he stated that the Soviet peace initiatives were not just "a communist maneuver aiming at the deception" of the West, but "corresponded to the true needs and wishes of the Soviet Union." ${ }^{31}$ Although Kreisky's contribution to the solution of the Cuban missile crisis was not his own initiative, he nevertheless supported journalist Walter Lippman's proposal of a rocket trade-off between Soviet missiles in the Caribbean and US Jupiter missiles in Turkey. ${ }^{32}$ It comes therefore hardly as

${ }^{26}$ Kommuniquéverhandlungen, July 1960, in ÖStA, AdR, BMAA GZ. 70033-6/60, Z. 79965$6 \mathrm{pol} / 60$. This characterization paralleled the assessment of the US ambassador to Austria, who in 1961 considered Kreisky to be "the strongest bulwark we have in Austria." Kofler, Kennedy und Österreich, 82 .

${ }^{27}$ Höll, "The Foreign Policy of the Kreisky Era," 36-40; Pape, Ungleiche Brüder, 479-481. Cf. Bruno Kreisky, "Neue Perspektiven der politischen Ordnung in Mitteleuropa: Rede vor der EuropaUnion in Basel am 3. April 1968," in idem, Neutralität und Koexistenz, 124-134, 125. Kreisky's Atlanticism and his critical attitude towards convergency were appreciated by the West German conservative diplomat Helmut Allardt, Moskauer Tagebuch: Beobachtungen, Notizen, Erlebnisse, 3rd ed. (Düsseldorf: Econ, 1973), 295; 387. For his clashes with Raab, Khrushchev, and Gromyko, see above, page 120, 129.

${ }^{28}$ Nikita Khrushchev, Khrushchev Remembers: The Last Testament, ed. by Strobe Talbott (Boston: Little Brown, 1974), 501.

${ }^{29}$ See above, pages 105-106.

${ }^{30}$ Soviet embassy Bonn to Soviet MFA, 23 November 1960, in AVPRF, 66/39/79/23, 1-6.

${ }^{31}$ Kreisky, Neutralität und Koexistenz, 122.

32 Kofler, "Kreisky - Brandt - Khrushchev," 179-180. 
a surprise that the SPÖ, when forming a minority government in 1970, was not attacked by the Soviet press and received praise and blessings from even the Austrian communists - something that would not have been possible ten years earlier. However, on the occasion of Kreisky's inauguration, both the Austrian-communist Volksstimme as well as Izvestiia issued the traditional warnings that Austria was not to deviate from its traditional path of foreign policy. ${ }^{33}$

Kreisky's attitude that an active and, on occasion, mediatory role in international politics was of the highest priority and the most effective tool of Austrian foreign and defense policy was in alignment not only with Austria's security interests as defined by prominent experts in international law, ${ }^{34}$ but also with the Soviet understanding of Austria's role as a neutral. The growing convergence of Soviet and Austrian interests with regard to foreign policy activism was reflected by the Austrian government's adoption of the Soviet thesis that a neutral country "cannot be content with the role of merely observing foreign development," as expressed in Kreisky's 1979 government policy statement. ${ }^{35}$ Even earlier, his SPÖ - albeit unsuspectingly - had subscribed to the concept of "active" neutrality.

In the early 1970s, with progressing détente the expression of "peaceful coexistence," once anathema in the West because of its Janus-faced character and its declared aim of promoting the transition of the West to communism, became part of the vocabulary in East-West declarations. Notwithstanding a number of Austrian gaffes, such as that committed during the 1960 Khrushchev visit, the term had been cautiously circumscribed in the West and in UN declarations during the 1960s as "peaceful and friendly relations" or even "cooperation," 36 as for instance in the UN "Declaration on Principles of International Law Concerning Friendly Relations and Cooperation among States" of 24 October 1970, which the Soviet side claimed to contain the principles of "peaceful coexistence." ${ }^{37}$ However, in the wake of détente, the term had been adopted by Austrian and other Western diplomats. ${ }^{38}$ Kreisky himself, who was well aware that the term was ambivalent and full of "meaningless and misleading" interpretations, nevertheless, in the spring of 1968, praised "peaceful coexistence" for having ended the Cold War in Europe.${ }^{39}$ During his visit to Moscow in January 1971, Foreign Minister Kirchschläger claimed that "the maxim of Austria's foreign policy remains peaceful coexistence," 40 the Prin-

${ }^{33}$ Moser, "Die Stellung der Kommunistischen Partei Österreichs," 48.

${ }^{34}$ Cf. Zemanek, "Austria's Policy of Neutrality," 20; Neuhold, "The Permanent Neutrality," 56.

${ }^{35}$ Quoted in Haymerle, "Die Beziehungen zur Großmacht im Osten," 189.

${ }^{36}$ Lewin, "Grundprinzipien des modernen Völkerrechts," 74. For a critical analysis of the content and development of "peaceful coexistence" from 1956 until the mid-1970s, see Standenat to Austrian MFA, 22 December 1975, in ÖStA, AVA, NL Bielka, File 115.

${ }^{37}$ Schweisfurth, "Einleitung," 15-16.

${ }^{38}$ Ginther, Neutralität, 99-105; Verdross, Die immerwährende Neutralität Österreichs, 75-79.

39 Bruno Kreisky, "Neue Perspektiven der politischen Ordnung in Mitteleuropa: Rede vor der Europa-Union in Basel, 3 April 1968," in idem, Neutralität und Koexistenz, 124-134, 125.

40 Österreichische Zeitschrift für Außenpolitik 11 (1971), 46. Cf. the communiqué ibid., 48. 
ciples of Relations between the USSR and France of the same year also used the once forbidden term, and the Basic Principles of US-Soviet Relations, signed by Richard Nixon and Brezhnev in 1972, even stated that there was "no alternative to conducting the mutual relations on the basis of peaceful coexistence." ${ }^{\prime 1}$ Kreisky's statement that the alternative to "peaceful coexistence" was "nonexistence" 42 - a notion that had its genesis in Soviet propaganda - had become mainstream opinion; later Austrian diplomats and leaders would repeat the Soviet claim that AustrianSoviet relations had been the "first example" of "peaceful coexistence." ${ }^{33}$ Kreisky himself adopted the Soviet terminology when he stated that "the importance of all these [mutual] visits went far beyond the framework of our bilateral relations: By means of the Austrian example, peaceful coexistence was demonstrated and further détente induced." ${ }^{4}$

With the beginning of the new West German Ostpolitik under Willy Brandt, it became easier for Austria to continue its Nachbarschaftspolitik, though it was less exclusive..$^{45}$ Already in 1967 the FRG had offered the "people's democracies" full diplomatic relations, thus, de facto abandoning the Hallstein Doctrine. ${ }^{46}$ After Brandt's rise to leadership in Bonn, Foreign Minister Rudolf Kirchschläger stressed in 1970 that his country was now "in the happy position of no longer having to make special mention of Ostpolitik as such." ${ }^{\prime 47}$ During Kreisky's chancellorship, Austria's travel diplomacy to Eastern Europe was intensified and the government's center of gravity shifted somewhat in this direction. In the years 1956-69, the Aus-

${ }^{41}$ Quoted in Tunkin, Theory of International Law, 72-73. On the two declarations, cf. Heinz Fiedler, "Politische Verträge mit westlichen Staaten und Entwicklungsländern," in Dietrich Geyer (ed.), Osteuropa-Handbuch Sowjetunion Außenpolitik III: Völkerrechtstheorie und Vertragspolitik (Cologne: Böhlau, 1976), 194-223, 203-205. On US-Soviet détente, see Sovetsko-amerikanskie otnosheniia: gody razriadki, 1969-1976: sbornik dokumentov (Moscow: Mezhdunarodnye otnosheniia, 2007), on the US-Soviet memorandum, cf. Raymond L. Garthoff, Détente and Confrontation: American-Soviet Relations from Nixon to Reagan, 2nd ed. (Washington, DC: Brookings Institution, 1994), 326-335.

${ }^{42}$ Bruno Kreisky, Voraussetzungen der Koexistenz (Freiburg im Breisgau: Rombach, 1960), 9. Cf. Mojoryan [Modzhorian], "Neutrality in Present-Day International Law," 218: "The only alternative for mankind is peaceful coexistence or catastrophic thermonuclear war."

${ }^{43}$ Conversation Kreisky with Kosygin, Vienna, 2 July 1973, in SBKA, Länder, UdSSR 4; Protokoll über den bilateralen Meinungsaustausch, 12-13 June 1975, in ÖStA, AdR, II-Pol, Z. 225.18.02/12-II.3/75.

44 Ansprache Kreisky in Moskau, 28 May 1974, in UdSSR - Österreich, 165-167. Emphasis mine.

${ }^{45}$ Alexander Jehn, "Nachbarschaftspolitik im Donauraum: Die besonderen Beziehungen Österreichs zur Tschechowakei, zu Ungarn und Jugoslawien in der Ära Kreisky" (PhD thesis, Würzburg: 1996). Cf. Bielka, "Österreich und seine volksdemokratischen Nachbarn."

${ }^{46}$ In 1967, diplomatic relations were established with Romania and Yugoslavia. Loth, Overcoming the Cold War, 92-94. On Brandt's Ostpolitik, cf. Peter Bender, Die Neue Ostpolitik und ihre Folgen (Munich: dtv, 1995); on the GDR's viewpoint, cf. Mary E. Sarotte, Dealing with the devil. East Germany, détente, and Ostpolitik, 1969-1973 (Chapel Hill: University of North Carolina Press, 2001).

${ }^{47}$ Die Presse, 6 June 1970. 
trian president, chancellor and foreign minister paid 159 official visits to OEEC (OECD) states and only 64 to CMEA members, but in the years 1970-84 the score had become 153 to $113 .{ }^{48}$ Although no Austrian chancellor ever challenged Finnish president Kekkonen's record of thirty-one visits to the USSR, ${ }^{49}$ Josef Staribacher, Kreisky's minister of commerce, paid seventeen official visits to the Soviets, but failed to travel to the United States a single time. ${ }^{50}$ While this record can be explained, to a certain extent, as being the result of the bilateral trade commission sessions, it also reflects a shift in Austria's economic interests.

On the bilateral level, during the Kreisky years, which were undoubtedly the most active period of Austrian foreign affairs since 1955, ${ }^{51}$ the exchange of highlevel visits in a demonstratively friendly atmosphere between Moscow and Vienna continued. Negotiations dealt with bilateral political, economic, and cultural relations as well as exchanges of opinion concerning the international situation, détente, disarmament, the UN agenda and the CSCE.

During Kosygin's visit to Vienna in July 1973, both sides expressed their wish to raise the level of the bilateral cooperation and to intensify the exchange of information. A number of agreements were signed, including a treaty on economic, scientific-technical and industrial collaboration, and a program on bilateral cultural and scientific cooperation. With regard to the CSCE, Kosygin expressed the Soviet hope for Austrian "cooperation" (i.e. its support for Soviet proposals) and stated that the conference would be successful only if all participants "accepted European reality as it is," many. The communiqué praised the importance of the state treaty and neutrality for détente, the deepening of the bilateral ties, and the open and trusting atmosphere of the talks. ${ }^{53}$ Kosygin's arrival was interpreted in Vienna as proof that the neutrals' free-trade agreements with the EEC in 1972 had not damaged Soviet-Austrian relations. During the official talks, the premier had not touched upon the EEC issue; only in a press conference, in response to a question posed by a journalist, did Kosygin refer to the Soviet-Austrian exchange of memoranda confirming that the Austrian arrangement with the Common Market did not contradict neutrality or

${ }^{48}$ Skuhra, "Austria and the New Cold War," 123.

${ }^{49}$ Kari Möttölä, "Managing the Finnish-Soviet Relationship: Lessons and Experiences," in Bo Huldt and Atis Lejins (eds.), European Neutrals and the Soviet Union (Stockholm: The Swedish Institute of International Affairs, 1985), 35-57, 51.

${ }^{50}$ Karsh, Neutrality and Small States, 153.

${ }^{51}$ Höll, "The Foreign Policy of the Kreisky Era," 53.

52 Ansprache Kosygin in Wien, 2 July 1973, in UdSSR - Österreich, 149-152. Cf. Conversations Kreisky with Kosygin, Vienna, 2-3 July 1973, in SBKA, Länderboxen, UdSSR 4.

${ }^{53}$ Offizieller Besuch des Herrn Bundeskanzlers in der Sowjetunion, May 1974, in SBKA, Länderboxen, UdSSR 3. The communiqué is printed in Vneshniaia politika 1973, 85-89. See also Österreichische Zeitschrift für Außenpolitik 13 (1973), 225-229. Cf. the Soviet draft communiqué in Austrian embassy Moscow to Austrian MFA, Kommuniquévorschlag, 26 June 1973, in ÖStA, AdR, BMAA, II-Pol, GZ. 32.376-6/73, Z. 40.810. 
the state treaty ${ }^{54}$ That in the coming years the Kremlin reduced the intensity of its demand that neutrals maintain economic equidistance from both economic blocs might be attributed to the fact that the USSR, due to exports of natural gas, in the 1970s achieved an active trade balance with Western Europe. ${ }^{55}$ On the occasion of the fiftieth anniversary of the establishment of diplomatic contacts between Austria and the Soviet state, the latter's prime minister, in his congratulatory telegram, characterized the relations as having "passed the test of time" and as being "consolidated and multifaceted." ${ }^{56}$ On the twentieth jubilee of the signing of the state treaty, Radio Moscow mentioned the continuous improvements in the relations and stated: "The Soviet Union and the Republic of Austria are, despite differing historical fates and social systems, united by a wide circle of mutual interests in various areas, including politics, economy, and culture."

Kreisky's return visit to Moscow from 28 May to 1 June 1974 was primarily economically motivated. A slight shadow was cast on the trip - but not, as one would have expected, by the presence in the Austrian delegation of the right-wing Freedom Party's chairman and former SS Obersturmführer Friedrich Peter, whose unit had taken part in the mass murder of thousands of Soviet Jews during World War II. ${ }^{57}$ The clouds over the meeting were caused by Austrian newspaper reports on the Warsaw Pact's alleged Polarka war plan, which had been revealed to the West by a Czech defector, Major General Jan Šejna. The plan foresaw a Warsaw Pact attack on Yugoslavia through Austria. ${ }^{58}$ As usual in such cases, the Eastern bloc denied the message and attacked the messenger. Although Kreisky remained firm and stated that the Austrian government neither could nor would exert censorship on the Austrian media, the negotiations ended positively. Another stumbling block was Kreisky's insistence that the CSCE would not come to a successful conclusion if a satisfactory solution for the neutrals' demands regarding human contacts was not found. ${ }^{59}$ Due to a "diplomatic cold," which was most probably caused by such differences, a meeting with Brezhnev was cancelled on short notice by the Soviet

${ }^{54}$ Pressekonferenz Kosygin, 5 July 1973, in ÖStA, AdR, BMAA, II-Pol, GZ. 32.376-6/73; Protokoll über das Arbeitsgespräch mit MP Kosygin, 2-3 July 1973, ibid., Z. 42.521.

${ }^{55}$ Scarlis, Neutralität, 150-152.

${ }^{56}$ Offizieller Besuch des Herrn Bundeskanzlers in der Sowjetunion, May 1974, in SBKA, Länderboxen, UdSSR 3.

${ }^{57}$ Peter had already traveled to the USSR at an earlier point in time. Reise von Klubobmann Peter, 22 Dezember 1972, ÖStA, AdR, BMAA, II-Pol, GZ. 152.498-6/72, Z. 168.496. In 1970-71, Peter's FPÖ had supported Kreisky's minority government. In 1975, Simon Wiesenthal published documents on Peter's war-time past. Kreisky reacted by accusing Wiesenthal of using "mafia methods" and of collaboration with the Nazis. In 1992, Peter left the FPÖ in protest against Jörg Haider and the party's anti-EU line.

${ }^{58}$ The plan was published in Austrian journals in 1974. Its authenticity, however, remained questioned. Harrod, "Felix Austria," 737-740.

${ }^{59}$ Conversation Kreisky with Kosygin, 31 May 1974, in SBKA, NL Thalberg, Depositum 1, Box 2, File 3; Scarlis, Neutralität, 119. 
side. Nonetheless, Gromyko praised the "positive role" of the neutrals in preparing the $\mathrm{CSCE},{ }^{60}$ and the bilateral communique underlined the quality of the bilateral relations and the importance of the subjects touched upon in the talks. These included the agenda of the United Nations, peace enforcing measures, security in Europe, as well as arms limitation. ${ }^{61}$

When Kreisky went to Moscow in February 1978, he was granted the honor of being received by Brezhnev, who remarked that the two sides had found "a common language." ${ }^{\prime 62}$ The CPSU secretary used the occasion for repeating the Soviet praise for the state treaty being a catalyst for European détente, and stressed that on the whole it was in the best interests of small countries to support the CSCE process and resist all attempts at the Cold War being re-launched. ${ }^{63}$ Despite such encouragement, Brezhnev did not conclude the meeting with Kreisky without polemicizing against Western insistence on improved standards of human rights, or without calling on the chancellor to join the struggle against the deployment of US neutron warheads in Europe. In the draft communiqué, the Soviet side made an attempt to put Austria at the front of the Soviet propaganda chart against Western rearmament and in favor of Soviet proposals at the Belgrade CSCE meeting. The Austrian delegation, however, saw through this tactic, and the Soviet draft was modified. ${ }^{64}$ The CPSU secretary later agreed to hold the SALT-II signing ceremony and the summit meeting with Jimmy Carter in June 1979 in the Austrian capital.

In May 1975 and 1980, Andrei Gromyko attended the ceremonies on the occasion of the twentieth and twenty-fifth anniversaries of the signing of the state treaty in Vienna. ${ }^{65}$ Prime Minister Nikolai Tikhonov visited Austria from 6 to 10

${ }^{60}$ Quoted in Zhiriakov, SSSR - Avstriia, 102. Cf. Speech Kosygin in the Austrian embassy, May 1974, in AVPRF, 66/53/114/12, 64-67.

${ }^{61}$ Wortlaut des sowjetisch-österreichischen Kommuniqués, 31 May 1974, in Österreichische Zeitschrift für Außenpolitik 14 (1974), 182-186; Vneshniaia politika 1974, 71-76. Cf. Haymerle, "Die Beziehungen zur Großmacht im Osten," 170-171; F. Gorjunow, "Ersprießliche Bilanz," in Neue Zeit, no. 23 (1974), 16.

${ }^{62}$ Conversation Kreisky with Brezhnev, [February 1978], in SBKA, Länderboxen, UdSSR 3. For a summary of Brezhnev's statement, see pages 330-333.

${ }^{63}$ Cf. Igor Melnikov, "Partner im Alpenland," in Neue Zeit, no. 7 (1980), 12-13.

${ }^{64}$ Information, [February 1978], in SBKA, Länderboxen, UdSSR 4, File Moskaureise; Aus dem sowjetisch-österreichischen Kommuniqué, 9 February 1978, in UdSSR - Österreich, 190-192; Vneshniaia politika 1978, 12-15. Cf. Conversation Kreisky with Kosygin, 7 February 1978, in SBKA, Länderboxen, UdSSR 4, File Moskaureise.

6525 Jahre Staatsvertrag: Protokolle des Staatsaktes (Vienna: Österreichischer Bundesverlag, 1981); 25 Jahre Staatsvertrag: Protokolle des wissenschaftlichen Symposions (Vienna: Österreichischer Bundesverlag, 1981). Gromyko's speech is also printed in Vneshniaia politika Sovetskogo Soiuza i mezhdunarodnye otnosheniia 1980 (Moscow: Mezhdunarodnye otnosheniia, 1981), 67. On Kreisky's conversation with Gromyko in Vienna in May 1980 on issues concerning Afghanistan, the Near East, and the United States, see Hinteregger, Im Auftrag Österreichs, 260-263. 
April 1981, in his first (and only ${ }^{66}$ ) journey as an incumbent Soviet head of government to a Western country. During his trip, both sides lauded the high level of the talks, stating that they were the "result of the permanent efforts of both sides, their joint interest in mutually profitable cooperation, and the high esteem held by the Soviet and Austrian peoples towards one another." ${ }^{67}$ As usual, the state treaty and Austria's neutrality were stressed as positive phenomena, and agreement regarding various international issues was emphasized. The resumption of the Soviet leaders' habit of choosing Austria as the destination of their first Western visit was quite telling with regard to the cooling of East-West relations, since during détente Kosygin and Brezhnev had broken with the tradition and chosen France instead. ${ }^{68}$

In the years 1979-83, visits were paid to the USSR not only by the Austrian foreign minister, but also by the ministers of defense, of transport and communications, of trade, commerce and industry, of agriculture and forestry, of social affairs, and of building and technology. ${ }^{69}$ Until then, i.e. from 1955 until 1978, no less than twelve mutual visits had been undertaken by the Austrian and Soviet heads of state and government, by foreign ministers, as well as party leaders - and this number does not include the dozens of trips by various other ministers and delegations. In 1981 and 1982, trips were undertaken on the Austrian side by Kirchschläger as federal president, ${ }^{70}$ a parliamentarians' delegation, four delegations of different provincial administrations, a group of VOEST-Alpine representatives and a group of Austrian bankers that included the former minister of finance Hannes Androsch and the later chancellor Franz Vranitzky. ${ }^{71}$

After Kreisky stepped down in 1983, his successor, Fred Sinowatz, was welcomed in Moscow a few months later. ${ }^{72}$ Sinowatz had paid his first foreign visit as chancellor to the "people's democracy" Hungary, a fact that was very well received in Moscow. The Hungarian ambassador expressed to his Soviet colleague his high opinion of this "intelligent and knowledgeable politician with great diplomatic talent," ${ }^{73}$ a politician who, at home, never managed to escape the shadow of Kreisky and was subjected to mockery about his clumsiness.

${ }^{66}$ Hinteregger, Im Auftrag Österreichs, 236.

${ }^{67}$ Quoted in I.G. Zhiriakov, SSSR i Avstriia posle Khelsinki (Moscow: Molodaia gvardiia, 1983), 13. Cf. the communiqué, 11 April 1981, in Vneshniaia politika Sovetskogo Soiuza i mezhdunarodnye otnosheniia 1981 (Moscow: Mezhdunarodnye otnosheniia, 1982), 27-30.

${ }^{68}$ Oudenaren, Détente in Europe, 77.

${ }^{69}$ Neuhold, "Austria and the Soviet Union," 95.

${ }^{70}$ See the communiqué, 30 May 1982, in Vneshniaia politika Sovetskogo Soiuza i mezhdunarodnye otnosheniia 1982 (Moscow: Mezhdunarodnye otnosheniia, 1983), 41-43. Cf. Sowjetunion heute 28, no. 7-8 (1982), 8-11.

${ }^{71}$ Außenpolitischer Bericht (1982), 401-402.

72 Österreichisches Jahrbuch für internationale Politik 1 (1984), 216-217.

${ }^{73}$ Conversation Ambassador Efremov with Ambassador Rande, 21 November 1983, in AVPRF, 66/62/135/8, 4-9. Mikhail T. Efremov was the Soviet ambassador in Austria from 1975 until 
In general, during the 1970s Soviet-Austrian relations were described by both sides as "friendly" or even "excellent." The passage concerning Austria in Brezhnev's report to the twenty-fifth CPSU congress in 1976 read: "In general, our relations to the West European countries can be assessed positively. This also regards our relations to Great Britain and Italy. In addition we appreciate the traditional good-neighborly relations with Finland, the Scandinavian countries, Austria, Belgium and the other European states." ${ }^{.74}$ An Austrian report listed the characteristics used by the Soviet side to describe Soviet-Austrian relations: multifaceted, strong, generally good, ascending, developing well, and successful; the bilateral cooperation was characterized as broad, mutually beneficial, and fruitful. ${ }^{75}$ Brezhnev and Kosygin declared themselves "good friends of Austria," press regularly repeated the paradigm of Austria being an "example of peaceful coexistence." 77

\section{The USSR and Austria on the international stage}

While from 1955, Austrian politicians saw international activity promoting mutual understanding and détente as a means not only to raise their country's profile but also its security, the Kremlin's interest in the matter was twofold - first, to promote neutrality by boosting Austria's international prestige, and second, to gain the neutral country's support for Soviet initiatives. This included, as mentioned above, the Soviets drawing on Austria's good services as a mediator in the Berlin crisis. In 1965, the Austrian ambassador in Moscow had been used as a back channel for communicating Soviet proposals on Vietnam to the US embassy ${ }^{78}$ and in January 1966, after the British prime minister had announced his intention to hold talks in Moscow, a Soviet intermediary asked the Austrian embassy in Moscow to forward Soviet proposals regarding an extension of the current pause in the US bombing campaign in North Vietnam to Harold Wilson. ${ }^{79}$ The Soviet side, which had expressed the wish that the British embassy in Moscow not be informed, demanded that the US air raids and all troop transports to South Vietnam be ceased immediately, with no conditions. If this were done, North Vietnam would be prepared to start talks. In light of the recent visit to Hanoi by a Soviet delegation headed by

1986. For a short biography of Ambassador Efremov who had served as the Soviet ambassador to the GDR in 1971-75, see Kudriashov (ed.), General'nyi sekretar' L.I. Brezhnev 1964-1982, 230.

${ }^{74}$ Breshnew, Rechenschaftsbericht [XXV. Parteitag], 25.

75 Bilaterale politische Beziehungen Österreich - Sowjetunion, [1981], in SBKA, Länderboxen, UdSSR 5, File Offizieller Besuch des MP der UdSSR Tichonov, April 1981.

${ }^{76}$ Zhiriakov, SSSR i Avstriia v 1945-1975 gody, 50;

77 Stifter, "Das politische Österreichbild," 236.

${ }^{78}$ Caroline Kennedy-Pipe, Russia and the World (New York: Arnold, 1998), 131.

79 Telegram Wodak to Austrian MFA, top secret, 14 January 1966, in ÖStA, AVA, E/1785 Wodak, File 99/2; Telegram Bielka to Austrian embassy Moscow, 24 January 1966, ibid. 
CPSU Presidium member Aleksandr Shelepin, the Austrian embassy considered the offer genuine. Wilson communicated his interest in the proposals, despite their one-sidedness. Although the British premier's trip in July brought no success, the Soviet side remained interested in Austria's efforts in the Vietnam War. In March 1968, most probably on Soviet instructions, Hungarian diplomats arranged a meeting between North Vietnam's ambassador to Hungary, Hoang Luong, and Foreign Minister Waldheim in Vienna. When Waldheim mentioned the meeting in a conversation with Deputy Foreign Minister Vasilii Kuznetsov, the Soviet diplomat encouraged Waldheim to continue the Austrian mediation efforts. ${ }^{80}$

Another tactic for raising the neutral's profile and thus the prestige of neutrality, and for gaining Austria's support for Soviet proposals concerned the United Nations. Despite the Kremlin's variable attitude towards the UN, ${ }^{81}$ this organization was, over the decades, one of the most important forums for Soviet initiatives. Prior to the 1960s, the General Assembly had generally been balanced in favor of the West. In order to shift this balance of power, the USSR was interested in integrating the decolonized states of Asia and Africa into the UN, of which the majority were nonaligned. Neutral Austria was also part of this picture. Although in December 1955, the USSR, most probably for tactical reasons, had turned down a draft resolution outlined by Brazil and New Zealand concerning the admission of eighteen countries to the UN, among them Austria, the country was shortly thereafter admitted into the United Nations together with fifteen of these states. ${ }^{82}$ Both sides - Austria as a rule, the Soviet Union since 1955 and particularly following 1966 - were interested in raising the status of the United Nations, as was expressed in joint communiqués. ${ }^{83}$

${ }^{80}$ Conversation Waldheim with Kuznetsov, 20 March 1968, in ÖStA, AdR, BMAA, II-Pol, GZ. 110.044-6/68, Z. 115.353-6pol/68; Schlesinger, Austrian Neutrality in Postwar Europe, 129.

${ }^{81}$ Information für den Herrn Bundeskanzler, Die Evolution der sowjetischen Haltung in den Vereinten Nationen, [1974], in SBKA, Länderboxen, UdSSR, File Besuch des Herrn Bundeskanzlers in der Sowjetunion. Cf. Dallin, Die Sowjetunion und die Vereinten Nationen.

82 On 8 December the UN General Assembly recommended the accession of eighteen countries, among them Austria. Not included were divided states such as North and South Korea. In the Security Council, the delegate of the Republic of China (Taiwan) as a permanent member occupying the Chinese seat brought forward a motion regarding the accession of South Korea and South Vietnam. The USSR vetoed this motion, and China retaliated with a veto against the UN membership of Mongolia, thus inducing the USSR to veto the accession of all nonsocialist countries, including Austria. Only after the West had withdrawn Japan from the list of candidates did the USSR agreed on withdrawing Mongolia from the list, thus allowing the remaining sixteen countries to enter the UN. Strasser, Österreich und die Vereinten Nationen, 31-32. By blocking Japan's accession to the United Nations, it seems that the USSR wanted to retain leverage over the Western veto against the socialist nominees. Harto Hakovirta, East-West Conflict and European Neutrality (Oxford: Clarendon Press, 1988), 59.

${ }_{83}$ Wortlaut des gemeinsamen sowjetisch-österreichischen Kommuniqués, 31 May 1974, in Österreichische Zeitschrift für Außenpolitik 14 (1974), 182-186, 184. 
In order to lift the prestige of neutrality in the $\mathrm{UN}$ and to restrain the influence of the West in this organization, the USSR supported the Austrian candidacy for hosting the headquarters of the International Atomic Energy Agency (since 1956) and of the UN Industrial Development Organization (since 1967), as well as, in 1979, for becoming the location for the third seat of the United Nations. It also supported Austria's application for nonpermanent membership in the UN Security Council in 1973-74, and for Waldheim's candidacy as UN secretary general in 1971 and 1976. In 1960, at the height of his struggle to make the UN more "neutral," Khrushchev even proposed the transfer of the main UN headquarters from New York to Vienna. ${ }^{84}$ This proposal, however, was declined by the Austrian government. Although the United States did not agree with the Soviet suggestion to hold the 1955 summit in Vienna (so that neutrality would not be promoted for West Germany), ${ }^{85}$ with Soviet consent - and despite Khrushchev's preference for Helsinki ${ }^{86}$ - the Austrian capital was nonetheless chosen as the site for the Kennedy-Khrushchev summit in 1961, for the SAL and MBFR talks, for a Brezhnev-Carter summit including the SALT-II signing ceremony, for US-Soviet meetings of foreign ministers such as between Gromyko and Kissinger in 1975 and Gromyko and Shultz in 1985, another meeting between Gromyko and West German foreign minister Hans Dietrich Genscher at the height of the rearmament debate in 1983, a CSCE follow-up meeting in 1986-89, and for several major UN conferences. Naturally, some of the regular international gatherings commemorating the signing of the state treaty in the Austrian capital were also used for high diplomacy: US Secretary of State Dean Rusk discussed the situation in Vietnam when he met with his Soviet colleague in Vienna in 1965, and at the twenty-fifth anniversary of the state treaty, Secretary of State Edmund Muskie met with Gromyko the first time. ${ }^{87}$

The Soviet efforts to use Austria to promote communist initiatives, as well as to monitor Austria's viewpoint, included establishing regular bilateral talks that aimed at coordinating the two countries' foreign policies. These efforts to harmonize Soviet and Austrian approaches concerned various international questions, both within the United Nations and without. Although Austrian diplomats in the 1980s insisted that until then there had been only a single Soviet attempt to influence Austria's voting in the UN General Assembly, ${ }^{88}$ it cannot be ignored that, for

${ }^{84}$ Verclytte, "Austria between East and West," 113. On Austria's policy as a nonpermanent member in the UN Security Council, see Christian Pellegrini, "Die Rolle Österreichs im Sicherheitsrat der Vereinten Nationen: Möglichkeiten kleinstaatlicher Außenpolitik" (Vienna, MA Thesis, 1994).

${ }^{85}$ Stourzh, Um Einheit und Freiheit, 524.

${ }^{86}$ Khrushchev felt that "the Finns had a better understanding of our policy than the Austrians." Khrushchev, Khrushchev Remembers: The Last Testament, 492.

87 Anatoly Dobrynin, In Confidence: Moscow's Ambassador to America's Six Cold War Presidents 1962-1986 (New York: Times Books, 1995), 139, 456.

${ }^{88}$ Haymerle, "Die Beziehungen zur Großmacht im Osten," 153. This referred to a vote concerning the Hungarian crisis of 1956, when the USSR delegate told his Austrian colleague that casting a vote would not suit a neutral country. Cf. Rauchensteiner, Die Zwei, 346. 
the most part, the intensive bilateral Soviet-Austrian dialog on issues concerning the agenda of the United Nations had, from the Soviet side, this very aim: to influence Austria's voting. This went back to as early as May 1958, when the Soviet Foreign Ministry noted that Austria, during the 1956 and 1957 sessions of the UN General Assembly, had, "in a series of important international questions, adopted a position undesirable to us." "Similar criticism had been voiced by Deputy Foreign Minister Valerian Zorin, who, in a conversation with the Austrian ambassador in 1957, found fault with the voting behavior of Austria regarding the Soviet intervention in Hungary, behavior that, in his eyes, "destroyed the credit Austria had gained among the socialist states, who had hoped for more objectivity." ${ }^{90}$ Consequently, the Soviet embassy in Austria recommended "informing the Austrian government in advance of our position on those questions where support from Austria is desirable for us." ${ }^{91}$ This, the ministry argued, would not only result in Austria adopting certain Soviet positions, but would also be conducive to "separating Austria from the Anglo-American bloc." Discussions about the Austrian voting behavior in the UN became an issue that was regularly brought up by Soviet officials in their talks with the Austrian ambassador. Bischoff reported in 1959: "The Russians, doubtlessly, imagine that a solid Austrian policy of neutrality should find its expression in grosso modo balanced voting at crucial decisions over a certain period of time. ${ }^{.92}$ Indeed, a similar opinion was voiced by Soviet diplomats in the 1960 s, when they criticized that the Austrian vote was "too often for the West." ${ }^{\prime 93}$ After Austria, together with the majority of the UN General Assembly, had turned down the Mongolian proposal to condemn the US-supported landing of Cuban émigré forces in Cuba in April 1961, the Soviet delegate Valerian Zorin openly criticized the Austrian conduct as having left the course of neutrality ${ }^{94}$ Before the session, the Soviet ambassador in Vienna had solicited Austrian support for the motion. The Soviet criticism was repeated during Chancellor Gorbach's visit to Moscow. In a conversation with Kreisky, Gromyko claimed that the Austrian voting behavior did not conform with neutrality - a groundless allegation that was parried by the Austrian minister with his usual response that similar reproaches by certain Western states were proof of Austria's objectiveness. ${ }^{95}$

In general, however, the pattern emerged of Soviet diplomats communicating in advance which Austrian decision they hoped to see in the impending session of the General Assembly, be it for a Soviet draft declaration against Western military

\footnotetext{
${ }^{89}$ Lun'kov to Novikov, 26 May 1958, in AVPRF, 66/37/72/13, 9.

${ }^{90}$ Bischoff to Austrian MFA, 16 November 1957, ÖStA, AdR, AVA, NL E/1770: Bischoff, File 126.

${ }^{91}$ Lun'kov to Novikov, 26 May 1958, in AVPRF, 66/37/72/13, 9.

92 Bischoff to Austrian MFA, 17 October 1959, in ÖStA, AdR, BMAA, II-Pol, GZ. 236.711-pol/59, Z. 249.334 .

${ }_{93}$ Wodak to Kreisky, 6 August 1964, in ÖStA, AdR, BMAA, Pol. Berichte Moskau.

${ }_{94}$ Zhiriakov, SSSR i Avstriia v 1945-1975 gody, 62; Kofler, Kennedy und Österreich, 40, 106.

${ }_{95}$ Information, 1962, Kopie, in ÖStA, AVA, NL E/1736 Bielka, File 115.
} 
bases in the Third World in 1966, or for Soviet disarmament initiatives. ${ }^{96}$ A similar habit of alerting the neutral was acquired by other powers as well, in particular the United States. When neutrals like Austria and Sweden subscribed to Soviet projects, even if in a modified way as was the case regarding a declaration against colonialism in 1960, their support was widely propagandized in communist media ${ }^{97}$ Here, again, it was not only Austria itself that mattered to Soviet politicians; the small neutral was expected to serve as a model for similar Western states. Since Austria, due to the alphabetical order that ballots were cast, was among the first countries to vote, Soviet diplomats hoped, as was intimated by Gromyko to Waldheim, that its voting behavior might exert some influence on other permanent neutrals and small Western states..$^{98}$

Hence, in a growing number of cases, international issues were included on the agenda at bilateral Soviet-Austrian meetings. Although the most important Soviet attempt to use Austria as a promoter of Soviet ideas, encouraging it to call for the CSCE, failed, ${ }^{99}$ in other cases the Soviet side succeeded. In their March 1968 meeting, Gromyko pushed Waldheim to publish declarations regarding Vietnam and Israel. ${ }^{100}$ Both issues were included in the communiqué, albeit with modified wording. ${ }^{101}$ When the ministers met in New York later that year, Gromyko showed his interest in the Austrian attitude towards the Soviet proposals in the UN General Assembly and stated that the USSR expected many countries to follow the Austrian example. ${ }^{102}$ In order to make sure that Austria was aware of the Soviet position on various issues, two months later the Soviet minister proposed establishing regular consultations between Soviet and Austrian diplomats and political representatives. Waldheim agreed to the idea. But while Austria's opinions hardly had an effect on the superpower, these consultations bore the risk of the USSR exerting influence on the smaller neutral. ${ }^{103}$ Austria was the third Western country (following France and the United States) to establish such opinion exchanges with Soviet leaders on a regular basis. ${ }^{104}$

${ }^{6}$ Conversation Tončić-Sorinj with Gromyko, New York, 30 September 1966, Copy, in ÖStA, AVA, NL E/1736 Bielka, File 115; Austrian embassy Moscow to Austrian MFA, 21 September 1971, in ÖStA, AdR, BMAA, II-Pol, GZ., Z. 110.219-6/71.

${ }^{97}$ Haymerle to Kreisky, 17 January 1961, in ÖStA, AdR, BMAA, II-Pol, Pol. Berichte Moskau.

${ }^{98}$ Conversation Waldheim with Gromyko, New York, 23 September 1969, in ÖStA, AdR, BMAA, II-Pol. GZ. 164.082-6/69, Z. 165.373-6/69.

${ }_{99}$ See above, pages 162-171.

${ }^{100}$ Conversation Waldheim with Gromyko, 22 March 1968, in ÖStA, AdR, BMAA, II-Pol, GZ. 110.044-6/68, Z. 115.353-6pol/68.

101 Aus dem sowjetisch-österreichischen Kommuniqué, 24 March 1968, in UdSSR - Österreich, 134-136.

102 Telegram Austrian embassy New York to Austrian MFA, 24 September 1968, in ÖStA, AdR, BMAA, II-Pol, GZ. 164.082-6/69, Z. 164.089.

${ }_{103}$ Conversation Gromyko - Waldheim, 21 May 1968, in AVPRF 66/47/101/11, 49-56.

104 Zhiriakov, Sovetskii Soiuz - Avstriia, 104. 
Through the postwar years, Austria took a friendly position on many occasions towards Soviet initiatives. This is not to say that Austria always ceded to Soviet pressure. Nevertheless, as outlined above, there were a number of coinciding interests between the two states. In the debate on the question of colonies during the fifteenth session of the UN General Assembly, Austria explicitly welcomed the Soviet contribution to the subject - but this did not risk the alienation of too many countries, since the resolution was adopted by eighty-nine votes with nine abstentions. In the UN Economic Commission for Europe, which had repeatedly been used by the USSR in its attempt to contain and undermine the EEC, ${ }^{105}$ Austria also supported a number of Soviet proposals. ${ }^{106}$ Other cases of parallel positions existed with regard to the Soviet and Austrian assessments of détente and the Near East problem. ${ }^{107}$ In March 1960, the Austrian parliament welcomed the Supreme Soviet's 1959 initiative for disarmament, and the Austrian government, in many joint communiqués with the Soviet government, greeted disarmament as a political necessity. After the USSR, in the UN General Assembly in 1959, voted in favor of an Austrian-Swiss-Japanese initiative to call for a ban on nuclear tests, Austria, in return, 1960 declared its support of the respective Soviet proposal. Austria also took a positive stance towards the proposed nonutilization of force ${ }^{108}$ and nuclear nonproliferation, and in 1967 the neutral and the Soviet Union co-authored a draft resolution on these matters that was adopted in the twenty-second session of the UN General Assembly.

In some cases, the score was kept even by mutually supporting the other side's candidacies in the UN. After the USSR had promoted Waldheim's candidacy as a UN secretary general, Austria signaled support for the Belorussian candidacy for nonpermanent membership in the Security Council. ${ }^{109}$ On principle, the Austrian delegate to the UN General Assembly was instructed to vote according to "factual considerations," rather than with an eye to East-West bloc voting patterns. ${ }^{110}$ In a few cases, Austria voted with the East when the same was done by a large majority of states. In general, however, the country supported the West, albeit from the late 1960 s, voting with small Western states rather than with the US. When the Soviet Union, in the twelfth session of the General Assembly in 1957, brought forward a

${ }^{105}$ Mueller, "Die UdSSR und die europäische Integration," 636, 638, 651.

106 Zhiriakov, Sovetskii Soiuz - Avstriia, 44-47. Cf., on Soviet and Austrian positions in the UN, Information für den Herrn Bundeskanzler, Offizieller Besuch des Herrn Bundeskanzler in Moskau, 1974, in SBKA, Länderboxen, UdSSR 3.

107 Zhiriakov, SSSR - Avstriia, 66-69; 93; 149. Cf. Zhiriakov, SSSR i Avstriia v 1945-1975 gody, 59-72. On other topics of multilateral diplomacy, cf. N.I. Egorova and I.A. Aggeeva (eds.), Mnogostoronnaia diplomatiia $v$ gody kholodnoi voiny (Moscow: Institut Vseobshchei Istorii Rossiiskoi Akademii Nauk, 2008).

${ }^{108}$ Zhiriakov, Sovetskii Soiuz - Avstriia, 49.

109 Offizieller Besuch des Vorsitzenden Kosygin, 25 June 1973, in ÖStA, AdR, BMAA, II-Pol, GZ. 32.376-6/73, Z. 39.973-4a/73.

110 Strasser, Österreich und die Vereinten Nationen, 83-87; 92-106. 
draft resolution supporting "peaceful coexistence," which was opposed by Western states due to the ambiguous nature of the concept as a means for fostering the transition to socialism, an Indian-Yugoslav-Swedish draft that supported the "peaceful relations among states," but avoided the Soviet propaganda term, was adopted unanimously. Four years later, Austria - together with the West - rejected another attempt to make the idea mandatory. Soviet projects for reforming the United Nations into a more Soviet-friendly organization were also discarded by the European neutrals, including Finland. ${ }^{111}$ Furthermore, Austria did not support proposals sponsored by the Soviet Union and its satellites with regard to Cuba and Cambodia. In the case of the Soviet military interventions in Hungary, Czechoslovakia and Afghanistan, Austria tried to express its disapproval - very much in contrast to Finland, which abstained from voting against the Soviet Union in these instances. ${ }^{112}$ In 1973-74, Austria gave a positive appraisal of the Soviet proposal on banning nuclear weapons, supported another on a global conference on disarmament, but abstained from voting in a third case that proposed cutting defense budgets by 10 percent. ${ }^{113}$ Throughout the 1960 s, Austria abstained from supporting the accession of the People's Republic of China to the United Nations. When the risk of doing so had diminished, Austria - as one of the first Western countries - recognized the People's Republic of China in 1971 and the GDR in 1973, although in the latter case, only after the two German states had signed the Grundlagen treaty. ${ }^{114}$ Despite repeated Soviet interventions, Austrian foreign policy had - out of loyalty to the United States - hitherto rejected recognizing the communist regime in Beijing at the expense of Taiwan. ${ }^{115}$ Among the other neutrals, Sweden in particular was applauded by Soviet propaganda for championing the PRC's accession to the United Nations.

Although Austria's voting pattern in the UN General Assembly rarely coincided with the Soviet bloc, over the first twenty years of its membership, its voting record index, on a spectrum ranging from 0 (i.e. voting with the Soviet bloc) to 100 (i.e. voting with the United States), fell from 95 (1956) to 63 (1976), ${ }^{116}$ thus

${ }^{111}$ Haymerle to Kreisky, 28 November 1960, in ÖStA, AdR, BMAA, II-Pol, Pol. Berichte Moskau.

112 Hanhimäki, "The Lure of Neutrality," 269; Steve Lindberg, "Finnish Neutrality in a Changing Environment," in Bo Huldt and Atis Lejins (eds.), European Neutrals and the Soviet Union (Stockholm: The Swedish Institute of International Affairs, 1985), 7-34, 20.

${ }_{113}$ Materialy dlia peregovorov s kantslerom Avstrii Kreiskii, [30 April 1974], in AVPRF, 66/53/114/12, 86-95.

${ }^{114}$ Höll, "The Foreign Policy of the Kreisky Era,” 38; Ginsburgs, "Neutralism à la Russe," 34.

115 Kofler, Kennedy und Österreich, 108-109.

116 Neuhold, "Austria and the Soviet Union," 100. Cf. Paul Luif, "Österreich zwischen Ost und West: Österreichs Abstimmungsverhalten in der Generalversammlung der UN," in Österreichisches Jahrbuch für Politik 1984 (1985), 261-274, 263. US analyses of the 1983 session of the General Assembly, however, indicate a much lower voting conformity of Austria with the United States, and rank Austria with only 36.7 percent, the last but one of all OECD states. The difference between the US data and that of Luif can be explained insofar as Luif compared the Austrian voting 
showing a clear weakening of its Western-oriented loyalty and growing independent-mindedness or "neutrality." During the same period, this phenomenon can also be seen in countries like Ireland (falling from 100 to 80) and Sweden (falling from 80 to 67$)$. By the early 1980 s, the voting pattern of Ireland had declined still further (to 68), while Austria's and Sweden's voting record remained stable in the 60s - where Finland had ranked ever since 1956. This deviated notably, on one hand, from other small West European democracies that were NATO members, such as the Netherlands whose voting coefficient was between 83 and 100; on the other hand, however, it was far from the voting behavior of the nonaligned states, with Yugoslavia ranging between 9 and 33 and India between 25 and 36. An analysis of Austria's voting patterns in the 1970 s demonstrated that the highest affinity existed with countries like Ireland (89.5/100), Denmark (88.6/100) or Iceland (86/100), while the similarity with the United States was intermediate $(51.3 / 100)$ and with the USSR quite low (25.4/100). ${ }^{117}$ In embattled cases, however, Austria's voting behavior in the 1980s became, in comparison to other neutrals, "conspicuously cautious," with many abstentions. ${ }^{118}$ In 1978, former vice-chancellor Fritz Bock even proposed that Austria abstain from all votes. ${ }^{119}$ Nevertheless, Austria avoided being absorbed by the communist or the nonaligned bloc in the United Nations.

At the CSCE preparatory talks in Dipoli, Austria tempered its support for the Western proposal of parallel talks on MBFR by endorsing the Soviet bid for the Ten Principles Guiding the Relations between Participating States. ${ }^{120}$ Although the Soviet media's reaction to the Austrian support of the Western call for talks on MBFR had been the hope that the neutral, in the future, would display "more independence," certain Austrian activities at the CSCE meetings themselves were highly commended by the same media. The steady flow of Soviet propaganda addressing Austria and the other neutrals during the CSCE can be interpreted as an attempt, by means of praise, encouragement, demands, criticism, or even threats, to influence their behavior and to induce or suppress certain actions. ${ }^{121}$ While the Soviet representative at the CSCE repeatedly reproached the neutrals for not being active enough, ${ }^{122}$ it seems that, from the Soviet perspective, the desired position of the neutrals was to be active promoters of the conference idea itself, but silent support-

record not with the US position, but with the general "Western" one, and only took those cases into account in which there was a united position of the United States, the United Kingdom, and France against the USSR. For further detail on the various cases, see Schlesinger, Austrian Neutrality in Postwar Europe, 90-91.

117 Peter Jankowitsch, "Das Problem der Äquidistanz: Die Suche der Zweiten Republik nach außenpolitischen Leitlinien," in Manfried Rauchensteiner (ed.), Zwischen den Blöcken: NATO, Warschauer Pakt und Österreich (Vienna: Böhlau, 2010), 451-495, 476.

${ }_{118}$ Skuhra, "Austria and the New Cold War," 120.

119 Molden, "Die 'Ost-West-Drehscheibe,"” 754.

${ }^{120}$ Zhiriakov, Sovetskii Soiuz - Avstriia, 57; idem, SSSR i Avstriia v 1945-1975 gody, 83.

${ }_{121}$ Petersson, The Soviet Union and Peacetime Neutrality, 87-90.

122 Fischer, Neutral Power in the CSCE, 171. 
ers of Eastern proposals, or at least passive hosts for the negotiations. Thus, Prime Minister Kosygin's visit to Vienna from 2 to 5 July 1973 as well as his trips to the two Scandinavian neutrals in the same year served, at least in part, to ensure that they would support Eastern proposals and not waver at the CSCE. ${ }^{123}$ Earlier visits by Soviet diplomats, such as the deputy head of the Soviet delegation to Helsinki, Lev Mendelevich, had served the same objective. ${ }^{124}$

The neutrals, however, envisaged their role differently; they promoted their own ideas and in some important cases, even supported Western ones. The differences between the neutrals and the states of the Warsaw Pact on questions of military security, disarmament, confidence building measures (information about armed maneuvers), mediation, and human contacts, ${ }^{125}$ as they developed before and during the conference, must have disappointed the Soviet Union. The Soviet side had hoped that at least Austria, Sweden and Finland would be less outspoken and more manageable than was indeed the case. Most of the neutral and nonaligned $(\mathrm{N}+\mathrm{N})$ group's initiatives were annoying to the Kremlin rather than pleasing. Despite Soviet resistance, human rights issues were included in the famous Basket III of the conference, as had been proposed by the Western and neutral states, and all Soviet attempts at restricting their legal value by claiming that sovereignty was superior to human rights were repulsed. On the other side, Kreisky's peculiar idea to include the Near East issue on the CSCE agenda ${ }^{126}$ was rebuffed by the Kremlin (and also by the West), as were the Swiss proposal concerning a mechanism for a peaceful settlement of disputes and Sweden's and Austria's drafts regarding military security and the idea of not only linking disarmament to the conference, but actually including it. In the latter case, the Soviet Union tried to assuage Austria's disappointment by proposing Vienna as a site for MBFR talks. ${ }^{127}$ When the Soviet strategy to block conventional arms control and disarmament negotiations had failed, further Soviet tactics aimed at, unsuccessfully, including the neutrals in the talks and thus either reassigning such negotiations to the state-to-state level (thereby weakening NATO) or putting the blame for refusals on the United States.

At the signing ceremony of the Helsinki Final Act, the Soviet side must have been particularly annoyed at three points stressed by Kreisky: the continuing ideological struggle between communism and liberal democracy, the Western determination to achieve a breakthrough for democracy, and the right of every country

\footnotetext{
${ }^{123}$ Scarlis, Neutralität, 172-173.

124 Steiner, Diplomatie - Politik, 48. In 1972, Steiner was Political Director in the Austrian MFA.

${ }^{125}$ Fischer, Neutral Power in the CSCE, 120-138, 177-187, 240-245, 250-254, 263-266, 278-297; Scarlis, Neutralität, 104-108, 110-119; Schalhorn, "Sowjetische Westeuropapolitik I," 133-135.

${ }^{126}$ See Kreisky's speech in the Consultative Assembly of the Council of Europe, 25 January 1971, in Jacobsen, Mallmann, Meier, Sicherheit und Zusammenarbeit in Europa (KSZE) II/1, 260-262, 262.

127 Wettig, Europäische Sicherheit, 176.
} 
to choose its own political system as declared in the Final Act. Kreisky turned the anti-Western orientation of "peaceful coexistence" into an anti-communist one:

"Hundreds of millions of people live in countries that are strongly linked to the idea of political democracy; other hundreds of millions live in countries where the political ideas of communist parties have been realized [...] It would make little sense to diminish or ignore the fundamental differences between these different political systems and societal orders. Therefore it should be welcomed that, again and again, it has been shown that coexistence - which we perceive as the form of peaceful relations possible today - does not apply to the field of ideology. I welcome this clarification, because the Western states are determined to help the idea of democracy to gain a breakthrough $[\ldots] .{ }^{\prime 128}$

When at a conference in 1976 the chancellor aired the idea that Helsinki might exert influence on the public sentiment and social order in the USSR, he was reproached by Soviet propaganda. ${ }^{129}$

${ }^{128}$ Kreisky's speech is printed in Jacobsen, Mallmann, Meier, Sicherheit und Zusammenarbeit in Europa (KSZE) II/2, 856-859, 858. Cf. Oliver Rathkolb, Internationalisierung Österreichs seit 1945 (Innsbruck: Studienverlag, 2006), 63.

129 W. Iwanow and D. Nikolajew, "Wider den Geist der Entspannung," in Neue Zeit, no. 44 (1976), 26-27. 


\section{A Thorn in the Side: Personal and Cultural Contacts}

Soviet dissidents, the Jewish exodus from the USSR, and the Austrian media

During the Kreisky era, what tensions that arose in Soviet-Austrian relations came mainly from Austrian media reports about the fate of Soviet dissidents. Various hardships in the USSR also weighed on its Jewish population, thus influencing many of them to emigrate. ${ }^{1}$ The maltreatment of critical intellectuals in the Eastern bloc and the restrictions on Soviet citizens who were willing to emigrate created an uproar among their West European and North American colleagues. Austrian intellectuals, in an open letter to Kosygin, protested against the "drastic steps taken by the Soviet government, such as imprisonment, deportation and confinement in psychiatric wards, against citizens who use their right for analyzing and criticizing the current conditions." ${ }^{2}$ Among the signatories of the appeal were journalists and the newspaper editors Paul Blau, Fritz Csoklich and Günther Nenning, writer Hilde Spiel, artists, a few trade unionists, and members of parliament, including Heinz Fischer. Most of them were social democrats or had no party affiliation; however, a number of conservative university professors, such as Erich Streissler, also supported the initiative. A second appeal by social democrats and trade unionists such as Anton Benya, Bruno Pittermann, Franz Probst and Felix Slavik, which aimed at pressuring Soviet authorities to allow Jewish citizens to emigrate, was dismissed by Soviet diplomats as "Zionist propaganda."

Trying to support Soviet dissidents was not without risk. After the Austrian Foreign Ministry intervened on behalf of two dissidents who had been sentenced to death, employees at the Austrian embassy in Moscow were subject to Soviet criticism. ${ }^{4}$ When an Austrian exchange student in the USSR was accused by Soviet authorities of having tried to smuggle refugees out of the country, he could only be saved from imprisonment by another intervention.

${ }^{1}$ Zubok, A Failed Empire, 186-188; Natan Sharansky with Ron Dermer, The Case for Democracy: The Power of Freedom to Overcome Tyranny and Terror (Green Forest: Balfour, 2006), 112-123.

2 APA, 3 July 1970, in ÖStA, AdR, BMAA, II-Pol, GZ. 80916-6/70, Z. 89223.

${ }^{3}$ Quoted in Wodak to Kirchschläger, Streng Vertraulich, 2 June 1971, in ÖStA, AdR, BMAA, IIPol, GZ. 105.880-6/71, Z.113.202.

${ }^{4}$ Austrian embassy Moscow to Austrian MFA, 20 January 1971, Copy, in ÖStA, AdR, BMAA, IIPol, File Informationen für Herrn Botschafter Dr. Halusa; Karl Vogelmann, 18 August 1971, ibid., GZ. 106.113-6/71, Z.116.855. 
During and after the CSCE meetings in 1973-75, freedom in the USSR diminished considerably. The Soviet regime lost no time in cracking down on humanrights activists and groups who had been inspired by the Helsinki declaration. ${ }^{5}$ In October 1977, Soviet physicist and dissident Andrei Sakharov appealed to all signatory states of the Helsinki agreement to protest the restrictions imposed by communist regimes on free emigration. In several letters to the prime ministers Kosygin and Tikhonov, Kreisky intervened on behalf of Soviet dissident (and later Israel's minister) Anatolii (Nathan) Shcharanskii, ${ }^{6}$ imprisoned human-rights activist Ida Nudel, ${ }^{7}$ the family of ballet dancer Rudolf Nureyev, as well as other people eager to emigrate. The much-adored dancer had settled in Vienna, after defecting from his country. ${ }^{8}$ In 1982 alone, the number of hardship cases pending in Soviet-Austrian negotiations reached sixty. Austria, according to its ambassador in Moscow, was the only Western state, whose interventions were answered by the Soviet government. ${ }^{9}$ However, the success of the Austrian efforts was "disappointing," 10 as seen in the Soviet handling of Kreisky's appeal to Soviet leader Iurii Andropov to let imprisoned dissident Iurii Orlov emigrate to Austria. On Andropov's order, the official letter was intentionally left unanswered by the Kremlin. ${ }^{11}$ Due to his engagement for Soviet dissidents, a public lecture by Kreisky in Moscow was cancelled and the chancellor was criticized in the Soviet press. ${ }^{12}$ Responses of this kind were not unusual: When the Canadian prime minister, Pierre Elliott Trudeau, wrote a letter to Andropov on behalf of Anatolii Shcharanskii, Andropov, the former chief of the KGB and of hundreds of political prisons, labor camps and isolators who had staged the prosecution of countless dissidents, ordered: "Reply to the Canadian: 'We

${ }^{5}$ Svetlana Savranskaya, "Human Rights Movement in the USSR after the Signing of the Helsinki Final Act, and the Reaction of the Soviet Authorities," in Leopoldo Nuti (ed.), The Crisis of Détente in Europe: From Helsinki to Gorbachev, 1975-1985 (London: Routledge, 2009), 26-40; idem, "Unintended Consequences: Soviet Interests, Expectations, and Reactions to the Helsinki Final Act," in Oliver Bange and Gottfried Niedhart (eds.), Helsinki 1975 and the Transformation of Europe (New York: Berghan, 2008), 175-190.

${ }^{6}$ SBKA, Länderboxen, UdSSR 5.

${ }^{7}$ Kreisky to Tikhonov, 19 November 1982, in SBKA, Länderboxen, UdSSR 7.

${ }^{8}$ Hannes Leidinger and Verena Moritz, Russisches Wien: Begegnungen aus vier Jahrhunderten (Vienna: Böhlau, 2004), 190.

9 Liedermann to Austrian MFA, On Soviet-Austrian Relations, 23 November 1985, in ÖStA, AVA, NL E-1736: Bielka, File 115. For the full text, see pages 333-338.

${ }^{10}$ Information Austrian MFA, 7 October 1982, in SBKA, Länderboxen, UdSSR 7.

${ }^{11}$ Kreisky to Andropov, 5 July 1983, in RGANI, 89/28/26, 5. A note to Andropov originating from the Central Committee apparatus recommending leaving Kreisky's intervention without an answer bears the handwritten words "Soglasen [I agree]. Andropov." Information for Andropov, 29 July 1983, ibid., 89/37/38, 2.

12 Oliver Rathkolb, "International Perception of Austrian Neutrality," in Günter Bischof, Anton Pelinka, and Ruth Wodak (eds.), Neutrality in Austria, Contemporary Austrian Studies 9 (New Brunswick: Transaction, 2001), 69-91, 81; Ginther, Neutralität und Neutralitätspolitik, 72. 
don't need to prove our humanity, Mr. Prime Minister. It is part of the very nature of our society." "13

Such claims notwithstanding, from 1945 to 1968 , 8,296 Soviet Jews had left their country for Israel. In the early 1970s, despite the rising emigration fees, the exodus accelerated, with 13,711 leaving in 1971 and 34,733 in $1973 .{ }^{14}$ The United States tried to pressure the Soviet regime into letting all people willing to emigrate do so. Most Jewish emigrants from the USSR left via Austria. In 1960, only 106 people had used this route, but by the early 1970s the numbers had risen steeply, to 13,082 in 1971 and 31,804 in 1973, and thus almost all the Soviet Jewish emigrants of these years. ${ }^{15}$ From 1960 until 31 August 1973, a total of more than 72,000 Jews had emigrated from the Soviet Union by traveling to Austria. But after three immigrants and one customs officer were kidnapped in Austria in September 1973 by Palestinian terrorists, the Viennese government agreed to close the transit camp of the Jewish Agency in Schönau. However, a new procedure was found to enable Jewish migrants leaving the USSR to enter Austria with transit visas and, from 1977, their number rose again, in 1979 surpassing its previous high point. In 1980, due to new Soviet restrictions, the number dropped again significantly, with emigration resuming its rise only after Gorbachev's perestroika, reaching an all-time high of 71,000 in 1989 alone. ${ }^{16}$ From 1955 to 1989 , a total of more than 200,000 Jews from the USSR passed through Austria. ${ }^{17}$

The sad fate of the Soviet dissidents and Soviet Jewish population did not remain unnoticed by Austrian journalists, who did their best to make the Austrian public aware of the urgent situation. In 1974, Erhard Hutter, the Austrian Broadcasting Corporation's (ORF) representative, who in February 1972 had received his accreditation as the first - and, in the early 1970s, the only - permanent Austrian correspondent in Moscow, ${ }^{18}$ filmed the documentary Zwischen

${ }^{13}$ Quoted in Dmitri Volkogonov, Autopsy for an Empire: The Seven Leaders Who Built the Soviet Regime (New York: Free Press, 1998), 374.

${ }_{14}$ B. Morozov (ed.), Evreiskaia emigratsiia v svete novykh dokumentov (Tel-Aviv: Ivrus, 1998), $169 ; 230$.

15 SBKA, Länderboxen, UdSSR 7. Cf. O.V. Budnitskii and O.V. Belova (eds.), Evreiskaia emigratsiia iz Rossii 1881-2005 (Moscow: Rosspen, 2008).

16 Außenpolitischer Bericht (1989), 431.

${ }^{17}$ Gehler, Österreichs Außenpolitik, 407. Other sources give the total as having been 270,199 people in the years 1968 through 1986. Rathkolb, "International Perception of Austrian Neutrality," 82. Cf. Eduard Stanek, Verfolgt, verjagt, vertrieben: Flüchtlinge in Österreich (Vienna: Europa, 1985); Vladimir Vertlib, Osteuropäische Zuwanderung nach Österreich 1976-1991 unter besonderer Berücksichtigung der jüdischen Immigration aus der Sowjetunion (Vienna: Verlag der Österreichischen Akademie der Wissenschaften, 1995). The total number of Soviet Jews leaving for Israel in the years 1945-1974 was 99,500; in the years 1975-1980 it was 153,500. Morozov, Evreiskaia emigratsiia, 16.

${ }^{18}$ Information Bundesministerium für Auswärtige Angelegenheiten, Zl. 12.285-PI/73, 25 June 1975, in SBKA, Länderboxen, UdSSR 2. Up to the 1970s, Austrian journalists, such as Otto Schulmeister and Hugo Portisch, visited the USSR mainly as members of journalist delegations. 
Nobelpreis und Irrenhaus [Between the Nobel Prize and the Madhouse] about the forced hospitalization of dissidents in psychiatric wards. ${ }^{19}$ In the USSR, both officials and the media were outraged. An internal report of the Soviet embassy in Austria criticized Hutter's production as having "a nonobjective character and containing unjustified criticism [...] It must not be ignored that recently Austrian television has joined the campaign for the "protection of human rights in socialist countries." "20 The Soviet Foreign Ministry filed a complaint with the Austrian embassy, and finally in 1978 Hutter was expelled from the USSR on charges of anti-Sovietism and smuggling. ${ }^{21}$ An Austrian protest that the Soviet measures violated the Helsinki Final Act was rejected by the Soviet embassy. ${ }^{22}$ During his visit to Moscow in December 1978, Foreign Minister Pahr raised the issue, but met with no success. Complaints about human rights abuses in the Soviet Union were far from rare, and in May 1977 Brezhnev told all Soviet ambassadors that these complaints were part of an "anti-Soviet campaign under the false mask of defending human rights." ${ }^{23}$ To historian Vladislav Zubok, it seems that "Soviet leaders, products of Stalinist political culture, simply could not understand why [Western politicians] paid so much attention to the fate of individual dissidents." ${ }^{24}$ They ordered their mouthpieces to fight back against Western leaders and journalists - and did not consider the consequences this would have on the bilateral relations with the West. Being attacked by Soviet media, Austrian journalists, on their side, increasingly posed the question whether the Austrian government was perhaps too friendly and obedient towards Moscow, and not being rewarded by the big neighbor. ${ }^{25}$

Meanwhile, the Novosti Press Agency (APN) and the Soviet embassy in Vienna had launched a counter campaign, and, in the first three months of 1977, sent out no less than twenty-three APN bulletins in up to four hundred copies each, in order to "neutralize the massive anti-Soviet propaganda" and to whitewash the Soviet treatment of dissidents. ${ }^{26}$ The Austrian-communist Volksstimme, which had gained notoriety for providing Soviet media falsified accusations against the Aus-

Austrian newspapers relied on correspondents from the German media; Heinz Lathe, and later, Uwe Engelbrecht of the Kölner Anzeiger wrote for Die Presse. During the 1980s, the USSR maintained nine permanent correspondents in Austria. Information Medienwesen in der UdSSR, in SBKA, Länderboxen, UdSSR 6, File Staatsbesuch Kirchschläger, May 1982.

19 File Offizieller Besuch des Herrn Bundeskanzler in der Sowjetunion, May 1974, in SBKA, Länderboxen, UdSSR 3.

20 Soviet embassy Vienna to Soviet MFA, 24 June 1977, in AVPRF, 66/56/120/31, 34-40.

${ }^{21}$ Archiv der Gegenwart, 22113, 12 October 1978; File Arbeitsbesuch der Herrn Bundeskanzlers in der SU, 6 February 1978, in SBKA, Länderboxen, UdSSR 4.

${ }_{22}$ Österreichische Zeitschrift für Außenpolitik 18 (1978), 288.

${ }_{23}$ Quoted in Volkogonov, Autopsy for an Empire, 282.

${ }^{24}$ Zubok, A Failed Empire, 256.

${ }^{25}$ Molden, "Die 'Ost-West-Drehscheibe'," 759-760.

${ }^{26}$ Soviet embassy Vienna to Soviet MFA, 8 July 1977, in AVPRF, 66/56/120/31, 41-43. 
trian government and for its noncritical neo-Stalinist stance, had dismissed earlier Western reports about the Soviet regime's campaign against dissidents, in particular Andrei Sakharov, as "anti-Soviet hysteria";27 it now joined the Soviet media campaign in defense of the Soviet human rights record.

The Hutter affair petered out, Otto Hörmann was appointed Hutter's successor, and some friendly signs in the area of media politics appeared. Austrian journalists, from 1976 on, were granted one-year multiple-entry visas to the USSR, ${ }^{28}$ and in February 1982 a cooperation agreement between the ORF and the Soviet Gosteleradio was even signed.

However, problems continued as long as human rights violations in the USSR persisted and the Soviet regime was afraid of having the truth exposed about its treatment of dissidents. The sensitive reaction of the Soviet regime to criticism from abroad had already long put strain on Soviet-Austrian relations. Not only during the crises of 1956 and 1968 did Soviet diplomats demand that Austrian representatives "suppress this kind of campaigns" and "hostile acts." ${ }^{29}$ This systematic pressure was aimed at effectively silencing foreign criticism of Soviet policy; the communist doctrine of neutrality, which included abstaining from hostile propaganda as one of the obligations of a permanently neutral state, served as a pretext for such interference. In the 1970s and 80s, the critical Austrian journalists Barbara Coudenhove-Kalergi and Paul Lendvai, who reported on communist human-rights violations, were repeatedly attacked in the Soviet press as being anti-Soviet. ${ }^{30} \mathrm{On}$ 26 January 1983, Izvestiia charged the Austrian media with the defamation of the Soviet Union, and Ambassador Helmut Liedermann was called into the Soviet ministry to be told that Austrian news coverage allegedly "aimed at creating a feeling of hostility in Austria against the Soviet Union and its policies." ${ }^{31}$ A few weeks later, a Soviet diplomat lamented that Soviet-Austrian relations would be excellent, if only Austrian media reports were not so "problematic."32

In 1980, Austria's relations with East European dissidents even spilled over into the sphere of Soviet-Austrian cultural relations, with the USSR refusing to grant the necessary visas to the Czech dissident and actor Pavel Landovsky, who was scheduled to join the Vienna Burgtheater company on its tour to Moscow. In the end

${ }^{27}$ Austrian embassy Moscow to Austrian MFA, 3 September 1973, in ÖStA, AdR, BMAA, II-Pol, GZ. 30.205-6/73, Z. 44.485.

${ }^{28}$ Zhiriakov, Sovetskii Soiuz - Avstriia, 112.

${ }^{29}$ See, e.g., Vorsprache des sowjetischen Botschafters, 22 August 1969, in ÖStA, AdR, BMAA, IIPol, GZ. 152.678-6/69, Z. 162.361-6/pol/69; Telegram Wodak to Austrian MFA, 29 May 1970, ibid., GZ. 80916-6/70, Z. 87195, Protokoll über den bilateralen Meinungsaustausch, 12-13 June 1975, ibid., Z. 225.18.02/12-II.3/75.

${ }^{30}$ Stifter, "Das politische Österreichbild," 131.

31 Austrian embassy Moscow to Austrian MFA, 1 February 1983, in SBKA, Länderboxen, UdSSR 6.

${ }^{32}$ Aktenvermerk Hinteregger, 25 February 1983, in SBKA, Länderboxen, UdSSR 6. 
the theater cancelled its trip. ${ }^{33}$ The Soviets were again outraged when the Vienna International Festival 1981 staged a play by Czech dissident Vaclav Havel. To retaliate, the Soviet side withdrew its participation in the festival. After the affair had calmed down, the Burgtheater finally traveled to Moscow in 1982 (albeit without Landovsky), and two years later the Kirov theater company toured Austria.

Cultural exchange, tourism, and the image of the other

Despite these and other ${ }^{34}$ problems, there were also friendly developments in cultural relations. The June 1969 visit of the Soviet minister of cultural affairs to Austria ensured that cultural relations did not suffer from the Czechoslovakian crisis. In May 1972 Ekaterina Furtseva's Austrian counterpart, Fred Sinowatz, returned her visit. Each year Soviet-Austrian cultural exchange was specified by a memorandum on specific projects. In 1982, the agreement between the two academies of sciences, which had come into effect ten years earlier, was renewed.

In general, the Kreisky era was characterized by a considerable intensification in bilateral cultural exchanges - even though the Austrian embassy in Moscow criticized that Austria's cultural export was hindered by many obstacles, whereas the "Soviet Union, as a matter of course, expects all means of presenting its culture to be placed at its disposal in Austria." ${ }^{35}$ The major emphasis clearly rested on high culture. ${ }^{36}$ In 1971 the Bolshoi and Staatsoper companies toured through Austria and the USSR, respectively, in the following year the Albertina and Pushkin Museums exchanged traveling exhibits, and in 1974, the Vienna Symphony performed in the Soviet Union for two weeks. This tour led to a positive assessment by the Soviet Ministry of Culture, namely, that nowadays "the Austrian authorities pay a lot of attention to cultural contacts with the Soviet Union." ${ }^{37}$ Musicians from both countries participated in festivals organized by the other side, such as the Wiener Festwochen and the Soviet Haydn festival in 1982. A year earlier, an Austrian tragicomedy about a passive Austrian bystander who unintentionally became a resister against the Nazi regime, Der Bockerer, was a contender in the Moscow film festival competition. The number of exchange students was, in the 1970s, doubled from five to ten students from each country annually, each staying for nine months, and in the

${ }^{33}$ Hinteregger, Im Auftrag Österreichs, 250. Cf. Kulturelle Beziehungen, May 1982, in SBKA, Länderboxen, UdSSR 6, File Staatsbesuch Kirchschläger.

${ }^{34}$ In 1973, the director of the State Opera, Rudolf Gamsjäger, in a conversation with the Soviet ambassador in Austria, Aristov, complained that the Soviet Goskontsert agency had until then either declined or ignored Austrian proposals for a second tour of the State Opera to the USSR. Aristov to Furtseva, 15 January 1973, in AVPRF, 66/52/111/6, 2.

${ }^{35}$ Liedermann to Austrian MFA, On Soviet-Austrian Relations, 23 November 1985, in ÖStA, AVA, NL E-1736: Bielka, File 115. For the full text, see pages 333-338.

${ }^{36}$ Neuhold, "Austria and the Soviet Union," 103.

37 Soviet Ministry of Culture to Soviet MFA, 7 May 1974, in AVPRF, 66/53/114/12, 107-114. 
early 1980s, increased to twelve apiece. Moreover, from each side, four professors, three language teachers, and four language students were given the chance to study and do research in the other country for up to nine months. ${ }^{38}$ These numbers were, however, still very low in comparison with other bilateral exchanges. From the mid1970s, the Austrian Institute for Telecommunication Engineering regularly worked together with the Soviet Academy of Sciences. In 1982, a conference was convened on the history of bilateral relations between Austria and the USSR. ${ }^{39}$ Among the Austrian participants were some revisionist historians who avoided harsh criticism of past Soviet policies. In the next years, Soviet research on Austria was intensified through the work of the analyst Abdulkhan Akhtamzian, who was based at the Moscow State Academy of International Relations, and by the historian and political scientist Ivan Zhiriakov. ${ }^{40}$ Millions of copies of books by Austrian authors such as Zweig, Josef Roth, Rilke, Musil, Doderer, Csokor, as well as by more contemporary authors such as Bachmann, Frischmuth, Handke and Hochwälder continued to be published in Russian and were regularly exhibited in the USSR. ${ }^{41}$

Soviet and Austrian culture continued to be presented to the wider public by the Austrian-Soviet Society, under its president Anton Sattler and secretary Margaretha Klug, and the Soviet-Austrian Friendship Society, under its president Petr Alekseev, Izvestiia's editor in chief. ${ }^{42}$ Since the communists in the ÖSG were no longer perceived as a political threat by Austrian officials, the minister for education and culture, Herta Firnberg, accepted the honorary presidency of the society. In 1979, the ÖSG headquarters were visited by the federal president, Rudolf Kirchschläger, who became a frequent honorary guest and speaker at the ceremonies and symposiums sponsored by the society. From 1974, the two societies regularly organized Austrian days in the USSR and Soviet days in Austria. Regional partnerships were established between Austrian provinces and Soviet republics such as Burgenland and Moldavia, Upper Austria and Ukraine, and Vorarlberg and Armenia; sister city partnerships were concluded between Dushanbe and Klagenfurt, Tbilisi and Innsbruck, as well as other cities. ${ }^{43}$ In 1980 , Austrian days were held in Ukraine, and in 1982, Uzbek days in Austria. In 1977 the ÖSG organized 1,149 events

${ }^{38}$ File Offizieller Besuch des Herrn Bundeskanzler in der Sowjetunion, May 1974, in SBKA, Länderboxen, UdSSR 3; Kulturelle Beziehungen, May 1982, ibid., UdSSR 6, File Staatsbesuch Kirchschläger.

${ }^{39}$ Historikersektion der ÖSG (ed.), Österreich und die Sowjetunion 1918-1955: Beiträge zur Geschichte der österreichisch-sowjetischen Beziehungen (Vienna: ÖSG, 1984).

40 Abdulchan Achtamsjan, "Die Sowjetunion und Österreich in der Zeit der Vorbereitung und des Abschlusses des Staatsvertrages 1945-1955," in Historikersektion, Österreich und die Sowjetunion, 131-144; Zhiriakov, SSSR - Avstriia; idem, Sovetskii Soiuz - Avstriia.

${ }^{41}$ Kulturelle Beziehungen, May 1982, in SBKA, Länderboxen, UdSSR 6, File Staatsbesuch Kirchschläger; Sowjetunion heute 26, no. 11 (1980), 15.

42 Sowjetunion heute 27, no. 1 (1981), 14-15.

${ }^{43}$ Zhiriakov, Sovetskii Soiuz - Avstriia, 112, 162; File ÖSG, in SBKA, Länderboxen, UdSSR 4. 
with 578,413 visitors; ${ }^{44}$ in 1979 the focus was on the upcoming Olympic Games in Moscow, which were promoted in traveling exhibits with twenty-nine stations all over Austria. ${ }^{45}$

The ÖSG regularly organized so-called Friendship Trains, bringing young people to the land of the soviets. In the early 1970s, about 5,000 Austrians visited the USSR annually. Soviet tourism in Austria reached approximately the same numbers, with roughly half of the Soviet visitors traveling on the Danube on cruise boats chartered by Inturist. These tourists stayed for an average of five days. Soviet tourists arriving by bus stayed an average of twelve days in Austria, four of them in Vienna. ${ }^{46}$ By the end of the 1970s, the number of Soviet arrivals in Austria had climbed to more than 23,000 and overnight stays to more than 96,000 per annum. With the end of détente these numbers fell significantly. In 1982, the USSR ranked only twenty-ninth as the country of origin of tourists visiting Austria, falling even lower than such countries as Egypt, South Africa, or Mexico. ${ }^{47}$

In an opinion poll during the late 1970s, the Soviet Union ranked eighth (the same ranking as Hungary) of the countries and organizations Austrians wanted their homeland to have good and close relations with - behind the FRG, Switzerland, the United States, Italy, international organizations, Yugoslavia, and the Scandinavian countries. ${ }^{48}$ Without the promotion of active cultural exchange and without détente in general, such a result could hardly be explained given the negative image of the Soviet invasion in Czechoslovakia and of the maltreatment of Soviet dissidents.

The dearth of official controversies did not mean, however, that the Soviet Union fully approved of Austria's political system and politics: While Kreisky and Sinowatz were usually portrayed in a favorable manner ${ }^{49}$ Soviet media in the late 1970s and early 1980s still reported disapprovingly about Austrian capitalism and "social partnership," highlighting the high rate of unemployment, and criticizing Austrian social democracy as compromising too much..$^{50}$ This apparently seemed necessary to the Soviet leadership inasmuch Austria was a capitalist state and, therefore, by definition according to the Marxist-Leninist doctrine, necessarily had to suffer from social tensions and crises..$^{51}$ On 8 January 1983, Pravda charged Austria with being too tolerant with regard to neo-Nazis. ${ }^{52}$ Since the 1940 s the Soviet

${ }_{44}$ Annual report ÖSG on 1977, in SBKA, Länderboxen, UdSSR 4.

${ }^{45}$ Annual report ÖSG on 1979, ibid.

${ }^{46}$ Information über den Touristenverkehr, in SBKA, Länderboxen, UdSSR 3.

${ }^{47}$ Information Wirtschaftsbeziehungen, May 1982, in SBKA, Länderboxen, UdSSR 6, File Staatsbesuch Kirchschläger.

${ }^{48}$ Neuhold, "Austria and the Soviet Union," 100.

49 Stifter, "Das politische Österreichbild," 190, 199.

${ }^{50}$ Lobova, "Die Moskauer Perzeption,” 115. Cf. Pravda, 6 October 1976.

${ }^{51}$ Information, Bundesministerium für Auswärtige Angelegenheiten, Z1. 12.285-PI/73, 25 June 1975, in SBKA, Länderboxen, UdSSR 2.

52 Österreichische Zeitschrift für Außenpolitik 23 (1983), 33. 
press had repeatedly pointed out the threat of neo-Nazism. Particularly during the phase of Austria's EEC ambitions in the 1960s and when the neo-Nazi NDP was founded in Austria in 1967, Radio Moscow and Izvestiia had accused Austria of tolerating neo-Nazism, and they continued to do so whenever it seemed appropriate to issue a warning towards the Austrian government. ${ }^{53}$ Interestingly, Soviet and Austrian-communist attacks against the FPÖ as an allegedly pan-German and neo-Nazi party, which had been repeatedly named in Soviet media as one of the forces responsible for Austria's striving towards the EEC, began to be fewer after $1968 .^{54}$ In the mid-1970s, internal Soviet reports and its media sharply criticized both the existence of approximately thirty organizations with allegedly neo-Nazi leanings and the Austrian government's argument that banning them would make it more difficult to monitor their members' activities. ${ }^{55}$ Further Soviet concern was expressed about annual gatherings of former Sudeten Germans in Austria. ${ }^{56}$ The demonstrations in Vienna against NATO rearmament by members of the Austrian anti-war movement were praised by Soviet media, ${ }^{57}$ but not a word was said about the marches against the Soviet war in Afghanistan.

The 1972 riots against bilingual town signs being erected, on the order of Kreisky, in Slovene and German-speaking Carinthian communities were described in the Soviet press as an "alarming sign of an anachronistic nationalism" of the Carinthian German-speaking population. ${ }^{58}$ Until then, the fate of the Slovene minority in southern Austria had not been an issue in Soviet-Austrian relations. Despite the fact that in 1949 the USSR had made sure that an article concerning the protection of the ethnic minorities in Austria was included in the state treaty, ${ }^{59}$ the most the Soviet ambassador undertook in this regard was to hand over Slovene complaints about Austria's nonfulfillment of the resulting obligations. When representatives of the Slovene minority, one year after the signing of the state treaty, filed a protest with the Austrian government about the insufficient implementation of the article, the Soviet side decided "not to take any further steps" but "to carefully watch over

${ }^{53}$ Stifter, "Das politische Österreichbild," 172. Cf. G. Nikolajew, "Die Neonazis in Österreich," in Neue Zeit, no. 37 (1969), 30-31.

${ }^{54}$ Moser, "Die Stellung der Kommunistischen Partei Österreichs," 59.

${ }^{55}$ Report, 28 April 1975, in AVPRF, 66/54/115/13, 34-35. Cf. I. Melnikow, "nicht verharmlosen!," in Neue Zeit, no. 2 (1979), 14.

56 Telegram Austrian embassy New York to Austrian MFA, 24 September 1968, in ÖStA, AdR, BMAA, II-Pol, GZ. 164.082-6/69, Z. 164.089; Radio Moscow, 24 May 1977.

57 Y. Kalugin, "Facts and Figures: Austria," in International Affairs, no. 1 (January 1984), 141.

58 Information, Bundesministerium für Auswärtige Angelegenheiten, Zl. 12.285-PI/73, 25 June 1975, in SBKA, Länderboxen, UdSSR 2.

59 Stourzh, Um Einheit und Freiheit, 155-161. Cf. Franz Matscher, "Die Minderheitenregelungen im Staatsvertrag," in Arnold Suppan, Gerald Stourzh, and Wolfgang Mueller (eds.), The Austrian State Treaty 1955: International Strategy, Legal Relevance, National Identity (Vienna: Verlag der Österreichischen Akademie der Wissenschaften, 2005), 783-819. 
the implementation" of the relevant matters. ${ }^{60}$ In the spring of 1957, the Soviet ambassador handed over a further Slovene protest addressed to the four powers about Austria's laxness in protecting the rights of the Slovene minority. ${ }^{61}$

Three years after the bilingual signs had been forcefully removed by Austrian nationalists, the Soviet embassy, in an internal report, stated that conditions for the Slovene-speaking minority in Carinthia, which had been discriminated against by Austria for decades, had not changed. They had been defamed and provoked, not only by Carinthian Heimat organizations and the right-wing FPÖ, but also by the nationalist wing of the conservative People's Party and even by the social democrats' provincial branch. Thus, the embassy stated, the anti-Semitic attacks by Carinthian nationalists and social democrats against Kreisky that had followed his order regarding the bilingual signs were the "peculiar finale of a development of which his own party is also guilty." ${ }^{\prime 2}$ However, the Soviet side was reluctant to side openly with Yugoslavia, which, on its side, was involved in quarrels with Bulgaria over questions concerning Macedonia. Furthermore, the nonregulation of the Carinthian problem provided the Soviet Union a lever over the governments of both Yugoslavia and Austria. After the disintegration of the Soviet Union and Yugoslavia, the issue, due to the populist stance of Carinthia's provincial administration and the passivity of the Austrian government, is, in 2010, still unresolved.

${ }^{60}$ Timoshchenko to Lapin, 23 June 1956, in AVPRF, 66/35/66/24, 9. A copy of the note of protest ibid., 10.

${ }^{61}$ Conversation Lapin with Figl, 28 March 1957, in AVPRF, 66/36/68/10, 12-14.

${ }^{62}$ Report Romanov, On the state treaty and the Slovene minority, 18 April 1975, in AVPRF, $66 / 54 / 115 / 13,1-30$. 


\section{Booming, but not Enough: Economic Relations}

Soviet-Austrian relations in the 1970 s were clearly concentrated on economic questions. This was due, at least partially, to the fact that, for the Austrian side, economic relations did not develop as well as might have been expected. The main legal framework had been formed by a five-year trade agreement signed in 1970 . During Kosygin's visit in 1973, the first ten-year program on economic, scientific-technical, and industrial cooperation was agreed upon, and in 1975 a ten-year agreement on the exchange of goods and payments followed. On the occasion of Kreisky's 1978 trip to Moscow, a memorandum on the expansion of bilateral trade and economic cooperation was signed, which led to the conclusion of the 1981-90 long-term program on development and broadening of economic cooperation. ${ }^{1}$ In 1985 this agreement was extended for another decade. In addition to these bilateral treaties, from 1975 the USSR, concurrent to its aim of negotiating an agreement between the CMEA and the EC, ${ }^{2}$ pressed Austria to start negotiations on a treaty with the Eastern economic bloc. ${ }^{3}$

Industrial cooperation was overseen by the Soviet-Austrian Mixed Commission for Economic, Scientific, and Technical Cooperation, founded in 1968. It met annually under the chairmanship of the two countries' ministers for foreign trade. The agreements signed in 1973 and 1975 on scientific, technical, and industrial cooperation made such bilateral projects easier. ${ }^{4}$ Again, Austria (after Finland and France) was among the first Western countries to sign agreements on long-term economic and scientific cooperation with the USSR. ${ }^{5}$ Areas of cooperation included the building of industrial plants and infrastructure, Soviet participation in the planning of power stations and oil refineries in Austria, and Austrian contributions to the planning and construction of Soviet freeways, steel plants, paper mills, and chemical factories, as

${ }^{1}$ Zhiriakov, Sovetskii Soiuz - Avstriia, 105-106.

2 Mueller, "Die UdSSR und die europäische Integration," 651-657.

3 Austrian embassy Moscow to Austrian MFA, 27 April 1981, in SBKA, Länderboxen, UdSSR 6.

${ }^{4}$ Abkommen über die Entwicklung der wirtschaftlichen, wissenschaftlich-technischen und industriellen Zusammenarbeit zwischen Österreich und der UdSSR, 1 February 1973; Programm zur Vertiefung der österreichisch-sowjetischen wirtschaftlichen, wissenschaftlich-technischen und industriellen Zusammenarbeit, 3 July 1973; Langfristiges Abkommen über den Waren- und Zahlungsverkehr zwischen Österreich und der UdSSR, 30 May 1975, in Mayrzedt and Hummer, 20 Jahre österreichische Neutralitäts- und Europapolitik 2, 153-164. Cf. Max Fälbl, "Die österreichisch-sowjetischen Wirtschaftsbeziehungen: Zum Besuch des Außenhandelsministers des UdSSR, N. S. Patoličev, in Österreich," in Österreichische Osthefte 15, no. 1 (1973), 12-19.

${ }_{5}$ Zhiriakov, Sovetskii Soiuz - Avstriia, 105. 
well as factories for food, machine-building, wood-working, and rail construction. Among the first Austrian companies to cooperate with Soviet firms were the state-owned steel producers VOEST-Alpine and Schöller-Bleckmann, Chemie Linz, and the machine-building factories Haid, Plasser \& Theurer, and Voith. Although it might have been perceived an affront to other beer brewing areas such as Bavaria and Bohemia, it was the Austrian beer brewery Schwechater that negotiated with the Soviet breweries "Stepan Razin" and "Krasnaia Bavaria" [Red Bavaria] and provided them needed equipment. ${ }^{6}$ In 1978, five or six Austrian companies were involved in joint Austrian-Soviet projects, but by the 1980s the numbers had risen to more than a hundred. They were involved in ventures with a volume of 300 million schillings. ${ }^{7}$ Between 1980 and 1985, 204 Austrian patents were registered in the USSR, and, respectively, 300 Soviet patents in Austria. In order to carry out financial transactions, an office of the Soviet Donaubank opened in Vienna in 1974.

In 1981 alone, more than one hundred Austrian companies presented their products at seventeen international exhibits and fairs in the USSR. Austria continued chiefly to sell finished or semi-finished products and capital goods such as boats, factory equipment, and machinery (35.5 percent of Austrian exports to the USSR in 1974), iron, steel and metal products (23.6 percent), chemicals and pharmaceuticals (10.5 percent), textiles, shoe leather and rubber products (9.5 percent), consumer goods ( 8.9 percent) ${ }^{8}$ and from 1982, wheat. Some 75 percent of the Soviet deliveries consisted of energy sources such as gas, oil, and coal, as well as various types of ore, pulp, and wood. In 1968, the USSR began to sell natural gas, and by 1971 the volume had reached 1.5 billion cubic meters per annum. In 1973, Austria expressed its interest in increasing gas imports to 4.5 billion. The Soviet side was ready to increase deliveries to 2.5 billion in return for Austrian pipes and material for pipelines, and in 1974, 1975, and 1982 protocols were concluded concerning additional deliveries. Moreover, in 1974 Austria signed a contract for Soviet uranium deliveries to supply Austria's first nuclear power plant - a project that, due to a negative referendum, in the end was aborted. Another field of Soviet-Austrian bartering was a 1975-79 deal between VOEST-Alpine and the USSR concerning Austrian deliveries of sheet steel in return for 700,000 tons of Soviet iron ore per annum. ${ }^{9}$ By 1979 , VOEST-Alpine's exports of sheet steel to

${ }^{6}$ Soviet State Committee for Science and Technology to Soviet MFA, 30 April 1974, in AVPRF, 66/53/114/12, 96-102.

7 Zhiriakov, SSSR - Avstriia, 136-137. Cf. Gregor Riedl, "Die Entwicklung und Bedeutung der Wirtschaftsbeziehungen zwischen Österreich und der Sowjetunion im Zeitraum von 1965 bis 1980" (MA Thesis, Vienna, 1983).

${ }^{8}$ Report Soviet embassy Vienna to Soviet MFA, 18 April 1974, in AVPRF, 66/53/114/12, 27-31.

9 Austrian embassy Moscow to Austrian MFA, 4 January 1980, in SBKA, Länderboxen, UdSSR 5. In the negotiations during Kosygin's visit, the Soviet side had offered 350,000 tons of iron ore and 750,000 tons of coal per annum. Report Soviet embassy Vienna to Soviet MFA, 18 April 1974, in AVPRF, 66/53/114/12, 27-31. 
the USSR had reached 252,000 tons for automobile production, and 129,000 tons for pipes. ${ }^{10}$

Altogether, Soviet-Austrian trade in the 1970s was characterized by a sharp increase in the exchange of goods. The first half of the decade was the heyday of Austria's Osthandel, which grew faster than Austrian exports to OECD countries. In the 1960s, it had taken ten years for Soviet-Austrian trade to double. However, in the 1970s, only five years were needed for it to double, and by 1984, Soviet-Austrian trade had quadrupled. Within one decade, Soviet imports of Austrian machinery even quintupled. ${ }^{11}$ Nevertheless, the Soviet share of Austrian trade remained relatively constant. Of Austrian imports, it ranged between 1.9 percent in 1973 and 6.2 percent in 1981, on average about 3.8 percent; as a receiver of Austrian exports, the USSR remained between 2.8 (1976) and 4.5 percent (1984). Of the destinations of Austria's exports to CMEA states, in this period the USSR fell from number one to number four (behind Hungary, Poland and the CSSR). This was reflected by the fact that the Austrian share in the imports of non-Soviet CMEA states, which reached about 5 percent in the 1970s, was higher than the Austrian share in Soviet imports (below 1 percent). ${ }^{12}$ However, of the East European countries, from which Austria imported goods, the USSR, due to its exports of energy sources, remained in first position. ${ }^{13}$

Table 4: Soviet-Austrian trade 1973-1984

\begin{tabular}{|r|r|r|r|r|r|r|r|}
\hline & $\begin{array}{c}\text { Austrian } \\
\text { exports }\end{array}$ & $\begin{array}{c}\text { Change from } \\
\text { previous year }\end{array}$ & $\begin{array}{c}\text { Share of } \\
\text { Soviet } \\
\text { imports }\end{array}$ & $\begin{array}{c}\text { Soviet } \\
\text { exports }\end{array}$ & $\begin{array}{c}\text { Change from } \\
\text { previous year }\end{array}$ & $\begin{array}{c}\text { Share of } \\
\text { Austrian } \\
\text { imports }\end{array}$ & Balance \\
\hline 1973 & $1,776.6$ & -18.4 & 0.5 & $2,650.7$ & 1.1 & 1.9 & -874.1 \\
\hline 1974 & $3,511.8$ & 97.7 & 0.9 & $4,423.7$ & 66.9 & 2.6 & -911.9 \\
\hline 1975 & $3,762.2$ & 7.1 & 0.8 & $5,543.8$ & 25.3 & 3.4 & $-1,781.6$ \\
\hline 1976 & $4,244.6$ & 12.8 & 0.7 & $7,533.2$ & 35.9 & 3.7 & $-3,288.6$ \\
\hline 1977 & $4,607.9$ & 8.6 & 0.9 & $8,422.2$ & 11.8 & 3.6 & $-3,814.3$ \\
\hline 1978 & $5,375.8$ & 16.7 & 0.8 & $8,870.6$ & 5.3 & 3.8 & $-3,494.8$ \\
\hline 1979 & $6,822.4$ & 26.9 & 1.0 & $10,269.3$ & 15.8 & 3.8 & $-3,446.9$ \\
\hline 1980 & $6,177.3$ & -9.5 & 0.9 & $13,262.4$ & 29.1 & 4.2 & $-7,085.1$ \\
\hline 1981 & $7,719.0$ & 25.0 & 0.9 & $20,854.9$ & 57.2 & 6.2 & $-13,135.9$ \\
\hline 1982 & $9,409.7$ & 21.9 & 0.9 & $16,866.7$ & -19.1 & 5.1 & $-7,457.0$ \\
\hline 1983 & $10,782.3$ & 14.6 & 1.3 & $14,856.0$ & -11.9 & 4.3 & $-4,073.7$ \\
\hline 1984 & $14,072.9$ & 30.5 & 1.3 & $19,625.3$ & 32.1 & 5.0 & $-5,552.4$ \\
\hline
\end{tabular}

Source: Butschek, Statistische Reihen; Vneshniaia togovlia

Exports in millions of Austrian schillings; changes and shares in percent.

${ }^{10}$ Austrian embassy Moscow to Austrian MFA, 7 March 1980, in SBKA, Länderboxen, UdSSR 5.

11 A. Podkopayev, "International Economic Cooperation USSR - Austria," in International Affairs, no. 2 (February 1984), 145-147, 146.

${ }_{12}$ OECD Economic Outlook 28 (1980), 125. On the Austrian share in Soviet imports, see below, pages $240-241$

13 Information Bundeskanzleramt, Zl. 72.535/30-7/74, 15 May 1974, in SBKA, Länderboxen, UdSSR 3. 
The soaring growth had two main reasons and did not come without problems. The first reason was Brezhnev's attempt to solve economic problems by importing Western technology. From the twenty-fourth congress of the CPSU in 1971 until 1975, Soviet foreign trade grew by 186 percent, with its focus on Western countries, ${ }^{14}$ the Western share of Soviet foreign trade rose from 14 percent in 1970 to 34 in $1980 .{ }^{15}$ The second reason was the growing Austrian need for Soviet natural gas and other fuels, whose imports jumped from 4,155 million schillings in 1975 (with total Austrian imports from the USSR worth 5,544 million) to 18,661 million in 1981 (with total Austrian imports worth 20,855 million). ${ }^{16}$

\section{Austria's dependency and trade deficit}

The first problematic tendency resulting from this development was Austria's growing dependency. In the 1970 s, more than 95 percent of Austrian imports of natural gas and more than 66 percent of Austria's annual consumption came from the USSR. In addition, Austria imported 79 percent of its coal and 53 percent of its electricity from the CMEA, making it the OECD country with the highest energy dependency on the Eastern bloc. ${ }^{17}$ In 1982, the fourth agreement on Soviet natural gas deliveries was signed, covering the period until $2000 .{ }^{18}$ For Hanspeter Neuhold, professor of international relations, these figures raised "the question of whether Austria's dependence on East European energy is so heavy that it also constitutes a political problem and may pose a threat to the country's security in crisis situations." ${ }^{19}$ In the political discourse, Neuhold cautioned, such questions weren't tackled seriously enough by political leaders. As opinion polls of 1981 indicate, Austrians were aware of their dependency. However, 79 percent considered this dependency unavoidable and 78 percent expressed the opinion that it did not restrict Austria's freedom of action. In 1985, Helmut Liedermann, the Austrian ambassador to Moscow, also recommended diversifying Austria's energy imports - without much success, as it turned out. ${ }^{20}$ Today Austria still imports more than 60 percent of its natural gas consumption and more than 90 percent of its natural gas imports from Russia.

${ }^{14}$ Joseph Nogee and Robert Donaldson, Soviet Foreign Policy since World War II (New York: Macmillan, 1992), 281.

${ }^{15}$ Hauke, "Handelspolitik und Außenwirtschaftsbeziehungen," 219.

${ }^{16}$ Cf. Information Austrian Ministry for Trade and Industry, Zl. 21.198.6/4-II-6/78, January 1978, in SBKA, Länderboxen, UdSSR 3.

17 Skuhra, "Austria and the New Cold War," 131.

18 Podkopayev, "International Economic Cooperation USSR - Austria," 146.

19 Neuhold, "Austria and the Soviet Union," 101f. Cf. Harald Glatz, "Abhängigkeit im Bereich von Rohstoffen und Energie," in Helmut Kramer et al., Österreich im internationalen System: Zusammenfassung der Ergebnisse und Ausblick (Vienna: Braumüller, 1983), 118-127.

${ }^{20}$ Liedermann to Austrian MFA, On Soviet-Austrian Relations, 23 November 1985, in ÖStA, AVA, NL E-1736: Bielka, File 115. For the full text, see pages 333-338. 
In addition, the dependence of many Austrian exporting industries on the Soviet market, as had developed in the 1960s, increased. This led to problems as well, as many businesses in neutral countries relying on the "secure" export of their products to the East became less competitive in the West, ${ }^{21}$ running thereby into existential problems once the Soviet orders ceased to be regular. A special case study for this kind of development was the Korneuburg ship building industry, which over the previous thirty years had sold its large sea vessels almost exclusively to the USSR, ${ }^{22}$ among them more than 160 barges, ships, and cruise boats, including the famous "Anton Chekhov" riverboat. ${ }^{23}$ When Soviet orders slowed, the state-owned shipyards suffered a downturn; they were sold and, in 1993, closed down. ${ }^{24}$ Another example of this kind of dependence was a pipe plant in Kindberg, which also produced almost exclusively for the Soviet market and was, from the late 1980s, left without orders. ${ }^{25}$

A second problematic development in Soviet-Austrian trade during the Kreisky era was that the balance turned steadily against Austria. Until 1970, due to several clearing agreements, trade had been generally balanced, with a slight tilt against the USSR. The trade agreement signed in 1970 was the first to have no fixed quotas and to clear in freely convertible currency. During the oil crisis of the 1970s, the agreement did not provide Austria any protection against skyrocketing energy prices. Between 1970 and 1974, the price of oil increased by almost 200 percent and the price of natural gas was quick to follow. Whereas in 1970, the USSR had charged Austria 485 million schillings for 931,000 tons of oil, in 1974 the price had more than doubled to 1.3 billion schillings for only 841,000 tons. ${ }^{26}$ The same tendencies affected the price of natural gas. In 1975, Austria had spent 1.5 billion schillings on natural gas imports from Russia; by 1981 it had become 11 billion. ${ }^{27}$ As a consequence, during the two oil crises 1973-74 and 1980-81, the value of Soviet exports to Austria jumped some 66.9 percent and 57 percent respectively. While Austria's exports jumped an even higher margin (in 1974 some 97 percent) and Austrians were able to shift their exports somewhat to products with a higher value added, including chemicals, increasingly they lagged behind Austrian energy imports. In 1977, Austrian imports from the USSR were 1.8 times higher than Austrian exports, in 1982 it was even 2.7 times. The exploding Austrian trade deficit

${ }^{21}$ Bengt Sundelius, "Dilemmas and Strategies for the Neutral Democracies," in idem (ed.), The Neutral Democracies in the New Cold War (Boulder: Westview, 1987), 11-32, esp. 18.

${ }^{22}$ Hinteregger, Im Auftrag Österreichs, 238.

${ }^{23}$ Zhiriakov, SSSR - Avstriia, 134.

${ }^{24}$ Stefan Wunderl, "Die Geschichte der Schiffswerft Klosterneuburg" (MA Thesis, Vienna, 2008).

${ }^{25}$ Liedermann to Austrian MFA, On Soviet-Austrian Relations, 23 November 1985, in ÖStA, AVA, NL E-1736: Bielka, File 115. For the full text, see pages 333-338.

${ }^{26}$ Resch, "Der österreichische Osthandel," 535.

${ }^{27}$ Hubert Isak, "Österreichs Außenwirtschaftsbeziehungen," in Renate Kicker, Andreas Khol, Hanspeter Neuhold (eds.), Außenpolitik und Demokratie in Österreich: Strukturen - Strategien - Stellungnahmen (Salzburg: Neugebauer, 1983), 259-288, 268. 
with the Soviet Union ${ }^{28}$ of more than 3.8 billion schillings (1977) became the main topic of Kreisky's visit to the Kremlin in 1978. ${ }^{29}$ While Brezhnev dismissed the deficit as temporary and - in comparison with Austria's trade deficit with the FRG - small, Kreisky and Staribacher aimed at scouting out Soviet orders. Although the chancellor was accompanied by a large delegation of industrialists, the trend remained unchanged: Austria continued to import more, and more expensive, Soviet gas, but was unable to sell enough goods to compensate for these energy purchases. The second oil crisis in the aftermath of the Iranian revolution of 1979 reinforced this trend. From 1979 to 1981 the Austrian trade deficit almost quadrupled, to 13.1 billion schillings.

This was, at least in part, a consequence of the Soviet cutback on imports of Western machinery in the second half of the 1970s. ${ }^{30}$ Another reason was Austria's inability to adapt to a growing competitiveness in Soviet foreign trade. In 1960 and due to the compensation for the economic provisions of the state treaty, neutral Austria had possessed a good position among Western countries as a trading partner of the USSR. When détente started to bear fruit and the USSR liberalized its foreign trade, the pressure of competition among West European trading partners of the USSR grew. This was correctly recognized by the Austrian side: ${ }^{31}$ its importance as a Western partner of the Soviet Union sank, and the country's share in Soviet foreign trade dropped in comparison to other Western states. In the second half of the 1960s, France had extended large loans to the USSR, thus becoming an important Western trading partner of the Kremlin. By the 1970s, West Germany, which in 1970 had concluded an agreement on selling 1.2 million tons of large-diameter steel pipes for pipelines in return for buying Soviet natural gas, had already surpassed France considerably. ${ }^{32}$ In 1972, the FRG became (again, for the first time since 1960) the most important Western trading partner of the USSR - a position it would develop and uninterruptedly defend until 2009. Particularly on the Soviet import market for iron, steel, and chemicals, Austrian exporters had to cede to Western competitors, mostly from West Germany, France, and Italy. While Soviet-Austrian trade in 1955 had reached roughly the same volume as that between the Soviet Union and West Germany, the latter in 1973 was more than six time bigger. The Austrian share in Soviet imports from OECD countries plunged from 4.3 percent in 1965 to 1.7 percent in 1976 . This was paralleled by a decline in the importance of

${ }^{28}$ Ilse Korenjak, "Die Entwicklung des österreichisch-sowjetischen Außenhandels 1955 bis 1982” (MA Thesis, Vienna, 1983), 104.

${ }^{29}$ Conversation Kreisky with Kosygin, 7 February 1978, in SBKA, Länderboxen, UdSSR 3; Kreisky with Brezhnev, ibid; Staribacher Diary, 6-8 February 1978, in SBKA.

${ }^{30}$ Hanson, The Rise and the Fall of the Soviet Economy, 156.

${ }^{31}$ File Offizieller Besuch des Herrn Bundeskanzler in der Sowjetunion, May 1974, in SBKA, Länderboxen, UdSSR 3.

${ }^{32}$ Loth, Overcoming the Cold War, 106; Alvin Z. Rubinstein, Soviet Foreign Policy since World War II (New York: Harper Collins, 1992), 127-128. 
other neutral states like Sweden and Finland, whose shares in Soviet imports from OECD countries also dropped, from 3.5 to 1.7 percent and from 17 to 9.9 percent respectively. In contrast, the share of West Germany and the United States, which had formerly been considered hostile countries to the USSR, rose from 10.9 to 19.6 percent and from 3.3 to 12.8 percent. ${ }^{33}$

Although it fell significantly after the Austrian post-state treaty deliveries to the Soviet Union were over, the Austrian share in Soviet imports, over the 1970s, remained around 0.8 percent. As the table and the diagram below indicate, this was much less than the share of leading Western exporters such as the FRG, where between 3.1 (1970) and 7.3 percent (1975) of all Soviet imports originated, France ( 2.3 to 3.2 percent), and Italy (1.9 to 3 percent). The Austrian share was also much smaller than that of other neutral or nonaligned states such as Finland (2.6 to 4.1 percent) or Yugoslavia (2.1 to 4.8 percent). This does not call into question the obvious fact that Austria's share in Soviet imports was often larger than the shares of other Western economies of comparable size. Particularly in the 1960s and the 1980s, Austria thus ranked higher than Belgium, Sweden, and Switzerland (which prior to the creation of a bilateral trade commission in 1973 had developed almost no trade with the USSR ${ }^{34}$ ), despite having been surpassed by Sweden in the 1970s and by all of them in 1975 .

Disadvantages to Austrian trade were a consequence of this international trend resulting from détente. These were reinforced by various factors, one being high Austrian prices. The Austrian Ministry of Trade, which had warned of a "shortage of orders" from the mid-1970s, had to concede that in many cases, the bids of Austrian companies, such as tenders for pipes or for pipe cleaning machinery, had not been competitive enough. Negotiations on new Soviet orders were therefore "disappointing"; the Soviet side estimated the value of Soviet orders not secured in 1976-77 by Austrian firms due to their lack of competitiveness at 100 million rubles. ${ }^{35}$ In the case of a gas purification plant bought by the USSR in 1978, the Italian offer was some 20 percent less than the Austrian one. ${ }^{36}$ In another case, the USSR accepted France's bid for a reprocessing plant for natural gas. Such disadvantages seem to have been made even worse by a lack of coordination and skill, as well as by the negligence of Austrian companies to attempt to overcome the rising obstacles. On the occasion of his 1976 trip to the Soviet Union, Minister of Trade Staribacher was, in his own words, "exasperated" with the low quality of informa-

${ }^{33}$ Various statistics, Austrian Ministry for Trade and Industry, in SBKA, Länderboxen, UdSSR 3; Eberhard Schulz, Moskau und die europäische Integration (Munich: Oldenbourg, 1975), 230231.

34 Scarlis, Neutralität, 151.

35 Information, Austrian Ministry for Trade and Industry, Zl. 21.198.6/4-II-6/78, January 1978, in SBKA, Länderboxen, UdSSR 3.

36 Austrian embassy Moscow to Austrian MFA, 26 January 1978, in SBKA, Länderboxen, UdSSR 4. 


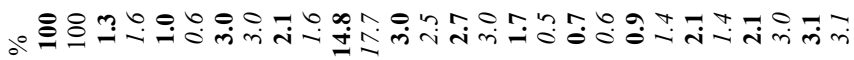

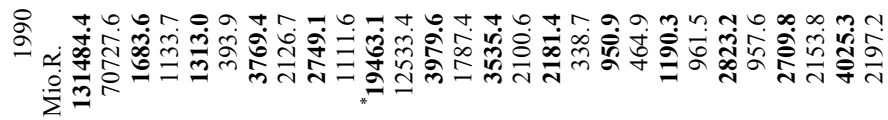

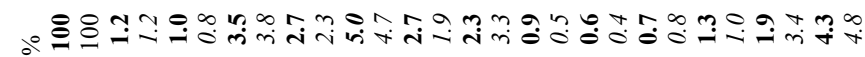

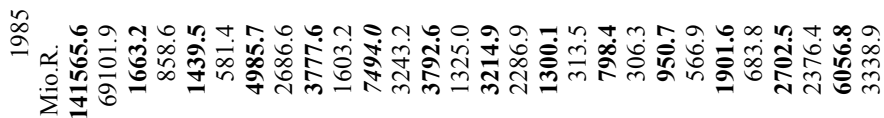

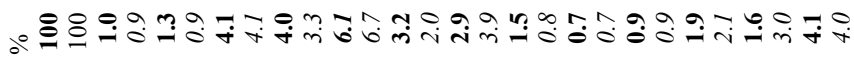

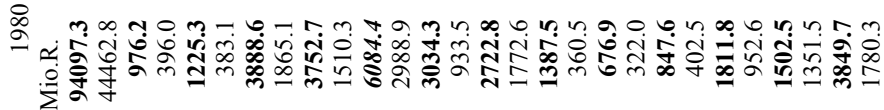

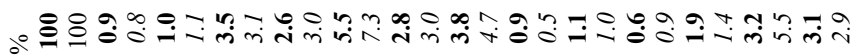

告

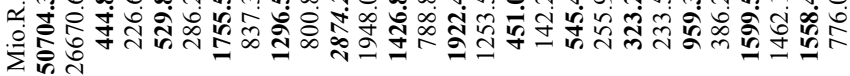

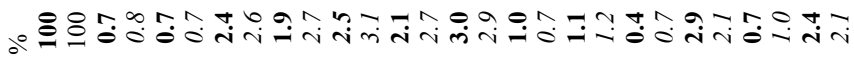

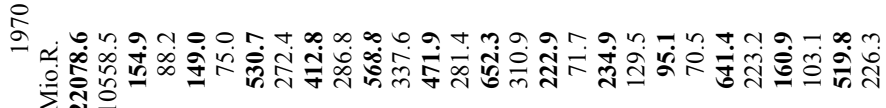

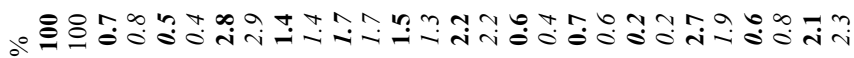

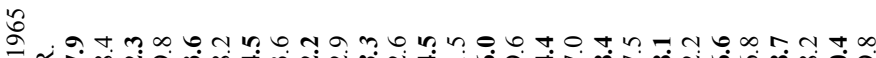

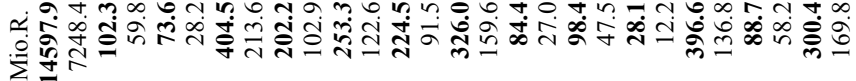

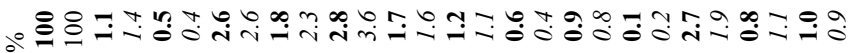

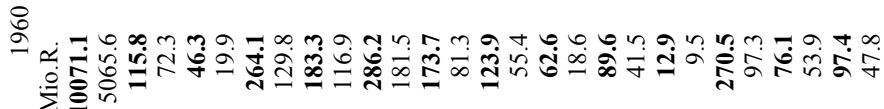

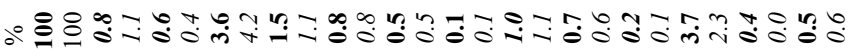

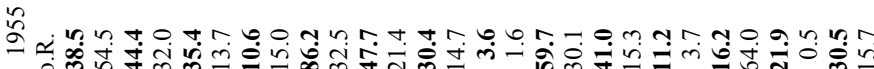

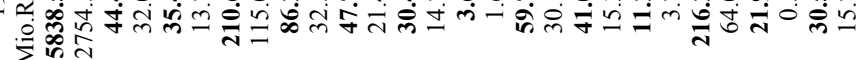

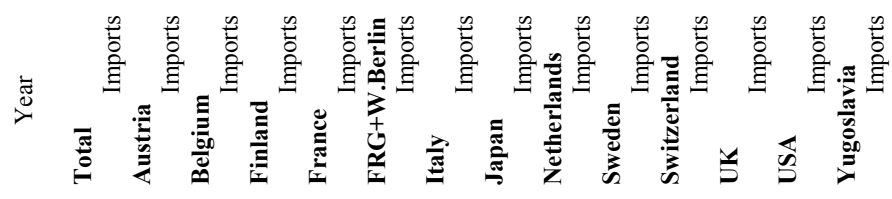




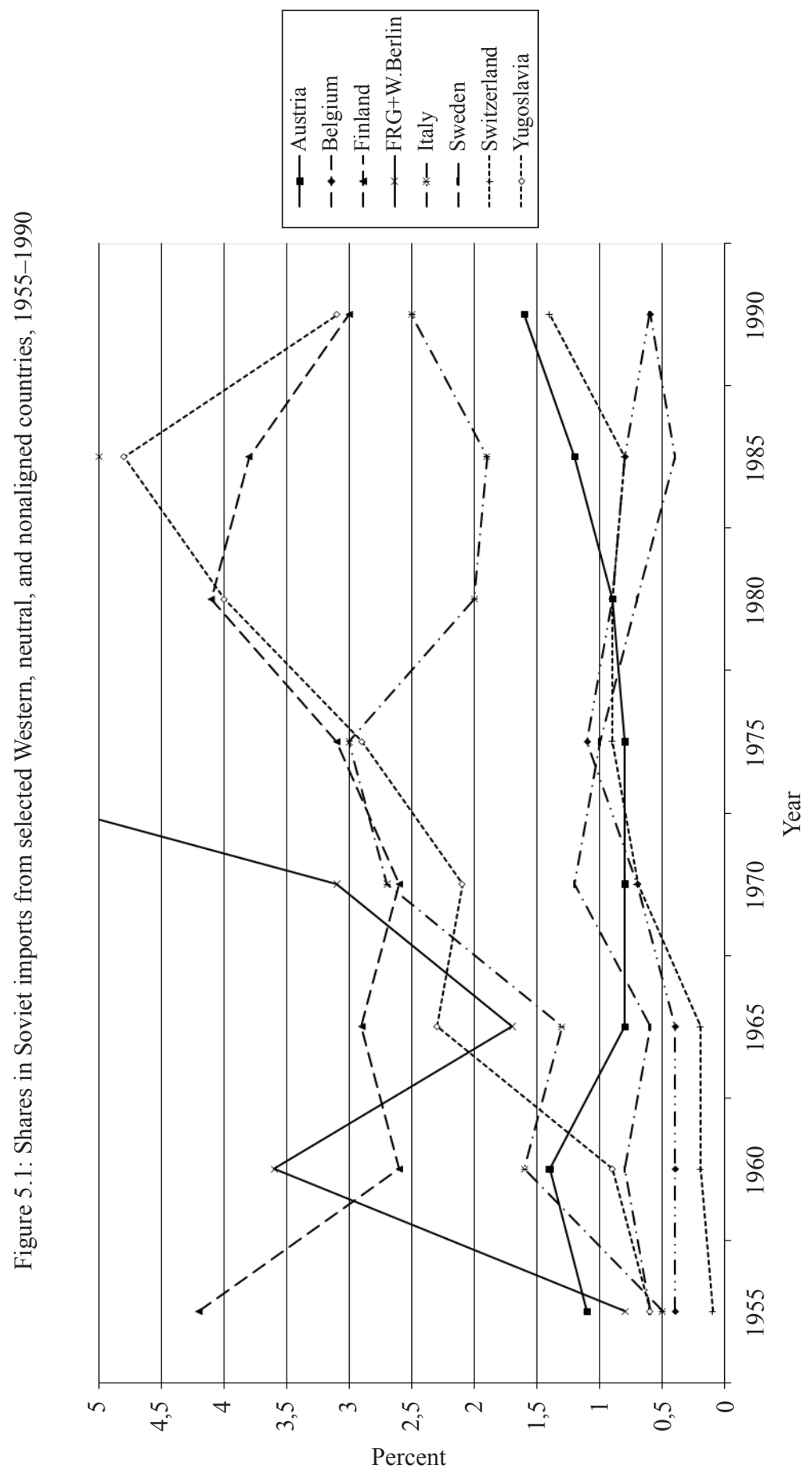


tion material prepared by a major Austrian company that had hoped to secure some Soviet orders. ${ }^{37}$ As Ambassador Hinteregger pointed out, many Austrian firms sent junior managers to Moscow, who had no chance of making direct contacts with Soviet decision makers. In addition, in the negotiations on a Soviet-West European pipeline, Austria had not prepared a careful plan with regard to pipes, gas, and loans. ${ }^{38}$ His successor Liedermann stated sarcastically that in order to gain Soviet orders it was no longer sufficient to rely on the "Vine Louse Effect," which had characterized Soviet-Austrian relations in $1955 .{ }^{39}$

When the USSR announced in 1978 that the Olympic Village for the 1980 Games would be built exclusively by Soviet companies, and all efforts to establish a joint venture to assemble Soviet Lada Taiga and Niva cars in Austria failed, ${ }^{40}$ the Austrian embassy expressed its "disappointment" that Austria - despite the increase in bilateral trade - had not received a major Soviet order for more than fifteen years. ${ }^{41}$ In particular, the embassy complained about the Soviet "discrimination" against Austria as compared to West Germany, whose fine trading position with the USSR had not been harmed by its boycott of the Moscow Olympic Games - a fact that should be considered by those who, for trade reasons, oppose boycotting mass events that are used for political purposes such as the Olympic Games despite violations of human rights in the organizing country.

37 Staribacher Diaries, 16-21 July 1976, in SBKA.

38 Amtsvermerk Hinteregger, 14 October 1981, in SBKA, Länderboxen, UdSSR 6; Hinteregger, "Erinnerungen an Moskau," 247.

${ }^{39}$ Liedermann to Austrian MFA, On Soviet-Austrian Relations, 23 November 1985, in ÖStA, AVA, NL E-1736: Bielka, File 115. For the full text, see pages 333-338. According to a 1955 cartoon by E. H. Köhler, the Austrian delegation in April 1955 had won Soviet consent to signing the state treaty by performing the Heurigen song "Die Reblaus" ("The Vine Louse"). Simplicissimus, no. 17 (1955), 3. Cf. http://www.demokratiezentrum.org/wissen/galleries/zum-staatsvertrag-gallery. html?index $=1058$.

${ }^{40}$ Hinteregger, "Erinnerungen an Moskau," 249-250. Talks on the project had been a major focus of Foreign Minister Willibald Pahr's visit to Moscow in December 1978. Österreichische Zeitschrift für Außenpolitik 18 (1978), 299. On the visit, cf. W. Jelagin, "Entspannungsfördernd," in Neue Zeit, no. 52 (1978), 17.

${ }^{41}$ Austrian embassy Moscow to Austrian MFA, July 1980, in SBKA, Länderboxen, UdSSR 6. 


\section{The Final Peak of the Cold War}

The final peak of the Cold War had many causes. During the years of détente, the Soviet Union had continued the arms race and annually assigned about 8 percent of its GDP and 16.5 percent of its budget for the armed forces and weaponry; if one includes indirect costs related to the military industry, altogether 40 percent of the country's budget was spent on military build-up. ${ }^{1}$ In the decade following 1972 , the USSR built more than 4,100 ground-based and sea-launched Intercontinental Ballistic Missiles, whereas the United States produced about 920. While Soviet dissidents criticized the "ruinous super-militarization"2 of their country and saw the signs of a deepening economic and societal crisis, the ailing Brezhnev, addicted to tranquillizers and on the edge of physical and mental collapse, "followed the lead of the military." ${ }^{\prime 3}$ His gerontocratic successors Iurii Andropov, who in a brief period at the helm of the Kremlin staged a new wave of persecution of dissidents, and Konstantin Chernenko, who was not fit for any political initiatives at all, did nothing to avert the imminent breakdown.

In the West, the USSR was again perceived as a menace. New heavy and flexible Soviet intermediate-range "Pioneer" missiles, the so-called SS-20, which were deployed from 1976 by the hundreds in Eastern Europe, led to NATO's Double-Track Decision to offer arms limitation talks to the Warsaw Pact and, if they failed, to deploy new Western missiles. The violations of human rights in the Soviet Union, in particular the issue of Jewish migration, the Soviet invasion in Afghanistan, and the invocation of martial law in Poland, which were all followed by Western sanctions against the Eastern regimes, contributed to the breakdown of détente. This was marked by the US refusal to ratify SALT-II and a sharp upsurge in Soviet antiWestern propaganda, in particular against Jimmy Carter and the Strategic Defense Initiative (SDI) of his successor Ronald Reagan. ${ }^{4}$ Further nails were hammered into détente's coffin in the fall of 1983, when the Soviet air force shot down a civilian South Korean airplane, leaving all 269 people on board dead, and when the Soviet delegation walked out of the arms control negotiations in Geneva.

In Soviet statements of the early 1980s, it was repeated that "peaceful coexistence" was not to be mistaken for "détente," but rather "a specific instrument of the

\footnotetext{
${ }^{1}$ Zubok, A Failed Empire, 208, 242, 277.

${ }^{2}$ Quoted in Wolkogonow, Die sieben Führer, 282. Cf. ibid., 341-343, 359-361, 389, 413.

3 Georgi Arbatov, The System: An Insider's Life in Soviet Politics (New York: Times, 1992), 201203.

${ }^{4}$ Ulam, Dangerous Relations, 226, 271.
} 
class struggle." While the end of détente was attributed to "subjective factors" such as "the sharp upswing of militaristic and aggressive tendencies in the policy of the USA," " no reference was made to the Soviet arms build-up or to the interventions in Poland and Afghanistan. In particular, the latter invasion of a nonaligned country strained the USSR's relations not only with the Western world, but also with the Third World - a consequence that had been foreseen by Gromyko, who in a Politburo session in early 1979 voiced his concern that in the case of a Soviet intervention, "all the nonaligned countries will be against us." Indeed, the Soviet invasion was condemned by the UN General Assembly by a tenfold majority. Brezhnev, who in the wake of the 1979 nonaligned states' summit in Havana had identified its participants as "natural allies" of the Soviet Union, ${ }^{8}$ made a clumsy attempt at mending fences by sending greetings to the nonaligned countries and claiming that "the development of the friendship and cooperation with the nonaligned countries, which are one of the most important links in the joint front in the peoples' struggle for peace and freedom, was and remains the principal position of the Soviet Union." "The deterioration of Soviet relations with the neutral and nonaligned states contained another inconvenience: the Kremlin had hoped that they would support the West European "peace movement's" struggle against Western rearmament (the Eastern side of the arms race had escaped most Western activists' attention). Andropov, in his report to the Central Committee plenum on 14-15 June 1983 , tried to encourage the neutrals and, even more, the "peace movement" to increase activities against Western rearmament. ${ }^{10}$

In publications by Soviet experts, the neutrals were invited to contribute to the denuclearization of Western and Central Europe, to an end of the Western embargo against the USSR, and, in general, to a "Europeanization" of European affairs, ${ }^{11}$ i.e. the elimination of the US presence in Western Europe and the yielding of West European states to neutralization. These strategies were accompanied by the Soviet definition of permanent neutrality and nonalignment being adapted. While earlier Soviet publications had attempted to activate the permanent neutrals by blurring the

5 A. Gromyko, "V. I. Lenin i vneshniaia politika Sovetskogo gosudarstva,“ in Kommunist 59, no. 6 (1983), 11-32, 26.

${ }^{6}$ D. Tomashevsky, "Lenin's Concept of Peaceful Coexistence and the Imperialist Challenge," in International Affairs, no. 5 (May 1982), 3-13.

7 Quoted in Zubok, A Failed Empire, 260.

${ }^{8}$ Hakovirta, "East-West Tensions," 205.

9 Privetstvie L. I. Brezheva neprisoedinivshimsia stranam, 9 February 1981, in Vneshniaia politika Sovetskogo Soiuza i mezhdunarodnye otnosheniia 1981 (Moscow: Mezhdunarodnye otnosheniia, 1982), 11.

${ }^{10}$ Plenum TsK KPSS 14-15 iiunia 1983g.: Stenograficheskii otchet (Moscow: Izdatel'stvo politicheskoi literatury, 1983), 130.

${ }^{11}$ Viktor A. Kremenyuk, "The European Neutrals and Soviet-American Relations," in Hanspeter Neuhold and Hans Thalberg (eds.), The European Neutrals in International Affairs, Laxenburg Papers 7 (Vienna: Braumüller, 1984), 93-103, 99-101. 
differences between permanent neutrality and nonalignment, the fourth edition of the Diplomatic Handbook dropped the notion of "positive neutrality," 12 which previously had been used for expanding the peacetime obligations of the permanently neutral states by theoretically linking the neutrals with the nonaligned states.

For the European neutrals, the new Cold War brought new dilemmas. Their maneuvering space became more restricted and they came increasingly under pressure, both domestically and internationally. The West and the domestic Right criticized the neutral's lack of solidarity with Western ideals and human rights, while the East and the domestic Left tended to criticize neutral governments as still displaying too much cohesion with the West. ${ }^{13}$ When the United States, as a result of the new peak in the Cold War, stepped up the COCOM high technology embargo, many West European states and the neutrals, in contrast to the 1940s, insisted on preserving economic links to the communist states. ${ }^{14}$ Therefore, US attempts to block a Soviet gas pipeline project from Urengoi to Western Europe failed - a failure that was celebrated by communist propaganda as a victory. From the Soviet side, pressure on the neutrals was increased, particularly in the north, by military build-up in the Murmansk region and by frequent violations of Swedish airspace and territorial waters. This culminated in the "Whiskey on the rocks" crisis of 1981, when a Soviet submarine of the so-called Whiskey Class, armed with nuclear torpedoes, became trapped by an underwater rock two kilometers from a Swedish naval base. While spying was one of the objectives of such Soviet intrusions, they also aimed at demoralizing the neutral's efforts in self-defense and at "emphasizing the futility of military defense for small powers." ${ }^{15}$ The Swedish initiative to include the northwestern USSR into a proposed Nordic nuclear-weapons free zone (a project that Khrushchev and Brezhnev had encouraged since 1959) was rejected by the Kremlin indignantly. ${ }^{16}$

12 "Neitralitet," in A. A. Gromyko et al. (eds.), Diplomaticheskii slovar' 2, 4th ed. (Moscow: Nauka, 1985), 271-272; "Neprisoedineniia dvizhenie," ibid., 277-278.

${ }^{13}$ Karl E. Birnbaum, "East-West Relations and the Position of the European Neutrals," in Bo Huldt and Atis Lejins (eds.), European Neutrals and the Soviet Union (Stockholm: The Swedish Institute of International Affairs, 1985), 1-6; Sundelius, "Dilemmas and Strategies for the Neutral Democracies," 11; Neuhold, "The Neutral States of Europe," 127.

${ }^{14}$ John W. Young, "Western Europe and the End of the Cold War, 1979-1989," in Melvyn P. Leffler and Odd Arne Westad (eds.), The Cambridge History of the Cold War III: Endings (Cambridge: University Press, 2010), 289-310, 296.

15 Andrén, "Swedish-Soviet Relations: An Overview," 78 (quotation), 69, 74-75; Gunnar Jervas, "Sweden in a Less Benign Environment," in Bengt Sundelius (ed.), The Neutral Democracies in the New Cold War (Boulder: Westview, 1987), 57-74, 66.

${ }^{16}$ Scarlis, Neutralität, 167. On the NWFZ, cf. Hentilä, "The Soviet Union, Finland, and the 'Northern Balance,"' 251; Lev Voronkov, Non-Nuclear Status to Northern Europe (Moscow: Nauka, 1984), 93-134. 
Finland was also put under Soviet pressure by being invited to hold joint military exercises with the USSR.${ }^{17}$ In addition, the country (and the Kremlin) had to master the retirement of Kekkonen (after twenty-five years in power) and the USSR demanded the continuation of the "Paasikivi-Kekkonen Line of Finnish-Soviet friendship" under his successor Mauno Koivisto. ${ }^{18}$ In the United Nations, the Finnish representative abstained from voting on the Soviet intervention in Afghanistan, while condemning (together with Sweden) that of the United States in Grenada.

Due to growing Soviet pressure, it does not come as a surprise that the majority of the Swedish population which had entertained friendly feelings towards the Eastern superpower during most of the 1970s, perceived it by the early 1980s as unfriendly or even a permanent threat to peace. In addition, in an opinion poll, 40 percent spoke out in favor of Sweden being assisted by NATO in the case of a Soviet threat, while only 4 percent advocated soliciting Soviet assistance against a threat by NATO. The Swiss government, too, was "alarmed by the fact that, in their eyes, the Soviet Union took advantage of the period of détente and of the political weakness of the United States after the Vietnam disaster and increased her armaments." ${ }^{19}$ In contrast to some Austrian, Swedish, and even West German politicians, the Swiss minister of defense, Georges André Chevallaz, saw NATO's Double-Track Decision as a legitimate and necessary response to the insecurity created by Soviet policy. Pierre Aubert, the Confederation's minister of foreign affairs, was similarly critical of the numerous communist violations of the Helsinki declaration. In response to growing international tension, Switzerland remained committed to upholding its military capabilities and, at the Stockholm Conference for Disarmament in Europe, rejected Yugoslav and Swedish proposals for reducing all armed forces close to borders and for creating a Central European nuclear-weapons free zone. In his memoirs, Andrei Gromyko did not hide his contempt for the Swiss position. ${ }^{20}$

\section{To boycott or not to boycott?}

In Austria's foreign policy a shift was perceivable during the late Kreisky years and under his successor Fred Sinowatz. The 1968 student revolts and the protests against the US intervention in the Vietnam War had brought a mood swing within many West European societies, in particular within leftist student organizations and social democratic parties. A more left-wing foreign political posture was considered desirable, and the tone moved away from a balanced Atlanticism towards

17 Jacobson, Finnland im neuen Europa, 80.

18 Raimo Väyrynen, "Adaptation of a Small Power to International Tensions: The Case of Finland," in Bengt Sundelius (ed.), The Neutral Democracies in the New Cold War (Boulder: Westview, 1987), 33-56, 39-42, 48, 52.

19 Hans Vogel, "Switzerland and the New Cold War," in Bengt Sundelius (ed.), The Neutral Democracies in the New Cold War (Boulder: Westview, 1987), 95-116, 107.

${ }^{20}$ Gromyko, Memories, 225. 
an uncritical support of the "anti-imperialist" movements of Mao, Ho Chi Minh, and Che Guevara. Those who favored this shift knew little and cared less about the Eastern bloc and its dissidents, about containment or deterrence. An Italian student slogan of 1968 read: "We are not with Dubček, we are with Mao." ${ }^{21}$ Although they voiced their criticism against US interference in East Asia and Nicaragua, they kept a remarkably low profile regarding the Soviet invasions of Czechoslovakia and Afghanistan or the declaration of martial law in Poland. While they organized demonstrations against the counterdeployment of Pershings and cruise missiles in Western Europe, the preceding Soviet deployments of SS-20s in the East had not been protested with similar vigor.

Olof Palme, neutral Sweden's social democratic prime minister, criticized US policy harshly and sent aid to the communist North Vietnamese government, moves that were followed by Soviet praise ${ }^{22}$ and the withdrawal of the US ambassador from Sweden. In contrast, Kreisky, who had been perceived a bulwark of proWestern steadfastness in the 1960s, refrained for the most part from excessive antiAmericanism. Nonetheless, from the late 1970s, a growing distance of Kreisky to the United States could be discerned. The chancellor, who in 1986 intimated to Gorbachev's assistant Vadim Zagladin that he considered Ronald Reagan "the worst US president ever, ${ }^{23}$ was critical not only of US interventions in Central America, but also of the economic sanctions that the United States had invoked immediately after the communist regime had imposed martial law in Poland, as well as of NATO's Double-Track Decision. After Kreisky's retirement in 1983, the shift to the left reached the Foreign Ministry, which was taken over from the diplomat Willibald Pahr by the left-wing party officer Erwin Lanc. ${ }^{24}$ Nicaragua became a focus of social democratic foreign activism, the Sandinista regime being uncritically supported with a loan of 72 million schillings and with visits by high-ranking delegations and enthusiastic "brigades," while the Nicaraguan opposition was ignored.

In the General Assembly session of 1981, Foreign Minister Pahr had classified "the illegal [Soviet] occupation of Afghanistan" as a "heavy burden on the policy of détente." ${ }^{25}$ This did not mean, however, that the Austrian government was prepared to join the resulting Western boycott of the Eastern bloc. When Lanc' successor Leopold Gratz traveled to Poland, in 1984, he continued a tradition in Austrian-East

${ }^{21}$ Quoted in Tony Judt, Postwar: A History of Europe Since 1945 (New York: Penguin, 2005), 390. On the "Peace Movement," see ibid., 591.

${ }_{22}$ Scarlis, Neutralität, 102; Karsh, Neutrality and Small States, 164.

${ }^{23}$ Conversation Zagladin with Kreisky, 9 September 1986, in Gorbachev Fond (hereafter: GF), 4840.

${ }^{24}$ Robert Kriechbaumer, Zeitenwende: Die SPÖ-FPÖ Koalition 1983-1987 in der historischen Analyse, aus der Sicht der politischen Akteure und in Karikaturen von Ironimus (Vienna: Böhlau, 2008), 440, 459-470.

${ }^{25}$ Erklärung von Außenminister Dr. Willibald Pahr vor der 36. Generalversammlung der Vereinten Nationen, 1 October 1981, in Österreichische Zeitschrift für Außenpolitik 21 (1981), 353-356, 355. 
European relations by breaking the isolation of Poland that had been imposed by the West after the introduction of martial law. Similarly, Kirchschläger had visited Poland a few weeks after the regime's massacre of demonstrating workers in Danzig in 1971, and when the Eastern bloc's first independent trade union went on strike, Kreisky warned the Polish workers not to obstruct the delivery of Polish coal to Austria. ${ }^{26}$ After the banning of "Solidarity" and the declaration of martial law in 1981, Kreisky had given the Polish opposition movement a cold shoulder, ${ }^{27}$ and Foreign Minister Pahr publicly cautioned the West about invoking sanctions against the communist regimes in Warsaw and Moscow. While martial law was still in force, Austria received the Polish vice-premier Mieczyslaw Rakowski. The economic sanctions by the West against the communist regime in 1981 were never supported by Austria nor was the flight boycott against the Soviet Union after flight KAL 007 was shot down. In the latter case, Austria, France and Greece were the only Western countries that did not join the boycott. ${ }^{28}$ Although the leaders of the GDR and Bulgaria, Erich Honecker and Todor Zhivkov, due to the new Cold War, cancelled their trips to the FRG in 1984, Sinowatz agreed to visit the communist states. The 1980 Olympic Games in Moscow were boycotted by a number of Western countries due to the Soviet invasion in Afghanistan. Despite this boycott and a call from humanitarian NGOs not to participate, Austria joined the games and was praised for this decision by Gromyko. ${ }^{29}$

Therefore, it is not surprising that the twenty-sixth CPSU congress in February 1981 lauded "Austria, Sweden, Belgium, Cyprus and several other European states" as being Western countries that the USSR maintained "successful relations with," ${ }^{30}$ though only after US policy and NATO had been castigated and the collaborations with France, West Germany, Finland, Turkey and Greece had been praised. Gromyko told Gratz in October 1984 that relations were good. As Ambassador Mikhail Efremov assured his Austrian counterpart Gerald Hinteregger, Andropov considered Austria "our friend." ${ }^{31}$ On the Austrian side, Sinowatz even

${ }^{26}$ Klaus Bachmann, "Poland and Austria," in Arnold Suppan and Wolfgang Mueller (eds.), Peaceful Coexistence or Iron Curtain? Austria, Neutrality, and Eastern Europe in the Cold War and Détente, 1955-1989 (Vienna: Lit, 2009), 354-383, 376; Molden, "Die 'Ost-West-Drehscheibe,"” $763,766$.

27 Joanna Gajdek, "Der mittelbare Nachbar: Österreichvorstellungen in Polen 1970-1995," in Oliver Rathkolb, Otto M. Maschke, and Stefan August Lütgenau (eds.), Mit anderen Augen gesehen: Internationale Perzeptionen Österreichs 1955-1990, Österreichische Nationalgeschichte 2 (Vienna: Böhlau, 2002), 651-675, 661. Cf. Franz Loidl (ed.), Pressestimmen zu Dr. Kreiskys Äußerungen über,,Solidarność " und die Kirche in Polen und Österreich (Vienna: Katholische Akademie, 1982).

${ }^{28}$ Skuhra, "Austria and the New Cold War," 128; Neuhold, "Austria and the Soviet Union," 110.

${ }^{29}$ Conversation Kreisky with Gromyko, 17 May 1980, in SBKA, Länderboxen, UdSSR 6.

${ }^{30}$ XXVI. Parteitag der KPdSU: Rechenschaftsbericht des Zentralkomitees der Kommunistischen Partei der Sowjetunion und die nächsten Aufgaben der Partei in der Innen- und Außenpolitik, Berichterstatter: L.I. Breshnew, Generalsekretär des ZK der KPdSU, 23. Februar 1981 (Berlin: Dietz, 1981), 34.

31 Aktenvermerk Hinteregger, 25 February 1983, in SBKA, Länderboxen, UdSSR 6; Österreichisches Jahrbuch für internationale Politik 1 (1984), 199. 
characterized the Austrian-Soviet relations as "excellent" and "unstrained by any problems." ${ }^{32}$ In an interview with Manfred Scheuch of Austria's Arbeiter-Zeitung in 1983, Tikhonov commended neutrality in general and Soviet-Austrian relations in particular, but rejected the newspaper editor's assessment that Soviet actions, too, might have contributed to the recent exacerbation of international relations. ${ }^{33}$

\section{Trade or embargo?}

The cooling down of East-West relations after 1979 did not harm Austrian foreign trade with the USSR; on the contrary, its importance strengthened, and Austria, one more (last) time, was able to benefit from its role as a "bridging factor." ${ }^{34}$ The following rain of Soviet orders seems to have been a consequence of a conversation between Kreisky and Gromyko in May 1980, in which the chancellor had expressed his desire to reduce the Austrian trade deficit with the USSR. ${ }^{35}$ The Soviets voiced their rising interest in Austrian technology in 1980, and in the following year, VOEST-Alpine received an order for an optics factory worth 370 million schillings and Voith for a paper mill worth 940 million. As well, ten tugboats worth 570 million and three passenger boats worth 822 million were ordered from the Korneuburg docks. ${ }^{36}$ While these deals, though large, could not be considered exceptional, Tikhonov, on his trip to Austria in 1981, brought a Soviet order for 800,000 tons of oil pipes from VOEST-Alpine worth 14 billion schillings - a commodity that, due to the Cold War, could not be purchased on Western markets. ${ }^{37}$ The same year, the Linz plant, whose transactions with the USSR had reached 3.8 billion schillings per year, delivered its fourth million tons of steel plates and had received its twentieth million tons of coal. ${ }^{38}$ In March 1982, VOEST-Alpine obtained an order to build in Zhlobin in the Belarus SSR, together with the Soviet company Metallurgimport, a steel plant with the capacity of producing 500,000 tons of sheet metal and 200,000 tons of crude metal per annum. The plant was opened by Chancellor Sinowatz in November 1984. ${ }^{39}$

32 Quoted in Lobova, "Die Moskauer Perzeption," 135; Zhiriakov, Sovetskii Soiuz-Avstriia, 77.

33 Sowjetunion heute, no. 11 (1983), 4-5.

34 Andrea Komlosy, "Österreichs Brückenfunktion und die Durchlässigkeit des Eisernen Vorhanges," in Gertrude Enderle-Burcel, Dieter Stiefel, and Alice Teichova (eds.), Zarte Bande: Österreich und die europäischen planwirtschaftlichen Länder, MÖSTA Sonderband 9 (Innsbruck: Studienverlag, 2006), 73-105, 96-97, 103.

35 The author's interview with Ambassador Hinteregger, 23 June 2009. Cf. idem, Im Auftrag Österreichs, 260-263.

${ }^{36}$ Bilaterale Wirtschaftsbeziehungen UdSSR - Österreich, [1981], in SBKA, Länderboxen, UdSSR 5, File Offizieller Besuch des MP der UdSSR Tichonov.

37 Archiv der Gegenwart, 24445, 10 April 1981.

${ }_{38}$ APA, 9 April 1981.

${ }_{39}$ Neuhold, "Austria and the Soviet Union," 102. 
Due to such stimulus, the Austrian share in Soviet imports recovered and rose from 0.9 (1981) to 1.3 (1983) and even to a high of 1.6 percent (1990). In 1985, it ranked between the United Kingdom and Italy. This was, nevertheless, still far below the leading Western trading partner of the USSR, the FRG, and other neutral and nonaligned states such as Finland and Yugoslavia. ${ }^{40}$ From the Austrian perspective, exporting to the USSR regained in importance. In 1983, Austria sent 12.1 percent of its exports to the Soviet Union. Other OECD countries sent an average of 3.3 percent of their exports to the USSR, with Finland's 27.7 percent, however, forming an exceptional peak. ${ }^{41}$ Of all destinations of Austrian exports, the USSR ranked sixth; of the countries of origin of Austrian imports, the USSR ranked third.

Austria also continued to export strategic goods such as high-quality steel and technology to CMEA states, for which the neutral was increasingly criticized by the United States, from 1982, for violating the COCOM embargo and accused of aiding East European countries to circumvent the same..$^{42}$ The accusations eased after Kreisky's visit to the United States in 1983 and significant Austrian concessions. ${ }^{43}$ At the same time, however, Soviet warnings were delivered that Austria should not give in to US demands. ${ }^{44}$ Since Austria itself depended on high-technology imports from the United States, it reluctantly bowed to COCOM demands. The Austrian role in Western high technology exports to the Eastern bloc seems to have been overestimated; in 1981, US studies showed the Austrian share at 1.8 percent, much less than the CMEA imported from West Germany (28.9 percent), Japan (21.8 percent), France and Italy (11.8 and 9 percent), and even less than from Finland ( 7 percent), Sweden ( 4.5 percent), or the United States ( 3.3 percent) ${ }^{45}$ During 1983, the US government reached understandings on restrictions of re-exporting US high technology with neutral countries, including Austria, Finland and Sweden. Switzerland refused to adhere formally to these agreements, but nonetheless restricted its exports to communist countries. In 1984, the Austrian foreign trade act was amended for the same reason. When in 1988 the COCOM embargo lists were unofficially adopted by the Austrian government, the last peak of the Cold War was nevertheless already over. ${ }^{46}$

${ }^{40}$ Hauke, "Handelspolitik und Außenwirtschaftsbeziehungen," 220-221.

${ }^{41}$ Neuhold, "Austria and the Soviet Union," 100.

${ }^{42}$ Höll, "The Foreign Policy of the Kreisky Era," 48; Philip Windsor, "Neutral States in Historical Perspective," in Joseph Kruzel and Michael Haltzel (eds.), Between the Blocs: Problems and Prospects for Europe's Neutral and Nonaligned States (Cambridge: University Press, 1989), 3-9, 8; Linda Melvern, Nick Anning, and David Hebditch, Techno-Bandits: How the Soviets are Stealing America's Future (Boston: Houghton Mifflin, 1984), 142-144.

${ }^{43}$ Kramer, "Strukturentwicklung der Außenpolitik 1945-2005," 819; John M. Luchak, “Amerikanisch-österreichische Beziehungen von 1955 bis 1985" (PhD Thesis, Vienna, 1987), 426-427.

${ }^{44}$ Neuhold, "Austria and the Soviet Union," 99.

45 Dörfer, "The European Neutrals in the Strategy of the Reagan Administration," 194.

46 Jan Stankovsky, "Österreich und das COCOM," in WIFO Monatsberichte no. 3 (1990), 148-155. 


\section{Summary: Declining Soviet Interest in Neutrality despite Austria's Efforts}

The decade from 1973 through 1982 was undoubtedly the most relaxed in Soviet-Austrian postwar relations: There was no major Soviet armed intervention in Austria's neighborhood and no Eastern propaganda campaign against alleged deviations from neutrality. Soviet satisfaction about having finally accomplished the convening of the CSCE contributed to this relaxation, as did the Soviet relief at the neutrals having become neither members nor associates of the EC, but merely having signed agreements on free trade. The Soviet attitude towards West European integration relaxed somewhat as well, although this was a rather tactical move aimed at fostering détente. In general, the Soviet resistance to the steadily growing European Community was not given up.

Once the CSCE had been convened, the general importance of neutrality and the neutrals for Soviet policy, as well as of Austria in particular, was reduced. This seemed to be, on one hand, a result of the international sea change: Détente had established direct and, from the Soviet perspective, relatively fruitful contacts with Western states such as Italy, France, the FRG, and later, even the United States. Hence, the neutrals were no longer needed to promote Soviet proposals. With the fragility of the Eastern bloc in mind, the Soviet Union even scaled back attempts of undermining the Western alliance by luring its members into some kind of neutral nirvana, and neutrality was promoted by the Kremlin less aggressively than in earlier years. On the other hand, the behavior of the neutrals at the CSCE did not exactly reflect what the Soviet Union had hoped for, and the Kremlin reacted by assigning them a less important role.

During the late Brezhnev years, Soviet diplomacy in Europe, in general, lost some of its impetus and many diplomatic conversations lacked content. The Kremlin had always put great emphasis on the propaganda value of mutual visits and bilateral communiqués and used the visits of guests from Western and neutral states for promoting its agenda. The Austrian side, however, seems neither to have been clear about its goals nor to have addressed them consistently enough to the Kremlin - probably out of fear of straining the delicate Soviet mood. ${ }^{1}$ Once there were no landmark goals to be achieved and no further results in the rapprochement between the "states of different social systems" to be celebrated, the lack of substance became quite apparent.

${ }^{1}$ Liedermann to Austrian MFA, 23 November 1985, in ÖStA, AVA, NL Bielka, File 115. For the full text, see pages 333-338. 
Nonetheless, both Soviet and Austrian actors seemed interested in letting their relations appear as friendly as possible. What bilateral tensions that did arise came mainly from human rights violations in or by the USSR and from Austrian media reports about and protests against them. The Soviet leadership seemed prepared to test the bilateral relationship by expelling Austrian journalists and demanding that no criticism of the Soviet Union be published. While in the 1950s and 60s, some Austrian politicians had been ready to try to moderate the Austrian public opinion about the USSR, in general, Kreisky rejected such attempts.

The last phase of the Cold War brought two developments for the neutral democracies. On one hand, the systemic need for their bridge building activities rose. On the other, the rising tension level also restricted their maneuvering space and their opportunities for third-party intervention. ${ }^{2}$ Austria tried to keep its options open by not joining the Western embargo and boycott, thus helping the communist regimes out of their isolation.

Already before the last peak of the Cold War had reached its climax, the drift of Austria's neutrality from the Swiss towards the Finnish model, as had begun in the aftermath of 1956 and been reinforced in 1968, was continued. The idea of "armed neutrality" and Austria's obligation for self-defense against external aggression as stipulated in the neutrality law of 1955 was increasingly treated by Kreisky and Foreign Minister Kirchschläger as obsolete. ${ }^{3}$ In Kreisky's interpretation of neutral policy, military deterrence became less important than global travel diplomacy, disarmament, criticism against US interventions (although during martial law in Poland and the Soviet invasion of Afghanistan, his stance was much less outspoken), and the Near East problem. ${ }^{4}$ While this reorientation of Austria's foreign policy towards global activism was mainly seen as the strategy of a weak international actor to secure its independence, ${ }^{5}$ it was accompanied by the parallel weakening of its previous interpretation of neutrality and the tendency to transform features of Austria's foreign policy into obligations of neutrality ${ }^{6}$ - thus becoming still closer to the Soviet understanding of neutrality.

This type of tendency in Austria's practice of neutral policy sparked quite a lot of discussion. In a monograph by the professor of international law Konrad Ginther, published in 1975, it was claimed that the Austrian government had, already in the late 1960s, given up the initial concept of neutrality, based on the Swiss model, in

${ }^{2}$ Sundelius, "Dilemmas and Strategies for the Neutral Democracies," 19; Skuhra, "Austria and the New Cold War," 119

${ }^{3}$ Ginther, Neutralität und Neutralitätspolitik, 122.

${ }^{4}$ Paul Luif, “Austria's Permanent Neutrality - Its Origins, Development, and Demise," in Günther Bischof, Anton Pelinka, Ruth Wodak (eds.), Neutrality in Austria, Contemporary Austrian Studies 9 (New Brunswick: Transaction, 2001), 129-159, 137-138.

5 Höll, "Kleinstaaten," 169.

${ }^{6}$ Franz Cede, "Österreichs Neutralität und Sicherheitspolitik nach dem Beitritt zur Europäischen Union," in Zeitschrift für Rechtsvergleichung 36, no. 4 (1995), 142-148, 143. 
favor of a more Soviet-friendly interpretation and that the Austrian interpretation of neutrality approached the Soviet "peaceful coexistence" policy. ${ }^{7}$ As indications for this development, Ginther analyzed Austrian political declarations of the period from 1955 to 1973 and cited the sinking importance being given to armed neutrality and neutrality's legal foundations by Waldheim, Kreisky, and Foreign Minister Rudolf Kirchschläger; furthermore he criticized the invocation of the neutral country's permanent political obligation to an "active peace policy" as a surrogate for armed defense, which reflected the Soviet thesis of "peaceful coexistence," and, instead of a status that was legally defined, the creation of a "myth of positive neutrality equaling peace and security" that was legally vague and ideologically predisposed, despite being politically influential and universally applicable.

Similar criticism of Kreisky's interpretation of neutral policy was brought forward by the Christian-democratic professor of international law Felix Ermacora, who rejected the thesis that the "secondary obligations" of permanent neutrality, i.e. the obligation to avoid any measures that might render maintaining neutrality impossible in the case of war, were legally binding. He argued that the theory of "secondary obligations" had been construed by German lawyers in the interwar period with the aim of justifying, ex post facto, Germany's violation of Belgian neutrality in World War I. After World War II and still remembering Nazi Germany pressure on Switzerland, the thesis had been adopted first in the Swiss doctrine, which he classified as "politically predetermined" and unable to "withstand scientific critique," macora conceded, however, that observing the "secondary obligations" in peacetime was a matter of prudence, he claimed that, in order not to limit the neutral's freedom of action, such obligations had to be defined as restrictively as possible. Following this line of thinking, Ermacora considered the thesis that neutrality was incompatible with EEC membership as also having been politically predetermined. In addition, he criticized Kreisky having adopted the thesis that a "good foreign policy" and not the readiness to defend the country was the best guarantee for neutrality. By subscribing to the Swiss doctrine and augmenting it with Soviet theses, Austrian leaders and lawyers, in Ermacora's eyes, had contributed to bloating the neutral's legal obligations, reducing its freedom of action, and to underpinning Soviet demands. ${ }^{9}$

The Austrian ambassador to Moscow also recommended that the government "counter more consistently" the Soviet attempts at "blurring the limits of international law and foreign policy," attempts that were perceived as harmful to Austria's

\footnotetext{
${ }^{7}$ Konrad Ginther, Neutralität und Neutralitätspolitik. Die österreichische Neutralität zwischen Schweizer Muster und sowjetischer Koexistenzdoktrin (Vienna: Springer, 1975), 143-155.

${ }^{8}$ Felix Ermacora, 20 Jahre österreichische Neutralität (Frankfurt: Metzner, 1975), 123, 73-74, 80, $117-118$.

${ }^{9}$ Ibid., 19, 114, 123, 137, 167-172.
} 
interests. ${ }^{10}$ Such passivity, Ambassador Helmut Liedermann warned, might lead to Soviet claims regarding legal obligations resulting from neutrality being internationally recognized. In addition, it was suggested that the Austrian government should not let itself be blinded by "empty phrases" about the state treaty and neutrality, but be more articulate in communicating to Moscow its own interests and needs - something that had been neglected so that the delicate bilateral relationship would not be strained.

More general charges of "neutralism" were made by the oppositional ÖVP, which accused Kreisky in the late 1970s of neglecting the country's traditional bonds to the West, while appeasing the East. ${ }^{11}$ In particular, the eastward shift of the travel diplomacy of Kreisky and his ministers, and his harsh criticism of US policy in contrast to his lack of outspokenness regarding Soviet actions had raised concerns among more pro-Western Austrians.

Some of Ginther's and Ermacora's theses aroused criticism and consternation in the diplomatic and political establishment, and officials in the Foreign Ministry discarded them as "completely wrong." 12 They were rejected by Karl Zemanek ${ }^{13}$ and Alfred Verdross, who argued that a "permanently neutral state [...] cannot restrict itself to being an island of peace by staying away from international conflicts, but must conduct an active policy of neutrality with the aim of contributing to the consolidation of general peace and international security." ${ }^{14}$ Verdross moreover made it clear that the Western understanding of "peaceful coexistence," as had been adopted by many states and the United Nations, differed significantly from the Soviet understanding and excluded ideological matters.

While all sides in the scholarly debate emphasized that Austria's neutrality should not be understood as a free ticket for carelessness and isolationism, Austrian opinion polls of the late 1970s and early 80s underlined the effects of a considerable mental "neutralization": Austria was seen by 75 percent as "zone of peace" between the alliances, 55-63 percent deemed it unlikely that war would affect Austria, and 17-31 percent even felt that this was impossible at all. When asked what the main guarantor for peace was, 75 percent named neutrality; only 10 percent expected the Bundesheer to be able to deter a potential aggressor. ${ }^{15}$ More than 50

${ }^{10}$ Liedermann to Austrian MFA, 23 November 1985, in ÖStA, AVA, NL Bielka, File 115. For the full text, see pages 333-338.

${ }^{11}$ Kriechbaumer, Die Ära Kreisky, 266-267.

12 Ginther, "Austria's Policy of Neutrality and the Soviet Union," 67, 83 note 5.

${ }^{13}$ Karl Zemanek, “'Zeitgemäße' Neutralität?,” in Österreichische Zeitschrift für Außenpolitik 16 (1976), 355-367, 356, 362-363; idem, ““Zeitgemäße’ Neutralität? - Schlussbemerkungen,” ibid. 17 (1977), 134-136, 135.

${ }_{14}$ Verdross, Die immerwährende Neutralität Österreichs, 48, 73-79; quotation ibid., 73.

${ }^{15}$ Ferdinand Trauttmansdorff, "Österreichs Außenpolitik als Sicherheitspolitik," in Renate Kicker, Andreas Khol, and Hanspeter Neuhold (eds.), Außenpolitik und Demokratie in Österreich: Strukturen - Strategien - Stellungnahmen (Salzburg: Neugebauer, 1983), 235-258, 241-245, 250. 
percent were against acquiring defense missiles. ${ }^{16}$ With regard to ideological neutralism, which had been consistently rejected by Austrian leaders since 1955, 52 percent spoke out in favor thereof; supported by 30 percent was the idea of passing a law restricting freedom of speech, if opinions were expressed that contained criticism of a foreign power; and a majority was against official interventions in cases of civil rights movements being suppressed in the USSR or other cases of human rights violations. ${ }^{17}$ Only 44 percent welcomed a foreign policy that aimed at supporting such groups in Eastern Europe. ${ }^{18}$

${ }^{16}$ Harrod, "Felix Austria?," 290.

${ }^{17}$ Hanspeter Neuhold, "Österreichs Außenpolitik in den Ost-West-Beziehungen," in Renate Kicker, Andreas Khol, Hanspeter Neuhold (eds.), Außenpolitik und Demokratie in Österreich: Strukturen - Strategien - Stellungnahmen (Salzburg: Neugebauer, 1983), 290-320, 318-319.

${ }_{18}$ Nils Andrén, "Looking at the Superpowers," in Bengt Sundelius (ed.), The Neutral Democracies and the New Cold War (Boulder: Westview, 1987), 160-181, 163. 



\section{THE AFTERMATH, 1985-1991}

"The content of n[eutrality] changed in every historical epoch according to the influence of economic, social, and political conditions of the given epoch, in particular the character of war." "Neitralitet," in A. Ia. Vyshinskii (ed.), Diplomaticheskii slovar'2, 1st ed. (Moscow: Gospolitizdat, 1950), 230-234, 230. 



\section{The End of the Cold War, European Integration, and the Obsolescence of the Special Relationship}

The advent of Mikhail Gorbachev did not bring immediate change to international politics - at least none that was discernable to foreign observers. In his first years in power, the Soviet leader rather pursued limited goals such as improving the international climate, building mutual trust, stopping the nuclear arms race and torpedoing the American SDI project. ${ }^{1}$ However, while the Soviet economic and societal crisis was obscured by Gorbachev's energetic personality and optimism, the seeds of ideas such as common principles of humanity and global interdependence were about to fundamentally alter international relations and contribute to the end of the Cold War. The decline in international tensions, as could be felt from 1987, ${ }^{2}$ affected the small and neutral powers in two ways: On one hand, their maneuvering space increased; on the other, the attention that was given to the neutrals by the superpowers decreased.

\section{Gorbachev, Austria's EC application, and the disintegration of the USSR}

When President Kirchschläger traveled to Moscow to attend Konstantin Chernenko's funeral in 1985, he was received by Mikhail Gorbachev, who expressed his satisfaction with Austria's role in international politics, particularly détente. ${ }^{3}$ Despite such assurances, Austria was not important enough to be the first Western country visited by the new Soviet leader, who, like Brezhnev before him, went first to France. He consulted the French president François Mitterrand before his planned meeting in November with US president Ronald Reagan in Geneva for negotiations on arms' limitations. No breakthrough was achieved at the summit.

Internal repercussions in Austria over the debate concerning the role of President-elect Kurt Waldheim in the German Wehrmacht during the deportations and mass killings of Jews in Greece in World War II, and the rise of the FPÖ as a rightwing, anti-establishment and anti-immigrant movement under the leadership of Jörg Haider did not affect Soviet-Austrian relations - although both were noted in

\footnotetext{
${ }^{1}$ Archie Brown, "The Gorbachev Revolution and the End of the Cold War," in Melvyn P. Leffler and Odd Arne Westad (eds.), The Cambridge History of the Cold War III: Endings (Cambridge: University Press, 2010), 244-266.

2 Anthony D’Agostino, Gorbachev's Revolution, 1985-1991 (Basingstoke: Macmillan, 1998), 117-118.

3 Österreichisches Jahrbuch für internationale Politik 2 (1985), 214.
} 
the Kremlin. In the Soviet media, Vranitzky was depicted as "capable technocrat," Haider as a "far right, openly pro-German nationalist," a "multi-millionaire," and the "leader of the neo-Nazis." In the Waldheim affair, former Chancellor Kreisky, in 1986, warned the CPSU official Vadim Zagladin to be cautious in handling the case of the newly elected Austrian president ${ }^{5}$ (whom Kreisky himself had promoted for the position of a UN secretary general fifteen years earlier). When Waldheim, in 1990, asked Gorbachev for a meeting, the Soviet leader's aide Anatolii Cherniaev recommended that he not be received. ${ }^{6}$ Nevertheless, the Soviet leadership, in contrast to the US administration's decision to put the Austrian president on a "watch list," did not publish any official statement concerning Waldheim and remained appreciative of his actions as Austrian foreign minister from 1968 to 1970 and the secretary general of the United Nations Organization from 1971 to 1982.

Soviet-Austrian bilateral political relations continued to be as cordial as they had ever been. When Sinowatz met Gorbachev in April 1986, both sides expressed full support for the Helsinki process. The "excellent and amicable" relations ${ }^{7}$ were also not strained by the Soviet reluctance to inform its neighbors of the dangerous effects of the nuclear catastrophe in Chernobyl. In the fall of 1988, an agreement on timely information in the case of nuclear accidents was signed, and a month later, a contract on the joint "Austromir" space mission was concluded. ${ }^{8}$ Sinowatz' successor, Franz Vranitzky, underlined his approval of perestroika when he received his Soviet colleague Nikolai Ryzhkov in Vienna in $1987 .{ }^{9}$ Soviet foreign minister Eduard Shevardnadze traveled to Vienna in November of 1986, January and March of 1987, and October of 1988; his Austrian counterpart, Alois Mock, returned the visit in September of 1988, and Vranitzky followed in October of 1988, accompanied by a delegation of no less than eighty representatives of Austrian companies. In a single year, 1988, six members of the Austrian government were received in Moscow. ${ }^{10}$

It soon became clear, however, that the more intense Soviet-Western negotiations became, the less important Austrian mediation or promotion of Soviet ideas was. The sinking geopolitical importance of Austria for the Kremlin was mirrored by the Soviet media, which in earlier decades had repeatedly praised Austria's role in "peaceful coexistence" and détente, and from time to time had criticized certain aspects of Austrian policy. In the Gorbachev years, however, the media signaled its

${ }^{4}$ Quoted in Lobova, "Die Moskauer Perzeption," 124-125; Stifter, "Das politische Österreichbild," 214.

${ }^{5}$ Conversation Zagladin with Kreisky, 9 September 1986, in GF, 4840.

${ }^{6}$ Cherniaev to Gorbachev, 11 November 1990, in GF, 2/1. I am grateful to Prof. Oliver Rathkolb for granting me access to his copy of this document.

7 Österreichisches Jahrbuch für internationale Politik 4 (1987), 179.

${ }^{8}$ Zhiriakov, Sovetskii Soiuz - Avstriia, 154.

9 Österreichisches Jahrbuch für internationale Politik 4 (1987), 222.

${ }_{10}$ Außenpolitischer Bericht (1988), 588. 
lack of interest in Austria, and a growing de-ideologization could be noted. Most ideological assertions disappeared with regard to Austria, its social democracy and the "social partnership" were increasingly depicted positively, and its economy, social insurance and school system were even portrayed as promising models. ${ }^{11}$

Bilateral meetings were increasingly shaped by an issue that had overshadowed Soviet-Austrian relations during the 1960s and that resurfaced in the late 1980s. When the conservative People's Party again became part of a governing "grand coalition" with the social democrats in 1987, they advocated the country's application for full membership in the European Community, albeit with reservations regarding the country's neutrality. This option had been considered possible by certain legal experts since the 1960s, in particular by Michael Schweitzer. ${ }^{12}$ Since article 223 and 224 of the EEC Treaty of 1957 contained a sort of neutrality clause that provided the possibility of a member to deviate, for reasons of national security, from the rules of the community as established by the treaty, some international law experts rejected the majority opinion of their colleagues that EEC membership and neutrality were incompatible. ${ }^{13}$ Moreover, Schweitzer and his colleague Waldemar Hummer stressed that the EC of the 1980s was not as supranational as the EEC of the early 1960s, which is why they considered a neutral's membership in the EC possible. Among other facts and documents that served as evidence for the new standpoint, the lawyers cited, most ironically, the Soviet-Austrian trade agreement of October 1955, which mentioned the possibility that any of the contracting parties might conclude a customs union with a third country. With this new legal advice supporting the compatibility thesis in their hands, by 1989 the People's Party's leadership had managed to convince their reluctant coalition partner of the desirability of this option. The social democrats had moved in this direction only slowly. In 1987, the SPÖ chairman, Chancellor Vranitzky, had ruled out EC membership as incompatible with neutrality, ${ }^{14}$ thus following a decade-old Soviet (and, in fact, also Austrian) line of argumentation; by October 1988, in Moscow, he conceded that "as long as the two military-political blocs exist in Europe," membership in the EC would violate neutrality. ${ }^{15}$ The chancellor spoke out against "rushing into" the community and pledged that the conservation of neutrality would be a prerequisite for Austria's possible entry into the EC. ${ }^{16}$

${ }^{11}$ Stifter, "Das politische Österreichbild," 53, 122; Lobova, "Die Moskauer Perzeption," 116.

${ }^{12}$ Schweitzer, Dauernde Neutralität, 241-242, 246-247, 291-292.

13 Waldemar Hummer and Michael Schweitzer, Österreich und die EWG: Neutralitätsrechtliche Beurteilung der Möglichkeit einer Dynamisierung des Verhältnisses zur EWG (Vienna: Signum, 1987), 295.

14 Österreichisches Jahrbuch für internationale Politik 4 (1987), 178.

${ }^{15}$ Ibid. 5 (1988), 311-312.

${ }^{16}$ Conversation Gorbachev with Vranitzky, 11 October 1988, in GF, 1/1. I am grateful to Prof. Oliver Rathkolb for granting me access to his copy of this document. Cf. Lobova, "Die Moskauer Perzeption," 107. 
However, in Moscow, the possibility of conserving neutrality when joining the EC was strongly questioned by many "orthodox" Soviet officials, who still considered the community to be the economic branch of NATO. This attitude was to be found among "old thinkers" in the Central Committee apparatus and the Soviet Foreign Ministry, including the head of the Third European Department, Aleksandr Bondarenko, whose department was responsible for German-speaking countries. The Soviet ambassador to Bonn, Iulii Kvitsinskii, stated at a party conference in 1988 that "more and more European states may begin to be sucked into the EEC, and via the EEC into NATO." ${ }^{17}$ Nevertheless, the Soviet side, due to Gorbachev's "new course" of reduced interference in foreign countries' internal affairs, and particularly in consideration of the rapidly intensifying debate in Soviet think tanks on the correct attitude towards the community, ${ }^{18}$ did not rule out rapprochement in Austrian-EC relations completely. The Austrian ambassador Herbert Grubmayr reported that several informal groups in the Soviet Foreign Ministry had emerged, one even advocating Austria's entry into the EC in order to render the organization less dominated by NATO countries and have Austria promote neutrality within it. ${ }^{19}$ In November 1987, the deputy director of the Institute for World Economy and International Relations (IMEMO) of the Soviet Academy of Sciences, Vladimir Shenaev, told Austrian journalists that their country's relation to the EC was frequently discussed in Moscow. The decision, Shenaev stated, had to be made by Austria itself, but the country had to retain its neutral status. As long as Austria's integration was only "political and economical," it was considered compatible with neutrality; only military integration was unacceptable. ${ }^{20}$

This position was the most liberal stance that had yet been communicated, and some weeks later the Soviet ambassador in Austria, Gennadii Shikin, even felt the need to deny reports that his government was supporting Austria's application for EC membership. He repeated his position of January $1987,{ }^{21}$ namely, that the USSR understood Austria's economic situation and its desire for rapprochement with the EC. ${ }^{22}$ But when considering the development of the EC towards political integration, full membership by Austria had been ruled out by the USSR. In May 1988, the new director of IMEMO, Evgenii Primakov, repeated that Austria's entry into the EC would be "problematic with regard to neutrality." ${ }^{23}$ An even more critical position was reflected in two major academic studies in 1987 and 1988. Ivan Zhiri-

${ }^{17}$ Quoted in Zubok, "The Soviet Attitude," 42.

${ }^{18}$ Mueller, Die UdSSR und die europäische Integration, 659.

${ }^{19}$ Grubmayr, "In zwei Wochen gehst Du nach Moskau," 147. This idea had been launched by Austrian circles in the late 1950s, but rejected by the USSR. See above, page 140.

${ }^{20}$ Österreichisches Jahrbuch für internationale Politik 4 (1987), 260.

${ }^{21}$ Gehler, Österreichs Außenpolitik, 624-626.

22 Österreichisches Jahrbuch für internationale Politik 5 (1988), 251. Cf. Gerhard Kunnert, Österreichs Weg in die Europäische Union (Vienna: Österreichische Staatsdruckerei, 1993), 109.

${ }_{23}$ Österreichisches Jahrbuch für internationale Politik 5 (1988), 274. 
akov assessed that economic relations with the EC would not be profitable for the Austrian economy and recommended Osthandel; a dissertation by Oleg Ermakov underlined that Austria's relations to the FRG had already reached an intensity that made it difficult for Austria to maintain sovereignty and neutrality, and that integration into the EC would render this completely impossible. ${ }^{24}$

Against this background, the Soviet reaction during Vranitzky's visit to Moscow in October of 1988 was awaited with great interest. Before the trip, Izvestiia on 31 August and Trud on 25 September had set an ambivalent tone by, on one hand, reporting on Austrian popular doubts about their leaders' "spookily" naive attitude towards the EC, and, on the other, underlining the difference between the EC and NATO and expressing understanding for Austria's ambitions. ${ }^{25}$ Still in September, Shevardnadze had warned his Austrian counterpart Alois Mock in Moscow that Austria joining the EC might tilt the balance of forces in Europe ${ }^{26}$ In his conversation with Vranitzky on 11 October, Gorbachev acknowledged that economic integration was an objective process. However, he opined that it was unavoidable for integration not to affect the political sphere and therefore it would make it impossible for Austria to observe neutrality. If Austria were to stay out of the EC, Gorbachev stated, its importance as a neutral country would grow. ${ }^{27}$ When the Soviet leader questioned the concept of "limited sovereignty" within the EC, Vranitzky - according to the Soviet protocol - pledged that Austria would counteract any attempts at achieving closer military-political or economic structures in Western Europe. If this was meant sincerely, it clearly contradicted the EC's goal, outlined in the 1957 Rome Treaty, to form an "ever closer union." In any case, given the traditional Soviet aversion to "closed Western blocs," this pledge must have sounded good in Soviet ears. While Gorbachev did not exert any pressure, Prime Minister Ryzhkov, in his talk with Vranitzky, made it clear that Austria's admission into the EC would be perceived by the USSR as a violation of neutrality. ${ }^{28}$

Although it had not succeeded in convincing the Soviet side of its standpoint (if it had tried at all), in the summer of 1989 the Austrian government sent a letter to Brussels asking for admission into the EC while reserving its neutrality. Some EC member states' leaders that considered the creation of the European Economic Area a priority and Austrian neutrality an impediment for the EC's common foreign and security policy were not pleased at all. Belgian foreign minister Mark Eyskens

${ }^{24}$ I. Zhiriakov, "Sovetsko-Avstriiskie otnosheniia i problema bezopasnosti i sotrudnichestva v Evrope 1945-1986" (PhD Thesis, Moscow, 1987), 50; O. Ermakov, "Vneshniaia politika Avstrii i razvitie sovetsko-avstriiskikh otnoshenii v 80ye gody" (PhD Thesis, Moscow, 1988), 17.

${ }_{25}$ Stifter, "Das politische Österreichbild,"101-102.

26 Österreichisches Jahrbuch für internationale Politik 5 (1988), 304.

${ }^{27}$ Conversation Gorbachev with Vranitzky, 11 October 1988, in GF, 1/1.

${ }^{28}$ Gehler, Österreichs Außenpolitik, 624-626, 587, 617-619. Cf. Otto Klambauer, Der Kalte Krieg in Österreich: Vom Dritten Mann zum Fall des Eisernen Vorhanges (Vienna: Ueberreuter, 2000), 166. 
even proposed discussing Austria's neutrality and admission into the EC with the Soviet Union - thus implicitly questioning the country's sovereignty and maturity as a foreign-policy actor. The Soviet position also remained unchanged. An aidemémoire, handed over to the Austrian government by the Soviet ambassador on 20 August, stated that the participation of a neutral state in a Union "that will pursue a common foreign and security policy [...] would lead to a loss of real possibilities to implement its neutral policy," policies to which Austria continued to be obliged. ${ }^{29}$ While praising Austrian neutrality as the "most precious political asset the republic owns" and a "major factor for stability and mutual trust in Europe," the Soviet memorandum expressed "concern" about Austria's application for EC membership. Moreover, the Soviet side underlined its hope that Austria would stick to earlier commitments as well as, if the conservation of the country's neutrality within the EC turned out to be impossible, that the Viennese government would give up its integration efforts. This moderate formulation implied that, under certain conditions, neutrality and EC membership might be compatible, thus marking a return to Shenaev's relatively liberal position of 1987.

The dismissive stance of both the USSR and the EC eased once the dimensions of the changes of 1989 had become clear. On 27 June 1989, Alois Mock and his Hungarian counterpart Gyula Horn cut a hole in the barbed wire at the Austro-Hungarian border that had been part of the Iron Curtain between Eastern and Western Europe. The opening of the border allowed thousands of East Germans to flee their country to the West, triggering the breakdown of the communist regimes in East Berlin, then Prague, and then of the Eastern bloc altogether. ${ }^{30}$ Following the opening of the Berlin Wall in November and the fall of the communist regime in Prague, in December the fence at the Austro-Czech border was also cut.

It took a bit of time for the Ballhausplatz to realize that not only the Iron Curtain, but also a window of opportunity for Austria had opened. On 27 October 1989, the astonished Ambassador Grubmayr communicated to Vienna a declaration made by Gorbachev in Helsinki, in which it had been stated that all countries were entitled to decide independently which international organizations they wanted to join. Grubmayr felt that, from now on, this could serve as a point for defending Austria's EC ambitions. ${ }^{31}$

Although some hardliners in the Soviet Foreign Ministry and Central Committee apparatus feigned ignorance of Gorbachev's statement, such an Austrian strat-

${ }^{29}$ Soviet aide-mémoire to the Austrian government, 10 August 1989, in Michael Gehler, Österreichs Weg in die Europäische Union (Innsbruck: Studienverlag, 2009), 285-287.

${ }^{30}$ On the revolutions of 1989, see Timothy Garton Ash, We the People: The Revolutions of '89 Witnessed in Warsaw, Budapest, Berlin, and Prague (Cambridge: Granta Books, 1990); Jacques Levesque, The Enigma of 1989: The USSR and the Liberation of Eastern Europe. (Berkeley: University of California Press, 1997).

31 The author's interview with Ambassador Grubmayr, 15 July 2009. Cf. Grubmayr, "Streiflichter aus meiner Moskauer Zeit,” 270. 
egy turned out to be unnecessary. Three reasons for this change can be extrapolated: Gorbachev realized that the USSR did not have the power to prevent Austria from joining the EC; the Soviet attitude towards the EC had changed in 1988 towards cooperation; and the Kremlin began to appreciate the value of having a reliable neutral country in the EC. When the social democrat and former foreign minister Erwin Lanc told Zagladin in January of 1990 that Austria could not join the EC since this would hamper neutrality, ${ }^{32}$ he was repeating an argument that even the Soviet leader himself was about to abandon. Lanc also reproduced the ancient Soviet propaganda thesis that the EC, a "child of the Cold War," had been founded "to tie Europe to NATO." In contrast to this type of Austrian statement, the director of the Institute for European Studies of the Soviet Academy of Sciences, Vitalii Zhurkin, who came to Vienna for a lecture in May 1990, declared that the good relations between Austria and the USSR would be the basis for Soviet consent of Austria's integration into the EC. ${ }^{33}$

However, it was only after the Soviet prime minister, Valentin Pavlov (who later joined the communist putsch against Gorbachev), had reminded Austria in June 1991 of its obligation to neutrality and after the putsch itself that the Soviet president told Vranitzky on 30 September 1991: "I see this step [i.e. Austria's entrance into the EC] as a sovereign step of Austria - as a normal element of the European process. You can freely decide yourselves what and when you want it." ${ }^{34}$ During the conversation, the Austrian chancellor had merely informed Gorbachev about the start of the Austrian-EC negotiations on full membership without asking for Soviet approval..$^{35}$ As Vranitzky declared afterwards, the Soviet-Austrian talks, in contrast to earlier meetings, had not touched on neutrality at all. A year earlier, in November 1990, Austria had already used the window of opportunity to declare certain articles of the Austrian state treaty regarding defense (among others, the missile ban) obsolete - after the 2+4 Treaty had lifted similar restrictions on Germany, and Finland had also unilaterally declared certain provisions of its peace treaty obsolete. None of the signatory powers rejected this move. ${ }^{36}$

${ }^{32}$ Conversation Zagladin with Lanc, 22 January 1990, in GF, 7250.

33 Österreichisches Jahrbuch für internationale Politik 7 (1990), 131.

${ }^{34}$ Quoted in Klambauer, Der Kalte Krieg, 190. Only parts of the Soviet protocol have been released to date. Cf. Conversation Gorbachev with Vranitzky, 30 September 1991, in GF, 1/1. I am grateful to Prof. Oliver Rathkolb for granting me access to his copy of this document. See also Bauer, Russische Umbrüche, 68.

${ }^{35}$ Letter Friedrich Bauer to the author, 7 September 2009. Cf. the Austrian protocol of the Conversation Gorbachev with Vranitzky, Austrian embassy Moscow to Austrian MFA, Z. 3.5/49-A/91, 4 October 1991. I am grateful to Ambassador Bauer for granting me access to his copy of this document.

${ }^{36}$ Helmut Türk, "Die Wende 1989/90 und die Obsoleterklärung einiger Artikel des Staatsvertrages," in Arnold Suppan, Gerald Stourzh, and Wolfgang Mueller (eds.), The Austrian State Treaty 1955: International Strategy, Legal Relevance, National Identity (Vienna: Verlag der Österreichischen 
In the meantime, the disintegration and economic crisis of the Soviet Union had become apparent. In February 1990, Peter Jankowitsch, the former Austrian foreign minister, after a visit to Moscow and talks with members of the CPSU central committee and with the opposition, expressed concern "about the growing tensions within the Soviet Union," ${ }^{37}$ and in May, after the Lithuanian declaration of independence, Foreign Minister Alois Mock even considered the situation in the USSR to be dangerous. The Soviet crackdown on the Baltic independence movements ${ }^{38}$ in January 1991 was criticized only mildly: Vranitzky stated he was convinced that Gorbachev, who had earned historic recognition for "fighting inhumane communist structures," was not changing his mind and "marching in the old direction," and Mock said that Gorbachev had obviously made the decision under pressure by hardliners and the military. ${ }^{39}$ When Soviet violence and human rights violations in the Baltics continued, the Austrian ambassador to Moscow was ordered to ask the Soviet government for an explanation.

The uncertain situation within the USSR was reflected in public opinion polls in Austria that were conducted from November 1990 to January 1991 among 2,000 Austrian citizens: 15 percent believed that the Soviet Union would soon turn into a liberal democracy, whereas 47 percent expected the current unstable situation to continue; 26 percent did not believe that the Union would be preserved, but 8 percent feared a return to authoritarianism in Russia. ${ }^{40}$ Only 7 percent of all respondents were confident that the Soviet Union would be able to transform into a functioning market economy without Western help, 73 percent believed that Western assistance would be crucial, and 15 percent expected that the transformation would fail. The percentage of those who believed that the Soviet position in world politics would remain the same, and those who believed that it would lose in importance was 39 each.

After the communist putsch in Moscow in August 1991, ${ }^{41}$ Waldheim, Vranitzky, and Mock signaled their concern and expressed their hope that all democratic and political achievements within the USSR and Europe would be preserved. The Austrian government's declaration of 21 August, however, proved to be a grave misjudgment. In the two days that had passed since the overthrow, the Russian

Akademie der Wissenschaften, 2005), 821-837. During his visit to Vienna in October 1990, Eduard Shevardnadze, the Soviet foreign minister, had given green light for the Austrian initiative.

37 Österreichisches Jahrbuch für internationale Politik 7 (1990), 112.

${ }^{38}$ Brown, The Gorbachev Factor, 279-283. On the Western reaction, see Kristina Spohr Readman, "Between political rhetoric and realpolitik calculations: Western diplomacy and the Baltic independence struggle in the Cold War endgame," in Cold War History 6, no. 1 (2006), 1-42.

39 Österreichisches Jahrbuch für internationale Politik 8 (1991), 70-71, 76.

${ }^{40}$ Hanspeter Neuhold and Paul Luif (eds.), Das außenpolitische Bewusstsein der Österreicher: Aktuelle internationale Probleme im Spiegel der Meinungsforschung (Vienna: Braumüller, 1992), 202-203; 364; see also Waltraut Urban, "Die Veränderungen in Osteuropa," ibid., 1-26.

${ }^{41}$ On the putsch, see John B. Dunlop, The Rise of Russia and the Fall of the Soviet Empire (Princeton: University Press, 1993), 186-255. 
government and the international community had, after some hesitation, reacted resolutely: Russian president Boris El'tsin's call for a general strike against the usurpers was followed by hundreds of thousands of Russians; US president George Bush expressed support for El'tsin and declared that the United States still regarded Gorbachev the legal and legitimate head of state; the EC ministers froze all nonhumanitarian economic aid for the USSR; and demonstrators in support of democracy in the USSR gathered in front of the Soviet embassy in Vienna. In contrast, the Austrian coalition spoke out against "sterile agitation" and called on the "Soviet leadership" to solve all problems strictly by nonviolent means and to respect international obligations. ${ }^{42}$ The wording of the declaration, addressing the putschists as new "leadership" and avoiding any judgment of the putsch, was harshly criticized by the oppositional FPÖ and Green parties as an act of "anticipatory obedience." The Austrian declaration of 21 August was even more embarrassing in view of the fact that El'tsin as well as the leading Western powers had already condemned the putsch two days earlier.

Although the putsch disintegrated after three days and Gorbachev returned to power on 22 August (which Vranitzky called the happiest day of the year), the breakup of the USSR could not be stopped. On 22 December, Alois Mock acknowledged that the formation of the Community of Independent States (CIS) was an important step. Mikhail Gorbachev, who would resign as Soviet president three days later, was praised for having achieved the generally peaceful dissolution of the Eastern bloc and transformation of the USSR.

\section{Humanitarian aid and economic relations}

A month earlier, Vranitzky had received the special envoy of Russian president El'tsin, Sergei Stankevich, and criticized the reluctant stance of the biggest Western economies to financially support the Soviet Union. Among Western leaders, Gorbachev's unclear economic strategy indeed had left the impression that the USSR would turn out a bottomless pit. However, it was wrong, Vranitzky stated, to invite Gorbachev to the G7 session in London in July and then pose the introduction of capitalism as a precondition for Western help. The chancellor assured Stankevich that Austria would be ready if Russia needed food. ${ }^{43}$ An opinion poll revealed that 25 percent of the Austrians favored helping Russia as actively as possible; 23 percent were not sure, while 40 percent wanted to leave such efforts to the EC..$^{44}$ Despite this high percentage of reluctant persons in this poll, Austrians had donated five billion schillings for the victims of a major earthquake in Armenia in December 1988. The disaster had led to a wave of Western help for the Soviet population

\footnotetext{
${ }^{42}$ Wiener Zeitung, 20 and 21 August 1991, 1-2.

43 Österreichisches Jahrbuch für internationale Politik 8 (1991), 109.

${ }^{44}$ Gehler, Österreichs Außenpolitik, 593.
} 
- something that was only too readily forgotten in Russia, when in the 1990s and 2000 s, the notion of Western hostility was again spread by the official media. A village built by the Austrian Red Cross in Leninakan was inaugurated by Josef Riegler in 1990. In April 1991, the Austrian vice-chancellor, in Minsk, handed over fifty million schillings for victims of the Chernobyl disaster. ${ }^{45}$

In the economic sphere, the Gorbachev era had seen a steady decline of SovietAustrian relations. Trade fell from 32.5 billion schillings in 1985 to 17 billion in 1987, while the Austrian deficit in bilateral trade turned quickly into a Soviet one. A major cause was the economic crisis in the Soviet Union and sinking energy prices. From 1980 to 1988, the prices of oil and natural gas fell by 58 and 41 percent respectively. In 1981, the value of Soviet exports to Austria decreased by 19 percent, in 1986 even by 30 percent. ${ }^{46}$ The Soviet share in Austrian exports fell from its all-time high of 6.2 percent in 1981 to 3.8 percent in 1985 to 1.9 percent in 1991, in Austrian imports, from 4.4 percent to 1.6 percent. ${ }^{47}$ By 1989, the Soviet debt to Austria had risen to 44.3 billion schillings (making Austria the fifth-largest foreign creditor after West Germany, Japan, Italy, and France ${ }^{48}$ ), and Austria granted the USSR a loan of one billion schillings. ${ }^{49}$ The structure of Soviet-Austrian trade remained relatively unchanged, with Soviet deliveries of natural gas and orders of Austrian machinery prevailing.

Table 6: Soviet-Austrian trade 1985-1990

\begin{tabular}{|r|r|c|c|c|c|c|r|}
\hline & $\begin{array}{c}\text { Austrian } \\
\text { exports }\end{array}$ & $\begin{array}{c}\text { Change from } \\
\text { previous year }\end{array}$ & $\begin{array}{c}\text { Share of } \\
\text { Soviet } \\
\text { imports }\end{array}$ & $\begin{array}{c}\text { Soviet } \\
\text { exports }\end{array}$ & $\begin{array}{c}\text { Change from } \\
\text { previous year }\end{array}$ & $\begin{array}{c}\text { Share of } \\
\text { Austrian } \\
\text { imports }\end{array}$ & Balance \\
\hline 1985 & $13,409.9$ & -4.9 & 1.2 & $19,150.9$ & -2.4 & 4.4 & $-5,741.0$ \\
\hline 1986 & $10,483.1$ & -21.8 & 1.3 & $12,497.0$ & -34.7 & 3.1 & $-2,013.9$ \\
\hline 1987 & $8,503.1$ & -18.9 & 1.0 & $8,501.3$ & -32.0 & 2.1 & 1.8 \\
\hline 1988 & $11,022.2$ & 29.6 & 1.1 & $8,633.1$ & 1.6 & 1.9 & $2,389.1$ \\
\hline 1989 & $11,473.4$ & 4.1 & 1.4 & $8,522.3$ & -1.3 & 1.7 & $2,951.1$ \\
\hline 1990 & $10,075.1$ & -12.2 & 1.6 & $10,242.2$ & 20.2 & 1.8 & -167.1 \\
\hline
\end{tabular}

Source: Butschek, Statistische Reihen; Vneshniaia togovlia

Exports in millions of Austrian schillings; changes and shares in percent.

Nonetheless, the era saw a rapid rise in the number of joint ventures. The first such venture was launched in the presence of Austrian minister of trade Robert Graf in 1987 and oversaw the construction of a paper mill by Voith and a Soviet

\footnotetext{
${ }^{45}$ Außenpolitischer Bericht (1991), 681.

${ }^{46}$ Resch, "Der österreichische Osthandel," 550.

${ }^{47}$ Butschek, Statistische Reihen.

${ }^{48}$ Philip Zelikow and Condoleezza Rice, Germany Unified and Europe Transformed: A Study in Statecraft (Cambridge, Mass.: Harvard University Press, 1996), 259.

49 Außenpolitischer Bericht (1989), 625.
} 
company. ${ }^{50}$ The next year, fifteen joint ventures were registered, in 1989 sixty-nine, and in 1991 approximately $250 .{ }^{51}$ Among Austrian companies involved were the producer of trucks, Steyr-Daimler-Puch, and VOEST-Alpine Industrieanlagenbau, which in 1988 received a Soviet order for expanding the metallurgical plant of Zhlobin in the Belarus SSR. There were collaborative projects on biotechnology, information and communication technology, and protection of the environment. At least fourteen projects included construction on Soviet soil, such as a winter sports resort built by Austrian companies in Gudauri, Georgia.

\section{Human contacts, scientific and cultural cooperation}

In the scientific, cultural, and humanitarian sphere, cooperation flourished during the Gorbachev years. In July 1990, Alois Mock, at the opening of a diplomacy seminar in Salzburg, praised the Soviet leader, without whom the generally peaceful changes in East-West relations and in Eastern Europe would not have been possible. Exchanges of teachers and students were intensified. In June 1989, pupils from Moscow stayed in Vienna for a number of weeks, living and going to school with Austrian colleagues, and on the Austrian side, the prestigious Schottengymnasium high school participated in the exchange by sending some of its students to Moscow. ${ }^{52}$ The following year, eighty pupils from Lithuania visited Austria, while young athletes from Georgia were coached at a training camp in Tyrol ${ }^{53}$ After the disintegration of the Soviet Union, many of these exchange programs were discontinued and young people were deprived of this channel for meeting foreign colleagues and broadening their mental horizons. An excellent means of reducing narrow nationalist views was lost.

The newly established interchurch relations remained uneasy. Even after visits by the archbishop of Vienna, Cardinal Franz König, to Moscow in 1980 and 1988 and his initiatives to foster dialog by means of his Vienna-based Pro Oriente Forum, founded in 1964 for this very purpose, the Russian-Orthodox Church remained reserved. ${ }^{54}$ The Armenian Church, however, developed cordial relations to the Catholics.

In 1987 and 1990, new agreements on cultural cooperation were signed. An exhibit in Moscow of Austrian fin-de-siècle paintings, including Gustav Klimt's "The Kiss," attracted 150,000 visitors, ${ }^{55}$ an Austrian movie festival in the Soviet capital

${ }^{50}$ Österreichisches Jahrbuch für internationale Politik 4 (1987), 248.

${ }_{51}$ Zhiriakov, Sovetskii Soiuz - Avstriia, 158; Außenpolitischer Bericht (1991), 683.

52 Außenpolitischer Bericht (1989), 626.

${ }^{53}$ Zhiriakov, Sovetskii Soiuz - Avstriia, 162.

${ }^{54}$ Hinteregger, "Erinnerungen an Moskau," 254-256. König's second trip had been strongly supported by Bruno Kreisky in his conversation with Gorbachev's aide Zagladin. Conversation Zagladin with Kreisky, 9 September 1986, in GF, 4840.

${ }_{55}$ Außenpolitischer Bericht (1990), 634. 
more than 300,000. ${ }^{56}$ When in 1988, the performance in Moscow of the popular Austrian folk-music show "Musikantenstadl" was broadcast throughout the USSR on television, it was watched by millions of Soviet citizens. Later that year, the talk show "Café Central" was also televised from Moscow. The most spectacular scientific collaboration was the Austromir program, which started in October 1991. Austrian cosmonauts Clemens Lothaller and Franz Viehböck participated in a Soviet space flight project and conducted several tests, some of them with Austrian equipment. The Austromir cooperation, which had been agreed upon during Vranitzky's 1988 visit to the USSR, had been preceded by bilateral cooperation in the "Vega" space project. Austria was the first and only Western country to participate in such a Soviet space flight program, and Austromir became the last major scientific cooperation between Austria and the USSR.

$$
* * *
$$

The end of the Cold War had caused a major change in the international arena: The superpowers intensified their direct contacts, the Soviet bloc disappeared, a reunified Germany emerged as a player on the European field, the former Soviet satellites demanded entrance into NATO and the EC, and talks of a "unification of Europe" became frequent. In this environment, the role of neutral mediators sank. In the Austrian case, this sea change led not only to a loss of mediatory importance but also to a fundamental change of policy: the end of respecting Soviet interpretations of neutrality and the decision to join the European Community.

The following reinterpretation of Austria's neutrality became more visible in 1990-91 with the measures taken by the United Nations in response to the Iraqi occupation of Kuwait. The right for transporting military equipment and for overflights was granted to the US-led coalition and the ban on such transports was lifted for UN operations. ${ }^{57}$ In addition, Austria declared the missile-ban resulting from the state treaty obsolete. All these steps marked a sharp deviation from the hitherto valid Verdross Doctrine of comprehensive neutrality and the advent of what experts later christened the "Avocado Doctrine" - the reduction of neutrality "to its hard core." 58

\footnotetext{
${ }^{56}$ Ibid. (1986), 641.

${ }_{57}$ Manfred Rotter, "Von der integralen zur differentiellen Neutralität," in Europäische Rundschau 19, no. 3 (1991), 23-36; Gehler, Finis Neutralität, 28.

58 Cede, "Österreichs Neutralität und Sicherheitspolitik," 143.
} 
"Thus it will always happen that he who is not your friend will demand your neutrality, whilst he who is your friend will entreat you to declare yourself with arms." Nicolò Machiavelli, The Prince, translated by W. K. Marriott $(1515,1908)$, chapter xxi. 



\section{Conclusions}

The late Gorbachev years marked the end of a distinct era in Soviet-Austrian relations, an era that had begun in 1955 with the final negotiations on the state treaty and its subsequent conclusion. It was one of the most intense and, for the most part, friendliest periods in bilateral relations between Vienna and Moscow. With the consolidation of blocs, the emergence of thermonuclear weapons, and the declining acceptability of a war between the superpowers, "peaceful coexistence" had been declared as a strategy to reduce tensions while continuing the international struggle in the areas of ideology, science, economy and society by nonviolent means. From 1955 on, after Austria had been chosen by the Kremlin as a model for this coexistence, the Soviet leadership had adopted a patronizing stance towards Austria, which, on its part, was relieved to be freed of the postwar quadripartite occupation. The price for the Soviet withdrawal was neutrality, which reflected the Kremlin's interests and, in fact, had been promoted by the USSR in the Austrian case as a means for keeping the country, which had hitherto been a "secret ally of the West," out of NATO, separating it from its traditional Western patrons, controlling and influencing its foreign policy, and for making it a promoter of neutrality and Soviet proposals in the West. In order to make neutrality attractive to the West, the Kremlin was determined to present Austria as an "example" for the benefits a Western state might reap from becoming neutral.

The communist approach towards peacetime neutrality was subject to Soviet interests in a double sense. First, the USSR advocated neutrality or neutralization when this was beneficial to the motherland of socialism, since under certain conditions neutrality can have "nonneutral" consequences. When these consequences favored the USSR, as in the case of Lithuania in 1920 or Austria in 1955, neutrality was welcomed. When they were displeasing to the Soviet leaders, pledges of neutrality were ignored by the Kremlin, as in the case of Finland during the Brezhnev era. It also seems possible to draw the conclusion that the neutralization of nonsocialist states was promoted by the Soviet government when chances for soon gaining preponderance in that country were low. Secondly, the communist interpretation of neutrality was also linked to Soviet interests. Neutralizing a country was seen as a means to draw it nearer the socialist bloc, not only keep it away from the opposing one. This aim was to be achieved through a special neutrality doctrine, which included responsibilities that, if fulfilled, were likely to foster the neutral's rapprochement with the East. This doctrine was comprised of a few rights for the neutral but also many duties, including the obligation not to join NATO or the EEC, as well as to promote Soviet diplomatic goals, to maintain friendly rela- 
tions with the East, and to curb criticism of Soviet policy. Many of these concepts had been adopted by the nonaligned countries, and the Soviet government strove to make them binding for the European neutrals too, through tutelage, propaganda and the spreading of communist theories of international law. As their authors readily acknowledged, neutrality meant different things at different times, and the various Soviet interpretations of the neutrals' obligations were always formulated in accordance with the prevailing political agenda. While in the 1950s, the containment of NATO and other pro-Western alliances and blocs seems to have been the main function of neutrality from the Soviet point of view, through the 1960s the promotion of decolonization by the nonaligned states and of an all-European summit by the neutrals gained importance. Once détente was achieved, the role of the neutrals diminished, and it remained so except during the last peak of the Cold War, when their value for Soviet policy again rose rather briefly.

The Soviet aim to neutralize certain areas did not only apply to the neutral and nonaligned states. Indeed, some scholars argue that it was a Soviet strategy to gradually neutralize all of Western Europe, and that the Kremlin, "through a combination of blandishment, pressure, and looming military superiority, [sought] to promote a change of policy and outlook in Western Europe that would assure Soviet hegemony in Eastern Europe and set the stage for effective political preeminence over Western Europe as well." It seems quite evident that Moscow was interested in undermining the stability of the Western bloc, be it NATO, the EEC, or the European-American partnership. In fact, Soviet foreign policy encouraged the adoption of neutrality or at least of neutralist policies and postures in all of Western Europe. Since this Soviet fostering of neutrality and neutralism never included the promotion of a neutral group, one may draw the conclusion that neutrality, in Soviet eyes, was also a strategy for fragmenting the opposing bloc without creating a new one.

The neutrals were used as tools in this Soviet strategy - as role models and promoters of neutrality. In order to spread neutrality and neutralism in the West and to make it attractive to West European states, the USSR granted the neutrals special privileges. This included demonstratively friendly treatment of the neutrals and economic benefits, as well as praise for neutrality in general and the individual neutrals in particular. Applause for a neutral meant, first and foremost, praise for and the promotion of neutrality or neutralism. Moreover, treating the neutrals in a friendly manner was an easy way for improving the image of neutrality and, in fact, of the USSR abroad.

Since the USSR wanted the neutrals to embody and promote a specific Soviet approach to neutrality, it attempted to push the neutrals' understanding and practice of neutral policy in this direction. Neutrality provided the Kremlin a lever over the neu-

\footnotetext{
${ }^{1}$ George Ginsburgs and Alvin Z. Rubinstein, "Finlandization: Soviet Strategy or Geopolitical Footnote?," in idem (eds.), Soviet Foreign Policy Toward Western Europe (New York: Praeger, 1978), $3-16,4$.
} 
trals, and Soviet leaders and propaganda consistently claimed the right, by referring to the communist teachings of neutrality to tell the neutrals what to do and what not. Soviet praise, criticism and warnings were voiced in official and media statements, which created a sort of "verbal straitjacket" for the neutrals. ${ }^{2}$ Since their neutrality was not as "total" as the Kremlin wished, they were from time to time criticized for this defect. As neutrality gave the USSR a measuring stick for evaluating their politics, any unwanted act was attacked as being at odds with neutrality. This included things such as Switzerland's refusal to ban nuclear weapons, Sweden's maintaining a strong army, and Austria's, Sweden's and Switzerland's striving to reach an association agreement with the European Economic Community. These policies were harshly condemned in Soviet statements. On the other hand, desired behavior was encouraged and praised, such as Finnish proposals for nuclear-weapons free zones, Swedish criticism of US policy, and efforts to call for an all-European summit. Even the "old familiar tune" of the ritualistic and seemingly redundant annual articles commemorating the Finnish-Soviet Friendship and Cooperation Treaty, the Austrian state treaty in May and declaration of neutrality in October, which were time and again invoked as sanctified and value-laden symbols, albeit amorphous ones, served a certain aim: They were written not for Soviet eyes but for those of the respective neutral's embassy, and meant to underline the say the USSR claimed to have in the respective country's matters and remind its government of the Soviet watchdog, thus promoting desired behavior and limiting undesired.

However, the practical use of Soviet published opinion was not only aimed at the neutral itself, but also its international environment: Whenever it seemed necessary to praise Soviet détente policy, set the tone for a friendly exchange of opinions, or promote neutrality, Austria and Finland were extolled as a models of "peaceful coexistence"; whenever it seemed necessary for Soviet policy to diminish their attraction for Eastern Europe or to communicate Soviet displeasure, warnings and fantastic accusations were published, such as during the Hungarian and Czechoslovakian crises when Austria was depicted as a playground of villains or enemies, or after the "Prague Spring," when the Soviet recognition of Finland's neutrality was withdrawn. It is therefore not entirely correct to say that the international environment did not affect Soviet relations to the neutrals. It is rather the case that the Soviet Union, in general, wanted to contain long-term effects of international crises on the usability of neutrality and the neutrals as a model.

This applied especially to Austria, which was chosen by the USSR as a showcase for the benefits of neutrality and "peaceful coexistence." The small country on the border between East Central and Western Europe was an unlikely partner for the Eurasian superpower. That Austria became the Soviet choice was most probably due to the fact that the USSR had been involved in the multilateral state treaty, and promoted and subsequently recognized Austria's neutralization. Both, the state

\footnotetext{
${ }^{2}$ Petersson, The Soviet Union and Peacetime Neutrality, 97, 48.
} 
treaty and neutrality, were more directly connected to the USSR than, for instance, Swiss or Swedish neutrality. Nonetheless, Austria was linked less tightly to the Soviet Union than was Finland, another Soviet "showcase of sorts," Finnish-Soviet Friendship Treaty. In 1955, Austria declared its intention to follow the Swiss rather than the Finnish model. In order to reinforce the Soviet claim of authority, communist voices covered up the fact that Austrian neutrality was not stipulated in the state treaty. They also chose to ignore that even earlier, the Western allies had agreed on Austria's neutrality if self-chosen and that all sides consented to the declaration of neutrality. Instead, Soviet politicians and media stressed the importance of the bilateral Soviet-Austrian Moscow memorandum as a basis for the state treaty and neutrality. There was some historic truth in this interpretation: After the USSR had obstructed negotiations for years, the actual breakthrough on the state treaty and neutrality was achieved by Austrian and Soviet delegations, outlined in a bilateral quid-pro-quo, and only then reported to the West. Such interpretations aimed at sustaining the tacit claim of a "special" Soviet-Austrian relationship and the Soviet right to interpret Austria's neutrality - either because of the Soviet participation in the forming of the state treaty or the Moscow memorandum. However, from the point of view of international law, this claim was clearly rejected by Austrian experts. A similar struggle over the authority to interpret the state treaty and neutrality concerned the role of the USSR, on one hand, and that of the Western powers, on the other, in the treaty negotiations: When Austrian statements did not adopt the official Soviet version that the treaty had been concluded largely thanks to Soviet efforts, the Soviet side voiced displeasure through official channels as well as the media. While this kind of feud about historical truth might seem insignificant, it characterized the constant, albeit low-key, Cold War about who held the final authority to interpret the world. This was a struggle that affected Soviet-Austrian relations as well. Since historical facts are often used to strengthen legal claims, these discussions were anything but irrelevant.

The struggle for the right to define Austria's obligations as a neutral was fought in the media and in public statements. Experts of international law, both Soviet and Austrian, joined this debate. On both sides, their interpretations reflected the shifts in high level policy. Soviet lawyers sought to theoretically substantiate an evergrowing list of alleged neutrality obligations. While in general, Austrian experts rejected such demands, many of them, including the most influential, tended towards increasing the neutrals' obligations. Only after Gorbachev had brought a change to the world's image of the Soviet Union did those experts who advised a limited definition of the "secondary obligations" of the neutrals gain predominance in Austria.

Although this was often claimed by Soviet leaders and experts, the successful development of Soviet-Austrian relations was not just because of parallel interests. In general, the two partners followed rather divergent aims. Keeping the neutral

\footnotetext{
${ }^{3}$ Hanhimäki, "The Lure of Neutrality: Finland and the Cold War," 262.
} 
country out of the Western blocs such as NATO and the EEC and detaching it as far as possible from the West, particularly from West Germany (the Anschluss trauma) and the United States, Austria's postwar patron, was a paramount goal of the Kremlin. This implied that the Kremlin aimed at making the country "as neutral as possible" (following the Finnish rather than the Swiss example). Making Austria more neutral in the Soviet sense, i.e. separating it from the US, making it protest Western overflights, ruling out its membership in NATO, the ECSC or the EEC, and even seeing it possibly fighting Western blocs, was the leitmotiv of Soviet policy towards Austria. Among the Soviet aims was also to keep Austria militarily weak - a reflection not only of the Soviet teachings of neutrality, but also of a certain distrust vis-à-vis the neutral. At least in this regard, the role of neutralization had not changed since the times of Machiavelli. ${ }^{4}$ Periodic Soviet demands that Austria's neutrality be "total," comprising not only abstention from NATO but also complete symmetry or equidistance in political and economic relations and even in public opinion, were to serve this aim. In the words of a leading Austrian diplomat and ambassador to Moscow, over the years the USSR "took regular steps to influence Austria's decision-making." ${ }^{5}$ It attempted to mold Austria's interpretation of neutral policy, as well as to shift that interpretation from a permanent to a positive one and thus, to "Finlandize" it.

To Austria this seemed neither possible nor desirable. The neutral was interested in retaining its independence from the Eastern bloc; it did not want to be Finlandized. ${ }^{6}$ While the Kremlin wanted Austria's neutrality to be "total," Austria

${ }^{4}$ Kreisky repeatedly referred to Machiavelli's neutrality thesis. See, e.g., Bruno Kreisky, Die Herausforderung: Politik an der Schwelle des Atomzeitalters (Düsseldorf: Econ, 1963), 116. Cf. Gerald Stourzh, "Some Reflections on Permanent Neutrality," in August Schou and Arne Olav Brundtland (eds.), Small States in International Relations, Nobel Symposium 7 (Stockholm: Almquist \& Wiksell, 1971), 93-98, 96. For the "Orvellian dimensions" of "total" neutrality, see ibid.

${ }^{5}$ Haymerle, "Die Beziehungen zur Großmacht im Osten," 175.

6 The term "Finlandization" emerged in West Germany during the 1960s to describe the process of gradual implementation of self-censorship and submission to Soviet wishes in a Western democracy. A volume published in the late 1970s listed the following features of Finlandization: "1) responsiveness in foreign policy to Soviet preferences; 2) avoidance of alliance with countries deemed by the Soviet Union to be competitors or rivals; 3) acceptance of neutrality in peace or war; 4) abstention from membership in regional and international groupings considered unfriendly by Moscow; 5) restraint over the media in one's country to muffle or minimize criticism of the USSR, so as to avoid possible provocation; 6) compensatory gestures in commercial and cultural contacts with the USSR, extending to treaties and diplomatic consultations, to offset disparities in the relationship with the USSR, on the one hand, and West European countries, on the other; and 7) openness to penetration by Soviet ideas and media. In other words, the term Finlandization describes the behavior of a country whose foreign policy and domestic politics are strongly conditioned by a conscious desire to mollify and maintain friendly relations with Moscow, at the expense if need be of close ties with formal allies and traditional friends or of its own sovereignty." George Ginsburgs and Alvin Z. Rubinstein, "Finlandization," 5. 
was and remained a Western-minded parliamentarian democracy. It did not give up its principles of free speech, but, in general and despite increasing self-censorship, rather defended their implementation, even under Soviet criticism. There was, until 1967-68, an Austrian political aim running directly counter to Soviet interests: Austria's rapprochement with the EEC. For a number of reasons, the USSR tried to block this - and, at least until 1987, did so successfully.

Other aims of the two countries, however, proved better reconcilable. One was the Soviet aim of making its relations with Austria a model of "peaceful coexistence" and of demonstrating that these friendly relations were possible mainly due to neutrality. The Soviet attitude towards Austria was, thus, to a large extent defined by the Soviet view of neutrality in general and "by the utility and value of Austria as a showcase" and promoter of the benefits of neutrality. ${ }^{7}$ Soviet propaganda presented Soviet-Austrian relations as proof not only of the possibility of "peaceful and mutually beneficial relations and cooperation between countries of different political systems," but also of the correctness of Soviet policy and of the successes of neutrality. The Soviet interest in promoting such coexistence and neutrality in the West was compatible with the Austrian interest in lowering the Cold War's intensity and fostering détente. While both sides followed different aims in promoting détente and while the Soviet strategy of "peaceful coexistence" had more goals than just relaxing international tensions, it was clear to most Austrian governments that it was easier to maintain neutrality and independence in times of détente. Austria was also intent on normalizing its relationship to the superpower in the East, the signatory of the state treaty that had made it particularly hard to conclude the same. Together with the state treaty and normalization of bilateral relations came the chance of developing contacts and economic cooperation, and Austria proved eager to do so in order to increase the country's wealth and security.

Furthermore, both sides were interested in Austria conducting an "active" policy of neutrality, including international mediation and contributions to détente: the Kremlin because it was interested in fostering the international attraction of neutrality by entrusting neutrals with honorable tasks, such as being "diplomatic postmen" in the Berlin crisis or the Vietnam War. Given the confrontation between the two global blocs, the Soviet Union was moreover determined to use Austria for promoting Soviet political initiatives in the West, particularly with regard to disarmament, détente, and the convocation of the CSCE. The Austrian government was willing to fulfill some of these wishes, because it was keen on gaining international

${ }^{7}$ Report Haymerle, 22 June 1963, in ÖStA, AdR, BMAA, II-Pol, GZ. 67129-6/64, Z. 75215-6/64. See also Haymerle to Kreisky, 12 December 1961, ibid., Pol. Berichte Moskau; Karasek to Kreisky, 9 April 1963, ibid.; and "Die Beziehungen Österreichs zur Sowjetunion: Vortrag Gesandten Haymerles vor dem vom Herrn Bundesminister ins Leben gerufenen vertraulichen außenpolitischen Kreis," 6 July 1964, in ÖIZG, NL 72: Fuchs, DO 834, File 45. These reports provide a comprehensive interpretation of Soviet-Austrian relations.

${ }^{8}$ Wodak to Bielka, 14 February 1966, in ÖStA, AVA, E/1785 Wodak, File 99/2. 
recognition and, thus, security. Consequently, both sides were interested in raising the country's international prestige. This seems to have been at the core of the oftinvoked parallelism of Soviet and Austrian interests. Since the United States shared this interest, Austria was able to perform this role on the international stage.

In particular, Raab's Ostpolitik and Kreisky's ambitions to foster détente and dialog dovetailed with Soviet wishes to rely on Austria as an icebreaker for ending the Eastern bloc's political and economic isolation. Austrian diplomacy was well aware of this fact, stating that "from Moscow's point of view, Austrian neutral policy is to foster a relaxation of tensions and the international dialog." ${ }^{.9}$ This obviously included Austria serving, on many occasions after various international crises from 1956 until 1983, as a door-opener and helping Soviet and East European regimes to escape the isolation into which they had fallen by virtue of their own policy. While Austria's Ostpolitik was highly appreciated by the United States as well, albeit for different reasons, the neutral's circumventing of the Western embargo against the East was less to their liking.

From the Soviet perspective, Austria was also to act (and did act) as a scout for developing East-West trade. It was to provide the Soviet Union with goods that could not be purchased in other Western countries because of the lack of economic agreements or Western restrictions, including machinery, consumer goods, or pipes for pipelines. In particular, until East-West trade intensified in the 1960s, Austria was, very much like Finland, "the best [Western] shopping center in the neighborhood" for the Soviets. ${ }^{10}$ While Austrian hopes were ultimately disappointed that it might be chosen as a hub for USSR trade with Western Europe or natural gas exports, for the Soviet Union, the small, stable, and increasingly wealthy country with its Osthandel ambitions also served as a surrogate for Switzerland (to which the Soviet Union developed close relations only in the 1970s) and as a case study for Western economy. During their visits to Austria, Soviet leaders not only examined steel plants, power stations and farms, but also the kitchen and wine cellar of the Imperial Hotel in Vienna. ${ }^{11}$

Soviet policy towards Austria not only endorsed Austria as an international actor and had a generally friendly tone of communication, but it also sponsored numerous high-ranking visits. An Austrian internal report of 1968 stated: "Austria, since the conclusion of the state treaty, enjoys a privileged position in Moscow. This was not even changed by Austria's clear democratic policy during the Hungarian crisis 1956. Symptomatic for the good shape of Austrian-Soviet relations are the numerous exchanges of visits." ${ }^{\prime 2}$ A special characteristic of travel diplomacy was that whenever East-West relations cooled off, and particularly after international crises,

${ }^{9}$ File Staatsbesuch Kirchschläger, May 1982, in SBKA, Länderboxen, UdSSR 6.

${ }^{10}$ Jacobson, Finland, 72.

${ }^{11}$ Haymerle, "Die Beziehungen zur Großmacht im Osten," 185-186.

12 Information Sowjetunion, March 1968, in ÖStA, AdR, BMAA, II-Pol, GZ. 17042-6/67, Z. $31717-6 / 67$. 
Soviet leaders granted Austria the ostensible honor of being the first Western destination of official trips (Mikoian after the Hungarian crisis of 1957, Khrushchev after the failed Paris summit of 1960, Patolichev after the Czechoslovakian crisis of 1968, Tikhonov in 1981), or of being the first Western guest received in the Kremlin (Raab after Hungary in 1958, Maleta after Prague in 1969). In contrast, whenever détente was imminent Soviet leaders went to other Western countries first, mostly to France (Kosygin in 1966, Brezhnev in 1971, Gorbachev in 1985). With regard to Austria's international position, it seems remarkable that the frequency of Austrian visits to Moscow was much higher than to the Western signatories of the state treaty, with whom the neutral's social, political and economic values and goals had more in common. In order to raise the propagandistic value of such bilateral meetings, the Soviet side insisted on publishing lengthy communiqués. These hailed the state treaty, neutrality and the friendly bilateral relations between the USSR and Austria, and stressed Austrian concord with Soviet policies. While Soviet diplomats and leaders repeatedly attempted to talk their Austrian colleagues into making statements that were designed to support Soviet initiatives or condemn US or Israeli policy, conflicting views between the two sides were usually not reflected in this type of official documents. Moreover, Soviet leaders regularly (ab)used their meetings with Austrian politicians for excessive lecturing in anti-American propaganda.

Since public praise and public criticism were among the most effective Soviet means of promoting neutrality in the West, and also of shaping the neutral's politics, Austria was given more attention in the Soviet press than comparable Western states. ${ }^{13}$ This can be attributed to the above-mentioned use of the Soviet media as a semi-official mouthpiece for issuing warnings against undesirable actions such as rapprochement with the Common Market, for identifying alleged "foes of neutrality" within Austria and without, such as neo-Nazism, the FRG, the United States, NATO and the EEC, and for communicating encouragement regarding the convocation of the CSCE. Most of the Soviet attacks were, as Deputy Foreign Minister Semenov confessed, published "prophylactically"14 - apparently without concern whether they entailed interference in the neutral's domestic affairs. In some of these articles on Austria, its Communist Party, due to a political custom in the Soviet bloc, received more attention than it might have deserved if considering its actual share of the Austrian vote. In return, the KPÖ played the role of a tool of Soviet propaganda and watchdog of Austria's neutrality and pro-Soviet orientation. Fabricated KPÖ charges against the Viennese government, which were meant to intimidate as well as provide evidence for Soviet accusations, were repeated by the Soviet media without being verified. Also due to the Soviet practice of using the

${ }^{13}$ In the years 1956-85, the average annual numbers of articles concerning the neutral states in the main Soviet daily newspapers were: Finland 18; Austria 13; Sweden 4; and Switzerland 2. Petersson, The Soviet Union and Peacetime Neutrality, 8.

${ }^{14}$ Austrian embassy Moscow to Austrian MFA, 14 November 1969, in ÖStA, AdR, BMAA, Pol. Berichte Moskau. 
Western world as a dark backdrop against which life under the communist regime shone more brightly, Soviet media depictions of the Austrian political, social and economic system were distorted. But despite these systemic drawbacks, the Soviet media coverage of Austria was usually, as the Austrian embassy noted, "markedly friendly and inspired by the effort to depict it [=Austria] as a peaceful, openminded country, which is capitalist but nevertheless relatively progressive and not malevolent." ${ }^{\prime 15}$ Not the same can be said with regard to the Austrian media coverage of the USSR and its general image, which seems to have suffered particularly from the Soviet bloodshed in Hungary, the armed intervention in Czechoslovakia, and the oppression of Soviet dissidents. While the Kremlin was never shy in handing out criticism, the communist regime was sensitive if criticized itself and repeatedly demanded that the Austrian government suppress such statements. Nonetheless, it might be of interest to the analyst of international relations that the frank Austrian words about Soviet behavior in 1956 and the Soviet warnings against Austrian neoNazis or joining the EEC do not seem to have lastingly affected the friendly official relations between the two sides as long as they were interested in maintaining them.

The result of the various interests and policies of both sides, some parallel or complementary and others conflicting, was a special relationship between the two countries that, for the most part, was demonstratively friendly, even when it was disrupted by the Soviet interventions in Hungary and Czechoslovakia or overcast by Austria's ambitions to associate with the EEC. A certain role in the development of Soviet-Austrian relations seems to have been played by the personal relationship and empathy that appeared to develop particularly between Khrushchev and Mikoian (the latter being, on the occasion of bilateral meetings, frequently referred to as "the Austrian" by his Politburo colleagues) on one hand and Raab on the other. Due to the USSR's central role in creating and shaping Austria's neutrality and to the equally important role neutrality played in defining Soviet policy towards Austria, it has been suggested that the Soviet-Austrian relationship might be regarded as a "neutrality partnership." 16 Indeed, this would be an appropriate description, only if the concept of "partnership" did not imply voluntariness, equal rights, or a shared Weltanschauung.

It can be said that this relationship, particularly in the second half of the 1950s, differed fundamentally from Soviet relations to any other Western or neutral country. While the Soviet attitude towards neutralism and the neutrals was merely a sideshow (albeit from time to time an important one) of Soviet policy towards Western Europe and the Third World, as a group the neutrals were so heterogeneous and the Soviet relations with them differed to such a degree "that it is hardly valid to speak of a Soviet design for dealing with them as a group." ${ }^{\prime 17}$ There were significant

\footnotetext{
15 Austrian embassy Moscow to Austrian MFA, 16 January 1967, ibid., II-Pol, GZ. 13844-6/67, Z. 15037-6/67.

${ }_{16}$ Ermacora, 20 Jahre österreichische Neutralität, 118.

${ }^{17}$ Hakovirta, "The Soviet Union and the Varieties of Neutrality," 569.
} 
differences between the neutrals, such as the legal basis of their neutrality, their geo-strategic locations, the level of their international activities, their economic interdependence with the Eastern bloc, and their ability to defend themselves. The USSR had a much greater leverage over Austria and Finland, whose neutrality was, as a result of the Soviet role in the postwar settlement with these two countries and in the genesis of their postwar status, linked to the Soviet Union. They were located at the Soviet (bloc's) border, militarily weak, and exposed to Soviet pressure. It is also clear that the Austrian and Finnish cases were similar in having a relatively fresh experience of neutrality, which proved susceptible to external influences, particularly from the Soviet side. Of all the neutral states in Europe, Finland had by far the highest rate of economic and political exchanges with the Soviet Union and was, by virtue of these factors as well as its geographic proximity, the most vulnerable to Soviet interference. Within most parameters, Soviet-Austrian relations can be compared rather to the Soviet-Finnish than to Soviet-Swedish or Soviet-Swiss relations, which barely existed. Indeed, Soviet officials referred not only to Austria as a model for other Western states, but also to Finland as a model for Austria. Nonetheless, it would be incorrect to ignore the fact that the Kremlin's leverage and interference in Austrian affairs were significantly lower than in the case of Finland, and Austria's maneuvering space was much wider; no Soviet "night frost" or "note crisis" was staged against Austria, and Austrian self-censorship never reached the degree found in Finland.

Austria thus avoided being Finlandized, as did Western Europe, and, according to some accounts, even Finland..$^{18}$ For the most part, Austria's trade patterns remained firmly oriented towards OECD countries, and the CMEA's share in Austria's trade was as low as $8-15$ percent. Austria reserved the right of interpreting its neutrality and, in general, did not yield to Soviet demands, although over time it is clear that it did adopt certain Soviet features of neutralism. But the Soviet hopes of Finlandizing Austria or "neutralizing" all of Western Europe turned out to be in vain.

It should be noted that, at least in part due to Soviet "stick and carrot" policy, the Austrian interpretation of neutrality changed over the years. It is clear that Austria's neutral policy was never determined exclusively by its governments and lawyers but also by the surrounding world, and the Soviet Union played a paramount role in this regard. It seems understandable that a small neutral country, with no allies backing it, is more susceptible to pressure of this type from great powers than would be a member of an alliance. Gradual tugging by a large power may, over time, lead to new interpretations and understandings in a small country, and persistent pressure erodes the autonomy of a small state's decision-making. Since Austria had never officially or legally defined its "neutrality doctrine," the interpretation

${ }^{18}$ George Maude, "Has Finland been Finlandized?," in George Ginsburgs and Alvin Z. Rubinstein (eds.), Soviet Foreign Policy Toward Western Europe (New York: Praeger, 1978), 43-65, 62. 
thereof fluctuated. In contrast to its original interpretation of neutrality, Austria drifted in the direction of the Soviet understanding and even adopted a few characteristics of Finnish neutrality. ${ }^{19}$ These included taking initiatives that were expected to please the USSR as well as self-censorship - although these were implemented to a much less pronounced extent than in Finland. Austria also had much stronger economic ties with the East than had, for example, Switzerland. In addition, Austria lacked the Swiss or Swedish determination to create a strong deterrent and neglected armed defense, relying rather, as did Finland, on notions of "active" neutrality as a tool for achieving security. Whether neutrality would have indeed protected the small country located on the battle line between the blocs if a general war between the Warsaw Pact and NATO had broken out is, however, highly doubtful.

The progressive adoption of Soviet interpretations (and Finnish characteristics) of neutrality by Austrian politicians is demonstrated in their ideas concerning economic integration, public opinion and "active" neutrality, the downgrading of armed neutrality and self-defense, as well as the reluctance to express Austrian interpretations. It seems questionable that Austria's neutral policy would have developed the way it did, i.e. that the country protested US overflights or abandoned Western integration, without the presence of the Soviet watchdog. Furthermore, Austria's readiness to speak out openly for freedom, human rights, and democracy in Eastern states became increasingly "neutralized" after the country's courageous declarations against the Soviet bloodshed in Hungary in 1956. This growing "neutralization," which paralleled repeated Soviet protests against foreign criticism, can be seen in the rather cautious Austrian reactions to the Soviet crackdown on Czechoslovakia in 1968, to the invasion in Afghanistan in 1979, to the introduction of martial law in Poland in 1981, to the Soviet downing of a Korean passenger aircraft in 1983, and even to the abortive communist putsch in the Soviet Union in 1991. While in 1956 the Austrian army had been ordered to defend the country's borders, in 1968 it was instructed to stay away from the same. In contrast to earlier promises to the West and in contrast its own declaration of neutrality, the Austrian government consistently neglected the country's defense, choosing instead to rely on an "active" foreign policy - thus reflecting Soviet notions about the futility of the Western neutrals' self-defense and their mission to foster détente. It seems likely that this "neutralization" was a result of, among other factors, repeated Soviet calls for a more pro-Soviet version of neutrality, Soviet warnings as well as encouragement. These constant reprimands led to self-censorship, self-restriction, and retreat into the Schrebergarten of virtual security. Today Austria's "mental neutralization" might be seen in the country's reluctance to join the Western alliance and/or step up self-defense, a lack of solidarity with the victims of aggression, human rights viola-

${ }^{19}$ Cf. Bengt Sundelius, "Introduction," in idem (ed.), The Neutral Democracies in the New Cold War (Boulder: Westview, 1987), 1-10, 7: "Inspired by the example of Swiss neutrality, the Austrian version has over time developed in the direction of the [...] Finnish type." 
tions, or political pressure, and a general unwillingness to get involved in foreign affairs. $^{20}$

Since Soviet relations to Austria were designed to fulfill a distinct function in the international environment, they were subject to changes in this environment. In the late 1950s and early 60s, Austria was not only praised by the Soviet Union as a model of "peaceful coexistence," but was also repeatedly asked by the USSR to offer its services, as for example in the German question, the Berlin crisis, the Vietnam War, and the convocation of the CSCE. Some fifteen years later, détente had materialized, the Berlin crisis and the Vietnam War had been settled, and the CSCE was on its way. Willy Brandt and, later, Richard Nixon became trusted partners of the Kremlin, and Austrian mediatory services were no longer needed. Similarly, Austria's pioneering position in trade with the USSR was lost during détente, as the Soviet Union began to develop its economic ties to other, larger Western states such as Italy, France and West Germany. While in the 1950s and 60s, the Kremlin had used Austria as a tool for neutralizing Western Europe, these efforts were scaled back after 1968. This is not to say that Austria immediately became irrelevant once détente started. The neutral country's services and support were still needed at the CSCE, in the United Nations, and during the last phase of the Cold War. However, while the number of bilateral exchanges of opinion rose, their political significance fell. Gorbachev's new policies and the sea change in East-West relations in the late 1980s made the special relationship between the USSR and Austria obsolete. Once the Cold War was over, there was no longer any need for this "good example of peaceful coexistence."

${ }^{20}$ Neuhold, "The Permanent Neutrality," 59, speaks of an "alarming degree of ignorance" with regard to security issues. The Cold War was seen by the Austrian public as a conflict that did not affect Austria. Manfred Rotter, “Unter Wahrung der Neutralität," in Zukunft, no. 1 (1990), 5-11, 10; Oliver Rathkolb, Die paradoxe Republik: Österreich 1945 bis 2005 (Vienna: Zsolnay, 2005), 42-46. Rathkolb argues that Austrians tend to equate their country's small size and neutrality with security and wealth and not to exhibit solidarity in security issues. In a 2004 survey, 15 percent of questioned Austrians responded that their country should not come to the help of another EU member state if it were attacked. Ibid., 423. 


\section{Documents}

Document 1: Conversation A. Mikoian - J. Raab, Vienna, 24 April 1957

Besprechung im Bundeskanzleramt am 24.IV.1957

Anwesend:

von sowjetischer Seite:

Erster Stellvertretender Vorsitzender des Ministerrates der UdSSR, A. I. MIKOJAN

Stellvertretender Außenhandelsminister F. N. KUMYKIN

Botschafter I. L. ILJITSCHOW

Botschafter S. G. LAPIN

Botschaftsrat W. I. Klotschek

von österreichischer Seite:

Bundeskanzler Ing. Julius RAAB

die Bundesminister Dr. Ing. FIGL, Dr. KAMITZ, Dr. BOCK, HELMER, Ökonomierat THOMA, Ing. WALDBRUNNER

die Staatssekretäre Dr. KREISKY und GRUBHOFER

Leitende Beamte des Bundeskanzleramtes,

des Bundeskanzleramtes-Ausw[ärtige] Angelegenheiten,

der Ressortministerien

Der Bundeskanzler begrüßte den Stellvertretenden Ministerialpräsidenten Mikojan namens der Bundesregierung und im eigenen Namen.

Mikojan: Ich, möchte zunächst nochmals danken für die liebenswürdige Einladung und bin beauftragt, Ihnen die herzlichsten Grüße des Vorsitzenden des Präsidiums des Obersten Sowjets, Woroschilow, zu übermitteln, ferner des Herrn Ministerpräsidenten Bulganin und meiner Kollegen Chruschtschow und Malenkow.

Bundeskanzler Raab: Ich bitte Sie, diese Grüße ebenso herzlich zu erwidern. Ich erinnere mich mit Vergnügen an die Zeit, da wir in Moskau mit allen diesen Herren beisammen waren.

Mikojan: Ich möchte heute die Gelegenheit ergreifen, um gewisse Fragen zu besprechen. Die Neutralität Österreichs anerkennen wir und wir wollen keine Einmischung in österreichische Angelegenheiten vornehmen, wir wünschen auch, daß dies niemand tun möge. Es mag dies eine bloße Deklaration sein, aber jede Dekla- 
ration, die ausgesprochen wird, muß auch durch die Tat unterstrichen werden. Jeder will nachprüfen, ob den Worten die Taten folgen. Darin liegt für niemand etwas Beleidigendes. Wenn wir kritisch untersuchen, so haben wir den Eindruck, daß Sie keinen Grund haben, uns Vorwürfe zu machen. Wenn etwas gegen uns vorliegt, bitte ich es in freundschaftlicher Weise zu sagen. Dies ist eine sehr wichtige Bedingung und Voraussetzung dafür, daß sich kein Unmut anhäuft. Man soll Gefühle nicht verbergen, sondern sofort aussprechen. Ich habe schon gestern gesagt, daß die Erklärung der Neutralität durch das österreichische Parlament große Bedeutung im internationalen Leben hat. Es ist dies ein großer Beitrag des österreichischen Volkes zur Sache des Friedens. Wir haben dies geschätzt und schätzen es jetzt noch. Da ich aber mit Ihnen in freundschaftlichem Gespräch beisammen bin und kein Diplomat sein will, kann ich als Gast offener sagen, was ich denke. Wir sind mit einigen Taten und Worten Österreichs in der letzten Periode nicht ganz zufrieden. Wir schreien nicht, weil wir nicht die Beziehungen verschlechtern wollen und hoffen, daß dies alles nur vorübergehend ist und daß gewisse Dinge wieder beseitigt werden, wenn sich die Kontakte bessern. Einige dieser Fragen betreffen die Beziehungen zur Sowjetunion direkt. Sie sind mit der Neutralität verbunden. Ihre Neutralität ist noch jung. Sie befindet sich erst in Stadium der Reife.

Uns hat der Zwischenfall an der Grenze mit dem sowjetischen Soldaten sehr mißfallen. Wir verstehen schon, daß solche Unfälle vorkommen können, es ging uns aber sehr nahe, daß der österreichische Gendarm nicht nur nicht bestraft, sondern noch ausgezeichnet wurde. Ich denke, daß dies nicht in Interesse des österreichischen Volkes und seiner Beziehungen zu uns gelegen ist. Ungarn ist sowohl unser wie auch Ihr Nachbar. Wir haben engere Beziehungen zu Ungarn als Sie auf Grund des Warschauer Paktes, wir sind mit unseren Militäreinheiten nahe an Ihrer Grenze postiert. Es ist uns daher nicht ganz gleichgültig, welche Beziehungen Sie zu Ungarn haben. Aber es ist für uns sehr wichtig, daß sich die Beziehungen zwischen Ihnen und Ungarn wieder bessern. Wir wollen die Interessen des österreichischen Volkes verstehen und sie auch wahrnehmen. Wir können nicht verstehen, welches Interesse Österreich haben sollte, sich in ungarische Angelegenheiten einzumengen. Die Ereignisse in Ungarn waren eine große Sache und wir wollen ihre Ursachen hier nicht weiter untersuchen. Eines kann man aber sagen, nämlich daß gewisse österreichische leitende Organe, besonders die Polizei, sich hätten ruhiger betragen können.

Wenn man vom Standpunkt der Neutralität ausgeht, dann hat Österreich einige Schritte unternommen, die wir nicht billigen konnten. Solche Schritte waren die Untersagung des Weltgewerkschaftsbundes und des Weltfriedensrates. Bei uns kann niemand glauben, daß diese Organisationen eine Bedrohung der Souveränität Österreichs bedeutet haben. Man sagt bei uns eher, daß dies eine amerikanische Einstellung der Österreicher war. Ich hoffe, daß Minister Helmer meine Worte nicht so auffaßt, daß wir uns in innere österreichische Angelegenheiten einmengen. Ich hoffe, daß niemand daran zweifelt, daß wir von Österreich nichts wollen. Wir wol- 
len nur, daß Österreich unabhängig und neutral bleibt und Beziehungen zu allen Ländern pflegt. Wir wollen Österreich nicht in irgendeinem Block sehen, weil Österreichs Rolle als neutraler Staat für den Frieden nützlicher ist als irgendetwas anderes. Es ist nicht richtig, daß der Osten keine Beziehungen zum Westen haben wolle und einen eisernen Vorhang aufrichte. Wir lassen Leute von allen Ländern zu uns herein, auch solche, die gegen uns eingestellt sind. Viele von ihnen, die als Gegner zu uns kommen, kehren zurück als weniger heftige Gegner.

Die Ereignisse in Ägypten und Ungarn haben den Prozeß der Entspannung der Weltlage unterbrochen. Aber jede schlechte Sache hat auch ihre guten Seiten. So haben auch diese Ereignisse eine Probe aufs Exempel gemacht, ob ein Frieden von Seiten Amerikas und Rußlands gewünscht wird oder nicht. Wenn eines dieser beiden Länder den Krieg gewollt hätte, wäre ein neues Inferno unvermeidlich gewesen. Aber beide haben sich überzeugt, daß keiner von ihnen den Krieg wolle, und das dient nun dazu, daß der unterbrochene Proze $\beta$ wieder fortgesetzt werden kann. Das State Department hat den Austausch von Delegationen wieder aufgenommen. Auch die Engländer haben wieder begonnen, die Kontakte wieder [sic] aufzunehmen. Wir ergreifen alle Maßnahmen, um die Entspannung zu verstärken und unsere Bemühungen in der Frage der Abrüstung sind wohl genügend bekannt, ebenso wie die Vorschläge von unserer Seite. Man hat uns früher beschuldigt, daß unsere Vorschläge nur propagandistischer Natur seien, aber diese Beschuldigungen erhebt heute niemand mehr. Man sieht nun doch ein, daß unsere Vorschläge doch [sic] ernsthaft gemeint sind. Wir sind dafür, daß die Atomwaffen verboten werden. Es gibt in London einen Vorschlag [von] Stassen, daß man die Erzeugung der Atomwaffen einstellen solle, aber die bereits vorhandenen Waffen sollen gelagert und die Versuche fortgesetzt werden. Wir sind der Überzeugung, daß man auch die vorhandenen Waffen vernichten und die Versuche einstellen muß. Die Amerikaner und Engländer sind anscheinend noch nicht so weit, um zu einem Abkommen gelangen zu können. Wir haben einseitig unsere Armee um 1,800.000 Mann gekürzt. Wir wären Dummköpfe, wenn wir einseitig die Atomwaffen und die Versuche einstellen würden. Aber in den anderen Fragen hat man den Eindruck, daß etwas vorwärts geht. Man hat von westlicher Seite den Vorschlag auf Reduktion auf je 1 1 12 Millionen Mann gemacht. Als wir uns einverstanden erklärt haben, hat man aber zurückgezogen. Jetzt schlägt Stassen eine Reduktion auf $2 \frac{1}{2} 2$ Millionen Mann vor und beantragt auch das Rüstungsbudget um 10-15 Prozent zu kürzen. Wir können diesen Vorschlag als ungenügend nicht annehmen, aber er ist wenigstens ein Beweis dafür, daß man die Rüstung nicht erweitern will. Vom Westen wurde viel von Kontrolle gesprochen und seinerzeit der Plan [von] Baruch vorgeschlagen. Es ist ein positiver Schritt, daß dieser Plan zurückgezogen worden ist. Von amerikanischer Seite wurde auch örtlich unbegrenzte Kontrolle durch Luftaufnahmen vorgeschlagen. Davon ist jetzt auch nicht mehr die Rede. Wir halten den neuen Vorschlag, daß man mit einer begrenzten Abrüstung in Zentraleuropa durch Reduzierung der Landstreitkräfte und Luftüberwachung beginnen sollte, für positiv 
und realistisch. Wenn man mit einem großen Abrüstungsprogramm nicht beginnen kann, dann eben mit einem kleineren. Wenn ein Gebiet von $800 \mathrm{~km}$ diesseits und jenseits der Elbe entmilitarisiert würde und die Militärstärke verringert werden könnte, wäre dies ein sehr bedeutender Schritt zum Frieden. Wenn beide Blöcke sich mit einer solchen Land- und Luftkontrolle einverstanden erklären, so wird ein plötzlicher Krieg unmöglich sein. Wenn man sich davon überzeugt, daß sich dieser erste Schritt bewährt, kann man weitere Schritte der Entspannung gehen. Ich hege die Hoffnung, daß die österreichische Regierung diese unsere Bestrebungen mit Sympathie verfolgt, und zwar deshalb, weil viele andere Staaten dies auch tun. Unsere Vorschläge sind aufrichtig, sachlich und realistisch.

Bundeskanzler Ing. Raab:

Da ich von dem Rechte eines offenen Gespräches Gebrauch machen möchte, komme ich zunächst zurück auf unsere Gespräche in Moskau. Unser Bestreben war es damals, die Neutralität Österreichs in der Verfassung festzulegen. Wir haben bei Unterzeichnung des Staatsvertrages unserem Parlament ein Verfassungsgesetz vorgelegt, welches vom Parlament mit der entsprechenden Mehrheit beschlossen wurde. Der Gedanke der Neutralität ist heute im österreichischen Volk fest verankert und es gibt wenig Gegenstimmen. Das Volk hat erkannt, daß unsere damalige Entscheidung eine richtige war. Es ist Pflicht der Regierung und des Volkes, sich strikte an dieses Verfassungsgesetz zu halten, und ich glaube auch, daß man keine Klagen dagegen vorbringen kann. Wir haben bei den Vereinten Nationen immer getrachtet, bei den Abstimmungen unserer Rolle als neutraler Staat gerecht zu werden. Das werden wir auch in Zukunft so halten. Was der Herr Ministerpräsident als Anklagen vorgebracht hat, kann man höchstens als läßliche Sünden bezeichnen. Der erste Fall: Der Gendarm hat nach den österreichischen Gesetzen gehandelt, sein Vorgehen wurde gerichtlich genau untersucht. Die Auszeichnung hat er nicht wegen des Vorfalls bekommen, sondern für die Pflichterfüllung durch lange Zeit. Wir haben selber eine Reihe von Verlusten gehabt durch Schüsse, die von drüber der Grenze [sic] herübergekommen sind. Wir werden den Fall nochmals untersuchen und vielleicht auch den Gendarmen versetzen, um den Vorfall aus der Welt zu schaffen.

Was nun Ungarn anbelangt, so haben wir keinen Stacheldraht gezogen. Wir waren jahrhundertelang in einem Staat beisammen und es bestehen zwischen unseren Staatsbürgern viele familiäre Bindungen. Wir haben uns sehr darüber gefreut, als die Ungarn den Stacheldraht entfernten und als der Reiseverkehr verdichtet wurde. Wir haben ein innigeres Verhältnis mit Ungarn sehr begrüßt. Wir haben uns in keiner Weise um die inneren politischen Verhältnisse Ungarns gekümmert. Wir haben in der Folge festgestellt, daß im Osten verschiedene Auffassungen über den Kommunismus geherrscht haben und daß dies zu Wirren geführt hat. Wir haben den Ausbruch der Revolution in Ungarn aus den Zeitungen gelesen. Wir haben damals einen Appell gerichtet, die Kampfhandlungen einzustellen, weil bei derartigen Kämpfen immer Unschuldige zum Handkuß kommen. Wir haben keinen 
Kontakt gehabt mit Leuten, die den Aufstand gemacht haften, wir kennen sie nicht, wir hatten nur plötzlich tausende und tausende Flüchtlinge aufzunehmen, die über die Grenze kamen. Wir wurden verschiedentlich beschuldigt, Waffen geliefert zu haben. Ich möchte hier klar feststellen, daß Österreich keinerlei Waffen nach Ungarn geliefert hat.

Mikojan: Vielleicht haben aber andere Staaten das österreichische Territorium zu Waffenlieferungen benützt.

Bundeskanzler Raab: Nein, das war nicht der Fall. Wir haben unsere Neutralität nicht verletzt. Österreich war stets bestrebt, die Flüchtlinge möglichst rasch von der Grenze wegzubekommen, um Zwischenfälle zu vermeiden. Es sind fast 180.000 nach Österreich gekommen und nur ein ganz geringer Teil davon ist nach Ungarn zurückgekehrt. Österreich hat für die Versorgung dieser Flüchtlinge große finanzielle Opfer gebracht. Wir sind nach wie vor dafür, daß sich unser Verhältnis zu Ungarn bessert. Bei uns kann jeder in unser Land herein oder hinaus, wie er will.

Die Auflösung der zwei Organisationen erfolgte nach den österreichischen Gesetzen, weil sie eine einseitige Politik verfolgt haben und wir dies nicht von Österreich aus geschehen lassen wollten. Es steht ihnen der Rekurs an unsere Gerichte offen.

Was der Herr Ministerpräsident über die Abrüstung gesagt hat, so werden Sie in uns immer Leute finden, die jede Abrüstung, jedes Verbot der Atomwaffen unterstützen werden. Wir werden keinen Anlaß vorübergehen lassen, für den Frieden einzutreten. Wir haben keine Atomwaffen und wollen sie auch gar nicht. Das ganze Problem ist eine Auseinandersetzung zwischen den beiden Blöcken, von uns wird immer der Ruf nach Abrüstung erklingen.

Ich mochte noch einige Bemerkungen anfügen. Es betrifft dies die Lieferungen von Öl und Waren. Diese sind während der ersten zwei Jahre ordnungsgemäß durchgeführt worden und ich stelle mit Vergnügen fest, daß die Abnahme von Ihrer Seite sachlich einwandfrei erfolgt ist. Wir haben heuer im Winter Schwierigkeiten mit der Heizölversorgung gehabt und danken Ihnen für Ihr Entgegenkommen. Was die anderen Lieferungen anbelangt, jene der 150 Millionen Dollar, so stelle ich fest, daß das erste Jahr voll ausgeliefert ist, das zweite ist ziemlich fertig, und für das dritte Jahr sind schon Aufträge für die halbe Summe hinausgegeben worden. Die Übernahme und die Rückstellung der Wechsel erfolgte klaglos und ziemlich rasch, wofür wir ebenfalls dankbar sind. Wir haben aber hier eine Bitte vorzutragen, von der ich hoffe, daß Sie sie bewilligen werden. Wir haben in der Warenlieferung außer der 1 Million Tonnen Erdöl für die Erdölgebiete noch weitere 200.000 Tonnen vorgesehen. Ich möchte ersuchen, ob wir nicht statt dieser 200.000 Tonnen andere Waren liefern könnten, weil wir im eigenen Lande Schwierigkeiten mit der Heizölversorgung haben. Ich habe schon gestern über den Handelsvertrag gesprochen, ob wir diesen nicht ausweiten könnten. Die Schwierigkeiten bestehen vor allem darin, daß wir nur Ware gegen Ware tauschen können. Rußland könnte doch auch ein wenig dafür zahlen. Zusammenfassend 
möchte ich sagen, daß wir auf dem Boden unserer Verträge stehen, daß wir alles machen wollen, um den Frieden zu sichern.

Mikojan: Was die konkreten Fragen betrifft, so möchte ich sagen, daß die Aufklärungen nicht ganz befriedigend waren. Was der Herr Bundeskanzler über Österreichs Politik in der Zukunft gesagt hat, bin ich zufrieden. Österreich hat doch Interesse an der Freundschaft mit Ungarn.

Bundeskanzler Raab: Die ungarischen Minister sollen uns nicht als Schuldige hinstellen.

Mikojan: Wenn die Österreicher aber doch schuldig sind? Treffen Sie sich doch mit ihnen, damit Sie sich aussprechen können.

Bundeskanzler Raab: Sie sollen nicht Ihre Popularität auf unsere Kosten zu erreichen versuchen.

Mikojan: Sagen Sie es Ihnen doch.

Bundeskanzler Raab: Wir sind dafür, daß wieder normale Verhältnisse mit Ungarn geschaffen werden.

Mikojan: Was die Lieferungsverpflichtungen anbelangt, kann ich feststellen, daß Österreich sie korrekt erfüllt hat und daß noch kein einziger Grund zu einer Kritik vorhanden war. Wir können nur für die gewissenhafte Erfüllung danken. Was ich aus den Veröffentlichungen über die österreichische Wirtschaft entnommen habe, so kann man den Eindruck gewinnen, daß sich Österreichs Wirtschaft günstig entwickelt hat. Je besser die Wirtschaft Österreichs und der Welt ist, desto sicherer ist die Sache des Friedens und desto besser unsere Beziehungen. Was die konkrete Frage betrifft, möchte ich sagen: durch das Abkommen ist festgesetzt worden, daß die Mengen und die Auswahl der Waren zu spezifizieren wären. Was 1957 betrifft, haben wir schon planmäßig eingeteilt. Ich glaube nicht, daß man etwas umstoßen kann. Was nun 1958 anbelangt, halte ich es nicht für ausgeschlossen, Gespräche über den Austausch von Warenpositionen durchzuführen. Was den Handel betrifft, entspricht er nicht den Möglichkeiten, die wir haben. Selbstkritisch möchte ich sagen, daß der größere Teil der Schuld an unserer Außenhandelsorganisation liegt. Wir sollten beide Maßnahmen ergreifen, daß wir den Handel steigern.

Bundeskanzler Raab: Im Herbst könnten wir neue Handelsvertragsverhandlungen beginnen.

Mikojan: Es wäre vorteilhafter, einen mehrjährigen Handelsvertrag abzuschlieBen, da dieser stabiler ist.

Ich werde gerne meiner Regierung weitergeben, daß Österreich seine Verpflichtungen aus dem Staatsvertrag einhalten und seine Neutralität wahren wird.

Zum Abschluß möchte ich den Herrn Bundeskanzler offiziell einladen, nach der Sowjetunion zu kommen, und zwar noch heuer, wenn es aber nicht gehen sollte, im nächsten Jahr. Es steht ihm frei, von seinen Regierungsmitgliedern mitzunehmen, wen er will. Meine Einladung gilt auch für den Herrn Vizekanzler, entweder mit dem Herrn Bundeskanzler oder gesondert. Ich würde mich auch freuen, den Herrn 
Außenminister bei uns begrüßen zu können und wir würden auch den Herrn Staatssekretär Dr. Kreisky gerne bei uns sehen

Bundeskanzler Ing. Raab: Ich danke für die freundliche Einladung und werde trachten, ihr sobald wie möglich nachzukommen.

Source: ÖStA, AdR, BMAA, II-Pol., GZ. 215.864-pol/57, Z. 222.278-pol/57.

Document 2: Personal letter N. Bulganin - J. Raab, 8 January 1958

Sehr geehrter Herr Bundeskanzler!

Die Sowjetregierung richtete am 10. Dezember 1957 an die Regierung Österreichs sowie an die Regierungen der anderen Mitgliedstaaten der Vereinten Nationen eine Note, in der sie ihrer tiefen Besorgnis über die gegenwärtige internationale Lage Ausdruck verlieh und eine Reihe von Vorschlägen machte, die zur Einstellung des „kalten Krieges“ und des Wettrüstens sowie zur Befreiung der Völker von der Gefahr eines Atomkrieges beitragen sollten.

Nach diesem Appell der Sowjetregierung traten in der Weltpolitik einige Ereignisse ein, die noch dringender von allen an der Erhaltung des Friedens interessierten Staaten schnelle Maßnahmen für die Sicherheit der Völker erfordern, damit diese ohne Furcht vor dem morgigen Tag leben können. Man kann doch die Tatsache nicht unbeachtet lassen, dass auf der Dezembertagung des NATO-Rates, obgleich sich auch nüchterne Stimmen bei der Beurteilung der gegenwärtigen internationalen Lage vernehmen ließen, Beschlüsse gefasst wurden, die eine weitere Intensivierung des atomaren Wettrüstens sowie die Schaffung von Atom- und Raketenbasen auf den Territorien der Mitgliedstaaten der NATO vorsehen. Es ist leicht einzusehen, dass die Durchführung dieser Beschlüsse, insbesondere die Schaffung von Abschussbasen für Raketen in Italien die Souveränität und die Sicherheit des neutralen Österreich ernstlich bedrohen würde. Diese Beschlüsse können nur zu einer Verschärfung des „kalten Krieges“, zu einer Vergrößerung der Kriegsgefahr und zu einer weiteren Vertiefung des gegenseitigen Misstrauens der Staaten untereinander führen.

Eine solche Entwicklung in den internationalen Beziehungen ruft bei den Völkern berechtigte Beunruhigung hervor, was vor allem darin zum Ausdruck kommt, dass jetzt fast überall die Forderung nach notwendigen dringlichen Maßnahmen zur Gesundung der internationalen Lage erhoben wird.

Wir stellen mit Genugtuung fest, dass die von der Sowjetunion in ihren Noten an die Regierungen der Mitgliedstaaten der UN unterbreiteten Vorschläge, die das Ziel verfolgen, durch gemeinsame Anstrengungen eine Abschwächung der internationalen Spannung zu erreichen, in vielen Ländern der Erde, darunter auch in Österreich, positiv aufgenommen wurden und immer ausgedehntere Unterstützung finden. Besonders weitgehende Anerkennung findet der Gedanke an Unterredungen der Staatsmänner des Ostens und des Westens auf höchster Ebene. 
In Anbetracht dessen richtete die Sowjetregierung an die Regierungen der Mitgliedstaaten des Nordatlantik-Paktes und an die Teilnehmerstaaten des Warschauer Vertrages den Vorschlag, im Laufe der nächsten zwei bis drei Monate eine Konferenz der führenden Staatsmänner unter Beteiligung der Regierungschefs abzuhalten. Auf dieser Konferenz wären in erster Linie die aktuellsten und dringlichsten Fragen zu erörtern, wie das Problem der Abrüstung - darunter die Frage des Verzichtes auf die Anwendung von Kernwaffen und der Einstellung der Kernwaffenversuche -, den Abschluss eines Nichtangriffspaktes zwischen den Mitgliedstaaten der NATO und des Warschauer Vertrages, die Schaffung einer atomwaffenfreien Zone in Europa, die Einstellung der Kriegspropaganda, die Förderung der internationalen Handels-Probleme, an deren Lösung auch Staaten interessiert sind, die an diesen oder anderen Gruppierungen nicht beteiligt sind.

Die Sowjetregierung misst der Tatsache große Bedeutung bei, dass gegenwärtig eine ganze Reihe von Staaten, die militärischen Gruppierungen fernstehen und eine Politik der Neutralität betreiben, aktiv für eine Abschwächung der internationalen Spannung und für eine Regelung der ungelösten Streitfragen auf dem Verhandlungswege eintreten. Deshalb ist die Sowjetregierung der Ansicht, dass eine Teilnahme solcher Staaten an einer Konferenz führender Staatsmänner auf höchster Ebene einen positiven Einfluss auf den Gang der Verhandlungen und auf die Fassung von Beschlüssen zur Sicherung des Friedens und der Förderung einer breiten internationalen Zusammenarbeit haben könnte.

Unserer Meinung nach, Herr Bundeskanzler, könnte das neutrale Österreich, das im Herzen Europas zwischen den beiden Mächtegruppierungen gelegen ist und schon allein auf Grund dieses Umstandes an der Erhaltung des Friedens interessiert sein muss, einen wesentlichen Beitrag zur Abschwächung der internationalen Spannung und zur Wiederherstellung des Vertrauens in den Beziehungen zwischen den Staaten leisten. Man wird daher den Worten des Herrn Bundespräsidenten Österreichs, A. Schärf, in seiner Neujahrsbotschaft nur beipflichten können, dass Österreich auf Grund seiner Neutralitätspolitik jetzt mit anderen Staaten zusammenarbeiten kann, „wenn es um den Dienst am Frieden geht, den die Menschheit so heiß ersehnt".

Selbstverständlich sind wir uns bewusst, Herr Bundeskanzler, dass sich auf einer solchen Konferenz nicht auf einen Schlag sämtliche ungelöste Probleme, welche gegenwärtig die Völker der Erde so tief beunruhigen, bereinigen lassen. Jedoch bestehen alle Voraussetzungen dafür, um sich über die dringlichsten Fragen zu verständigen, deren Lösung einen guten Anfang für eine Milderung der internationalen Spannung darstellen würde.

Wir sind der Auffassung, dass zur Erreichung dieses erhabenen Zieles am besten die Einberufung einer Konferenz auf der Ebene der Regierungschefs beitragen würde, die, mit weitgehenden Vollmachten ausgestattet, mit dem größten Erfolg die akuten Fragen, welche die internationale Läge komplizieren, erörtern und die notwendigen Bedingungen für die Wiederherstellung des Vertrauens und die Sicherung 
eines dauerhaften Friedens schaffen könnten. Eine Konferenz der Regierungschefs ist umso zweckmäßiger, als keine Sicherheit darüber besteht, dass die Einberufung einer Konferenz auf Außenministerebene zu positiven Resultaten führen würde, da bereits jetzt einige in Betracht kommende Teilnehmer an einer Konferenz auf solcher Ebene sich gegen Verhandlungen aussprechen.

Zusammen mit diesem Schreiben übermittle ich Ihnen, Herr Bundeskanzler, die Vorschläge der Sowjetregierung zu den Problemen der Abschwächung der internationalen Spannung, die auf einer solchen Konferenz erörtert werden könnten.

Wir haben mit großer Genugtuung ihre [sic] Rede vom 5. Jänner ds. J. zur Kenntnis genommen, in der Sie Verhandlungen zwischen den Staaten des Westens und des Ostens zur Sicherung des Friedens bereits in der ersten Hälfte des Jahres 1958 als zweckmäßig bezeichneten und erklärten, dass Österreich gern an solchen Verhandlungen teilnehmen würde. Diese Ihre Äußerung berechtigt zu der Hoffnung, dass die österreichische Regierung die Vorschläge der Sowjetregierung mit entsprechender Aufmerksamkeit prüfen, einer Teilnahme an der vorgeschlagenen Konferenz der Staatsmänner günstig gegenüberstehen und an der Einberufung und am Erfolg einer solchen Konferenz mitwirken würde.

Mit aufrichtiger Hochachtung

N. Bulganin

8. Jänner 1958

Уважаемый господин Федеральный Канцлер,

Советское правительство обратилось 10 декабря 1957 года к правительству Австрии, так же как и к правительствам других стран-членов ООН, с нотой, в которой выразило свою глубокую озабоченность нынешним состоянием международной обстановки и внесло ряд предложений, направленных к тому, чтобы содействовать прекращению „холодной войны“, прекращению гонки вооружений и избавлению народов от угрозы атомной войны.

После этого обращения Советского правительства в мире произошли события, которые еще более настоятельно требуют от всех государств, заинтересованных в сохранении мира, принятия неотложных мер по обеспечению безопасности народов с тем, чтобы они могли жить без страха за свой завтрашний день. Ведь нельзя пройти мимо того факта, что на декабрьской сессии Совета Североатлантического союза, хотя и раздавались трезвые голоса при оценке существующей международной обстановки, однако вместе с тем были приняты решения, предусматривающие дальнейшее усиление гонки ядерных вооружений, создания атомных и ракетных баз на территориях государств-членов НАТО. Нетрудно видеть, что осуществление этих решений, в частности, создание площадок для запуска ракет в Италии, подвергало бы серьезной угрозе суверенитет и безопасность нейтральной Австрии. Эти решения не могут не вести к обострению „холодной войны“, 
усилению военной опасности и дальнейшему усилению взаимного недоверия государств друг к другу.

Такое развитие в международных отношениях вызывает законную тревогу у народов, что находит свое выражение прежде всего, в том, что сейчас почти повсеместно выдвигаются требования, о необходимости принять безотлагательные меры по оздоровлению международной обстановки.

Мы с удовлетворением констатируем, что предложения, выдвинутые Советским Союзом в нотах правительствам стран-членов ООН, имеющие целью общими усилиями достигнуть ослабления международной напряженности, были встречены положительно и находят сейчас все более широкую поддержку во многих странах мира, в том числе и в Австрии. Особенно широкое признание встречает идея переговоров государственных деятелей Востока и Запада на самом высоком уровне.

Учитывая это, Советское правительство направило правительствам государств-членов Северо-атлантического союза и государств-участников Варшавского договора предложение провести в течение ближайших двухтрех месяцев совещание руководящих деятелей государств с участием глав правительств. На совещании предлагается обсудить в первую очередь наиболее актуальные и назревшие вопросы, такие как проблема разоружения, в том числе вопросы об отказе от применения ядерного оружия и о прекращении его испытаний, заключение пакта о ненападении между государствамиучастниками НАТО и Варшавского договора, создание в Европе зоны, свободной от атомного оружия, прекращение пропаганды войны, содействие развитию международной торговли и некоторые другие вопросы, в решении которых заинтересованы также и государства, не участвующие в тех или иных группировках.

Советское правительство придает большое значение тому, что в настоящее время целый ряд государств, стоящих в стороне от военных группировок и проводящих политику нейтралитета, активно выступает за ослабление международной напряженности, за урегулирование нерешенных спорных вопросов путем переговоров. Вот почему Советское правительство считает, что участие таких государств в совещании руководящих деятелей на самом высоком уровне могло бы оказать положительное влияние на ход переговоров и принятие решений, имеющих целью обеспечение мира и развитие широкого международного сотрудничества.

По нашему мнению, господин Канцлер, нейтральная Австрия, которая расположена в центре Европы между двумя группировками держав, и уже в силу одного этого не может быть не заинтересована в сохранении мира, своим участием в этом совещании могла бы внести существенный вклад в дело по ослаблению международной напряженности и восстановления доверия в отношениях между государствами. Нельзя не присоединиться поэтому к словам Федерального Президента Австрии господина А.Шерфа в 
его новогоднем послании, что Австрия в результате проведения ею политики нейтралитета может теперь сотрудничать с другими государствами, „если речь идет о службе делу мира, которого страстно желает человечество“.

Разумеется, господин Канцлер, мы отдаем себе отчет в том, что на таком совещании невозможно решить за один раз все неурегулированные проблемы, глубоко волнующие ныне народы мира. Однако имеются все предпосылки, чтобы договориться по наиболее неотложным вопросам, решение которых положило бы хорошее начало ослаблению международной напряженности.

Мы полагаем, что достижению этой благородной цели лучше всего содействовал бы созыв совещания на уровне глав правительств которые, обладая широкими полномочиями, смогли бы с наибольшим успехом подвергнуть обсуждению назревшие вопросы, осложняющие международную обстановку, и создать необходимые условия для восстановления доверия и обеспечения прочного мира. Совещание глав правительств тем более целесообразно, поскольку нет уверенности в том, что созыв совещания на уровне министров иностранных дел приведет к положительным результатам, имея в виду, что уже теперь некоторые возможные участники совещания на таком уровне высказываются против переговоров.

С этим письмом я направляю Вам, господин Канцлер, предложения Советского правительства по вопросам ослабления международной напряженности, которые могли бы быть обсуждены на таком совещании.

Мы с большим удовлетворением ознакомились с Вашей речью от 5 января с.г., в которой Вы говорите о целесообразности проведения уже в первой половине 1958 года переговоров между государствами Запада и Востока по обеспечению прочного мира и заявляете, что Австрия будет охотно участвовать в таких переговорах. Это Ваше выступление позволяет надеяться, что правительство Австрии с должным вниманием изучит предложения Советского правительства, благожелательно отнесется к участию в предлагаемом совещании государственных деятелей и со своей стороны будет содействовать созыву и успеху такого совещания.
С искренним уважением,
Н. Булганин
8 января 1958 года.

Source: ÖStA, AdR, BMAA, II-Pol., GZ. 227.665-pol/57, Z. 227.678-pol/57; GZ. 544.297-pol/58, Z. 544.588-pol/58. 


\section{Document 3: Conversation N. Khrushchev - A. Schärf and B. Kreisky, Moscow, 13 October 1959}

Amtsvermerk über Mitteilungen des Herrn Bundesministers betreffend Besprechungen zwischen dem Herrn Bundespräsidenten und Ministerpräsidenten Chruschtschow vom 13. Oktober 1959.

Das Gespräch, das nur für etwa 20-30 Minuten vorgesehen war, dauerte mehr als eineinhalb Stunden. Es enthielt viele positive Aspekte. Der Ministerpräsident befleißigte sich eines sehr maßvollen und überhaupt nicht agitierenden Tones.

Diskutiert wurden folgende Themata:

1. Österreichische Neutralität.

Ministerpräsident Chruschtschow warf der österreichischen Delegation vor, daß Österreich seine Neutralität einseitig auslege, weil es die DDR nicht anerkannt hat.

Darauf erklärte der Herr Bundesminister, daß es sich bei Neutralität um kein absolutes Prinzip handle, im übrigen Österreich in Übereinstimmung mit den Moskauer Vereinbarungen dem Beispiel der Schweiz folge, die diplomatische Beziehungen auch nur mit der BRD und nicht mit der DDR unterhalte. Beide Staaten haben lange gemeinsame Grenzen mit der BRD, die allen jenen Staaten, die Pankow anerkennen, mit dem Abbruch diplomatischer Beziehungen gedroht habe. Dies könne sich jedoch weder die Schweiz noch Österreich leisten, beide Staaten folgen in dieser Frage dem Utilitätsprinzip.

Ministerpräsident Chruschtschow erklärte hierauf, daß die BRD eine Botschaft in Moskau unterhalte, obwohl die Sowjetunion mit der DDR diplomatische Beziehungen habe, worauf der Herr Bundesminister replizierte, daß Bonn sich gegenüber der Sowjetunion eben aus dem Utilitätsprinzip eine Ausnahme von seiner übrigen außenpolitischen Praxis gemacht habe; hierauf erklärte der sowjetische Ministerpräsident lachend, er wolle die Sache nicht bis zur völligen Klarheit weiterführen.

2. Deutschlandproblem.

Nach Ansicht Ministerpräsident Chruschtschows ist für die Sowjetunion eine Lösung in Europa nur akzeptabel, wenn einem bürgerlichen Westdeutschland ein sozialistisches Ostdeutschland gegenübersteht, die miteinander einen Wettstreit auf dem Gebiete der friedlichen Koexistenz führen. Auf diese Art soll der Klassenkampf in Deutschland weitergeführt werden. Man werde bis auf weiteres mit zwei deutschen Staaten rechnen müssen. Als Realist müsste man annehmen, daß kein Staat den anderen von der Überlegenheit seines Systems überzeugen könne. Chruschtschow erklärte etwa wörtlich: „Wir sind Kommunisten. Glauben Sie denn wirklich, daß wir ein Land, das sich wie die DDR im Prozeß der sozialistischen Umwandlung befindet, wieder ausliefern werden? Es ist doch undenkbar, daß wir die DDR nicht unterstützen werden." (Nach Besprechungen von Camp Davis [recte: Camp David] bestehe keine Aussicht auf Wiedervereinigung. Der 
gegenwärtige status quo in Deutschland werde bis auf weiteres perpetuiert werden.")

Bezüglich des Berliner Problems erklärte Ministerpräsident Chruschtschow, daß diese Frage ohne Gewalt und unter Berücksichtigung des Prestiges aller Beteiligten gelöst werden müsse. Der Osten sei bereit, den zwei Millionen Westberlinern alle Garantien, beispielsweise auch im Rahmen der UNO, zu geben. Es müsse jedoch das Prinzip anerkannt werden, daß das Territorium Westberlins als Teil der DDR angesehen werde [sic]. Bonn habe in Westberlin nicht zu suchen. Daß Westberlin als ein Teil der BRD betrachtet werde, sei völlig unannehmbar.

Die Sowjetunion werde versuchen, mit beiden Deutschland einen Friedensvertrag zu schließen. Falls dies jedoch nicht möglich sein sollte, werde die Sowjetunion einen Vertrag mit der DDR allein schließen und erwarte, daß diesem Friedensvertrag auch die anderen Mächte beitreten werden. Chruschtschow hofft, daß die Westmächte in dieser Beziehung nicht dieselben Dummheiten machen werden wie Molotow bezüglich des japanischen Friedensvertrages, dem die Sowjetunion bekanntlich nicht beigetreten ist und in dem nach Ansicht Chruschtschows eigentlich nichts enthalten sei, was die Sowjetunion nicht unterschreiben hätte können. Im gegenwärtigen Zeitpunkt sei allerdings ein Betritt der Sowjetunion zum japanischen Friedensvertrag äußerst schwierig.

\section{3. Österreichischer Staatsvertrag.}

Außer dem oben erwähnten Angriff gegen Molotow in Angelegenheit des japanischen Friedensvertrages sprach Chruschtschow auch im Zusammenhang mit dem Abschluß des österreichischen Staatsvertrages über seine Gegensätze zu Molotow. Chruschtschow habe Molotow etwa zweite Hälfte 1954 gefragt, ob er (Molotow) den Krieg wünsche, denn nur unter dieser Voraussetzung könne sich Chruschtschow die weitere Anwesenheit sowjetischer Truppen in Österreich, die einen Keil in der Richtung Frankreich vortreiben, erklären. Es habe in der Folge eine große innerpolitische Auseinandersetzung gegeben. (Chruschtschow ist der Mann, der den österreichischen Staatsvertrag gebracht hat ${ }^{+}$).

\section{Abrüstung.}

Chruschtschow sprach über die Sinnlosigkeit des Weiterrüstens. (Nach Ansicht des Herrn Bundesministers decken sich die Anschauungen Chruschtschows über das beiderseitige Vernichtungspotential mit denen der führenden Staatmänner der USA.) Chruschtschow habe Eisenhower mitgeteilt, daß er mit dem relativ geringen Aufwand von 30 Milliarden Rubel genügend atomare und thermonukleare Waffen erzeugen könne, um damit den Westen zu vernichten. Chruschtschow brachte die-

\footnotetext{
*) Aus meinen Aufzeichnungen geht nicht eindeutig hervor, ob es sich bei diesem Klammersatz um eine Mitteilung Chruschtschows an die österreichische Delegation oder um eine persönliche Lagebeurteilung des Herrn Bundesministers handelt. [Footnote in the original].

+) Auch bei diesem Satz bin ich mir nicht im klaren, ob es sich hiebei um eine Äußerung Chruschtschows oder eine Bemerkung des Herrn Bundesministers über Chruschtschow gehandelt hat. [Footnote in the original].
} 
se Zahl in eine Relation mit den im Laufe des Siebenjahresplanes zu erzielenden Einsparungen auf dem Energiesektor durch die Umstellung von Kohle auf Erdgas. Chruschtschow führte weiter aus, daß der gegenseitige Sättigungsgrad an atomaren Rüstungen bald erreicht sei und daher für die Großmächte das Aufrüsten bzw. die Erhaltung des Vernichtungspotentials immer billiger und nicht teurer kommen werde. Hingegen werden die Rüstungen auf dem konventionellen Sektor teuerer und nicht etwa billiger werden.

Eiselsberg, m.p.

Source: ÖStA, AdR, BMAA, II-Pol., GZ. 236.711-pol/59, Z. 249.522-pol/59.

Document 4: Conversation A. Gorbach - N. Khrushchev, Moscow, 29 June 1962

Protokoll über die Unterredung einer österreichischen Regierungsdelegation unter Führung von Bundeskanzler Dr. Alfons Gorbach mit dem sowjetischen Ministerpräsidenten N. S. Chruschtschow am 29. Juni 1962 im Kreml.

Anwesend

auf österreichischer Seite:

Bundeskanzler Dr. Gorbach

Bundesminister Dr. Kreisky

Staatssekretär Dr. Steiner

Sektionschef Dr. Chaloupka

Generalsekretär Dr. Bielka-Karltreu

Sektionschef Dr. Meznik

Botschafter Dr. Haymerle

Gesandter Dr. Thalberg

Legationsrat Dr. Karasek

Legationssekretär Dr. Linhart

Attaché Dr. Hinteregger

auf sowjetischer Seite:

Ministerpräsident Chruschtschow

Erster Stellvertretender Ministerpräsident Mikojan

Außenminister Gromyko

Stellvertretender Außenminister Semjonow

Stellvertretender Außenhandelsminister Borissow

Leiter der 3. Europäischen Abteilung Ilitschow

Leiter der Presseabteilung im Außenministerium Samjatin

Botschafter Awilow

Botschaftsrat Iljuchin, 3. Europäische Abteilung

Beginn der Unterredung: $10 \mathrm{Uhr}$ 
Ende der Unterredung: $13 \mathrm{Uhr}$

Ministerpräsident Chruschtschow: Ich möchte zuerst unseren Gästen das Wort erteilen. Sie können sprechen, so viel sie wollen und was sie wollen. Das ist die sozialistische Demokratie.

Bundeskanzler Gorbach: Wir sind zu Ihnen gekommen, weil wir den Wunsch hatten, uns mit Ihnen bekannt zu machen und die Kontakte meines Vorgängers fortzusetzen.

Wir haben keine Wünsche vorzubringen, aber wenn wir einen haben, so ist es der, daß das Vertrauensverhältnis, das zwischen Österreich und Rußland besteht, nicht erschüttert wird, sondern durch diese Aussprache eine Unterstreichung erfährt.

Ich glaube, daß diesem Vertrauen am besten gedient ist, wenn man alle Fragen mit aller Offenheit bespricht, damit man weiß, wie man dran ist und das Gefühl der Ehrlichkeit sich der anderen Seite mitteilt.

Ich würde es sehr begrüßen und möchte den Herrn Ministerpräsidenten bitten, uns seine Meinung über die weltpolitische Lage zu entwickeln, da dies von großem Interesse für uns wäre. Sodann möchten wir einige Fragen besprechen, die unsere eigenen Interessen berühren, soweit auf sowjetischer Seite Fragen bestehen, sind wir bereit, alle diese zu diskutieren.

Chruschtschow: Wir schätzen eine solche Stellungnahme sehr, in der Sie sagen, daß Sie die guten Beziehungen zwischen unseren beiden Staaten hochhalten. Wir haben, wie Sie wissen, die besten Gefühle für das österreichische Volk und stellen auch keinerlei Ansprüche gegenüber dem österreichischen Volk, mit Ausnahme eines einzigen Anspruches: in Frieden und Freundschaft zu leben und daß Österreich neutral bleibe und dementsprechend seine Politik führe, sowohl innen- als auch außenpolitisch, um auf diese Weise die Neutralität zu stärken und dem Frieden zu dienen.

Wenn Sie den Wunsch äußern, daß wir zuerst unsere Meinung über die internationale Lage darlegen, so sind wir damit einverstanden. Dieser Wunsch entspringt, wie mir scheint, dem Standpunkt der Neutralität.

Ich habe sohin mit zwei Kapitalisten zu tun, ich begann die Kontakte mit ihrem Vorgänger Raab, der von sich sagte, er sei ein ganz kleiner Kapitalist, und nun mit Ihnen, Herr Bundeskanzler, der Sie sein Werk fortsetzen.

Ich werde mich bemühen, die internationale Lage so darzustellen, wie ich sie sehe. Es ist dies nicht meine persönliche Meinung, sondern dieser Standpunkt ist auch jener der sowjetischen Regierung.

Wie soll man nun an die Beurteilung der internationalen Lage herangehen? Ich glaube, man kann von einer guten und einer schlechten Seite ausgehen.

Das schlechte ist, daß sich die Teilung der Welt immer mehr vertieft. Die Grenzen zeichnen sich immer stärker ab und die Kräfte auf beiden Seiten wachsen immer mehr. Was aber alarmierend und gefährlich ist, ist, daß ein solcher Streit wohl 
nicht in eine militärische Auseinandersetzung münden könnte, wo der eine Teil gewinnen und der andere Teil verlieren würde. Denn heute sind die modernen Mittel des Krieges auf die völlige Vernichtung gerichtet. Wenn früher vielleicht der Krieg so geführt wurde, wie Sie es gestern im Ballett sahen, wo man mit dem Messer durch persönliche Geschicklichkeit einige Feinde überwinden konnte, heute können ganze Millionen Menschen vernichtet werden.

Unsere Experten sagen hinsichtlich der Bundesrepublik Deutschland, die sich am aggressivsten gegenüber den sozialistischen Ländern gebärdet, daß eine 50 Millionen-Tonnen-Bombe das ganze Land vernichten könne. Dieselbe Lage besteht hinsichtlich Frankreich, Italien und anderen Ländern. Auf der anderen Seite gibt es dieselben Mittel der Vernichtung. Der Unterschied ist nur, daß bei uns in irgendwelchen Urwaldwinkeln irgendwelche Menschen überbleiben würden. Bei den Franzosen, Deutschen und Engländern würde nichts überbleiben.

Amerika ist heute nicht mehr das ferne Land über dem Ozean. Wir können Millionen-Tonnen-Bomben auf Amerika werfen und alle Industrie- und Verwaltungszentren vernichten. Die amerikanischen Militärs sagen eine Dummheit, wenn sie behaupten, daß wir weniger Bomber haben als sie. Wir werden bald überhaupt keine Bomber mehr haben, da diese Waffe schon veraltet ist, wie etwa die Kavallerie gegenüber den Tanks. Als ob wir nicht verstünden, daß unsere Flugzeuge nicht bis in die USA gelangen können, ebenso gelangen die amerikanischen Flugzeuge nicht bis in die UdSSR. Die Raketen jedoch gelangen ans Ziel. Obwohl wir bereits die Möglichkeit haben, Raketen abzuschießen, können wir nicht behaupten, daß dies eine 100\%ige Möglichkeit ist. Darum ist die Raketenwaffe noch immer eine furchtbare Waffe. Wir haben solche Vorräte an Nuklearwaffen und Raketen, daß mit einem Schlag Europa und alle Länder mit NATO-Basen vernichtet werden können. Wir nehmen das schlimmste an und halten uns deshalb nicht für unverletzlich. Wir nehmen daher an, daß auch der Gegner über solche Vernichtungswaffen verfügt.

Bei einer solchen Lage wäre es angebracht, Verständnis und Vernunft zu zeigen. Diese Vernunft sehen wir bisher nicht. Das Wettrüsten geht weiter, die Atomtests werden weitergeführt und es ist so, daß durch die Fortsetzung dieser Tests durch die Amerikaner auch wir dazu gezwungen sind.

Sie stellen uns unakzeptable Bedingungen für die Einstellung der Tests. Die nationalen Mittel, die Versuche zu überwachen und zu verfolgen, sind ausrechend. Die Amerikaner wollen Inspektoren in unser Land schicken, das können wir freilich nicht akzeptieren.

Seit dem Ende des Weltkrieges sind 17 Jahre vergangen und es gibt noch keinen Friedensvertrag mit Deutschland. Die Verhandlungen, die wir mit den USA in dieser Frage geführt haben, haben keine schlechten Ergebnisse erzielt und gegenseitiges Verständnis gefunden. Es bleibt nur eine Frage: West-Berlin.

Wir sind der Meinung, daß in der Frage West-Berlin solche Bedingungen geschaffen werden müssen, die zur Entspannung zwischen Ost und West führen, und dafür müßte eine freie Stadt Berlin geschaffen werden und die Besatzungstrup- 
pen abgezogen werden. West-Berlin ist heute ein Zankapfel und vom militärischen Gesichtspunkt für den Westen kein Vorteil, auch wenn dort Truppen stehen. Die 12.000 Mann, die heute dort sind, haben keine militärische Bedeutung. Folglich will der Westen diesen Brückenkopf für aggressive Handlungen gegen den Osten behalten. Der Freund unseres österreichisches Gastes, Herr Brandt, treibt eine völlig unvernünftige Politik. Seine Reden sind unvernünftig. In seiner letzten Rede spricht er von einem Seelenkrieg. Wie uns ein Repräsentant der Bundesrepublik sagte, trocknet West-Berlin aus, und wenn die internationale Spannung bleibt, hat West-Berlin keine Aussicht auf Entfaltung. Es bedarf eines Zuflusses an Kapital. Man muß den Bewohnern Zuversicht geben, daß sie leben können. Wenn die drei westlichen Okkupationsmächte bleiben, sind wir gezwungen, eine Politik zu führen, die unserer Unzufriedenheit Ausdruck gibt.

In Berlin gibt es mehr Todesfälle als Geburten. Das Kapital fließt ab, die Intelligenz sieht keine Möglichkeiten und wandert ab. Der Westen behauptet, eine solche Politik sei im Interesse der West-Berliner. Das Gegenteil ist der Fall. Es ist gegen die Interessen der West-Berliner und dient nur den Interessen der aggressiven revanchistischen Kreise. Das ist die Lage zwischen Ost und West.

Wir sind noch eine gewisse Zeit lang bereit, Gespräche über diese Fragen zu führen. Doch die Plattform dafür wird immer enger und enger. Man kann sagen, daß sie bereits sehr eng geworden ist. Wir sind mit dem Verbleiben von Militär in West-Berlin nicht einverstanden. Wir werden den Friedensvertrag unterzeichnen, und die militärische Verbindung mit West-Berlin abbrechen. Wir werden keine Blockade erklären, die Verbindung für den Transport von Lebensmitteln und die übrige Versorgung wird bleiben. Unsererseits wird die Nichteinmischung gewahrt bleiben.

Man droht uns mit Krieg. Ich glaube, daß diese Drohung unbedacht ist. Der Westen kann uns nicht drohen und sagen, wir werden euch bei den Ohren nehmen, wenn ihr den Vertrag unterzeichnet, dafür ist ihre Hand zu kurz. Wir haben selbst eine längere Hand.

Unsere Position ist folgende: Liquidierung der Überreste des Weltkrieges. Wir kämpfen für eine Unterzeichnung des Friedensvertrages. Das ist die moralische Seite, eine sehr starke Seite. Und wenn wir den Friedensvertrag unterzeichnet haben, so würden die anderen durch unsere Truppen, die an der Grenze stehen, durchbrechen müssen. Das heißt, daß sie die Aggressoren sein werden.

Wenn die anderen, wie sie sagen, zwei Millionen Menschen verteidigen wollen und dafür die ganze Welt in einen Nuklearkrieg stürzen wollen, dann ist klar, welche Seite im Recht und welche im Unrecht ist. Ich kann freilich für Verrückte keine Garantie übernehmen. Vielleicht hat der Westen bereits den Verstand verloren und beginnt einen Krieg. Aber eines stärkt uns in unserer Auffassung: Wenn uns der Westen droht mit dem Krieg, dann wird er selbst die Früchte ernten.

Jetzt zur Frage der Abrüstung: 
Wir sind in aufrichtigster Weise bereit, auf die Abrüstung einzugehen. Aber die Amerikaner wollen keine Abrüstung sondern eine Kontrolle der Rüstung. Wir sind gegen das. Wir sind für kontrollierte Abrüstung, aber gegen eine Kontrolle der Rüstung. Wenn wir eine Kontrolle der Rüstung sowohl von der einen als auch von der anderen Seite haben, wird der Krieg noch früher beginnen. Jetzt wissen wir nicht genau, worüber der Westen verfügt, und der Westen weiß nicht genau, worüber wir verfügen. Wir lesen diverses Geschwätz über das, was wir angeblich haben. In Wirklichkeit wissen sie im Westen einen Dreck darüber, ebenso wenig wissen wir. Das ist nicht schlecht, das müssen wir so beibehalten. Wenn wir es wissen würden, so würden beide Seiten versuchen, ihre militärischen Kräfte nachzuziehen, um den anderen zu übertreffen. Das ist unvermeidlich, und vielleicht liegt auch die Versuchung darin, von irgend einer Seite den Krieg zu beginnen. MacNamara hat unlängst eine Auffassung vertreten, die keiner Kritik standhält. Er sagte, daß man bei einem Nuklearkrieg die Bomben nicht auf Städte und Industriezentren werden solle, sondern nur auf militärische Ziele. Was heißt das, etwa, daß man auf Enten schießen soll? Es handelt sich doch um Atom- und Wasserstoffbomben. Diese haben einen unglaublichen Wirkungsradius. Woher sollte ich auch wissen, wo die Rüstungszentren der Amerikaner liegen und ebenso kann auch die andere Seite nicht wissen, wo wir unsere Zentren haben. Wir wissen, wo Washington, New York, Chikago [sic], Pittsburgh usw. liegen. Wenn also ein Krieg beginnt, kann man die Amerikaner nicht von dem Versuch abhalten, einen Schlag auf die Lebenszentren zu führen. Daher ist die Auffassung von MacNamara eine Art Schlafmittel für die öffentliche Meinung. Was MacNamara gesagt hat, dient dazu, um die Psychologie der Öffentlichkeit an die Möglichkeit eines Kernkrieges zu gewöhnen, und den Kampf der Öffentlichkeit gegen eine solche Aggression zu schwächen. Der Mensch soll an den Gedanken gewöhnt werden, daß dieser Krieg gar nicht so furchtbar sei. Das ist ein sehr gefährlicher Weg, und wir werden ihn entlarven.

Obzwar die Presse des Westens behauptet, daß die Hand des Westens zu einem gentlemen's-agreement entgegengestreckt sei, halten wird das für etwas anderes. Wenn einmal ein Krieg entsteht, wird er umfassend sein und alles vernichten. Das ist die Situation, sie zeigt ein bewölktes Bild. Aber sie hat auch eine gute Seite für uns, da die Amerikaner keine Übermacht haben. Wir haben dieselben Waffen und auch in derselben Menge, wie unser Gegner, und was die Raketenwaffen betrifft, sind wir überlegen. Unsere militärische Grundlage basiert auf Raketen und nicht auf Bombenflugzeugen, wie im Westen.

Unsere Aussichten im wirtschaftlichen Wettbewerb mit dem Westen sind hoffnungsreich. Das ökonomische Wachstum ist größer bei uns als im Westen. Der Westen verliert von Jahr zu Jahr Positionen, wir wachsen und gewinnen. Doch das ist weder für den Westen noch für den Osten gefährlich. Das ist friedlicher Wettbewerb, das ist Koexistenz. Das ist der Kampf zweier Systeme, welches von beiden produktiver ist, welches siegen wird. 
Dieser Sieg geht nicht über die Leichen der Menschen. Im Gegenteil: bei diesem Kampf erzielt jede Seite Gewinn, weil sowohl der Kapitalismus als auch der Sozialismus wachsen wird. Doch unsere Tempi der Entwicklung sind größer. Diesen Wettbewerb halten wir für vernünftig. Der Westen zeigt jedoch diese Vernunft nicht und versteht sie auch nicht. Der Westen führt eine Politik der Diskriminierung in den wirtschaftlichen Beziehungen. Der Amerikaner treibt mit uns faktisch keinen Handel. Ist das vernünftig? Jetzt betreiben die europäischen Länder die Politik des Gemeinsamen Marktes. Auch das ist Diskriminierung. Hier gibt es wenige wirtschaftliche Hebel, sondern es sind Hebel, die im Interesse einer politischen Aggression in Bewegung gesetzt wurden. Man kann auch Handel treiben ohne Gemeinsamen Markt. Ein wirklich gemeinsamer allgemeiner Markt, dessen Grenzen die unseres Planeten sind, für einen solchen gemeinsamen Markt sind wir. Wir sind jedoch gegen einen gemeinsamen Markt, der durch politische Ziele beschränkt ist. Das ist eine heilige Allianz gegen die Länder des Sozialismus. Man versucht es schönzufärben mit der Behauptung, er hätte nur wirtschaftliche Ziele. Aber selbst die Organisatoren sagen, daß der politische Aspekt über den wirtschaftlichen und handelsmäßigen überwiegt. Wir werden mit allen uns verfügbaren Mitteln dagegen ankämpfen.

Was die wirtschaftliche Seite des Gemeinsamen Marktes betrifft, möchte ich sagen, daß wir ihn nicht fürchten. Wir vermögen Handel zu treiben und können den Konkurrenzkampf aushalten. Diese Seite der Frage beunruhigt uns nicht. Wir verfügen sowohl über einen unermeßlichen Markt als auch über unbeschränkte Quellen an Rohstoffen und menschlicher Arbeitskraft. In der Frage der Entwicklung der Wissenschaft und Technik sind der Sowjetunion keine Grenzen gesetzt. Amerika ist das führende Land des Kapitalismus; doch hat es bisher bezüglich der Weltraumflüge nicht das erreicht, was wir erreicht haben, und Weltraumflug, das bedeutet die Verdichtung der Gehirnenergie. Wir sind die ersten gewesen. Amerika hat nur drei Erdumkreisungen gemacht, wir siebzehn. Jetzt kann man freilich das wiederholen, was bereits gemacht wurde. Columbus war der erste, der nach Amerika kam, nach ihm kamen Millionen anderer Menschen. Columbus verbleibt in der Geschichte, das nachherige Kommen der vielen anderen kann niemand mehr in Erstaunen versetzen.

Ich sagte, daß es eine schlechte und eine gute Seite der gegenwärtigen Situation gibt. Die schlechte ist, daß wir wie auch die anderen gleichsam blind einem Abgrund des Krieges zustreben. Je mehr wir unsere Rüstung steigern, desto näher kommen wir dem Abgrund. Denn bereits jetzt haben Tausende von Menschen unmittelbar mit Raketen und Atombomben zu tun, und es kann jeden Augenblick passieren, vielleicht ohne böse Absicht, sondern nur durch einen psychischen Defekt, daß eine Rakete ausgelöst wird und der Krieg beginnt. Unsere Militärs erzählen eine Anekdote: Ein Rekrut der Raketentruppen wird zur Bedienung der Waffe angelernt. Aber der junge Mann besitzt noch nicht die nötigen militärischen Fähigkeiten. Er hat sich auf einem bestimmten Platz nicht so umgewendet, wie er sollte. Der 
Offizier fragte ihn: Warum hast du dich nicht so umgedreht, wie es sich gehört? Für dich ist es nur ein kleiner Fehler, aber Holland existiert nicht mehr, da du auf einen Knopf gedrückt hast beim Umwenden. - Dieser Fehler konnte darum geschehen, weil der Rekrut nicht genügend gebildet war, und solche Menschen gibt es viele. Nicht alles hängt von der Regierung ab. Von uns hängt der Befehl ab, ob ein Krieg begonnen werden soll oder nicht. Aber Fehler können auch so passieren. Das ist das Gefährliche an der Lage.

Mit Bezug auf die Wirtschaft, Kultur und Wissenschaft sind wir in einem Stadium des ständigen Aufstieges, und hier werfen wir der alten kapitalistischen Welt den Fehdehandschuh entgegen: Wenn sie von der Richtigkeit ihre Systems überzeugt ist, warum muß es Krieg geben? Laßt uns friedlichen Wettbewerb treiben. Wenn ihr System wirtschaftliche und moralische Vorzüge hat, so wird es siegen. Aber wir sind der Ansicht, daß wir eure Erben sein werden. Laßt uns diesen Streit ohne Krieg entscheiden. Laßt die Zeit, die Geschichte entscheiden, sie ist der beste Richter.

Unsere innenpolitische Lage ist eine sehr gute. Unsere Wirtschaft ist im Wachsen begriffen. Wir haben freilich noch nicht alles ausgenützt. Unsere Möglichkeiten sind größer als der gegenwärtige Ausnutzungsgrad. Auch die Landwirtschaft ist im Steigen begriffen, und wenn wir jetzt harte Worte über die Landwirtschaft sagen, so nicht deshalb, weil sich die Landwirtschaft nicht entwickelt, sondern deshalb, weil die Landwirtschaft dem erforderlichen Tempo der Entwicklung nicht entspricht. Das wichtigste ist hier, daß Stalin seinerzeit eine unrichtige Politik gegenüber der Landwirtschaft betrieben hat, da er die landwirtschaftliche Frage nicht richtig begriffen hat. Wir müssen dafür die Rechnung bezahlen. Und es gelingt uns nicht immer, denn wir haben mit Stalin lange gelebt und gearbeitet und manche Mängel sind geblieben. Wir machen alle Anstrengungen, um uns von diesen Mängeln zu befreien. Ich glaube, daß wir in den nächsten Jahren im landwirtschaftlichen Sektor eine starke Position erreichen werden. Hiefür sind die wirtschaftlichen, die technischen und die wissenschaftlichen Möglichkeiten vorhanden. Es sind dies unbegrenzte Möglichkeiten. Wir können also hinsichtlich der Erzeugung von Lebensmitteln unsere Bevölkerung auf das Fünffache anwachsen lassen und sie dennoch ernähren.

Sie werden nun in unserem Land eine Reise unternehmen und selbst sehen, wieviele Wälder, wieviele Sümpfe es noch gibt, und das alles können wir meliorieren. Wir haben niedrige Ernteerträge. Das ist schlecht, aber das ist auch unsere Reserve. Denn wenn wir heute zehn Zentner ernten, und im Westen sind es dreißig Zentner, so haben wir die Möglichkeit, die Erträge auf das Dreifache zu steigern. Ich betrachte das als ermutigend. Zu dieser Steigerung auf das Dreifache brauchen wir nicht viel: eine Verbesserung der landwirtschaftlichen Technik, der Düngung, der Schädlingsbekämpfung. Das ist ohne weiteres möglich, und das werden wir auch erreichen.

Es wird im Westen davon geredet, daß Rußland durch eine schwere Krise geht. Aber diese Leute werden eine schwere Enttäuschung erleben. Der amerikanische 
Farmer Garst war mehrere Male bei mir zu Besuch, und ich war bei ihm. Er ist ein kluger Mann, ein sehr reicher Mann, versteht etwas von der Landwirtschaft und ist sehr vernünftig. Ich las Garsts Brief, in dem er schreibt: „Ich glaube, Sie sind auf dem richtigen Weg, aber Sie müssen mehr Kapital in die Landwirtschaft investieren." Das ist richtig. Wir bezahlen dafür, daß Stalin der Landwirtschaft Kräfte entnahm, aber keine gab. Er war ein schlechter Wirtschafter: Er wollte reiten, ohne das Pferd zu füttern. Er hat das eben nicht verstanden. Stalin hat viel Gutes, wirklich Gutes, aber auch Schlechtes getan. Wirklich gut war, daß er ein ergebener Marxist war, mit seinem ganzen Wesen, und doch war er hart wir eine Eiche.

Er hat viel Schaden dem Land und der Partei verursacht. Deshalb haben wir ihm gegenüber ein zwiespältiges Gefühl. Das eine Gefühl ist, daß wir unter seiner Führung Großartiges erreicht haben, und das andere Gefühl, daß wir ohne seine Führung noch mehr erreicht hätten. Ich sage es manchesmal zu meinen Genossen: Ich sah, daß eine Entscheidung schlecht war, aber ich hatte keinen Einfluß auf Stalin. Damals dachte ich: Welche Kraft hat der Staat und welche Kraft der MarxismusLeninismus, daß trotz der idiotischen Gesetze Stalins das Land weiterwuchs.

Sehen Sie doch selbst: Der ganze Bestand unserer Armee wurde bei Beginn des Krieges vernichtet, und trotzdem haben wir gewonnen. Wenn alle diese Leute am Leben geblieben wären, hätten wir Hitler sogleich zu Pulver zerrieben. Wir mußten die Ukraine verlassen, das reichste Land unseres Staates.

Das ist die Situation. Wir schauen ermutigt in die Zukunft. Der Kernwaffenkrieg ist in demselben Grad für die Gegner gefährlich wir für uns. Wenn ein Krieg begonnen werden sollte, wird es uns schlecht gehen, aber auch der Gegner wird nicht geschont. Wenn jedoch der gesunde Menschenverstand siegt und der Krieg vermieden wird, dann können wir der Zukunft entgegensehen und mit der ganzen Welt in Wettbewerb treten. Und wir sichern den Völkern unter dem Sozialismus eine bessere Zukunft als unter dem Kapitalismus.

Ich weiß nicht, ob ich nun alles über die Lage gesagt habe.

Mikojan: Du hast alles gesagt, und gut gesagt.

Bundeskanzler: Ihre realistische [sic] Einschätzung der Weltlage ist nicht ohne Eindruck auf mich geblieben.

Wenn wir auch ein kleiner Staat sind, sind wir doch täglich mit diesen Fragen konfrontiert und müssen uns mit den Problemen des Gleichgewichts des Schreckens befassen. Viele Leute fragen sich: Hat es überhaupt einen Sinn, sich in der Wirtschaft zu betätigen, für die Zukunft zu planen, ist nicht alles umsonst, wenn ein Krieg kommt.

Wir können als kleiner Staat nur eines tun: Bei uns, wo wir leben, Ordnung halten, zu arbeiten und wenn es darauf ankommt, unsere Stimme zu erheben und für den Frieden einzutreten. Wir begrüßen alle Bestrebungen, die dem Frieden dienen und haben alle Maßnahmen, die Sie, Herr Ministerpräsident, diesbezüglich unternommen haben, mit großer Sympathie begrüßt. Auch in den internationalen Organisationen haben wir uns bei den Fragen der Abrüstung nicht der Stimme ent- 
halten, sondern haben aktiv unsere Stimme erhoben. Wir sind initiativ gewesen, damit wir einen Stabilitätsfaktor im Sinne der Neutralität in unserem Raum aufrechterhalten können. Dafür ist es unerläßlich, daß wir den Lebensstandard erhalten können.

Es ist bei uns sehr wichtig, daß die Leute mit dem Hirn denken und nicht unter dem Einfluß von Magenkrämpfen Entscheidungen treffen. Und darum überprüfen wir alles, was geeignet ist, im Rahmen der Neutralität und im Rahmen der Verpflichtungen des Staatsvertrages unsere Wirtschaft zu erhalten und den Lebensstandard zu heben, und die Diskriminierung zu verhindern, Herr Ministerpräsident, Sie kennen die Lage. Wir exportieren große Mengen von Waren in Märkte, die wir sonst nicht absetzen könnten.

Bundesminister Kreisky: Das, was der Herr Ministerpräsident gesagt hat, war sehr klar und eindrucksvoll. Ich habe schon die Ehre gehabt, Ihre Darlegungen bereits bei vier Konferenzen, die wir gehabt haben, zu hören. Doch gibt es hier einige Dinge, bei denen ich mir nicht klar geworden bin, wie diese Probleme gelöst werden sollen. Es sind dies meiner Ansicht nach folgende:

1. Abrüstung: Die Formulierung ist sehr einleuchtend, nämlich, daß man nicht die Rüstung kontrollieren soll, sondern die Abrüstung. Aber bei dem großen Mißtrauen, daß es auf beiden Seiten gibt, erhebt sich die Frage: Wie kann man abrüsten, wie kann man den anderen überzeugen, daß man abgerüstet hat? Ist es nicht notwendig, ein Exempel zu statuieren, indem man gewisse kontrollierte Bereiche schafft und mit der Kontrolle der Abrüstung beginnt, um sich zu überzeugen, ob ein solches System funktioniert oder nicht.

2. Berlin: Ich verstehe eine Reihe von Argumenten, aber eines verstehe ich nicht: Die West-Berliner stützen sich auf die Anwesenheit der Westmächte. Wie soll man die Furcht von den Berlinern nehmen, wenn das westliche Militär weggeht? Davon habe ich mich selbst überzeugt, das ist eine Tatsache.

3. Wie soll der große Weltmarkt aussehen ohne Grenzen? Wie sollen die Warenlieferungen bezahlt werden? Das sind alles sehr komplizierte Dinge, die sehr eingehender Studien und Prüfungen bedürfen.

4. Ergänzend zum Herrn Bundeskanzler möchte ich noch sagen: Was die wirtschaftliche Entwicklung betrifft, stellen wir uns diese in Österreich so vor: Ein Teil der ungeheuren Stärke der Sowjetunion liegt in dem gigantischen Wirtschaftsgebiet. Was die Ressourcen betrifft, hat die Sowjetunion bereits heute einen Markt von 200 Millionen Menschen und mehr. Die meisten Leute fassen die europäische Integration so auf, daß es in Europa so werden soll, wie in der Sowjetunion, nämlich ein einziger großer Markt. Es gibt Leute, die den Gemeinsamen Markt als politisches Ziel sehen. Aber primär geht es darum, einen Markt zu schaffen, wie es ihn in den USA und in Sowjetunion schon lange gibt.

Wenn Herr Chruschtschow gesagt hat, daß er den Wettstreit wünscht und der kapitalistischen Welt den Fehdehandschuh zuwirft, so möchte dazu sagen, daß der Westen kein rein kapitalistisches System mehr ist, sondern eine Mischform. Durch 
die Integration wird ein großer Markt geschaffen. Dies ist ein Teil der Auseinandersetzung. Wenn wir uns nicht für den friedlichen Wettbewerb vorbereiten, werden wir unterliegen.

Chruschtschow: Als Sie von unserer Bevölkerung sprachen, haben Sie 200 Millionen gesagt und 20 Millionen unterschlagen.

Was den Kapitalismus betrifft, möchte ich sagen, daß sich die Reformisten der gleichen Methode bedienen wollen, wie der Gelehrte Woronow, der eine Theorie der Verjüngung der Menschen ausgearbeitet hat. Sie nehmen also an, daß Ihr Kapitalismus nach dieser Methode verjüngt worden ist?

Bundesminister Kreisky: Ganz im Sinne der marxistischen Analyse wurden neue Elemente entwickelt, die vor 100 Jahren noch nicht vorhanden waren. Es entstanden neue Eigentumsformen, eine neue Sozialpolitik, neue Grundsätze zwischen Kapital und Arbeit, neue Elemente hinsichtlich der Arbeitskräfte. Das alles gab es vor 100 Jahren noch nicht.

Chruschtschow: Nun zu den einzelnen Fragen.

1. Abrüstung: Was die Idee der Schaffung eines Vorfeldes zur Erprobung des Vertrauens betrifft, sind wir damit einverstanden. Wir würden bereit sein, eine Kontrolle über die Streitkräfte in Deutschland zu akzeptieren. Wir schlugen vor, $800 \mathrm{~km}$ nach Westen und Osten von einer bestimmten Linie einen Bereich zu schaffen, in dem alle Waffen unter Kontrolle gestellt werden. Man hätte Vertreter der Kontrollorgane bei allen Waffengattungen, das wäre gut. Durch eine $800 \mathrm{~km}$-Zone wäre ein plötzlicher Angriff schon ausgeschlossen. Unser Vorschlag ging dahin, die Kontrolle auf alle Häfen, Flugplätze, Eisenbahnknoten und wichtige Straßenkreuzungen zu erstrecken. Wenn eine solche Entscheidung getroffen würde, könnte keine Seite einen plötzlichen Angriff unternehmen, weil Truppenverschiebungen ohne Wissen des Gegners nicht möglich wären. Die Luft, die Erde, Eisenbahnen und Straßen und das Meer würden im ganzen Land, das heißt auch in der Sowjetunion, unter Kontrolle stehen. Wir sind weit gegangen in dieser Richtung, um Verständnis und eine vernünftige Lösung zu finden. Es wurde jedoch alles abgelehnt.

Außenminister Gromyko: Unser Vorschlag war im Detail $800 \mathrm{~km}$ nach Westen und sogar einen größeren Bereich nach dem Osten, um die Amerikaner zu befriedigen.

Bundesminister Kreisky: Es hat ein einziges Kontrollorgan nach dem Krieg gegeben, das wirklich funktioniert hat: die Vier im Jeep. Das hat nur funktioniert, weil man ein sehr intelligentes System angewandt hat: Jeder hat bei sich selber kontrolliert, aber die drei anderen haben darauf gesehen, daß er tatsächlich kontrolliert. Auf diese Weise wurden auch Erwägungen der Souveränität respektiert.

Chruschtschow: Ich bin 1946 in Wien gewesen und habe alle vier Sektoren besucht. Ich konnte überallhin ungehindert passieren. Wenn die Leute heute ehrlich wären, dann würde es keine Überfälle geben. Die von uns vorgeschlagene Kontrolle über die Verbindungswege, Flugplätze usw. paralysiert die Möglichkeit eines Überfalles. Die Amerikaner aber wollen eine Kontrolle über die Rüstung, sie 
wollen nämlich durch Spionage alles erfassen, vor allem die Möglichkeit und die Chancen des Gegners für Überfälle. Dafür sind wir nicht. Wir sind dafür, wenn tatsächlich die volle Abrüstung akzeptiert wird.

Für den Vorschlag MacNamaras, nur militärische Objekte anzugreifen, müßte man wissen, wo sich diese befinden. Das kann man nur durch Spionage erfahren. Als Eisenhower 1955 in Genf den Vorschlag der „offenen Himmel“ machte, sagte er etwas für die Militärs sehr Wichtiges: Er sagte mir auf die Frage, wozu dies gut sei, fragen Sie nur Ihren Schukow, der wird Ihnen schon sagen, warum dies wichtig ist. Das ist militärische Offenheit, wenn auch nicht sehr diplomatisch. Er sagte das, was er dachte. Bei diesem Gespräch war auch Rockefeller anwesend, er war sein Berater. Das ist Spionage. Das ist vorteilhaft für jene Seite, die den Krieg anstrebt. In dieser Frage ist unser Standpunkt sehr klar.

2. Die Angst der Berliner: Was kann ich dazu sagen? Wenn man jemanden schreckt, indem man sagt, daß ich ihn auffressen will, und ich sage, daß dies nicht wahr ist, da ich mich nicht von Menschen ernähre, wie kann ich das beweisen? Wir sagen zu den Berlinern, wir brauchen Berlin nicht. Was bedeuten 3 Millionen Menschen für uns? Bei uns ist der jährliche Zuwachs $3 \frac{1}{2} 2$ Millionen. Für unsere Männer ist das die Arbeit einer Nacht. Wir sagen das, aber man sagt Nein: Wir fürchten euch, wir wollen Waffen und Streitkräfte. Dagegen kann man keinen Disput führen, weil es unvernünftig ist. Wenn sie uns nicht glauben, soll die UNO ihnen Truppen hinstellen. Die argumentieren, daß sich niemand in die inneren Angelegenheiten Berlins einmischen soll. Sie sagen, nicht die UNO, sondern wir, die USA, England und Frankreich machen das. Dann beginnen wir eben, uns Gedanken zu machen, wozu für sie die Truppen dort notwendig sind? Seinerzeit sind sie als unsere Alliierte dort hingekommen, jetzt sind sie dort als unsere Gegner. Daher haben wir guten Grund, diesen Truppen zu mißtrauen und ebenso den Ländern, die Truppen in WestBerlin haben. Daher wäre es das vernünftigste, dort UNO-Truppen einzusetzen.

Bundesminister Kreisky: Auch für die Zufahrt?

Chruschtschow: Das ist eine andere Frage. Die Schweiz ist ein Binnenland und einen Zugang gibt es nur auf Grund von Vereinbarungen mit anderen Ländern. Nach Österreich haben Zugang nur solche Länder, die entsprechende Abkommen abgeschlossen haben. Die Türkei kann nicht direkt zu euch, sondern muß sich mit anderen Ländern einigen. Das gilt auch für Amerika und die Sowjetunion. Auch wir können mit Österreich keinen direkten Kontakt haben, sondern nur mit Erlaubnis Ungarns und der Tschechoslowakei.

Bundesminister Kreisky: Bei Berlin ist die Situation anders. Ein freies Berlin wäre die Schaffung eines Staates in einem anderen Staat. Es muß ja Sicherheiten geben, wie man zu ihm kommen kann, sonst ist es keine echte Freistadt.

Chruschtschow: Die Frage des Zuganges besteht, das bestreiten wir nicht. Aber es gibt eine Praxis in der Welt, daß man, um Zugang zu einem Staat zu erhalten, mit jedem Staat eine Vereinbarung schließen muß, über dessen Gebiet man gehen muß, um dorthin zu gelangen. Die DDR ist ein souveräner Staat, ein Zugang ist nur mit 
ihrer Zustimmung möglich. Es kann keine internationale Kontrolle der Zugänge geben. Die Amerikaner haben sich das ausgedacht, aber die Deutschen haben schon Einspruch dagegen erhoben und wir sind gegen das eine und das andere. Jetzt kontrolliert die DDR gemeinsam mit uns die Zugänge. Warum sollten wir unsere Rechte aufgeben und sie einer internationalen Kommission überantworten? Das wird nur dann sein, wenn sie uns zwingen, zu kapitulieren. Das ist ohne Krieg nicht möglich. Wir werden unsere Rechte verteidigen und auch die Rechte der DDR.

Wir wollten die Situation des Präsidenten der USA erleichtern. Er hat eine unvernünftige Rede gehalten, und eine internationale Kontrolle gefordert. Wir wollten seiner Person eine Aufmerksamkeit erweisen und schlugen deshalb ein internationales Organ nicht über die Kontrolle für Zugänge, sondern ein Arbitrage-Organ für Streitfälle bezüglich der Zugänge vor.

Bundeskanzler: Ich glaube, das verstanden zu haben. Sie wünschen ein freies Berlin und wollen, daß die Frage der freien Zufahrt in einem Vertrag mit der DDR geregelt wird. Wären nun die Vertragspartner ein freies Berlin und auf der anderen Seite die DDR?

Chruschtschow: Ich weiß nicht, welche internationale Praxis hier besteht, aber Partner müßte jedes Land sein, das über die DDR nach Berlin gelangen will. Ich glaube, daß West-Berlin einen Status hätte, der durch Vertrag bestimmt ist: Unabhängigkeit und Garantie des Zuganges der ganzen Welt. Dieser Vertrag müßte mit der Unterschrift der DDR versehen sein, es wäre also nicht für jeden Fall separat zu unterschreiben. Aber die anderen Länder, die über das Territorium der DDR nach Berlin gelangen wollen, müßten mit dieser Abkommen abschließen. Das diskriminiert in keiner Weise, das ist eine allgemeine Praxis. Wir wollen, daß diese Praxis auf West-Berlin ausgedehnt wird.

Bundesminister Kreisky: Damit kein Mißverständnis entsteht, möchte ich sagen, daß wir nicht so vermessen sind zu glauben, die Frage lösen zu können. Es geht uns nur um Verständnis der Frage; darum sprechen wir mehr über Berlin als über Laos, weil uns Berlin näherliegt.

Chruschtschow: Das ist verständlich, auch wir sprechen mehr über Berlin als über Laos.

Bundeskanzler Gorbach: Um nach Berlin fahren zu können, ist ein Visum erforderlich. Damit erhebt sich aber die Frage der Anerkennung der DDR.

Chruschtschow: Hier kann ich Ihnen nicht helfen. Als ich in Amerika war, haben wir unter anderem auch über die Frage der Anerkennung gesprochen. Ich habe damals gesagt, Amerika hat uns 16 Jahre lang nicht anerkannt. Die Amerikaner antworteten darauf: Aber Ihr Zar hat Amerika 26 Jahre nicht anerkannt. Ich sagte Ihnen, unser Zar war eben ein Trottel, warum muß man diese Dummheiten wiederholen? Es ist hier eine Analogie zur Anerkennung der DDR.

Bundesminister Kreisky: Ich verstehe eines nicht. Es würde eine gewisse Minderwertigkeit im Status von West-Berlin bestehen. Über den Zutritt nach Österreich entscheidet Österreich, über den Zutritt in die DDR entscheidet die DDR. Aber 
West-Berlin wäre von einem dritten Staat abhängig. Es wäre als keine wirklich freie Stadt, nicht im Sinne einer Vollwertigkeit.

Chruschtschow: Sie widersprechen sich selbst und der Praxis. Um nach London zu gelangen, muß ich mit Dänemark ein Abkommen über die Erlaubnis zum Überfliegen des Territoriums treffen. Das machen wir auch, das ist normal. Wenn wir da nicht machen würden, wäre das abnormal und würde die Souveränität verletzen.

Bundesminister Kreisky: Aber es gibt viele Möglichkeiten nach England zu gelangen, nicht nur über Dänemark.

Chruschtschow: Ich nenne Ihnen ein anderes Beispiel, die Mongolei. Wenn ein amerikanischer Botschafter dorthin gesendet wird, muß sich Amerika mit uns oder den Chinesen einigen, sonst kommt er nicht nach Ulan-Bator. Wollen Sie vielleicht den Vorschlag machen, einen internationalen Weg über unser Territorium zu legen? Das ist kein realistischer Vorschlag.

Bundesminister Kreisky: Die jetzige Lage West-Berlins ist aber so, daß eine freie Zufahrt aus dem Westen besteht. Warum sollte man diese Lage verschlechtern?

Chruschtschow: Der jetzige freie Zugang besteht nur auf der Basis des Okkupationsregimes. Das ist ein Überbleibsel des Krieges. Die drei Mächte benützen dies für ihre Ziele. Damals waren sie unsere Alliierten, jetzt sind sie unsere Gegner. Daher können wir weiterhin eine solche Lage nicht dulden. Um sie dieses Rechtes zu entkleiden, werden wir den Friedensvertrag unterzeichnen. Sie werden ihre Kraft verlieren, wie der Tschorno Mor (= legendäre Gestalt), der seine Kraft verlor, als man ihm den Bart abschnitt.

Die Amerikaner haben eine solche Operation mit uns schon mit Japan gemacht. Sie haben einen Friedensvertrag unterzeichnet, nicht aber wir. Sie haben uns unserer Rechte entkleidet, und unsere Vertreter mußten aus Tokio weg.

Bundesminister Kreisky: Das wollen Sie also mit den Engländern, Franzosen und Amerikanern machen?

Chruschtschow: Ja.

Bundeskanzler Gorbach: Wir dürfen nicht vergessen, daß Berlin eine kleine Insel ist. Es handelt sich um zwei verschiedene Systeme. In kurzer Zeit müßte Berlin von der DDR, das es umschließt, aufgesogen werden. So wird es von den anderen auch offenbar gesehen.

Chruschtschow: Das verstehe ich. Aber wieviel Jahre hat die Sowjetunion existieren müssen in kapitalistischer Einkreisung? Die kapitalistische Welt wollte unser gesellschaftliches System liquidieren. Sie haben aktive Maßnahmen ergriffen, und die Amerikaner, Franzosen, Engländer, Japaner haben ihre Truppen geschickt. Die Deutschen sind bis zum Kaukasus gelangt. Aber alle haben wir zerschlagen.

$\mathrm{Zu}$ den West-Berlinern sagen wir: Wir wollen uns nicht in die inneren Verhältnisse einmischen, aber wenn die West-Berliner selbst ein anderes System wollen, so kann ich keine Garantie geben, daß das bisherige weiterbesteht. Beim Treffen mit Kennedy in Wien sagte dieser, man solle eine Garantie des status quo in der Welt geben. Wir sind unter bestimmten Bedingungen damit einverstanden. Da je- 
des Land seine volle Souveränität haben soll, muß es über seine soziale Ordnung selbst entscheiden. Kennedy war damit nicht einverstanden, er sprach von innenpolitischer Infiltration. Ich sagte, was sollen wir tun? Sollen wir Gendarmen spielen? Wenn ein Volk seine Struktur verändern will, sollen wir sagen: nein, das dürft ihr nicht? Das ist die Logik eines Verrückten.

Mikojan: Es könnte auch sein, daß in Österreich einmal die Mehrheit eine sozialistische Ordnung will.

Chruschtschow: Oder es könnte auch sein, daß in Österreich einmal die Bourgeoisie die Oberhand behält und den sozialistischen Partner aus der Koalition hinaustreibt. Was sollen wir tun: Gendarmen schicken? Die Amerikaner haben auch einmal gegen England revoltiert und haben gekämpft. Sollte man die Gendarmen schicken, um den Engländern zu helfen? Die Angst vor dem Kommunismus nimmt den Leuten den klugen Menschenverstand.

Wir schlagen daher das Vernünftigste vor, das niemandem Schaden zufügen kann und das Prestige beider Seiten wahrt. Wir unterzeichnen einen Friedensvertrag und werden die Lage fixieren, die sich als Resultat des Zweiten Weltkrieges ergeben hat. Was kann man Vernünftigeres wünschen? Aber bisher wurde keine Vereinbarung erreicht.

Wir wissen, daß der Westen die sozialistische Ordnung in der DDR liquidieren will. Das verstehe ich. Sogar in der UdSSR will der Westen diese Ordnung liquidieren. Wir wollen in der BRD die sozialistische Ordnung errichten, das wäre die gerechteste Lösung. Aber das ist ein rein subjektiver Wunsch. Man muß die Lage realistisch einschätzen und in der ganzen Welt realistische Lösungen suchen. Wir sind dafür, daß jedes Land selbst zu entscheiden hat. Wir wollen uns nicht in die inneren Angelegenheiten der kapitalistischen Länder einmischen.

Bundeskanzler: Aber wie entscheidet das Volk? Durch die freien Wahlen?

Chruschtschow: Es ist nicht immer so, daß Wahlen sozialpolitische Fragen entscheiden können. Es gibt auch Revolutionen, und die Ergebnisse derselben werden dann erkannt. Oder nehmen Sie das Beispiel Pakistan: In demokratischen Wahlen wurde ein Präsident gewählt. Dann kamen die Generale und setzten ihn ab. Jetzt ist ein General Präsident. Oder zum Beispiel die Türkei oder die lateinamerikanischen Staaten. Entscheidet wirklich alles das Parlament? Das entscheiden oft Halsabschneider. Je mehr Halsabschneider es gibt, desto eher erkennt sie Amerika an. Alle Welt erkennt den Zaren (Schah) an. Wie kam er auf den Thron? Sein Vater kam, ließ Köpfe rollen und proklamierte sich zum Schah. Er diente bei Budjonnj, der Halsabschneider, und dann sagte er, er sei von Gott eingesetzt. Aber wir sagen, das ist Angelegenheit der Perser. Es kann auch dem jetzigen Schah passieren, daß sein Kopf abgeschlagen wird. Er war unser Gast hier, und wir haben auf sein Wohl getrunken.

Wir Kommunisten wollen, daß das Volk die Entwicklung der menschlichen Gesellschaft auf der Grundlage der demokratischen Basis weiterführe. Aber nehmen Sie z.B. die Demokratie in Frankreich. Vor de Gaulle haben die Kommunisten 110 Abgeordnete im Parlament. Jetzt stimmen für die Kommunistische Partei mehr 
Franzosen als früher. Aber Abgeordnete sind jetzt um ein Zehntel weniger als früher. Was ist das für eine Demokratie? Wird das französische Volk damit einverstanden sein? Ich will mich nicht einmischen, aber das ist eine Machination mit den Stimmen.

Die Geschichte ist an Beispielen reich. Auch bei uns hat es eine solche Lage gegeben. Die Arbeiter und Bauern hatten sechs Abgeordnete in der Duma, die Kapitalisten und Gutsbesitzer die große Mehrheit. Was sollten wir machen? Einzig das, was Lenin gemacht hat. Auch andere Völker können dies tun. Wenn das Parlament nicht die Rechte gibt, kann das Volk auf die Straße gehen und sich die Rechte holen. Die demokratischeste Art zur Macht gelangt: Wir haben 4 Jahre lang mit den Füßen gestimmt. Wir haben unsere eigene Reaktion und die ganze Welt, die unserer Reaktion half, besiegt. Unser russischer Bauer hat das alles auf seinem Buckel ertragen. Das ist Abstimmung, das ist Demokratie. Das wollen wir jedem Volk zuerkennen.

4. Weltmarkt und europäischer Markt

Ein Weltmarkt bedeutet, daß alle ihre Produkte auf der Basis des gegenseitigen Vorteils mit den Ländern ihrer Wahl austauschen können. Wir haben gute Geschäftsverbindungen mit Ihnen: Sie verkaufen uns Ihre Produkte, wir verkaufen Ihnen unsere. Sie kaufen bei uns, was für Sie vorteilhaft ist und umgekehrt. Das haben wir nicht erfunden, sondern das hat die Geschichte uns überliefert. Wir haben z.B. einen sehr guten Handel mit Italien. Heute kommt Kossygin von dort zurück und wird wahrscheinlich gute Ideen mitbringen. Wenn die Preise entsprechend sind, werden wir wahrscheinlich bei FIAT die Errichtung einer Traktorenfabrik mit einem jährlichen Ausstoß von 100.000, vielleicht sogar 120.000 Traktoren in Auftrag geben. Wenn die Preise vorteilhaft sind, werden wir eben nicht kaufen. Wir treiben heute einen guten Handel mit Japan und Westdeutschland, unser Handel mit Frankreich und England ist auch nicht schlecht. Ein einziges Land treibt keinen Handel mit uns: die Vereinigten Staaten von Amerika. Wer hat einen Nutzen von einer solchen Politik? Sie gereicht uns und den Amerikanern zum Nachteil, und zwar wirtschaftlich und politisch. Das ist Diskriminierung.

Jetzt schlägt auch die EWG eine solche Politik ein, und es hebt sich die Frage, wofür? Sie betreibt gleichfalls Diskriminierung. Ihre Politik ist gegen die schwach entwickelten Länder gerichtet. Wir werden dagegen ankämpfen und jene Kräfte unterstützen, die sich gegen eine solche Diskriminierung wehren.

Wir fürchten diesen Block weder in wirtschaftlicher, noch in politischer Hinsicht. Einen politischen Block gibt es heute schon, daher wird sich aus dem Zusammenschluß der EWG in politischer Hinsicht keine Änderung ergeben. Allerdings wird daraus eine weitere Forcierung der Spannung entstehen, und dagegen werden wir ankämpfen. Wir glauben, daß diese Politik unvernünftig, aggressiv und voller Risken ist.

Etwas ganz anderes ist ein allgemeiner Weltmarkt: Er gibt jedem Land die Möglichkeit, ohne Diskriminierung seine wirtschaftlichen Quellen auszunützen. Wie könnte diese von uns eingenommene Position eine schlechte sein? 
Bundeskanzler: Bei unserem kürzlichen Staatsbesuch in Frankreich hat General de Gaulle auch über die EWG gesprochen und dabei ausdrücklich festgestellt, daß diese kein gegen den Osten gerichtetes Instrument sei. Er könne sich vielmehr vorstellen, daß die EWG sich als ein Instrument zur Belebung des Ost-West-Handels erweisen könne.

Chruschtschow: Bezüglich dessen, was ich vorhin über Frankreich gesagt habe, möchte ich Sie bitten, daß das nicht die Presse gelangt, da ich unsere Beziehungen nicht verschlechtern will. Davon hätte niemand einen Nutzen. Das, was ich über die reaktionäre Konstitution Frankreichs gesagt habe, könnte ich genauso gut de Gaulle selber sagen. Er wird besser wissen, warum er die Verfassung geändert hat, um einer Minderheit der Bevölkerung die Mehrheit im Parlament zu verschaffen. Aber das ist eine Angelegenheit der Franzosen. Sie sollen sich selbst zurechtfinden, intelligent genug sind sie dafür.

Als Hitler und Mussolini die Achse begründeten, sagen sie, daß dies für den Frieden sei. Als Hitler Österreich schluckte, sagte er, daß dies den Frieden in Europa festige. Österreich war wohl damit nicht einverstanden?

Bundesminister Kreisky: Wir haben bei dem Gespräch mit General de Gaulle den Eindruck gehabt, daß das, was er über den Osthandel sprach, sehr ehrlich gemeint war. De Gaulle spricht nicht viel über Wirtschaft, weil sie ihn nicht interessiert. Deshalb ist es umso bemerkenswerter, daß er ausführlich über die EWG und den Osthandel sprach. Er bezeichnete die EWG ausdrücklich als wirtschaftliche und nicht als politische Vereinigung. Ich fragte ihn, ob wir all dies bei unserem kommenden Besuch in Moskau Herrn Chruschtschow sagen könnten? De Gaulle bejahte dies und fügte hinzu, daß wir auch sagen sollten, Frankreich habe gleichfalls den Staatsvertrag unterzeichnet und auch Frankreich habe ein eminentes Interesse an der Aufrechterhaltung der Unabhängigkeit und Neutralität Österreichs.

Chruschtschow: Ich habe sehr angenehme Gespräche mit de Gaulle geführt und denke an ihn mit Hochachtung. Was allerdings die politische Weltanschauung betrifft, sind wir Leute entgegengesetzter Pole. Trotzdem können wir nicht umhin, uns gegenseitig zu achten. Was de Gaulle in Algerien macht - ich weiß nicht, ob irgendjemand anderer dies machen könnte. Dieser Beitrag muß anerkannt werden. Der Gesinnungsgenosse unseres österreichischen Gastes, Herr Guy Mollet, könnte so etwas nicht tun.

Bundesminister Kreisky: Da haben Sie recht.

Chruschtschow: Wir haben hier im gleichen Raum mit Guy Mollet im Sommer 1956 Gespräche geführt. Wir haben ihm geraten: Löst doch die algerische Frage. Er sagte darauf: Wir können es nicht machen, das Algerien frei wird. Frankreich würde dadurch seine Größe verlieren und Algerien würde von den Amerikanern geschluckt werden. Ich entgegnete ihm, daß Vietnam 7 Jahre lang gekämpft hat und seine Freiheit errungen hat und daß sich auch die Algerier 7 Jahre durchkämpfen werden, um schließlich die Freiheit zu erringen. 
Wir müssen de Gaulle die gebührende Achtung erweisen, da er ungeachtet seines hohen Alters und seiner politischen Einstellung den Geist der Zeit verstanden hat. In anderen Fragen sind wir jedoch völlig verschiedener Meinung.

Ich weiß nicht, was Ihnen de Gaulle zur Frage des Gemeinsamen Marktes gesagt hat, aber ich glaube, daß er den Gemeinsamen Markt anders auffaßt, als er es gesagt hat. In dieser Gemeinschaft überwiegt der politische Charakter den ökonomischen. Sie wissen das selbst sehr gut, und wenn Sie daheim bei sich über diese Frage sprechen, sagen Sie das auch. Und in dieser Auffassung stimmen wir mit Ihnen überein.

Wir sprechen die Bitte aus: Laßt uns unsere Beziehungen gut bauen und gebe Gott, daß Sie nicht in diese Gemeinschaft eintreten, denn das wäre ein schwerer Schlag für Österreich und seine Neutralität.

Österreich hat sich in der Welt eine gute Position durch seine Neutralität erworben. Eine solche Sache würde der Neutralitätspolitik ein Ende machen. Das wäre eine Art von Anschluß, und damit eine direkte Verletzung des Staatsvertrages, den wir auch unterschrieben haben. Schauen Sie sich den Text an: Dort steht es genau geschrieben. Der Staatsvertrag wurde nicht nur von uns sondern auch von Ihnen unterzeichnet.

Österreich wäre sodann an einen Block angeschlossen, der gegen uns eine bestimmte Haltung einnimmt.

Unsere Position in dieser Frage ist folgende: Österreich muß verstehen, seine geographische Lage richtig zu beurteilen. Dieser geographischen Lage entspricht am besten der von uns gemeinsam unterzeichnete Staatsvertrag und die auf Grund dieses Vertrages geführte Politik. Die anderen Länder, die den Staatsvertrag mitunterzeichnet haben, sollen mit Verständnis eine solche Politik unterstützen.

Wir sind gegen eine Diskriminierung des Handels Österreichs mit anderen Ländern. Wenn die westlichen Länder eine solche Politik der Diskriminierung stützen, würden sie gegen den Staatsvertrag verstoßen und damit auch gegen die Politik der Neutralität sein, die durch den Staatsvertrag begründet wurde. Das würde bedeuten, daß durch einen Druck wirtschaftlicher Natur das Wesen des Staatsvertrages verändert würde. Es würde sich eine andere Lage ergeben und auch unsere Beziehungen würden sich ändern. Das wollen wir nicht. Wir wünschen dem österreichischen Volk Wohlergehen und Entfaltung. Sie grenzen an sozialistische Länder, und eine Weiterführung der Politik der Neutralität würde dem entsprechen und Österreich würde den richtigen Platz als neutrales Land finden. Das ist das beste.

Wieviele Jahre leben wir schon mit den Afghanen in Nachbarschaft. Unsere gemeinsame Grenze ist mehr als $2000 \mathrm{~km}$ lang. Wir sind freilich politisch und wirtschaftlich viel stärker als Afghanistan. Doch wir haben damit keinen Mißbrauch getrieben. Der König von Afghanistan hat keinerlei Forderungen gegen uns, und auch wir haben keine gegen ihn. Staatlich gesehen sind wir extreme Pole. Aber es ist ein selbständiger Staat und wir achten die Unverletzlichkeit dieses Staates. 
Auch auf Afghanistan wird ein gewisser Druck ausgeübt, doch führt der Staat seine Politik mit Vernunft. Wenn es den Afghanen gelingt, trotz dieses Druckes eine vernünftige Politik zu führen, muß es auch Österreich möglich sein, seine Politik der Neutralität vernünftig und kraftvoll weiterzuführen. Wenn sie eine andere Position einnehmen, haben sie die Politik der Neutralität verlassen und sich in eine Gemeinschaft unserer Gegner begeben. Wir würden dies mit großem Bedauern zur Kenntnis nehmen. Wir würden dies so ansehen, daß das was mein Freund, der „Kleinkapitalist“" Raab, gebaut hat, von meinem zweiten Freund Gorbach bereits wieder zerstört wurde.

Bundeskanzler: Die Ausführungen des Herrn Ministerpräsidenten waren sehr bemerkenswert. Wir waren sehr interessiert daran, daß dieses Gespräch zustande kam, weil Fragen besprochen wurden, die österreichische Interessen unmittelbar berühren. Das Wirksamwerden der EWG ist außerhalb unserer Kompetenz gelegen. Wir wurden dadurch vor neue wirtschaftspolitische Realitäten gestellt.

$54 \%$ unseres Außenhandels gehen in die EWG. Wenn die EWG durch Großbritannien erweitert wird, wird sich dieser Prozentsatz bis $62 \%$ erhöhen. Wir bitten um Verständnis dafür, daß wir uns Sorge darüber machen, wie wir unsere Waren weiterhin in die Länder exportieren können, weil am 1. Juli eine neue Zollsenkung wirksam wird, die es noch schwieriger machen wird, die Zollbarrieren zu überwinden. Es ist uns darum zu tun, ein tragbares wirtschaftspolitisches Konzept mit Ihnen zu besprechen, wie wir unsere Waren weiterhin in diese Länder ausführen können.

Wie in allen unseren außenpolitischen Entscheidungen gelten auch hiebei folgende Prinzipien, und ich möchte mit allem Nachdruck bitten, daß uns hier Vertrauen geschenkt wird: Als oberster Maßstab hat zu gelten eine strikte Einhaltung der von uns freiwillig übernommenen immerwährenden Neutralität und die Loyalität gegenüber den Verpflichtungen aus dem Staatsvertrag ebenso wie den von uns eingegangenen internationalen Verpflichtungen. Für Österreich ist dies der feste Rahmen, den wir nicht überschreiten werden. Solange wir, die wir hier sitzen, die politischen Geschicke Österreichs bestimmen, wird dies das Gesetz unseres Handelns sein.

Chruschtschow: Wir wollen Ihnen in der Entwicklung Ihrer Handelsbeziehungen mit allen Ländern der Welt nicht im Wege stehen. 54 \% bzw. 62 \% Ihres Handels haben Sie mit diesen Ländern. Wir wollen selbst mit diesen Ländern Handel treiben und gute Handelsbeziehungen haben. Uns beunruhigt, sollten Sie Mitglied dieser Gemeinschaft werden, daß Sie in diesem Fall Ihre Unabhängigkeit verlieren würden und daß Sie dann die NATO-Politik betreiben müßten. Denn dieser Wirtschaftsblock ist ein Instrument der NATO. Dies sind nicht meine Worte, sondern sie wurden von den Organisatoren der EWG geprägt. Das hat auch Kennedy gesagt und Hallstein und andere maßgebende Leute. Das ist deren Politik, und wenn Sie in diese eintreten, so verlieren Sie die Möglichkeit, Ihre Politik der Neutralität weiterhin zu verfolgen. Diese Länder sollen Ihre Situation begreifen und mit Ihnen wei- 
terhin einen Handel treiben in einer so vorteilhaften Art wie bisher. Wir wünschen, daß Sie Handel nicht nur mit uns treiben, sondern auch mit anderen Ländern. Diese Länder sollen das verstehen.

Bundeskanzler: Damit kein Mißverständnis entsteht, möchte ich noch sagen, daß wir ausdrücklich erklärt haben, daß eine Mitgliedschaft bei der EWG wegen unserer Neutralität nicht in Frage kommt. Was wir wollen, ist, im Gespräch mit den Ländern Wege zu suchen, um jene Begünstigungen zu bekommen, damit unsere Waren in diese Länder exportiert werden können, aber nicht um den Preis von politischen Gegenleistungen. Es handelt sich darum, vorerst mit diesen Ländern darüber Gespräche zu führen, wobei wir uns auf die Prinzipien unserer Politik, nämlich die Neutralität und Loyalität gegenüber dem Staatsvertrag und den internationalen Verpflichtungen berufen werden. Es ist keine Rede von einem Eintritt, sondern von einem Gespräch darüber, welche Möglichkeiten für die Aufrechterhaltung unseres Handels mit diesen Ländern bestehen.

Chruschtschow: Wir müssen freilich auch mit Verständnis die Situation Ihres Landes betrachten. Die Schaffung des Gemeinsamen Marktes ist eine reale Tatsache, und Sie müssen freilich Handel treiben. Wir verstehen, daß Sie ohne Handel nicht leben können. Und es ist natürlich, daß Ihre Bemühungen dahin gehen, eine solche Situation zu erreichen, in der Ihr Handel mit diesen Ländern keinen Schaden leidet. Wir werden das mit Verständnis verfolgen. Doch das dürfte nicht den Staatsvertrag verletzen oder die Politik der Neutralität.

Wir möchten gerne die gleichen Möglichkeiten, die Sie mit dem Gemeinsamen Markt haben. Diese gleichen Möglichkeiten wollen wir mit Ihnen haben.

Bundeskanzler: Meinen Sie hier die Meistbegünstigung?

Chruschtschow: Ich sagte, wir wollen gleiche Möglichkeiten Ihres Handels mit der EEG und der Sowjetunion.

Hier wurde die Unterredung wegen des Zeitablaufes abgebrochen. Ministerpräsident Chruschtschow schlug vor, das Gespräch nach Möglichkeit nach dem Mittagessen fortzusetzen, bzw. die beiden Außenminister damit zu betrauen, wobei jedoch das Ergebnis ihrer Unterredung von den beiden Regierungschefs zu genehmigen wäre.

Source: SBKA, Länderboxen, UdSSR 1.

Document 5: Conversation N. Khrushchev - B. Pittermann, Moscow, 17 September 1962

Protokoll der Besprechung des Herrn Vizekanzlers mit Ministerpräsident Chruschtschow am 17. September 1962

Anwesend waren:

Von sowjetischer Seite: 
Der Erste Stellvertretende Ministerpräsident A. N. Kossygin

der Leiter der 3. Europäischen Abteilung im sowjetischen Außenministerium I. I. Iljitschow

der 2. Sekretär der Protokollabteilung im MID L. S. Tschernyschow

und Dolmetsch W. N. Popow

Von österreichischer Seite:

ao. und bev. Botschafter Dr. Heinrich Haymerle

Legationsrat Dr. Franz Karasek

Ministerialoberkommissär Dr. Fischer

Attaché Dr. Bukowski

Einleitend begrüßte Ministerpräsident Chruschtschow den Herrn Vizekanzler. Der Herr Vizekanzler überbrachte seinerseits die Grüße des Herrn Bundespräsidenten, des Herrn Bundeskanzlers, des Herrn Altbundeskanzlers Raab und anderer österreichischer Persönlichkeiten sowie, ,seit gestern auch die des Schachtes Nr. 31 in Donezk". Ministerpräsident Chruschtschow brachte seine Freude über den Besuch des Herrn Vizekanzlers zum Ausdruck.

$[\ldots]^{1}$

Ministerpräsident Chruschtschow: Im gegenwärtigen Augenblick ist es sehr schwer, die Weltlage richtig einzuschätzen, weil es so viele Imponderabilien gibt. Dies gilt insbesondere für Amerika. Es ist wie auf einer Hasenjagd, wo der Hase ständig Haken schlägt und Sprünge macht, die niemand erwartet. So dauert es lange, bis der Jäger ihn erlegen kann. Sehen Sie, und darum ist es schwer, die internationale Lage zu charakterisieren. Die USA hat die labilsten und inkonsequentesten Politiker. Ihre Politik ist weitgehend von ihrer momentanen Stimmung, von der Laune des Augenblicks bestimmt. Die Amerikaner wetteifern miteinander, wer am lautesten durch unanständiges Benehmen Gestank erzeugen kann. Es ist zwar keine diplomatische Ausdrucksweise, dafür aber umso deutlicher. Verantwortungslose Schreihälse, die da brüllen, man müsse Kuba erobern, eine Blockade verhängen, sowjetische Schiffe versenken usw. Sind das noch normale Menschen oder Irrsinnige? Was heißt Blockade? Das wäre doch Krieg! Jetzt fahren unsere Schiffe nach Kuba. Wir haben unseren Kapitänen Befehl gegeben, wenn man sie stoppt, nicht stehen zu bleiben, und wenn man auf sie schießt, zurückzuschießen. Deshalb haben wir unsere U-Boot-Flotte in Kampfbereitschaft gesetzt, und wenn man unsere Schiffe angreift, so werden unsere U-Boote eingreifen. Wir haben zwar schwache Seestreitkräfte, aber dafür eine starke U-Boot-Flotte. Das alles würde aber Krieg bedeuten.

Präsident Kennedy hat jetzt auf einer Pressekonferenz Erklärungen abgegeben, einerseits über die große Verantwortung, die auf seinen Schultern liegt, andererseits

\footnotetext{
${ }^{1}$ Six pages on economic relations omitted.
} 
daß er, wenn es sich als notwendig erweisen sollte, in Kuba eingreifen werde. Aber wer gibt ihm ein Recht dazu? Ihm gefällt die innere Ordnung in Kuba nicht. Wir haben die Türkei und Persien als Nachbarn, Zwischenruf Kossygin: Westberlin, und dort herrscht der Kapitalismus, was uns auch nicht paßt, trotzdem können wir deshalb diese Länder nicht angreifen. Wo kämen wir hin, wenn Gewalt vor Recht ginge? Wenn Gewalt Recht wäre, würde die Welt zu einem Irrenhaus. Das würde zur Auflösung der UNO und schließlich zu einem Weltkrieg führen.

Wir sind heute ein relativ starker Staat. Trotzdem versuchen wir nicht, auf andere Länder einen Druck auszuüben, sondern sind bestrebt, unsere Beziehungen zu anderen Ländern auf der Grundlage der Gleichberechtigung zu erhalten. So haben wir uns beispielsweise sehr bemüht, unsere Beziehungen mit Finnland zu verbessern. Finnland ist ein kleines Land; die Stadt Leningrad allein hat schon so viele Einwohner wie ganz Finnland. Das bedeutet aber keineswegs, daß wir Finnland gegenüber eine Politik der Beleidigungen, Demütigungen und Demonstrationen unserer Macht führen, so etwas wäre ausgesprochen sinnlos. Weil wir das nicht tun, sind heute unsere Beziehungen mit Finnland besser als mit irgendeinem anderen Land. Wir haben auch unseren militärischen Stützpunkt in Finnland aufgegeben, weil er unsere Beziehungen mit Finnland nur stören würde. Könnten wir etwa die Aufrechterhaltung eines Stützpunktes vor der Hauptstadt Finnlands damit rechtfertigen, daß Finnland uns eventuell angreifen könnte? Das wäre doch eine unsinnige Erklärung! Wer würde uns je glauben, daß Finnland die Absicht hatte, uns anzugreifen? Selbst wenn Finnland das wollte, könnte es dies nicht tun, und genau so Kuba: Wer soll glauben, daß Kuba allen Ernstes die USA bedroht? Wie wäre so etwas überhaupt möglich? Wie kann denn ein Hase einen Löwen fressen? Und wie können 7 Millionen Kubaner die USA erobern? Selbst wenn Castro so etwas wollte, könnte er es nicht!

Was die Amerikaner aufführen, ist die Politik eines Räubers. Ihr Standpunkt gegenüber diesem kleinen Land ist: Du willst mich fressen, daher fresse ich lieber Dich. Nur haben sich jetzt die Zeiten geändert.

Schauen Sie uns an und unsere Beziehungen zu unseren Nachbarstaaten. Eben erst war der König von Afghanistan bei uns. Wir haben eine $2500 \mathrm{~km}$ lange Grenze mit Afghanistan, aber keinen Konflikt mit diesem Land, und was uns betrifft, wird es einen solchen auch in Zukunft nicht geben. Wir sind fest entschlossen, mit Afghanistan in Freundschaft zu leben, und ich glaube, das wollen auch die Afghanen. Wir sind Kommunisten, Afghanistan ist ein Königreich, aber wir glauben, daß die innere Ordnung Innenangelegenheit eines jeden Landes ist und mischen uns da nicht ein. Jetzt arbeiten so viele von unseren Ingenieuren dort, aber ich habe bisher keine Beschwerde gehört, daß sie sich irgendwie gegen die afghanische Regierung betätigen. Das hat mir im übrigen auch der König von Afghanistan bestätigt, mit dem ich zusammen jagen war. 
Jetzt haben wir auch begonnen, unseren Konflikt mit Persien beizulegen und es scheint, daß es zu einer Verbesserung unserer Beziehungen mit diesem Land kommen wird. Auch unsere Beziehungen zu der Türkei werden immer besser.

Mit Ihnen haben wir alle Probleme gelöst. Seit dem Abschluß des Staatsvertrages entwickeln sich unsere Beziehungen normal. Wir wollen mit allen Ländern in Frieden leben, das ist unsere Parole. Wenn aber die Amerikaner Kuba überfallen, zwingt uns dies, die Grenze zwischen Krieg und Frieden zu überschreiten. Und dann werden wir uns die schwachen Stellen, die Achillesferse, der Amerikaner aussuchen und da ist vor allem Berlin. Berlin ist längst ein militärischer Stützpunkt der NATO, wie sehr auch die Amerikaner, Engländer und Franzosen beteuern, daß sie ihre eigenen Truppen dort stationiert haben.

Stikker selbst hat erklärt, daß gegebenenfalls Nato-Truppen Westberlin zu Hilfe kommen würden! Das ist doch der beste Beweis dafür, daß Westberlin eine NatoBase [sic] ist.

Neben Westberlin gibt es aber auch noch andere Orte, wo wir unser Verhältnis zu den Amerikanern einer Überprüfung unterziehen könnten. Im übrigen ist ja Amerika selbst heute nicht mehr unverwundbar! Die Zeiten sind vorbei, in denen der Atlantische Ozean eine unüberschreitbare Barriere gebildet hat, dazu ist heute die Raketentechnik schon viel zu weit entwickelt. Die heutige Waffentechnik und insbesondere die Atom-U-Boote kennen keine Grenzen. Deshalb ist es auch überholt, sich auf Flugzeugträger zu stützen, wie dies die Amerikaner tun. Ich habe ihnen schon oft gesagt, daß diese Flugzeugträger längst veraltet sind und nur ein Mittel sind, Geld aus der Staatskasse zu pumpen. (Zwischenruf Vizekanzlers: Und die Stahlwerke zu beschäftigen!) Wir haben auch vor fünf Jahren von Stalin zu 95 $\%$ fertige Kreuzer übernommen, aber wir haben sie zerlegt und eingeschmolzen. Wir legen jetzt unser Hauptgewicht auf unsere U-Boot-Flotte. Wir haben jetzt UBoote, die mit Raketen mit einer Reichweite bis zu 3000 km ausgestattet sind; was kann uns da die amerikanische Flotte noch anhaben? Gar nichts! Wenn sie uns angreifen sollten, werden wir ihnen mit unserer U-Boot-Flotte die gebührende Antwort erteilen! Aber das bedeutet Krieg und darum sind wir dagegen. Wir werden, soweit das von uns abhängt, nie und gegen niemanden Krieg anfangen. Wenn das aber vom Kapitol in Washington abhängt und gewisse Leute dort die Oberhand bekommen, dann ist ein Krieg durchaus möglich. Deshalb ist es sehr schwer, jetzt Genaues zu sagen, letzten Endes hängt alles von Kennedy ab. Wird er so viel gesunden Menschenverstand und Willenskraft haben, sich diesen Leuten energisch entgegenzustellen? Wenn ja, wird es keinen Krieg geben, wenn nein, wenn er Kuba angreifen sollte, dann ist ein Krieg unvermeidlich. Kuba ist ein souveräner Staat, und eine Verletzung seiner Souveränität würde die Grundlagen der internationalen Politik berühren. Der Fall Kuba übersteigt die Bedeutung des Landes Kuba. Sollen wir etwa eine Politik des Treuebruches und gewalttätigen Angriffes hinnehmen? Keineswegs! Wir werden Gewalt mit Gewalt beantworten. Wir haben genügend 
Mittel hiefür. Kennedy selbst weiß das sehr genau, das hat er mehrmals betont. Deshalb glaube ich auch, daß bei ihm schließlich die Vernunft siegen wird.

Vizekanzler Pittermann: Hat er die Kraft?

Ministerpräsident Chruschtschow: Ich kann dafür nicht bürgen. Darin liegt eben die Gefahr! Ich sage Ihnen ganz offen, die Politik Kennedys ist elastischer als die Eisenhowers, aber ich hatte ein sichereres Gefühl, als noch Dulles neben Eisenhower war. Dulles war zweifellos in allen seinen Gedanken ein Antikommunist, aber er hätte nie einen Krieg begonnen. Wir haben ihn in dieser Hinsicht auf die Probe gestellt. Als er gestorben war, sagte ich, wir werden noch an ihn denken. Auf ideologischem Gebiet war er zweifellos unser Feind Nr. 1, wie Sie im Westen zu sagen pflegen. Er war ein Meister der Dialektik und ging oft bis an die Grenze des Krieges, aber diese Grenze hat er nie überschritten! Dulles war ein sehr fester, aber vorsichtiger Politiker. Er war alt, er war erfahren und, wie ich schon sagte, einer der ausgeprägtesten Gegner des Kommunismus. Wenn er daher einmal sagte, bis hieher und nicht weiter, sonst gibt es Krieg, so glaubte man ihm das. Eisenhower stellte sich natürlich immer hinter ihn, aber praktisch war nicht Dulles unter Eisenhower, sondern eher umgekehrt. Eisenhower war sicherlich auch gegen den Krieg, das glaube ich ihm ohne weiteres. Jetzt ist er in der Opposition und für die amerikanische Politik nicht mehr verantwortlich, und jetzt stürzen sich die Republikaner wie eine Hundemeute auf Kennedy. Wird Kennedy genug Knüppeln finden, um diese Hunde zu verjagen und den Frieden zu erhalten? Ich möchte dafür nicht garantieren. Darum muß man die Weltlage als sehr labil bezeichnen, und das vor allem im Hinblick auf die Lage in USA! Das amerikanische Volk ist zweifellos gegen den Krieg, spielt aber in der amerikanischen Politik keine Rolle. Dort sind vor allem die zwei Parteien, die gegeneinander kämpfen, wie zwei Fliegen, die man in ein Glas setzt. Wer von den beiden besser oder schlechter ist, weiß ich nicht. Beide fürchten den Kommunismus, aber die Leidenschaft eines Verrückten kann zum Krieg führen. Sehen Sie, so beurteilen wir die Lage. Ob es einen Krieg geben wird oder nicht, ist schwer zu sagen. Weil jetzt die Amerikaner so ein Geschrei machen, haben wir unsere Streitkräfte in Kampfbereitschaft gebracht. Wir wollen hoffen, daß dieser Schritt nicht notwendig war. Was würde ein Krieg den Amerikanern bringen? Nur Zerstörung! Niemanden würde ein Krieg etwas anderes als Zerstörung bringen. Wissen Sie, wenn ein Staat von vernünftigen Politikern geleitet wird, kann man vorhersagen, wie er sich verhalten wird, aber für die Amerikaner kann selbst der Teufel nicht garantieren. Jetzt hat Kennedy 150.000 Reservisten einberufen lassen. Wozu, frage ich? Was hat er davon? 150.000, 300.000, eine Million, das ist doch alles bei einem Atomkrieg ganz gleich! Wir leben doch nicht mehr in der Zeit der Napoleonischen Kriege, als man mit Bajonetten kämpfte! In einem neuen Krieg würde man nicht einmal mehr mit Kanonen kämpfen, sondern nur mehr mit Atomwaffen. Sehen Sie, das muß man begreifen. Ein neuer Krieg wird nicht mehr Mann gegen Mann geführt, sondern gegen Industriezentren und Großstädte, und so etwa ist es kein Spiel für Kinder mehr. Soll er 150.000 Mann einberufen, wir 
können 300.000 Mann einberufen, glauben Sie nicht, daß wir das können? Aber was haben wir davon? Das würde doch für unsere Streitkräfte keine echte Stärkung bedeuten, denn heute wird militärische Macht doch nicht mehr nach Bajonetten gezählt! So etwas kostet nur Geld. Deshalb haben wir unsererseits auch keine zusätzlichen Truppen einberufen. Wir stützen uns hauptsächlich auf unsere Raketen, unsere Luftabwehr und unsere U-Boote, das genügt. Gott gebe uns, daß alles gut vorbeigeht.

Was die Frage Westberlin betrifft, halten wir es nicht für angebracht, vor den amerikanischen Kongreßwahlen Gespräche hierüber zu beginnen. Damit wollen wir bis nachher warten. Das heißt natürlich nicht, daß wir genau am 7 . November anfangen wollen, an dem Tag haben wir Feiertag, aber nachher können wir unsere Kontakte mit den Westmächten wieder aufnehmen und unsere Gespräche fortsetzen, freilich alles unter der Voraussetzung, daß die Amerikaner keinen Krieg wegen Kuba beginnen. Ein Krieg auf Kuba, ein Angriff auf unsere Schiffe ist so viel wie ein Angriff auf uns! Hoffen wir aber, daß das nicht der Fall sein wird und daß die Vernunft siegt. Ich glaube an den gesunden Menschenverstand Präsident Kennedys; er hat auf mich einen sehr guten Eindruck gemacht. Vielleicht war das auch die Besonderheit der Wiener Atmosphäre, aber ich habe den Eindruck gewonnen, daß er ein zwar junger, aber sehr kluger und verständnisvoller Mensch ist. Wird er aber imstande sein, diese schwierige Lage zu meistern, um seiner Opposition wirksam entgegenzutreten? Das wird eine schwere Prüfung für ihn! Wenn aber alles gut geht, und kein Krieg wegen Kuba ausbricht, und man uns nicht provozieren wird, glaube ich, daß wir die Frage Westberlin für einen späteren Zeitpunkt aufschieben können. Vielleicht für die zweite Novemberhälfte, vielleicht fahre ich dann selbst zur UNOSitzung. Das ist noch nicht sicher, aber es ist nicht ausgeschlossen. Vielleicht kann ich auch dort selbst mit Kennedy zusammentreffen, wenn die Lage uns das ermöglichen sollte, und wir könnten einen ausgiebigen Meinungsaustausch miteinander haben. Aber auch das ist noch ungewiß. Wenn wir aber zu keinem Verständnis über Berlin gelangen sollten, dann werden wir einen Friedensvertrag mit der DDR abschließen, dann werden wir praktisch alle Verbindungen kontrollieren und die militärischen Zugänge der Westmächte sperren. Das wird keine Blockade für die Westberliner Bevölkerung bedeuten; die Westberliner werden nach wie vor freien Zutritt zu ihrer Stadt haben. Wir werden aber auf dem Standpunkt stehen, daß mit der Unterzeichnung eines Friedensvertrages mit der DDR der Kriegszustand auf dem Territorium der DDR zu Ende und das Recht der Westmächte auf Stationierung ihrer Truppen außer Kraft getreten ist. Wir sind jedoch nach wie vor zu einer Verständigung mit der anderen Seite bereit. Ich habe unseren Standpunkt auf dem Weltfriedenskongreß dargelegt. Den gleichen Standpunkt nehmen wir auch heute ein, und ich glaube, daß dieser Standpunkt der einzig mögliche und vernünftige ist. Kennedy selbst und andere Regierungschefs haben erklärt, daß sie diese Zustände nicht für normal halten, und Kennedy sagte mir, das ist eine Erbschaft, die man ihm hinterlassen hat. Das ist aber keineswegs etwas, was man nicht ändern kann. Wenn 
es uns nicht gelingen wird, das Problem Westberlin zu lösen, so werden wir immer am Rande eines Krieges schweben. Westberlin bedeutet für uns nichts und auch für den Westen nichts, es ist nur ein Krisenherd. Was bedeutet es denn wirklich für die Westmächte? Gar nichts! Sie behaupten, sie wollen die Freiheit der Westberliner sichern, aber das wollen wir doch auch! Niemand bedroht diese Freiheit! Um was geht es also? Wenn es nach uns geht, ziehen wir alle Truppen zurück und beseitigen damit diesen Krisenherd.

Ich erkläre hiemit, daß wir nach wie vor zu Kompromissen bereit sind. Ein solcher Kompromißvorschlag wäre die vorläufige Stationierung von UNO-Truppen in Westberlin als Garantie für die Freiheit der Westberliner. Was könnten wir ihnen noch vorschlagen, um beide Seiten zu befriedigen? Aber wenn sie hiefür absolut kein Verständnis haben, werden wir eben doch den Friedensvertrag mit der DDR abschließen, und dann wollen wir sehen, ob sie um ihren Korridor nach Westberlin kämpfen werden.

Zwei Fragen sind es also, von denen die Weltlage abhängt, Kuba und Berlin. Werden wir durchkommen, und wie? Kuba ist ein souveräner Staat und Mitglied der UNO, was auf ihm vorgeht, ist seine innere Angelegenheit. Daß sich Amerika in die Innenangelegenheiten eines fremden Staates einmischen will, berührt die Interessen aller übrigen souveränen Staaten. So entstand die ganze Kuba-Frage. Die USA und Kuba sind Mitglieder der Vereinten Nationen. Wenn die USA die Grundsätze der UNO beherzigen und sich nicht in die Innenangelegenheiten anderer Staaten einmischen, so wird es keine Kuba-Krise geben.

Und noch einmal zur Frage Westberlin. Ich habe schon einmal gesagt, daß ich für die beste Lösung den Abschluß eines Friedensvertrages, die Schaffung einer freien Stadt Westberlin und die Aufnahme der DDR sowie der Bundesrepublik in die UNO halte. Vorübergehend können auch UNO-Truppen Westberlin stationiert werden, wobei wir volle Garantien für die Verbindungen geben, so wie etwa auch zwischen der Schweiz und den übrigen Staaten, auch solchen, an die sie nicht grenzt, Verbindungen bestehen.

Kossygin: Genau so bei Österreich.

Ministerpräsident Chruschtschow: Ja, auch Österreich, hat Verbindungen mit allen Ländern, aber eben auf Grundlage von internationalen Verträgen. Einige besonders Kluge erklären, man muß einen Korridor durch die DDR nach Westberlin schaffen. Diesen Neunmalklugen antworte ich, daß wir dies ablehnen, weil wir keinen Präzedenzfall schaffen wollen. So haben die Amerikaner die Mongolei anerkannt. Dorthin kann man nur durch die Sowjetunion oder durch China kommen. Heißt das jetzt, daß die Amerikaner jetzt die Einräumung eines Korridors durch die Sowjetunion zur Mongolei verlangen können? (Chruschtschow klopft sich auf die Stirn und auf sein Gesäß) Man muß eben unterscheiden zwischen dem Körperteil, auf dem man sitzt, und dem, mit dem man denkt, aber bei manchen Leuten dürften diese Unterschiede nicht so klar bestehen. Und nicht nur Staatsmänner müssen diesen Unterschied machen, sondern auch die Leute, die unter ihnen stehen. 
Trotzdem hoffe ich, daß es keinen Krieg geben wird. Man kann viel schwätzen, aber man solle sich genau überlegen, bevor man auf gewisse Knöpfe drückt.

Besonders laute Schreier sind Adenauer und de Gaulle, die sich eben getroffen haben, um die alte deutsch-französische Liebe neu zu beleben. Das wird aber keine Liebesheirat, sondern nur eine Vernunftsehe. De Gaulle will Adenauer an sich drücken und dadurch seine Stellung in Europa stärken, und Adenauer möchte das gleiche, für Westdeutschland wieder einen Weg in die Weltpolitik finden. Keiner der beiden bringt dem anderen jedoch eine echte Zuneigung entgegen, ihre Umarmungen und Küsse sind alles Berechnung. Ich bin aber überzeugt, daß, wenn sich die Weltlage so entwickelt, daß wir vor der Wahl stehen, Krieg oder Frieden, de Gaulle und Adenauer sich auf jene Kreise stützen, die einen Krieg entfesseln möchten. Dabei wissen sie, daß, wenn ein neuer Krieg ausbricht, zwar alle Länder ein großer Schade treffen wird, Frankreich und Deutschland aber überhaupt nicht mehr existieren werden, sie würden einen Atomkrieg nicht überleben. Jeder vernünftige Mensch muß das einsehen. Aber vielleicht hat de Gaulle immer das Bild Napoleons vor sich und glaubt, daß er größer als Napoleon ist. Und so etwas ist sehr gefährlich. Sehen Sie, so sehen wir die internationale Lage.

England vertritt eine Politik, die nicht seine eigene ist. England glaubt nicht an einen militärischen Konflikt und ist gegen Militärstützpunkte auf seinem Gebiet. Die englische Labour Party hat für unsere Deutschlandpolitik sogar großes Verständnis. Ich habe vor kurzem einen Labour-Abgeordneten empfangen, der mir ein persönliches Schreiben von Hugh Gaitskell überbrachte. Gaitskell möchte sich im Dezember oder Anfang Jänner mit mir treffen. Ich hatte mit dem Labour-Abgeordneten ein ausführliches Gespräch und habe ihm unsere Politik auseinandergesetzt. Er sagte, es sei eine vernünftige Politik, und die Labour Party könnte dieser Politik zustimmen! Was ich jetzt sage, ist nicht für die Presse, aber während meines Gespräches mit U Thant - ich möchte ihm keine Unannehmlichkeiten bereiten, aber er erzählte mir, daß er in London mehrere Gespräche mit Labour-Abgeordneten führte und alle in der Frage Westberlin unseren Vorschlägen voll zustimmen, die ich auf dem Weltfriedenskongre $\beta$ dargelegt habe. Die englischen Labour-Zeitungen haben auch einen Aufruf gebracht, daß man meine Vorschläge zur Lösung der Berlinfrage aufgreifen soll.

Trotzdem glaube ich, daß dieser Zustand der Ungewißheit noch bis zu den amerikanischen Kongreßwahlen dauern wird. Momentan würde Kennedy schwerlich eine entschiedene Haltung einnehmen. Er würde zwar damit viel Unterstützung beim amerikanischen Volk finden, wird es aber trotzdem nicht wagen. Das ist eben das Wesen des Kapitalismus, und bestätigt die Prognose von Marx, daß sich der Kapitalismus überleben wird. Die amerikanischen Kapitalisten spielen mit dem Feuer, die Frage von Krieg und Frieden wird bei ihnen zum Spielball des Parteienschachers.

Vizekanzler Pittermann: Wir leben in einem gemischten System. Trotzdem ist es möglich, daß gerade bei diesem System, in dem wir auch zwei gleich starke 
Parteien haben, die in wirtschaftlichen und sozialen Fragen große Differenzen haben, eine gemeinsame Außenpolitik geführt wird. Auch wir haben in zwei Monaten Wahlen, und bei uns ist das Kräfteverhältnis noch viel ausgeglichener als in Amerika, wo Kennedy bei den Präsidentschaftswahlen eine Mehrheit von 100.000 Stimmen hatte. Aber in der Frage des Festhaltens an Neutralität und Loyalität zu beschlossenen Verträgen gibt es zwischen den österreichischen Regierungsparteien keine Differenz, so heftig sie sich auch im Wahlkampf gegenseitig bekämpfen werden.

Ministerpräsident Chruschtschow: Ich glaube, daß man das auch mit der besonderen Lage Österreichs, seiner wirtschaftlichen Stärke und Bevölkerungszahl erklären kann. Sie in Österreich können nicht die Rolle einnehmen, die die USA einzunehmen entschlossen sind, nämlich die Rolle eines Führers und Verteidigers des Kapitalismus. Deshalb spielen sich auch bei Ihnen Wahlen mehr um innere Fragen ab. Was aber die außenpolitischen Fragen und die Neutralität anlangt, haben die beiden Parteien bei Ihnen die gleiche Position. Bei Ihnen erhitzen sich während der Vorwahlzeit Leidenschaft über Fragen der Innenpolitik. In Amerika jedoch sind die Verhältnisse ganz anders und dort ist das oberste Ziel die Zurückwerfung des Kommunismus und der Kampf gegen den Kommunismus. Diese Fragen stehen dort im Vordergrund, und das ist sehr gefährlich. So eine Politik ist bezeichnend für die USA, selbst in England könnte sie nicht geführt werden. England hat heute keine solche Stellung mehr in der Welt. Und daraus erklärt sich die ganze amerikanische Politik der Ungewißheit, der Labilität, die Politik der Schreihälse. Und darin liegt die große Gefahr. Aber nicht wir waren es, die sich Amerika als unseren Gegenspieler ausgesucht haben. Das hat uns der liebe Gott gegeben, wie man bei Ihnen sagt. Darum müssen wir, wenn die Vernunft nicht mehr ausreicht, uns auf Raketen und Bomben stützen. Wir machen unsere Explosionen, die Amerikaner haben bereits angekündigt, daß sie auch ihrerseits wieder welche machen werden. Das ist kein lustiges Leben, aber das ist die Politik der Koexistenz. Wenn es nicht möglich sein wird, daß wir uns über die Abrüstung einigen, dann werden wir eben weiter in diesen Verhältnissen des Wettbewerbes leben müssen und versuchen müssen, ein Gleichgewicht, eine Balance zu halten, so sinnlos dies auch ist, aber was können wir tun? Amerika will sich zu keiner Einigung über die Abrüstung bereitfinden, Kennedy unterschreibt nichts, weil er weiß, daß der Kongreß kein Abrüstungsabkommen genehmigen wird. Erst wenn einmal die Völker den Kapitalismus wegjagen und überall die Arbeitermacht aufrichten werden, dann wird vielleicht ewiger Friede auf Erden herrschen. Inzwischen warten und arbeiten wir, wir haben keine andere Wahl. $[\ldots]^{2}$

Source: ÖStA, AdR, BMAA, II-Pol., GZ. 73.544-6pol/62, Z. GZ. 73.544-6pol/62.

\footnotetext{
${ }^{2}$ Six pages on the economic development of the USSR, the weather, and an invitation to Austria omitted.
} 
Document 6: The Democratic Lawyers Association's Theses on Neutrality, Sofia, 14 October 1962

After consideration of the problems presented in Item 3 on the agenda, the Congress is of the opinion that the time is ripe for a fresh approach to the problem of neutrality. It considers that a definition of neutrality in terms of modern needs and realities is now possible, but that this demands a further study of the definition of aggression.

As a result of its discussions, the Congress has passed the following Resolution, that

At the end of this Congress the Council of the International Association of Democratic Lawyers be instructed to appoint a commission or commissions to prepare reliable definitions of neutrality and aggression.

The Congress considers that in dealing with the very important question of the definitions of neutrality and aggression, the commission or commissions to be set up under the terms of the Resolution should bear the following considerations in mind.

I .

The modern concept of neutrality differs profoundly from the traditional concept.

The traditional concept first and foremost defined the position of a country in wartime. In those days neutrality was based on the desire of certain countries to stand aloof from power politics and not be involved in wars between the great powers.

The contemporary legal concept of neutrality, on the other hand, is based essentially on the need to maintain peace and national sovereignty.

The policy of neutrality represents a positive attitude in favour of peace, peaceful coexistence between nations, and mutual understanding among men. It also enables new states to safeguard an independence which might be compromised in joining military blocs.

II.

Contemporary neutrality is consistent with the principles and purposes of the UN Charter and the general rules of modern international law.

It can take the following forms:

1) A unilateral declaration which creates rights and obligations for the neutral state, as well as for states which recognize it and establish diplomatic relations with it.

2) A bilateral agreement.

3) A multilateral treaty.

Permanent neutrality can be established by the first or the third of these methods. 
III.

The rights and obligations of states enjoying neutral status can essentially be defined in the following manner:

1) Nonparticipation in military blocs.

2) A formal and categorical ban on present or future foreign military bases on their soil, in the admission of foreign troops, and on the use of the national air space for espionage, nuclear war or other hostile purposes.

3) A ban on the possession of nuclear weapons.

4) The duty of maintaining good relations with all states without discrimination.

5) A neutral state should neither offer nor permit on its territory any aid or support, whether direct or indirect, to an aggressor.

6) Withdrawal from all pacts creating obligations which are incompatible with those deriving from a neutral status.

7) A neutral state is entitled to full respect for its political and economic sovereign rights. It may undertake its own defense or call for the help of other states in the event of aggression or an infringement of its neutrality.

Source: International Association of Democratic Lawyers (ed.), Legal Aspects of Neutrality: Proceedings of the Third Commission (Brussels: International Association of Democratic Lawyers, 1960), 113-114.

Document 7: Conversation A. Gromyko - K. Waldheim, Moscow, 22 March 1968 (translated from Russian)

$[\ldots]^{1}$

A. A. Gromyko states that the situation in Vietnam is very complicated and dangerous. The Americans have not ceased their military actions in Vietnam; on the contrary, there is talk about sending more troops to Vietnam. Johnson makes a declaration from time to time about being ready for a peaceful solution in Vietnam, but the reality shows how hypocritical such declarations are. This is corroborated by the fact that the Americans disrupt even the slightest contacts in Vietnam.

The number of states that condemn the policy of the US grows. Vietnam receives a growing amount of help from other states, in particular from the USSR, which is determined to help Vietnam also in the future, because it is convinced

\footnotetext{
${ }^{1}$ In a conversation on 19 March, the Austrian minister of foreign affairs classified the Soviet-Austrian relationship as "problem-free" and invited his Soviet colleague to visit Austria. Waldheim stressed that Austria "is not taking any steps in its relations with the EEC that might run counter to the state treaty or contradict the status of a neutral country." He repeated the earlier Austrian desire to be granted permission to buy defense missiles. Gromyko declared the state treaty and the law on Austria's neutrality "a very good basis for the further development of Soviet-Austrian relations," but warned against Austria's rapprochement with the EEC. Both sides underlined their interest in developing bilateral trade. AVPRF, 66/47/101/11, 23-26.
} 
that the case of the Vietnamese people is the right one, and victory will be on their side. The proposals of the Vietnamese government that were made, in particular by the minister of foreign affairs of the DRV, open the way for negotiations. However, to begin there must be an unconditional cessation of the bombardments of the DRV.

$\underline{K}$. Waldheim declared that [people] in Austria are following the situation in Vietnam with concern and are ready to do everything they can for the cessation of the Vietnam War. The minister reported that he has established contact with the DRV's ambassador in Budapest. In a conversation with him he declared that Austria advocates a solution of the Vietnam problem on the basis of the Geneva agreements of 1954, and that Austria is ready to offer its good services for regulating the conflict if both sides were to express a desire for this. It has been agreed to continue direct contacts with the DRV's ambassador.

$\mathrm{K}$. Waldheim posed the question whether and how a small country might contribute to the solution of the Vietnamese Question. The neutral states Austria, Sweden and Switzerland have offered their good services for a solution of the Vietnam problem. Austria is sending aid to Vietnam through the Red Cross.

A. A. Gromyko answered by stating that the question of mediation must be decided by the sides involved in the conflict. The Soviet Union calls on Austria to follow the example of a number of states and to raise its voice in favor of a cessation of aggression in Vietnam, in support of the just case of Vietnam. The Vietnamese people must be given the right to decide their own internal questions.

Regarding the problem of European security, A. A. Gromyko raised the issue of the FRG's policies and declared that, although the coalition government of the FRG has spoken following a new policy course, the facts do not corroborate this. The course of West Germany has become more subtle in its tactics. However, by its character, [the West German chancellor] Kiesinger repeats the model of the Adenauer era, albeit in a more even-handed way. The government of the FRG maintains its previous revanchist line regarding its borders, the GDR, and West Berlin. The posture of West Germany towards European security has also not changed. As before, the FRG is reaching out for nuclear arms and claims to represent all Germans. As before the war, Kiesinger even speaks of a "people without space," and Goebbels' propaganda motifs are heard again. In West Germany, this kind of forces are raising their head higher and higher, do not conceal that they follow Hitler's course, and openly speak about it at their meetings and conferences.

$[\ldots]^{2}$

When discussing security issues in Europe, some political leaders, tellingly, operate with general formulations and speak out for European security and allEuropean cooperation. However, as soon as concrete measures for preparing an allEuropean conference are discussed, nothing comes out of it [sluchaiutsia osechki]

${ }^{2}$ One paragraph on the danger of neo-Nazism omitted. 
and discord starts. Some politicians, unfortunately, do not speak out clearly for respecting the inviolability of European borders, although, in confidential conversations, they declare their support for this issue. Strong declarations about recognizing the borders in Europe, as they emerged after World War II, would correspond with Austria's interests too.

Some words about West Berlin. The British, French, and American representatives have signed a declaration that West Berlin is not part of the FRG. In practice, however, the US and Britain are encouraging the FRG to lay claims on West Berlin.

$\underline{\mathrm{K}}$. Waldheim stated that [people] in Austria recognize the danger of a return of Nazism, and are prepared to do everything necessary for not letting this happen.

The Austrian government recognizes the importance of all-European cooperation and the call for an all-European conference. It has studied the Soviet deliberations on this issue and agrees to continue to discuss these questions through diplomatic channels.

A. A. Gromyko agreed to continuing the exchange of opinions regarding these topics after the Austrian memorandum, dedicated to the problems of all-European cooperation, has been studied.

$[\ldots]^{3}$

Source: Zapis' besed A. A. Gromyko s ministrom inostrannykh del Avstriiskoi respubliki, K. Val'dkhaimom, 30 April 1968, in AVPRF, 66/47/101/11, 23-29, here 26-29.

Document 8: Conversation L. Brezhnev - B. Kreisky, Moscow, 8 February 1978

Arbeitsübersetzung aus dem Russischen

BILATERALE BEZIEHUNGEN

Gut, daß wir mit der österreichischen Seite eine gemeinsame Sprache sprechen, sowohl über Fragen der bilateralen Zusammenarbeit als auch über einen weiten Bogen internationaler zwischenstaatlicher Probleme. Unser Handel, der kulturelle, wissenschaftliche und sportliche Austausch weiten sich aus. Die vertragliche Grundlage unserer Beziehungen wird immer breiter. All dies bewirkt eine Genugtuung, die - wie ich glaube - auch der Herr Bundeskanzler teilt. Unsere gemeinsame Aufgabe, wie wir sie verstehen, besteht darin, das angesammelte Gut des Vertrauens und der guten Nachbarschaft zu mehren. Die Sowjetunion ist und wird für eine weitere konstruktive Zusammenarbeit mit dem neutralen Österreich eintreten. Dies ist unsere prinzipielle und langfristige Linie.

Wir bringen den Bemühungen der österreichischen Seite zur Auffindung neuer Wege für eine Belebung der österreichisch-sowjetischen wirtschaftlichen Zusammenarbeit Verständnis entgegen. Dabei wird die Aufmerksamkeit richtig auf die Anwendung solcher bewährten Formen gerichtet, wie es die langfristigen Vorhaben

\footnotetext{
${ }^{3}$ Four paragraphs concerning the Soviet condemnation of the position of Israel in the aftermath of
} the Six-Day War omitted. 
auf Kompensationsbasis, die Entwicklung der Kooperation, die Zusammenarbeit auf den Märkten dritter Länder darstellen. Unsere Stellen werden Weisungen erhalten, die entsprechenden Möglichkeiten unter Berücksichtigung von Vorschlägen der österreichischen Seite eingehend zu prüfen.

Was das Defizit im sowjetisch-österreichischen Handel betrifft, so steht es nicht dafür, dieses zu übertreiben. Heute ist es vorhanden, morgen vielleicht nicht mehr.

Handel ist eine dynamische Angelegenheit. Dabei ist dieses Defizit nicht groß. Jedenfalls ist es in keiner Weise mit dem Negativsaldo im österreichischen Handel, z. B. mit der BRD (50 Milliarden Schilling), zu vergleichen.

Wir glauben, daß es das wichtigste ist, eine kontinuierliche und zielstrebige Ausweitung der wirtschaftlichen Zusammenarbeit zwischen der Sowjetunion und Österreich auf der Basis des gegenseitigen Vorteils zu gewährleisten. In dieser Hinsicht mußten wir gemeinsam etwas tun.

\section{STAATSVERTRAG}

Dieses Vertragswerk zusammen mit dem Beschluß über die immerwährende Neutralität Österreich ist das wesentliche Element der Stabilität der Lage in Europa. Dies ist die beste Garantie für die Existenz eines unabhängigen selbständigen Österreichs, für das Wohlergehen seines Volkes. Die gesamte Nachkriegserfahrung beweist, daß die Einhaltung des Staatsvertrages, eine konsequente Verwirklichung der Neutralitätspolitik den Grundinteressen Österreichs, den Interessen seiner normalen Zusammenarbeit mit allen Staaten entsprechen.

Ich möchte betonen, daß es in bezug auf die Erfüllung der Bestimmungen des Staatsvertrages keine wie immer gearteten Verzerrungen geben sollte. Von unserer Seite wird den auf die Festigung der Unabhängigkeit des Landes und seiner internationalen Stellung gerichteten Bemühungen der österreichischen Regierung stets Verständnis und Unterstützung entgegengebracht werden.

Wir waren und bleiben Gegner jeglicher Versuche, dem neutralen Status und der Souveränität des österreichischen Staates einen Schaden zuzufügen, egal von welcher Seite sie ausgehen mögen.

\section{DIE ENTSPANNUNG UND DIE ROLLE DER NEUTRALEN STAATEN}

Wir kennen im allgemeinen die positive Rolle, welche Österreich in der Gruppe der europäischen neutralen Staaten spielt. Ich möchte der Hoffnung Ausdruck verleihen, daß es seinen Einfluß und seine Möglichkeiten für die Beseitigung von Schwierigkeiten auf dem Wege zu einer dauerhaften Entspannung, für eine Annäherung der Standpunkte in strittigen Fragen geltend machen und Versuchen einer Wiederbelebung der Politik „des kalten Krieges“ entgegenwirken wird. Wohl niemand anderer als die kleinen Staaten ist an der strengen Einhaltung ausnahmslos aller in Helsinki abgesprochenen Prinzipien der Beziehungen zwischen den Staaten, an der Behauptung der Gesetzlichkeit und Gerechtigkeit in internationalen Angelegenheiten interessiert. Um dieses Ziel zu erreichen, unternehmen wir alles, was in unserer Macht steht. 


\section{FRAGEN DER ABRÜSTUNG}

Sicherlich müssen wir in bezug auf die Festigung der Entspannung und des Friedens noch vieles tun. Unserer Meinung nach ist hier das Wichtigste - weniger allgemeine Debatten denn mehr praktische Schritte in der Abrüstung. Es wäre sehr wichtig, eine Unterbindung der Erzeugung von Nuklearwaffen zu vereinbaren und die Frage des Verbotes von Versuchen mit dieser Waffe zu Ende zu führen. Um die Frage in Gang zu bringen, haben wir - wie bekannt - sogar vorgeschlagen, ein Moratorium für Atomexplosionen auch für friedliche Zwecke zu beschließen. Im allgemeinen sind wir dafür, daß Kernwaffen und alle ihre Abarten für immer aus unserem Leben verbannt werden, und wir sind breit, alles dafür Notwenige zu tun. Ich freue mich feststellen zu können, daß die prinzipiellen Standpunkte der Sowjetunion und Österreichs in dieser Frage übereinstimmen.

\section{ÜBER DIE NEUTRONENBOMBE}

Ihr Erscheinen in Europa würde eine neue Situation schaffen und würde von uns verlangen, Gegenmaßnahmen zu ergreifen. Wahrscheinlich ist jemand daran interessiert, daß die Welt in ein neues Stadium des Rüstungswettlaufes mit allen daraus folgenden Konsequenzen hereingezogen wird. Über diese Bombe sagt man, sie zerstöre nicht, sie vernichte nur das Leben. Wem könnte eine derartige Aussicht recht sein? Immer mehr Menschen im Westen und auch in den USA erheben Proteste gegen Pläne der Erzeugung einer Neutronenbombe.

Ich habe in Botschaften meine Gedanken in Verbindung mit der Neutronenbombe an alle Staatsoberhäupter, die an der Europäischen Konferenz teilgenommen haben, darunter auch Ihnen, Herr Bundeskanzler, direkt und offen dargelegt. Dies ist keineswegs ein Schritt der Propaganda. Wir appellieren an die Vernunft. Es ist noch nicht zu spät, diesen Neutronenwahnsinn zu stoppen. Wir schlagen ehrlich vor zu vereinbaren, gegenseitig auf die Herstellung dieser für alles Lebende unserer Erde unheilbringenden Waffe zu verzichten. Es liegt nun am Wort des Westens.

Ist es nicht klar, daß die Gefahr eines Atomkonfliktes in Europa im Falle der Verteilung einer neuen Abart von Kernwaffen in bedeutendem Maße ansteigen würde. Selbst die Befürworter einer Neutronenwaffe verheimlichen nicht, daß dabei die Schwelle eines Kernkonfliktes sicherlich nicht herabgesetzt werden würde. Es fragt sich nun, wer braucht so etwas und wozu soll es dienen.

Unsere gesamte Führung hofft, daß Österreich im Kampfe gegen die Verteilung von Neutronenwaffen in Europa nicht beiseite stehen wird.

Egal was wir heute besprechen mögen - die Aussichten des internationalen Handels oder die Möglichkeit der Ausweitung des kulturellen Austausches - all dies tritt in den Hintergrund im Vergleich mit der Frage der Sicherung des Friedens. Dieses Problem war für uns und wird auch weiterhin von erstrangiger Bedeutung sein.

\section{ÜBER BELGRAD}

Bevor wir die Frage besprechen, was nach dem Zusammentreffen in Belgrad zu tun ist, muß diese Begegnung zuerst ein gutes Ende erfahren; es darf eine weitere 
Verschleppung nicht zugelassen werden. Leider sind die Vertreter der USA und diejenigen, die mit ihnen gehen, mit allen Kräften bestrebt, diese Begegnung von der Annahme konstruktiver Verschlüsse abzuhalten und ihr eine Polemik zu rein propagandistischen Zwecken aufzuzwingen. All dies steht in einem krassen Widerspruch zu Sinn und Wort der Schlußakte. Es ist Zeit, mit derartigen Praktiken Schluß zu machen.

Es scheint, daß es ein allgemeines Einverständnis darüber gibt, 1980 in Madrid eine zweite Begegnung nach Art der von Belgrad durchzuführen. Über das Niveau dieser Begegnung müßte man noch Überlegungen anstellen. Ich würde nicht sagen, daß das gegenwärtige Vertreterniveau an der Begegnung in Belgrad nicht gerechtfertigt wäre. Wichtig sind die Endergebnisse. Dies hängt vor allem von der Politik der an der Begegnung teilnehmenden Länder ab. Was die Begegnung in Madrid betrifft, so wird uns das Leben selbst einen Wink geben, auf welcher Ebene dies durchzuführen wäre.

Sowohl jetzt, als auch nach der Begegnung in Belgrad ist es notwendig, alle Kräfte auf die Verwirklichung der Entspannung zu konzentrieren, insbesondere auf militärischem Gebiet.

Hier gibt es noch viele ungenützte Möglichkeiten und politische Reserven. Und es versteht sich von selbst, daß wir alle konsequent an der Verwirklichung sämtlicher Bestimmungen und Vereinbarungen der Schlußakte arbeiten müssen.

ÜBER DEN BESUCH IN ÖSTERREICH

Ich danke nochmals für die mir vom Bundespräsidenten Kirchschläger und von Ihnen zugekommene Einladung, Österreich einen freundschaftlichen Besuch abzustatten. Ich werde sicherlich mit großem Vergnügen in Österreich weilen. Ich sage das mit Sicherheit. Zur Frage der Festlegung des Termines jedoch wird man aller Wahrscheinlichkeit nach später zurückkommen müssen. Heute dazu etwas Bestimmtes zu sagen ist schwierig.

Source: SBKA, Länderboxen, UdSSR 4.

Document 9: Report Ambassador H. Liedermann - Austrian MFA, On AustrianSoviet Relations, 23 November 1985

Herrn Bundesminister für Auswärtige Angelegenheiten, WIEN

Die Beziehungen Österreichs zur kommunistischen Weltmacht UdSSR, deren Unterschrift unter jenem Vertragswerk steht, das als Fundament der von Österreich 1955 wiedererlangten außenpolitischen Unabhängigkeit gilt, sind für Österreich zweifellos von eminenter sicherheitspolitischer und existentieller Bedeutung. Die konsequente sachkundige Pflege und Weiterentwicklung dieser Beziehungen ist daher eine zentrale Aufgabe der österreichischen Außenpolitik.

In den letzten Jahren waren die österreichisch-sowjetischen Beziehungen durch das Paradoxon charakterisiert, daß sie sich zwar - an der Zahl der Besuchskon- 
takte gemessen - stark intensiviert haben; daß jedoch gleichzeitig das Verständnis der UdSSR für österreichische Interessen, die ungeachtet der Konstanten der österreichischen Außenpolitik einem Wandel unterliegen können, kaum zugenommen haben dürfte, weil man österreichischerseits in vielen Fällen von ihrer Artikulierung Abstand nahm. Nicht zuletzt deshalb sind die politischen Vorstellungen, die man im sowjetischen Führungsapparat von Österreich hat, noch immer von den Begriffen der 50er Jahre geprägt. Österreich ist für die Sowjets ein Element der „Deutschen Frage“, für das 1955 eine positive und dauerhafte Lösung gefunden wurde. Obwohl Österreich in den vergangenen 30 Jahren als immerwährend neutraler Staat in Mitteleuropa seine Probe bestanden hat und längst nicht mehr im Schatten „Deutschlands“ steht, werden die außen-, sicherheits- und wirtschaftspolitischen Aktivitäten Österreichs von der UdSSR noch immer zu sehr aus diesem Blickwinkel betrachtet, der Flexibilität gegenüber sich wandelnden österreichischen Interessen weitgehend ausschließt. Politische Kontakte, wie sie zwischen Österreich und der UdSSR gepflegt werden, sollten jedoch der Vermehrung des Verständnisses für die Interessen der jeweils anderen Seite dienen. Es wäre auch opportun, sowjetischen Bestrebungen, Staatsvertrag und Neutralitätsp o $1 \mathrm{i} \mathrm{t} \mathrm{i} \mathrm{k} \mathrm{als} \mathrm{ein} \mathrm{untrennbares} \mathrm{Ganzes} \mathrm{zu} \mathrm{betrachten,} \mathrm{das} \mathrm{-} \mathrm{wie} \mathrm{Staatspräsident}$ Gromyko unlängst gegenüber einer österreichischen Parlamentarierdelegation erklärt hat - einer „dynamischem Weiterentwicklung“ bedürfe, in geeigneter Form konsequent entgegenzutreten. Eine Verwischung der Grenzen zwischen völkerrechtlichen Verpflichtungen und autonomen außenpolitischen Entscheidungen, die den sich wandelnden österreichischen Interessen Rechnung tragen, wäre österreichischen Interessen abträglich.

Um die österreichischen Interessen gegenüber der UdSSR wirksam geltend machen zu können, bedarf es zunächst einmal einer gründlichen innerösterreichischen Bestandsaufnahme sowie der Abstimmung und verbindlichen Festlegung österreichischer Positionen. Widersprüchliche oder gar konträre Erklärungen österreichischer Repräsentanten böten der UdSSR die Möglichkeit, faktisch den österreichischen Handlungsspielraum einzuengen.

Ein Besuchsaustausch mit der UdSSR erfordert besonders gründliche Vorbereitung, um österreichische Anliegen klar artikulieren und sowjetische Vorstöße, die österreichischen Positionen zuwiderlaufen, parieren zu können. Sowjetischerseits wird jedem Satz in Kommuniqués, Tischreden und Presseerklärungen viel größere Bedeutung, als es im Westen üblich ist, beigemessen. Mündliche und schriftliche Enunziationen dieser Art dienen der UdSSR zu einem langsamen, oft unmerklichen Ausbau ihrer Positionen; auf sie wird bei gegebenem Anlaß Bezug genommen.

Wenn in der Vergangenheit die österreichisch-sowjetischen Beziehungen von offizieller Seite stets als „herzlich“ bis ,ausgezeichnet“ qualifiziert wurden, so resultiert dies weitgehend aus der Praxis, differierende politische Einschätzungen auf beiden Seiten unerwähnt zu lassen. Nicht immer fragt man sich vor Antritt einer Reise in die UdSSR, was man hier politisch konkret erreichen will. In den österrei- 
chisch-sowjetischen Beziehungen ist seit längerem die Tendenz zu verspüren, die Erörterung heikler Fragen wie etwa

- die Bedeutung einer wirksamen Landesverteidigung zur Sicherung der Neutralität und Souveränität Österreichs, die wohl auch die Verfügbarkeit moderner Verteidigungswaffen einschließt (z.B. Flieger- und Panzerabwehrraketen) und

- die Frage einer allfälligen künftigen Neugestaltung der Beziehungen Österreichs zu einer sich wandelnden Europäischen Gemeinschaft (EG)

auszuklammern. Prima vista sind sowohl eine „Raketenbewaffnung“ des Bundesheeres als auch eine österreichische Mitgliedschaft bei der EG für die UdSSR tabu, weil sie der gängigen sowjetischen Staatsvertragsinterpretation widersprechen. Gleichzeitig bedingt jedoch die technologische, politische und wirtschaftspolitische Entwicklung der letzten 3 Jahrzehnte eine künftige Auseinandersetzung mit diesen Themen. Prognosen abzugeben, wie die sowjetische Haltung im Falle einer österreichischen Relevierung dieser Fragen aussehen wird, wären zum gegenwärtigen Zeitpunkt verfrüht. Die innerösterreichische Diskussion zur Vorbereitung der österreichischen Positionen gegenüber der UdSSR sollte hinter verschlossenen Türen stattfinden. Es wäre unrichtig, die Erörterung heikler Fragen mit der UdSSR nur deshalb weiter auszuklammern, um „die Beziehungen nicht zu belasten“. Es ist zwar eine Tatsache, daß die UdSSR als Signatarmacht des Staatsvertrages über potentielle Mechanismen verfügt, um militär- und außenpolitisch wichtige Schritte Österreichs zu erschweren und allenfalls zu blockieren. Diesen Umstand jedoch stillschweigend hinzunehmen, würde auf die Dauer einem Akzeptieren sowjetischer Standpunkte gleichkommen

Im wirtschaftlichen Bereich sollte Österreich erkennen, daß es sich gegenüber der UdSSR keineswegs immer und überall in einer „Demandeur“-Position befindet. Österreich ist für die UdSSR ein westlicher Wirtschaftspartner, mit dem sie wertvolle Devisen erwirtschaftet. In den Jahren 1980 bis 1984 waren dies auf Grund des bedeutenden Handelsbilanzaktivums zugunsten der UdSSR immerhin $37 \mathrm{Mrd}$ öS. Beim offiziellen Besuchsaustausch mit der UdSSR steht Österreich meist unter dem Erwartungsdruck, daß bedeutende Geschäftsvereinbarungen für die österreichische Exportwirtschaft abgeschlossen werden. Sowjetischerseits könnte dadurch der Eindruck erweckt werden, daß Österreich bei offiziellen Besuchen mit wirtschaftlichen Aufträgen seitens des Sowjetstaates belohnt werden möchte. So reiste beispielsweise Ministerpräsident Tichonow im April 1981 mit einem Großauftrag für Nahtlosröhren nach Österreich, welche die Errichtung des seit seiner Inbetriebnahme bis heuer defizitären VOEST-Werkes in Kindberg zur Folge hatte. Ob die Gewinnspannen im Handel mit der UdSSR stets dem politischen Einsatz entsprechen, sollte einmal eingehend geprüft werden. Die Schiffswerft Korneuburg-Linz produziert fast ausschließlich für den sowjetischen Markt. Neuerdings ist zu beobachten, daß die UdSSR an ausgewählte österreichische Klein- und Mittelbetriebe, die um ihr Überleben kämpfen, Aufträge erteilen. Die UdSSR schafft sich damit 
in immer mehr Bereichen der österreichischen Wirtschaft ein Netz abhängiger Firmen.

Auf dem Energiesektor erreichten die österreichischen Importe aus der UdSSR im Jahre 1984 mit 16,3 Mrd öS eine Rekordhöhe. Im Vergleich zu 1983 stiegen die österreichischen Erdgaseinfuhren, wertmäßig um 71 \%. Auch im 1. Halbjahr 1985 nahmen die sowjetischen Erdgaslieferungen nach Österreich um 23,6 \% zu. Gleichzeitig gingen allerdings die Erdöl- und Kohleimporte aus der UdSSR im 1. Halbjahr 1985 teilweise drastisch zurück. Langfristig wird jedoch auch mit österreichischen Strombezügen aus der UdSSR zu rechnen sein (Stromaustauschvertrag aus 1983). Welche Entwicklungen die österreichischen Energieimporte aus der UdSSR in Zukunft nehmen werden, ist noch nicht klar abzusehen. Es sollte jedoch rechtzeitig an Importplafonds gedacht werden, zumindest dort, wo eine vernünftige alternative Bezugsquelle vorhanden ist.

Die Perspektiven für eine Ausweitung des Außenhandels mit der UdSSR scheinen deshalb begrenzt zu sein, weil nach sowjetischer Außenhandelsstatistik bereits ein Aktivum für Österreich vorliegt. Langfristig könnte nur unter der Voraussetzung mehr in die Sowjetunion exportiert werden, wenn auch Österreich mehr sowjetische Waren importiert. Dies könnte mangels geeigneten Warenangebots nur auf dem Energie- und Rohstoffsektor möglich sein. Ob dies aber wirklich den österreichischen Interessen und dem Bedarf entspricht, sollte Gegenstand grundsätzlicher Überlegungen sein.

Unverändert bemüht sich Österreich um humanitäre Fälle. Soweit bekannt, sind wir das einzige westliche Land, dem die Sowjetunion auch Reaktionen auf die bei offiziellen Besuchen übergebenen Interventionslisten für politisch Verfolgte offiziell mitteilt. Obwohl diese fast ausschließlich negativ sind, bleibt die erfreuliche Tatsache an sich, daß man Österreichs Eintreten sowjetischerseits ernst nimmt. Die Entwicklung im bilateralen und humanitären Bereich ist zwiespältig. Größtenteils gibt es bei Eheschließungen und Familienzusammenführungen keine Probleme, es sei denn, es handelt sich um Fälle in Österreich eingebürgerter ehem. jüdischer Sowjetemigranten. Die Botschaft war und ist ständig - mit oft erfreulichem Erfolg bemüht, auftretende Härtefälle durch Interventionen einer Lösung zuzuführen. Im Bereich der Besuchsreisen hingegen werden seit mehreren Jahren österreichischerseits Fälle anhängig gemacht, welche bei den sowjetischen Behörden aus meist nicht bekannten Gründen immer wieder auf taube Ohren stoßen.

Alles in allem kann aber unter Berücksichtigung der gegebenen Verhältnisse die Bilanz auf dem bilateralen konsularischen Sektor als im wesentlichen positiv angesehen werden.

Was den österreichisch-sowjetischen Kulturaustausch betrifft, der grundsätzlich nur in vertraglich abgesteckten Grenzen und Bahnen abgewickelt werden kann, geht die UdSSR mit größter Selbstverständlichkeit davon aus, daß ihr in Österreich alle Möglichkeiten zur Präsentation ihrer Kultur offenstehen. Umgekehrt ist Österreich bei seinen Bemühungen, in der UdSSR jene kulturellen Leistungen zu zeigen 
auf die unser Land stolz ist, ständig auf den verschiedensten Ebenen bis hin zu den kleinen praktischen Dingen mit Schwierigkeiten und Barrieren konfrontiert. Was in der UdSSR an österreichischer Kultur zugelassen wird, suchen sich die sowjetischen Stellen selbst aus. Dies gilt in besonderem Maße auch für die „Gesellschaften für Freundschaft und kulturelle Beziehungen“(ÖSG/SGÖ).

In allen Bereichen seiner Beziehungen zur UdSSR müßte sich Österreich wieder in vermehrtem Maße bewußt werden, daß österreichische Interessen verteidigt und Erfolge im wahrsten Sinne des Wortes schwer erarbeitet werden müssen. Österreich darf sich nicht durch Leerformeln, die im täglichen diplomatischen Verkehr mit kommunistischen Staaten gebraucht werden, beirren lassen, sondern sollte wieder jenen Mut fassen, der ihm in den 50er Jahren unter viel schwierigeren internationalen Bedingungen die Bewunderung der Weltöffentlichkeit eingebracht hat.

Tut man das nicht, so könnte Österreichs Politik, gegenüber den Oststaaten, vor allem gegenüber der UdSSR, bei anderen westlichen Ländern missverstanden werden. Der Westen könnte sich die Frage stellen, welches Ziel denn Österreich eigentlich mit so großem Einsatz gegenüber dem Osten verfolgt. Kann darauf keine Antwort gegeben werden, so könnte Österreichs Ansehen bei seinen westlichen Freunden Schaden leiden. Die österreichische Botschaft Washington vermittelte in ihrem Bericht Zl. 7-POL/85 ein umfassendes Bild über die Problematik der bilateralen Beziehungen zwischen Österreich und den USA und nannte in diesem Zusammenhang einige negative Züge des österreichischen Image in den USA. Die dort erwähnten Negativa stehen im Zusammenhang mit unserem Verhältnis zum Osten. In Österreich sollte man sich bei der Gestaltung der Politik gegenüber der UdSSR wieder vermehrt Gedanken über ein ausgewogenes ,give and take“ machen. Das österreichisch-sowjetische Verhältnis beruht auf einem gesunden Vertrauenspolster, der durchaus in vernünftigen Grenzen strapazierbar ist. Es wäre jedoch eine trügerische Hoffnung, angesichts bestehender sowjetischer Sympathien für Österreich zu glauben, nur durch „österreichischen Charme“ Erfolge in Verhandlungen mit der UdSSR erreichen zu können. Der „Reblaus-Effekt" bei der Vorbereitung des österreichischen Staatsvertrages, soferne dieser überhaupt wissenschaftlich fundierbar ist, kommt heute sicher nicht mehr zum Tragen.

Abschließend dürfen noch folgende organisatorische Maßnahmen konkret angeregt werden:

Schaffung eines eigenen UdSSR-Desk im BMAA analog zum Koordinator für das USA-Konzept. Nur die Zusammenfassung aller Bereiche der österreichischsowjetischen Beziehungen in der Hand eines UdSSR-Experten ermöglicht eine sorgfältige Prüfung österreichischer Interessen und einen konsequenten Aufbau österreichischer Positionen gegenüber der UdSSR. Sämtliche offiziellen und halboffiziellen Rußlandreisenden sollten möglichst vor und nach ihrer Reise zwecks Briefings und Debriefings mit dem BMAA Kontakt aufnehmen.

Erstellung eines längerfristigen Konzeptes zur Gestaltung unserer Beziehungen zur UdSSR, das in ein umfassendes Ost-West-Konzept, welches die Beziehungen 
Österreichs zu Westeuropa und den USA einschließt, einzuordnen wäre. Zum Unterschied vom USA-Konzept sollte es sich jedoch i.G. um interne vertrauliche außenpolitische Richtlinien handeln.

Der Botschafter

Source: ÖStA, AVA, NL E-1736: Bielka, Folder 115. 


\section{Soviet Ambassadors to Austria, Austrian Ambassadors to the USSR}

\begin{tabular}{|l|l|}
\hline $\begin{array}{l}\text { Ivan I. Il'ichev } \\
\text { 13 June 1953-31 March 1956 }\end{array}$ & $\begin{array}{l}\text { Norbert Bischoff } \\
\text { 3 July 1953-31 March 1960 }\end{array}$ \\
\hline Andrei A. Smirnov & Heinrich Haymerle \\
31 March 1956-14 October 1956 & 17 June 1960-2 June 1964 \\
\hline Sergei G. Lapin & Walter Wodak \\
19 October 1956-16 June 1960 & 7 July 1964-6 October 1970 \\
\hline Viktor I. Avilov & Heinrich Haymerle \\
16 June 1960-13 June 1965 & 3 December 1970-17 June 1974 \\
\hline Boris F. Podtserob & Heinrich Standenat \\
30 June 1965-20 September 1971 & 2 October 1974-17 May 1978 \\
\hline Averkii B. Aristov & Gerald Hinteregger \\
20 September 1971-11 July 1973 [sic] & 8 September 1978-11 July 1981 \\
\hline Mikhail T. Efremov & Helmut Liedermann \\
10 March 1975-24 October 1986 & 1 October 1981-25 November 1985 \\
\hline Gennadii S. Shikin & Herbert Grubmayr \\
24 October 1986-24 May 1990 & 27 November 1985-29 September 1990 \\
\hline Valerii I. Popov & Friedrich Bauer \\
10 August 1990-30 August 1996 & 15 October 1990-31 July 1995 \\
\hline
\end{tabular}

Source: Russian Embassy in Vienna, www.rusemb.at/botschaft/diebotschafter (2010); Information by the Austrian Ministry of European and International Affairs to the Author, 22 June 2009. 



\section{Abbreviations}

ABM Anti-Ballistic Missile

AdR Archiv der Republik [Archive of the Republic, Vienna, Austria]

APA Austria Presse Agentur [Austrian Press Agency]

APN Agentstvo Pechati Novosti [Novosti Press Agency]

AVPRF Arkhiv vneshnei politiki Rossiiskoi Federatsii [The Russian Federation's Archive of Foreign Policy, Moscow, Russia]

BA Bundesarchiv [Federal Archives, Berlin, Germany]

BMAA Bundesministerium für Auswärtige Angelegenheiten [Ministry of Foreign Affairs, Vienna, Austria]

BMLV Bundesministerium für Landesverteidigung [Ministry of Defense, Vienna, Austria]

CC Central Committee

CDSP Current Digest of the Soviet Press

CMEA Council of Mutual Economic Assistance

COCOM Coordinating Committee on Multilateral Export Controls

CPSU Communist Party of the Soviet Union

CSBM Confidence and Security Building Measures

CSCE Conference on Security and Cooperation in Europe

CWIHP Cold War International History Project

EA Europa-Archiv

EC European Community

ECSC European Coal and Steel Community

EEC European Economic Community

EFTA European Free Trade Association

ERP European Recovery Program

EU European Union

FO Foreign Office

FPÖ Freiheitliche Partei Österreichs [Austrian Freedom Party]

FRG Federal Republic of Germany

FRUS Foreign Relations of the United States

FTA Free Trade Area

GATT General Agreement on Tariffs and Trade

GDR German Democratic Republic

GF Gorbachev Foundation, Moscow, Russian Federation

GNP Gross national product

IAEA International Atomic Energy Agency

IMEMO Institut mirovoi ekonomiki i mezhdunarodnykh otnoshenii [Institute of World Economics and International Relations]

INF Intermediate Range Nuclear Forces

KPÖ Kommunistische Partei Österreichs [Communist Party of Austria]

MBFR Mutual balanced force reductions

MFA Ministry of Foreign Affairs

MÖSTA Mitteilungen des Österreichischen Staatsarchivs 
MRP Ministerratsprotokolle [Cabinet Protocols]

NATO North Atlantic Treaty Organization

NL Nachlass

$\mathrm{N}+\mathrm{N} \quad$ neutral and nonaligned states

NSC National Security Council

NSDAP Nationalsozialistische Deutsche Arbeiterpartei [National Socialist German Workers Party]

NYT New York Times

ÖAW Österreichische Akademie der Wissenschaften [Austrian Academy of Sciences]

OECD Organization for Economic Cooperation and Development

OEEC Organization for European Economic Cooperation

ÖGB Österreichischer Gewerkschaftsbund [Austrian Federation of Trade Unions]

ORF Österreichischer Rundfunk [Austrian Broadcasting Corporation]

OSCE Organization for Security and Cooperation in Europe

ÖSG Österreichisch-Sowjetische Gesellschaft [Austrian-Soviet Society]

ÖStA Österreichisches Staatsarchiv [Austrian State Archives, Vienna, Austria]

ÖVP Österreichische Volkspartei [Austrian People's Party]

ÖZA Österreichische Zeitschrift für Außenpolitik

PHP Parallel History Project on NATO and the Warsaw Pact

RGANI Rossiiskii gosudarstvennyi arkhiv noveishei istorii [Russian State Archives of Contemporary History, Moscow, Russia]

RGASPI Rossiiskii gosudarstvennyi arkhiv sotsial'no- politicheskoi istorii [Russian State Archives of Social and Political History, Moscow, Russia]

SALT Strategic Arms Limitation Talks / Treaty

SAPMO Stiftung Archiv der Parteien und Massenorganisationen der DDR [The GDR Political Parties' and Organizations' Archives, Berlin, Germany]

SBKA Stiftung Bruno-Kreisky-Archiv [Bruno Kreisky Archive, Vienna, Austria]

SDI Strategic Defense Initiative

SPÖ Sozialistische (since 1991: Sozialdemokratische) Partei Österreichs [Socialist (since 1991: Social democratic) Party of Austria]

SS Schutzstaffel

$\mathrm{UN}(\mathrm{O}) \quad$ United Nations (Organization)

UNRRA United Nations Relief and Rehabilitation Administration

US(A) United States (of America)

USIA Upravlenie Sovetskim imushchestvom v Avstrii [Administration of Soviet Enterprises in Austria]

USSR Union of Soviet Socialist Republics

VdU Verband der Unabhängigen [Union of Independents]

VÖEST Vereinigte Österreichische Eisen- und Stahlwerke [Austrian Steel Corporation] 


\title{
Bibliography
}

\author{
Interviews
}

Ambassador Herbert Grubmayr, 15 July 2009

Ambassador Gerald Hinteregger, 23 June 2009

\section{Archival Sources, Russian Federation}

\author{
AVPRF Arkhiv vneshnei politiki Rossiiskoi Federatsii, Moscow \\ Fond 66: Foreign Ministry of the USSR, Austrian Desk \\ GF Gorbachev Foundation, Moscow \\ Fond 1, opis 1: Conversation Gorbachev with Vranitzky, 11 October 1988 \\ Fond 1, opis 1: Conversation Gorbachev with Vranitzky, 30 September 1991 \\ Fond 2, opis 1: Cherniaev to Gorbachev, 11 November 1990 \\ Fond 3, Doc. 4840: Conversation Zagladin with Kreisky, 9 September 1986 \\ Fond 3, Doc. 7250: Conversation Zagladin with Lanc, 22 January 1990
}

RGANI Rossiiskii gosudarstvennyi arkhiv noveishei istorii, Moscow

Fond 2: Central Committee Plenums

Fond 5, opis 30: Department of the Central Committee

Fond 89: Collection of Documents

RGASPI Rossiiskii gosudarstvennyi arkhiv sotsial'no-politicheskoi istorii, Moscow

Fond 82: Papers of Viacheslav Molotov

\section{Archival Sources, Austria}

ÖIZG Österreichisches Institut für Zeitgeschichte, Vienna

NL 72: Papers of Martin Fuchs, Austrian Ministry of Foreign Affairs, secretary general

ÖStA Österreichisches Staatsarchiv, Vienna

AdR, BKA, MRP: Austrian Council of Ministers

AdR, BKA, Präsidium: Presidium of the Federal Chancellery

AdR, BMAA, Sektion II-Pol, UdSSR: Austrian Foreign Ministry, Political Department, Soviet Desk

AdR, BMAA, Politische Berichte Moskau: Reports of the Austrian Embassy in Moscow

AVA, NL E/1736: Papers of Erich Bielka, minister of foreign affairs

AVA, NL E/1770: Papers of Norbert Bischoff, ambassador to Moscow

AVA, NL E/1785: Papers of Walter Wodak, Austrian Ministry of Foreign Affairs, secretary general, ambassador to Moscow

SBKA Stiftung Bruno-Kreisky-Archiv, Vienna

Collection of documents from Russian archives 
Diaries of Josef Staribacher, minister of trade

Integration, Box 3-4: Austrian Foreign Ministry and Federal Chancellery, European Affairs

Länderboxen UdSSR, Box 1-7: Austrian Foreign Ministry and Federal Chancellery, Soviet Affairs

NL Thalberg, Depositum 1: Papers of Hans Thalberg

\section{Periodicals}

Archiv der Gegenwart (1955-1991).

Außenpolitischer Bericht (1982-1992).

Current Digest of the Soviet Press 7 (1955)-43 (1991).

Europa-Archiv 1 (1946)-46 (1991).

International Affairs (Moscow: Zanie, 1959-1991).

Keesing's Contemporary Archives: Record of World Events (1955-1991).

Letopis' gazetnykh statei (1958-1991).

Neue Zeit (Moscow: Trud, 1955-1981) = German-language ed. of Novoe vremia.

OECD Economic Outlook 9 (1971)-50 (1991).

Österreichisches Jahrbuch für internationale Politik 1 (1984)-8 (1991).

Österreichische Zeitschrift für Außenpolitik 1 (1960-61)-23 (1983).

Sowjetunion heute 1 (1955)-36 (1990).

Vneshnie ekonomicheskie sviazi SSSR (1988-1990).

Vneshniaia torgovlia SSSR (1960-1987).

\section{Published Sources and Memoirs}

Afanasyeva, O., “A Threat to Neutrality,” in International Affairs, no. 12 (December 1961), 85-86.

Akademie der Wissenschaften der UdSSR - Rechtsinstitut (ed.), Völkerrecht: Lehrbuch (Berlin: VEB Deutscher Zentralverlag, 1960), see also Koschewnikow, Koshewnikow, Kozhevnikov.

Aleksandrov-Agentov, A. M., Ot Kollontai do Gorbacheva: Vospominaniia diplomata, sovetnika A.A. Gromyko (Moscow: Mezhdunarodnye otnosheniia, 1994).

Allard, Sven, Diplomat in Wien: Erlebnisse, Begegnungen und Gedanken um den österreichischen Staatsvertrag (Cologne: Wissenschaft und Politik, 1965).

Allardt, Helmut, Moskauer Tagebuch: Beobachtungen, Notizen, Erlebnisse. 3rd ed. (Düsseldorf: Econ, 1973).

Allardt, Helmut, Politik vor und hinter den Kulissen: Erfahrungen eines Diplomaten zwischen Ost und West (Düsseldorf: Econ, 1979).

Andreyeva, M., and K. Dmitrieva, "The Soviet Union and Swedish Neutrality in the Second World War," in International Affairs, no. 9 (September 1959), 66-71.

Arbatov, Georgy, The System: An Insider's Life in Soviet Politics (New York: Times, 1992).

Bahr, Egon, Zu meiner Zeit (Berlin: Siedler, 1996).

Brandt, Willy, Erinnerungen (Berlin: Siedler, 1999).

Bauer, Friedrich, Russische Umbrüche: Von Gorbatschow über Jelzin zu Putin: Botschafter in Russland 1990 bis 1995 (Graz: Vehling, n.D.).

Begischew, Valeri, “Wo sich Europas Straßen kreuzen,” in Neue Zeit, no. 14 (1974), 14-16.

Békés, Csaba, Malcolm Byrne, and János M. Rainer (eds.), The 1956 Hungarian Revolution: A History in Documents (Budapest: Central European University Press, 2002).

Beletskii, Viktor N., Sovetskii Soiuz i Avstriia: Bor'ba Sovetskogo Soiuza za vozrozhdenie nezavisimoi i demokraticheskoi Avstrii i ustanovlenie s nei druzhestvennykh otnoshenii 1938-1960gg. (Moscow: Institut Mezhdunarodnykh otnoshenii, 1962).

Bovin, A. E., "Peaceful Coexistence," in A. M. Prokhorov et al. (eds.), Great Soviet Encyclopedia 16, 3rd ed. (New York: Macmillan, 1977), 625-627. 
Breshnew, L. I., Rechenschaftsbericht des Zentralkomitees der Kommunistischen Partei der Sowjetunion und die nächsten Aufgaben der Partei in der Innen- und Außenpolitik, Informationsbulletin Sonderausgabe 1 (Prague: Frieden und Sozialismus, 1976).

[Brezhnev, L. I.,] "Rechenschaftsbericht des Zentralkomitees der KPdSU an den XXIV. Parteitag der Kommunistischen Partei der Sowjetunion, Referent: L. I. Breshnew," 30 March 1971, in XXIV. Parteitag der Kommunistischen Partei der Sowjetunion 30. März-9. April 1971: Dokumente (Moscow: APN, 1971), 3-198.

Budnitskii, O. V. and O.V. Belova (eds.), Evreiskaia emigratsiia iz Rossii 1881-2005 (Moscow: Rosspen, 2008).

Chernikov, G., "Europe's Smaller Countries in the Capitalist System," in International Affairs, no. 1 (January 1982), 105-111.

Chruschtschow, N. S., Für dauerhaften Frieden und friedliche Koexistenz (Berlin: Dietz, 1959).

Chruschtschow, N. S., Rechenschaftsbericht des Zentralkomitees der Kommunistischen Partei der Sowjetunion an den XX. Parteitag 14. Februar 1956 (Moscow: Verlag für Fremdsprachige Literatur, 1956).

Chuev, Felix, and Albert Resis (eds.), Molotov Remembers: Inside Kremlin Politics: Conversations with Felix Chuev (Chicago: Ivan R. Dee, 1993).

Die Initiative der Sowjetunion brachte Österreich den Staatsvertrag: Dokumente und Materialien zum Abschluss des Staatsvertrages mit Österreich (Vienna: Sowjetischer Informationsdienst, 1955).

Die Kommunisten im Kampf für die Unabhängigkeit Österreichs: Sammelband (Vienna: Stern, 1955).

Die Warschauer Konferenz, Beilage zu Neue Zeit, no. 21 (1955).

Dobrynin, Anatoly, In Confidence: Moscow's Ambassador to America's Six Cold War Presidents 1962-1986 (New York: Times Books, 1995).

Dokumente zur Deutschlandpolitik III/3, no. 3: 1957, bearb. von Ernst Deuerlein, Gisela Biewer und Hansjürgen Schierbaum (Frankfurt am Main: Metzner, 1967).

Dokumente zur Deutschlandpolitik III/4, no. 1: 1 Jan.-20 Mar. 1958, bearb. von Ernst Deuerlein und Gisela Biewer (Frankfurt am Main: Metzner, 1969).

Dokumente zur Deutschlandpolitik III/4, no. 2: 20 Mar-31 Jul. 1958, bearb. von Ernst Deuerlein und Gisela Biewer (Frankfurt am Main: Metzner, 1969).

Dokumente zur Deutschlandpolitik IV/1, no. 1: 10 Nov. 1958-31 Jan. 1959, bearb. von Ernst Deuerlein und Hannelore Nathan (Frankfurt am Main: Metzner, 1971).

Dokumente zur Deutschlandpolitik IV/5: 1 Jul.-31 Dec. 1960, bearb. von Gunther Holzweißig (Frankfurt am Main: Metzner, 1973).

Druzhestvennyi vizit: Prebyvanie Predsedatel'ia Soveta Ministrov SSSR N.S. Khrushcheva v Avstriiskoi Respublike 30 iiuniia-6 iiulia 1960g. (Moscow: Gospolitizdat, 1960).

Durdenewski, W., "Zur schweizerischen Neutralität," in Neue Zeit, no. 22 (1955), 28-30.

Eiselsberg, Otto, Erlebte Geschichte 1917-1997 (Vienna: Böhlau, 1997).

Engels, Frederick, "Political Position of the Swiss Republic," [1853], in Karl Marx and Frederick Engels, Collected Works 12 (Moscow: Progress, 1979), 86-92.

Eppel, Peter, and Heinrich Lotter (eds.), Dokumentation zur österreichischen Zeitgeschichte 19551980 (Vienna: Jugend \& Volk, 1981).

Ermacora, Felix, Österreichs Staatsvertrag und Neutralität (Frankfurt am Main: Metzner, 1957).

Ermacora, Felix, 20 Jahre österreichische Neutralität (Frankfurt am Main: Metzner, 1975).

Ermakov, O., "Vneshniaia politika Avstrii i razvitie sovetsko-avstriiskikh otnoshenii v 80ye gody" (PhD Thesis, Moscow, 1988).

Falin, Valentin, Politische Erinnerungen (Munich: Droemer Knaur, 1993).

Foreign Relations of the United States, 1955-1957, XXVI: Central and Southeastern Europe (Washington, DC: Government Printing Office, 1992).

Foreign Relations of the United States, 1958-1960, IX: Berlin Crisis, Germany, Austria (Washington, DC: Government Printing Office, 1993). 
Foreign Relations of the United States, 1961-1963, XVI: Eastern Europe (Washington, DC: Government Printing Office, 1994).

Foreign Relations of the United States, 1963-1968, XVII: Eastern Europe (Washington, DC: Government Printing Office, 1996).

Frolow, M., "Neutralität auf Widerruf?," in Neue Zeit, no. 51 (1959), 12-14.

Für den Frieden und die Sicherheit in Europa: Konferenz der kommunistischen und Arbeiterparteien Europas zu Fragen der europäischen Sicherheit, Karlovy Vary, 24. bis 26. April 1967 (Berlin: Dietz, 1967).

Fursenko, A. A. et al (eds.), Prezidium TsK KPSS 1954-1964, 3 vols. (Moscow: Rosspen, 2003-2008).

Ganiushkin, B. V., Neitralitet i neprisoedinenie (Moscow: Mezhdunarodnye otnosheniia, 1965).

Ganiushkin, B. V., Sovremennyi neitralitet: Politika neitraliteta i postoiannyi neitralitet $v$ usloviakh bor'by za mir (Moscow: Institut mezhdunarodnykh otnoshenii, 1958).

Gehler, Michael, Der lange Weg nach Europa: Österreich von Paneuropa bis zum EU-Beitritt: Dokumente (Innsbruck: Studienverlag, 2002).

Goldwin, Robert A., Gerald Stourzh and Marvin Zetterbaum (eds.), Readings in Russian Foreign Policy (New York: Oxford University Press, 1959).

Gottschlich, Maximilian, Oswald Panagl, and Manfred Welan (eds.), Was die Kanzler sagten: Regierungserklärungen der Zweiten Republik 1945-1987 (Vienna: Böhlau, 1989).

Grinevskij, Oleg, Tauwetter: Entspannung, Krisen und neue Eiszeit (Berlin: Siedler, 1996).

Gromyko, A. A. (ed.), Die friedliche Koexistenz: Der Leninsche Kurs der Außenpolitik der Sowjetunion (Berlin: Staatsverlag der DDR, [1964]).

Gromyko, A. A., S. A. Golunskii, and V. M. Khvostov (eds.), Diplomaticheskii slovar', 2nd ed., 3 vols. (Moscow: Gospolitizdat, 1960-1964).

Gromyko, A. A., I. N. Zemskov, and V. M. Khvostov (eds.), Diplomaticheskii slovar', 3rd ed., 3 vols. (Moscow: Politizdat, 1971-1973).

Gromyko, A. A. et al. (eds.), Diplomaticheskii slovar', 4th ed., 3 vols. (Moscow: Nauka, 1984-1986).

Gromyko, Andrej, Erinnerungen (Düsseldorf: Econ, 1989).

Gromyko, A. A., and B. N. Ponomarjow (eds.), Geschichte der sowjetischen Außenpolitik 1945 bis 1976 (Berlin: Staatsverlag der DDR, 1978).

Gromyko, Andrei, Memories (London: Hutchinson, 1989).

Gromyko, A., "V. I. Lenin i vneshniaia politika Sovetskogo gosudarstva," in Kommunist 59, no. 6 (1983), 11-32.

Grubmayr, Herbert, "In zwei Wochen gehst Du nach Moskau,” in Demokratie und Geschichte (1999), $127-154$.

Grubmayr, Herbert, "Streiflichter aus meiner Moskauer Zeit," in Alfred Stirnemann and Gerhard Wilflinger (eds.), Russland und Österreich, Pro Oriente XXIII (Innsbruck: Tyrolia, 1999), 258-277.

Hinteregger, Gerald, "Erinnerungen an Moskau 1978-1981," in Alfred Stirnemann and Gerhard Wilflinger (eds.), Russland und Österreich, Pro Oriente XXIII (Innsbruck: Tyrolia, 1999), 244-257.

Hinteregger, Gerald, Im Auftrag Österreichs: Gelebte Außenpolitik von Kreisky bis Mock (Vienna: Amalthea, 2008).

International Association of Democratic Lawyers (ed.), Legal Aspects of Neutrality: Proceedings of the Third Commission (Brussels: International Association of Democratic Lawyers, 1960).

Iwanow, W., and D. Nikolajew, "Wider den Geist der Entspannung," in Neue Zeit, no. 44 (1976), 26-27.

Jacobsen, Hans-Adolph, Wolfgang Mallmann, and Christian Meier (eds.), Sicherheit und Zusammenarbeit in Europa (KSZE): Analyse und Dokumentation, 2 vols. (Cologne: Wissenschaft und Politik, 1973).

Jegorow, W. I., Friedliche Koexistenz und revolutionärer Prozess (Berlin: Staatsverlag der DDR, 1972). 
Jelagin, Wjatscheslaw, "Fundament der Neutralität," in Neue Zeit, no. 45 (1978), 8-9.

Karner, Stefan, Barbara Stelzl-Marx, and Alexander Tschubarjan (eds.), Die Rote Armee in Österreich: Dokumente (Vienna: Oldenbourg, 2005).

Karner, Stefan, Natalia Tomilina, and Alexander Tschubarjan (eds.), Prager Frühling: Das internationale Krisenjahr 1968: Dokumente (Vienna: Böhlau, 2008).

Kekkonen, Urho, A President's View (London: Heinemann, 1982).

Khrushchev, Sergei N., Nikita Khrushchev and the Creation of a Superpower (University Press: The Pennsylvania State University Press, 2000).

Khrushchev, Nikita S., For Victory in Competition with Capitalism (New York: Dutton, 1960).

Khrushchev, Nikita, Khrushchev Remembers, ed. by Strobe Talbott (Boston: Little Brown, 1970).

Khrushchev, Nikita, Khrushchev Remembers: The Glasnost Tapes, ed. by Jerrold Schechter and Vladimir Luchkov (Boston: Little Brown, 1990).

Khrushchev, Nikita, Khrushchev Remembers: The Last Testament, ed. by Strobe Talbott (Boston: Little Brown, 1974).

Khrushchev, Nikita, Memoirs of Nikita Khrushchev III: The Statesman, 1953-1964, ed. by Sergei Khrushchev (University Park: The Pennsylvania State University Press, 2007).

Khrushchev, N. S., O mirnom sosushchestvovanii (Moscow: Gospolitizdat, 1959).

Khrushchev, N. S., "On Peaceful Coexistence," in Foreign Affairs 38, no. 1 (October 1959), 1-18.

Khrushchev, N. S., Otchetnyi doklad Tsentral'nogo Komiteta Kommunisticheskoi partii Sovetskogo Soiuza XX s"ezdu partii (Moscow: Gospolitizdat, 1956).

Khrushchev, N. S., Otchet Tsentral'nogo Komiteta Kommunisticheskoi partii Sovetskogo Soiuza XXII s"ezdu partii (Moscow: Gospolitizdat, 1961).

Khrushchev, Nikita S., "The Task of Surpassing the U.S.A.," [1957], in Robert A. Goldwin, Gerald Stourzh, and Marvin Zetterbaum (eds.), Readings in Russian Foreign Policy (New York: Oxford University Press, 1959), 450-463.

Khrushchev, Nikita S., Vremia, liudi, vlast': Vozpominaniia (Moscow: Novosti, 1999).

Kleinert, Detlev, Willibald Pahr: Außenminister unter Kreisky: Analysen zum Zeitgeschehen (Vienna: Böhlau, 2010).

Kobliakov, I. K., G. G. Kuranov, and D. N. Mochalin, SSSR v bor 'be za nezavisimost'Avstrii (Moscow: Politizdat, 1965).

[Korovin, E. A.,] "Istoriia mezhdunarodnogo prava," in F.I. Kozhevnikov (ed.), Mezhdunarodnoe pravo (Moscow: Iurizdat, 1957), 24-85.

[Korowin, E. A.,] "Begriff, Quellen und System des Völkerrechts,“ in F.I. Koschewnikow (ed.), Völkerrecht (Hamburg: Hansischer Gildenverlag, 1960), 1-20.

Koschewnikow, F. I., "Die Gesetze und Gewohnheiten des Krieges," in idem (ed.), Völkerrecht (Hamburg: Hansischer Gildenverlag, 1960), 415-469.

Koschewnikow, F. I. (ed.), Völkerrecht (Hamburg: Hansischer Gildenverlag, 1960).

Koshewnikow, F. I. (ed.), Völkerrecht: Lehrbuch (Berlin: VEB Deutscher Zentralverlag, 1960).

Kozhevnikov, F. I. (ed.), Mezhdunarodnoe pravo (Moscow: Iurizdat, 1957).

Kreisky, Bruno, "Austria Draws the Balance," in Foreign Affairs 37, no. 2 (January 1959), 269-281.

Kreisky, Bruno, Neutralität und Koexistenz: Aufsätze und Reden (Munich: List, 1975).

Kreisky, Bruno, Der Mensch im Mittelpunkt: Der Memoiren dritter Teil, ed. by Oliver Rathkolb, Johannes Kunz, and Margit Schmidt (Vienna: Kremayr \& Scheriau, 1996).

Kreisky, Bruno, Die Herausforderung: Politik an der Schwelle des Atomzeitalters (Düsseldorf: Econ, 1963).

Kreisky, Bruno, Im Strom der Politik: Der Memoiren zweiter Teil (Vienna: Kremayr \& Scheriau, 1988).

Kreisky, Bruno, Reden, 2 vols. (Vienna: Verlag der Österreichischen Staatsdruckerei, 1981-1982).

Kreisky, Bruno, Voraussetzungen der Koexistenz (Freiburg im Breisgau: Rombach, 1960). 
Kreisky, Bruno, Zwischen den Zeiten: Erinnerungen aus fünf Jahrzehnten (Vienna: Kremayr \& Scheriau, 1988).

Kremenyuk, Viktor A., "The European Neutrals and Soviet-American Relations," in Hanspeter Neuhold and Hans Thalberg (eds.), The European Neutrals in International Affairs, Laxenburg Papers 7 (Vienna: Braumüller, 1984), 93-103.

Krestjaninow, R., "Positive Wandlungen,” in Neue Zeit, no. 1 (1977), 16.

Kriechbaumer, Robert (ed.), Die Ära Josef Klaus: Österreich in den „kurzen “ sechziger Jahren: Dokumente (Vienna: Böhlau, 1998).

Kudriashov, Sergei (ed.), General'nyi sekretar' L.I. Brezhnev 1964-1982, Vestnik Archiva Prezidenta: Spetsial'noe izdanie (Moscow: Vestnik Archiva Prezidenta, 2006).

Kynin, G. P., and J. Laufer (eds.), SSSR i Germanskii vopros 1941-1949: Dokumenty iz arkhiva vneshnei politiki, 3 vols. (Moscow: Mezhdunarodnye otnosheniia, 1996-2000).

Lenin, V. I., On Peaceful Coexistence (Moscow: Foreign Language Publishing, [1962]).

Lenin, V. I., "Tasks of the Left Zimmerwaldists in the Swiss Social Democratic Party," in idem, Collected Works 23, 4th English ed. (Moscow: Progress, 1964), 137-148.

[Levin, D. B., and G. P. Kaliuzhnaia (eds.)], Mezhdunarodnoe pravo (Moscow: Iuridicheskaia literatura, 1964).

Lewin, D. B., "Grundprinzipien des modernen Völkerrechts," in Drei sowjetische Beiträge zur Völkerrechtslehre (Hamburg: Hansischer Gildenverlag, 1969), 59-306. = Osnovnye problemy sovremennogo mezhdunarodnogo prava (Moscow: Gosiurizdat, 1958).

Lewin, D. B., and G. P. Kaljushnaja (eds.), Völkerrecht (Berlin: Staatsverlag der DDR, 1967).

Lisovskii, V. I., Mezhdunarodnoe pravo (Moscow: Vysshaia shkola, 1970).

Machiavelli, Nicolò, The Prince (1515).

Maksimova, M. (ed.), Ekonomicheskie gruppirovki v zapadnoi Evrope (Moscow: Nauka, 1969).

Mastny, Vojtech, and Malcolm Byrne (eds.), A Cardboard Castle? An Inside History of the Warsaw Pact 1955-1991 (Budapest: Central European University Press, 2005).

Mayrzedt, Hans, and Waldemar Hummer (eds.), 20 Jahre österreichische Neutralitäts- und Europapolitik 1955-1975, Österreichische Gesellschaft für Außenpolitik Schriftenreihe 9, 2 vols. (Vienna: Braumüller, 1976).

Meissner, Boris (ed.), Das Parteiprogramm der KPdSU 1903 bis 1961 (Cologne: Wissenschaft und Politik, 1962).

Melnikow, I., "nicht verharmlosen!," in Neue Zeit, no. 2 (1979), 14.

Melnikow, Igor, "Österreich - Land mit Funktion," in Neue Zeit, no. 48 (1974), 25-27.

Melnikov, Igor, "Partner im Alpenland," in Neue Zeit, no. 7 (1980), 12-13.

Mičunović, Veljko, Moskauer Tagebücher 1956-1958 (Stuttgart: Klett-Cotta, 1982).

Mikoian, Anastas I., Tak bylo: Razmyshleniia o minuvshem (Moscow: Vagrius, 1999).

Ministerium für auswärtige Angelegenheiten der UdSSR (ed.), UdSSR-Österreich 1938-1979 (Moscow: Novosti, 1980).

"Mirnoe sosushchestvovanie," in A.A. Gromyko, S. A. Golunskii, and V.M. Khvostov, Diplomaticheskii slovar' 2, 2nd ed. (Moscow: Gospolitizdat, 1961), 297-300.

Modzhorian, L. A., Politika neitraliteta (Moscow: Znanie, 1962).

Mojoryan [Modzhorian], L. A., "Neutrality in Present-Day International Law," in Grigory Tunkin (ed.), Contemporary International Law: Collection of Articles (Moscow: Progess, 1969), 216232.

Molden, Fritz, Besetzer, Toren, Biedermänner: Ein Bericht aus Österreich, 1945-1962 (Vienna: Molden, 1980).

Morozov, B. (ed.), Evreiskaia emigratsiia v svete novykh dokumentov (Tel-Aviv: Ivrus, 1998).

Motschalin, Dmitri, “Österreich nach den Wahlen,” in Neue Zeit, no. 12 (1966), 23-24.

Mueller, Wolfgang, Arnold Suppan, Norman Naimark, and Gennadij Bordjugov (eds.), Sowjetische Politik in Österreich: Dokumente aus russischen Archiven: Sovetskaia politika v Avstrii: Doku- 
menty iz Rossiiskikh arkhivov 1945-1955 (Vienna: Verlag der Österreichischen Akademie der Wissenschaften, 2005).

"Neitralitet," in O. Iu. Shmidt et al. (eds.), Bol'shaia Sovetskaia Entsiklopediia 41 (Moscow: OGIZ, 1939), 487-489.

"Neitralitet," in A. M. Prokhorov et al. (eds.), Bol'shaia Sovetskaia Entsiklopediia 17, 3rd ed. (Moscow: "Sovetskaia entsiklopediia," 1974), 422.

"Neitralitet," in A. Ia. Vyshinskii (ed.), Diplomaticheskii slovar' 2, 1st ed. (Moscow: Gospolitizdat, 1950), 230-234.

"Neitralitet," in A. A. Gromyko, S. A. Golunskii, and V. M. Khvostov (eds.), Diplomaticheskii slovar' 2, 2nd ed. (Moscow: Gospolitizdat, 1961), 392-395.

"Neitralitet," in A. A. Gromyko, I. N. Zemskov, and V. M. Khvostov (eds.), Diplomaticheskii slovar' 2, 3rd ed. (Moscow: Politizdat, 1973), 373-374.

"Neitralitet," in A. A. Gromyko et al. (eds.), Diplomaticheskii slovar' 2, 4th ed. (Moscow: Nauka, 1985), 271-272.

"Neitralitet pozitivnyi," in A. A. Gromyko, S. A. Golunskii, and V. M. Khvostov (eds.), Diplomaticheskii slovar' 2, 2nd ed (Moscow: Gospolitizdat, 1961), 395-396.

"Neitralitet postoiannyi," in A. A. Gromyko, S. A. Golunskii, and V. M. Khvostov (eds.), Diplomaticheskii slovar' 2, 2nd ed (Moscow: Gospolitizdat, 1961), 396-397.

"Neitral'nye gosudarstva," in O. Iu. Shmidt et al. (eds.), Bol'shaia Sovetskaia Entsiklopediia 41 (Moscow: OGIZ, 1939), 495-497.

Nenning, Günther, "Die Neutralitätslegende," in Heute, 31 October 1959, 1.

Nenning, Günther, "Das 'Freiwillige' unserer Neutralität," in Heute, 7 November 1959, 4.

Nenning, Günther, "Österreich will, was es muss," in Heute, 14 November 1959, 4.

Nenning, Günther, "Neutralität auf Widerruf," in Heute, 21 November 1959, 4.

Nenning, Günther, "UNO-Beitritt verletzte die Neutralität," in Heute, 28 November 1959, 4.

Nenning, Günther, "Neutralität und EWG-Beitritt," in Heute, 5 December 1959, 5.

"Neprisoedineniia dvizhenie," in A. A. Gromyko et al. (eds.), Diplomaticheskii slovar' 2, 4th ed. (Moscow: Nauka, 1985), 277-278.

"Neprisoedineniia politika," in A. A. Gromyko, I. N. Zemskov, and V. M. Khvostov (eds.), Diplomaticheskii slovar' 2, 3rd ed., (Moscow: Politizdat, 1971), 379-380.

"Neprisoedineniia printsip," in A. M. Prokhorov et al. (eds.), Bol'shaia Sovetskaia Entsiklopediia 17, 3rd ed. (Moscow: "Sovetskaia entsiklopediia," 1974), 498-499.

"Neutrality," in A. M. Prokhorov et al. (eds.), Great Soviet Encyclopedia 17, 3rd ed. (New York: Macmillan, 1974), 518-519.

Nikolajew, G., "Die Neonazis in Österreich," in Neue Zeit, no. 37 (1969), 30-31.

Nikolayev, G., "Foreign Capital in Austria," in International Affairs, no. 9 (September 1971), 93-96.

Novosel'tsev, E. N., Vneshniaia politika Avstrii (Moscow: Mezhdunarodnye otnosheniia, 1962).

Okhantsev, S., "An Example of Peaceful Coexistence," in International Affairs, no. 9 (1958), 85-86.

Organizatsiia Varshavskogo Dogovora: Dokumenty i materialy, 1955-1975 (Moscow: Gospolitizdat, 1976).

Orlow, Juri, "BRD - Österreich: Gefährliche Liebschaft," in Neue Zeit, no. 46 (1977), 14-26.

Osnitskaya, G., "Neutrality and the Common Market," in International Affairs, no. 6 (June 1962), $52-55$.

"Plenum Transcripts, 1955-1957," in Cold War International History Project Bulletin 10 (1998), 34-60.

Plenum TsK KPSS 18-21 iiunia 1963g.: Stenograficheskii otchet (Moscow: Izdatel'stvo politicheskoi literatury, 1963).

Plenum TsK KPSS 14-15 iiunia 1983g.: Stenograficheskii otchet (Moscow: Izdatel'stvo politicheskoi literatury, 1983). 
Poljanow, Nikolaj, "Europa, die Politik der Neutralität und Österreich,” in Österreichische Zeitschrift für Außenpolitik 6 (1966), 443-451.

Polyanov, N., "Austria, Neutrality, Europe," in International Affairs, no. 9 (September 1973), 82-88.

"Postoiannyi Neitralitet," in A. Ia. Vyshinskii (ed.), Diplomaticheskii slovar' 2, 1st ed. (Moscow: Gospolitizdat, 1950), 439-440.

Podkopayev, A., "International Economic Cooperation USSR - Austria," in International Affairs, no. 2 (February 1984), 145-147,

Prokhorov, A. M. et al. (eds.), Bol'shaia Sovetskaia Entsiklopediia, 3rd ed., 31 vols. (Moscow: Sovetskaia Entsiklopediia, 1970-1981).

Prusakov, Iu. M., Neitralitet v sovremennom mezhdunarodnom prave (Moscow: Znanie, 1972).

Rozanov, G., "Austria: Twenty Years of Independent and Democratic Development," in International Affairs, no. 6 (June 1975), 66-72.

Ruggenthaler, Peter (ed.), Stalins großer Bluff: Die Geschichte der Stalinnote in sowjetischen Dokumenten (Munich: Oldenbourg, 2007).

Sal'kovskii, O. V., Ekonomicheskoe polozhenie rabochego klassa Avstrii posle vtoroi mirovoi voiny (Moscow: Sotsekgiz, 1958).

Sanakojew, Schalwa, and Nikolai Kaptschenko, Theorie der Außenpolitik des Sozialismus (Berlin: Staatsverlag der DDR, 1979).

Savenok, G., Venskie vstrechi (Moscow: Voennoe izdatel'stvo, 1961).

Schenk, Fritz (ed.), Kommunistische Grundatzerklärungen 1957-1971 (Cologne: Wissenschaft und Politik, 1972).

Schilcher, Alfons (ed.), Österreich und die Großmächte: Dokumente zur österreichischen Außenpolitik 1945-1955 (Vienna: Geyer, 1980).

Schramm, Friedrich-Karl, Wolfram-Georg Riggert, and Alois Friedel (eds.), Sicherheitskonferenz in Europa: Dokumentation 1954-1972: Die Bemühungen um Entspannung und Annäherung im politischen, militärischen, wirtschaftlichen, wissenschaftlich-technologischen und kulturellen Bereich (Frankfurt am Main: Metzner, 1972).

Sejna, Jan, We Will Bury You (London: Sidgwick \& Jackson, 1982).

Semjonow [Semenov], Wladimir S., Von Stalin bis Gorbatschow: Ein halbes Jahrhundert in diplomatischer Mission (Berlin: Nicolai, 1995).

Sergeev, Rostislav, and Ludwig Steiner, "Die österreichisch-sowjetischen Beziehungen 1953-1955 und der Weg zum Staatsvertrag," in Arnold Suppan, Gerald Stourzh, Wolfgang Mueller (eds.), The Austrian State Treaty 1955: International Policy, Legal Relevance, National Identity (Vienna: Verlag der Österreichischen Akademie der Wissenschaften, 2005), 205-213.

Sergeev, Rostislav, "Wie der Durchbruch in der österreichischen Frage erreicht wurde," in Arnold Suppan, Gerald Stourzh, and Wolfgang Mueller (eds.), The Austrian State Treaty 1955: International Policy, Legal Relevance, National Identity (Vienna: Verlag der Österreichischen Akademie der Wissenschaften, 2005), 195-204.

Sharansky, Natan, with Ron Dermer, The Case for Democracy: The Power of Freedom to Overcome Tyranny and Terror (Green Forest: Balfour, 2006).

Siegler, Heinrich, Österreich Chronik 1945-1972 (Vienna: Siegler, 1972).

Siegler, Heinrich, Österreichs Weg zu Souveränität, Neutralität, Prosperität (Bonn: Siegler, 1959).

Sofronov, A. V., Zarubezhnye vstrechi (Moscow: Sovetskii pisatel', 1952).

Sovremennik, "Das österreichische Beispiel," in Neue Zeit, no. 20 (1955), 6-8.

Sovremennik, "Österreichs Neutralität und ihre Bedeutung," in Neue Zeit, no. 21 (1955), 7-9.

Stalin, J., Economic Problems of Socialism in the USSR (Moscow: Foreign Languages Publishing, 1952).

Stalin, J., For Peaceful Coexistence: Postwar Interviews (New York: International Publishers, 1951).

Steiner, Ludwig, Diplomatie-Politik: Ein Leben für die Einheit Tirols: Ein Leben für Österreich 1972-2007 (Bozen: Athesia, 2008). 
Stourzh, Gerald, and Peter Jankowitsch, "Wie steht es mit unserer Neutralität?," in Heute, 12 December 1959,6 .

Thirring, Hans, Mehr Sicherheit ohne Waffen: Denkschrift an das österreichische Volk und seine gewählten Vertreter (Vienna: Jugend und Volk, [1962]).

Timashkova, K., "Neitral'nye strany v usloviiakh imperialisticheskoi integratsii," in M.M. Maksimova (ed.), Ekonomicheskie gruppirovki v zapadnoi Evropy (Moscow: Nauka, 1969), 269-280.

Tiunov, O. I., Neitralitet v mezhdunarodnom prave (Perm: Gosudarstvennyi universitet im. Gor'kogo, 1968).

Tomashevsky, D., “Lenin's Concept of Peaceful Coexistence and the Imperialist Challenge," in International Affairs, no. 5 (May 1982), 3-13.

Tončić-Sorinj, Lujo, Erfüllte Träume: Kroatien - Österreich - Europa (Vienna: Amathea, 1982).

Tunkin, G. I., Das Völkerrecht der Gegenwart (Berlin: Staatsverlag der DDR, 1963). = Voprosy teorii mezhdunarodnogo prava (Moscow: Iurizdat, 1962).

Tunkin, G. I., "Der ideologische Kampf und das Völkerrecht," in Drei sowjetische Beiträge zur Völkerrechtslehre (Hamburg: Hansischer Gildenverlag, 1969), 307-461. = Ideologicheskaia bor 'ba i mezhdunarodnoe pravo (Moscow: Mezhdunarodnye otnosheniia, 1967).

Tunkin, G. I., "Grundlagen des modernen Völkerrechts," in Drei sowjetische Beiträge zur Völkerrechtslehre (Hamburg: Hansischer Gildenverlag, 1969), 1-57. = Osnovy sovremennogo mezhdunarodnogo prava (Moscow: Vyshaia partiinaia shkola TsK KPSS, 1956).

Tunkin, G. I., Theory of International Law (Cambridge, Mass.: Harvard University Press, 1974).

Tunkin, Gregorij I., Völkerrechtstheorie (Berlin: Berlin Verlag, 1972). = Teoriia mezhdunarodnogo prava (Moscow: Mezhdunarodnye otnosheniia, 1970).

Verdross, Alfred, Die immerwährende Neutralität der Republik Österreich (Vienna: Österreichischer Bundesverlag, 1958).

Verdross, Alfred, Die immerwährende Neutralität der Republik Österreich, 2nd ed. (Vienna: Österreichischer Bundesverlag, 1966).

Verdross, Alfred, Die immerwährende Neutralität Österreichs (Vienna: Geschichte und Politik, 1980).

Verdross, Alfred, Völkerrecht, 3rd ed. (Vienna: Springer, 1955).

Verosta, Stephan, Die dauernde Neutralität: Ein Grundriss (Vienna: Manz, 1967).

Vidyasova, L., "An Impressive Example of Peaceful Coexistence," in International Affairs, no. 8 (August 1960), 11-15.

Vneocherednoi s"ezd Kommunisticheskoi partii Sovetskogo Soiuza: Stenograficheskii otchet (Moscow: Gospolitizdat, 1959).

Vneshniaia politika Sovetskogo Soiuza i mezhdunarodnye otnosheniia 1961-1982 (Moscow: Mezhdunarodnye otnosheniia, 1962-1983).

Vneshniaia torgovlia SSSR 1922-1981: Iubileinyi statisticheskii sbornik (Moscow: Finansy i statistika, 1982).

Vneshniaia torgovlia SSSR za 1959-1963 gody: Statisticheskii sbornik (Moscow: Vneshtorgizdat, 1965).

VÖEST, Die 2millionste Tonne VÖEST-Stahl für die UdSSR: Dvukhmillionaia tonna stali firmy VEST dlia SSSR (Linz: no publisher, 1971).

Voronkov, Lev, Non-Nuclear Status to Northern Europe (Moscow: Nauka, 1984).

Vyshinskii, A. Ia. (ed.), Diplomaticheskii slovar', 1st ed., 2 vols. (Moscow: Gospolitizdat, 19481950).

Waldheim, Kurt, Im Glaspalast der Weltpolitik (Düsseldorf: Econ, 1985).

Waldheim, Kurt, The Austrian Example (London: Weidenfeld and Nicholson, 1973).

Wictora, Oskar, 10 Jahre österreichische Integrationspolitik 1956-1966 (Vienna: Bundesministerium für Handel und Wiederaufbau, [1966]).

Wodak, Walter, Diplomatie zwischen Ost und West (Graz: Styria, 1976). 
Woslenskij, Michael S., "Friedliche Koexistenz aus sowjetischer Sicht," in Osteuropa 23, no. 11 (1973), 848-855.

Woslenskij, Michael S., "Klassenkampf - Kalter Krieg - Kräfteverhältnis - Koexistenz,” in Osteuropa 24, no. 4 (1974), 259-269.

Zarusky, Jürgen (ed.), Die Stalinnote vom 10. März 1952: Neue Quellen und Analysen (Munich: Oldenbourg, 2002).

XXIV. Parteitag der Kommunistischen Partei der Sowjetunion 30. März-9. April 1971: Dokumente (Moscow: APN, 1971).

XXVI. Parteitag der KPdSU: Rechenschaftsbericht des Zentralkomitees der Kommunistischen Partei der Sowjetunion und die nächsten Aufgaben der Partei in der Innen- und Außenpolitik, Berichterstatter: L.I. Breshnew, Generalsekretär des ZK der KPdSU, 23. Februar 1981 (Berlin: Dietz, 1981).

\section{Books, Articles, MA and PhD Theses}

Achtamsjan, Abdulchan, "Die Sowjetunion und Österreich in der Zeit der Vorbereitung und des Abschlusses des Staatsvertrages 1945-1955," in Historikersektion der Österreichisch-Sowjetischen Gesellschaft (ed.), Österreich und die Sowjetunion 1918-1955: Beiträge zur Geschichte der österreichisch-sowjetischen Beziehungen (Vienna: ÖSG, 1984), 131-144.

Agrell, Wilhelm, "Silent allies and hostile neutrals: Nonaligned states in the Cold War," in Vojtech Mastny, Sven G. Holtsmark, and Andreas Wenger (eds.), War Plans and Alliances in the Cold War: Threat Perceptions in the East and West (London: Routledge, 2006), 141-162.

Agstner, Rudolf, Gertrude Enderle-Burcel, and Michaela Follner, Österreichs Spitzendiplomaten zwischen Kaiser und Kreisky: Biographisches Handbuch des Höheren Auswärtigen Dienstes 1918 bis 1959 (Vienna: Dokumentationsarchiv des österreichischen Widerstandes, 2009).

Albrich, Thomas, Klaus Eisterer, Michael Gehler, and Rolf Steininger (eds.), Österreich in den Fünfzigern (Innsbruck: Studienverlag, 1995).

Allard, Sven, Russia and the Austrian State Treaty: A Case Study of Soviet Policy in Europe (University Park: Pennsylvania University Press, 1970).

Allison, Roy, Finland's Relations with the Soviet Union, 1944-84 (New York: St. Martin's Press, 1985).

Allison, Roy, The Soviet Union and the Strategy of Non-Alignment in the Third World (Cambridge: University Press, 1988).

Andrén, Nils, "Looking at the Superpowers," in Bengt Sundelius (ed.), The Neutral Democracies and the New Cold War (Boulder: Westview, 1987), 160-181.

Andrén, Nils, "Swedish-Soviet Relations: An Overview," in Bo Huldt and Atis Lejins (eds.), European Neutrals and the Soviet Union (Stockholm: The Swedish Institute of International Affairs, 1985), 59-81.

Angerer, Thomas, "Frankreich und die Österreichfrage: Historische Grundlagen und Leitlinien 1945 1955" (PhD Thesis, Vienna, 1996).

Angerer, Thomas, "Für eine Geschichte der österreichischen Neutralität," in Michael Gehler and Rolf Steininger (eds.), The Neutrals and the European Integration, 1945-1995 (Vienna: Böhlau, 2000), 702-708.

Angerer, Thomas, "Re-launching East-West Negotiations while Deciding West German Rearmament: France, the Paris Treaties, and the Austrian State Treaty 1954/55," in Arnold Suppan, Gerald Stourzh, Wolfgang Mueller (eds.), The Austrian State Treaty 1955: International Policy, Legal Relevance, National Identity (Vienna: Verlag der Österreichischen Akademie der Wissenschaften, 2005), 265-334. 
Bachmaier, Peter, "Austrian-Bulgarian Cultural Relations," in Arnold Suppan and Wolfgang Mueller (eds.), Peaceful Coexistence or Iron Curtain? Austria, Neutrality, and Eastern Europe in the Cold War and Détente, 1955-1989 (Vienna: Lit, 2009), 478-499.

Bachmann, Klaus, "Poland and Austria," in Arnold Suppan and Wolfgang Mueller (eds.), Peaceful Coexistence or Iron Curtain? Austria, Neutrality, and Eastern Europe in the Cold War and Détente, 1955-1989 (Vienna: Lit, 2009), 354-383.

Bader, William B., Austria between East and West, 1945-1955 (Stanford: University Press, 1966).

Bartsch, J. M., "Der sowjetische und der österreichische Außenhandel und ihre beiderseitigen Beziehungen" (PhD Thesis, Graz, 1958).

Bauer, Robert A., The Austrian Solution: International Conflict and Cooperation (Charlottesville: University Press of Virginia, 1982).

Behrmann, Lilly, Peter Proché, and Wolfgang Strasser (eds.), Bibliographie zur Außenpolitik der Republik Österreich seit 1945 (Vienna: Braumüller, 1974).

Beschloss, Michael R., Kennedy v. Khrushchev: The Crisis Years, 1960-63 (London: Faber and Faber, 1991).

Bielka, Erich, Peter Jankowitsch, Hans Thalberg (eds.), and Reinhold Wagnleitner (red.), Die Ära Kreisky: Schwerpunkte österreichischer Außenpolitik (Vienna: Europaverlag, 1983).

Bielka, Erich, "Österreich und seine volksdemokratischen Nachbarn," in idem, Peter Jankowitsch, Hans Thalberg (eds.), and Reinhold Wagnleitner (red.), Die Ära Kreisky: Schwerpunkte österreichischer Außenpolitik (Vienna: Europaverlag, 1983), 195-231.

Biever, André, "L'Autriche et les origines de l'Ostpolitik de la République fédérale d'Allemagne," in Relations Internationales 114 (2003), 213-230.

Binder, Dieter A., "Trittbrettfahrer des Kalten Krieges," in Johann Starlinger (ed.), Armee, Zeitgeist und Gesellschaft 1955-2005 (Vienna: Wissenschaftskommission beim Bundesministerium für Landesverteidigung, [2006]), 57-65.

Bindschedler-Robert, Denise, "Völkerrecht und Neutralität aus sowjetischer Sicht," in Österreichische Zeitschrift für Außenpolitik 5, no. 3 (1965), 144-163.

Birnbaum, Karl E., "East-West Relations and the Position of the European Neutrals," in Bo Huldt and Atis Lejins (eds.), European Neutrals and the Soviet Union (Stockholm: The Swedish Institute of International Affairs, 1985), 1-6.

Birnbaum, Karl E., and Hanspeter Neuhold (eds.), Neutrality and Non-Alignment in Europe, Laxenburg Papers 4 (Vienna: Braumüller, 1981).

Bischof, Günter, Austria in the First Cold War: The Leverage of the Weak (Basingstoke: Palgrave, 1999).

Bischof, Günter, “'Austria looks to the West.' Kommunistische Putschgefahr, geheime Wiederbewaffnung und Westorientierung am Anfang der fünfziger Jahre," in Thomas Albrich, Klaus Eisterer, Michael Gehler, Rolf Steininger (eds.), Österreich in den Fünfzigern (Innsbruck: Studienverlag, 1995), 183-209.

Bischof, Günter, Michael Gehler, and Anton Pelinka (eds.), Austrian Foreign Policy in Historical Context, Contemporary Austrian Studies 14 (New Brunswick: Transaction, 2006).

Bischof, Günter, Anton Pelinka, and Ruth Wodak (eds.), Neutrality in Austria, Contemporary Austrian Studies 9 (New Brunswick: Transaction, 2001).

Bischof, Günter, “Österreich - ein ,geheimer Verbündeter“ des Westens?,” in Michael Gehler and Rolf Steininger (eds.), Österreich und die europäische Integration 1945-1993: Aspekte einer wechselvollen Entwicklung (Vienna: Böhlau, 1993), 425-450.

Bischof, Günter and Anton Pelinka (eds.), The Kreisky Era in Austria, Contemporary Austrian Studies 2 (New Brunswick: Transaction, 1994).

Bischof, Günter, "The Making of the Austrian Treaty and the Road to Geneva," in idem, Saki Dockrill (eds.), Cold War Respite: The Geneva Summit of 1955 (Baton Rouge: Louisiana State University Press, 2000), 117-154. 
Bischof, Günter, Anton Pelinka, and Dieter Stiefel (eds.), The Marshall Plan in Austria, Contemporary Austrian Studies 8 (New Brunswick: Transaction, 2000).

Bischof, Günter, "The Robust Assertion of Austrianism: Peaceful Coexistence in Austria after Stalin's Death," in Klaus Larres and Kenneth Osgood (eds.), The Cold War after Stalin's Death: A Missed Opportunity for Peace? (Lanham: Rowman \& Littlefield, 2006), 233-256.

Bischof, Günter and Dieter Stiefel (eds.), 80 Dollar: 50 Jahre ERP-Fonds und Marshall-Plan in Österreich (Vienna: Ueberreuter, 1999).

Black, Cyril E., Richard A. Falk, Klaus Knorr, and Oran R. Young, Neutralization and World Politics (Princeton: University Press, 1968).

Blasi, Walter, "Die Libanonkrise 1958 und die US Überflüge," in Erwin A. Schmidl (ed.), Österreich im frühen Kalten Krieg: Spione, Partisanen, Kriegspläne (Vienna: Böhlau, 2000), 239-259.

Boczek, Boleslaw A., "The Conceptual and Legal Framework of Neutrality and Nonalignment in Europe," in S. Victor Papacosma and Mark R. Rubin (eds.), Europe's Neutral and Nonaligned States: Between NATO and the Warsaw Pact (Wilmington: Scholarly Resources, 1989), 1-42.

Boden, Ragna, Die Grenzen der Weltmacht: Sowjetische Indonesienpolitik von Stalin bis Brežnev (Stuttgart: Franz Steiner, 2006).

Bogoliubova, N. M., and Iu. V. Nikolaeva, Russko-avstriiskie kul'turnye sviazi v XVIII-XXI vv. (St. Petersburg: SPbKO, 2010).

Bonjour, Edgar, Geschichte der Schweizerischen Neutralität (Basel: Helbing und Lichtenhahn, 1978).

Bonwetsch, Bernd, "Sowjetische Westeuropapolitik II," in Dietrich Geyer (ed.), Osteuropa-Handbuch Sowjetunion: Außenpolitik 1955-1973 (Cologne: Böhlau, 1976), 146-228.

Bracht, Hans Werner, Ideologische Grundlagen der sowjetischen Völkerrechtslehre (Cologne: Wissenschaft und Politik, 1964).

Brooks, Jeffrey, Thank you, Comrade Stalin! Soviet Public Culture from Revolution to Cold War (Princeton: University Press, 2001).

Brown, Archie, The Gorbachev Factor (Oxford: University Press, 1996).

Brown, Archie, "The Gorbachev Revolution and the End of the Cold War," in Melvyn P. Leffler and Odd Arne Westad (eds.), The Cambridge History of the Cold War III: Endings (Cambridge: University Press, 2010), 244-266.

Burtscher, Wolfgang, "Österreichs Annäherung an den Europarat von 1949 bis zur Vollmitgliedschaft im Jahre 1956," in Waldemar Hummer and Gerhard Wagner (eds.), Österreich im Europarat 1956-1986: Bilanz einer 30jährigen Mitgliedschaft (Vienna: Verlag der Österreichischen Akademie der Wissenschaften, 1988), 37-52.

Butschek, Felix, Statistische Reihen zur österreichischen Wirtschaftsgeschichte (Vienna: WIFO, 1999).

Cede, Franz, "Österreichs Neutralität und Sicherheitspolitik nach dem Beitritt zur Europäischen Union," in Zeitschrift für Rechtsvergleichung 36, no. 4 (1995), 142-148.

Conze, Eckart, Ulrich Lappenküper, and Guido Müller (eds.), Geschichte der internationalen Beziehungen: Erneuerung und Erweiterung einer historischen Disziplin (Cologne: Böhlau, 2004).

Craig, Gordon A., and Francis L. Loewenheim (eds.), The Diplomats, 1939-1979 (Princeton: University Press, 1994).

Creuzberger, Stefan, Westintegration und neue Ostpolitik: Die Außenpolitik der Bonner Republik (Berlin: Bebra, 2009).

Dachs, Herbert, Peter Gerlich and Wolfgang C. Müller (eds.), Die Politiker: Karrieren und Wirken bedeutender Repräsentanten der Zweiten Republik (Vienna: Manz, 1995).

Dachs, Herbert, et al. (eds.), Politik in Österreich (Vienna: Manz, 2006).

D'Agostino, Anthony, Gorbachev's Revolution, 1985-1991 (Basingstoke: Macmillan, 1998).

Dallin, Alexander, Die Sowjetunion und die Vereinten Nationen (Cologne: Wissenschaft und Politik, 1965). 
Dallin, Alexander, Soviet Foreign Policy After Stalin (London: Methuen, 1962).

Dijk, Ruud van, et al. (eds.), Encyclopedia of the Cold War, 2 vols. (New York: Routledge, 2008).

Dijk, Ruud van, The 1952 Stalin Note Debate: Myth or Missed Opportunity for German Unification?, Cold War International History Project Working Paper 14 (Washington, DC: Woodrow Wilson Center, 1996).

Dörfer, Ingemar, "The European Neutrals in the Strategy of the Reagan Administration," in Bengt Sundelius (ed.), The Neutral Democracies in the New Cold War (Boulder: Westview, 1987), 182-197.

Dunlop, John B., The Rise of Russia and the Fall of the Soviet Empire (Princeton: University Press, 1993).

Ebon, Martin, The Soviet Propaganda Machine (New York: McGraw-Hill, 1987).

Edemskiy, Andrey, "Dealing with Bonn: Leonid Brezhnev and the Soviet Response to West German Ostpolitik," in Carole Fink and Bernd Schaefer (eds.), Ostpolitik, 1969-1974: European and Global Responses (Cambridge: University Press, 2009), 15-38.

Edmonds, Robin, Soviet Foreign Policy: The Brezhnev Years (Oxford: University Press, 1983).

Efremov, Aleksandr, Sovetsko-Avstriiskie otnosheniia posle vtoroi mirovoi voiny (Moscow: Gospolizdat, 1958).

Eger, Rainer, Krisen an Österreichs Grenzen: Das Verhalten Österreichs während des Ungarnaufstandes 1956 and der tschechoslowakischen Krise 1968 (Vienna: Herold, 1981).

Eger, Rainer, "Neutralität und Neutralismus als Möglichkeiten außenpolitischen Verhaltens,“ in Gottfried Karl Kindermann (ed.), Grundelemente der Weltpolitik, 3rd ed. (Munich: Piper, 1987), 292-307

Egorova, N. I., and A. O. Chubar'ian (eds.), Kholodnaia voina i politika razriadki: diskussionnye problemy (Moscow: Institut Vseobshchei Istorii Rossiiskoi Akademii Nauk, 2003).

Egorova, N. I., and I. A. Aggeeva (eds.), Mnogostoronnaia diplomatiia v gody kholodnoi voiny (Moscow: Institut Vseobshchei Istorii Rossiiskoi Akademii Nauk, 2008).

Enderle-Burcel, Gertrude, Dieter Stiefel, and Alice Teichova (eds.), Zarte Bande: Österreich und die europäischen planwirtschaftlichen Länder, MÖSTA Sonderband 9 (Innsbruck: Studienverlag, 2006).

Engerman, David C., "Ideology and the Origins of the Cold War, 1917-1962," in Melvyn P. Leffler and Odd Arne Westad (eds.), The Cambridge History of the Cold War I: Origins (Cambridge: University Press, 2010), 20-43.

English, Robert D., Russia and the Idea of the West: Gorbachev, Intellectuals and the End of the Cold War (New York: Columbia University Press, 2000).

Engman, Max, "Schicksalsgemeinschaft? Finland, the Soviet Union, and Finnish-Austrian Parallels in 1955," in Arnold Suppan, Gerald Stourzh, and Wolfgang Mueller (eds.), The Austrian State Treaty 1955: International Strategy, Legal Relevance, National Identity (Vienna: Verlag der Österreichischen Akademie der Wissenschaften, 2005), 373-396.

Erickson, Richard J., International Law and the Revolutionary State: A Case Study of the Soviet Union and Customary International Law (Leiden: Sijthoff, 1972).

Erlich, Victor, Modernism and Revolution: Russian Literature in Transition (Cambridge, Mass.: Harvard University Press, 1994).

Evangelista, Matthew, “Why Keep Such an Army?” Khrushchev's Troop Reductions, Cold War International History Project Working Paper 19 (Washington, DC: Woodrow Wilson Center, 1997).

Fälbl, Max, "Die österreichisch-sowjetischen Wirtschaftsbeziehungen: Zum Besuch des Außenhandelsministers des UdSSR, N. S. Patoličev, in Österreich," in Österreichische Osthefte 15, no. 1 (1973), 12-19.

Fiedler, Heinz, Der sowjetische Neutralitätsbegriff in Theorie und Praxis: Ein Beitrag zum Problem des Disengagement (Cologne: Politik und Wirtschaft, 1959).

Fiedler, Heinz, "Neutralität," in C. D. Kernig (ed.), Sowjetsystem und demokratische Gesellschaft: Eine vergleichende Enzyklopädie 4 (Freiburg: Herder, 1971), 782-796. 
Fiedler, Heinz, "Politische Verträge mit Westlichen Staaten und Entwicklungsländern," in Dietrich Geyer (ed.), Osteuropa-Handbuch Sowjetunion Außenpolitik III: Völkerrechtstheorie und Vertragspolitik (Cologne: Böhlau, 1976), 194-223.

Filitov, A. M., Germaniia v Sovetskom vneshnepoliticheskom planovanii, 1941-1990 (Moscow: Nauka, 2009).

Filitov, Aleksei, "The Post-Stalin Succession Struggle and the Austrian State Treaty," in Arnold Suppan, Gerald Stourzh, and Wolfgang Mueller (eds.), The Austrian State Treaty 1955: International Strategy, Legal Relevance, National Identity (Vienna: Verlag der Österreichischen Akademie der Wissenschaften, 2005), 121-143.

Fischer, Thomas, "'A Mustard Seed Grew into a Bushy Tree': The Finnish CSCE Initiative of 5 May 1969," in Cold War History 9, no. 2 (2009), 177-201.

Fischer, Thomas, "Die Sowjetunion, Österreich, und die finnische KSZE-Initiative vom 5. Mai 1969," in Wolfgang Mueller and Michael Portmann (eds.), Osteuropa vom Weltkrieg zur Wende (Vienna: Verlag der Österreichischen Akademie der Wissenschaften, 2007), 313-340.

Fischer, Thomas, Neutral Power in the CSCE: The N+N States and the Making of the Helsinki Accords (Baden-Baden: Nomos, 2009).

Foitzik, Jan (ed.), Entstalinisierungskrise in Ostmitteleuropa 1953-1956: Vom 17. Juni bis zum ungarischen Volksaufstand: Politische, militärische, soziale und nationale Dimensionen (Paderborn: Schöningh, 2001).

Frei, Daniel, Dimensionen neutraler Politik: Ein Beitrag zur Theorie der internationalen Beziehungen (Geneva: Institut Universitaire de Hautes Études Internationales, 1969).

Frei, Daniel, Neutrality and Non-Alignment: Convergencies and Contrasts (Zurich: Forschungsstelle politische Wissenschaft, 1979).

Freistetter, Franz, "Das strategische Konzept des Ostens und Österreich 1955-1970," in Manfried Rauchensteiner and Wolfgang Etschmann (eds.), Schild ohne Schwert? Das österreichische Bundesheer 1955-1970 (Graz: Styria, 1991), 29-60.

Fuhrer, Hans Rudolf, "Neutral zwischen den Blöcken: Österreich und die Schweiz," in Manfried Rauchensteiner (ed.), Zwischen den Blöcken: NATO, Warschauer Pakt und Österreich (Vienna: Böhlau, 2010), 193-252.

Fursenko, Aleksandr, and Timothy Naftali, Khrushchev's Cold War: The Inside Story of an American Adversary (New York: Norton, 2006).

Gaddis, John Lewis, The Cold War: A New History (London: Peguin, 2005).

Gajdek, Joanna, "Der mittelbare Nachbar: Österreichvorstellungen in Polen 1970-1995," in Oliver Rathkolb, Otto M. Maschke, and Stefan August Lütgenau (eds.), Mit anderen Augen gesehen: Internationale Perzeptionen Österreichs 1955-1990, Österreichische Nationalgeschichte 2 (Vienna: Böhlau, 2002), 651-675.

Garthoff, Raymond L., Détente and Confrontation: American-Soviet Relations from Nixon to Reagan, 2nd ed. (Washington, DC: Brookings Institution, 1994).

Gehler, Michael, "Austria and the European Integration," in Arnold Suppan and Wolfgang Mueller (eds.), Peaceful Coexistence or Iron Curtain? Austria, Neutrality, and Eastern Europe in the Cold War and Détente, 1955-1989 (Vienna: Lit, 2009), 142-163.

Gehler, Michael and Günter Bischof, “Austrian Foreign Policy after World War II,” in Günter Bischof, Michael Gehler, and Anton Pelinka (eds.), Austrian Foreign Policy in Historical Context, Contemporary Austrian Studies 14 (New Brunswick: Transaction, 2006), 1-24.

Gehler, Michael, Der lange Weg nach Europa: Österreich von Paneuropa bis zum EU-Beitritt: Darstellung (Innsbruck: Studienverlag, 2002).

Gehler, Michael, Finis Neutralität? Historische und politische Aspekte im europäischen Vergleich: Irland, Finnland, Schweden, Schweiz und Österreich, Center for European Integration Studies Discussion Paper C 92 (Bonn: Rheinische Friedrich-Wilhelms-Universität, 2001). 
Gehler, Michael, "From Non-Alignment to Neutrality: Austria’s Transformation during the First EastWest Détente, 1953-1958," in Journal of Cold War Studies 7, no. 4 (2005), 104-136.

Gehler, Michael, “'L'unique objectif des Soviétiques est de viser 1'Allemagne:' Staatsvertrag und Neutralität 1955 als „Modell“ für Deutschland?,” in Thomas Albrich, Klaus Eisterer, Michael Gehler, and Rolf Steininger (eds.), Österreich in den Fünfzigern (Innsbruck: Studienverlag, 1995), 259-297.

Gehler, Michael, "Neutralität und Neutralisierungspläne für Mitteleuropa? Österreich, Ungarn, Tschechoslowakei und Polen," in Dominik Geppert and Udo Wengst (eds.), Neutralität-Chance oder Chimäre? Konzepte des Dritten Weges für Deutschland und die Welt 1945-1990 (Munich: Oldenbourg, 2005), 105-131.

Gehler, Michael, Österreichs Außenpolitik der Zweiten Republik: von der alliierten Besatzung bis zum Europa des 21. Jahrhunderts (Innsbruck: Studienverlag, 2005).

Gehler, Michael, Österreichs Weg in die Europäische Union (Innsbruck: Studienverlag, 2009).

Gehler, Michael, and Rolf Steininger (eds.), Österreich und die europäische Integration 1945-1993: Aspekte einer wechselvollen Entwicklung (Vienna: Böhlau, 1993).

Gehler, Michael, “'to guarantee a country which was a military vacuum.' Die Westmächte und Österreichs territoriale Integrität 1955-1957," in Manfried Rauchensteiner (ed.), Zwischen den Blöcken: NATO, Warschauer Pakt und Österreich (Vienna: Böhlau, 2010), 89-134.

Gehler, Michael, "The Hungarian Crisis and Austria 1953-58: A Foiled Model Case?" in Günter Bischof, Anton Pelinka, and Ruth Wodak (eds.), Neutrality in Austria, Contemporary Austrian Studies 9 (New Brunswick: Transaction, 2001), 160-213.

Gehler, Michael, and Rolf Steininger (eds.), The Neutrals and the European Integration, 1945-1995 (Vienna: Böhlau, 2000).

Gehler, Michael, "Von Unabhängigkeitsgaranten zu internationalen Partnern: Die Signatarmächte des österreichischen Staatsvertrages 1955-2005," in Christian Fornwagner and Richard Schober (eds.), Freiheit und Wiederaufbau: Tirol in den Jahren um den Staatsvertrag (Innsbruck: Universitätsverlag Wagner, 2007), 21-36.

Gémes, Andreas, "Austria and Hungary," in Arnold Suppan and Wolfgang Mueller (eds.), Peaceful Coexistence or Iron Curtain? Austria, Neutrality, and Eastern Europe in the Cold War and Détente, 1955-1989 (Vienna: Lit, 2009), 301-327.

Gémes, Andreas, Austria and the 1956 Hungarian Revolution: Between Solidarity and Neutrality (Pisa: Edizioni Plus, 2008).

Gémes, Andreas, "Schade, schade, immer Spionage!," in Ibolya Murber and Zoltán Fónagy (eds.), Die Ungarische Revolution und Österreich 1956 (Vienna: Czernin, 2006), 207-242.

Geppert, Dominik, and Udo Wengst (eds.), Neutralität-Chance oder Chimäre? Konzepte des Dritten Weges für Deutschland und die Welt 1945-1990 (Munich: Oldenbourg, 2005).

Geyer, Dietrich (ed.), Osteuropa-Handbuch Sowjetunion: Außenpolitik, 3 vols. (Cologne: Böhlau, 1972-1976).

Ginsburgs, George, and Alvin Z. Rubinstein, "Finlandization: Soviet Strategy or Geopolitical Footnote?," in idem (eds.), Soviet Foreign Policy Toward Western Europe (New York: Praeger, 1978), $3-16$.

Ginsburgs, George, "Neutralism à la Russe," in idem and Alvin Z. Rubinstein (eds.), Soviet Foreign Policy Toward Western Europe (New York: Praeger, 1978), 17-39.

Ginsburgs, George, "Neutrality and Neutralism and the Tactics of Soviet Diplomacy," in The American Slavic and East European Review 19, no. 4 (1960), 531-560.

Ginther, Konrad, "Austria's Policy of Neutrality and the Soviet Union," in George Ginsburgs and Alvin Z. Rubinstein (eds.), Soviet Foreign Policy Toward Western Europe (New York: Praeger, 1978), 66-85.

Ginther, Konrad, Neutralität und Neutralitätspolitik: Die österreichische Neutralität zwischen Schweizer Modell und sowjetischer Koexistenzdoktrin (Vienna: Springer, 1975). 
Ginther, Konrad, Österreichs immerwährende Neutralität (Vienna: Geschichte und Politik, 1975).

Glasneck, Hedwig, "Die Sowjetunion und Österreich: Ein Beispiel für Beziehungen der friedlichen Koexistenz 1955-1965" (PhD Thesis, Halle, 1967).

Glatz, Ferenc (ed.), Der Österreichische Staatsvertrag 1955 (Budapest: Europa Institut, 2006).

Glatz, Harald, "Abhängigkeit im Bereich von Rohstoffen und Energie," in Helmut Kramer et al., Österreich im internationalen System: Zusammenfassung der Ergebnisse und Ausblick (Vienna: Braumüller, 1983), 118-127.

Goldgeier, James M., Leadership Style and Soviet Foreign Policy: Stalin, Khrushchev, Brezhnev, Gorbachev (Baltimore: Johns Hopkins University Press, 1994).

Gorodetsky, Gabriel, "The Formulation of Soviet Foreign Policy: Ideology and Realpolitik," in idem (ed.), Soviet Foreign Policy, 1917-1991: A Retrospective (London: Frank Cass, 1994), 30-44.

Gould-Davis, Nigel, "Rethinking the Role of Ideology in International Politics during the Cold War," in Journal of Cold War Studies 1, no. 1 (1999), 90-109.

Graf, Maximilian, "Austria and the GDR 1949-1972: Diplomatic and Political Contacts in the Period of Nonrecognition," in Arnold Suppan and Maximilian Graf (eds.) From the Austrian Empire to Communist East Central Europe (Vienna: Lit, 2010), 151-177.

Graf, Maximilian, "Internationale Reaktionen auf die Intervention der Warschauer-Pakt-Staaten in der ČSSR 1968" (MA Thesis, Vienna, 2008).

Granville, Johanna, "Neutral Encounters of the Paranoid Kind: Austria's Reactions to the Hungarian Crisis of 1956," in Günter Bischof, Michael Gehler, and Anton Pelinka (eds.), Austrian Foreign Policy in Historical Context, Contemporary Austrian Studies 14 (New Brunswick: Transaction, 2006), 143-169.

Granville, Johanna, "Of Spies, Refugees and Hostile Propaganda: How Austria dealt with the Hungarian Crisis of 1956," in History 91, no. 1 (2006), 62-90.

Hacker, Jens, "Neutralität, Neutralismus und Blockfreiheit," in Aus Politik und Zeitgeschichte, no. 18 (1983), 3-20.

Hafner, Gerhard, "Die permanente Neutralität in der sowjetischen Völkerrechtslehre," in Österreichische Zeitschrift für öffentliches Recht 19, no. 2-3 (1969), 215-258.

Hafner, Gerhard, “Österreichs Neutralität 1955-2005," in Thomas Olechowski (ed.), Fünfzig Jahre Staatsvertrag und Neutralität (Vienna: WUV-Universitätsverlag, 2006), 15-44.

Häikiö, Martti, "Finland's Neutrality 1944-1994," in Michael Gehler and Rolf Steininger (eds.), The Neutrals and the European Integration, 1945-1995 (Vienna: Böhlau, 2000), 199-217.

Hakovirta, Harto, East-West Conflict and European Neutrality (Oxford: Clarendon, 1988).

Hakovirta, Harto, "East-West Tensions and Soviet Politics of European Neutrality," in Bengt Sundelius (ed.), The Neutral Democracies in the New Cold War (Boulder: Westview, 1987), 198-217.

Hakovirta, Harto, "The Soviet Union and the Varieties of Neutrality in Western Europe," in World Politics 35, no. 4 (1983), 563-585.

Hamel, Stephan, "Eine solche Sache würde der Neutralitätspolitik ein Ende machen: Die österreichischen Integrationsbestrebungen 1961-1972," in Michael Gehler and Rolf Steininger (eds.), Österreich und die europäische Integration 1945-1993: Aspekte einer wechselvollen Entwicklung (Vienna: Böhlau, 1993), 55-86.

Hanhimäki, Jussi M., Containing Coexistence: America, Russia, and the "Finnish Solution," 1945 1956 (Kent, Ohio: Kent State University Press, 1997).

Hanhimäki, Jussi M., "Containment, Coexistence, and Neutrality: The Return of the Porkkala Naval Base as an Issue in Soviet-American Relations, 1955-1956," in Scandinavian Journal of History 18, no. 3 (1993), 217-228.

Hanhimäki, Jussi M., "Détente in Europe, 1962-1975," in Melvyn P. Leffler and Odd Arne Westad (eds.), The Cambridge History of the Cold War II: Crises and Détente (Cambridge: University Press, 2010), 198-218. 
Hanhimäki, Jussi M., "The Lure of Neutrality: Finland and the Cold War," in Klaus Larres and Kenneth Osgood (eds.), The Cold War after Stalin's Death: A Missed Opportunity for Peace? (Lanham: Rowland \& Littlefield, 2006), 257-276.

Hanisch, Ernst, Der lange Schatten des Staates: Österreichische Gesellschaftsgeschichte im 20. Jahrhundert, Österreichische Geschichte hg. von Herwig Wolfram (Vienna: Ueberreuter, 1994).

Hanisch, Ernst, "Josef Klaus," in Herbert Dachs, Peter Gerlich, Wolfgang C. Müller (eds.), Die Politiker: Karrieren und Wirken bedeutender Repräsentanten der Zweiten Republik (Vienna: Manz, 1995), 299-306.

Hanson, Philip, The Rise and Fall of the Soviet Economy: An Economic History of the USSR from 1945 (London: Longman, 2003).

Harrod, Andrew E., "Felix Austria? Cold War Security Policy between NATO, Neutrality, and the Warsaw Pact, 1945-1989" (PhD Thesis, Medford, 2007).

Haug, Hans, Neutralität und Völkergemeinschaft (Zurich: Polygraphischer Verlag, 1962).

Hauke, Harald, "Handelspolitik und Außenwirtschaftsbeziehungen der Sowjetunion von 1945 bis 1991" (PhD Thesis, Vienna, 1994).

Haymerle, Heinrich, "Die Beziehungen zur Großmacht im Osten," in Erich Bielka, Peter Jankowitsch, Hans Thalberg (eds.), and Reinhold Wagnleitner (red.), Die Ära Kreisky: Schwerpunkte österreichischer Außenpolitik (Vienna: Europaverlag, 1983), 143-193.

Heller, Otto, "Die Schild-Schwert-These und die Neutralen: Eine strategisch/operative Betrachtung über die Zeit von der Aufstellung des zweiten Bundesheeres bis zum Beginn der Reform 1970," in Manfried Rauchensteiner and Wolfgang Etschmann (eds.), Schild ohne Schwert? Das österreichische Bundesheer 1955-1970 (Graz: Styria, 1991), 61-88.

Hentilä, Seppo, Neutral zwischen den beiden deutschen Staaten: Finnland und Deutschland im Kalten Krieg (Berlin: BWV, 2006).

Hentilä, Seppo, "The Soviet Union, Finland, and the 'Northern Balance,"” in Wilfried Loth (ed.), Europe, Cold War, and Coexistence, 1953-1965 (London: Frank Cass, 2004), 239-257.

Hilger, Andreas, Mike Schmeitzner, and Clemens Vollnhals (eds.), Sowjetisierung oder Neutralität? Optionen sowjetischer Besatzungspolitik in Deutschland und Österreich 1945-1955 (Göttingen: Vandenhoeck \& Ruprecht, 2006).

Hilger, Andreas, "The Soviet Union and India: The Khrushchev Era and its Aftermath until 1966," in idem, Anna Locher, Roland Popp, Shana Goldberg, Matthias Pintsch (eds.), Indo-Soviet Relations Collection (Zurich: Parallel History Project, 2009), http://www.php.isn.ethz.ch/collections/ coll_india/intro_khrushchev.cfm? navinfo $=56154$.

Historikersektion der ÖSG (ed.), Österreich und die Sowjetunion 1918-1955: Beiträge zur Geschichte der österreichisch-sowjetischen Beziehungen (Vienna: ÖSG, 1984).

Hixson, Walter L., Parting the Curtain: Propaganda, Culture, and the Cold War, 1945-1961 (New York: St. Martin's Griffin,1998).

Hoensch, Jörg K., Sowjetische Osteuropa-Politik 1945-1975 (Kronberg: Athenäum, 1977).

Höll, Otmar, "Kleinstaaten im Spannungsfeld von Autonomie und Abhängigkeit am Beispiel Österreichs" (Habil. Thesis, Vienna, 1989).

Höll, Otmar, "The Foreign Policy of the Kreisky Era," in Günter Bischof and Anton Pelinka (eds.), The Kreisky Era in Austria, Contemporary Austrian Studies 2 (New Brunswick: Transaction, 1994), 32-71.

Höll, Otmar, "The Politics of International Thinking: The International Significance of Bruno Kreisky," in Gertraud Diendorfer (red.), Bruno Kreisky (Vienna: Museum der Stadt Wien, 1998), 105116.

Holloway, David, "Nuclear Weapons and the Escalation of the Cold War," in Melvin Leffler, Odd Arne Westad (eds.), The Cambridge History of the Cold War I: Origins (Cambridge: University Press, 2010), 376-397. 
Holloway, David, Stalin and the Bomb: The Soviet Union and Atomic Energy, 1939-1956 (New Haven: Yale University Press, 1994).

Huldt, Bo and Atis Lejins (eds.), European Neutrals and the Soviet Union (Stockholm: Swedish Institute of International Affairs, 1986).

Hummer, Waldemar, and Willibald Girkinger, "Neutralitätsregeln und Bereichsspezifika der österreichischen Neutralitätspolitik," in Österreichische Zeitschrift für Politikwissenschaft 8, no. 3 (1979), 299-325.

Hummer, Waldemar, and Michael Schweitzer, Österreich und die EWG: Neutralitätsrechtliche Beurteilung der Möglichkeit einer Dynamisierung des Verhältnisses zur EWG (Vienna: Signum, 1987).

Iber, Walter, Die sowjetische Mineralölverwaltung in Österreich (SMV), 1945-1955 (Innsbruck: Studienverlag, 2010).

Isak, Hubert, "Österreichs Außenwirtschaftsbeziehungen," in Renate Kicker, Andreas Khol, Hanspeter Neuhold (eds.), Außenpolitik und Demokratie in Österreich: Strukturen - Strategien - Stellungnahmen (Salzburg: Neugebauer, 1983), 259-288.

Jacobson, Max, Finnish Neutrality: A Study of Finnish Foreign Policy since the Second World War (London: Hugh Evelyn, 1968).

Jacobson, Max, Finland in the New Europe (Westport: Praeger, 1998).

Jankowitsch, Peter, "Das Problem der Äquidistanz: Die Suche der Zweiten Republik nach außenpolitischen Leitlinien," in Manfried Rauchensteiner (ed.), Zwischen den Blöcken: NATO, Warschauer Pakt und Österreich (Vienna: Böhlau, 2010), 451-495.

Jarczabek, Wanda, Hope and Reality: Poland and the Conference on Security and Cooperation in Europe, 1964-1989, Cold War International History Project Working Paper 56 (Washington, DC: Woodrow Wilson Center, 2008).

Jehn, Alexander, "Nachbarschaftspolitik im Donauraum: Die besonderen Beziehungen Österreichs zur Tschechowakei, zu Ungarn und Jugoslawien in der Ära Kreisky” (PhD Thesis, Vienna, 1996).

Jenny, Christian, Konsensformel oder Vorbild? Die Entstehung der österreichischen Neutralität und ihr Schweizer Muster (Bern: Haupt, 1995).

Jervas, Gunnar, "Sweden in a Less Benign Environment," in Bengt Sundelius (ed.), The Neutral Democracies in the New Cold War (Boulder: Westview, 1987), 57-74.

Johnson-Freese, Joan, “Austria," in S. Victor Papacosma and Mark R. Rubin (eds.), Europe's Neutral and Nonaligned States: Between NATO and the Warsaw Pact (Wilmington: Scholarly Resources, 1989), 161-180.

Judt, Tony, Postwar: A History of Europe Since 1945 (New York: Penguin, 2005).

Kähönen, Aappo, The Soviet Union, Finland, and the Cold War: The Finnish Card in Soviet Foreign Policy, 1956-1959 (Helsinki: Suomalaisen Kirjallisuuden Seura, 2006).

Karner, Stefan, Barbara Stelzl-Marx, Alexandr Tschubarjan (eds.), Die Rote Armee in Österreich: Krasnaia armiia $v$ Avstrii, 1945-1955 (Graz: Oldenbourg, 2005).

Karner, Stefan, Natalia Tomilina, Alexander Tschubarjan et al. (eds.), Prager Frühling: Das internationale Krisenjahr 1968 (Vienna: Böhlau, 2008).

Karsh, Efraim, Neutrality and Small States (London: Routledge, 1988).

Kastner, Georg, "Hilfsaktionen der Vereinten Nationen für die Volksrepublik Ungarn," in Ibolya Murber and Zoltán Fónagy (eds.), Die Ungarische Revolution und Österreich 1956 (Vienna: Czernin, 2006), 187-206.

Katzer, Nikolaus, "Ideologie und Pragmatismus in der sowjetischen Außenpolitik," in Aus Politik und Zeitgeschichte, no. 1-2 (2009), 3-10.

Kelsen, Hans, The Communist Theory of Law (New York: Praeger, 1955).

Kernig, C. D. et al. (eds.), Sowjetsystem und demokratische Gesellschaft: Eine vergleichende Enzyklopädie, 5 vols. (Freiburg: Herder, 1966-1972). 
Kennedy-Pipe, Caroline, Russia and the World (New York: Arnold, 1998).

Khormach, I. A., SSSR - Italiia i blokovoe protivostoianie v Evrope (Moscow: Institut Rossiiskoi istorii Rossiiskoi akademii nauk, 2005).

Kicker, Renate, Andreas Khol, Hanspeter Neuhold (eds.), Außenpolitik und Demokratie in Österreich: Strukturen - Strategien - Stellungnahmen: Ein Handbuch (Salzburg: Neugebauer, 1983).

Kirchschläger, Rudolf, "Integration und Neutralität," in Erich Bielka, Peter Jankowitsch, Hans Thalberg (eds.), and Reinhold Wagnleitner (red.), Die Ära Kreisky: Schwerpunkte österreichischer Außenpolitik (Vienna: Europaverlag, 1983), 61-95.

Klambauer, Otto, Der Kalte Krieg in Österreich: Vom Dritten Mann zum Fall des Eisernen Vorhanges (Vienna: Ueberreuter, 2000).

Klambauer, Otto, "Die sowjetische Wirtschaftspolitik in Österreich," in Andreas Hilger, Mike Schmeitzner, and Clemens Vollnhals (eds.), Sowjetisierung oder Neutralität? Optionen sowjetischer Besatzungspolitik in Deutschland und Österreich (Göttingen: Vandenhoeck, 2006), 435-450.

Knight, Robert, "Staatsvertrag und Nationalsozialismus: Ein unvermeidbarer Zusammenhang," in Zeitgeschichte 32, no. 4 (2005), 215-227.

Kobliakov, I. K., G. G. Kuranov, and D. N. Mochalin, SSSR v bor'be za nezavisimost'Avstrii (Moscow: Politizdat, 1965).

Kofler, Martin, "Eine Art „Nabel der Welt": Österreich und der Chruschtschow-Besuch 1960,” in Zeitgeschichte 26, no. 6 (1999), 397-416.

Kofler, Martin, "Kreisky - Brandt - Khrushchev: The United States and Austrian Mediation during the Berlin Crisis 1958-1963," in Günter Bischof, Michael Gehler, and Anton Pelinka (eds.), Austrian Foreign Policy in Historical Context, Contemporary Austrian Studies 14 (New Brunswick: Transaction, 2006), 170-185.

Kofler, Martin, "Juni 1961: Das Wiener Gipfeltreffen Chruschtschow - Kennedy," in Monika Sommer (ed.), Die Augen der Welt auf Wien gerichtet: Gipfel 1961 Chruschtschow - Kennedy (Innsbruck: Studienverlag, 2005), 14-31.

Kofler, Martin, Kennedy und Österreich: Neutralität im Kalten Krieg (Innsbruck: Studienverlag, 2003).

Kofler, Martin, "Neutral, Host, and Mediator: Austria and the Vienna Summit of 1961," in Günter Bischof, Anton Pelinka, and Dieter Stiefel (eds.), The Marshall Plan in Austria, Contemporary Austrian Studies 8 (New Brunswick: Transaction, 2000), 48-57.

Komlosy, Andrea, "Österreichs Brückenfunktion und die Durchlässigkeit des Eisernen Vorhanges," in Gertrude Enderle-Burcel, Dieter Stiefel, and Alice Teichova (eds.), Zarte Bande: Österreich und die europäischen planwirtschaftlichen Länder, MÖSTA Sonderband 9 (Innsbruck: Studienverlag, 2006), 73-105.

Korenjak, Ilse, "Die Entwicklung des österreichisch-sowjetischen Außenhandels 1955 bis 1982” (MA Thesis, Vienna, 1983).

Köstenberger, Julia, "The Great Waltz/Bol'shoi Val's," in Karin Moser (ed.), Besetzte Bilder: Film, Kultur und Propaganda in Österreich 1945-1955 (Vienna: Filmarchiv Austria, 2005), 303-322.

Kramer, Helmut, et al., Österreich im internationalen System: Zusammenfassung der Ergebnisse und Ausblick (Vienna: Braumüller, 1983).

Kramer, Helmut, "Strukturentwicklung der Außenpolitik 1945-2005," in Herbert Dachs et al. (eds.), Politik in Österreich (Vienna: Manz, 2006), 807-837.

Kramer, Mark, "Declassified Materials from CPSU Central Committee Plenums: Sources, Context, Highlights," in Cold War International History Project Bulletin 10 (1998), 7-25.

Kramer, Mark, "Ideology and the Cold War," in Michael M. Cox (ed.), Twentieth Century International Relations 2: The Rise and Fall of the Cold War (London: Sage, 2008), 26-68.

Kramer, Mark, "International Politics in the Early Post-Stalin Era: A Lost Opportunity, a Turning Point, or More of the Same?," in Klaus Larres and Kenneth Osgood (eds.), The Cold War after 
Stalin's Death: A Missed Opportunity for Peace? (Lanham: Rowman \& Littlefield, 2006), xiiixxxiv.

Kramer, Mark, "The Early Post-Stalin Succession Struggle and Upheavals in East-Central Europe: Internal-External Linkages in Soviet Policy Making (Part 1)," in Journal of Cold War Studies 1, no. 1 (1999), 3-55.

Kramer, Mark, "The Early Post-Stalin Succession Struggle and Upheavals in East-Central Europe: Internal-External Linkages in Soviet Policy Making (Part 2)," in Journal of Cold War Studies 1, no. 2 (1999), 3-38.

Kramer, Mark, "The Early Post-Stalin Succession Struggle and Upheavals in East-Central Europe: Internal-External Linkages in Soviet Policy Making (Part 3)," in Journal of Cold War Studies 1, no. 3 (1999), 3-66.

Kramer, Mark, "The Soviet Union and the 1956 Crises in Poland and Hungary: Reassessment and New Findings," in Journal of Contemporary History 33, no. 2 (1998), 163-214.

Kraus, Hans-Christof, and Thomas Nicklas (eds.), Geschichte der Politik: Alte und Neue Wege, Historische Zeitschrift Beihefte 44 (Munich: Oldenbourg, 2007).

Kriechbaumer, Robert, "Alfons Gorbach," in Herbert Dachs, Peter Gerlich, Wolfgang C. Müller (eds.), Die Politiker: Karrieren und Wirken bedeutender Repräsentanten der Zweiten Republik (Vienna: Manz, 1995), 160-167.

Kriechbaumer, Robert, Die Ära Kreisky: Österreich 1970-1983 in der historischen Analyse, im Urteil der politischen Kontrahenten und in Karikaturen von Ironimus (Vienna: Böhlau, 2004).

Kriechbaumer, Robert, Zeitenwende: Die SPÖ-FPÖ Koalition 1983-1987 in der historischen Analyse, aus der Sicht der politischen Akteure und in Karikaturen von Ironimus (Vienna: Böhlau, 2008).

Kruzel, Joseph, and Michael Haltzel (eds.), Between the Blocs: Problems and Prospects for Europe's Neutral and Nonaligned States (Cambridge: University Press, 1989).

Kunnert, Gerhard, Österreichs Weg in die Europäische Union (Vienna: Österreichische Staatsdruckerei, 1993).

Larmola, Heikki, "Finnland zwischen sowjetischem Versuchslabor und beginnendem KSZE-Prozess," in Stefan Karner et al. (eds.), Prager Frühling: Das internationale Krisenjahr 1968 (Vienna: Böhlau, 2008), 633-657.

Larres, Klaus, and Kenneth Osgood (eds.), The Cold War after Stalin's Death: A Missed Opportunity for Peace? (Lanham: Rowman \& Littlefield, 2006).

Larson, Deborah Welch, "Crisis Prevention and the Austrian State Treaty," in International Organization 41, no. 1 (1987), 27-60.

Leffler, Melvyn P. and Odd Arne Westad (eds.), The Cambridge History of the Cold War, 3 vols. (Cambridge: University Press, 2010).

Leidinger, Hannes, and Verena Moritz, Russisches Wien: Begegnungen aus vier Jahrhunderten (Vienna: Böhlau, 2004).

Leonhard, Alan T. (ed.), Neutrality: Changing Concepts and Practices (Lanham: University Press of America, 1988).

Levesque, Jacques, The Enigma of 1989: The USSR and the Liberation of Eastern Europe (Berkeley: University of California Press, 1997).

Liebhart, Karin, and Andreas Pribersky, "Die Mythisierung des Neubeginns: Staatsvertrag und Neutralität," in Emil Brix, Ernst Bruckmüller, Hannes Stekl (eds.), Memoria Austriae I: Menschen, Mythen, Zeiten (Vienna: Geschichte und Politik, 2004), 392-417.

Light, Margot, The Soviet Theory of International Relations (New York: St. Martin's, 1988).

Lindberg, Steve, "Finnish Neutrality in a Changing Environment," in Bo Huldt and Atis Lejins (eds.), European Neutrals and the Soviet Union (Stockholm: The Swedish Institute of International Affairs, 1985), 7-34. 
Lobova, Ludmilla, "Die Außenpolitik und Neutralität Österreichs aus Sicht der UdSSR 1955-1972," in Arnold Suppan, Gerald Stourzh, and Wolfgang Mueller (eds.), The Austrian State Treaty 1955: International Strategy, Legal Relevance, National Identity (Vienna: Verlag der Österreichischen Akademie der Wissenschaften, 2005), 891-922.

Lobova, Ludmilla, "Die Moskauer Perzeption politischer, ökonomischer und sozialer Entwicklungen in Österreich in den 1980er und 90er Jahren," in Oliver Rathkolb, Otto Maschke, and Stefan Lütgenau (eds.), Mit anderen Augen gesehen: Internationale Perzeptionen Österreichs 1955-1990, Österreichische Nationalgeschichte 2 (Vienna: Böhlau, 2002), 91-160.

Lobova, Ludmilla, "Russland und die Neutralität Österreichs: Aktuelle Einschätzungen vor dem Hintergrund des Verhältnisses zur NATO," in Jahrbuch für internationale Sicherheitspolitik (2000), 371-389.

Logue, John, "Sweden," in S. Victor Papacosma and Mark R. Rubin (eds.), Europe's Neutral and Nonaligned States: Between NATO and the Warsaw Pact (Wilmington: Scholarly Resources, 1989), 71-102.

Loth, Wilfried, Die Sowjetunion und die deutsche Frage (Göttingen: Vandenhoeck \& Ruprecht, 2007).

Loth, Wilfried, Die Teilung der Welt: Geschichte des Kalten Krieges 1941-1955, rev. ed. (Munich: Deutscher Taschenbuchverlag, 2000).

Loth, Wilfried (ed.), Europe, Cold War, and Coexistence, 1953-1965 (London: Frank Cass, 2004).

Loth, Wilfried, "German Historians and the German Question in the Cold War," in Juhana Aunesluoma and Pauli Kettunen (eds.), The Cold War and the Politics of History (Helsinki: Edita, 2008), $169-188$.

Loth, Wilfried, and Jürgen Osterhammel (eds.), Internationale Geschichte: Themen - Ergebnisse Aussichten (Munich: Oldenbourg, 2000).

Loth, Wilfried, "Neutralität im Kalten Krieg," in Michael Gehler and Rolf Steininger (eds.), The Neutrals and the European Integration, 1945-1995 (Vienna: Böhlau, 2000), 80-83.

Loth, Wilfried, Overcoming the Cold War: A History of Détente (Basingstoke: Palgrave, 2001).

Loth, Wilfried, and Georges-Henri Soutou, (eds.), The Making of Détente: Eastern and Western Europe in the Cold War, 1965-1975 (London: Routledge, 2008).

Luchak, John M., “Amerikanisch-österreichische Beziehungen von 1955 bis 1985” (PhD Thesis, Vienna, 1987).

Ludlow, N. Piers, "European Integration and the Cold War," in Melvyn P. Leffler and Odd Arne Westad (eds.), The Cambridge History of the Cold War II: Crises and Détente (Cambridge: University Press, 2010), 179-197.

Luif, Paul, “Austria's Permanent Neutrality - Its Origins, Development, and Demise," in Günther Bischof, Anton Pelinka, and Ruth Wodak (eds.), Neutrality in Austria, Contemporary Austrian Studies 9 (New Brunswick: Transaction, 2001), 129-159.

Luif, Paul, Der Wandel der österreichischen Neutralität: Ist Österreich ein sicherheitspolitischer „Trittbrettfahrer"? 2nd ed. (Vienna: Austrian Institute for International Affairs, 1998).

Luif, Paul, "Neutralität - Neutralismus - Blockfreiheit: Ideologien und Interessen," in Österreichische Zeitschrift für Politikwissenschaft 8, no. 3 (1979), 269-285.

Luif, Paul, "Österreich und die europäische Integration 1985-1995," in Michael Gehler and Rolf Steininger (eds.), The Neutrals and the European Integration, 1945-1995 (Vienna: Böhlau, 2000), 680-701.

Luif, Paul, "Österreich zwischen Ost und West: Österreichs Abstimmungsverhalten in der Generalversammlung der UN," in Österreichisches Jahrbuch für Politik 1984 (1985), 261-274.

Lyon, Peter, Neutralism (Leicester: University Press, 1963).

Mack, Karlheinz, “Aspekte des Neutralitätsverständnisses in verschiedenen Gesellschaftssystemen, in Österreichische Osthefte 17, no. 3 (1975), 254-257.

Mähr, Wilfried, Der Marshallplan in Österreich (Graz: Styria, 1989). 
Malek, Martin, "Österreich und der Auflösungsprozess des Warschauer Paktes 1989-1991," in Manfried Rauchensteiner (ed.), Zwischen den Blöcken: NATO, Warschauer Pakt und Österreich (Vienna: Böhlau, 2010), 557-614.

Malicek, Heike, "Die Beziehungen Österreich-Sowjetunion 1945 bis 1975: Ein pragmatisches Verhältnis" (MA Thesis, Vienna, 1995).

Martin, Jessica E., "Peaceful Coexistence," in Ruud van Dijk et al (eds.), Encyclopedia of the Cold War (New York: Routledge, 2008), 689-690.

Mastny, Vojtech, "Imagining war in Europe: Soviet strategic planning," in idem, Sven G. Holtsmark, and Andreas Wenger (eds.), War Plans and Alliances in the Cold War: Threat perceptions in the East and West (London: Routledge, 2006), 14-45.

Mastny, Vojtech, "Kremlin Politics and the Austrian Settlement," in Problems of Communism 31 (July-August 1982), 37-51.

Mastny, Vojtech, "Soviet Foreign Policy 1953-1962," in Melvyn P. Leffler and Odd Arne Westad (eds.), The Cambridge History of the Cold War I: Origins (Cambridge: University Press, 2010), 312-333.

Mastny, Vojtech, The Cold War and Soviet Insecurity: The Stalin Years (New York: Oxford University Press, 1996).

Mastny, Vojtech, "The Soviet Union and the Origins of the Warsaw Pact in 1955," http://www.php.isn. ethz.ch/collections/coll_pcc/into_VM.cfm (accessed 2008).

Mastny, Vojtech, "The Launching of the Warsaw Pact and Soviet Grand Strategy," in Arnold Suppan, Gerald Stourzh, and Wolfgang Mueller (eds.), The Austrian State Treaty 1955: International Strategy, Legal Relevance, National Identity (Vienna: Verlag der Österreichischen Akademie der Wissenschaften, 2005), 145-162.

Matscher, Franz, "Die Minderheitenregelungen im Staatsvertrag," in Arnold Suppan, Gerald Stourzh, and Wolfgang Mueller (eds.), The Austrian State Treaty 1955: International Strategy, Legal Relevance, National Identity (Vienna: Verlag der Österreichischen Akademie der Wissenschaften, 2005), 783-819.

McWhinney, Edward, Peaceful Coexistence and Soviet-Western International Law (Leyden: Sythoff, 1964).

Mehnert, Klaus, “Friedliche Koexistenz - Eine deutsche Meinung,” in Osteuropa 24, no. 4 (1974), 270-274.

Meier-Walser, Reinhard, Die Außenpolitik der monocoloren Regierung Klaus in Österreich 19661970 (Munich: Tuduv, 1988).

Meissner, Boris (ed.), Sowjetunion und Völkerrecht 1917 bis 1962: Eine bibliographische Dokumentation (Cologne: Wissenschaft und Politik, 1963).

Meissner, Boris, Dietrich Frenzke, and Erika Chilecki (eds.), Sowjetunion und Völkerrecht 1962 bis 1973: Bibliographie und Analyse (Cologne: Wissenschaft und Politik, 1977).

Meissner, Boris, "Triebkräfte und Faktoren sowjetischer Außenpolitik," in idem and Gotthold Rhode, Grundfragen sowjetischer Außenpolitik (Stuttgart: Kohlhammer, 1970), 9-40.

Melvern, Linda, Nick Anning, and David Hebditch, Techno-Bandits: How the Soviets are Stealing America's Future (Boston: Houghton Mifflin, 1984).

Merl, Stephan, “Außenpolitik und Wettlauf der Systeme," in Stefan Plaggenborg (ed.), Handbuch der Geschichte Russlands V/1 (Stuttgart : Hiersemann, 2002), 273-308.

Menzel, Eberhard, "Vorwort des deutschen Herausgebers," in F.I. Koschewnikow (ed.), Völkerrecht (Hamburg: Hansischer Gildenverlag, 1960), xi-xxvii.

Merhaut-Gurevitsch, Evelina, "Die Innen- und Außenpolitik Österreichs in der sowjetischen Presse 1954-1961" (MA Thesis, Vienna, 1995).

Milward, Alan S., "European Uses of Neutrality," in Wiener Zeitschrift zur Geschichte der Neuzeit 1, no. 1 (2001), 103-116. 
Molden, Berthold, "Das Bundeskanzleramt, Auswärtige Angelegenheiten, und seine Rolle in der österreichischen Kulturaußenpolitik gegenüber den osteuropäischen Staaten 1945-1959” (MA Thesis, Vienna, 1999).

Molden, Berthold, “Die 'Ost-West-Drehscheibe': Österreichs Medien im Kalten Krieg,” in Manfried Rauchensteiner (ed.), Zwischen den Blöcken: NATO, Warschauer Pakt und Österreich (Vienna: Böhlau, 2010), 687-774.

Molin, Karl, "Central Issues of Swedish Neutrality Policy," in Michael Gehler and Rolf Steininger (eds.), The Neutrals and European Integration (Vienna: Böhlau, 2000), 261-275.

Molin, Karl, "The Supportive Observer: Sweden and the Austrian State Treaty 1955," in Arnold Suppan, Gerald Stourzh, Wolfgang Mueller (eds.), The Austrian State Treaty 1955: International Policy, Legal Relevance, National Identity (Vienna: Verlag der Österreichischen Akademie der Wissenschaften, 2005), 397-415.

Moser, Aurel B.J., "Die Stellung der Kommunistischen Partei Österreichs zur österreichischen Neutralitätspolitik von 1955-1972" (PhD Thesis, Salzburg, 1973).

Möttölä, Kari, "Managing the Finnish-Soviet Relationship: Lessons and Experiences," in Bo Huldt and Atis Lejins (eds.), European Neutrals and the Soviet Union (Stockholm: The Swedish Institute of International Affairs, 1985), 35-57.

Mueller, Wolfgang, "Der Warschauer Pakt und Österreich 1955-1991," in Manfried Rauchensteiner (ed.), Zwischen den Blöcken: NATO, Warschauer Pakt und Österreich (Vienna: Böhlau, 2010), 135-191.

Mueller, Wolfgang, Die sowjetische Besatzung in Österreich 1945-1955 und ihre politische Mission (Vienna: Böhlau, 2005).

Mueller, Wolfgang, "Die UdSSR und die europäische Integration," in Michael Gehler (ed.), From the Common Market to European Union Building: 50 Years of the Rome Treaties (Vienna: Böhlau, 2009), 617-662.

Mueller, Wolfgang, "Gab es eine verpasste Chance? Die sowjetische Haltung zum Staatsvertrag," in Arnold Suppan, Gerald Stourzh and Wolfgang Mueller (eds.), The Austrian State Treaty 1955: International Strategy, Legal Relevance, National Identity (Vienna: Verlag der Österreichischen Akademie der Wissenschaften, 2005), 89-120.

Mueller, Wolfgang, "Peaceful Coexistence, Neutrality, and Bilateral Relations across the Iron Curtain," in idem and Arnold Suppan (eds.), Peaceful Coexistence or Iron Curtain? Austria, Neutrality, and Eastern Europe in the Cold War and Détente, 1955-1989 (Vienna: Lit, 2009), 7-28.

Mueller, Wolfgang, "Stalin and Austria: New Evidence on Soviet Policy in a Secondary Theatre of the Cold War, 1938-1953/55," in Cold War History 6, no. 1 (2006), 63-84.

Mueller, Wolfgang, "The Soviet Union and Early West European Integration: From the Brussels Treaty to the ECSC and EEC, 1947-1957," in Journal of European Integration History 15, no. 2 (2009), 67-85.

Mueller, Wolfgang and Hannes Leidinger, "Tiefes Misstrauen - begrenztes Interesse: Die österreichisch-sowjetischen Beziehungen 1918 bis 1955," in Arnold Suppan, Klaus Koch, Walter Rauscher, and Elisabeth Vyslonzil (eds.), Von Saint-Germain zum Belvedere: Österreich und Europa 1919-1955 (Vienna: Oldenbourg, 2006), 70-114.

Müller, Wolfgang C., "Bruno Kreisky," in Herbert Dachs, Peter Gerlich, Wolfgang C. Müller (eds.), Die Politiker: Karrieren und Wirken bedeutender Repräsentanten der Zweiten Republik (Vienna: Manz, 1995), 353-365.

Mugrauer, Manfred, "Der Prager Frühling und die Parteikrise der KPÖ," in Stefan Karner et al. (eds.), Der Prager Frühling 1968: Das internationale Krisenjahr (Vienna: Böhlau, 2008), 1043-1061.

Mugrauer, Manfred, “Zwischen Erschütterung, neuer Offenheit und „Normalisierung“: Die KPÖ, der 20. Parteitag der KPdSU und die Ungarn-Krise 1956," in Wolfgang Mueller and Michael Portmann (eds.), Osteuropa vom Weltkrieg zur Wende (Vienna: Verlag der Österreichischen Akademie der Wissenschaften, 2007), 257-298. 
Murber, Ibolya, and Zoltán Fónagy (eds.), Die Ungarische Revolution und Österreich 1956 (Vienna: Czernin, 2006).

Narinski, M., "La construction européenne vue par l’URSS de 1948 à 1953,“ in Saki Dockrill, Robert Frank, Georges Henri Soutou and Antonio Varsori (eds.), L'Europe de l'Est et de l'Ouest dans la Guerre froide 1948-1953 (Paris: PUPS, 2002), 61-72.

Neuhold, Hanspeter, "Außenpolitik, dauernde Neutralität und internationale Organisationen aus österreichischer Sicht," in Friedrich Koja and Gerald Stourzh (eds.), Österreich - Schweiz: Ähnlichkeiten und Kontraste (Vienna: Böhlau, 1986), 229-263.

Neuhold, Hanspeter, "Austria and the Soviet Union," in Bo Huldt and Atis Lejins (eds.), European Neutrals and the Soviet Union (Stockholm: Swedish Institute of International Affairs, 1986), 83-118.

Neuhold, Hanspeter, and Paul Luif (eds.), Das außenpolitische Bewusstsein der Österreicher: Aktuelle internationale Probleme im Spiegel der Meinungsforschung (Vienna: Braumüller, 1992).

Neuhold, Hanspeter, "Der Staatsvertrag als Grundlage der österreichischen Außenpolitik," in Alois Mock, Ludwig Steiner, Andreas Khol (eds.), and Rainer Stepan (red.), Neue Fakten zu Staatsvertrag und Neutralität (Vienna: Politische Akademie, [1980]), 157-180.

Neuhold, Hanspeter, and Karl Zemanek, "Die österreichische Neutralität im Jahre 1967," in Österreichische Zeitschrift für Außenpolitik 8, no. 1 (1968), 14-32.

Neuhold, Hanspeter, and Karl Zemanek, "Die österreichische Neutralität im Jahre 1968," in Österreichische Zeitschrift für Außenpolitik 9, no. 2 (1969), 144-169.

Neuhold, Hanspeter, "Österreichs Außenpolitik in den Ost-West-Beziehungen,” in Renate Kicker, Andreas Khol, Hanspeter Neuhold (eds.), Außenpolitik und Demokratie in Österreich: Strukturen - Strategien - Stellungnahmen (Salzburg: Neugebauer, 1983), 290-320.

Neuhold, Hanspeter, "Permanent Neutrality and Nonalignment: Similarities and Differences," in Robert A. Bauer (ed.), The Austrian Solution: International Conflict and Cooperation (Charlottesville: The University Press of Virginia, 1982), 161-204.

Neuhold, Hanspeter, "Supermächte und Neutralität," in Emil Brix, Thomas Fröschl, Josef Leidenfrost (eds.), Geschichte zwischen Freiheit und Ordnung: Gerald Stourzh zum 60. Geburtstag (Graz: Styria, 1991), 299-316.

Neuhold, Hanspeter and Hans Thalberg (eds.), The European Neutrals in International Affairs, Laxenburg Papers 7 (Vienna, Braumüller, 1984).

Neuhold, Hanspeter, "The Neutral States of Europe: Similarities and Differences," in Alan T. Leonhard (ed.), Neutrality: Changing Concepts and Practices (Lanham: University Press of America, 1988), 97-144.

Neuhold, Hanspeter, "The Permanent Neutrality of Austria," in Karl E. Birnbaum and Hanspeter Neuhold (eds.), Neutrality and Non-Alignment in Europe, Laxenburg Papers 4 (Vienna: Braumüller, 1981), 44-61.

Newton, Julie M., Russia, France, and the Idea of Europe (Palgrave: Macmillan, 2003).

Niedhart, Gottfried, "The East-West Problem as Seen from Berlin: Willy Brandt's Early Ostpolitik," in Wilfried Loth (ed.), Europe, Cold War, and Coexistence, 1953-1965, Cold War History 4 (London: Frank Cass, 2004), 285-296.

Nogee, Joseph, and Robert Donaldson, Soviet Foreign Policy since World War II (New York: Macmillan 1992).

Ogley, Roderick, The Theory and Practice of Neutrality in the Twentieth Century (London: Routledge \& Kegan Paul, 1970).

Olechowski, Thomas (ed.), Fünfzig Jahre Staatsvertrag und Neutralität (Vienna: WUV-Universitätsverlag, 2006).

Opelland, Torsten, "Gerhard Schröder and the First Ostpolitik," in Wilfried Loth (ed.), Europe, Cold War, and Coexistence, 1953-1965, Cold War History 4 (London: Frank Cass, 2004), 274-284. 
Oudenaren, John van, Détente in Europe: The Soviet Union and the West (Durham: Duke University Press, 1991).

Ouimet, Matthew, The Rise and Fall of the Brezhnev Doctrine in Soviet Foreign Policy (Chapel Hill: The University of North Carolina Press, 2003).

Papacosma, S. Victor, and Mark R. Rubin (eds.), Europe's Neutral and Nonaligned States: Between NATO and the Warsaw Pact (Wilmington: Scholarly Resources, 1989).

Pape, Matthias, "Die Deutschlandinitiative des österreichischen Bundeskanzlers Julius Raab im Frühjahr 1958," in Vierteljahrshefte für Zeitgeschichte 48, no. 2 (2000), 281-318.

Pape, Matthias, Ungleiche Brüder: Österreich und Deutschland 1945-1965 (Cologne: Böhlau, 2000).

Petersson, Bo, The Soviet Union and Peacetime Neutrality in Europe: A Study of Soviet Political Language (Stockholm: MH Publishing, 1990).

Plate, Bernard von, Zur Position und Rolle der Neutralen Staaten in der Entwicklung der Europäischen Ost-West-Beziehungen (Eggenberg: Stiftung Wissenschaft und Politik, 1975).

Prozumenščikov, Michail, and Barbara Stelzl-Marx, “"Es scheint, dass der Winter in diesem Jahr sehr kalt wird': Zum Wiener Gipfeltreffen zwischen John F. Kennedy und Nikita Chruschtschow aus der Sicht des Zentralkomitees der KPdSU," in Monika Sommer (ed.), Die Augen der Welt auf Wien gerichtet: Gipfel 1961 Chruschtschow - Kennedy (Innsbruck: Studienverlag, 2005), 34-59.

Prozumenščikov, Michail, "Nach Stalins Tod: Sowjetische Österreichpolitik 1953-1955," in Stefan Karner and Barbara Stelzl-Marx (eds.), Die Rote Armee in Österreich: Beiträge (Graz: Oldenbourg, 2005), 729-753.

Rainio Niemi, Johanna, "Small State Cultures of Consensus: State Traditions and Consensus-Seeking in the Neo-Corporatist and Neutrality Policies in Post-1945 Austria and Finland" (PhD Thesis, University of Helsinki, 2008).

Ramundo, Bernard A., Peaceful Coexistence: International Law in the Building of Communism (Baltimore: Johns Hopkins Press, 1967).

Rathkolb, Oliver, “Außenansichten auf Staatsvertrag und Neutralität zwischen Mythos und Realpolitik," in Ernst Bruckmüller (ed.), Wiederaufbau in Österreich 1945-1955: Rekonstruktion oder Neubeginn? (Vienna: Geschichte und Politik, 2006), 162-185.

Rathkolb, Oliver, “'Austria - Sieve to the East:' Austria's Neutrality during the East-West Economic War 1945/1948/1989" (Paper presented at the IEHC, Helsinki, 2006). http://www.helsinki.fi/ iehc2006/papers3/Rathkolb.pdf .

Rathkolb, Oliver, "Austria's Ostpolitik in the 1950s and 1960s: Honest Broker or Double Agent?" in Austrian History Yearbook XXVI (1995), 129-146.

Rathkolb, Oliver, "Der Wiederbeginn der diplomatischen Beziehungen zwischen Österreich und der Sowjetunion 1945-1947 zwischen Kaltem Krieg und österreichischer Innenpolitik," in Mitteilungen des Österreichischen Staatsarchivs 50 (2003), 157-166.

Rathkolb, Oliver, "Die Kreisky-Ära 1970-1983," in Rolf Steininger and Michael Gehler (eds.), Österreich im 20. Jahrhundert 2: Vom Zweiten Weltkrieg bis zur Gegenwart (Vienna: Böhlau, 1997), 305-353.

Rathkolb, Oliver, Die paradoxe Republik: Österreich 1945 bis 2005 (Vienna: Zsolnay, 2005).

Rathkolb, Oliver, Internationalisierung Österreichs seit 1945 (Innsbruck: Studienverlag, 2006).

Rathkolb, Oliver, "International Perceptions of Austrian Neutrality," in Günter Bischof, Anton Pelinka, and Ruth Wodak (eds.), Neutrality in Austria, Contemporary Austrian Studies 9 (New Brunswick: Transaction, 2001), 69-91.

Rathkolb, Oliver, "The Kreisky Era: 1970-1983,” in Rolf Steininger, Günter Bischof, and Michael Gehler (eds.), Austria in the Twentieth Century (New Brunswick: Transaction, 2002), 263-293.

Rathkolb, Oliver, Washington ruft Wien. US-Großmachtpolitik gegenüber Österreich 1953-1963 (Vienna: Böhlau, 1997).

Rauchensteiner, Manfried, Die Zwei: Die große Koalition in Österreich 1945-1966 (Vienna: Bundesverlag, 1987). 
Rauchensteiner, Manfried, "Sandkästen und Übungsräume: Operative Annahmen und Manöver des Bundesheeres 1955-1979," in idem (ed.), Zwischen den Blöcken: NATO, Warschauer Pakt und Österreich (Vienna: Böhlau, 2010), 253-322.

Rauchensteiner, Manfried, Spätherbst 1956: Die Neutralität auf dem Prüfstand (Vienna: Bundesverlag, 1981).

Rauchensteiner, Manfried, Stalinplatz 4: Österreich unter alliierter Besatzung (Vienna: Steinbauer, 2005).

Rauchensteiner, Manfried, “The 'Big Two': The Grand Coalition, 1945-1966 and 1987-2000,” in Rolf Steininger, Günter Bischof, and Michael Gehler (eds.), Austria in the Twentieth Century (New Brunswick: Transaction, 2002), 235-262.

Rauchensteiner, Manfried (ed.), Zwischen den Blöcken: NATO, Warschauer Pakt und Österreich (Vienna: Böhlau, 2010).

Reiter, Erich, and Georg Bautzmann, "Kriegsführungspläne des Warschauer Paktes in der so genannten Zeit des Kalten Krieges," in Erich Reiter and Ernest König (eds.), Österreichs Neutralität und die Operationsplanungen des Warschauer Paktes, Informationen zur Sicherheitspolitik 20 (Vienna: Landesverteidigungsakademie, 1999), 11-14.

Reiter, Erich, and Ernest König (eds.), Österreichs Neutralität und die Operationsplanungen des Warschauer Paktes, Informationen zur Sicherheitspolitik 20 (Vienna: Landesverteidigungsakademie, 1999).

Reitinger, Monika, "Österreich in den Augen der Sowjetliteratur nach 1945” (PhD Thesis, Vienna, 1969).

Rentola, Kimmo, "Der Vorschlag einer europäischen Sicherheitskonferenz und die stille Krise zwischen Finnland und der Sowjetunion," in Dominik Geppert and Udo Wengst (eds.), Neutralität - Chance oder Chimäre? Konzepte des Dritten Weges für Deutschland und die Welt 1945-1990 (Munich: Oldenbourg, 2005), 177-202.

Resch, Andreas, "Der österreichische Osthandel im Spannungsfeld der Blöcke," in Manfried Rauchensteiner (ed.), Zwischen den Blöcken: NATO, Warschauer Pakt, und Österreich (Vienna: Böhlau, 2010), 497-556.

Resch, Andreas, "Die Außenhandelsbeziehungen zwischen dem RGW-Raum und Österreich in der Nachkriegszeit," in Gertrude Enderle-Burcel, Dieter Stiefel, and Alice Teichova (eds.), Zarte Bande: Österreich und die europäischen planwirtschaftlichen Länder, MÖSTA Sonderband 9 (Innsbruck: Studienverlag, 2006), 39-72.

Rey, Marie-Pierre, La tentation du rapprochement: France et URSS à l'heure de la détente 19641974 (Paris: Sorbonne, 1991).

Reynolds, David, One World Divisible: A Global History Since 1945 (London: Penguin, 2000).

Richmond, Yale, Cultural Exchange and the Cold War: Raising the Iron Curtain (University Park: The Pennsylvania State University Press, 2003).

Riedl, Gregor, "Die Entwicklung und Bedeutung der Wirtschaftsbeziehungen zwischen Österreich und der Sowjetunion im Zeitraum von 1965 bis 1980" (MA Thesis, Vienna, 1983).

Riklin, Alois, Weltrevolution oder Koexistenz? (Zurich: Schweizerischer Aufklärungsdienst, 1969).

Roberts, Geoffrey, A Chance for Peace: The Soviet Campaign to End the Cold War, 1953-1955, Cold War International History Project Working Paper 57 (Washington, DC: Woodrow Wilson Center, 2008).

Roberts, Geoffrey, The Soviet Union in World Politics: Coexistence, Revolution, and Cold War, 1945 1991 (London: Routledge, 1999).

Röhrlich, Elisabeth, Kreiskys Außenpolitik: Zwischen österreichischer Identität und internationalem Programm (Göttingen: V\&R unipress, 2009).

Romano, Angela, From Détente in Europe to European Détente: How the West Shaped the Helsinki CSCE (Brussels: Peter Lang, 2009). 
Rotter, Manfred, "Der Staatsvertrag," in Reinhard Sieder, Heinz Steinert, Emmerich Tálos (eds.), Österreich 1945-1995: Gesellschaft Politik Kultur (Vienna: Verlag für Gesellschaftskritik), 122 132.

Rotter, Manfred, Die dauernde Neutralität (Berlin: Duncker \& Humblot, 1981).

Rotter, Manfred, "Unter Wahrung der Neutralität," in Zukunft, no. 1 (1990), 5-11.

Ruane, Kevin, The Rise and Fall of the European Defence Community (Basingstoke: Macmillan, 2000).

Rubin, Mark R., and Laurent Wehrli, "Switzerland," in S. Victor Papacosma and Mark R. Rubin (eds.), Europe's Neutral and Nonaligned States: Between NATO and the Warsaw Pact (Wilmington: Scholarly Resources, 1989), 43-70.

Rubinstein, Alvin Z., Soviet Foreign Policy since World War II (New York: Harper Collins, 1992).

Ruggenthaler, Peter, "Der Neutralität verpflichtet: die sowjetisch-österreichischen Beziehungen 1968," in Stefan Karner et al. (eds.), Der Prager Frühling 1968: Das internationale Krisenjahr (Vienna: Böhlau, 2008), 993-1006.

Savranskaya, Svetlana, "Human Rights Movement in the USSR after the Signing of the Helsinki Final Act, and the Reaction of the Soviet Authorities," in Leopoldo Nuti (ed.), The Crisis of Détente in Europe: From Helsinki to Gorbachev, 1975-1985 (London: Routledge, 2009), 26-40.

Savranskaya, Svetlana, and William Taubman, "Soviet Foreign Policy, 1962-1975," in Melvyn P. Leffler and Odd Arne Westad (eds.), The Cambridge History of the Cold War II: Crises and Détente (Cambridge: University Press, 2010), 134-157.

Savranskaya, Svetlana, "Unintended Consequences: Soviet Interests, Expectations, and Reactions to the Helsinki Final Act," in Oliver Bange and Gottfried Niedhart (eds.), Helsinki 1975 and the Transformation of Europe (New York: Berghan, 2008), 175-190.

Scarlis, Stelianos, Neutralität in Europa aus sowjetischer Sicht im Zeitalter der Entspannung: Die Rolle der neutralen Staaten Europas in der Außenpolitik der Sowjetunion 1969-1975 (Munich: Tuduv, 1984).

Schalhorn, Bernhard, "Sowjetische Westeuropapolitik I," in Dietrich Geyer (ed.), Osteuropa-Handbuch Sowjetunion: Außenpolitik 1955-1973 (Cologne: Böhlau, 1976), 61-145.

Schätz, Alfred, "Die sowjetische Militärpolitik im Kalten Krieg und die österreichische dauernde Neutralität" (PhD Thesis, Vienna, 2008).

Schlesinger, Thomas O., Austrian Neutrality in Postwar Europe: The Domestic Roots of a Foreign Policy (Vienna: Braumüller, 1972).

Schmidl, Erwin A., "Die österreichische Reaktion auf die Ereignisse in Ungarn 1956 und der Einsatz des Bundesheeres an der ungarischen Grenze," in Ibolya Murber and Zoltán Fónagy (eds.), Die Ungarische Revolution und Österreich 1956 (Vienna: Czernin, 2006), 93-115.

Schmidl, Erwin A. (ed.), Die Ungarnkrise 1956 und Österreich (Vienna: Böhlau, 2003).

Schmidl, Erwin A. (ed.), Österreich im frühen Kalten Krieg: Spione, Partisanen, Kriegspläne (Vienna: Böhlau, 2000).

Schmidl, Erwin, "The Warsaw Pact and Austria: Threats and Threat Perceptions," in Arnold Suppan and Wolfgang Mueller (eds.), Peaceful Coexistence or Iron Curtain? Austria, Neutrality, and Eastern Europe in the Cold War and Détente, 1955-1989 (Vienna: Lit, 2009), 203-217.

Schneider, Heinrich, "Die österreichische Neutralität und die europäische Integration," in Michael Gehler and Rolf Steininger (eds.), The Neutrals and the European Integration, 1945-1995 (Vienna: Böhlau, 2000), 465-496.

Schulz, Eberhard, Moskau und die europäische Integration (Munich: Oldenbourg, 1975).

Schweisfurth, Theodor, "Einleitung," in Gregorij I. Tunkin, Völkerrechtstheorie (Berlin: Berlin Verlag, 1972), 9-19.

Schweisfurth, Theodor, "Entwicklung und ideologische Grundlagen der sowjetischen Völkerrechtstheorie," in Dietrich Geyer (ed.), Osteuropa-Handbuch Sowjetunion Außenpolitik III: Völkerrechtstheorie und Vertragspolitik (Cologne: Böhlau, 1976), 27-48. 
Schweisfurth, Theodor, Sozialistisches Völkerrecht? Darstellung - Analyse - Wertung der sowjetmarxistischen Theorie vom Völkerrecht „,neuen Typs “ (Berlin: Springer, 1979).

Schweitzer, Michael, Dauernde Neutralität und europäische Integration (Vienna: Springer, 1977).

Schwimmer, Walter, "Der Europarat: Entstehungsgeschichte, Rolle und Stellenwert für Österreich," in Waldemar Hummer (ed.), Österreich im Europarat 1956-2006: Bilanz einer 50jährigen Mitgliedschaft (Vienna: Böhlau, 2008), 55-96.

Sheehan, James J., "What Does It Mean To Be Neutral? Postwar Austria from a Comparative Perspective," in Amir Eshel, Roland Hsu, Wolfgang Mueller, Arnold Suppan (eds.), Austria and Central Europe Since 1989 (Vienna: forthcoming).

Sheehan, James J., Where Have All the Soldiers Gone? The Transformation of Modern Europe (Boston: Houghton Mifflin, 2008).

Sinigoj, Gabriele, Indien und Blockfreiheit als außenpolitische Strategie (New York: Lang, 1998).

Sipos, Péter, “Österreichs Neutralität in der internationalen Politik 1955-1989," in Ferenc Glatz (ed.), Der Österreichische Staatsvertrag 1955 (Budapest: Europa Institut, 2006), 65-70.

Skuhra, Anselm, "Austria and the New Cold War," in Bengt Sundelius (ed.), The Neutral Democracies in the New Cold War (Boulder: Westview, 1987), 117-147.

Skuhra, Anselm, "Österreichs Sicherheitspolitik," in Herbert Dachs et al. (eds.), Politik in Österreich (Vienna: Manz, 2006), 838-854.

Snyder, Timothy, The Red Prince: The Secret Lives of a Habsburg Archduke (New York: Basic Books, 2008).

Spohr Readman, Kristina, "Between political rhetoric and realpolitik calculations: Western diplomacy and the Baltic independence struggle in the Cold War endgame," in Cold War History 6, no. 1 (2006), 1-42.

Stanek, Eduard, Verfolgt, verjagt, vertrieben: Flüchtlinge in Österreich (Vienna: Europa, 1985).

Stankovsky, Jan, "Österreich und das COCOM," in WIFO Monatsberichte no. 3 (1990), 148-155.

Stearman, William L., "An Analysis of Soviet Objectives in Austria," in Robert A. Bauer, The Austrian Solution: International Conflict and Cooperation (Charlottesville: University Press of Virginia, 1982), 99-125.

Stearman, William Lloyd, The Soviet Union and the Occupation of Austria: An Analysis of Soviet Policy in Austria, 1945-1955 (Bonn: Siegler, 1961).

Steiner, Kurt, "Negotiations for an Austrian State Treaty," in Alexander L. George, Philip J. Farley, and Alexander Dallin (eds.), U.S.-Soviet Security Cooperation: Achievements, Failures, Lessons (New York and Oxford: Oxford University Press 1988), 46-82.

Steiner, Ludwig, "Zur Außenpolitik der Zweiten Republik," in Erich Zöllner (ed.), Diplomatie und Außenpolitik Österreichs (Vienna: Österreichischer Bundesverlag, 1977), 169-187.

Steininger, Rolf, Günter Bischof, and Michael Gehler (eds.), Austria in the Twentieth Century (New Brunswick: Transaction, 2002).

Steininger, Rolf, Der Staatsvertrag: Österreich im Schatten von deutscher Frage und Kaltem Krieg (Innsbruck: Studienverlag, 2005).

Steininger, Rolf, and Michael Gehler (eds.), Österreich im 20. Jahrhundert 2: Vom Zweiten Weltkrieg bis zur Gegenwart (Vienna: Böhlau, 1997).

Steininger, Rolf, "Österreichs 'Alleingang' nach Brüssel 1963-1969," in Michael Gehler and idem (eds.), The Neutrals and European Integration (Vienna: Böhlau, 2000), 577-644.

Steininger, Rolf, "1955: The Austrian State Treaty and the German Question," in Diplomacy \& Statecraft 3, no. 3 (1992), 494-522.

Stiefel, Dieter, and Schumpeter Gesellschaft (eds.), Der „Ostfaktor “: Österreichs Wirtschaft und die Ostöffnung 1989 bis 2009 (Vienna: Böhlau, 2009).

Stifter, Ruth, "Das politische Österreichbild in der sowjetischen Berichterstattung vom Beginn der Zweiten Republik bis zum Zusammenbruch der UdSSR" (MA Thesis, Vienna, 1998). 
Stirnemann, Alfred, and Gerhard Wilflinger (eds.), Russland und Österreich, Pro Oriente 23 (Innsbruck: Tyrolia, 1999).

Stone, Norman, "Andrei Gromyko as Foreign Minister: The Problems of a Decaying Empire," in Gordon A. Craig and Francis L. Loewenheim (eds.), The Diplomats, 1939-1979 (Princeton: University Press, 1994), 593-608.

Stourzh, Gerald, "Der österreichische Staatsvertrag in den weltpolitischen Entscheidungsprozessen des Jahres 1955," in Arnold Suppan, Gerald Stourzh, and Wolfgang Mueller (eds.), The Austrian State Treaty 1955: International Strategy, Legal Relevance, National Identity (Vienna: Verlag der Österreichischen Akademie der Wissenschaften, 2005), 965-995.

Stourzh, Gerald, "Der österreichische Staatsvertrag und die Voraussetzungen seines Zustandekommens," in 25 Jahre österreichischer Staatsvertrag: Symposium, veranstaltet von der Österreichischen Akademie der Wissenschaften und der Akademie der Wissenschaften der UdSSR in der Zeit vom 12.-19. April 1980 in Moskau (Vienna: Verlag der Österreichischen Akademie der Wissenschaften, 1981), 65-76.

Stourzh, Gerald, "Die Entstehungsgeschichte des österreichischen Neutralitätsgesetzes," in Thomas Olechowski (ed.), Fünfzig Jahre Staatsvertrag und Neutralität (Vienna: WUV-Universitätsverlag, 2006), 67-94.

Stourzh, Gerald, "Grundzüge der österreichischen Außenpolitik, 1945-1960," in Anton Kolabek (ed.), Österreichische Zeitgeschichte im Geschichtsunterricht (Vienna: Österreichischer Bundesverlag, 1961), 185-211.

Stourzh, Gerald, "Once More about Austria's Neutrality," in International Affairs, no. 4 (April 1962), 110.

Stourzh, Gerald, "The Austrian State Treaty and the International Decision Making Process in 1955," in Austrian History Yearbook 38 (2007), 208-228.

Stourzh, Gerald, "Some Reflections on Permanent Neutrality," in August Schou and Arne Olav Brundtland (eds.), Small States in International Relations, Nobel Symposium 7 (Stockholm: Almquist \& Wiksell, 1971).

Stourzh, Gerald, "The Origins of Austrian Neutrality," in Alan T. Leonhard (ed.), Neutrality: Changing Concepts and Practices (Lanham: University Press of America, 1988), 35-57. Reprinted in From Vienna to Chicago and Back: Essays on Intellectual History and Political Thought in Europe and America (Chicago: The University of Chicago Press, 2007), 248-271.

Stourzh, Gerald, Um Einheit und Freiheit: Staatsvertrag, Neutralität und das Ende der Ost-WestBesetzung Österreichs 1945-1955, 5th rev. ed. (Vienna: Böhlau, 2005).

Stourzh, Gerald "Zur Geschichte der österreichischen Neutralität," in Österreich in Geschichte und Literatur 5, no. 6 (1961), 273-288, 275.

Stöver, Bernd, Der Kalte Krieg 1947-1991: Geschichte eines radikalen Zeitalters (Munich: Beck, 2007).

Strasser, Wolfgang, Österreich und die Vereinten Nationen: Eine Bestandsaufnahme von 10 Jahren Mitgliedschaft (Vienna: Braumüller, 1967).

Sundelius, Bengt, "Dilemmas and Strategies for the Neutral Democracies," in idem (ed.), The Neutral Democracies in the New Cold War (Boulder: Westview, 1987), 11-32.

Sundelius, Bengt (ed.), The Neutral Democracies in the New Cold War (Boulder: Westview, 1987).

Suppan, Arnold, "Jugoslawien und der österreichische Staatsvertrag," in Arnold Suppan, Gerald Stourzh, and Wolfgang Mueller (eds.), The Austrian State Treaty 1955: International Strategy, Legal Relevance, National Identity (Vienna: Verlag der Österreichischen Akademie der Wissenschaften, 2005), 430-471.

Suppan, Arnold, Jugoslawien und Österreich 1918-1938: Bilaterale Außenpolitik im europäischen Umfeld (Vienna: Oldenbourg, 1996).

Suppan, Arnold, "Neueste Forschungen zum österreichischen Staatsvertrag," in Ferenc Glatz (ed.), Der Österreichische Staatsvertrag 1955 (Budapest: Europa Institut, 2006), 21-29. 
Suppan, Arnold, “Österreichs Ostpolitik 1955-1989," in Ibolya Murber and Zoltán Fónagy (eds.), Die Ungarische Revolution und Österreich 1956 (Vienna: Czernin, 2006), 75-92.

Suppan, Arnold, and Wolfgang Mueller (eds.), Peaceful Coexistence or Iron Curtain? Austria, Neutrality, and Eastern Europe in the Cold War and Détente, 1955-1989 (Vienna: Lit, 2009).

Suppan, Arnold, Gerald Stourzh, and Wolfgang Mueller (eds.), The Austrian State Treaty 1955: International Strategy, Legal Relevance, National Identity (Vienna: Verlag der Österreichischen Akademie der Wissenschaften, 2005).

Stykalin, A. S., "XX s"ezd KPSS: otkliki v Vengrii i Avstrii," in G. G. Litavrin, T. V. Volokitina, and R. P. Grishina (eds.), 1956 god: Sbornik statei (Moscow: Institut Slavianovedeniia Rossiiskoi akademii nauk, 2008), 220-235.

Széles, Róbert, "Die strategischen Überlegungen des Warschauer Paktes für Mitteleuropa in den 70er Jahren und die Rolle der Neutralen," in Manfried Rauchensteiner (ed.), Tausend Nadelstiche: Das österreichische Bundesheer in der Reformzeit 1970-1978 (Graz: Styria, 1994), 25-45.

Szentesi, Renáta, "Anschuldigungen gegen Österreich von Seiten der Sowjetunion und der KPÖ während der Ungarnkrise von 1956 anhand österreichischer Quellen," in Ibolya Murber and Zoltán Fónagy (eds.), Die Ungarische Revolution und Österreich 1956 (Vienna: Czernin, 2006), 243282.

Tarschys, Daniel, "Neutrality and the Common Market: The Soviet View," in Cooperation and Conflict 6, no. 1 (1971), 65-75.

Taubman, William, Khrushchev: The Man: His Era (London: Simon \& Schuster Free Press, 2003).

Thomas, Daniel C., The Helsinki Effect: International Norms, Human Rights, and the Demise of Communism (Princeton: University Press, 2001).

Thoß, Bruno, "Festschreiben oder Auflockern der Blockkonfrontation? Der NATO-Beitritt der Bundesrepublik Deutschland im Kontext von Sicherheit und Entspannung," in Arnold Suppan, Gerald Stourzh, Wolfgang Mueller (eds.), The Austrian State Treaty 1955: International Policy, Legal Relevance, National Identity (Vienna: Verlag der Österreichischen Akademie der Wissenschaften, 2005), 33-56.

Thoß, Bruno, "Modellfall Österreich? Der österreichische Staatsvertrag und die deutsche Frage 1954/55," in Bruno Thoß and Hans-Erich Volkmann (eds.), Zwischen Kaltem Krieg und Entspannung. Sicherheits- und Deutschlandpolitik der Bundesrepublik im Mächtesystem der Jahre 1953-1956 (Boppard: Boldt, 1988), 93-136.

Trachtenberg, Mark, "The Structure of Great Power Politics, 1963-1975," in Melvyn P. Leffler and Odd Arne Westad (eds.), The Cambridge History of the Cold War II: Crises and Détente (Cambridge: University Press, 2010), 482-502.

Trauttmansdorff, Ferdinand, "Österreichs Außenpolitik als Sicherheitspolitik," in Renate Kicker, Andreas Khol, Hanspeter Neuhold (eds.), Außenpolitik und Demokratie in Österreich: Strukturen - Strategien - Stellungnahmen (Salzburg: Neugebauer, 1983), 235-258.

Türk, Helmut, "Die Wende 1989/90 und die Obsoleterklärung einiger Artikel des Staatsvertrages," in Arnold Suppan, Gerald Stourzh, and Wolfgang Mueller (eds.), The Austrian State Treaty 1955: International Strategy, Legal Relevance, National Identity (Vienna: Verlag der Österreichischen Akademie der Wissenschaften, 2005), 821-837.

Uhl, Heidemarie, "Österreich ist frei! Re-Inszenierungen österreichischer Nachkriegsmythen im Jubiläumsjahr 2005," in Gilbert Carr (ed.), Fünfzig Jahre Staatsvertrag: Schreiben, Identität und das unabhängige Österreich (Munich: Iudicium, 2008), 28-36.

Uhl, Matthias, and Vladimir Ivkin, "Operation Atom: The Soviet Union's Stationing of Nuclear Missiles in the German Democratic Republic," in Cold War International History Project Bulletin, no. 12-13 (2001), 299-307.

Uibopuu, Henn-Jüri, Die sovjetische Doktrin der friedlichen Koexistenz als Völkerrechtsproblem (Vienna: Notring, 1971). 
Ulam, Adam B., Dangerous Relations: The Soviet Union and World Politics, 1970-1982 (New York: Oxford University Press, 1983).

Ulam, Adam B., Expansion and Coexistence: Soviet Foreign Policy, 1917-73, 2nd ed. (New York: Praeger, 1974).

Ullmann, Paul, "Austria and Romania," in Arnold Suppan and Wolfgang Mueller (eds.), Peaceful Coexistence or Iron Curtain? Austria, Neutrality, and Eastern Europe in the Cold War and Détente, 1955-1989 (Vienna: Lit, 2009), 456-477.

Ullmann, Paul, "Das Russlandbild der österreichischen Diplomatie in den ersten drei Jahrzehnten nach dem Ende des 2. Weltkrieges" (unpublished paper, Vienna, n.d.).

Umbach, Frank, Das rote Bündnis: Entwicklung und Zerfall des Warschauer Paktes 1955 bis 1991 (Berlin: Links, 2005).

Urban, Waltraut, "Die Veränderungen in Osteuropa," in Hanspeter Neuhold and Paul Luif (eds.), Das außenpolitische Bewusstsein der Österreicher: Aktuelle internationale Probleme im Spiegel der Meinungsforschung (Vienna: Braumüller, 1992), 1-26.

Väyrynen, Raimo, "Adaptation of a Small Power to International Tensions: The Case of Finland," in Bengt Sundelius (ed.), The Neutral Democracies in the New Cold War (Boulder: Westview, 1987), 33-56.

Vatlin, A. Iu., Avstriia v XX veke (Moscow: Drofa, 2006).

Verclytte, Thomas M., "Austria between East and West," in N.I. Egorova and A.O. Chubar'ian (eds.), Kholodnaia voina i politika razriadki: diskussionnye problemy 1 (Moscow: Institut Vseobshchei Istorii Rossiiskoi Akademii Nauk, 2003), 103-116.

Verosta, Stephan, “Außenpolitik,” in Erika Weinzierl and Kurt Skalnik (eds.), Österreich: Die Zweite Republik (Graz: Styria, 1972), 295-343.

Vertlib, Vladimir, Osteuropäische Zuwanderung nach Österreich 1976-1991 unter besonderer Berücksichtigung der jüdischen Immigration aus der Sowjetunion (Vienna: Verlag der Österreichischen Akademie der Wissenschaften, 1995).

Vigor, Peter H., The Soviet View of War, Peace, and Neutrality (London: Routledge, 1975).

Vloyantes, John, "Finland," in S. Victor Papacosma and Mark R. Rubin (eds.), Europe's Neutral and Nonaligned States: Between NATO and the Warsaw Pact (Wilmington: Scholarly Resources, 1989), 137-159.

Vogel, Hans, "Switzerland and the New Cold War," in Bengt Sundelius (ed.), The Neutral Democracies in the New Cold War (Boulder: Westview, 1987), 95-116.

Volkogonov, Dmitri, Autopsy for an Empire: The Seven Leaders Who Built the Soviet Regime (New York: Free Press, 1998).

Wandycz, Piotr, "Adam Rapacki and the Search for European Security," in Gordon A. Craig and Francis L. Loewenheim (eds.), The Diplomats, 1939-1979 (Princeton: University Press, 1994), 289-317.

Wegan, Katharina, "Gedächtnisort: Staatsvertrag: Über österreichische Eigenbilder zum Staatsvertragsjubiläum," in Moritz Csáky and Klaus Zeyringer (eds.), Inszenierungen des kollektiven Gedächtnisses: Eigenbilder, Fremdbilder (Innsbruck: Studienverlag, 2002), 193-219.

Weiß, Florian, “'Gesamtverhalten: Nicht in den Vordergrund stellen.' Die österreichische Bundesregierung und die westeuropäische Integration 1947-1957," in Michael Gehler and Rolf Steininger (eds.), Österreich und die europäische Integration 1945-1993 (Vienna: Böhlau, 1993), 21-54.

Westad, Odd Arne, The Global Cold War: Third World Interventions and the Making of Our Times (Cambridge: University Press, 2005).

Wettig, Gerhard, Chruschtschows Berlinkrise 1958 bis 1963: Drohpolitik und Mauerbau (Munich: Oldenbourg, 2006).

Wettig, Gerhard, "Das sowjetische Koexistenz-Konzept: Grundlage eines friedlichen Verhältnisses zwischen Ost und West?," in Osteuropa 24, no. 3 (1974), 180-187. 
Wettig, Gerhard, Europäische Sicherheit: Das europäische Staatensystem in der sowjetische Außenpolitik 1966-1972 (Düsseldorf: Bertelsmann, 1972).

Wildhaber, Luzius, "Neutralität, Außenpolitik und internationale Organisationen aus Schweizer Sicht," in Friedrich Koja and Gerald Stourzh (eds.), Österreich - Schweiz: Ähnlichkeiten und Kontraste (Vienna: Böhlau, 1986), 209-227.

Williams, Warren W., "British Policy and the Occupation of Austria" (PhD Thesis, University of Wales, Swansea, 2004).

Willetts, Peter, The Non-Aligned Movement: The Origins of a Third World Alliance (London: Pinter, 1982).

Widmer, Sigmund, "Forms of Neutrality," in Joseph Kruzel and Michael Haltzel (eds.), Between the Blocs: Problems and Prospects for Europe's Neutral and Nonaligned States (Cambridge: University Press, 1989), 17-28.

Windsor, Philip, "Neutral States in Historical Perspective," in Joseph Kruzel and Michael Haltzel (eds.), Between the Blocs: Problems and Prospects for Europe's Neutral and Nonaligned States (Cambridge: University Press, 1989), 3-9.

Wohnout, Helmut, and Martin Eichtinger, Alois Mock: Ein Politiker schreibt Geschichte (Vienna: Styria, 2008).

Wolkogonow, Dmitri, Die sieben Führer (Frankfurt: Societätsverlag, 2001).

Young, John W., "Western Europe and the End of the Cold War, 1979-1989," in Melvyn P. Leffler and Odd Arne Westad (eds.), The Cambridge History of the Cold War III: Endings (Cambridge: University Press, 2010), 289-310.

Zelikow, Philip, and Condoleezza Rice, Germany Unified and Europe Transformed: A Study in Statecraft (Cambridge, Mass.: Harvard University Press, 1996).

Zemanek, Karl, "Austria's Policy of Neutrality: Constants and Variables," in Hanspeter Neuhold and Hans Thalberg (eds.), The European neutrals in international affairs, Laxenburg Papers 7 (Vienna, Braumüller, 1984), 17-24.

Zemanek, Karl, "Wirtschaftliche Neutralität," in Juristische Blätter 81, no. 10-11 (1959), 249-251.

Zemanek, Karl, “'Zeitgemäße' Neutralität?," in Österreichische Zeitschrift für Außenpolitik 16 (1976), 355-367.

Zemanek, Karl, “'Zeitgemäße' Neutralität? - Schlussbemerkungen,” in Österreichische Zeitschrift für Außenpolitik 17 (1977), 134-136.

Zhiriakov, I. G. Sovetskii Soiuz - Avstriia: Na puti k sozdaniiu obshcheevropeiskogo doma (Moscow: Akademiia obshchestvennykh nauk TsK KPSS, 1991).

Zhiriakov, I. G., "Sovetsko-Avstriiskie otnosheniia i problema bezopasnosti i sotrudnichestva v Evrope 1945-1986" (PhD Thesis, Moscow, 1987).

Zhiriakov, I. G., SSSR - Avstriia: itogi i perspektivy sotrudnichestva (Moscow: Mezhdunarodnye otnosheniia, 1985).

Zhiriakov, I. G., SSSR i Avstriia posle Khelsinki (Moscow: Molodaia gvardiia, 1983).

Zhiriakov, I. G., SSSR i Avstrija v 1945-1975 gody (Moscow: Molodaia gvardiia, 1982).

Zubok, Vladislav, A Failed Empire: The Soviet Union in the Cold War from Stalin to Gorbachev (Chapel Hill: University of North Carolina Press, 2007).

Zubok, Vladislav, "CPSU Plenums, Leadership Struggles, and Soviet Cold War Politics," in Cold War International History Project Bulletin 10 (1998), 28-33.

Zubok, Vladislav, and Constantine Pleshakov, Inside the Kremlin's Cold War: From Stalin to Khrushchev (Cambridge, Ma.: Harvard University Press, 1996).

Zubok, Vladislav, Khrushchev and the Berlin Crisis 1958-1962, Cold War International History Project Working Paper 6 (Washington, DC: Woodrow Wilson Center, 1993).

Zubok, Vladislav, Soviet Intelligence and the Cold War. The "Small" Committee of Information, 1952-53, Cold War International History Project Working Paper 4 (Washington, DC: Woodrow Wilson Center, 1992). 
Zubok, Vladislav, "The Soviet Attitude towards European Neutrals during the Cold War," in Michael Gehler and Rolf Steininger (eds.), The Neutrals and the European Integration, 1945-1995 (Vienna: Böhlau, 2000), 29-43.

25 Jahre österreichischer Staatsvertrag: Symposium, veranstaltet von der Österreichischen Akademie der Wissenschaften und der Akademie der Wissenschaften der UdSSR in der Zeit vom 12.-19. April 1980 in Moskau (Vienna: Verlag der Österreichischen Akademie der Wissenschaften, 1981).

25 Jahre Staatsvertrag: Protokolle des Staatsaktes (Vienna: Österreichischer Bundesverlag, 1981).

25 Jahre Staatsvertrag: Protokolle des wissenschaftlichen Symposions (Vienna: Österreichischer Bundesverlag, 1981). 



\section{Index}

Adenauer, Konrad 75, 78, 84, 106, 118, 120, $121,149,199,325,329$

Afghanistan

- neutrality 44, 51-52

- Soviet intervention 221, 233, 245-246, 248249, 254, 285

- USSR 51, 316, 320

Alekseev, Petr F. 231

Andropov, Iurii V. 226, 245-246, 250

Androsch, Hannes 214

Aristov, Averkii B. 172, 339

Aubert, Pierre 248

Austria

- "Austromir" space project 262, 272

- Anschluss 14, 21, 75, 118-119, 139, 141, 143-146, 149, 153, 155-156, 162, 171, 279

- communism 13, 26, see also KPÖ

- culture see Cultural relations

- defense policy $182-185,200$

- image in the USSR $81,83,100,194,232$, 262,283

- location 13, 15, 23

- media 84, 111, 177-178, 194, 212, 225, 227-228, 283

- media correspondents in the USSR 227-228

- neo-Nazism 75, 82, 146, 232-233

- neutrality $16,21,26-27,30,68-74,86$, 127-130, 198-200, 254-256, 272, 278-280, 284-285

- Ostpolitik 130, 198, 210

- postwar occupation 13-14, 16

- Slovene minority 233

- state treaty $13,15,21-24,26,27$

- tourism see Travel

- trade see Economic relations

Avilov, Viktor I. 143, 147, 151, 153, 339

Bandung conference (1955) 19, 51

Bauer, Friedrich 339

Belgrade convention see Danube convention

Benya, Anton 225

Beriia, Lavrentii P. 46
Berlin conference (1954) 16, 47, 162

Berlin crisis (1958-1961) 54, 78, 105-106, 116, 150, 215, 299, 302-303, 308, 310-312, 321, 323-325

Bindschedler, Rudolf 68

Bischoff, Norbert 84-86, 91, 93-95, 100, 105, $113,151,192,218,339$

Blau, Paul 225

Bock, Fritz 152-153, 155, 167, 187, 222

Bondarenko, Aleksandr A. 143, 264

Brandt, Willy 105-106, 199, 204, 208, 210, 286, 303

Brezhnev, Leonid I. 34, 135-136, 138, 161, 163, 165, 168, 172, 187, 191, 203-205, 210, 212-215, 217, 228, 238, 240, 245-247, 261, 282,330

Bulganin, Nikolai A. 50-51, 80, 95, 103-104, 163, 287, 293, 295, 297

Bulganin notes (1957-58) 103-104, 293, 295, 297

Bush, George H. W. 269

Carter, Jimmy 213, 217, 245

Chernenko, Konstantin U. 245

Cherniaev, Anatolii S. 262

Chevallaz, Georges André 248

Chicherin, Georgii V. 18

China, People's Republic of 19, 62, 203, 221

China, Republic of 216

Chou En-Lai 19

CMEA 160, 172, 211, 235

COCOM 125, 247, 252

Communist Party of Austria see KPÖ

Coudenhove-Kalergi, Barbara 229

CSCE 104, 157, 161-165, 167, 169-170, 172174, 197, 211-212, 222-223, 329

Csoklich, Fritz 225

Cuba 218

Cuban missile crisis 150,208

Cultural relations 111-114, 159, 192-193, 229230, 271

Czechoslovakia 92 
- "Prague Spring" 175

- Soviet intervention 135, 170, 175, 178, 221, 249, 283, 285

Czernetz, Karl 96

Danube convention 108-110, 129, 131

Decolonization 20, 42, 48, 63, 137, 216

de Gaulle, Charles 150-151, 155, 167, 171, 313, 315-316, 325

Demichev, Petr N. 156, 166

Denmark 45, 52-53, 136, 144, 167, 222

Dichand, Hans 194

Drimmel, Heinrich 119, 195

Dulles, John Foster 24, 47, 75, 322

\section{EC 265-267}

Economic relations 13, 20, 64, 122-123, 125 126, 189-191, 211, 235-241, 244, 249-252, 270,281

ECSC 138-140, 145-146

EDC 46

EEC 131, 136-137, 140-164, 166-168, 171173, 199-200, 211, 255, 263-264

Efremov, Mikhail T. 214-215, 250, 339

EFTA 141-142, 144, 171-172, 190, 192

Eiselsberg, Otto 192, 300

Eisenhower, Dwight D. 14-15, 299, 310, 322

El'tsin, Boris N. 269

Erlander, Tage 53, 90

Ermacora, Felix 71, 141, 255-256

Estonia 44

Eyskens, Mark 265

Figl, Leopold 14, 87, 91, 107, 109, 143

Finland 52-53, 65, 80-81, 198, 215

- "night frost crisis" 67, 127

- "note crisis" 144

- CSCE 170, 223

- defense policy 183-184, 267

- EEC 172

- EFTA 141

- neutrality 44, 52, 54, 74, 118, 169, 206, 221

- trade 191, 241, 252

- UN 222

- USSR 21, 44, 53, 165, 169, 182, 235, 248, 250

Finlandization 279, 284

Fischer, Heinz 225

FPÖ 75, 140, 151, 233-234, 261, 269
France 23, 46, 68, 73, 78, 104, 112, 136, 140, $147,158,167,181,191,204,210,214,219$, 235, 240-241, 250, 252, 261, 270, 282, 286

Friendship Society, Austrian-Soviet 93, 113, 178, 194, 231

Friendship Society, Soviet-Austrian 194, 231

Furtseva, Ekaterina A. 116, 230

Gagarin, Iurii A. 78, 194

Gaitskell, Hugh 325

Ganiushkin, Boris V. 59, 61, 72, 146

Geneva conference (1954) 21, 329

Geneva conference (1955) 25, 50, 78

Geneva disarmament negotiations 103, 245, 261

Genscher, Hans Dietrich 217

Gerhardsen, Einar 53

Germany 13, 15, 23, 45, 66, 104

$-2+4$ Treaty 267

- division 14

- neutralization $16,46,47$

- World War II 44, 261

Germany, East 118, 150, 169

- Austria 157, 165-166, 169, 173

- revolution (1989) 266

- uprising (1953) 16

Germany, West 54-55, 75, 82, 86, 91, 105-106, $113,118,125,138-140,143,151,158,181$, $184,191,250$

- Anschluss 153, 156

- Moscow treaty 203

- NATO 15, 24-25, 46, 48, 50, 181

- Ostpolitik 199, 210, 221

- trade 240, 244, 252, 270

Ginther, Konrad 254-256

Glaser, Hugo 194

Gorbach, Alfons 142, 148, 150, 154, 300-303, $305,307,309,311-313,315,317$

Gorbachev, Mikhail S. 77, 261-262, 264-271, 282, 286

Graf, Ferdinand 111

Graf, Robert 270

Greece 15, 54, 104, 160, 250, 261

Gromyko, Andrei A. 22, 71, 73, 77, 94, 96, 105, $116,120,135,143,152,154,168-169,173$, 203, 208, 213, 217-219, 246, 248, 250-251, $300,309,328-331,334$

Grubhofer, Franz 93, 129, 130

Grubmayr, Herbert 264, 266, 339

Gygax, Fritz 99 
Haider, Jörg 261

Hallstein, Walter 317

Hammarskjöld, Dag 15, 127

Hansen, Hans Christian 53

Havel, Vaclav 230

Haymerle, Heinrich 151-153, 168, 197, 300, 319, 339

Herter, Christian 106

Hinteregger, Gerald 244, 250, 300, 339

Hitler, Adolf 21, 85, 118-119, 140, 156, 182, $307,315,329$

Hoang Luong 216

Hörmann, Otto 229

Horn, Gyula 266

Hungary 13, 89-91

- neutrality 49,96

- Soviet intervention 89,91-93

- uprising (1956) 89

Hutter, Erhard 227-229

Iceland 52,222

India $17,19,51,61,118,128,222$

Indonesia 17,51

Iran 44, 154

Israel 15, 104, 219, 226-227, 330

Italy $15,25,45,54,86,98,104,118,125,136$, $140,147,164,166,188,191,204,215,232$, 240-241, 252, 270, 286

Jankowitsch, Peter 268

Japan 45, 54-55, 191, 216, 252, 270, 312, 314

Jonas, Franz 168-169, 175, 177, 179, 189

Kabanov, Ivan G. 189

Karajan, Herbert von 193

Kekkonen, Urho 65, 67, 81, 144, 169-170, 172, 211, 248

Kennedy, John F. 27, 150, 217, 312-313, 317, 319, 321-323, 325-326

Khachaturian, Aram I. 114

Khrushchev, Nikita S. 18-22, 24-29, 34, 37, $43,47-49,51-55,57,77-78,80-81,85,95$, 104-106, 108-110, 116-122, 125, 127-128, 129-131, 135-136, 142, 144, 147-150, 154, $156-157,160,163,165,187,189,192-193$, 197, 207-209, 217, 247, 282-283, 287, 298-301, 303, 305, 307-313, 315, 317-319, 321-326

Kiesinger, Kurt Georg 329
Kirchschläger, Rudolf 171-174, 182, 209-210, 214, 231, 250, 254-255, 261, 333

Kissinger, Henry A. 217

Klaus, Josef 155-156, 159-162, 164-167, 175-176, 178-179, 182, 188, 198-200, 207

Klug, Margaretha 231

Koivisto, Mauno 248

König, Franz 271

Koplenig, Johann 194

Körner, Theodor 96, 97

Kosygin, Aleksei N. 81, 116, 135, 153, 164-165, 167, 173, 187-188, 190-191, 211, 214-215, $223,225-226,235,282$

KPÖ 13-14, 46-47, 82, 92, 110, 138, 141, 176, 209, 228, 282

Kreisky, Bruno 23, 37, 70, 84, 87, 96, 105-106, 119-120, 129-130, 140-141, 147, 149-150, $152-153,157,166,173-175,182-183,198-$ 199, 207-214, 218, 223-226, 230, 232-235, 239-240, 248-252, 254-256, 262, 271, 281, 293, 298-300, 308-312, 315, 330

Kroll, Hans 105

Kuznetsov, Vasilii V. 216

Kvitsinskii, Iulii A. 264

Lanc, Erwin 267

Landovsky, Pavel 229-230

Laos 52, 311

Lapin, Sergei G. 82, 92, 139, 287, 339

Lebanon crisis (1958) 107

Lendvai, Paul 229

Lenin, Vladimir I. 18, 43

Liedermann, Helmut 229, 238, 244, 256, 333, $335,337,339$

Lithuania 44, 271, 275

Lothaller, Clemens 272

Malenkov, Georgii M. 17, 21, 48

Maleta, Alfred 179, 282

Malta 42

Mauthausen concentration camp 118

Mayer-Gunthof, Franz Josef 179

Mendelevich, Lev I. 223

Mikoian, Anastas I. 22, 26, 77, 80-81, 97-100, $106,108,110,116,118,125,153,193,198$, 282-283, 287, 289, 291-292, 300, 307, 313

Mitterer, Otto 179,190

Mock, Alois 262, 265-266, 268-269, 271

Modzhorian, Lidiia A. 59 
Molotov, Viacheslav M. 18, 21-22, 25, 47, 72, $77,80,97,117,179$

Moscow memorandum 21, 26, 68-69, 72, 87, 141,278

Muskie, Edmund 217

Nagy, Ferenc 91

Nagy, Imre 91, 107, 110

NATO 15-16, 24-26, 37, 41, 45, 48-50, 52-54, $63,68,78,87-88,92,94,97,100,103-104$, $116,118,123,127-129,136-140,142-144$, 146-148, 151, 153, 155, 161-162, 165-166, 170-171, 178, 180-181, 183-184, 186, 197, 199, 206, 222-223, 245, 248-250, 264-265, $267,275,279,282,285,293-294,302,317$, 321,357

Natural gas 179, 188, 190, 192, 236, 238-240, 270

Nehru, Jawaharlal 19, 51

Nenning, Günther 130, 225

Netherlands 58, 104, 222

Neutrality

- Hague Conventions 41

- Western theory 41

- see also Austria, Finland, Hungary, Sweden, Switzerland, USSR

Nixon, Richard 204, 210, 286

Nonalignment 42, 49

Norway 52-53, 112, 116, 118, 136, 144

Nudel, Ida 226

Nureyev, Rudolf 226

Oistrakh, Igor 84, 114, 192

Orlov, Iurii F. 226

ÖSG see Friendship Society, Austrian-Soviet

Osipov, Nikolai T. 188

ÖVP 15, 70, 93, 110, 140, 155, 183, 234, 256, 263

Paasikivi, Juho 53, 170, 248

Pahr, Willibald 228, 244, 249-250

Palme, Olof 171, 249

Patolichev, Nikolai S. 179, 187, 190, 282

Pavlov, Valentin S. 267

Peaceful coexistence 16-20, 47, 57, 127, 204, 245

- Austria 109, 119, 200, 209, 224

- France 209

- India 19

- United States 210
Peter, Friedrich 212

Petitpierre, Max 90

Pittermann, Bruno 70, 129-130, 141, 150, 225, 318-319, 321-323, 325-326

Podgorny, Nikolai V. 156-158, 161, 163-164, 166-168, 171, 173

Podtserob, Boris F. 159, 176,-178, 339

Polianov, Nikolai 156, 164

Pollak, Oscar 111

Popovich, Pavel R. 194

Popov, Valerii I. 339

Porkkala, Soviet return of 21, 30, 53

Portisch, Hugo 194

Prader, Georg 177, 182

Primakov, Evgenii M. 264

Prisoners-of-war 44, 83, 116, 123

Probst, Franz 225

Raab, Julius 15, 65, 69-70, 73, 80-82, 86, 90-92, 94, 96, 98-99, 103-108, 110-111, 113-115, 117, 119-121, 123, 129-138, 141-142, 149, 199, 208, 281-283, 287, 289-293, 295, 297, 301, 317, 319,

Rapacki Plan 99, 103-104

Reagan, Ronald 184, 245, 249, 261

Repatriation 44, 83, 123

Richter, Sviatoslav 192

Riegler, Josef 270

Rösch, Otto 129, 181-183

Rostropovich, Mstislav 192

Rusk, Dean 217

Ryzhkov, Nikolai I. 262, 265

Sakharov, Andrei D. 226, 229

SALT 176, 203, 213, 217, 245

Sattler, Anton 231

Schärf, Adolf 111, 294, 298-299

Šejna, Jan 180, 212

Semenov, Vladimir S. 22, 139, 153, 157, 159160, 166, 172, 208, 282, 350

Shcharanskii, Anatolii (Nathan) 226

Shelepin, Aleksandr N. 216

Shenaev, Vladimir N. 264

Shepilov, Dmitrii T. 77, 95, 96

Shevardnadze, Eduard A. 262, 265

Shikin, Gennadii S. 264, 339

Shostakovich, Dmitrii D. 113, 194

Shultz, George P. 217

Sinowatz, Fred 214, 230, 232, 248, 250-251, 262 
Slavik, Felix 225

Smirnov, Andrei A. 112, 339

Socialist (Social democratic) Party of Austria see SPÖ

Spaak, Paul Henri 75, 137

Spiel, Hilde 225

SPÖ 70, 111, 130, 141, 150, 207, 209, 248-249, 263

Stalin, Iosif V. 13-18, 25, 28, 44-47, 77-79, 81, $83,85,100,104,116,306-307,321$

Stalin notes (1952) 16, 46

Standenat, Heinrich 339

Stankevich, Sergei B. 269

Staribacher, Josef 211, 240-241, 244

State Treaty see Austria, state treaty

Stikker, Dirk 321

Streissler, Erich 225

Suez crisis 78

Sweden 136, 144, 171, 182, 219, 221-223, 241, 248-249, 252, 277, 329

- defense policy 65,184

- neutrality 45, 52-53, 70, 118, 137

- USSR 65, 90, 136, 247, 250

Switzerland 45, 68, 71, 136, 142, 144, 150, 171, $182,192,277$

- defense policy $65,184,248$

- neutrality 41, 43, 45, 68, 70, 137

- trade 252

- USSR 207, 241, 281

Thompson, Llewellyn 87

Tikhonov, Nikolai A. 213, 226, 251, 282

Tito, Josip Broz 25, 77

Tiunov, Oleg I. 59, 72

Tončić-Sorinj, Lujo 160-161, 167, 219

Travel 84, 115, 195, 232

Trotskii, Lev D. 18

Trudeau, Pierre Elliott 226

Tschadek, Otto 100

Tunkin, Grigorii I. 56, 139, 205

Turkey 15, 44-45, 54, 104, 160, 208, 250

United Nations

- Austria 216-217, 221

- Finland 248

- Soviet policy 64, 137, 216, 221

United States 24, 26-27, 87, 90, 92-93, 104, 107-108, 118, 120-121, 125, 129, 131, 155, $168,199,221-222,232,249,252,279,281$

\section{USSR}

- image in Austria 100, 111, 178, 232, 283

- international law 35-36, 56, 57, 59-60, 205206, 246

- media 29, 81-82, 91, 100, 155, 164, 177, 200, $228,232,283$

- media correspondents in Austria 194

- neutrality 43-44, 46, 47, 49-54, 56-57, 59-65, 67, 137, 205-206, 246

- neutrality myth 54

- tourism see Travel

- trade see Economic relations

- see also Afghanistan, Austria, Czechoslovakia, Finland, Hungary, Sweden, Switzerland

U Thant, Sithu 325

Verdross, Alfred 56, 70, 141, 200, 255-256

Verosta, Stephan 200, 255

Viehböck, Franz 272

Vietnam 157, 168, 203, 215-217, 219, 248, $280,286,315,328,329$

Vranitzky, Franz 214, 262-263, 265, 267-269, 272

Waldbrunner, Karl 117

Waldheim, Kurt 167-169, 175, 177-179, 182, 188, 193, 199-200, 216-217, 219-220, 255, $261,262,268,328,329,330,331$

Warsaw Pact 16, 23, 37, 47, 49-50, 52, 54, 68, $104,163,165,170,175-176,180-181,183$, $185,194,199,203,212,223,-45,285,369$

Wiesenthal, Simon 212

Wilson, Harold 215

Wodak, Walter 89, 153, 156-157, 159, 172, 177,339

World Federation of Trade Unions 86, 98

World Peace Council 86, 98

World Youth Festival 114-115

Yugoslavia 15, 21, 42, 61, 77, 80, 94, 184, 210, $212,222,232,234,241,252$

Zagladin, Vadim V. 249, 262, 267, 271

Zhdanov, Andrei A. 14, 45

Zheltov, Aleksei S. 14

Zhivkov, Todor 169

Zhukov, Georgii K. 92, 94

Zhurkin, Vitalii V. 267

Zorin, Valerian A. 92, 110, 112, 145, 218 
